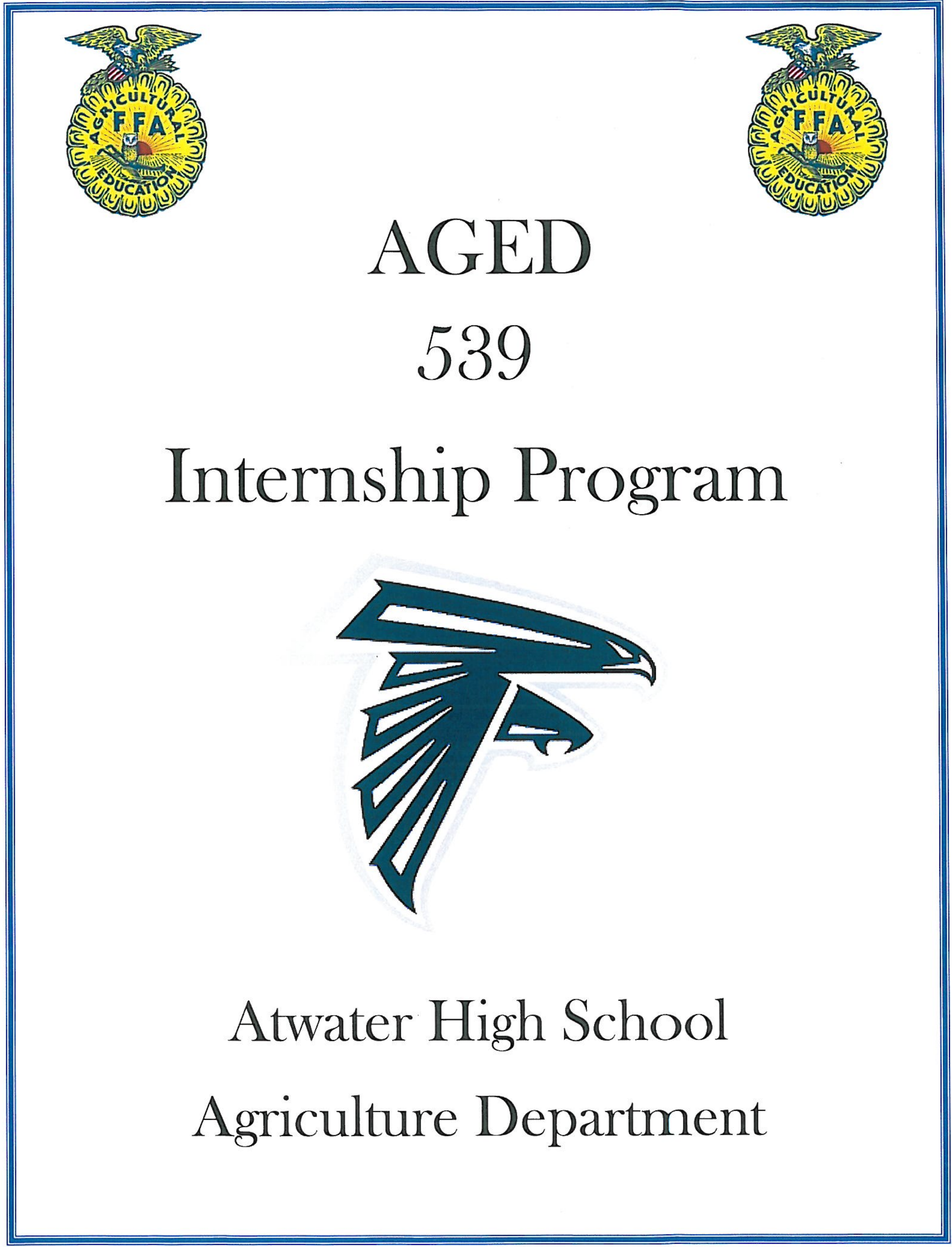




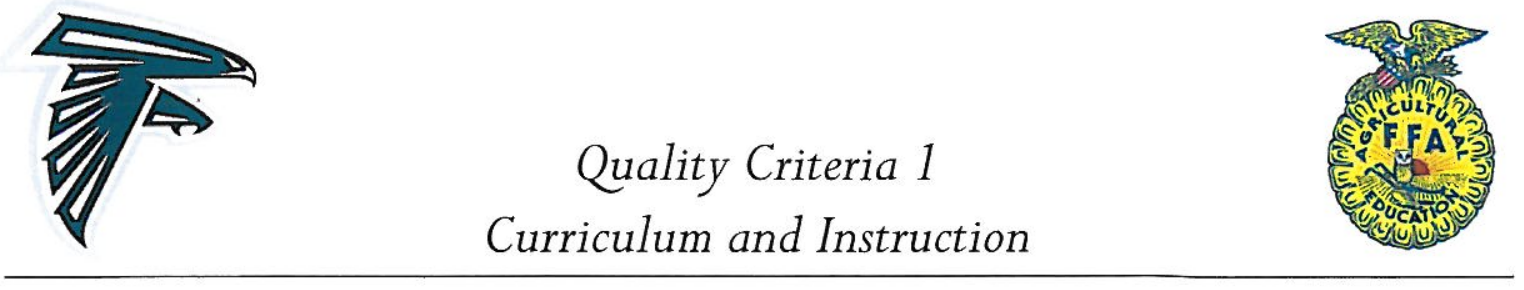

The Atwater High School Agriculture Department meets the quality criteria in the following ways; the use of agriculture education core curriculum, software, texts, facilities, instructional strategies, equipment, learning experiences, courses offered, hands-on learning, student projects, guest speakers, needs assessment, and so on. Each of the quality indicators is discussed in detail and how they are met within each criterion.

\section{Quality Criteria 1A:}

Atwater High School Agriculture Department incorporates the core curriculum where appropriate into our existing curriculum. When writing new curriculum the cluster standards are inserted into the appropriate areas as required. For example, the floral design curriculum includes the Ornamental Horticulture Cluster Standards, Visual Performing Arts Standards, and Language Arts and the Ag Standards.

\section{For Examples, Please see the following:}

\section{- Appendix $C$}

\section{Quality Criteria 1B:}

Atwater High School Agriculture Department meets this criterion through our Agriculture Career Pathway plan. It includes the major agriculture clusters such as plant science, animal science, ag business / communications and ag mechanics. It then gives a breakdown of the specific courses that have to be taken in order to complete that specific agricultural pathway. It also provides students with a list of other possible agriculture classes that they can take so that our students graduate with a well-rounded knowledge of the agriculture field.

The Atwater High School Agriculture Department staff has aligned our courses to both the Foundation Standards and Pathway Standards for Agriculture and Natural Resources Industry Sector. 
For Examples, Please See:

- Appendix A

- Appendix $C$

- Appendix R

\section{Quality Criteria 1C \& ID:}

Atwater High School currently has a list of all of the agriculture courses necessary for any pathway. The Agriculture Career Pathway list is provided to all counselors so that they may best advise our students as to the proper order of agriculture courses so that they complete their desired agriculture pathway. The master schedule includes the list of classes available for each grade level so that students can choose a course that follows their designated agriculture pathway. This pathway can is easily accessible to students and parents via the internet. The Agriculture Career Pathways can be viewed on our website under Agriculture Courses.

\section{For Examples, Please See:}

- Appendix R

\section{Quality Criteria 1E:}

Every agriculture course taught at Atwater High School includes agriculture career awareness information. The ROP courses focus more intensely on career information and preparing students for immediate employment or continuing education in an agriculture career. The Floral Design courses contain direct information regarding the current industry and job related field. The Ag science courses have career awareness information imbedded with each unit. For example the Genetic Engineering Unit contains career information bases on that related field.

For Examples, Please See:

- Appendix C 


\section{Quality Criteria 1F:}

The Atwater High School has two computer labs on campus that hold approximately 40 desktops. The high school also has 2 mobile laptop carts that carry 40 laptops. The Agriculture Department has the advantage of using one of the mobile laps in the Floral Design classes and Ag Econ class. We have a compilation of resources that include many software and hardware programs for improving the quality of our agriculture courses. We are constantly building our resources and purchasing new hardware and software to attain agriculture products that meet the needs of our agriculture curriculum and department. These equipment and materials are used often in the agriculture classes, such as the computerized record book, so that students have experience in our computer lab and are prepared for the technological areas of agriculture when they graduate. Four teachers are currently using SMART Airliners with the $S M A R T$ Notebook program and we have four sets of interactive response systems. All teachers utilize the computer labs on campus or the mini mobile laptops that are shared with other instructors on campus.

\section{Quality Criteria $1 G$}

The agriculture curriculum includes the use of computer-aided instruction by utilizing at least one of the following:

* Computerized Record Book

* Agriculture Term Paper

* Job Resume

* Portfolio Letter of Introduction
* Agriscience Fair Report

* Agriculture /FFA Speech Manuscript

* Job Cover Letter

* Other Agriculture Related Project

Currently the Atwater Agriculture curriculum utilizes computer-aided instruction in the following areas: Computerized Record Book for all students, Agriculture Term Papers for Agriculture Science and Business classes, Agriculture/FFA Speech Manuscripts for speaking contests or classroom speeches throughout the year, Job Resume, Cover Letter, Portfolio Letter of Introduction within each student portfolio for the Regional Occupation Program courses offered within our program, creating websites in floral design and completing large group projects utilizing Googledocs. Students also use the computer-aided instruction for agriculture \& science research, laboratory reports, project based websites and blogs and other computer generated activities through the Internet or high school. 


\section{Quality Criteria $1 \mathrm{H}$}

Recordkeeping is taught in all agriculture classes. Every student maintains and completes (closes out) either an actual SAE Project or Mock Problem.

Each student is required to complete a record book each year in at least one Ag class. Students who show animals, applying for their state degree or American degree complete their record books electronically. Electronic record books are kept in a file on the school data bases and are organized by first and last name. Students that complete the paper record books are kept in their student file folders in a filing cabinet in the shop office. These file folders also contain the R-2 student data sheets.

For Examples, Please See:
Appendix $A$
Appendix B
Appendix $C$

\section{Quality Criteria 11}

File Cabinets in the Atwater High School Agriculture Shop Office hold Record books of prior students until one year following graduation. These books are kept in student files, along with their Student Data Sheet. Each student also has their own file in the Atwater High School database where they maintain their computerized record books. These books can be maintained anytime in the Agriculture Department computer lab. Students who have graduated also have access to the Agriculture Department computers to update and maintain their records.

For Examples, Please See:

- Appendix $A$

- Appendix $B$ 


\section{Quality Criteria 1J}

Every course at Atwater High School meets graduation requirements as either a core class or an elective credit. Ag Life Science, Ag Environmental Science, Ag Earth Science and Ag Biology are courses where the student receives science credit for graduation and a-g credit. Floral Design is approved for Fine Arts a-g credit. Ag Economics and Ag Government have been approved for the a-g requirements. Our district is currently in the process of trying to approve all other Ag shop classes (Ag Shop Skills, Ag Mechanics, Ag Welding and Fabrication, Ag Wood, and Ag Small Engines) as a Fine Art a-g credit.

For Examples, Please See:

- Appendix C 


\section{Quality Criteria 2}

\section{Leadership and Citizenship Development}

The Atwater High School Agriculture Department has been working on improving the leadership and citizenship of the FFA members in its chapter. Students are required to participate in twelve FFA activities per year, which reflects in 10\% of their grade in each agriculture course. We encourage students to compete in the local and sectional contests to improve their leadership and communication skills. There are many opportunities in the Atwater FFA chapter to assist in community service activities including the Atwater Beautification project, local can food drives, Food to Farm Day, and Floral Outreach Events. It is our goal at Atwater High School to create leaders of our agriculture students through our courses and FFA leadership development activities.

\section{Quality Criteria 2A:}

Atwater FFA is chapter number CA0344, and the Atwater High School Agriculture Department is located in the Merced Union High School District, in Atwater, CA.

For Examples, Please See:

- Appendix X

\section{Quality Criteria 2B}

The Atwater FFA Program of Work is developed each year with information for students, administration, and community members about our Agriculture Program. It covers the pertinent information for fair projects, program goals, and Agriculture/FFA education. A copy of the Program of Work is also sent to the Regional Supervisor by December $15^{\text {th }}$.

For Examples, Please see:

- Appendix I 


\section{Quality Criteria 2C}

All Atwater High School Agriculture students are held accountable for participating in three FFA leadership activities quarterly for 10\% of their grade in each course. Annually each student will be graded upon participation in a total of twelve leadership activities through the FFA.

For Examples, Please see:

- Appendix C

\section{Quality Criteria 2D}

All students that are enrolled in the Atwater High School Agriculture Program are also entered on the R-2 as FFA Members. Dues are paid for every student enrolled in an Ag Department taught course. Students who enroll second semester are also added to the R-2 at that time. Atwater High School Agriculture Department courses have 100\% affiliation with the FFA. Each student is held accountable by participating in three FFA activities quarterly, as well as the fact that all agriculture students are official FFA members according to the FFA Roster for Atwater High School.

\section{For Examples, Please See:}

- Appendix C

- Appendix $X$

\section{Quality Criteria $2 E$}

Atwater High School Agriculture Program participates in a variety of FFA activities each school year. Each year our program is starting new activities and opportunities for our members to have a well-rounded agriculture experience.

For Examples, Please See:

- Appendix $U$ 


\section{Quality Criteria $2 F$}

Atwater High School students have participated in multiple activities at the local level. These can be verified by documentation within the Atwater Agriculture Department, and the Sectional Advisor. Students are required to participate in 12 local FFA activities annually based on 10\% of their agriculture course grade for the year.

\section{For Examples, Please See:}

Appendix $U$ 


\section{Quality Criteria 3 \\ Practical Application of Occupational Skills}

This criterion discusses how practical application of occupational skills is accomplished through classroom simulation of work-site experiences, community-based learning or entrepreneurship. These experiences are combined, coordinated, and evaluated with classroom instruction.

\section{Quality Criteria $3 A$}

Each student in the Atwater High School FFA program is expected to develop a type of SAE to enter in his or her record book. If a student does not have an SAE, then the advisors provide a simulated example for the student to use until their SAE is developed. We now have a school farm off campus where students can keep animal projects. The horticulture program is up and running to provide SAE projects for students. Student also have the opportunity to create floral arrangements for specific events as an SAE using outside class time.

\section{For Examples, Please See:}

- Appendix $A$

- Appendix B

- Appendix C

- Appendix $G$

- Appendix $R$

\section{Quality Criteria 3B}

First year students have either been engaged in a SAE project(s) or have a plan in place for a $S A E$, as verified by the Student Data-Career Plan.

The Atwater Agriculture Department uses the Student Data-Career Planning Sheet as a record of first year students as well as all Agriculture students SAE plans.

For Examples, Please See:

- Appendix $A$

- Appendix $C$

- Appendix $R$ 


\section{Quality Criteria 3C}

This criterion is partially met in the Atwater FFA program, but is in progress of achieving this standard. Currently, we have ROP courses, which provide our students with Agriculture SAE projects. $100 \%$ of students in these courses obtain an SAE through their ROP course. SAE projects for other students do not yet meet the $80 \%$ due to lack of facilities and opportunities for students. Our department is continually developing a school farm for animal projects and a complete horticulture program for plant science projects. These facilities will provide students with the opportunity to maintain an SAE projects on campus grounds, as many of our students do not have the availability of SAE projects at their homes.

For Examples, Please See:

- Appendix $C$

\section{Quality Criteria 3D}

Students enrolled in job placement programs are visited by their agriculture students every three weeks. Tri-weekly reports are completed for these students to keep account of their work at the jobsite. The Atwater Agriculture Department has a specific form for all other SAE projects that are completed when the agriculture teacher visits a student's projects. Each agriculture instructor is responsible for visiting their student's projects at least once each semester, based on the project duration.

For Examples, Please See:

- Appendix $E$

\section{Quality Criteria $3 E$}

The Atwater Agriculture Department has three department vehicles that are available for use at any time. 


\section{Quality Criteria 4 Qualified and Competent Personnel}

All Agriculture instructors at Atwater High School are fully credentialed agriculture instructors, with either a Master's degree finished or in progress. Each teacher is instructing in his/her areas of specialization, guaranteeing competency in the subject matter presented to agriculture students. The Agriculture instructors regularly attend in-services and professional development sessions to enhance their prior knowledge and update their instructional information.

\section{Quality Criteria $4 A$}

All agriculture teachers at Atwater High School are appropriately credentialed for the courses that they instruct. Each instructor has his or her agriculture specialist credential in addition to their clear credential and single subject credential in agriculture. As to date, three out of the five teachers have their Master's in Agriculture Education. The other two advisors are in the process of completing their Master's program in the next year.

For Examples, Please see:

- Appendix $T$

\section{Quality Criteria 4B}

Each Agriculture teacher attends four professional development activities either within Atwater High School, Merced Union High School District, and CATA, or individually. The Atwater Agriculture instructors all attend the CATA conference each year and take the "skills" courses related to their areas of teaching to update their own knowledge and information on the subjects. The agriculture instructors also attend educational development sessions, offered through Atwater High School and the Merced Union High School District.

For Examples, Please See:

- Appendix $W$ 


\section{Quality Criteria 4C}

The Atwater High School Agriculture instructors meet weekly to discuss upcoming events, future decisions within the department, and any reflection on events past.

For Examples, Please See:

- Appendix $B B$

\section{Quality Criteria 4D}

Atwater High School Agriculture Department members meet weekly to discuss upcoming events, concerns, teaching strategies, and reflections on past events/activities. The minutes are kept in a file within the agriculture office with some copies in the Comprehensive Program Plan.

For Examples, Please See:

- Appendix $B B$

\section{Quality Criteria $4 E$}

Atwater High School Agriculture instructors are reimbursed for personal expenses incurred while participating in FFA/SAE activities. Each instructor is reimbursed fully for participating in the CATA annual summer conference or any other professional development attended.

For Examples, Please See:

- Appendix NN 


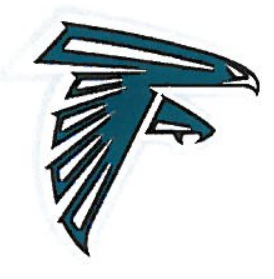

\section{Quality Criteria 6}

Community, Business

and Industry Involvement

The Advisory committee at Atwater High School consist of representatives from the community, businesses, school site staff, college instructors, ROP advisors, and other individuals having skills and knowledge of the occupations for the agriculture instruction provided.

The advisory committee follows a structured agenda that assists in the development and implementation of long-range and short-range plans to ensure that the program remains current. They cover the following areas in the agenda: instructional content, budgets, program promotion, student recruitment, facilities, equipment and materials, articulation agreements, program planning, job placement, SAE, FFA, Competencies, new technology, current and relevant instruction, textbooks and supplies, laboratory facilities and classroom space. There are written advisory committee minutes for each meeting in the program plan.

\section{Quality Criteria $6 A$}

The Agriculture Advisory Committee at Atwater meets twice a year in fall and spring. We have invited community, administrative, ROP, and school members and advisors to our meetings. Our superintendent will be attending our fall meeting, along with principals from our feeder middle schools. Recruitment and program direction are main focuses. Future goals include program pathways that are followed for all students entering the agriculture program in order to maintain retention and SAE projects.

For Examples, Please See:

- Appendix DD 


\section{Quality Criteria 6B}

The Agriculture Advisory Committee at Atwater meets twice a year in fall and spring. We have invited community, administrative, ROP, and school members and advisors to our meetings. Our superintendent will be attending our fall meeting, along with principals from our feeder middle schools. Recruitment and program direction are main focuses. Future goals include program pathways that are followed for all students entering the agriculture program in order to maintain retention and SAE projects.

For Examples, Please See:

- Appendix Q

\section{Quality Criteria 6C}

The Agricultural Advisory Committee has assisted in the development or revision of the Comprehensive Program Plan, as evidenced in the Ag. Advisory Committee minutes.

- Job Market Descriptions

- Total Program Goals \& Objectives

- Course Subject Matter Outlines

- 5 Year Facility \& Equipment Acquisition

- Graduate Follow Up

- Targeted Occupations
- Program Description-Courses, SAE, FFA

- Program Completion Standards

- Current Year Budget

- List of Active Placement Site

The Atwater Agricultural Advisory Committee has been presented with the current Program Plan and has helped to develop our program pathways and goals. Our committee members have provided us with guidance in placement sites, equipment and facilities maintenance \& repair, and our recruitment in the past year. The advice and aid has provided us with much information as we have been developing our program plan for this year. With the support of our Advisory Committee we have been successful during the past year in improving our FFA membership and community involvement. 


\section{Quality Criteria 7}

\section{Career Guidance}

Agriculture educators, staff, counselors, and career centers provide services and guidance to ensure that agriculture students enroll in courses that are consistent with their interests, abilities and goals. All students in the agriculture department are required to complete an information sheet that is kept on file and updated yearly in the department classroom.

Our department has ROP Agriculture courses that offer career planning portfolios, employability skills, articulation options, and career path goals which gives students the opportunity to experience and understand all of the future options in their career path goals. We also have articulation agreements in place with Merced College for our ROP courses that transfer from the high school. Our department is participating in an Agriculture Industry Day where students who are not aware of career opportunities in agriculture are able to come and discover which career paths they may have of interest. We also have a career-preparation day through ROP where our agriculture students have the opportunity to present a portfolio and participate in a job interview process in preparation for future career opportunities in their interest areas.

Many courses in the agriculture department are in progress of aligning with the UC/CSU A-G requirements. We have currently Ag Biology and Ag Earth Science that is aligned for science credit,. Floral Design meets the fine arts credit for UC/CSU. 


\section{Quality Criteria $7 \mathrm{~A}$}

Every agriculture course taught at Atwater High School includes agriculture career opportunities information. The ROP courses focus more intensely on career information and preparing students for immediate employment or continuing education in an agriculture career. The Floral Design courses contain direct information regarding the current industry and job related field. The Ag science courses have career awareness information imbedded with each unit. For example the Genetic Engineering Unit contains career information bases on that related field.

Every student is counseled when filling out the "Student Planning Form" on the back side of the "Student Data Sheet."

\section{For Examples, Please See:}

- Appendix A

- Appendix $C$

- Appendix $R$

\section{Quality Criteria $7 B$}

Each student in our agriculture program has an information sheet and a student data sheet is in progress. The information sheets cover our students' background information and agriculture areas of interest for our students. Our course requirements and classes offered have changed drastically in the past two years and we are deciding the pathways that will fit our program goals. A 4-year student data sheet for interest areas and career pathways will be in place for the next school year with appropriate course offerings and guides according to agriculture interest areas. These data sheets will be kept on file in the agriculture department and updated annually.

For Examples, Please See:

- Appendix A

- Appendix $R$ 


\section{Quality Criteria 7C}

Currently the Atwater Agriculture Department has all ROP courses aligned with $2+2$ agreements with Merced Junior College. This is our local community college where most of our college bound students will attend. In addition, we are articulating our courses to meet the UC/CSU A-G requirements for science and fine arts courses. Currently we have one class that meets the science requirements and the others meet the elective requirements. These should be in place with a definite response within the next two school years.

For Examples, Please See:

- Appendix MM 


\section{Quality Criteria 8}

Program Promotion

The Recruitment program at Atwater High School has been improved immensely in the past few years for the agriculture program. Our $8^{\text {th }}$ grade recruitment has been a priority since a new high school has been built in our city, and many of our students are no longer agriculturally aware. We have been coordinating with the middle school principals and counselors, finding opportunities to visit the students and promote our agriculture program. All of our programs are available to students with means to overcome financial barriers in place.

There are many recruitment activities and materials that we have developed to promote agriculture courses. Brochures are available to all middle school students that discuss our program and explain the courses offered, encouraging them to develop an area of interest so that they can easily fall into a specific agriculture pathway as they enter high school. We also participate in fun activities for the middle school students during FFA week such as petting zoos, and officer presentations. Previously we have invited $8^{\text {th }}$ graders to attend one of our meetings with a fun activity for them to participate in for free. Our largest focus for the upcoming years will be recruitment in the science and mechanics areas. The enrollment has increased in the past year and we continue to believe that with our recruitment we will have a steady increase of students enrolling in agriculture courses in the upcoming years. 


\section{Quality Criteria $8 \mathrm{~A}$}

The Atwater High School agriculture department has a program recruitment brochure to encourage the middle school students to enter into one of our pathways. We also have flyers that we distribute to the counselors and career technicians during the course enrollments students can see the courses in which they wish to enroll and then sign up according to the sheets provided. This encourages middle school students to follow an agriculture pathway of interest and sign up for the correct agriculture class as an incoming freshman.

\section{For Examples, Please See:}

- Appendix NN

\section{Quality Criteria $8 B$}

There are financial means for overcoming any barriers for participation in our programs. We have FFA activities and opportunities for students to earn their way for trips, jackets, and other needs or interests. During our SAE projects we aid students in loan programs through either our Ag Boosters or the local banks. They also have available areas to keep their projects, since many of our students do not have the appropriate locations at home. Leadership activities are always available for students and if they cannot afford a trip, then they can participate in fundraisers or other activities to earn a free trip.

\section{Quality Criteria 8C}

Our high school participates in many recruitment activities with local high schools during FFA week and before enrollment for the freshmen. We have a petting zoo that goes to the middle schools and our officers explain to them how the agriculture high school program runs at Atwater. The officers answer questions and encourage the students to enroll in agriculture courses for their freshman year in high school.

Atwater High school also developed a chapter meeting geared toward introducing FFA to the middle school students. Future freshmen were invited to attend a chapter meeting and participate in our FFA activities that followed. 
Our chapter officers also visit the middle schools before enrollment, handing out brochures of our program and explaining what pathways they may choose from. A list of the freshmen courses are available so that they can choose right then what pathway and courses in which they would enroll for their first freshman term.

\section{For Examples, Please See:}

- Appendix NN 


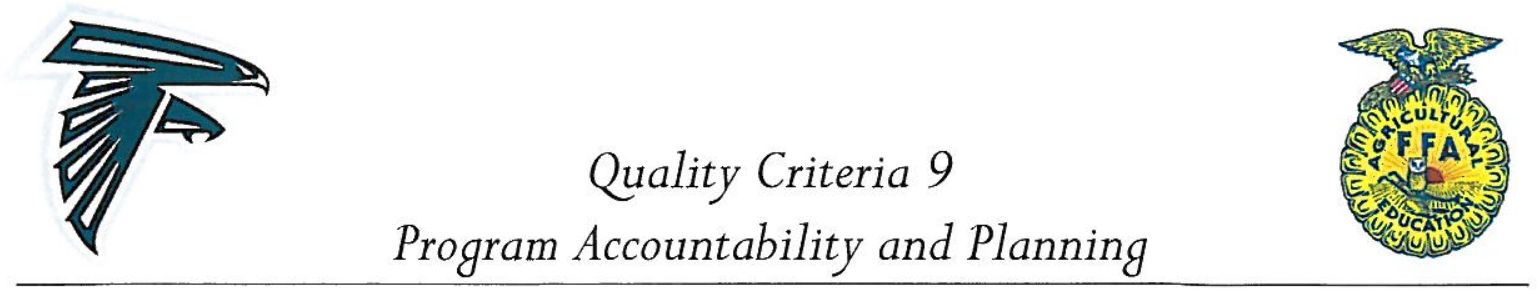

Our Comprehensive Program Plan is complete and we continually submit our proper paperwork to the Regional Supervisor on a regular basis within the due dates. We have a graduate followup system for our students. Last year we completed a Graduate follow-up survey for our ROP student, which was submitted to the Merced County ROP. This will be an annual task, with paperwork kept in department files and our Comprehensive Program Plan.

\section{Quality Criteria 9A}

A binder has been dedicated as the Comprehensive Program Plan. The Comprehensive Program Plan is update annually and the Regional Supervisor receives update every year.

\section{Quality Criteria 9B}

Updates of the Program Plan are sent to the Regional Supervisor by December $15^{\text {th }}$. These updates include: (1) Five Year Equipment Acquisition Schedule; (2) Chart of Staff Responsibilities; (3) FFA Program of Work; (4) Advisory Committee Roster; (5) Advisory Committee Minutes; and (6) Graduate Follow-up Results.

All items are up to date and sent to the Regional Supervisor.

For Examples, Please See:

- Appendix I

- Appendix $O$

- Appendix $Q$

- Appendix CC

- Appendix JJ 


\section{Quality Criteria 9C}

Each year, every graduated senior fills out a graduate follow-up survey. From the information on the survey, the students are contacted the following year to gather information and feedback. Each follow-up survey will be placed in the appropriate program completer's file within the agriculture department.

For Examples, Please See:

- Appendix $N$

- Appendix $O$

\section{Quality Criteria 9D}

The R-2 Graduate Follow-Up Data was collected and entered online by October $15^{\text {th }}$.

\section{Quality Criteria 9E}

This has been the largest focus of Atwater High School agriculture instructors for the past year. We have had an obvious growth in our program over the last three years. We have doubled in size and it is a major priority of our staff to keep the $1^{\text {st }}$ and $2^{\text {nd }}$ year students enrolled in Agriculture each year, The agriculture program has been through many changes and is finally settled in the course requirements between the agriculture program and our district requirements. Students have pathways to follow and are able to decide which courses they should enroll to stay in an agriculture path.

\section{For Examples, Please See:}

- Appendix $X$

\section{Quality Criteria $9 F$}

All reports, the R-2, Expenditure, and FFA Roster, have been submitted to the Regional Supervisor for the 2012-2013 school year. These reports are submitted annually on a timely basis to the regional supervisor and will continue in the future.

\section{For Examples, Please See:}

\section{- Appendix $X$}




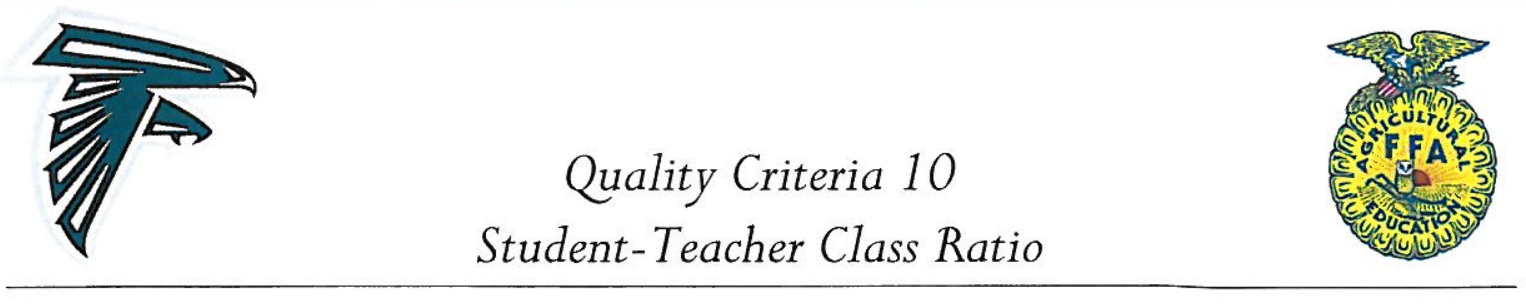

Atwater High School has an imbalance number of student-teacher ratios due to the budget cuts and not enough classes to lower the ratios within the district. Some of our classes meet this number or are close, but we also have a couple courses that do not meet the student-teacher ratio requirement for a well-established agriculture course.

As a department, our students enrolled in agriculture classes do not exceed 75 students per teacher. Also, the Atwater High School agriculture instructors do not receive a project supervision period, increasing the number of students per teacher within the year.

Our school and agriculture department continues to fight to accomplish the 20-student ratio for the shop and laboratory based classes, and also the 25 students enrolled in a standard classroom-based course. Currently, many of our classrooms size between $35-42$ students. This causes our ratios to exceed the maximum limit at this point in time. 


\section{Quality Criteria 10A}

At this point, our agriculture department does not meet these criteria. We are in the process of adjusting to our new growth. In the past four years we have grown from a staff of four full time teachers to six full time teachers. We currently have many laboratory-based courses with 10-15 students over the maximum for the 20 students per teacher ratio. All other laboratory-based courses come within 10-12 students of the 20 students per teacher requirement. As for the classroom-based courses, most courses also do not meet this requirement. With all the budget issues, we have seen our science based classes increase in class size. Most of our science based courses have between 37-40 students. However, as we wish to maintain a staff of six full time teachers we do not want to turn students away.

Classes that meet or are close to meeting Laboratory Requirements

-Wood Shop $2 / 3$ (Mr. Flatt) 18 Students

Classes that meet or are close to meeting Classroom-based Requirements

=None

For Examples, Please See:

-Appendix $X$

\section{Quality Criteria 10B}

Our ratio does not meet the 75 students per teacher at Atwater High School. Currently we have 103 students per teacher as our program is growing. This year, we have 407 students that are first year students.

We also do not have the opportunity for a project supervision period, which increases the number of students per teacher during the instruction year.

For Examples, Please See:

-Appendix $X$ 


\section{Quality Criteria 11 \\ Full Year Employment}

At Atwater High School we understand the importance of having full-time employment for the benefit of our agriculture students and their SAE projects.

Five out of the six Agriculture Instructors in the Atwater Department are on full-time contracts so that year-round activities in the agriculture program are conducted and fulfilled. Currently our instructors are not provided a project supervision period per the request of the Merced Union High School District. Each instructor receives 20\% of their salary for project supervision and SAE projects year-round. This compensation is part of our contract for year-round instruction.

\section{Quality Criteria 11A}

Five out of six of our agriculture instructors at Atwater High School are compensated 20\% of their salary, surpassing the minimum $\$ 2000$, for year-round instruction. All teachers are fulltime agriculture instructors within the school day and throughout the summers to provide adequate supervision of SAE projects.

For Examples, Please See:

- Appendix X 


\section{Quality Criteria 11B}

Atwater High School does not provide project supervision periods for its agriculture instructors due to the Merced Union High School district request. All instructors are provided a 20\% Extended Contract Stipend for their SAE project supervision during the school year and throughout the summer. This stipend is reflected in addition to the 9-month salary.

For Examples, Please See:

- Appendix $X$ 


\section{AGED 539 \\ Internship Program \\ $\underline{\text { Table of Contents }}$}

A. Student Data Sheets

B. Student Record Book

C. Course Outlines

D. Daily Grade Sheets

E. SAE Supervision Forms

F. Wall Chart of SAE Visits

G. SAE Student Summary

H. Board Approved SAE Policy

I. Program of Works

J. Board Approved FFA Policy

K. Recruitment Program

L. Chapter Scrapbook

M. Summer Activities Schedule 
N. Graduate Follow Up Survey

o. Graduate Status

P. Comprehensive Plan

Q. Advisory Committee Minutes

R. Student Program Plan

S. Proficiency Standards

T. Credentials

U. Calendar of Activities

V. Daily Logs

W. Professional Development Activities

X. $\quad R$-2 Report

Y. Extended Contract Rational

Z. Travel Plan

AA. CATA Membership

BB. Department Meeting Reports

CC. Wish List

DD. Advisory Committee Meeting Agendas 
EE. Advisory Committee Charter and By-Laws

FF. Budget Report

GG. District Allocations

HH. Districts Budget Process

II. Department Chairperson's Duties

JJ. Chart of Responsibilities

KK. Substitute Teacher Procedures and Plans

LL. Proficiency of Agriculture Students

MM. 2+2 College Articulations

NN. Reimbursements

OO. Point Awards System

PP. Chapter Goals

QQ. Permission Slip and Waiver Notice 


\section{$\underline{A}$ \\ Student Data Sheets}

Our student data sheet is devised specifically for the $R 2$ and program retention. At Atwater High School, students fill out both the hard copy of the student data sheet and an electronic forms online which places all their information into an excel document for the ease of $R 2$ entry. The online form makes it possible to enter over 860 students on the roster in a matter of a few hours. The data sheet has the students basic contact information, their future educational plans, career pathway, and four year plan. The hard copy of this information is placed in the student's file folder that is located in the filing cabinet in shop office. Each folder also contains their FFA record books and past student data sheets from that specific student.

\section{Attached you will find:}

- Student Data Sheet (2) 


\section{Atwater High School Student Data R2}

Please answer all questions to the best of your knowledge. If you have completed this survey in another $\mathrm{Ag}$ class this year, please do not fill out another one.

${ }^{*}$ Required

Last Name *

According to Atwater High School Records

First Name

According to Atwater High School Records

Street Address or P.O. Box

Example: 1234 Fruitland Ave or P.O. Box 1234

City

Example: Atwater or Winton

State

CA

\section{Zip Code}

Hint: Atwater 95301 and Winton 95388

\section{Year in Agriculture *}

Including this year how many total years have you been in an Ag class? (Ag Biology, Ag Life, Ag Earth Science, Horticulture, Floral Design, Ag Leadership, Explorations in Ag, Vet Science, small engines, all Woodshop classes, all welding classes, all shop classes count as an Ag class)

1 Year (This is my first year in an Ag Class)

2 Years

3 Years

4 Years (Addicted to Ag Classes!!! Lol)

\section{Grade Level *}

9th

10th

11th

12th 


\section{Gender * \\ Male \\ Female}

\section{Ethnicity *}

White

Black

Hispanic

Filipino

American Ind.

Asian/Pac.

0

Other:

\section{Program of Interest *}

Select the area that interests you most.

Ag Business Management

Ag Mechanics

Agriscience

Animal Science

Forestry

O.H. (Plants)

Plant/Soil Science

\section{Submit}

Powered by Google Docs

Report Abuse - Terms of Service - Additional Terms 
Last Name:

(Print your Last Name in big, clear letters)

First Name:

(Print your First Name in big, clear letters)

Address: (PO Box or Mailing Address)

City:

State:

Zip: (Atwater 95301 or Winton 95388)

Hispanic: Yes No (Check One)

Race: (Check One or more) $\square$ White $\quad \square$ Asian Indian $\quad \square$ Cambodian $\quad \square$ Chinese

\begin{tabular}{|c|c|c|}
\hline$\square$ Hmong & $\square$ Japanese & $\square$ Vietnamese \\
\hline$\square$ Black & $\square$ American Indian/Alaska Native & $\square$ Native Hawaiian/Pacific Island \\
\hline$\square$ Filipino & $\square$ Guamanian $\square$ Samoan & $\square$ Tahitian \\
\hline
\end{tabular}

Year in Ag: (Circle One) $\quad 1 \quad 2 \quad 3 \quad 4$

Grade: (Circle One) $\quad 9 \quad 10 \quad 11 \quad 12$

Gender: (Circle One) Male Female

Pathway: (Check One) $\quad \square$ Ag Business Management $\quad \square$ Ag Mechanics

$\begin{array}{ll}\square \text { Agriscience } & \square \text { Animal Science } \\ \square \text { Forestry } & \square \text { O.H. (Plants) }\end{array}$

Plant / Soil Science

\section{I am taking this course because: (Check One)}

$\square$ I plan a career in Agriculture $\quad \square$ Not a career in Agriculture $\quad \square$ Not interested, placed in class

Please indicate your plans after graduation: Pick one column and then check all that apply.

Go to Work Full-Time

_ No Further Education _Some College Later
Go to College

_Community College

_Four Year College

_Full-Time Student

_ Part-Time Student

_Agriculture Major

_Non-Agriculture Major
Go into Military 


\section{AGRICULTURAL EDUCATION - PLANNING SHEET | 2012-

Planned course of study to meet occupational goal. By school year, list all classes previously taken, currently being taken, and planned to be taken in the future.

\begin{tabular}{|c|c|c|c|}
\hline FRESHMAN YEAR & SOPHOMORE YEAR & JUNIOR YEAR & SENIOR YEAR \\
\hline$(20-)$ & $(20-)$ & $(20-\ldots)$ & $(20--)$ \\
\hline CLASS & CLASS & CLASS & CLASS \\
\hline \multirow[t]{2}{*}{ English 9} & English 10 & English 11 & English 12 \\
\hline & World Hist. & US History & Govt / Econ \\
\hline & & & \\
\hline & & & \\
\hline & & & \\
\hline & & & \\
\hline & & & \\
\hline
\end{tabular}

Supervised Agricultural Experience Project Plan (Project program should be related to career goal.)

\begin{tabular}{|c|c|c|c|c|c|c|c|}
\hline FRESHMAN YEAR & & SOPHOMORE & & JUNIOR YEAR & & SENIOR YEAR & \\
\hline SAE (Project Title) & SIZE & SAE (Project Title) & SIZE & SAE (Project Title) & SIZE & SAE (Project Title) & SIZE \\
\hline & & & & & & & \\
\hline & & & & & & & \\
\hline & & & & & & & \\
\hline
\end{tabular}

Planned Departmental Activities (List the FFA Activities you would like to or have participated in by school year.)

\begin{tabular}{|l|l|l|l|}
\hline FRESHMAN YEAR & \multicolumn{1}{l|}{ SOPHOMORE YEAR } & JUNIOR YEAR & SENIOR YEAR \\
\hline \hline & & & \\
\hline & & & \\
\hline & & & \\
\hline & & & \\
\hline & & & \\
\hline
\end{tabular}




\section{AGRICULTURAL EDUCATION - STUDENT DATA $\mid 2011$ - 2012}

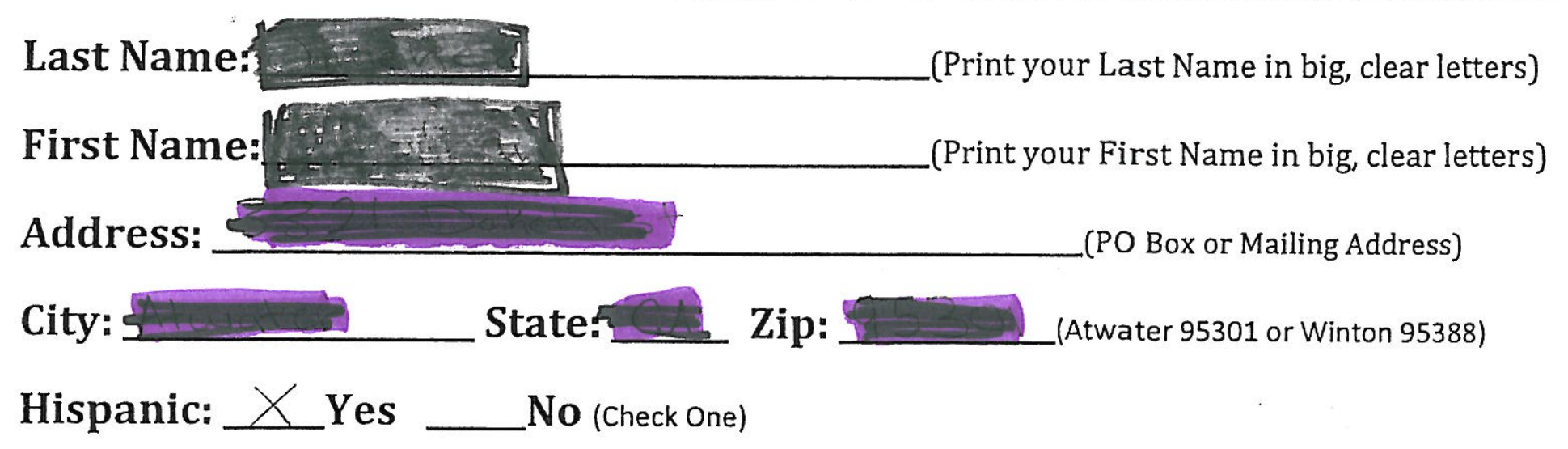

Race: (Check One or more) $-\nabla$ White $\quad \square$ Asian Indian $\quad \square$ Cambodian $\square$ Chinese

$\begin{array}{llll}\square \text { Hmong } & \square \text { Japanese } \quad \square \text { Korean } & \square \text { Laotian } & \square \text { Vietnamese } \\ \square \text { Black } & \square \text { American Indian/Alaska Native } & \square \text { Native Hawaiian/Pacific Island } \\ \square \text { Filipino } & \square \text { Guamanian } \square \text { Samoan } & \square \text { Tahitian }\end{array}$

Year in Ag: (Circle One) 1 (2) $3 \quad 4$

Grade: (Circle One) $\quad 9$ (10) 1112

Gender: (Circle One) Tale Female

Pathway: (Check One) $\square$ Ag Business Management $\quad$ Ag Mechanics

$\square$ Agriscience $\quad \square$ Animal Science

$\square$ Forestry $\square$ O.H. (Plants)

$\square$ Plant/Soil Science

\section{I am taking this course because: (Check One)}

I plan a career in Agriculture $\square$ Not a career in Agriculture $\quad \square$ Not interested, placed in class

Please indicate your plans after graduation: Pick one column and then check all that apply. Go to Work Full-Time

_No Further Education

_Some College Later

XGo to College

_Community College

XFour Year College

_Full-Time Student

X Part-Time Student

_ Agriculture Major

$\not$ Non-Agriculture Major Go into Military 


$$
\begin{array}{l|l}
\text { AGRICULTURAL EDUCATION - PLANNING SHEET } & \begin{array}{l}
2011- \\
2012
\end{array} \\
\hline
\end{array}
$$

Planned course of study to meet occupational goal. By school year, list all classes previously taken, currently being taken, and planned to be taken in the future.

FRESHMAN YEAR

$\frac{(2010-11)}{\text { CLASS }}$

\begin{tabular}{|c|}
\hline CLass \\
\hline English 9 \\
\hline Geography/Heatth \\
\hline Geometry \\
\hline Tegmen \\
\hline
\end{tabular}

Shopemils

As Biology

PE
SOPHOMORE YEAR

CLASS

English 10

World Hist.

Welding tech 1

Chemistry

Algebra 2/ trig

French 4
$(20.11-12)$

JUNIOR YEAR

$(2012-13)$

CLASS

English 11

Athletics
SENIOR YEAR

$(2013-14)$

CLASS

Supervised Agricultural Experience Project Plan (Project program should be related to career goal.).

FRESHMAN YEAR

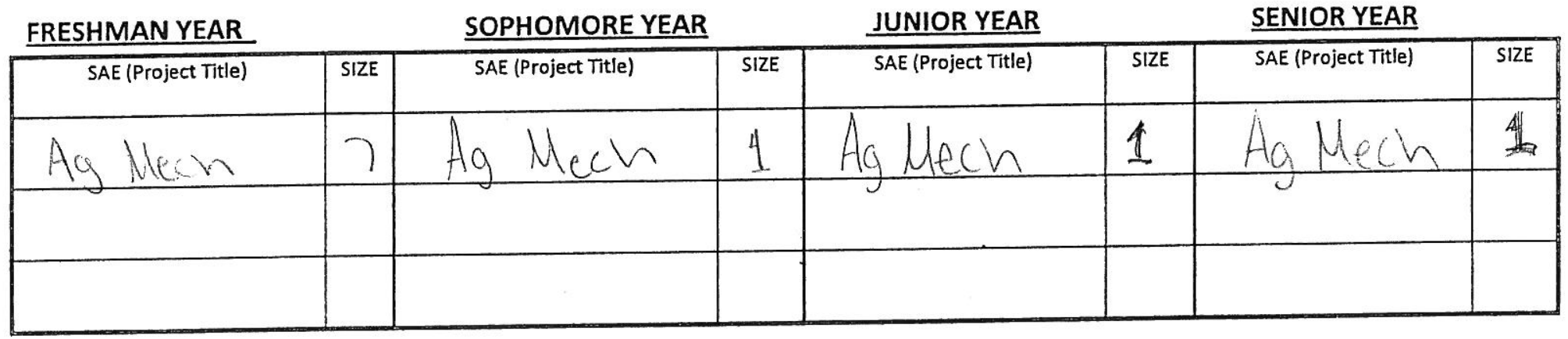

Planned Departmental Activities (List the FFA Activities you would like to or have participated in by school year.)

FRESHMAN YEAR

SOPHOMORE YEAR

JUNIOR YEAR

SENIOR YEAR

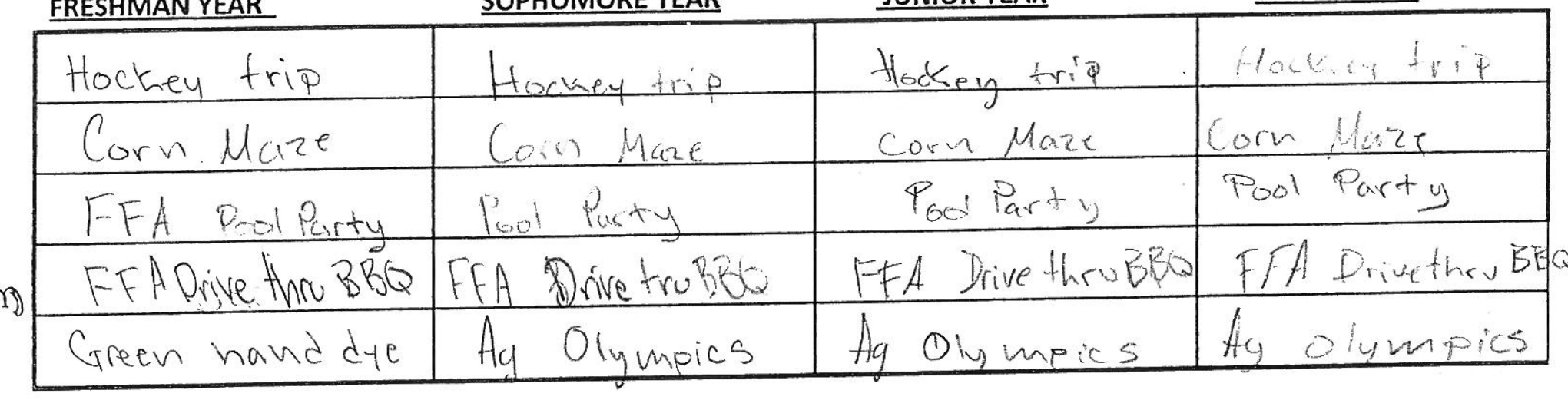


$\underline{B}$

Student Record Book

Each student is required to complete a record book each year in at least one Ag class. Students who show animals, applying for their state degree or American degree complete their record books electronically. Electronic record books are kept in a file on the school data bases and are organized by first and last name. Students that complete the paper record books are kept in their student file folders in a filing cabinet in the shop office. These file folders also contain the R-2 student data sheets.

Attached you will find:

- Student Record Book - Completed 


\section{CALIFORNIA AGRICULTURAL EDUCATION RECORD BOOK}

Name:

School:

Atwater High

Chapter:

Atwater

Year in Agriculture: 3

Beginning Date: $\quad \underline{01 / 01 / 12}$

Months: 12

Ending Date:

$12 / 31 / 12$

Instructor(s):

Flatt, Gossman, loimo, Kirschner,

Knapp, and Meredith.
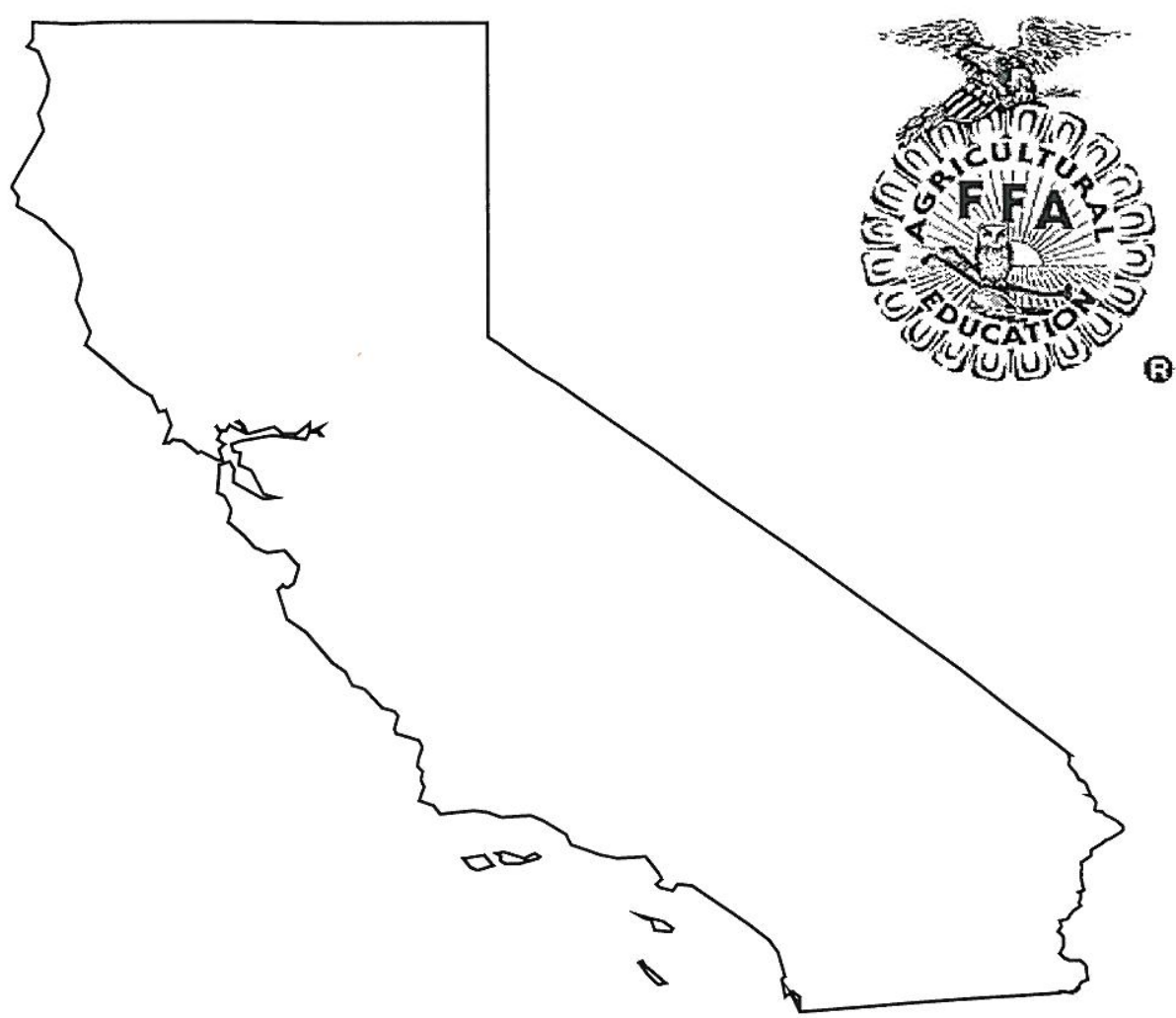

Revised: $12 / 1 / 2010$ 


\section{CALIFORNIA AGRICULTURAL EDUCATION RECORD BOOK}

\section{Contents}

Calendar of Events and Operations

Ownership Enterprise Agreements

Placement Enterprise Agreements

Budget

Journal

Enterprise Loan Payment Summary

Enterprise Accounts Receivable

Enterprise Accounts Payable

Current/Operating Inventory (Non-Depreciable Property Inventory)

Non-Current/Capital Operating Inventory (Non-Depreciable Property Inventory)

Non-Current/Capital Depreciable Inventory (Depreciable Property Inventory)

Financial Statement

Income Summary

Contribution to Family Support

Educational Expenses

FFA Activities

Community Service and School Activities

Weights and Measures

General Information 


\section{CALIFORNIA AGRICULTURAL EDUCATION RECORD BOOK}

Contains Information for the Following Enterprises:

Type

(A) Market Lamb

Ownership

(B) Floral Design

Paid Placement

(C)

(D) 
$\frac{\pi}{0}$
0
$\frac{\pi}{2}$
$\frac{\pi}{2}$

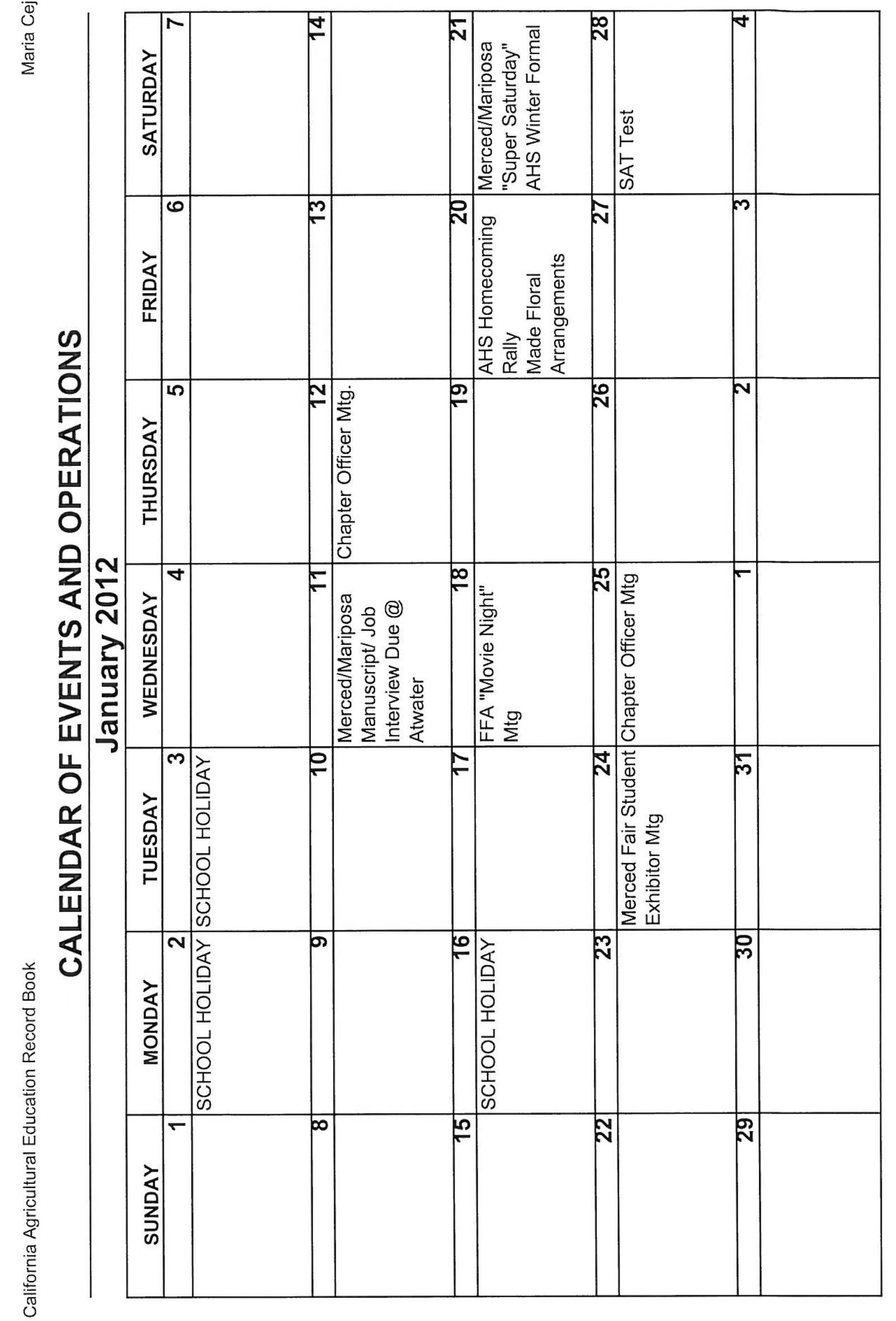

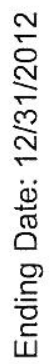




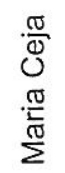

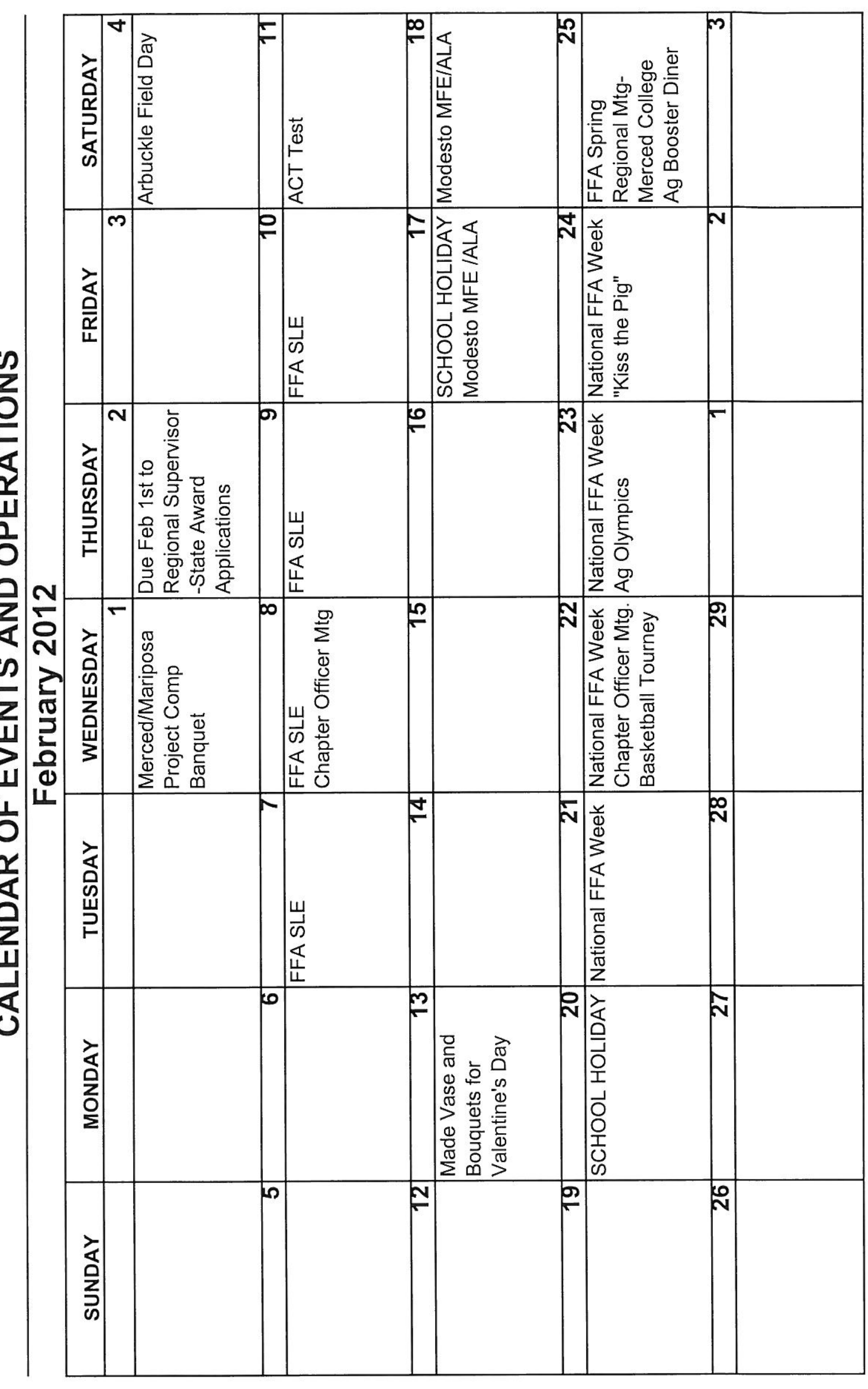

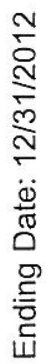


$\frac{\pi}{d}$
0
$\frac{\pi}{2}$
$\frac{\pi}{2}$

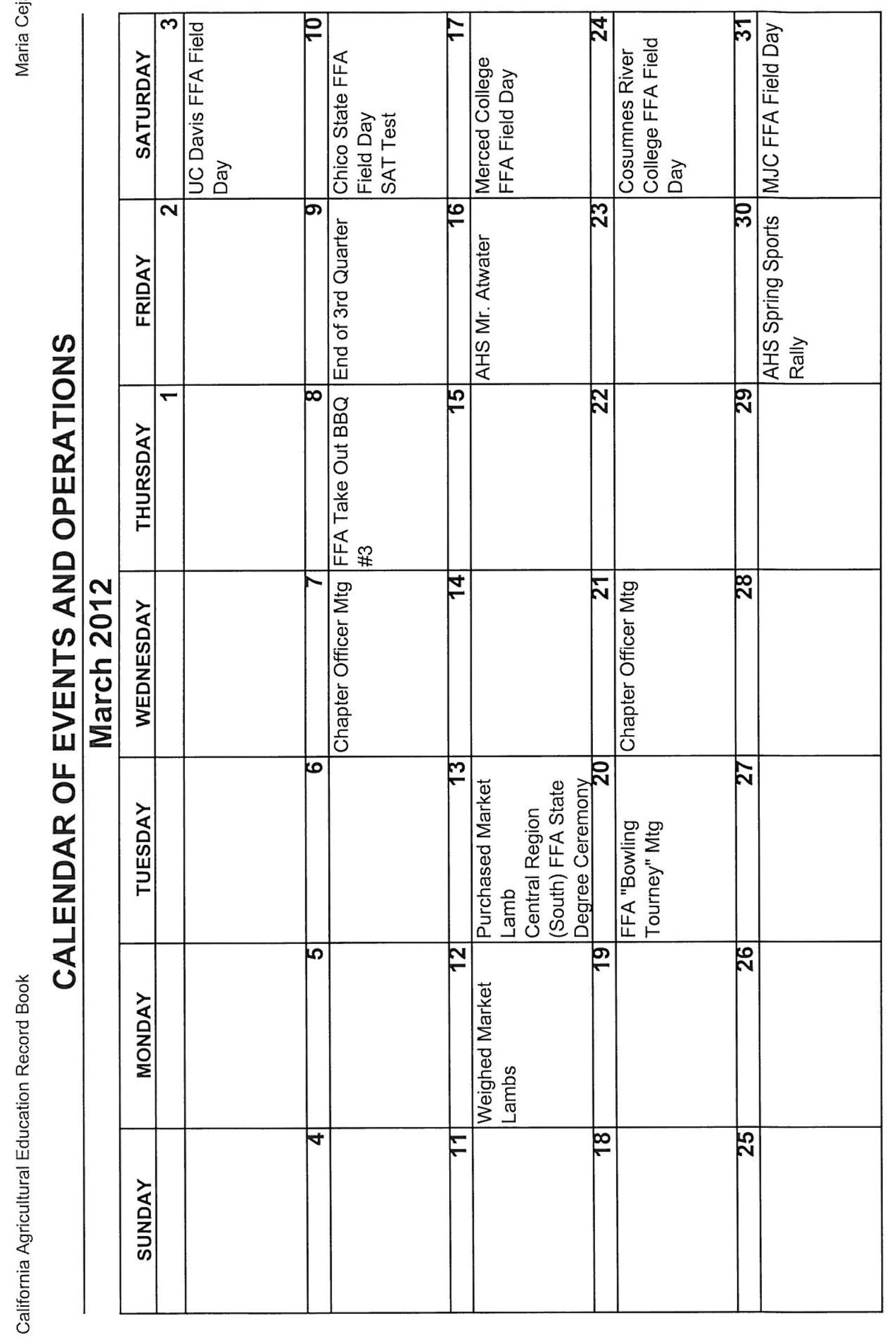

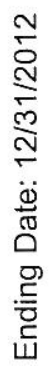


$\frac{\pi}{10}$
0
$\frac{\pi}{2}$
$\frac{\pi}{2}$

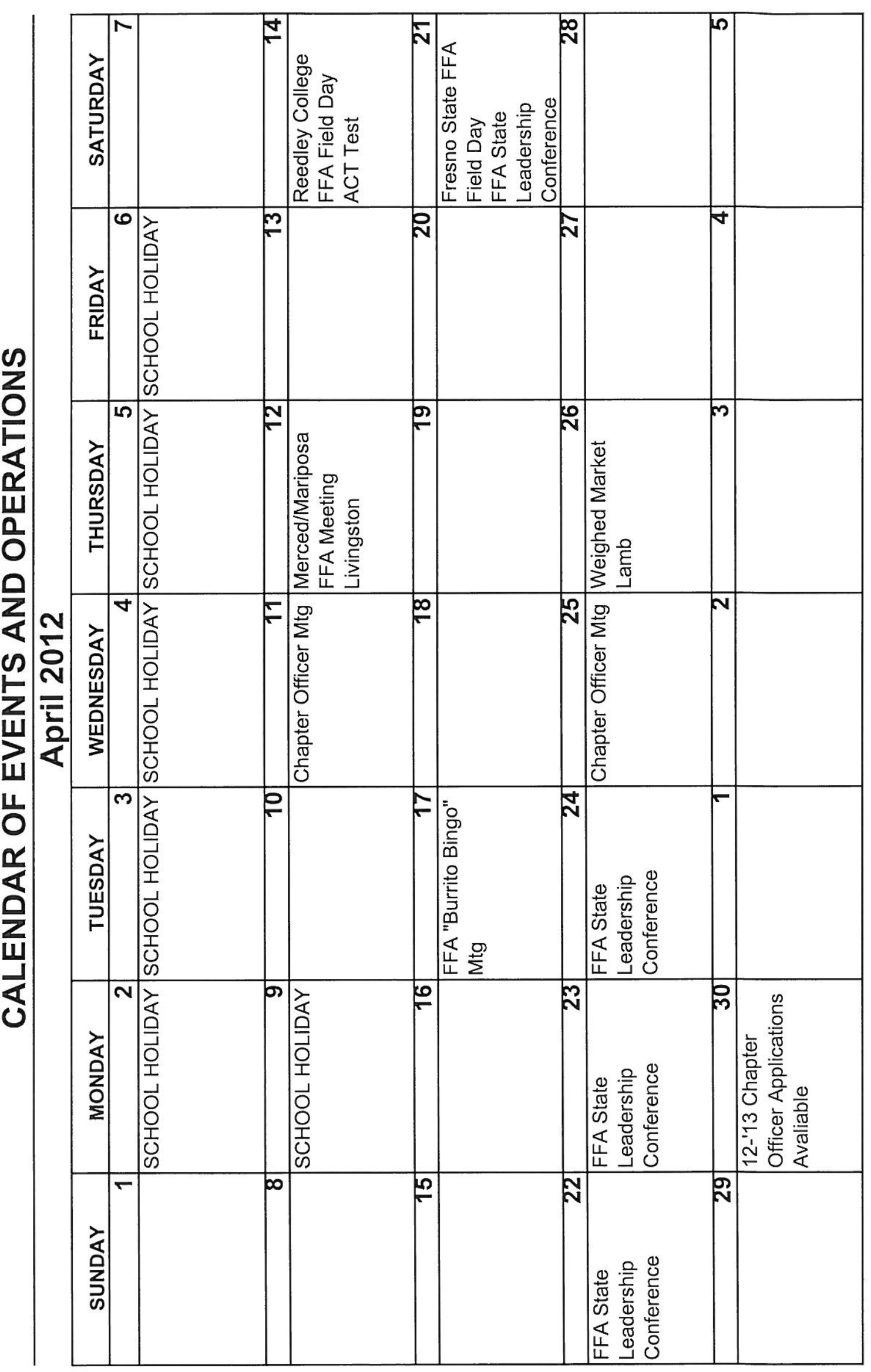

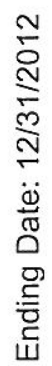


$\frac{\pi}{8}$
0
$\frac{\pi}{2}$
$\frac{\pi}{2}$

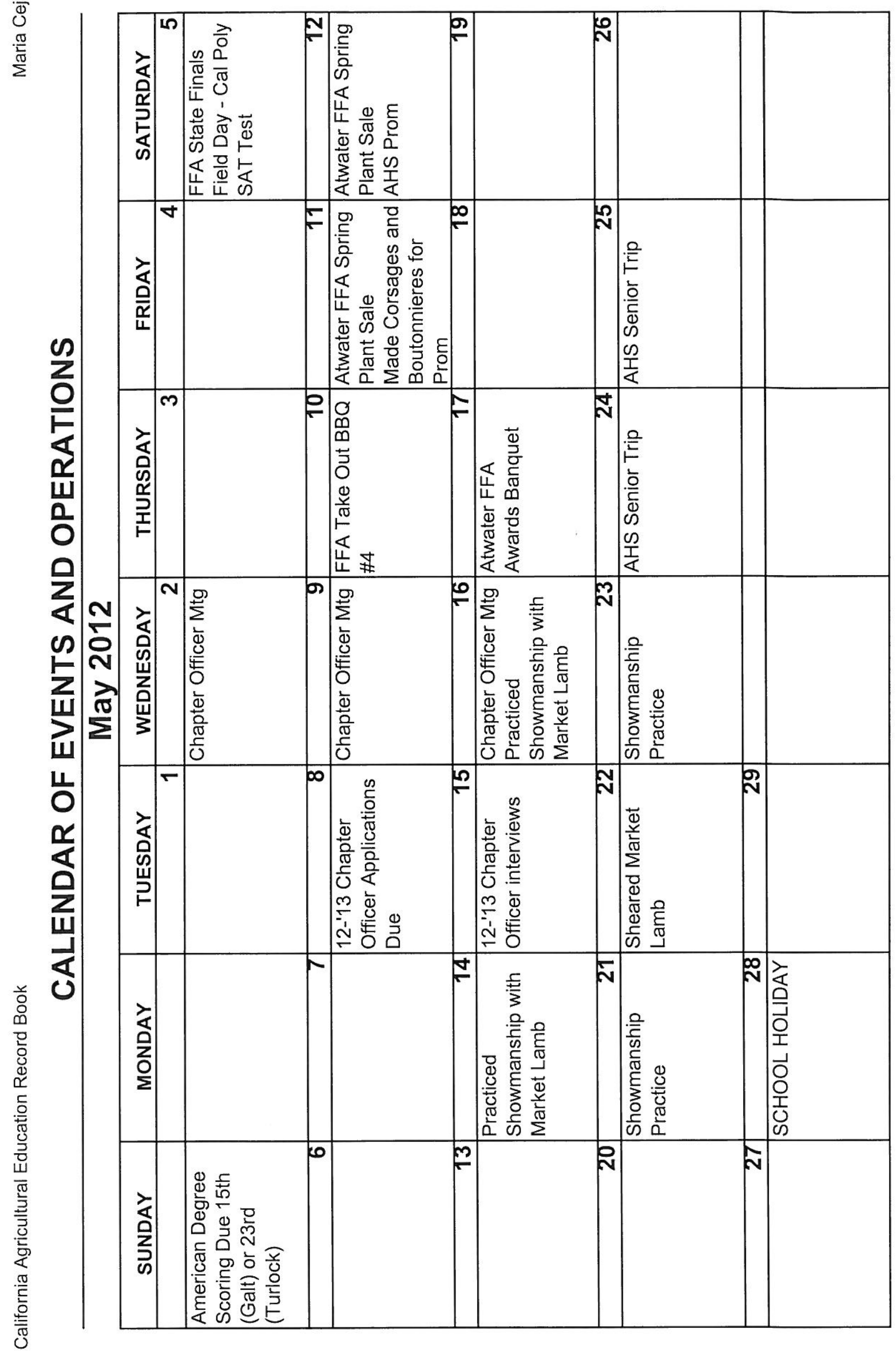

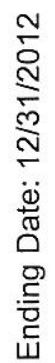


$\frac{\pi}{d}$
0
$\frac{\pi}{2}$
$\frac{\pi}{2}$

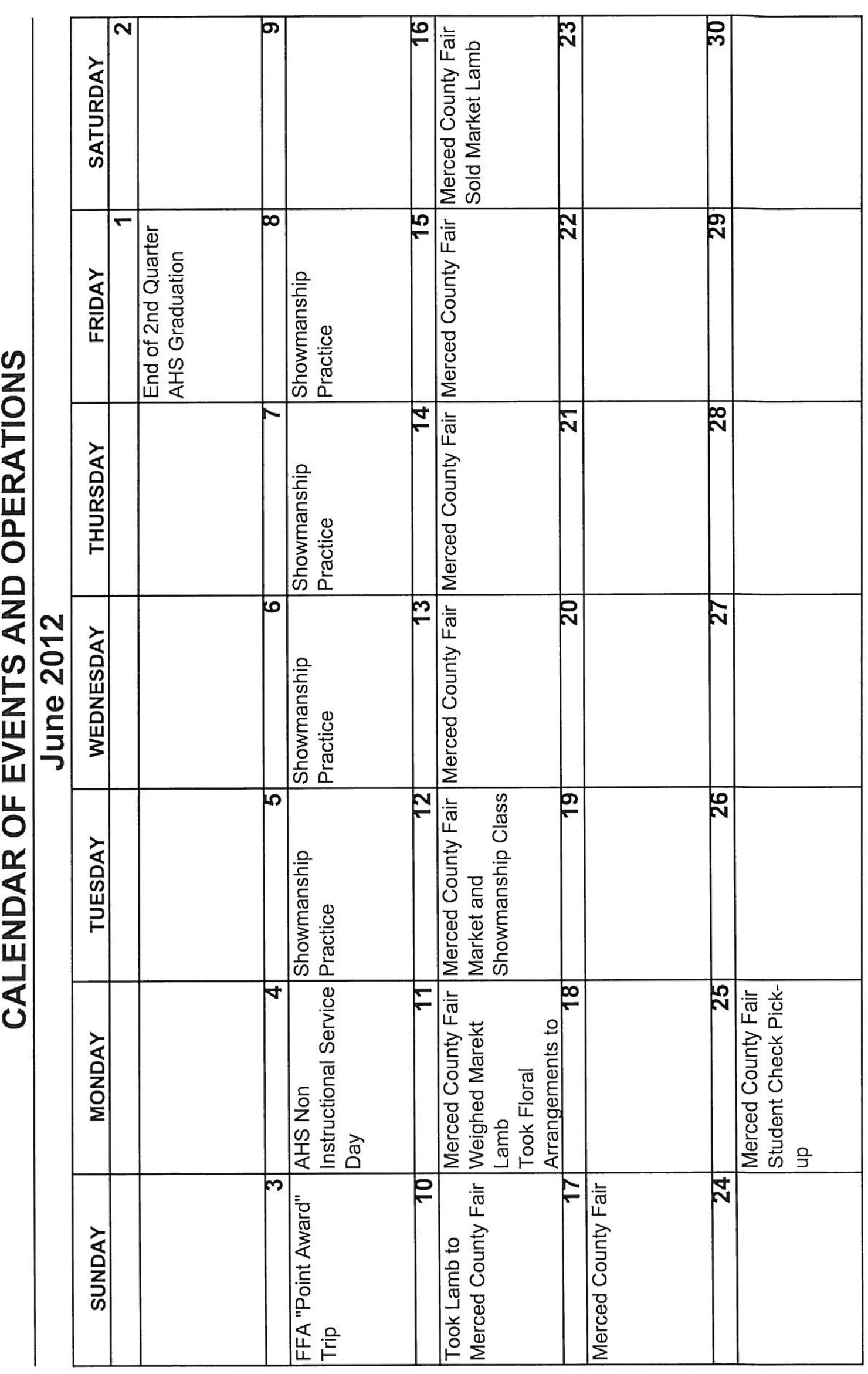

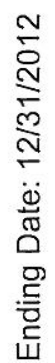


$\frac{\pi}{9}$
$\frac{\pi}{\frac{\pi}{2}}$
$\frac{\pi}{2}$

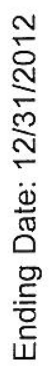

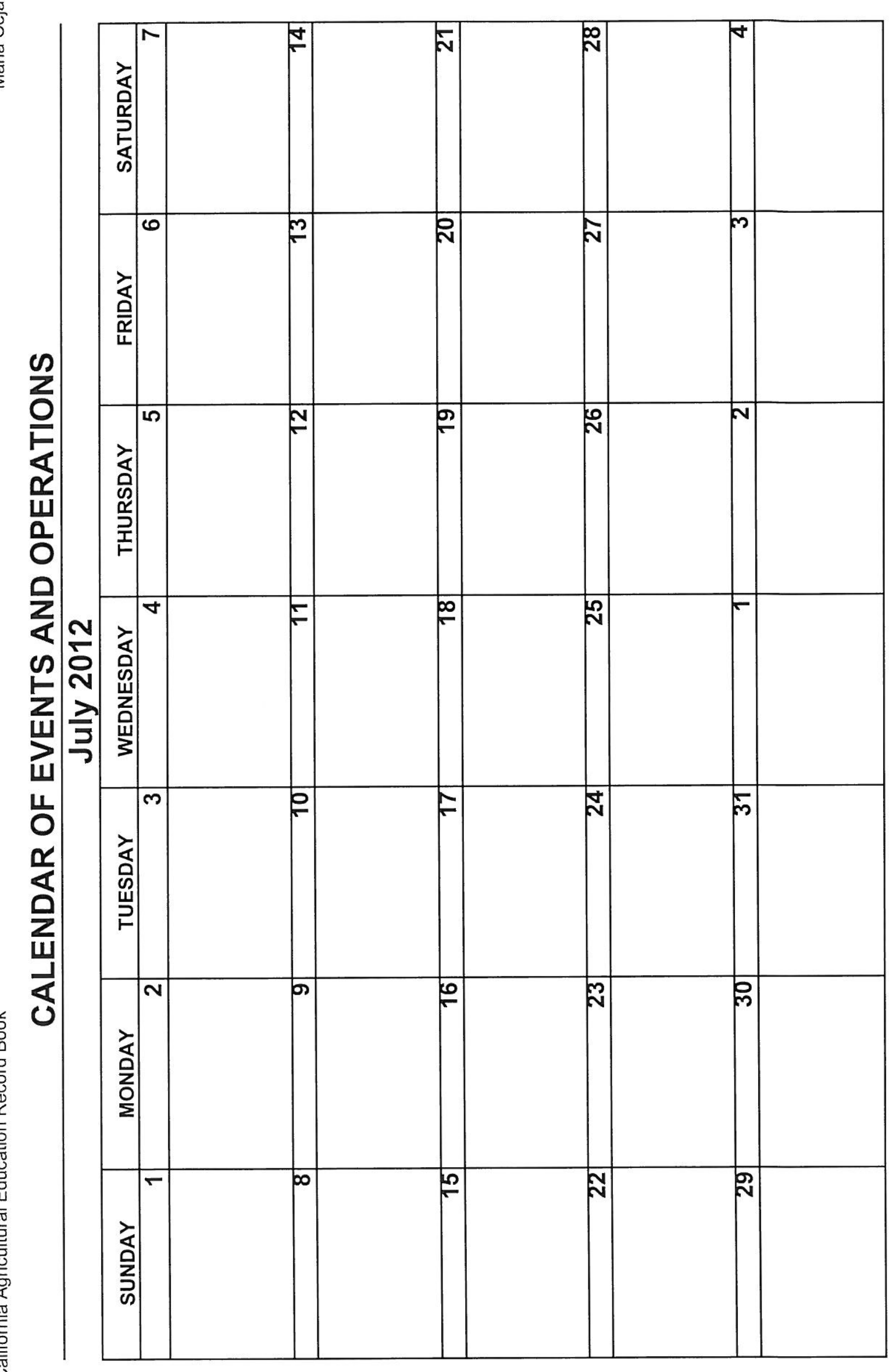


$\frac{\pi}{0}$
$\frac{0}{2}$
$\frac{\pi}{2}$
$\sum^{\frac{\pi}{2}}$

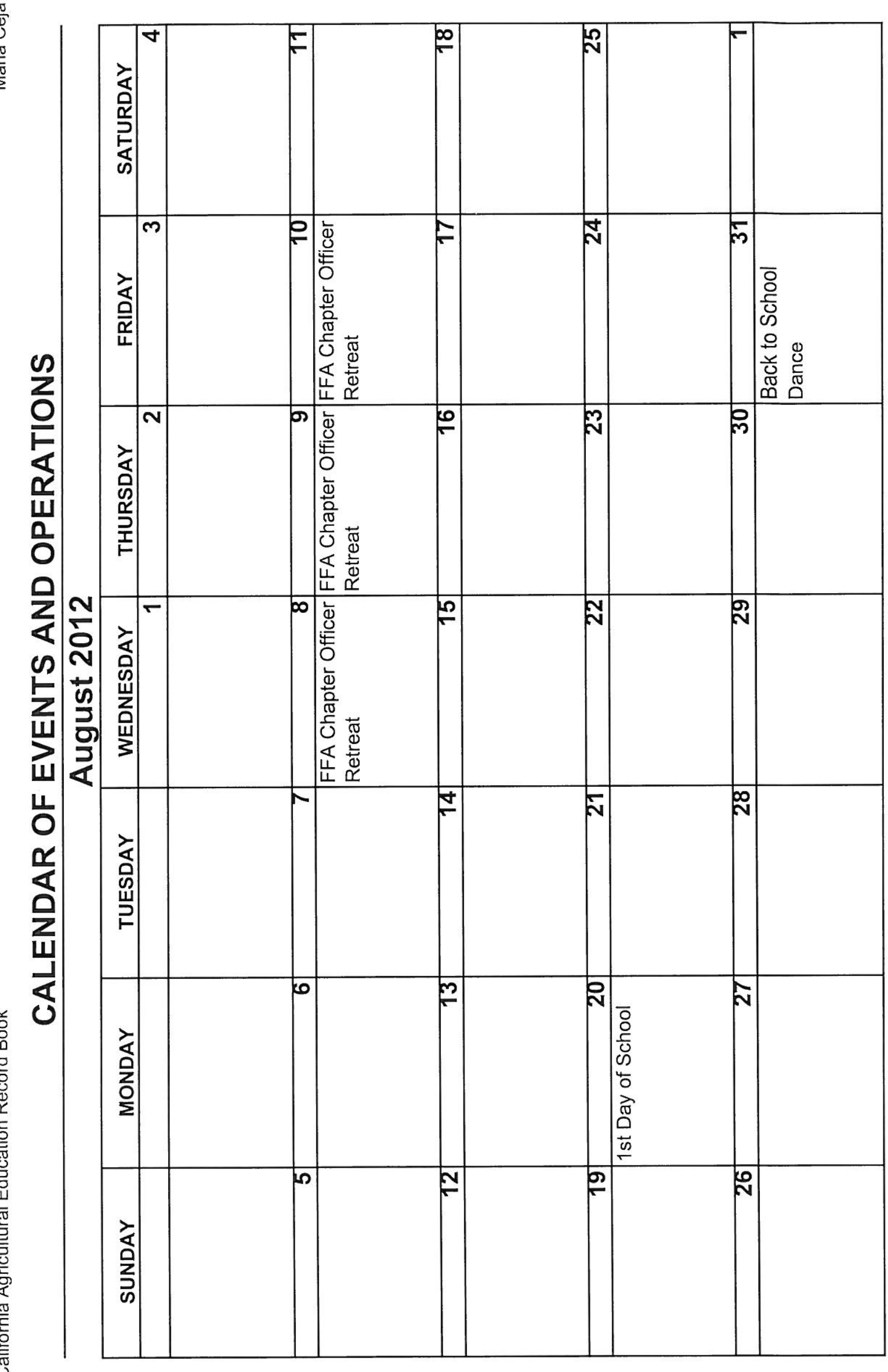


\begin{tabular}{l}
$\frac{\pi}{8}$ \\
0 \\
$\frac{\pi}{2}$ \\
$\frac{\pi}{2}$ \\
\hline
\end{tabular}

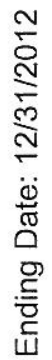
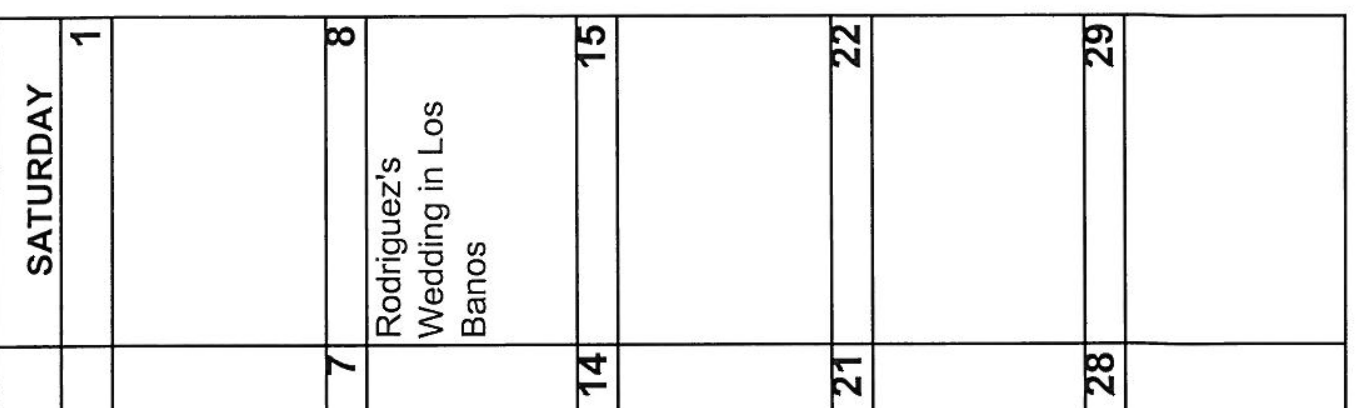



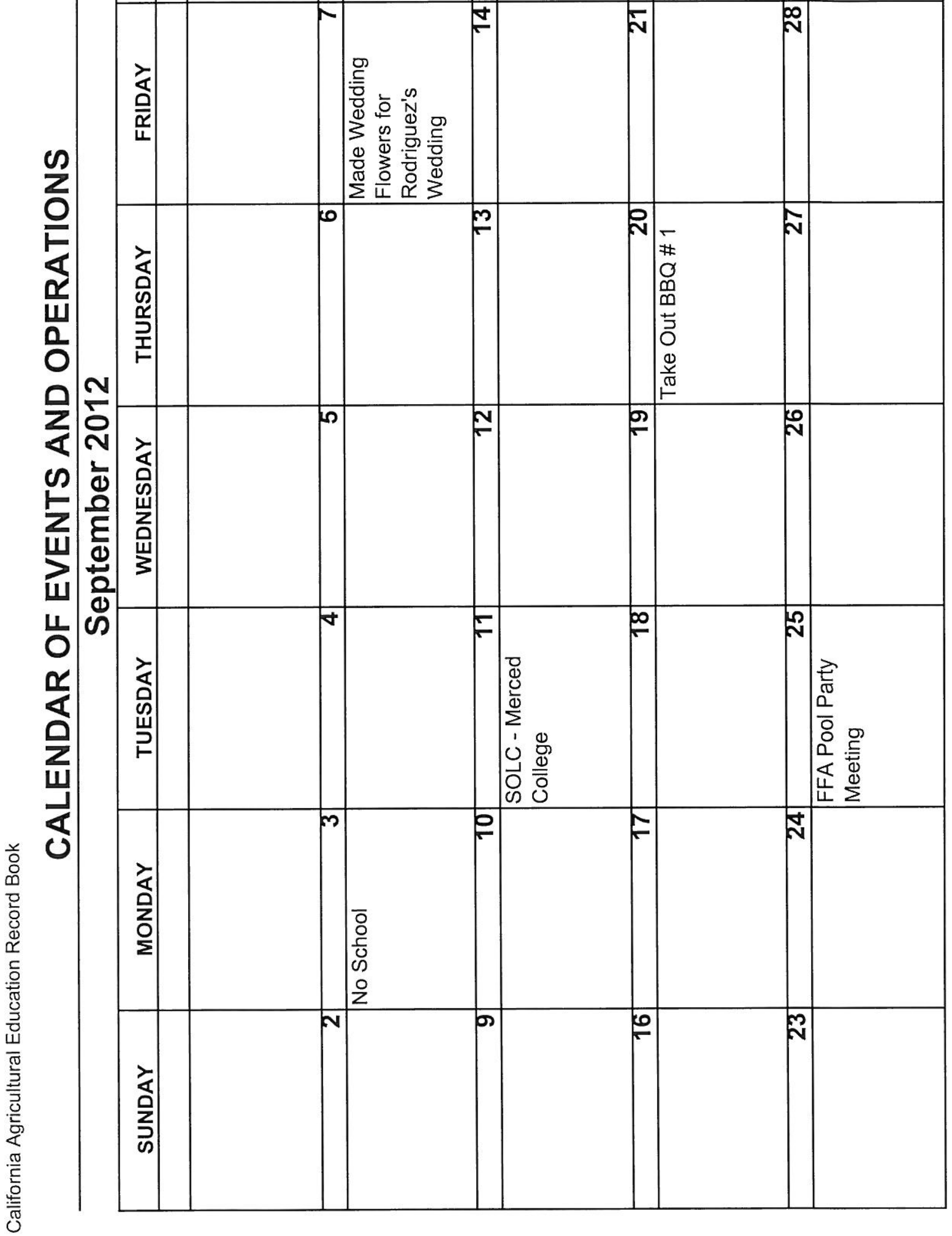


$\frac{\pi}{10}$
0
$\frac{\pi}{\frac{\pi}{6}}$
$\sum$

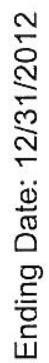
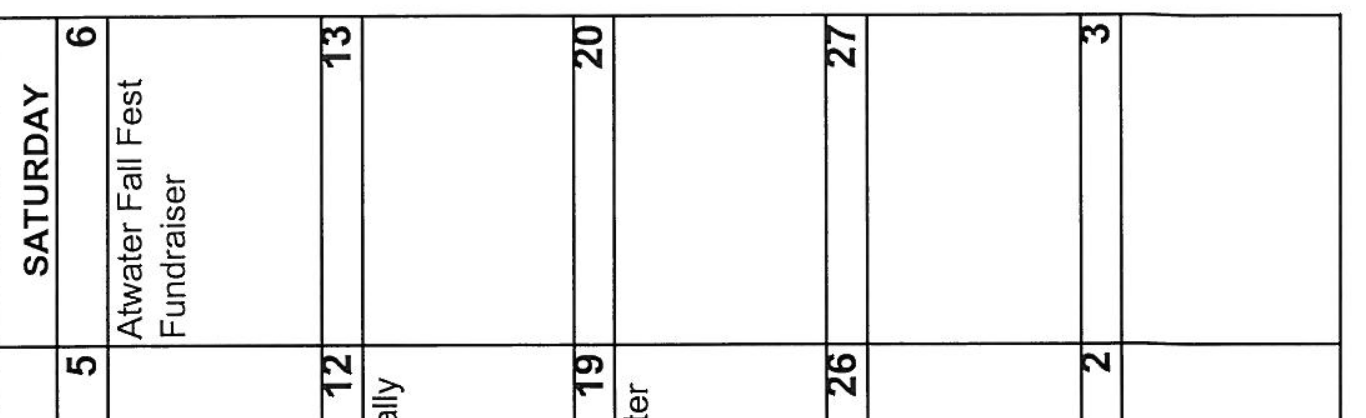

ن

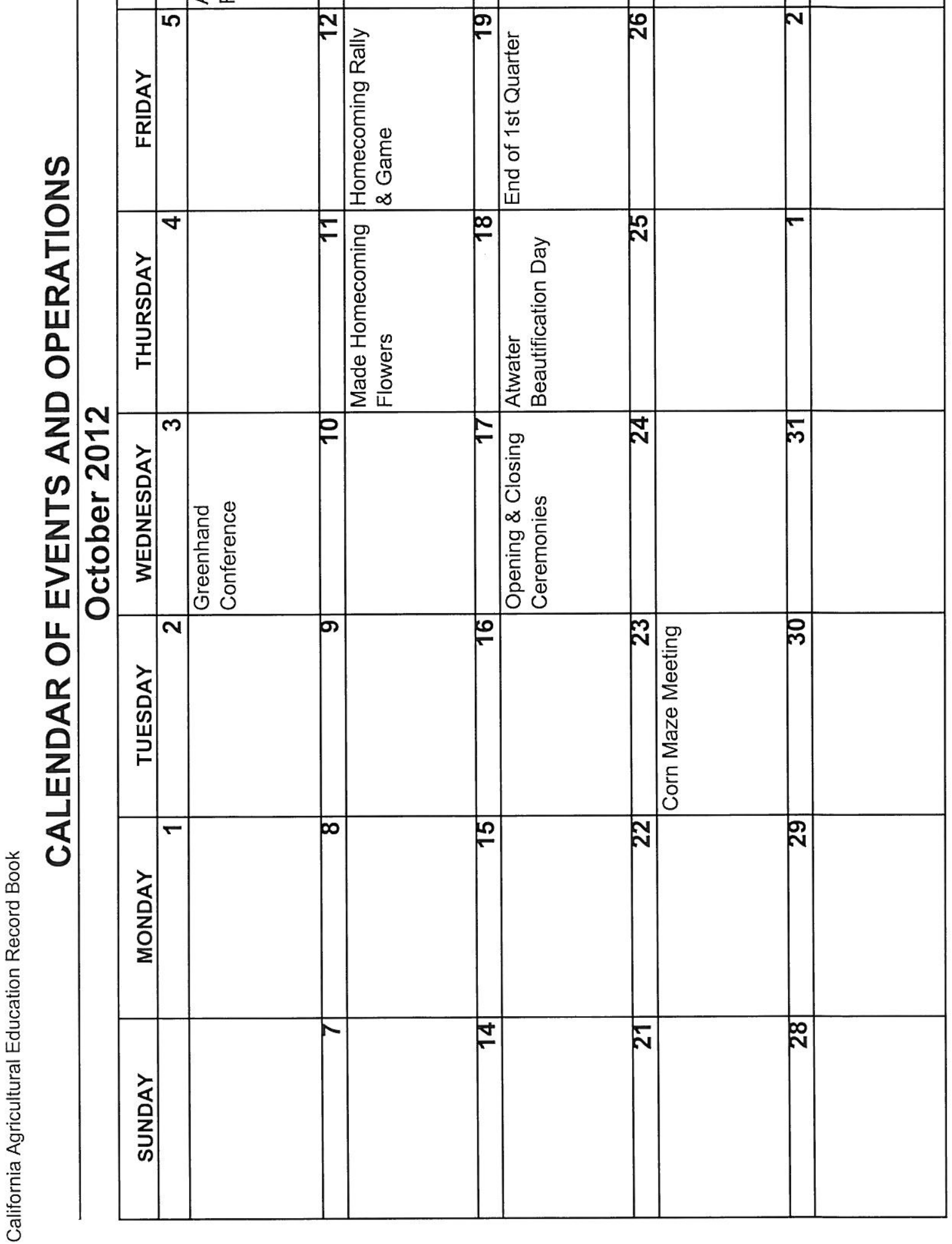


$\frac{\pi}{8}$
0
$\frac{\pi}{\frac{\pi}{2}}$
$\sum$

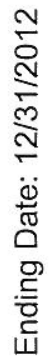

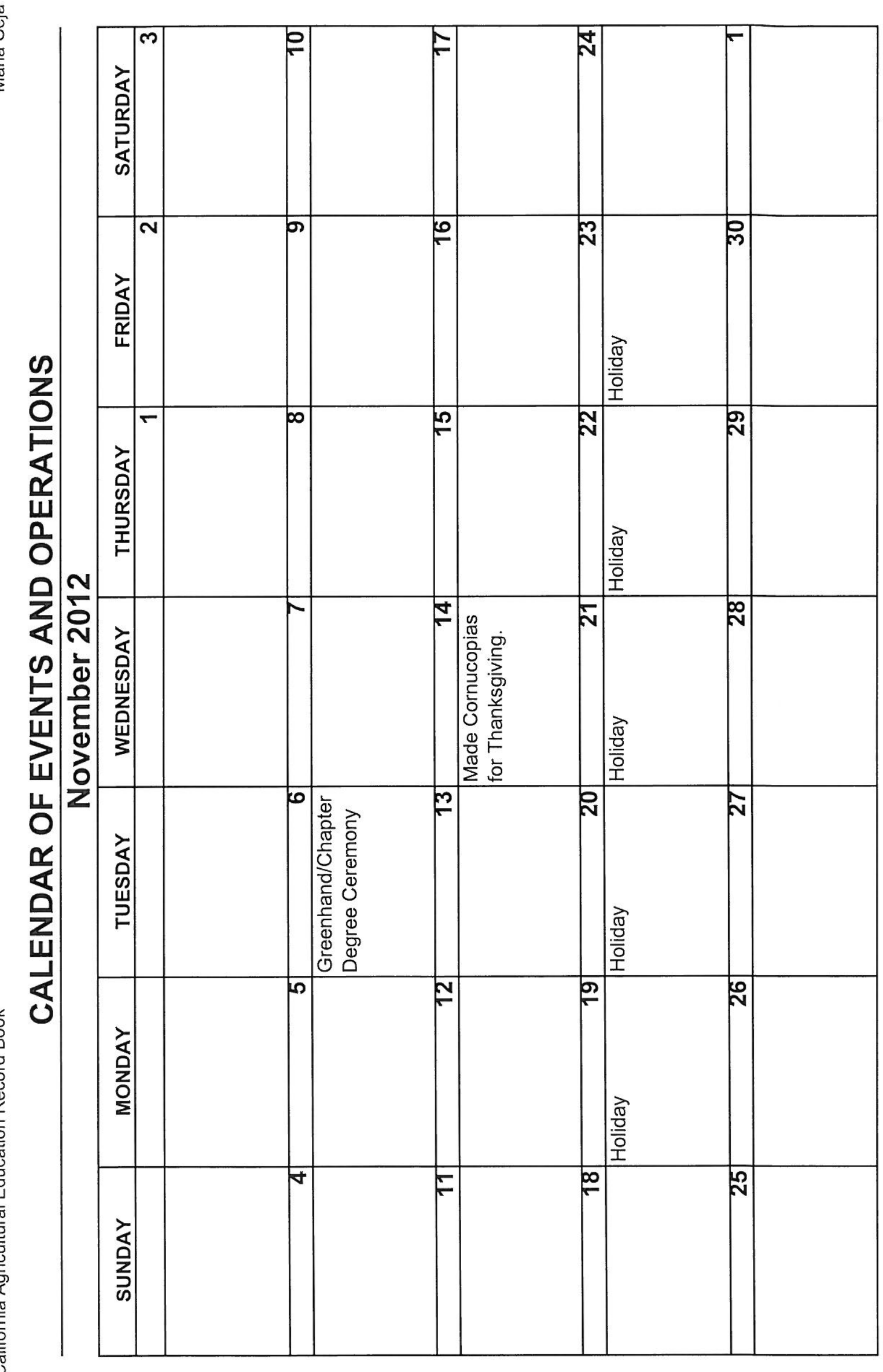


$\frac{\pi}{0}$
0
$\frac{0}{\frac{\pi}{\pi}}$
$\Sigma$

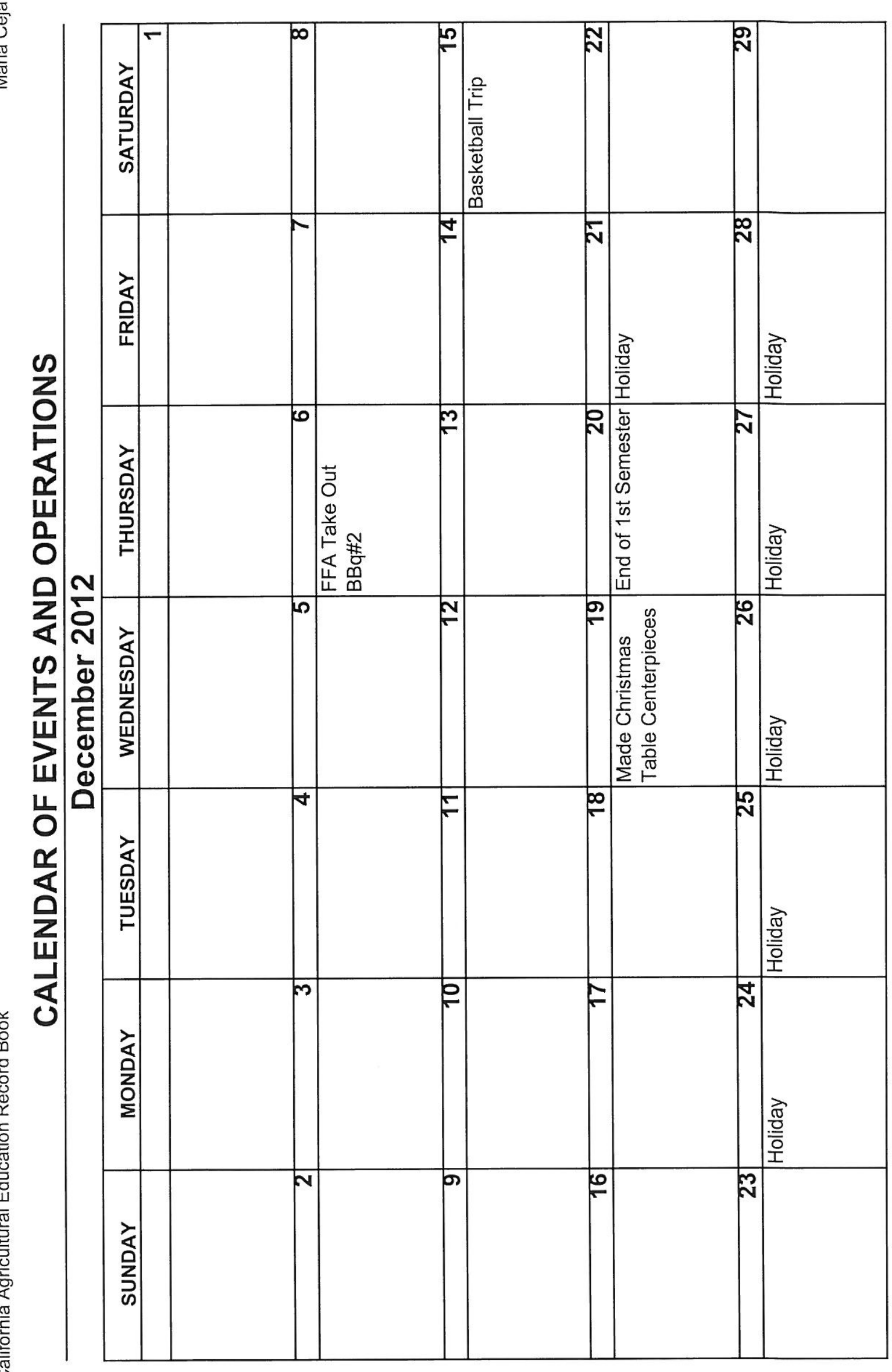

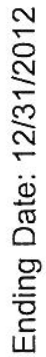




\section{OWNERSHIP ENTERPRISE AGREEMENT}

(Each enterprise requires a separate agreement)

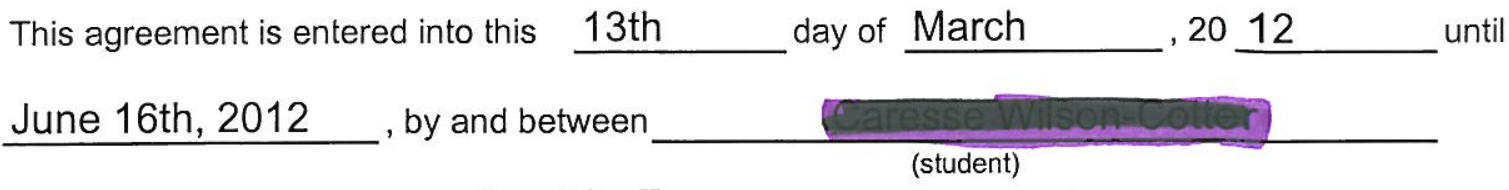

and

Arnold's Farm and covers the student's enterprise in:

(Other Party)

Market Lamb

(Name of Enterprise)

This agreement must contain statements concerning what each party is responsible to provide and/or benefits he/she will receive. Items that must be addressed are: equipment, land, buildings, capital (money), management, and profit or loss.

Please use complete sentences and be specific with details.

will work with the FFA advisor, Ms. loimo, to locate a quality lamb to be purchased at least sixty days prior to the Merced County Fair. purchase insurance for the lamb. Once the lamb has been purchased, it will be kept at the Arnold's Farm. will maintain the pens and shelter that will serve as the home of the lamb. Mr. Arnold will provide free of charge: shelter, lamb pen, electricity, and maintenance equipment. Mr. Arnold also agrees to provide access to clean water and an automatic waterer at no charge. aressure with the assistance from the FFA advisor, will make decisions relative to the lamb project. faressentison-Cotten will determine and cover the costs for feed, medicine, entry fees, grooming supplies, and show equipment. Mr. Arnold will provide the scale to

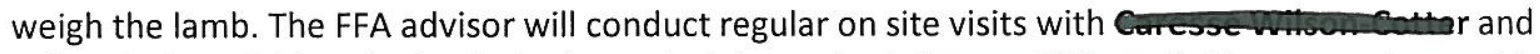

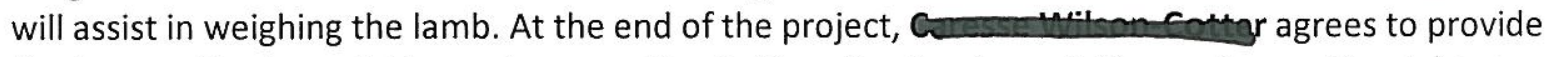
the buyer a thank you letter and a record book. Once the thank-you letter and record book have

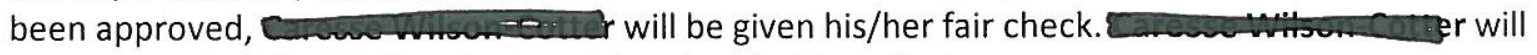
receive $100 \%$ of the profit or loss associated with this project.

Signatures

of Parties

Involved 


\section{PLACEMENT ENTERPRISE AGREEMENT}

(Paid and Unpaid Work Experience)

1 To provide a basis of understanding and to promote sound business relationships, this written agreement is established on January 1,2012 This work/training will start on January 1,2012 and will end on or about December 31, 2012 unless the arrangement becomes unstisfactory to either party. Atwater FFA Floral Department

3 Person (employer/trainer) responsible for training: Ms. loimo Wages: $\quad 30 \%$ of the Retail Cos $\quad$ Frequency of Payment One week after the event

5 Agricultural Job Skills to be Performed:

The student needs to perform the basic skills in floral arranging such as bow making, wiring and taping, floral ID, tool ID, and floral care. The student also needs to be able to create the basic floral designs such as: round arrangements, symmetrical arrangements, vase arrangements, corsages, boutonnieres, presentation bouquets and modern style table centerpieces.

6 IT IS UNDERSTOOD THAT THE EMPLOYER WILL:

The Atwater FFA Floral Department will provide the student with the proper materials, supplies and facility to create and construct arrangements. Atwater FFA will pay for the supplies, flowers, and materials that go into the arrangements and will provide the cooler to store the flowers. Atwater FFA will purchase the necessary supplies and equipment to cover the initial costs/investment of the project. The Atwater FFA will provide free of charge: floral cooler, floral materials, floral supplies and flowers / foliage. Atwater FFA will pay Caresse $30 \%$ of the retail costs one week after the event has occurred.

\section{THE STUDENT AGREES TO:}

Student will design, create and construct arrangements for various events held throughout the school year. Student will create arrangements for weddings, school dances, community events, and funerals. Student agrees to create floral arrangements such as corsages, boutonnieres, table centerpieces, presentation bouquets, wedding bouquets, and vase arrangements. 


\section{BUDGET}

The budget is your best estimate of income and expenses to determine net income. The budget is to be completed before the start of the enterprise.

All numerical entries should be rounded to the nearest whole dollar. Do not record decimal or cents.

\begin{tabular}{|c|l|r|r|l|l|}
\hline \multirow{2}{*}{ ESTIMATED EXPENSES } & \multicolumn{3}{c|}{ Enterprise } & \\
\cline { 2 - 6 } & \multicolumn{2}{|c|}{ Market Lamb } & Floral Design & & \\
\hline 1 & Market Lamb & 240 & & & \\
\hline 2 & Feed & 70 & & & \\
\hline 3 & Insurance & 11 & & & \\
\hline 4 & Show Supplies & 20 & & & \\
\hline 5 & Buyers Gift & & & & \\
\hline 6 & & & & & \\
\hline 7 & & & & & \\
\hline 8 & & & & & \\
\hline 9 & & & & & \\
\hline 10 & & & & & \\
\hline 11 & & & & & \\
\hline 12 & & & & & \\
\hline 13 & & & & & \\
\hline 14 & & & & & \\
\hline 15 & & & & & \\
\hline 16 & & & & & \\
\hline 17 & & & & & \\
\hline 18 & & & & & \\
\hline 19 & & & & & \\
\hline 20 & & & & & \\
\hline 21 & & & & & \\
\hline
\end{tabular}

\begin{tabular}{|c|c|c|c|c|c|}
\hline \multirow{2}{*}{\multicolumn{2}{|c|}{ ESTIMATED INCOME }} & \multirow{3}{*}{$\begin{array}{r}\text { Market Lamb } \\
390 \\
\end{array}$} & \multirow{3}{*}{$\begin{array}{r}\text { Floral Design } \\
300 \\
\end{array}$} & & \multirow{3}{*}{ 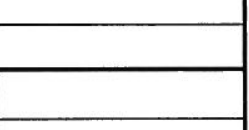 } \\
\hline & & & & & \\
\hline 22 & Market Lamb (130 lbs. @ 3.50/lb) & & & & \\
\hline \multicolumn{6}{|l|}{23} \\
\hline \multicolumn{6}{|l|}{24} \\
\hline \multicolumn{6}{|l|}{25} \\
\hline \multicolumn{6}{|l|}{26} \\
\hline \multicolumn{6}{|l|}{27} \\
\hline \multicolumn{6}{|l|}{28} \\
\hline \multicolumn{6}{|l|}{29} \\
\hline 30 & Total Income & 390 & 300 & 0 & 0 \\
\hline 31 & Total Expenses & 356 & 0 & 0 & 0 \\
\hline 32 & Net Income & 34 & 300 & 0 & 0 \\
\hline
\end{tabular}




\section{JOURNAL}

January 2012

\begin{tabular}{|c|c|c|c|c|c|c|c|}
\hline & & & Un & & & & (7) \\
\hline & & & & & & Expenses & Self \\
\hline & & & (3) No. & $\begin{array}{c}\text { (4) } \\
\text { Price }\end{array}$ & & & \\
\hline 1 & 20 & Made Winter Formal Corsa & onerres & & 60.00 & & 12 \\
\hline 2 & & & & & & & \\
\hline 3 & & & & & & & \\
\hline 4 & & & & & & & \\
\hline 5 & & & & & & & \\
\hline 6 & & & & & & & \\
\hline 7 & & & & & & & \\
\hline 8 & & & & & & & \\
\hline 9 & & & & & & & \\
\hline 10 & & & & & & & \\
\hline 11 & & & & & & & \\
\hline 12 & & & & & & & \\
\hline 13 & & & & & & & \\
\hline 14 & & & & & & & \\
\hline 15 & & & & & & & \\
\hline 16 & & & & & & & \\
\hline 17 & & & & & & & \\
\hline 18 & & & & & & & \\
\hline 19 & & & & & & & \\
\hline 20 & & & & & & & \\
\hline 21 & & & & & & & \\
\hline 22 & & & & & & & \\
\hline 23 & & & & & & & \\
\hline 24 & & & & & & & \\
\hline 25 & & & & & & & \\
\hline 26 & & & & & & & \\
\hline 27 & Total fo & page & & & 60.00 & 0.00 & 12 \\
\hline 28 & & & & & & & \\
\hline 29 & Total to & date & & & 60.00 & 0.00 & 12 \\
\hline
\end{tabular}


JOURNAL (continued)

January 2012

\begin{tabular}{|c|c|c|c|c|c|c|c|c|c|c|c|c|c|}
\hline \multicolumn{3}{|c|}{ Enterprise } & \multicolumn{3}{|c|}{ Enterprise } & \multicolumn{3}{|c|}{ Enterprise } & \multicolumn{3}{|c|}{ Enterprise } & & \\
\hline \multicolumn{3}{|c|}{ Market Lamb } & \multicolumn{3}{|c|}{ Floral Design } & & & & & & & \multirow{3}{*}{\multicolumn{2}{|c|}{$\begin{array}{l}\text { (E) }(11) \\
\text { Unpd. } \\
\text { Hours }\end{array}$}} \\
\hline (8) & (9) & (10) & (8) & (9) & (10) & (8) & (9) & (10) & (8) & (9) & (10) & & \\
\hline \multirow[t]{27}{*}{ Income } & Expenses & Hours & Income & Expenses & Hours & Income & Expenses & Hours & Income & Expenses & Hours & & \\
\hline & & & 60.00 & & 12 & & & & & & & & 1 \\
\hline & & & & & & & & & & & & & 2 \\
\hline & & & & & & & & & & & & & 3 \\
\hline & & & & & & & & & & & & & 4 \\
\hline & & & & & & & & & & & & & 5 \\
\hline & & & & & & & & & & & & & 6 \\
\hline & & & & & & & & & & & & & 7 \\
\hline & & & & & & & & & & & & & 8 \\
\hline & & & & & & & & & & & & & 9 \\
\hline & & & & & & & & & & & & & 10 \\
\hline & & & & & & & & & & & & & 11 \\
\hline & & & & & & & & & & & & & 12 \\
\hline & & & & & & & & & & & & & 13 \\
\hline & & & & & & & & & & & & & 14 \\
\hline & & & & & & & & & & & & & 15 \\
\hline & & & & & & & & & & & & & 16 \\
\hline & & & & & & & & & & & & & 17 \\
\hline & & & & & & & & & & & & & 18 \\
\hline & & & & & & & & & & & & & 19 \\
\hline & & & & & & & & & & & & & 20 \\
\hline & & & & & & & & & & & & & 21 \\
\hline & & & & & & & & & & & & & 22 \\
\hline & & & & & & & & & & & & & 23 \\
\hline & & & & & & & & & & & & & 24 \\
\hline & & & & & & & & & & & & & 25 \\
\hline & & & & & & & & & & & & & 26 \\
\hline 0.00 & 0.00 & 0 & 60.00 & 0.00 & 12 & 0.00 & 0.00 & 0 & 0.00 & 0.00 & 0 & 0 & 27 \\
\hline & & & & & & & & & & & & & 28 \\
\hline 0.00 & 0.00 & 0 & 60.00 & 0.00 & 12 & 0.00 & 0.00 & 0 & 0.00 & 0.00 & 0 & 0 & 29 \\
\hline
\end{tabular}

(Optional - expenses breakdown)

Total Feed

Total Other Cash 


\section{JOURNAL}

February 2012

\begin{tabular}{|c|c|c|c|c|c|c|c|}
\hline & & & Uni & & & & (7) \\
\hline & Date & & & & Income & Expenses & Self \\
\hline & & & (3) No. & $\begin{array}{c}(4) \\
\text { Price }\end{array}$ & & & \\
\hline 1 & 2 & Made Homecoming Flowers: Corsage & s, Boutonr & ieres, Bd & 50.00 & & 10 \\
\hline 2 & 13 & Made Valentine's Day Arrangements & & & 60.00 & & 10 \\
\hline 3 & & & & & & & \\
\hline 4 & & & & & & & \\
\hline 5 & & & & & & & \\
\hline 6 & & & & & & & \\
\hline 7 & & & & & & & \\
\hline 8 & & & & & & & \\
\hline 9 & & & & & & & \\
\hline 10 & & & & & & & \\
\hline 11 & & & & & & & \\
\hline 12 & & & & & & & \\
\hline 13 & & & & & & & \\
\hline 14 & & & & & & & \\
\hline 15 & & & & & & & \\
\hline 16 & & & & & & & \\
\hline 17 & & & & & & & \\
\hline 18 & & & & & & & \\
\hline 19 & & & & & & & \\
\hline 20 & & & & & & & \\
\hline 21 & & & & & & & \\
\hline 22 & & & & & & & \\
\hline 23 & & & & & & & \\
\hline 24 & & & & & & & \\
\hline 25 & & & & & & & \\
\hline 26 & & & & & & & \\
\hline 27 & Total fo & r page & & & 110.00 & 0.00 & 20 \\
\hline 28 & Total br & ought forward from previous month & & & 60.00 & 0.00 & 12 \\
\hline 29 & Total to & date & & & 170.00 & 0.00 & 32 \\
\hline
\end{tabular}


JOURNAL (continued)

February 2012

\begin{tabular}{|c|c|c|c|c|c|c|c|c|c|c|c|c|c|}
\hline \multicolumn{3}{|c|}{ Enterprise } & \multicolumn{3}{|c|}{ Enterprise } & \multicolumn{3}{|c|}{ Enterprise } & \multicolumn{3}{|c|}{ Enterprise } & \multirow{4}{*}{$\begin{array}{l}\text { (E) (11) } \\
\text { Unpd. } \\
\text { Hours }\end{array}$} & \\
\hline \multicolumn{3}{|c|}{ Market Lamb } & \multicolumn{3}{|c|}{ Floral Design } & & & & & & & & \\
\hline (8) & (9) & (10) & (8) & (9) & (10) & (8) & (9) & (10) & (8) & (9) & (10) & & \\
\hline Income & Expenses & Hours & Income & Expenses & Hours & Income & Expenses & Hours & Income & Expenses & Hours & & \\
\hline & & & 50.00 & & 10 & & & & & & & & 1 \\
\hline & & & 60.00 & & 10 & & & & & & & & 2 \\
\hline & & & & & & & & & & & & & 3 \\
\hline & & & & & & & & & & & & & 4 \\
\hline & & & & & & & & & & & & & 5 \\
\hline & & & & & & & & & & & & & 6 \\
\hline & & & & & & & & & & & & & 7 \\
\hline & & & & & & & & & & & & & 8 \\
\hline & & & & & & & & & & & & & 9 \\
\hline & & & & & & & & & & & & & 10 \\
\hline & & & & & & & & & & & & & 11 \\
\hline & & & & & & & & & & & & & 12 \\
\hline & & & & & & & & & & & & & 13 \\
\hline & & & & & & & & & & & & & 14 \\
\hline & & & & & & & & & & & & & 15 \\
\hline & & & & & & & & & & & & & 16 \\
\hline & & & & & & & & & & & & & 17 \\
\hline & & & & & & & & & & & & & 18 \\
\hline & & & & & & & & & & & & & 19 \\
\hline & & & & & & & & & & & & & 20 \\
\hline & & & & & & & & & & & & & 21 \\
\hline & & & & & & & & & & & & & 22 \\
\hline & & & & & & & & & & & & & 23 \\
\hline & & & & & & & & & & & & & 24 \\
\hline & & & & & & & & & & & & & 25 \\
\hline & & & & & & & & & & & & & 26 \\
\hline 0.00 & 0.00 & 0 & 110.00 & 0.00 & 20 & 0.00 & 0.00 & 0 & 0.00 & 0.00 & 0 & 0 & 27 \\
\hline 0.00 & 0.00 & 0 & 60.00 & 0.00 & 12 & 0.00 & 0.00 & 0 & 0.00 & 0.00 & 0 & 0 & 28 \\
\hline 0.00 & 0.00 & 0 & 170.00 & 0.00 & 32 & 0.00 & 0.00 & 0 & 0.00 & 0.00 & 0 & 0 & 29 \\
\hline
\end{tabular}

(Optional - expenses breakdown)

Total Feed
Total Other Cash 


\section{JOURNAL}

March 2012

\begin{tabular}{|c|c|c|c|c|c|c|c|}
\hline \multirow{3}{*}{ 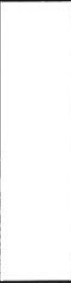 } & \multirow{3}{*}{$\begin{array}{c}\text { (1) } \\
\text { Date }\end{array}$} & \multirow{3}{*}{ (2) Description } & \multicolumn{2}{|c|}{ Units } & \multirow{3}{*}{$\begin{array}{c}(5) \\
\text { Income }\end{array}$} & \multirow{3}{*}{$\begin{array}{c}(6) \\
\text { Expenses }\end{array}$} & \multirow{3}{*}{$\begin{array}{c}(7) \\
\text { Hours } \\
\text { Self } \\
\text { Labor }\end{array}$} \\
\hline & & & \multirow[b]{2}{*}{ (3) No. } & \multirow[b]{2}{*}{\begin{tabular}{|c|}
$(4)$ \\
Price \\
\end{tabular}} & & & \\
\hline & & & & & & & \\
\hline 1 & 13 & Purchased Market Lamb & 1.00 & 234.00 & & 234.00 & 2 \\
\hline 2 & 13 & Purchased Livestock Insurance & 1.00 & 13.00 & & 13.00 & \\
\hline 3 & 31 & Monthly Feed Bill & & & & 15.21 & \\
\hline 4 & 31 & \multicolumn{2}{|l|}{ Monthly Feeding, Maitenance, \& Care } & & & & 15 \\
\hline 5 & & & & & & & \\
\hline 6 & & & & & & & \\
\hline 7 & & & & & & & \\
\hline 8 & & & & & & & \\
\hline 9 & & & & & & & \\
\hline 10 & & & & & & & \\
\hline 11 & & & & & & & \\
\hline 12 & & & & & & & \\
\hline 13 & & & & & & & \\
\hline 14 & & & & & & & \\
\hline 15 & & & & & & & \\
\hline 16 & & & & & & & \\
\hline 17 & & & & & & & \\
\hline 18 & & & & & & & \\
\hline 19 & & & & & & & \\
\hline 20 & & & & & & & \\
\hline 21 & & & & & & & \\
\hline 22 & & & & & & & \\
\hline 23 & & & & & & & \\
\hline 24 & & & & & & & \\
\hline 25 & & & & & & & \\
\hline 26 & & & & & & & \\
\hline 27 & Total fo & page & & & 0.00 & 262.21 & 17 \\
\hline 28 & Total b & ought forward from previous month & & & 170.00 & 0.00 & 32 \\
\hline 29 & Total to & date & & & 170.00 & 262.21 & 49 \\
\hline
\end{tabular}


JOURNAL (continued)

March 2012

\begin{tabular}{|c|c|c|c|c|c|c|c|c|c|c|c|c|c|}
\hline \multicolumn{3}{|c|}{ Enterprise } & \multicolumn{3}{|c|}{ Enterprise } & \multicolumn{3}{|c|}{ Enterprise } & \multicolumn{3}{|c|}{ Enterprise } & \multirow{4}{*}{$\begin{array}{l}\text { (E) }(11) \\
\text { Unpd. } \\
\text { Hours }\end{array}$} & \\
\hline \multicolumn{3}{|c|}{ Market Lamb } & \multicolumn{3}{|c|}{ Floral Design } & & & & & & & & \\
\hline \multirow{28}{*}{$\begin{array}{c}(8) \\
\text { Income }\end{array}$} & (9) & (10) & (8) & (9) & (10) & (8) & (9) & (10) & (8) & (9) & (10) & & \\
\hline & Expenses & Hours & Income & Expenses & Hours & Income & Expenses & Hours & Income & Expenses & Hours & & \\
\hline & 234.00 & 2 & & & & & & & & & & & 1 \\
\hline & 13.00 & & & & & & & & & & & & 2 \\
\hline & 15.21 & & & & & & & & & & & & 3 \\
\hline & & 15 & & & & & & & & & & & 4 \\
\hline & & & & & & & & & & & & & 5 \\
\hline & & & & & & & & & & & & & 6 \\
\hline & & & & & & & & & & & & & 7 \\
\hline & & & & & & & & & & & & & 8 \\
\hline & & & & & & & & & & & & & 9 \\
\hline & & & & & & & & & & & & & 10 \\
\hline & & & & & & & & & & & & & 11 \\
\hline & & & & & & & & & & & & & 12 \\
\hline & & & & & & & & & & & & & 13 \\
\hline & & & & & & & & & & & & & 14 \\
\hline & & & & & & & & & & & & & 15 \\
\hline & & & & & & & & & & & & & 16 \\
\hline & & & & & & & & & & & & & 17 \\
\hline & & & & & & & & & & & & & 18 \\
\hline & & & & & & & & & & & & & 19 \\
\hline & & & & & & & & & & & & & 20 \\
\hline & & & & & & & & & & & & & 21 \\
\hline & & & & & & & & & & & & & 22 \\
\hline & & & & & & & & & & & & & 23 \\
\hline & & & & & & & & & & & & & 24 \\
\hline & & & & & & & & & & & & & 25 \\
\hline & & & & & & & & & & & & & 26 \\
\hline 0.00 & 262.21 & 17 & 0.00 & 0.00 & 0 & 0.00 & 0.00 & 0 & 0.00 & 0.00 & 0 & 0 & 27 \\
\hline 0.00 & 0.00 & 0 & 170.00 & 0.00 & 32 & 0.00 & 0.00 & 0 & 0.00 & 0.00 & 0 & 0 & 28 \\
\hline 0.00 & 262.21 & 17 & 170.00 & 0.00 & 32 & 0.00 & 0.00 & 0 & 0.00 & 0.00 & 0 & 0 & 29 \\
\hline
\end{tabular}

(Optional - expenses breakdown)

Total Feed

Total Other Cash 


\section{JOURNAL}

\section{April 2012}

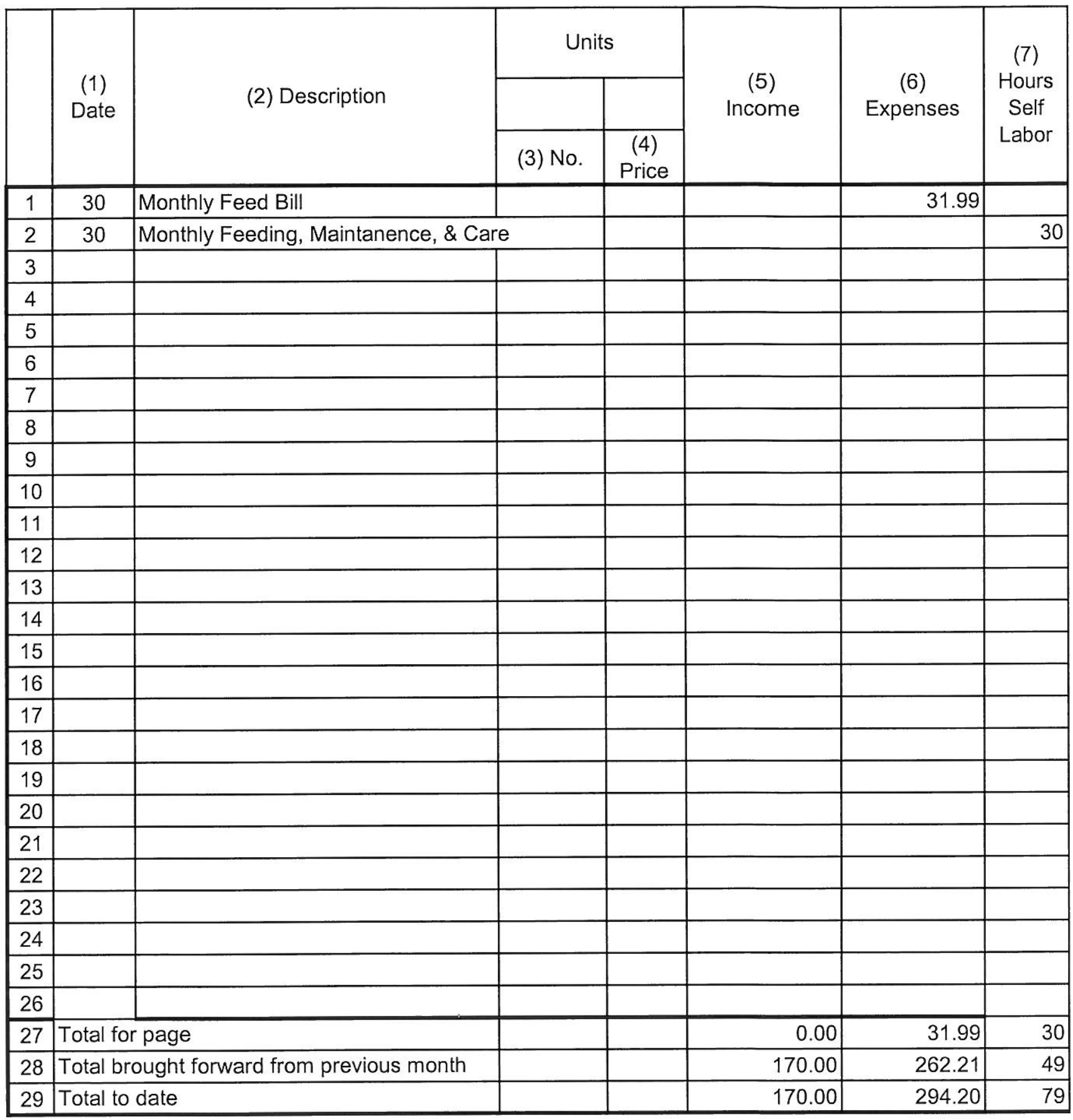


JOURNAL (continued)

April 2012

\begin{tabular}{|c|c|c|c|c|c|c|c|c|c|c|c|c|c|}
\hline \multicolumn{3}{|c|}{ Enterprise } & \multicolumn{3}{|c|}{ Enterprise } & \multicolumn{3}{|c|}{ Enterprise } & \multicolumn{3}{|c|}{ Enterprise } & \multirow{4}{*}{$\begin{array}{l}\text { (E) }(11) \\
\text { Unpd. } \\
\text { Hours }\end{array}$} & \\
\hline \multicolumn{3}{|c|}{ Market Lamb } & \multicolumn{3}{|c|}{ Floral Design } & & & & & & & & \\
\hline \multirow{28}{*}{$\begin{array}{c}\text { (8) } \\
\text { Income }\end{array}$} & (9) & (10) & (8) & (9) & (10) & (8) & (9) & (10) & (8) & (9) & (10) & & \\
\hline & Expenses & Hours & Income & Expenses & Hours & Income & Expenses & Hours & Income & Expenses & Hours & & \\
\hline & 31.99 & & & & & & & & & & & & 1 \\
\hline & & 30 & & & & & & & & & & & 2 \\
\hline & & & & & & & & & & & & & 3 \\
\hline & & & & & & & & & & & & & 4 \\
\hline & & & & & & & & & & & & & 5 \\
\hline & & & & & & & & & & & & & 6 \\
\hline & & & & & & & & & & & & & 7 \\
\hline & & & & & & & & & & & & & 8 \\
\hline & & & & & & & & & & & & & 9 \\
\hline & & & & & & & & & & & & & 10 \\
\hline & & & & & & & & & & & & & 11 \\
\hline & & & & & & & & & & & & & 12 \\
\hline & & & & & & & & & & & & & 13 \\
\hline & & & & & & & & & & & & & 14 \\
\hline & & & & & & & & & & & & & 15 \\
\hline & & & & & & & & & & & & & 16 \\
\hline & & & & & & & & & & & & & 17 \\
\hline & & & & & & & & & & & & & 18 \\
\hline & & & & & & & & & & & & & 19 \\
\hline & & & & & & & & & & & & & 20 \\
\hline & & & & & & & & & & & & & 21 \\
\hline & & & & & & & & & & & & & 22 \\
\hline & & & & & & & & & & & & & 23 \\
\hline & & & & & & & & & & & & & 24 \\
\hline & & & & & & & & & & & & & 25 \\
\hline & & & & & & & & & & & & & 26 \\
\hline 0.00 & 31.99 & 30 & 0.00 & 0.00 & 0 & 0.00 & 0.00 & 0 & 0.00 & 0.00 & 0 & 0 & 27 \\
\hline 0.00 & 262.21 & 17 & 170.00 & 0.00 & 32 & 0.00 & 0.00 & 0 & 0.00 & 0.00 & 0 & 0 & 28 \\
\hline 0.00 & 294.20 & 47 & 170.00 & 0.00 & 32 & 0.00 & 0.00 & 0 & 0.00 & 0.00 & 0 & 0 & 29 \\
\hline
\end{tabular}

(Optional - expenses breakdown)

Total Feed

Total Other Cash 


\section{JOURNAL}

May 2012

\begin{tabular}{|c|c|c|c|c|c|c|c|}
\hline & & & Un & & & & (7) \\
\hline & Date & & & & Income & Expenses & Self \\
\hline & & & (3) No. & $\begin{array}{c}(4) \\
\text { Price }\end{array}$ & & & \\
\hline 1 & 11 & Made Corsages and Boutonnieres fo & Prom & & 100.00 & & 12 \\
\hline 2 & 31 & Monthly Feed Bill & & & & 27.30 & \\
\hline 3 & 31 & Monthly Feeding, Maintanence, \& Ca & & & & & 31 \\
\hline 4 & & & & & & & \\
\hline 5 & & & & & & & \\
\hline 6 & & & & & & & \\
\hline 7 & & & & & & & \\
\hline 8 & & & & & & & \\
\hline 9 & & & & & & & \\
\hline 10 & & & & & & & \\
\hline 11 & & & & & & & \\
\hline 12 & & & & & & & \\
\hline 13 & & & & & & & \\
\hline 14 & & & & & & & \\
\hline 15 & & & & & & & \\
\hline 16 & & & & & & & \\
\hline 17 & & & & & & & \\
\hline 18 & & & & & & & \\
\hline 19 & & & & & & & \\
\hline 20 & & & & & & & \\
\hline 21 & & & & & & & \\
\hline 22 & & & & & & & \\
\hline 23 & & & & & & & \\
\hline 24 & & & & & & & \\
\hline 25 & & & & & & & \\
\hline 26 & & & & & & & \\
\hline 27 & Total for & page & & & 100.00 & 27.30 & 43 \\
\hline 28 & Total br & ought forward from previous month & & & 170.00 & 294.20 & 79 \\
\hline 29 & Total to & date & & & 270.00 & 321.50 & 122 \\
\hline
\end{tabular}


JOURNAL (continued)

May 2012

\begin{tabular}{|c|c|c|c|c|c|c|c|c|c|c|c|c|c|}
\hline \multicolumn{3}{|c|}{ Enterprise } & \multicolumn{3}{|c|}{ Enterprise } & \multicolumn{3}{|c|}{ Enterprise } & \multicolumn{3}{|c|}{ Enterprise } & & \\
\hline \multicolumn{3}{|c|}{ Market Lamb } & \multicolumn{3}{|c|}{ Floral Design } & & & & & & & \multirow{3}{*}{\multicolumn{2}{|c|}{$\begin{array}{c}\text { (E) }(11) \\
\text { Unpd. } \\
\text { Hours }\end{array}$}} \\
\hline (8) & (9) & (10) & (8) & (9) & (10) & (8) & (9) & (10) & (8) & (9) & (10) & & \\
\hline \multirow[t]{27}{*}{ Income } & Expenses & Hours & Income & Expenses & Hours & Income & Expenses & Hours & Income & Expenses & Hours & & \\
\hline & & & 100.00 & & 12 & & & & & & & & 1 \\
\hline & 27.30 & & & & & & & & & & & & 2 \\
\hline & & 31 & & & & & & & & & & & 3 \\
\hline & & & & & & & & & & & & & 4 \\
\hline & & & & & & & & & & & & & 5 \\
\hline & & & & & & & & & & & & & 6 \\
\hline & & & & & & & & & & & & & 7 \\
\hline & & & & & & & & & & & & & 8 \\
\hline & & & & & & & & & & & & & 9 \\
\hline & & & & & & & & & & & & & 10 \\
\hline & & & & & & & & & & & & & 11 \\
\hline & & & & & & & & & & & & & 12 \\
\hline & & & & & & & & & & & & & 13 \\
\hline & & & & & & & & & & & & & 14 \\
\hline & & & & & & & & & & & & & 15 \\
\hline & & & & & & & & & & & & & 16 \\
\hline & & & & & & & & & & & & & 17 \\
\hline & & & & & & & & & & & & & 18 \\
\hline & & & & & & & & & & & & & 19 \\
\hline & & & & & & & & & & & & & 20 \\
\hline & & & & & & & & & & & & & 21 \\
\hline & & & & & & & & & & & & & 22 \\
\hline & & & & & & & & & & & & & 23 \\
\hline & & & & & & & & & & & & & 24 \\
\hline & & & & & & & & & & & & & 25 \\
\hline & & & & & & & & & & & & & 26 \\
\hline 0.00 & 27.30 & 31 & 100.00 & 0.00 & 12 & 0.00 & 0.00 & 0 & 0.00 & 0.00 & 0 & 0 & 27 \\
\hline 0.00 & 294.20 & 47 & 170.00 & 0.00 & 32 & 0.00 & 0.00 & 0 & 0.00 & 0.00 & 0 & 0 & 28 \\
\hline 0.00 & 321.50 & 78 & 270.00 & 0.00 & 44 & 0.00 & 0.00 & 0 & 0.00 & 0.00 & 0 & 0 & 29 \\
\hline
\end{tabular}

(Optional - expenses breakdown)

Total Feed

Total Other Cash 


\section{JOURNAL}

June 2012

\begin{tabular}{|c|c|c|c|c|c|c|c|}
\hline & \multirow{3}{*}{$\begin{array}{l}(1) \\
\text { Date }\end{array}$} & \multirow{3}{*}{ (2) Description } & \multicolumn{2}{|c|}{ Units } & \multirow{3}{*}{$\begin{array}{c}(5) \\
\text { Income }\end{array}$} & \multirow{3}{*}{$\begin{array}{c}(6) \\
\text { Expenses }\end{array}$} & \multirow{3}{*}{$\begin{array}{c}(7) \\
\text { Hours } \\
\text { Self } \\
\text { Labor }\end{array}$} \\
\hline & & & \multirow[b]{2}{*}{ (3) No. } & \multirow[b]{2}{*}{$\begin{array}{c}\text { (4) } \\
\text { Price }\end{array}$} & & & \\
\hline & & & & & & & \\
\hline 1 & 16 & Monthly Feed Bill & & & & 13.65 & \\
\hline 2 & 16 & \multicolumn{2}{|l|}{ Monthly Feeding,Maintaince, and Care } & & & & 95 \\
\hline 3 & 16 & Sold Lamb at Merced County Fair & & & 641.25 & & \\
\hline 4 & 16 & \multicolumn{2}{|c|}{ Received Check Award for Floral Arrangements } & & 9.00 & & 6 \\
\hline \multicolumn{8}{|c|}{ (2: } \\
\hline \multicolumn{8}{|l|}{6} \\
\hline \multicolumn{8}{|l|}{7} \\
\hline \multicolumn{8}{|l|}{8} \\
\hline \multicolumn{8}{|l|}{9} \\
\hline \multicolumn{8}{|l|}{10} \\
\hline \multicolumn{8}{|l|}{11} \\
\hline \multicolumn{8}{|l|}{12} \\
\hline \multicolumn{8}{|l|}{13} \\
\hline \multicolumn{8}{|l|}{14} \\
\hline \multicolumn{8}{|l|}{15} \\
\hline \multicolumn{8}{|l|}{16} \\
\hline \multicolumn{8}{|l|}{17} \\
\hline \multicolumn{8}{|l|}{18} \\
\hline \multicolumn{8}{|l|}{19} \\
\hline \multicolumn{8}{|l|}{20} \\
\hline \multicolumn{8}{|l|}{21} \\
\hline \multicolumn{8}{|l|}{22} \\
\hline \multicolumn{8}{|l|}{23} \\
\hline 24 & & & & & & & \\
\hline 25 & & & & & & & \\
\hline 26 & & & & & & & \\
\hline 27 & Total for & r page & & & 650.25 & 13.65 & 101 \\
\hline 28 & Total br & ought forward from previous month & & & 270.00 & 321.50 & 122 \\
\hline 29 & Total to & date & & & 920.25 & 335.15 & 223 \\
\hline
\end{tabular}


JOURNAL (continued)

June 2012

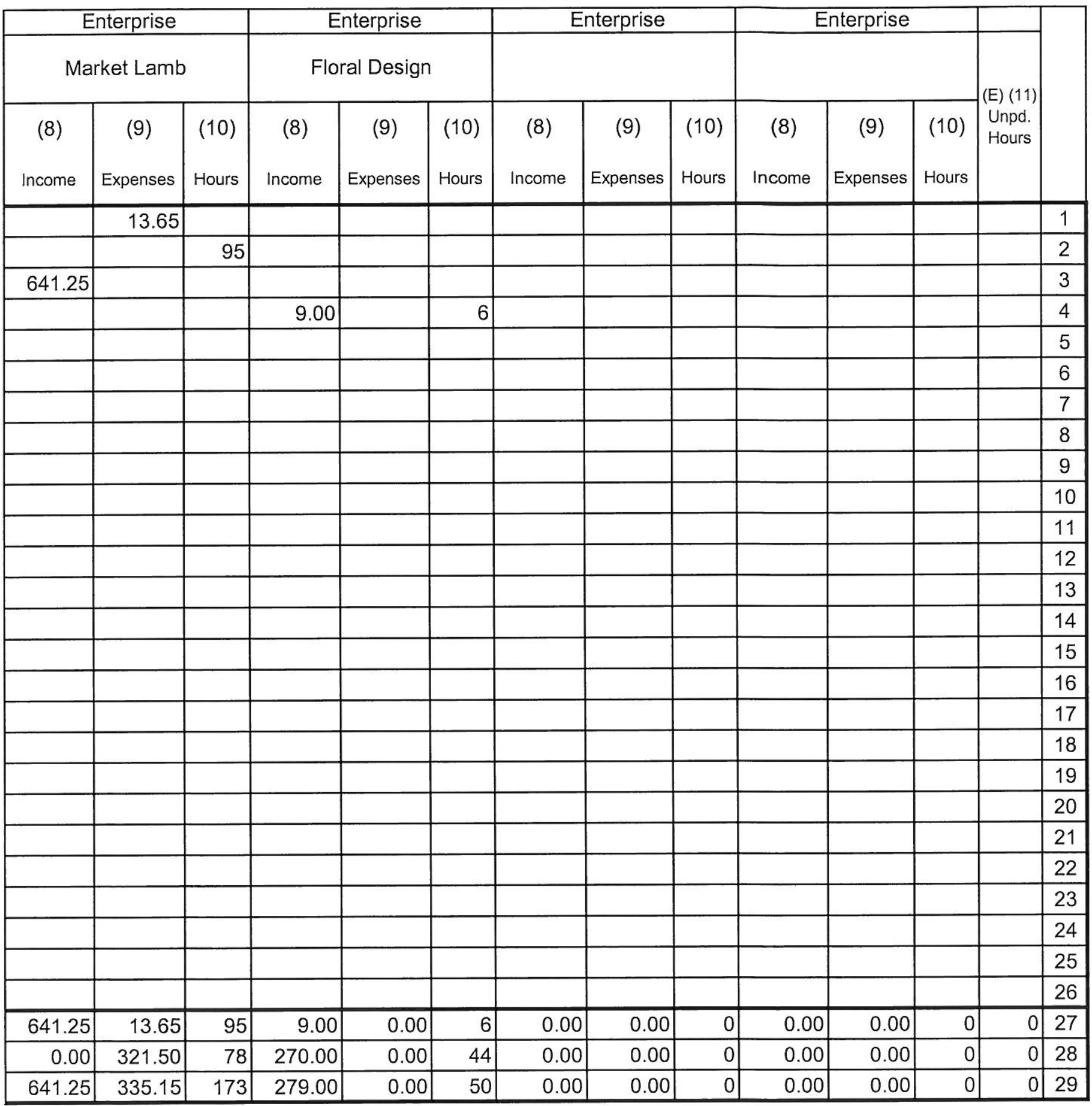

(Optional - expenses breakdown)

Total Feed

Total Other Cash 


\section{JOURNAL}

July 2012

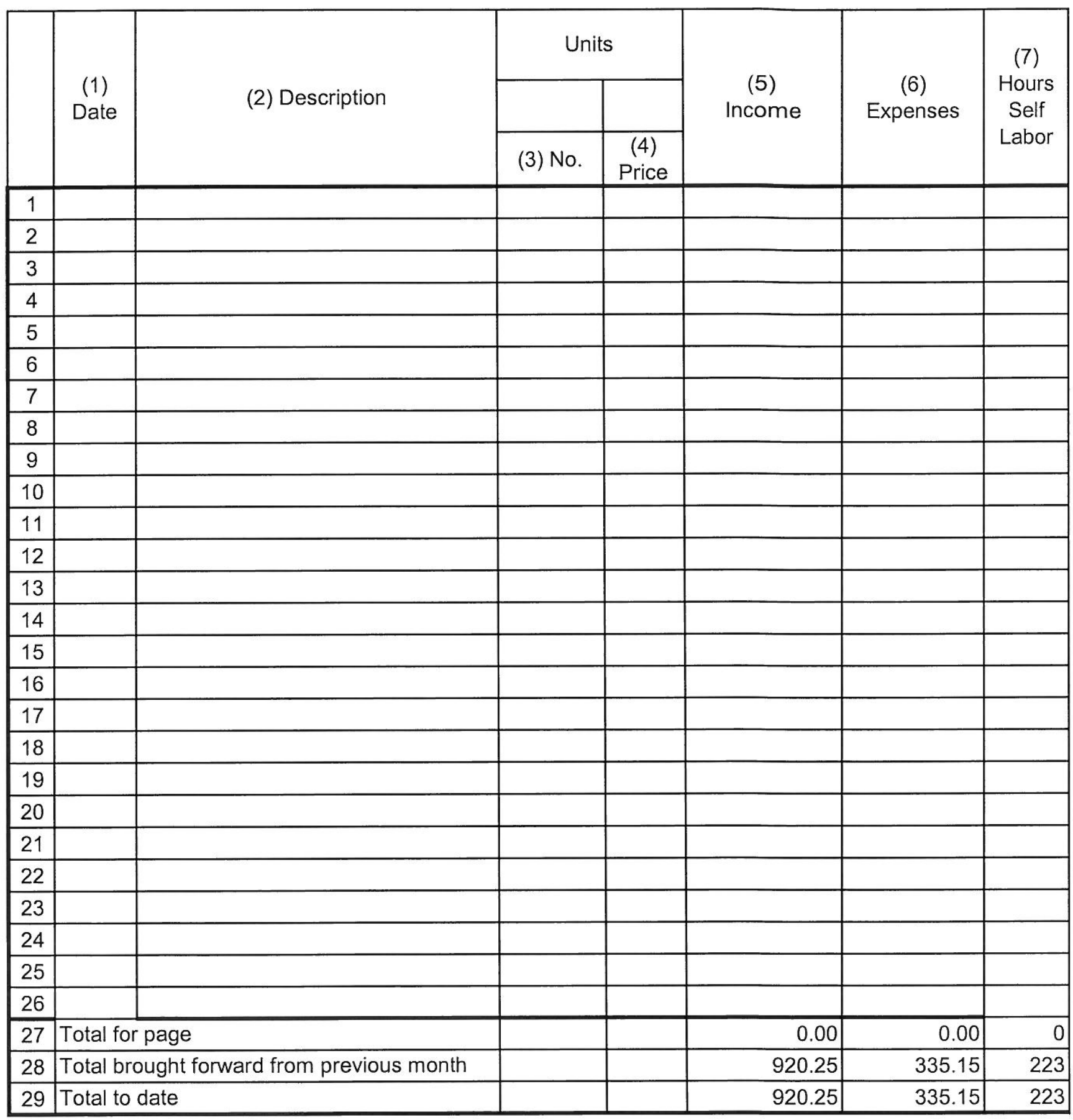


JOURNAL (continued)

July 2012

\begin{tabular}{|c|c|c|c|c|c|c|c|c|c|c|c|c|c|}
\hline \multicolumn{3}{|c|}{ Enterprise } & \multicolumn{3}{|c|}{ Enterprise } & \multicolumn{3}{|c|}{ Enterprise } & \multicolumn{3}{|c|}{ Enterprise } & \multirow{4}{*}{$\begin{array}{l}\text { (E) (11) } \\
\text { Unpd. } \\
\text { Hours }\end{array}$} & \\
\hline \multicolumn{3}{|c|}{ Market Lamb } & \multicolumn{3}{|c|}{ Floral Design } & & & & & & & & \\
\hline (8) & (9) & (10) & (8) & (9) & (10) & (8) & (9) & (10) & (8) & (9) & (10) & & \\
\hline Income & Expenses & Hours & Income & Expenses & Hours & Income & Expenses & Hours & Income & Expenses & Hours & & \\
\hline & & & & & & & & & & & & & 1 \\
\hline & & & & & & & & & & & & & 2 \\
\hline & & & & & & & & & & & & & 3 \\
\hline & & & & & & & & & & & & & 4 \\
\hline & & & & & & & & & & & & & 5 \\
\hline & & & & & & & & & & & & & 6 \\
\hline & & & & & & & & & & & & & 7 \\
\hline & & & & & & & & & & & & & 8 \\
\hline & & & & & & & & & & & & & 9 \\
\hline & & & & & & & & & & & & & 10 \\
\hline & & & & & & & & & & & & & 11 \\
\hline & & & & & & & & & & & & & 12 \\
\hline & & & & & & & & & & & & & 13 \\
\hline & & & & & & & & & & & & & 14 \\
\hline & & & & & & & & & & & & & 15 \\
\hline & & & & & & & & & & & & & 16 \\
\hline & & & & & & & & & & & & & 17 \\
\hline & & & & & & & & & & & & & 18 \\
\hline & & & & & & & & & & & & & 19 \\
\hline & & & & & & & & & & & & & 20 \\
\hline & & & & & & & & & & & & & 21 \\
\hline & & & & & & & & & & & & & 22 \\
\hline & & & & & & & & & & & & & 23 \\
\hline & & & & & & & & & & & & & 24 \\
\hline & & & & & & & & & & & & & 25 \\
\hline & & & & & & & & & & & & & 26 \\
\hline 0.00 & 0.00 & 0 & 0.00 & 0.00 & 0 & 0.00 & 0.00 & 0 & 0.00 & 0.00 & 0 & 0 & 27 \\
\hline 641.25 & 335.15 & 173 & 279.00 & 0.00 & 50 & 0.00 & 0.00 & 0 & 0.00 & 0.00 & 0 & 0 & 28 \\
\hline 641.25 & 335.15 & 173 & 279.00 & 0.00 & 50 & 0.00 & 0.00 & 0 & 0.00 & 0.00 & 0 & 0 & 29 \\
\hline
\end{tabular}

(Optional - expenses breakdown)

Total Feed
Total Other Cash 


\section{JOURNAL}

August 2012

\begin{tabular}{|c|c|c|c|c|c|c|c|}
\hline & & & Un & & & & (7) \\
\hline & Date & & & & Income & Expenses & Self \\
\hline & & & (3) No. & $\begin{array}{c}\text { (4) } \\
\text { Price }\end{array}$ & & & \\
\hline 1 & & & & & & & \\
\hline 2 & & & & & & & \\
\hline 3 & & & & & & & \\
\hline 4 & & & & & & & \\
\hline 5 & & & & & & & \\
\hline 6 & & & & & & & \\
\hline 7 & & & & & & & \\
\hline 8 & & & & & & & \\
\hline 9 & & & & & & & \\
\hline 10 & & & & & & & \\
\hline 11 & & & & & & & \\
\hline 12 & & & & & & & \\
\hline 13 & & & & & & & \\
\hline 14 & & & & & & & \\
\hline 15 & & & & & & & \\
\hline 16 & & & & & & & \\
\hline 17 & & & & & & & \\
\hline 18 & & & & & & & \\
\hline 19 & & & & & & & \\
\hline 20 & & & & & & & \\
\hline 21 & & & & & & & \\
\hline 22 & & & & & & & \\
\hline 23 & & & & & & & \\
\hline 24 & & & & & & & \\
\hline 25 & & & & & & & \\
\hline 26 & & & & & & & \\
\hline 27 & Total fo & page & & & 0.00 & 0.00 & 0 \\
\hline 28 & Total br & lght forward from previous month & & & 920.25 & 335.15 & 223 \\
\hline 29 & Total to & & & & 920.25 & 335.15 & 223 \\
\hline
\end{tabular}


JOURNAL (continued)

August 2012

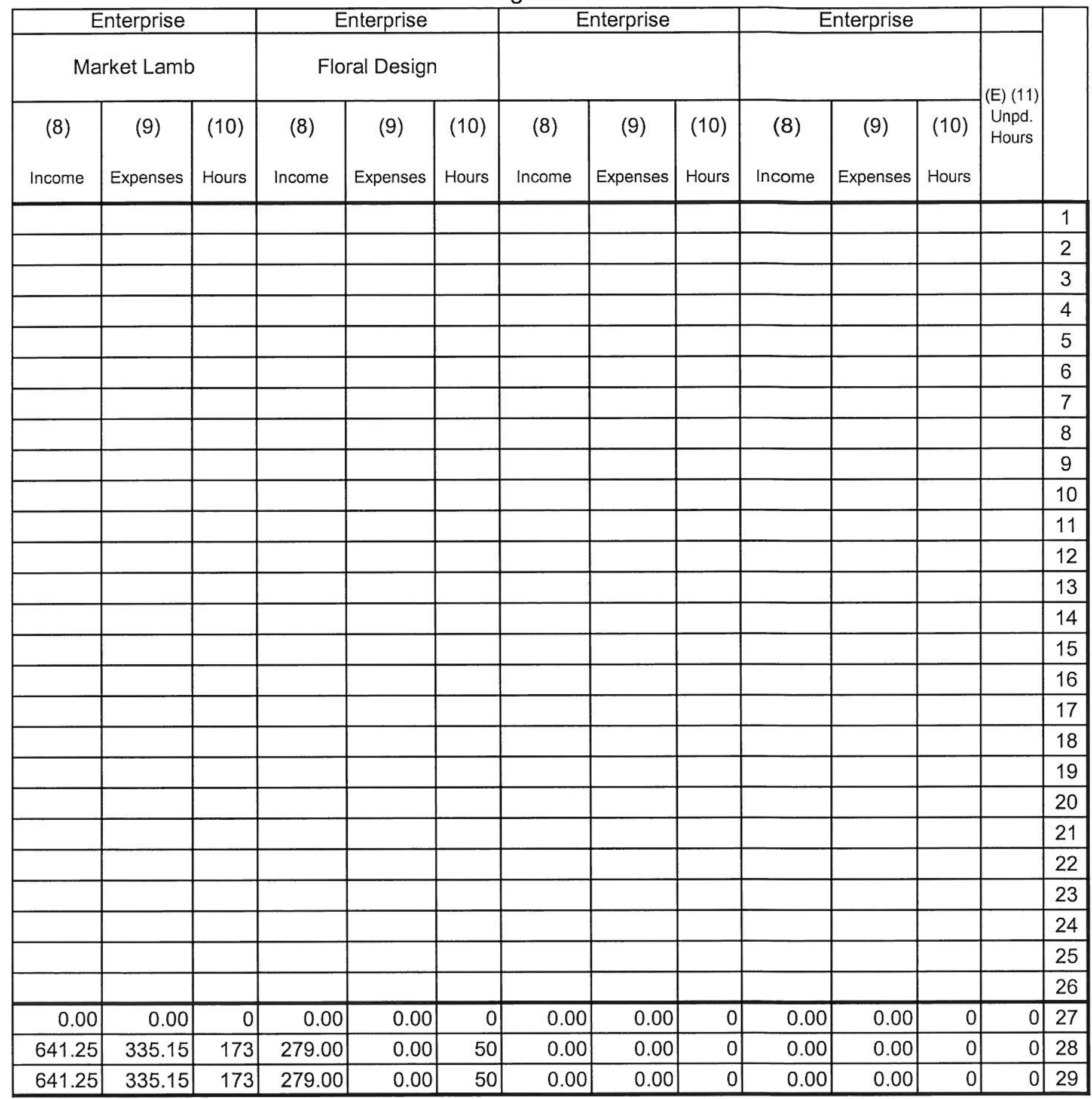

(Optional - expenses breakdown)

Total Feed

Total Other Cash 


\section{JOURNAL}

September 2012

\begin{tabular}{|c|c|c|c|c|c|c|c|}
\hline & & & Unit: & & & & (7) \\
\hline & Date & & & & & Expenses & Self \\
\hline & & & (3) No. & $\begin{array}{c}(4) \\
\text { Price }\end{array}$ & & & \\
\hline 1 & 7 & Made Wedding Flowers for Rodrigu & Wedding & & 250.00 & & 12 \\
\hline 2 & & & & & & & \\
\hline 3 & & & & & & & \\
\hline 4 & & & & & & & \\
\hline 5 & & & & & & & \\
\hline 6 & & & & & & & \\
\hline 7 & & & & & & & \\
\hline 8 & & & & & & & \\
\hline 9 & & & & & & & \\
\hline 10 & & & & & & & \\
\hline 11 & & & & & & & \\
\hline 12 & & & & & & & \\
\hline 13 & & & & & & & \\
\hline 14 & & & & & & & \\
\hline 15 & & & & & & & \\
\hline 16 & & & & & & & \\
\hline 17 & & & & & & & \\
\hline 18 & & & & & & & \\
\hline 19 & & & & & & & \\
\hline 20 & & & & & & & \\
\hline 21 & & & & & & & \\
\hline 22 & & & & & & & \\
\hline 23 & & & & & & & \\
\hline 24 & & & & & & & \\
\hline 25 & & & & & & & \\
\hline 26 & & & & & & & \\
\hline 27 & Total fo & page & & & 250.00 & 0.00 & 12 \\
\hline 28 & Total br & ought forward from previous month & & & 920.25 & 335.15 & 223 \\
\hline 29 & Total to & date & & & 1170.25 & 335.15 & 235 \\
\hline
\end{tabular}


JOURNAL (continued)

September 2012

\begin{tabular}{|c|c|c|c|c|c|c|c|c|c|c|c|c|c|}
\hline \multicolumn{3}{|c|}{ Enterprise } & \multicolumn{3}{|c|}{ Enterprise } & \multicolumn{3}{|c|}{ Enterprise } & \multicolumn{3}{|c|}{ Enterprise } & \multirow{4}{*}{$\begin{array}{l}\text { (E) }(11) \\
\text { Unpd. } \\
\text { Hours }\end{array}$} & \\
\hline \multicolumn{3}{|c|}{ Market Lamb } & \multicolumn{3}{|c|}{ Floral Design } & & & & & & & & \\
\hline (8) & (9) & (10) & (8) & (9) & (10) & (8) & (9) & (10) & (8) & (9) & (10) & & \\
\hline \multirow[t]{27}{*}{ Income } & Expenses & Hours & Income & Expenses & Hours & Income & Expenses & Hours & Income & Expenses & Hours & & \\
\hline & & & 250.00 & & 12 & & & & & & & & 1 \\
\hline & & & & & & & & & & & & & 2 \\
\hline & & & & & & & & & & & & & 3 \\
\hline & & & & & & & & & & & & & 4 \\
\hline & & & & & & & & & & & & & 5 \\
\hline & & & & & & & & & & & & & 6 \\
\hline & & & & & & & & & & & & & 7 \\
\hline & & & & & & & & & & & & & 8 \\
\hline & & & & & & & & & & & & & 9 \\
\hline & & & & & & & & & & & & & 10 \\
\hline & & & & & & & & & & & & & 11 \\
\hline & & & & & & & & & & & & & 12 \\
\hline & & & & & & & & & & & & & 13 \\
\hline & & & & & & & & & & & & & 14 \\
\hline & & & & & & & & & & & & & 15 \\
\hline & & & & & & & & & & & & & 16 \\
\hline & & & & & & & & & & & & & 17 \\
\hline & & & & & & & & & & & & & 18 \\
\hline & & & & & & & & & & & & & 19 \\
\hline & & & & & & & & & & & & & 20 \\
\hline & & & & & & & & & & & & & 21 \\
\hline & & & & & & & & & & & & & 22 \\
\hline & & & & & & & & & & & & & 23 \\
\hline & & & & & & & & & & & & & 24 \\
\hline & & & & & & & & & & & & & 25 \\
\hline & & & & & & & & & & & & & 26 \\
\hline 0.00 & 0.00 & 0 & 250.00 & 0.00 & 12 & 0.00 & 0.00 & 0 & 0.00 & 0.00 & 0 & 0 & 27 \\
\hline 641.25 & 335.15 & 173 & 279.00 & 0.00 & 50 & 0.00 & 0.00 & 0 & 0.00 & 0.00 & 0 & 0 & 28 \\
\hline 641.25 & 335.15 & 173 & 529.00 & 0.00 & 62 & 0.00 & 0.00 & 0 & 0.00 & 0.00 & 0 & 0 & 29 \\
\hline
\end{tabular}

(Optional - expenses breakdown)

Total Feed

Total Other Cash 


\section{JOURNAL}

October 2012

\begin{tabular}{|c|c|c|c|c|c|c|c|}
\hline & & & Unit & & & & \\
\hline & Date & & & & Income & Expenses & Self \\
\hline & & & (3) No. & $\begin{array}{c}(4) \\
\text { Price }\end{array}$ & & & \\
\hline 1 & 11 & Made Homecoming Corsages, Boutc & ieres, anc & Bouqua & 60.00 & & 10 \\
\hline 2 & & & & & & & \\
\hline 3 & & & & & & & \\
\hline 4 & & & & & & & \\
\hline 5 & & & & & & & \\
\hline 6 & & & & & & & \\
\hline 7 & & & & & & & \\
\hline 8 & & & & & & & \\
\hline 9 & & & & & & & \\
\hline 10 & & & & & & & \\
\hline 11 & & & & & & & \\
\hline 12 & & & & & & & \\
\hline 13 & & & & & & & \\
\hline 14 & & & & & & & \\
\hline 15 & & & & & & & \\
\hline 16 & & & & & & & \\
\hline 17 & & & & & & & \\
\hline 18 & & & & & & & \\
\hline 19 & & & & & & & \\
\hline 20 & & & & & & & \\
\hline 21 & & & & & & & \\
\hline 22 & & & & & & & \\
\hline 23 & & & & & & & \\
\hline 24 & & & & & & & \\
\hline 25 & & & & & & & \\
\hline 26 & & & & & & & \\
\hline 27 & Total for & page & & & 60.00 & 0.00 & 10 \\
\hline 28 & Total br & ought forward from previous month & & & 1170.25 & 335.15 & 235 \\
\hline 29 & Total to & date & & & 1230.25 & 335.15 & 245 \\
\hline
\end{tabular}


JOURNAL (continued)

October 2012

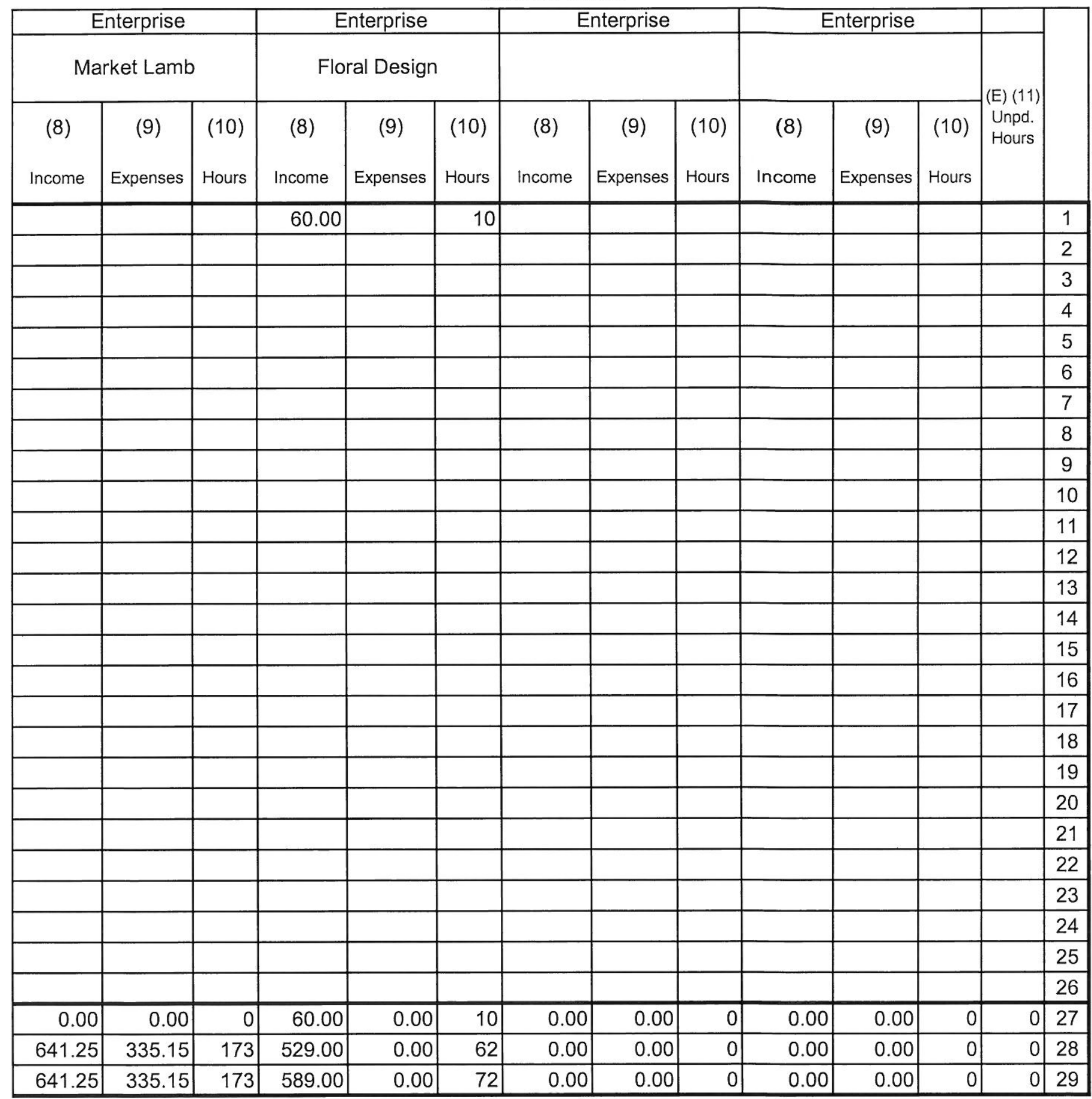

(Optional - expenses breakdown)

Total Feed

Total Other Cash 


\section{JOURNAL}

November 2012

\begin{tabular}{|c|c|c|c|c|c|c|c|}
\hline & \multirow{3}{*}{$\begin{array}{l}(1) \\
\text { Date }\end{array}$} & \multirow{3}{*}{ (2) Description } & \multicolumn{2}{|c|}{ Units } & \multirow{3}{*}{$\begin{array}{c}(5) \\
\text { Income }\end{array}$} & \multirow{3}{*}{$\begin{array}{c}(6) \\
\text { Expenses }\end{array}$} & \multirow{3}{*}{$\begin{array}{c}(7) \\
\text { Hours } \\
\text { Self } \\
\text { Labor }\end{array}$} \\
\hline & & & \multirow[b]{2}{*}{ (3) No. } & \multirow[b]{2}{*}{$\begin{array}{c}(4) \\
\text { Price }\end{array}$} & & & \\
\hline & & & & & & & \\
\hline 1 & 15 & Made Cornucopias for Thanksgiving & & & 50.00 & & 9 \\
\hline \multicolumn{8}{|c|}{ 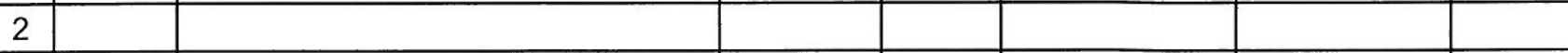 } \\
\hline \multicolumn{8}{|l|}{3} \\
\hline \multicolumn{8}{|l|}{4} \\
\hline \multicolumn{8}{|l|}{5} \\
\hline \multicolumn{8}{|l|}{6} \\
\hline \multicolumn{8}{|l|}{7} \\
\hline \multicolumn{8}{|l|}{8} \\
\hline \multicolumn{8}{|l|}{9} \\
\hline \multicolumn{8}{|l|}{10} \\
\hline \multicolumn{8}{|l|}{11} \\
\hline \multicolumn{8}{|l|}{12} \\
\hline \multicolumn{8}{|l|}{13} \\
\hline \multicolumn{8}{|l|}{14} \\
\hline \multicolumn{8}{|l|}{15} \\
\hline \multicolumn{8}{|l|}{16} \\
\hline \multicolumn{8}{|l|}{17} \\
\hline \multicolumn{8}{|l|}{18} \\
\hline \multicolumn{8}{|l|}{19} \\
\hline \multicolumn{8}{|l|}{20} \\
\hline \multicolumn{8}{|l|}{21} \\
\hline \multicolumn{8}{|l|}{22} \\
\hline 23 & & & & & & & \\
\hline 24 & & & & & & & \\
\hline 25 & & & & & & & \\
\hline 26 & & & & & & & \\
\hline 27 & Total fo & page & & & 50.00 & 0.00 & 9 \\
\hline 28 & Total br & ought forward from previous month & & & 1230.25 & 335.15 & 245 \\
\hline 29 & Total to & date & & & 1280.25 & 335.15 & 254 \\
\hline
\end{tabular}


JOURNAL (continued)

November 2012

\begin{tabular}{|c|c|c|c|c|c|c|c|c|c|c|c|c|c|}
\hline \multicolumn{3}{|c|}{ Enterprise } & \multicolumn{3}{|c|}{ Enterprise } & \multicolumn{3}{|c|}{ Enterprise } & \multicolumn{3}{|c|}{ Enterprise } & \multirow{4}{*}{$\begin{array}{c}\text { (E) (11) } \\
\text { Unpd. } \\
\text { Hours }\end{array}$} & \\
\hline \multicolumn{3}{|c|}{ Market Lamb } & \multicolumn{3}{|c|}{ Floral Design } & & & & & & & & \\
\hline (8) & (9) & (10) & (8) & (9) & (10) & (8) & (9) & (10) & (8) & (9) & $(10)$ & & \\
\hline Income & Expenses & Hours & Income & Expenses & Hours & Income & Expenses & Hours & Income & Expenses & Hours & & \\
\hline & & & 50.00 & & 9 & & & & & & & & 1 \\
\hline & & & & & & & & & & & & & 2 \\
\hline & & & & & & & & & & & & & 3 \\
\hline & & & & & & & & & & & & & 4 \\
\hline & & & & & & & & & & & & & 5 \\
\hline & & & & & & & & & & & & & 6 \\
\hline & & & & & & & & & & & & & 7 \\
\hline & & & & & & & & & & & & & 8 \\
\hline & & & & & & & & & & & & & 9 \\
\hline & & & & & & & & & & & & & 10 \\
\hline & & & & & & & & & & & & & 11 \\
\hline & & & & & & & & & & & & & 12 \\
\hline & & & & & & & & & & & & & 13 \\
\hline & & & & & & & & & & & & & 14 \\
\hline & & & & & & & & & & & & & 15 \\
\hline & & & & & & & & & & & & & 16 \\
\hline & & & & & & & & & & & & & 17 \\
\hline & & & & & & & & & & & & & 18 \\
\hline & & & & & & & & & & & & & 19 \\
\hline & & & & & & & & & & & & & 20 \\
\hline & & & & & & & & & & & & & 21 \\
\hline & & & & & & & & & & & & & 22 \\
\hline & & & & & & & & & & & & & 23 \\
\hline & & & & & & & & & & & & & 24 \\
\hline & & & & & & & & & & & & & 25 \\
\hline & & & & & & & & & & & & & 26 \\
\hline 0.00 & 0.00 & 0 & 50.00 & 0.00 & 9 & 0.00 & 0.00 & 0 & 0.00 & 0.00 & 0 & 0 & 27 \\
\hline 641.25 & 335.15 & 173 & 589.00 & 0.00 & 72 & 0.00 & 0.00 & 0 & 0.00 & 0.00 & 0 & 0 & 28 \\
\hline 641.25 & 335.15 & 173 & 639.00 & 0.00 & 81 & 0.00 & 0.00 & 0 & 0.00 & 0.00 & 0 & 0 & 29 \\
\hline
\end{tabular}

(Optional - expenses breakdown)

Total Feed

Total Other Cash 


\section{JOURNAL}

\section{December 2012}

\begin{tabular}{|c|c|c|c|c|c|c|c|}
\hline & & & Uni & & & & (7) \\
\hline & Date & & & & Income & Expenses & Self \\
\hline & & & (3) No. & $\begin{array}{c}(4) \\
\text { Price }\end{array}$ & & & \\
\hline 1 & 19 & Made Christmas Centerpieces & & & 50.00 & & 8 \\
\hline 2 & & & & & & & \\
\hline 3 & & & & & & & \\
\hline 4 & & & & & & & \\
\hline 5 & & & & & & & \\
\hline 6 & & & & & & & \\
\hline 7 & & & & & & & \\
\hline 8 & & & & & & & \\
\hline 9 & & & & & & & \\
\hline 10 & & & & & & & \\
\hline 11 & & & & & & & \\
\hline 12 & & & & & & & \\
\hline 13 & & & & & & & \\
\hline 14 & & & & & & & \\
\hline 15 & & & & & & & \\
\hline 16 & & & & & & & \\
\hline 17 & & & & & & & \\
\hline 18 & & & & & & & \\
\hline 19 & & & & & & & \\
\hline 20 & & & & & & & \\
\hline 21 & & & & & & & \\
\hline 22 & & & & & & & \\
\hline 23 & & & & & & & \\
\hline 24 & & & & & & & \\
\hline 25 & & & & & & & \\
\hline 26 & & & & & & & \\
\hline 27 & Total for & page & & & 50.00 & 0.00 & 8 \\
\hline 28 & Total br & ought forward from previous month & & & 1280.25 & 335.15 & 254 \\
\hline 29 & Total to & date & & & 1330.25 & 335.15 & 262 \\
\hline
\end{tabular}


JOURNAL (continued)

December 2012

\begin{tabular}{|c|c|c|c|c|c|c|c|c|c|c|c|c|c|}
\hline \multicolumn{3}{|c|}{ Enterprise } & \multicolumn{3}{|c|}{ Enterprise } & \multicolumn{3}{|c|}{ Enterprise } & \multicolumn{3}{|c|}{ Enterprise } & & \\
\hline \multicolumn{3}{|c|}{ Market Lamb } & \multicolumn{3}{|c|}{ Floral Design } & & & & & & & \multirow{3}{*}{\multicolumn{2}{|c|}{$\begin{array}{c}\text { (E) (11) } \\
\text { Unpd. } \\
\text { Hours }\end{array}$}} \\
\hline (8) & (9) & (10) & (8) & (9) & (10) & (8) & (9) & (10) & (8) & (9) & (10) & & \\
\hline \multirow[t]{27}{*}{ Income } & Expenses & Hours & Income & Expenses & Hours & Income & Expenses & Hours & Income & Expenses & Hours & & \\
\hline & & & 50.00 & & 8 & & & & & & & & 1 \\
\hline & & & & & & & & & & & & & 2 \\
\hline & & & & & & & & & & & & & 3 \\
\hline & & & & & & & & & & & & & 4 \\
\hline & & & & & & & & & & & & & 5 \\
\hline & & & & & & & & & & & & & 6 \\
\hline & & & & & & & & & & & & & 7 \\
\hline & & & & & & & & & & & & & 8 \\
\hline & & & & & & & & & & & & & 9 \\
\hline & & & & & & & & & & & & & 10 \\
\hline & & & & & . & & & & & & & & 11 \\
\hline & & & & & & & & & & & & & 12 \\
\hline & & & & & & & & & & & & & 13 \\
\hline & & & & & & & & & & & & & 14 \\
\hline & & & & & & & & & & & & & 15 \\
\hline & & & & & & & & & & & & & 16 \\
\hline & & & & & & & & & & & & & 17 \\
\hline & & & & & & & & & & & & & 18 \\
\hline & & & & & & & & & & & & & 19 \\
\hline & & & & & & & & & & & & & 20 \\
\hline & & & & & & & & & & & & & 21 \\
\hline & & & & & & & & & & & & & 22 \\
\hline & & & & & & & & & & & & & 23 \\
\hline & & & & & & & & & & & & & 24 \\
\hline & & & & & & & & & & & & & 25 \\
\hline & & & & & & & & & & & & & 26 \\
\hline 0.00 & 0.00 & 0 & 50.00 & 0.00 & 8 & 0.00 & 0.00 & 0 & 0.00 & 0.00 & 0 & 0 & 27 \\
\hline 641.25 & 335.15 & 173 & 639.00 & 0.00 & 81 & 0.00 & 0.00 & 이 & 0.00 & 0.00 & 0 & 0 & 28 \\
\hline 641.25 & 335.15 & 173 & 689.00 & 0.00 & 89 & 0.00 & 0.00 & 0 & 0.00 & 0.00 & 0 & 0 & 29 \\
\hline
\end{tabular}

(Optional - expenses breakdown)

Total Feed

Total Other Cash 


\section{ENTERPRISE LOAN PAYMENT SUMMARY}

NOTE: Entries of Interest Payments on this page must also be recorded in the Journal.

\begin{tabular}{|c|c|c|c|c|c|}
\hline $\begin{array}{c}\text { Date } \\
\text { Borrowed }\end{array}$ & $\begin{array}{c}\text { Name \& Address of Person or } \\
\text { Firm }\end{array}$ & Purpose of Loan & $\begin{array}{c}\text { Total } \\
\text { Amount } \\
\text { Borrowed } \\
\text { (Principal) }\end{array}$ & $\begin{array}{c}\text { Balance } \\
\text { Int. Rate }\end{array}$ & $\begin{array}{c}\text { Forward } \\
\text { From Prior } \\
\text { Year }\end{array}$ \\
\hline & & & & & \\
\hline
\end{tabular}

\begin{tabular}{|c|c|c|c|c|c|c|c|c|c|}
\hline \multirow{2}{*}{ Payment } & \multirow{2}{*}{ Date Paid } & \multicolumn{2}{|c|}{ Amount Paid } & \multirow{2}{*}{$\begin{array}{c}\text { Balance of } \\
\text { Principal } \\
\text { Owed }\end{array}$} & \multirow{2}{*}{ Payment } & \multirow{2}{*}{ Date Paid } & \multicolumn{2}{|c|}{ Amount Paid } & \multirow{2}{*}{$\begin{array}{c}\text { Balance of } \\
\text { Principal } \\
\text { Owed }\end{array}$} \\
\hline & & Interest & Principal & & & & Interest & Principal & \\
\hline$\# 1$ & & & & 0.00 & $\# 7$ & & & & 0.00 \\
\hline \#2 & & & & 0.00 & $\# 8$ & & & & 0.00 \\
\hline$\# 3$ & & & & 0.00 & $\# 9$ & & & & 0.00 \\
\hline$\# 4$ & & & & 0.00 & $\# 10$ & & & & 0.00 \\
\hline$\# 5$ & & & & 0.00 & $\# 11$ & & & & 0.00 \\
\hline$\# 6$ & & & & 0.00 & $\# 12$ & & & & 0.00 \\
\hline \multicolumn{7}{|c|}{ TOTAL FOR YEAR } & 0.00 & 0.00 & \\
\hline
\end{tabular}

\begin{tabular}{|c|c|c|c|c|c|}
\hline $\begin{array}{c}\text { Date } \\
\text { Borrowed }\end{array}$ & $\begin{array}{c}\text { Name \& Address of Person or } \\
\text { Firm }\end{array}$ & Purpose of Loan & $\begin{array}{c}\text { Total } \\
\text { Amount } \\
\text { Borrowed } \\
\text { (Principal) }\end{array}$ & $\begin{array}{c}\text { Balance } \\
\text { Int. Rate }\end{array}$ & $\begin{array}{c}\text { Forward } \\
\text { From Prior } \\
\text { Year }\end{array}$ \\
\hline & & & & & \\
\hline
\end{tabular}

\begin{tabular}{|c|c|c|c|c|c|c|c|c|c|}
\hline \multirow{2}{*}{ Payment } & \multirow{2}{*}{ Date Paid } & \multicolumn{2}{|c|}{ Amount Paid } & \multirow{2}{*}{$\begin{array}{c}\text { Balance of } \\
\text { Principal } \\
\text { Owed }\end{array}$} & \multirow{2}{*}{ Payment } & \multirow{2}{*}{ Date Paid } & \multicolumn{2}{|c|}{ Amount Paid } & \multirow{2}{*}{$\begin{array}{c}\text { Balance of } \\
\text { Principal } \\
\text { Owed }\end{array}$} \\
\hline & & Interest & Principal & & & & Interest & Principal & \\
\hline \#1 & & & & 0.00 & $\# 7$ & & & & 0.00 \\
\hline \#2 & & & & 0.00 & \#8 & & & & 0.00 \\
\hline \#3 & & & & 0.00 & \#9 & & & & 0.00 \\
\hline$\# 4$ & & & & 0.00 & $\# 10$ & & & & 0.00 \\
\hline \#5 & & & & 0.00 & \#11 & & & & 0.00 \\
\hline \#6 & & & & 0.00 & $\# 12$ & & & & 0.00 \\
\hline \multicolumn{7}{|c|}{ TOTAL FOR YEAR } & 0.00 & 0.00 & \\
\hline
\end{tabular}




\section{CONTRIBUTION TO SUPPORT OF FAMILY}

Entries should include SAE funds that the student has spent on necessary living expenses such as home rent or mortgage payments; electricity and heating; expenses for fuel, upkeep and maintenance of family automobile; healthcare, including life and health insurance premiums; and purchase of food and/or clothing for self and/or immediate family members.

\begin{tabular}{|l|l|l|l|}
\hline Date & Paid to & Description of Item & Amount \\
\hline & & & \\
\hline & & & \\
\hline & & & \\
\hline & & & \\
\hline & & & \\
\hline & & & \\
\hline & & & \\
\hline & & & \\
\hline & & & \\
\hline & & & \\
\hline
\end{tabular}

\section{EXPENSES FOR EDUCATIONAL PURPOSES}

Entries should include SAE funds used by the student for any/all of the following purposes: room and board while away from home for the expressed purpose of attending school; tuition, and registration and enrollment fees at an educational institution; books and related classroom supplies purchased expressly for educational purposes; and testing and/or application fees necessary for the purpose of advancing personal educational objectives.

\begin{tabular}{|l|l|l|l|}
\hline Date & Paid to & Description of Item & Amount \\
\hline & & & \\
\hline & & & \\
\hline & & & \\
\hline & & & \\
\hline & & & \\
\hline & & & \\
\hline & & & \\
\hline & & & \\
\hline & & & \\
\hline & & & \\
\hline
\end{tabular}


Entries on this page are made at the beginning and end of the year ONLY and are transferred to the

Financial Statement

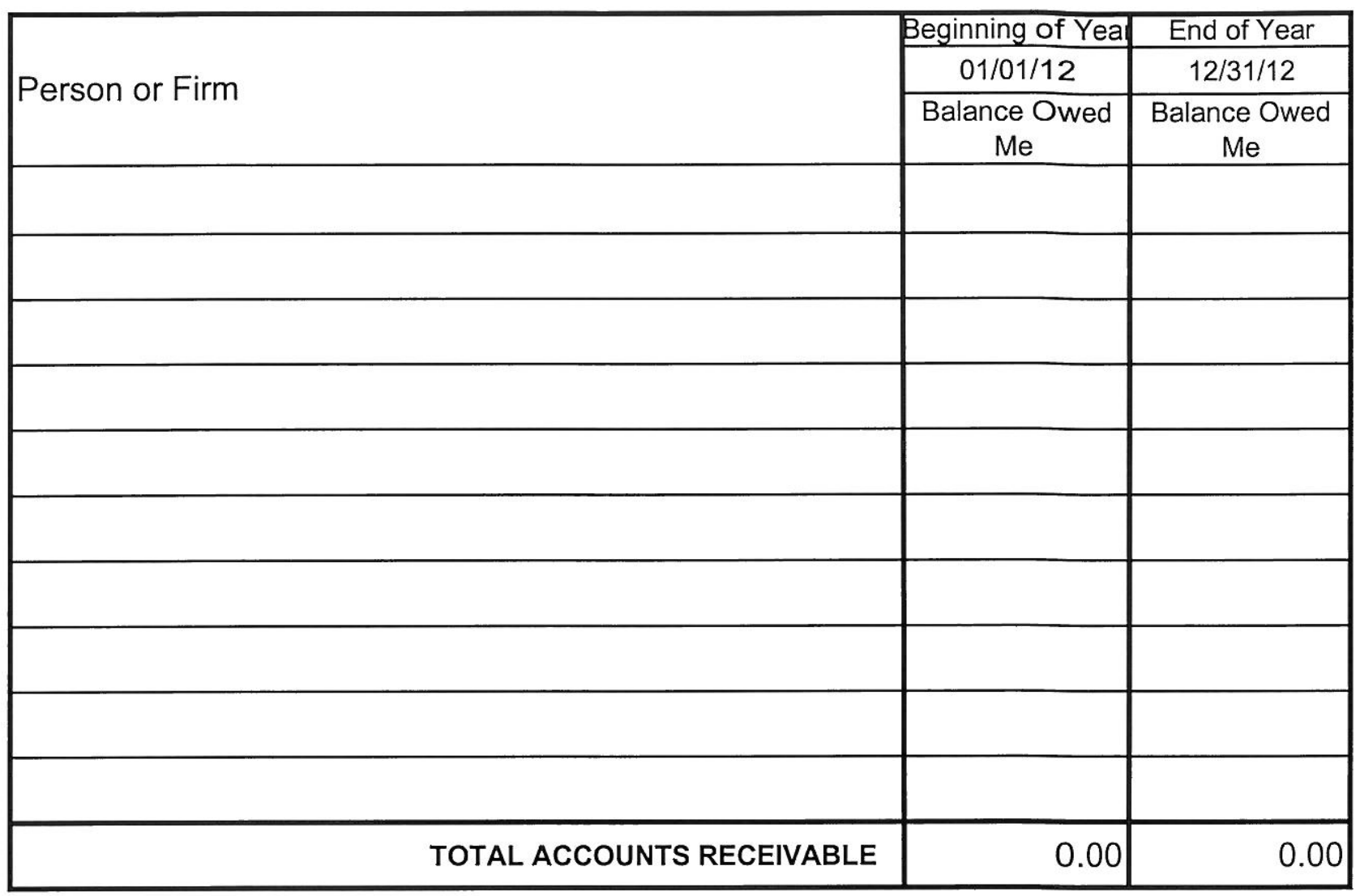

ENTERPRISE ACCOUNTS PAYABLE (other than loans)

Entries on this page are made at the beginning and end of the year ONLY and are transferred to the Financial Statement

\begin{tabular}{|l|c|c|}
\hline \multirow{2}{*}{ Person or Firm } & Beginning of Yea & End of Year \\
\hline & $01 / 01 / 12$ & $12 / 31 / 12$ \\
\hline & Balance I Owe & Balance I Owe \\
\hline & & \\
\hline & & \\
\hline & & \\
\hline & & \\
\hline TOTAL CHARGE ACCOUNTS & & \\
\hline & & \\
\hline
\end{tabular}




\section{CURRENT/OPERATING INVENTORY (NON-DEPRECIABLE PROPERTY INVENTORY)}

Entries should include items that will be consumed or sold within one year. Examples: feed, medicines, fertilizer, livestock intended for resale, annual crops, and nursery stock. Calculations should be made at the beginning and end of the year ONLY and transferred to the Financial Statement.

\begin{tabular}{|c|c|c|c|c|c|c|}
\hline \multirow{3}{*}{ DESCRIPTION OF ITEMS OWNED } & \multicolumn{3}{|c|}{ Beginning of Year } & \multicolumn{3}{|c|}{ End of Year } \\
\hline & \multicolumn{2}{|l|}{ Date } & $1 / 1 / 2012$ & Date & \multicolumn{2}{|c|}{$12 / 31 / 2012$} \\
\hline & $\begin{array}{l}\text { No. of } \\
\text { Units }\end{array}$ & $\begin{array}{c}\text { Value } \\
\text { Per } \\
\text { Unit }\end{array}$ & Total Value & $\begin{array}{l}\text { No. of } \\
\text { Units }\end{array}$ & $\begin{array}{c}\text { Value } \\
\text { Per } \\
\text { Unit }\end{array}$ & Total Value \\
\hline \multicolumn{7}{|l|}{ Enterprise Market Lamb } \\
\hline & & & & & & \\
\hline & & & & & & \\
\hline & & & & & & \\
\hline & & & & & & \\
\hline & & & & & & \\
\hline & & & & & & \\
\hline & & & & & & \\
\hline & & & & & & \\
\hline & & & & & & \\
\hline & & & & & & \\
\hline & & & & & & \\
\hline & & & & & & \\
\hline & & & & & & \\
\hline & & & & & & \\
\hline TOTALS FOR ENTERPRISE & & & 0 & & & 0 \\
\hline Enterprise $\quad$ Floral Design & & & & & & \\
\hline & & & & & & \\
\hline & & & & & & \\
\hline & & & & & & \\
\hline & & & & & & \\
\hline & & & & & & \\
\hline & & & & & & \\
\hline & & & & & & \\
\hline & & & & & & \\
\hline & & & & & & \\
\hline & & & & & & \\
\hline & & & & & & \\
\hline & & & & & & \\
\hline & & & & & & \\
\hline & & & & & & \\
\hline TOTALS FOR ENTERPRISE & & & 0 & & & 0 \\
\hline
\end{tabular}




\section{CURRENT/OPERATING INVENTORY (NON-DEPRECIABLE PROPERTY INVENTORY)}

Entries should include items that will be consumed or sold within one year. Examples: feed, medicines, fertilizer, livestock intended for resale, annual crops, and nursery stock. Calculations should be made at the beginning and end of the year ONLY and transferred to the Financial Statement.

\begin{tabular}{|c|c|c|c|c|c|c|}
\hline \multirow{3}{*}{ DESCRIPTION OF ITEMS OWNED } & \multicolumn{3}{|c|}{ Beginning of Year } & \multicolumn{3}{|c|}{ End of Year } \\
\hline & \multicolumn{2}{|c|}{ Date } & $1 / 1 / 2012$ & Date & \multicolumn{2}{|c|}{$12 / 31 / 2012$} \\
\hline & $\begin{array}{c}\text { No. of } \\
\text { Units }\end{array}$ & $\begin{array}{c}\text { Value } \\
\text { Per } \\
\text { Unit }\end{array}$ & Total Value & $\begin{array}{l}\text { No. of } \\
\text { Units }\end{array}$ & $\begin{array}{c}\text { Value } \\
\text { Per } \\
\text { Unit }\end{array}$ & Total Value \\
\hline \multicolumn{7}{|l|}{ Enterprise } \\
\hline & & & & & & \\
\hline & & & & & & \\
\hline & & & & & & \\
\hline & & & & & & \\
\hline & & & & & & \\
\hline & & & & & & \\
\hline & & & & & & \\
\hline & & & & & & \\
\hline & & & & & & \\
\hline & & & & & & \\
\hline & & & & & & \\
\hline & & & & & & \\
\hline & & & & & & \\
\hline & & & & & & \\
\hline TOTALS FOR ENTERPRISE & & & 0 & & & 0 \\
\hline \multicolumn{7}{|l|}{ Enterprise } \\
\hline & & & & & & \\
\hline & & & & & & \\
\hline & & & & & & \\
\hline & & & & & & \\
\hline & & & & & & \\
\hline & & & & & & \\
\hline & & & & & & \\
\hline & & & & & & \\
\hline & & & & & & \\
\hline & & & & & & \\
\hline TOTALS FOR ENTERPRISE & & & 0 & & & 0 \\
\hline TOTALS FOR ENTERPRISE & & & 0 & & & 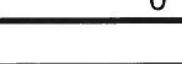 \\
\hline GRAND TOTAL & & & 0 & & & 0 \\
\hline
\end{tabular}




\section{NON-CURRENT/CAPITAL NON-DEPRECIABLE INVENTORY (NON-DEPRECIABLE PROPERTY INVENTORY)}

Entries should include: breeding livestock raised and land ONLY. Calculations should be made at the beginning and end of the year ONLY and transferred to the Financial Statement.

\begin{tabular}{|c|c|c|c|c|c|c|}
\hline \multirow{3}{*}{ DESCRIPTION OF ITEMS OWNED } & \multicolumn{3}{|c|}{ Beginning of Year } & \multicolumn{3}{|c|}{ End of Year } \\
\hline & \multirow{2}{*}{$\begin{array}{l}\text { Date } \\
\begin{array}{l}\text { No. of } \\
\text { Units }\end{array}\end{array}$} & \multicolumn{2}{|c|}{$1 / 1 / 2012$} & \multirow{2}{*}{\begin{tabular}{|l|}
$|c|$ \\
Date \\
$\begin{array}{l}\text { No. of } \\
\text { Units }\end{array}$
\end{tabular}} & \multicolumn{2}{|c|}{$12 / 31 / 2012$} \\
\hline & & $\begin{array}{l}\text { Value } \\
\text { Per } \\
\text { Unit }\end{array}$ & Total Value & & $\begin{array}{c}\text { Value } \\
\text { Per } \\
\text { Unit }\end{array}$ & Total Value \\
\hline \multicolumn{7}{|l|}{ Enterprise Market Lamb } \\
\hline & & & & & & \\
\hline & & & & & & \\
\hline & & & & & & \\
\hline & & & & & & \\
\hline & & & & & & \\
\hline & & & & & & \\
\hline & & & & & & \\
\hline & & & & & & \\
\hline & & & & & & \\
\hline & & & & & & \\
\hline & & & & & & \\
\hline & & & & & & \\
\hline & & & & & & \\
\hline & & & & & & \\
\hline TOTALS FOR ENTERPRISE & & & 요 & & & 0 \\
\hline Enterprise $\quad$ Floral Design & & & & & & \\
\hline & & & & & & \\
\hline & & & & & & \\
\hline & & & & & & \\
\hline & & & & & & \\
\hline & & & & & & \\
\hline & & & & & & \\
\hline & & & & & & \\
\hline & & & & & & \\
\hline & & & & & & \\
\hline & & & & & & \\
\hline & & & & & & \\
\hline & & & & & & \\
\hline & & & & & & \\
\hline & & & & & & \\
\hline TOTALS FOR ENTERPRISE & & & 0 & 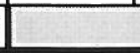 & & 0 \\
\hline
\end{tabular}




\section{NON-CURRENT/CAPITAL NON-DEPRECIABLE INVENTORY (NON-DEPRECIABLE PROPERTY INVENTORY)}

Entries should include: breeding livestock raised and land ONLY. Calculations should be made at the beginning and end of the year ONLY and transferred to the Financial Statement.

\begin{tabular}{|c|c|c|c|c|c|c|}
\hline \multirow{3}{*}{ DESCRIPTION OF ITEMS OWNED } & \multicolumn{3}{|c|}{ Beginning of Year } & \multicolumn{3}{|c|}{ End of Year } \\
\hline & Date & \multicolumn{2}{|c|}{$1 / 1 / 2012$} & Date & \multicolumn{2}{|c|}{$12 / 31 / 2012$} \\
\hline & $\begin{array}{l}\text { No. of } \\
\text { Units }\end{array}$ & $\begin{array}{c}\text { Value } \\
\text { Per } \\
\text { Unit }\end{array}$ & Total Value & $\begin{array}{l}\text { No. of } \\
\text { Units }\end{array}$ & $\begin{array}{c}\text { Value } \\
\text { Per } \\
\text { Unit }\end{array}$ & Total Value \\
\hline \multicolumn{7}{|l|}{ Enterprise } \\
\hline & & & & & & \\
\hline & & & & & & \\
\hline & & & & & & \\
\hline & & & & & & \\
\hline & & & & & & \\
\hline & & & & & & \\
\hline & & & & & & \\
\hline & & & & & & \\
\hline & & & & & & \\
\hline & & & & & & \\
\hline & & & & & & \\
\hline & & & & & & \\
\hline & & & & & & \\
\hline & & & & & & \\
\hline TOTALS FOR ENTERPRISE & & & 0 & & & 0 \\
\hline Enterprise & & & & & & \\
\hline & & & & & & \\
\hline & & & & & & \\
\hline & & & & & & \\
\hline & & & & & & \\
\hline & & & & & & \\
\hline & & & & & & \\
\hline & & & & & & \\
\hline & & & & & & \\
\hline & & & & & & \\
\hline & & & & & & \\
\hline & & & & & & \\
\hline TOTALS FOR ENTERPRISE & & & 0 & & & 0 \\
\hline GRAND TOTAL & & & 0 & & & 0 \\
\hline
\end{tabular}




\section{NON-CURRENT/CAPITAL DEPRECIABLE INVENTORY (DEPRECIABLE PROPERTY INVENTORY)}

Entries should include items that will be around more than one year, such as equipment, machinery, trucks, breeding or draft animals, perennial crops, trees, vines, and buildings. Purchase of these items must not be recorded in the journal. Items should be listed on this page at the time purchased (or time received in trade or as a gift). Calculations should be made at the beginning and end of the year ONLY and transferred to the Financial Slalement. When an item is first purchased, you must take EXACTLY one-half of a year's annual depreciation against that item during the year it was purchased regardless of when during the year the purchase was transacted. When an item is sold or traded, take EXACTLY one-half year's annual deprecialion against that item during the year in which it was sold or traded. All numerical entries should be rounded to the nearest whole dollar. Do NOT record decimals or cents anywhere on this page.

Date

$1 / 1 / 2012$

Description

\begin{tabular}{|l|l|l}
\hline Enterprise & Market Lamb
\end{tabular}
Date $12 / 31 / 2012$

\begin{tabular}{|c|c|c|c|c|c|l|l|c|}
\hline Col. (1) & Col. (2) & $\begin{array}{c}\text { Col. } \\
(3)\end{array}$ & $\begin{array}{c}\text { Col. } \\
(4)\end{array}$ & Column (5) & Column (6) & Column (7) & \multicolumn{2}{|c|}{ Assets Sold } \\
\hline $\begin{array}{c}\text { Date of } \\
\text { Purchase }\end{array}$ & $\begin{array}{c}\text { Basis } \\
\text { (cost) }\end{array}$ & $\begin{array}{c}\text { Class } \\
\text { (Years) }\end{array}$ & $\%$ & $\begin{array}{c}\text { Book Value } \\
\text { Beginning of } \\
\text { Year }\end{array}$ & $\begin{array}{c}\text { Depreciation } \\
\text { this Year }\end{array}$ & $\begin{array}{c}\text { Book Value } \\
\text { End of Year }\end{array}$ & Sale Price & $\begin{array}{c}\text { Capital } \\
\text { Gain or } \\
\text { Loss }\end{array}$ \\
\hline
\end{tabular}

\begin{tabular}{|l|l|l|l|l|l|l|l|l|l|}
\hline & & & & & & & & & \\
\hline
\end{tabular}


NON-CURRENT/CAPITAL DEPRECIABLE INVENTORY

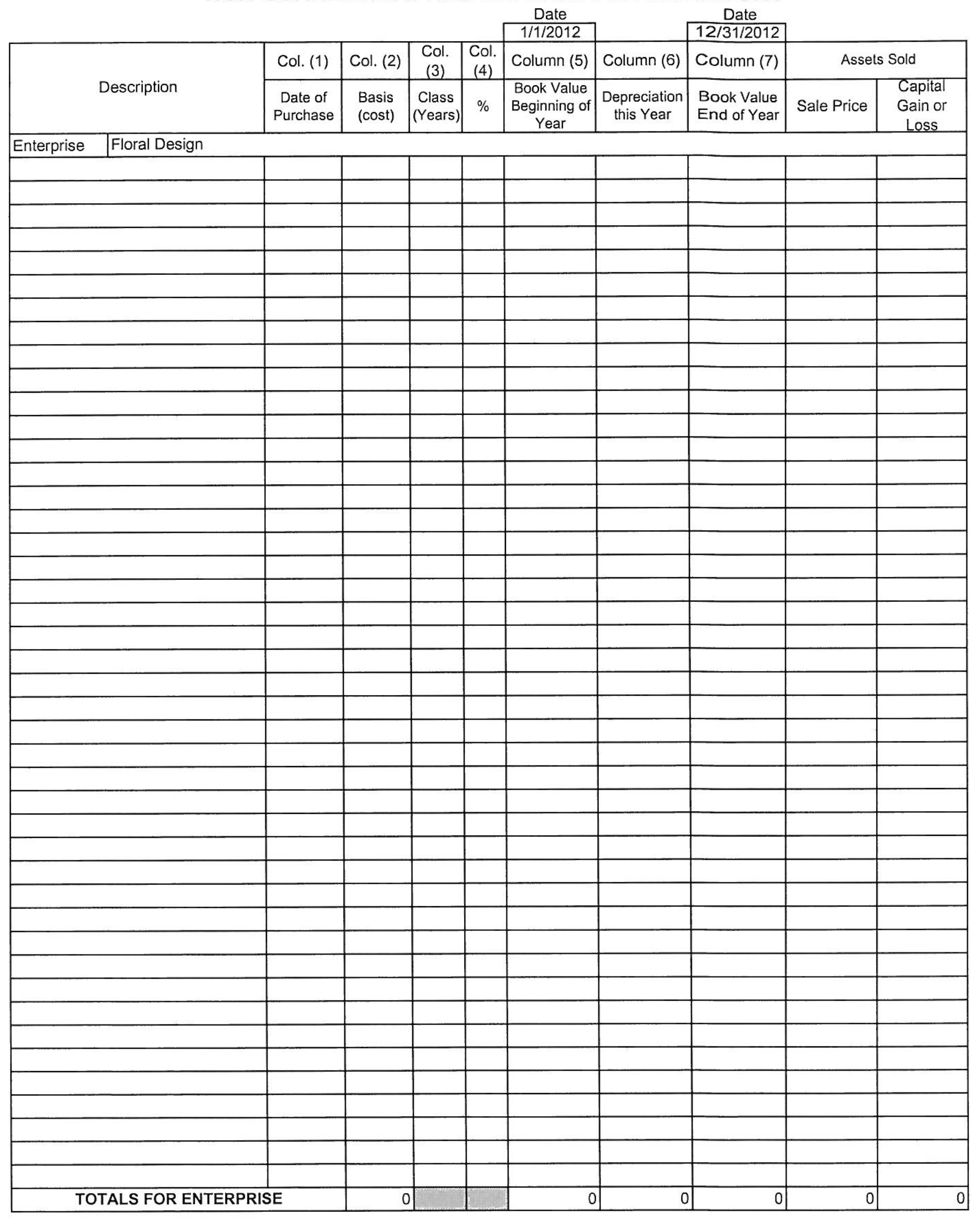


NON-CURRENT/CAPITAL DEPRECIABLE INVENTORY

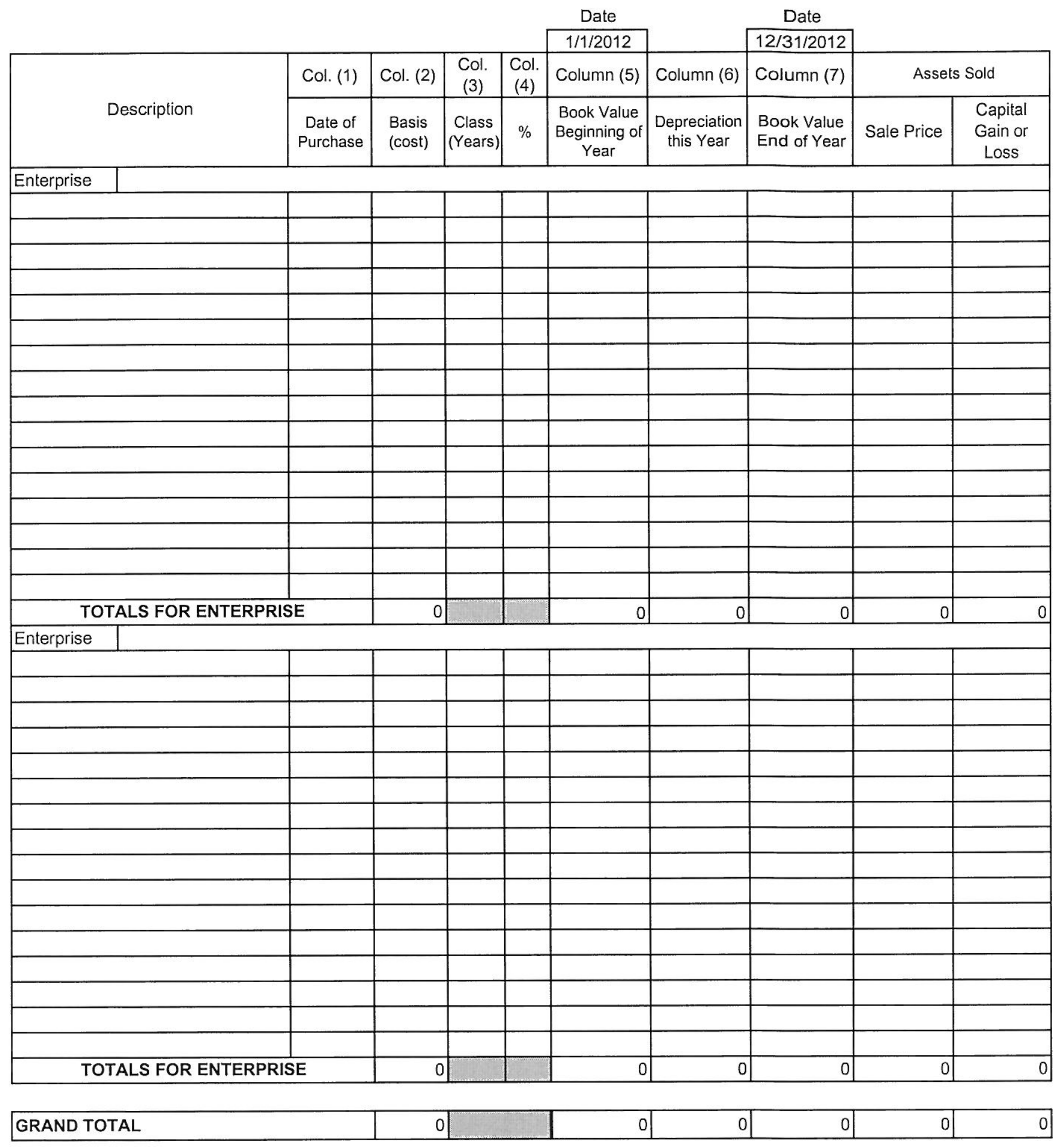




\section{FINANCIAL STATEMENT}

\begin{tabular}{|l|c|c|}
\hline \multicolumn{1}{|c|}{ ASSETS } & $\begin{array}{c}\text { Beginning of } \\
\text { Year } \\
01 / 01 / 12\end{array}$ & End of Year \\
& & $12 / 31 / 12$ \\
\hline $1 \quad$ Enterprise Assets & 717.75 & 1712.60 \\
\hline a) Cash on hand or in the bank earned from SAE enterprises & & \\
\hline b) Enterprise Accounts Receivable & & \\
\hline c) Value of Current/Operating Inventory & & \\
\hline d) Value of Non-Current/Capital Non-Depreciable Inventory & 717.75 & 1712.60 \\
\hline e) Value of Non-current/Capital Depreciable Inventory & \\
\hline TOTAL ENTERPRISE ASSETS & 200.00 & 200.00 \\
\hline 3 Personal Assets & & \\
\hline $\begin{array}{l}\text { a) Cash on hand or in the bank earned from non-SAE enterprises } \\
\text { sources }\end{array}$ & & \\
\hline b) & & \\
\hline c) & & \\
\hline d) & & 200.00 \\
\hline e) & 917.75 & 1912.60 \\
\hline TOTAL PERSONAL ASSETS & & \\
\hline TOTAL ASSETS & & \\
\hline
\end{tabular}

\section{LIABILITIES}

$6 \quad$ Enterprise Liabilities

a) Enterprise Loan Payments, "Balanced Owed"

b) Enterprise Accounts Payable

7 TOTAL ENTERPRISE LIABILITIES

8 Personal Liabilities

a)

b)

c)

d)

9 TOTAL PERSONAL LIABILITIES

10 TOTAL LIABILITIES

\section{NET WORTH}

11 ENTERPRISE NET WORTH (line 2 minus line 7)

12 PERSONAL NET WORTH (line 4 minus line 9)

13 TOTAL NET WORTH (line $11+$ line 12)

\begin{tabular}{|r|r|}
\hline 717.75 & 1712.60 \\
\hline 200.00 & 200.00 \\
\hline 917.75 & 1912.60 \\
\hline
\end{tabular}


INCOME SUMMARY for year ending December 31, 2012

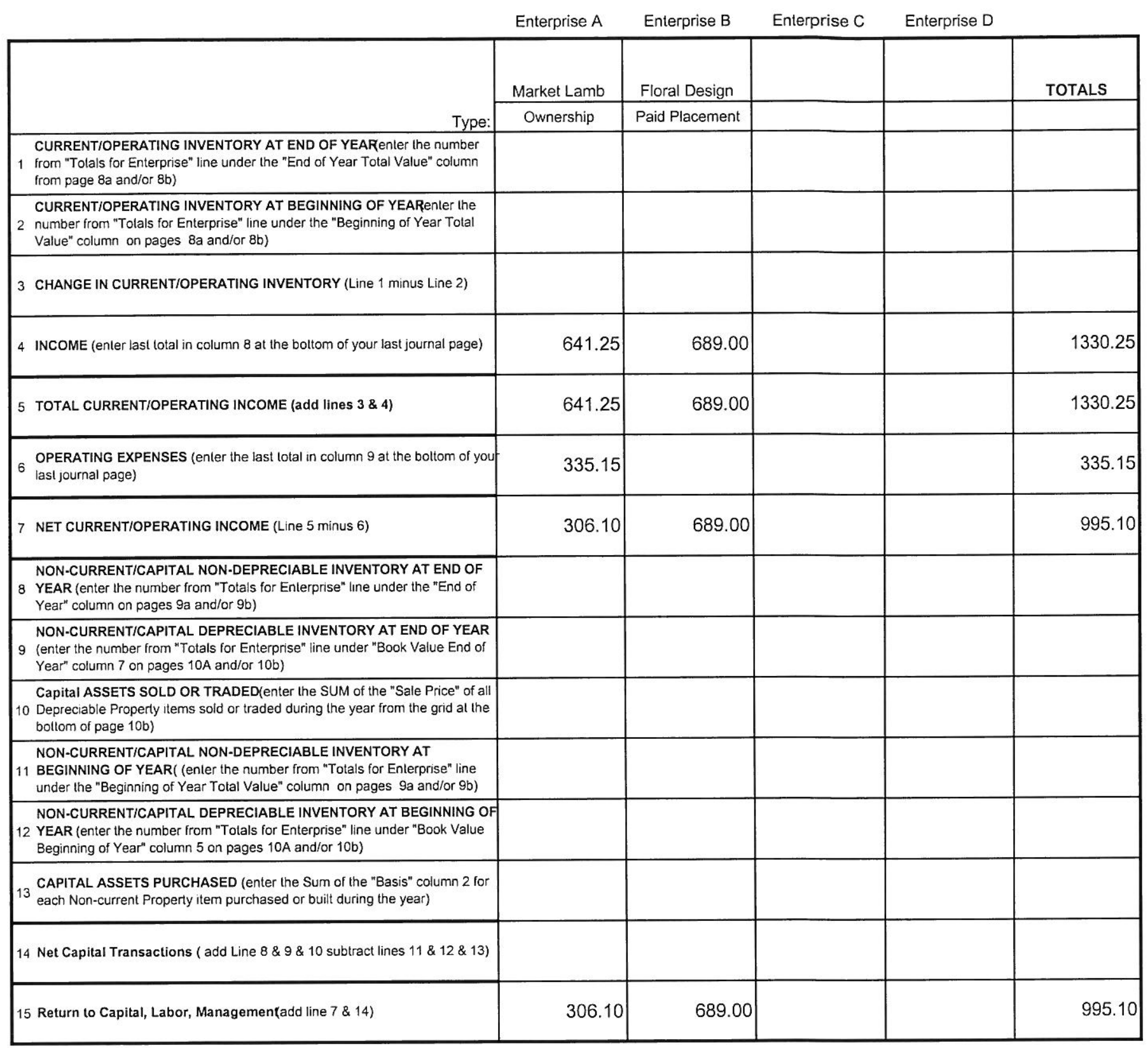

SUMMARY INFORMATION:

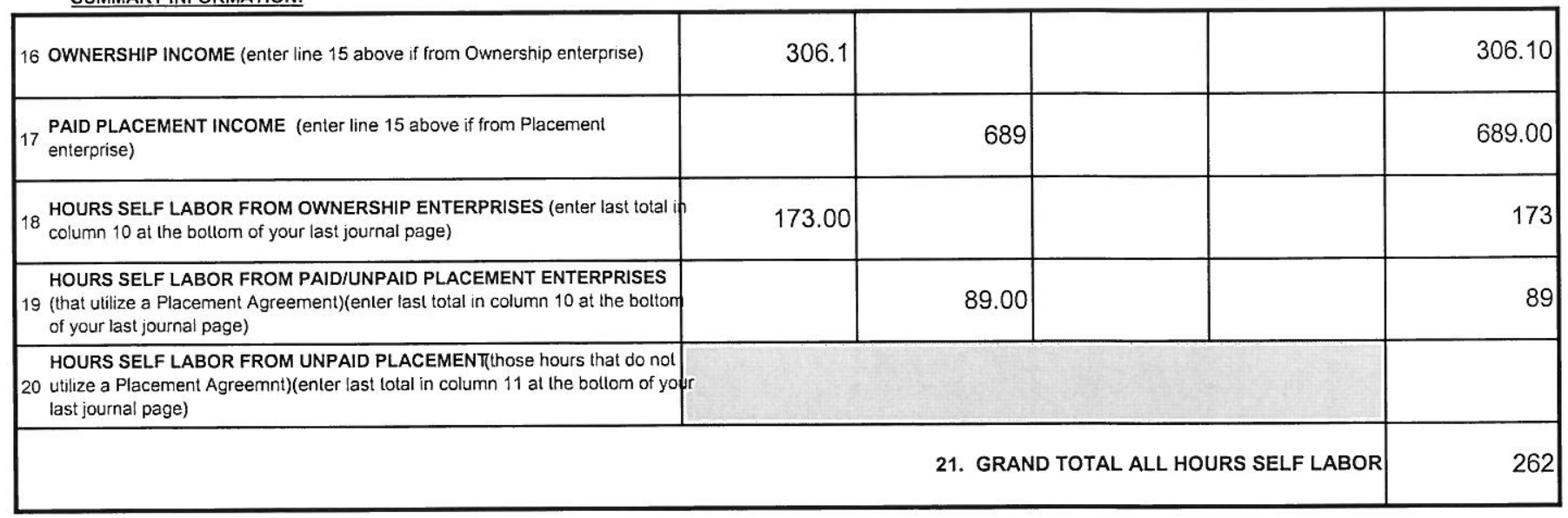




\section{FFA ACTIVITIES}

\section{A. Degrees Held in the FFA}

Enter date ONLY for degree earned during the year covered by this record book.

\begin{tabular}{|l|l|}
\hline \multicolumn{1}{|c|}{ Degrees } & Date Elected \\
\hline Greenhand FFA Degree & \\
\hline Chapter FFA Degree & \\
\hline State FFA Degree & \\
\hline
\end{tabular}

\section{B2. Parliamentary Proficiency}

During the year covered by this record book the student successfully passed a written examination, demonstrating proficiency in parliamentary law, under the supervision of the local agriculture instructor.

Date Examination Passed Instructor's Initials

\section{B1. Progress in Developing Parliamentary Skills}

Instructions: List here only those procedures of parliamentary law which you have never before listed in the previous record book and which you performed to the satisfaction of your chapter advisor this year.

\begin{tabular}{|l|l|c|c|}
\hline Date & $\begin{array}{l}\text { Procedure } \\
\text { Performed }\end{array}$ & $\begin{array}{c}\text { Where Performed } \\
\text { (i.e.classroom, ASB, FFA } \\
\text { Contest, Etc.) }\end{array}$ & $\begin{array}{c}\text { Advisor's } \\
\text { Initials }\end{array}$ \\
\hline & & & \\
\hline & & & \\
\hline & & & \\
\hline & & & \\
\hline & & & \\
\hline & & & \\
\hline & & & \\
\hline & & & \\
\hline & & & \\
\hline
\end{tabular}

\section{Speaking Engagements Promoting Agriculture and/or the Future Farmers of America (FFA)}

\begin{tabular}{|c|c|c|c|c|c|}
\hline No. & Date & $\begin{array}{c}\text { Formal speech } \\
\text { or Discussion } \\
\text { Leader (list } \\
\text { which one) }\end{array}$ & Group Speaking to/Leading Discussion with & Title/Topic & $\begin{array}{c}\text { Length } \\
\text { in } \\
\text { minutes }\end{array}$ \\
\hline 1 & $12 / 4$ & Speech & Leadership & Substainable Agriculture & 7 \\
\hline 2 & & & & & \\
\hline 3 & & & & & \\
\hline
\end{tabular}

D1. FFA Offices Held (List offices for which you began your service as an officer during the year covered by the book

\begin{tabular}{|c|c|c|c|c|c|c|}
\hline \multirow{2}{*}{ School Year } & Office & \multicolumn{3}{|c|}{ Indicate Level } \\
\cline { 4 - 7 } & & & Chapter & Section & Region & State \\
\hline & & & & & \\
\hline & & & & & \\
\hline
\end{tabular}

D2. Service on FFA Committees - List committees which began to function during the period covered by this book.

\begin{tabular}{|c|c|c|c|c|c|c|c|c|c|}
\hline & \multicolumn{2}{|c|}{ Chairman } & \multicolumn{5}{|c|}{ Indicate Level } & \multirow{2}{*}{ Responsibilities } \\
\hline & Yes & No & Chapter Section & Region & State & Nat'l & \\
\hline Awards Banquet & $\mathrm{X}$ & & $\mathrm{X}$ & & & & & Decorations, Script and Program \\
\hline & & & & & & & & \\
\hline & & & & & & & & \\
\hline & & & & & & & & \\
\hline & & & & & & & & \\
\hline
\end{tabular}




\section{FFA ACTIVITIES (Continued)}

E. Chapter Level Activities - List each FFA Chapter-level activity in which you participated in this year which fits under no other section on pages 13-16

\begin{tabular}{|c|c|c|}
\hline Date & Activity & Placing or Responsibility \\
\hline $01 / 18 / 12$ & FFA Movie Night Meeting & Attended \\
\hline $02 / 22 / 12$ & FFA Basketball Tourney(FFA Week) & Participated \\
\hline $02 / 23 / 12$ & Ag Olympics(FFA Week) & Participated \\
\hline $02 / 24 / 12$ & Kiss The Pig (FFA Week) & Participated \\
\hline 03/08/12 & FFA Take Out BBQ \#3 & Participated \\
\hline $03 / 20 / 12$ & FFA Bowling Tourney Meeting & Attended \\
\hline $04 / 17 / 12$ & FFA Burrito Bingo Meeting & Attended \\
\hline $05 / 10 / 12$ & FFA Take Out BBQ \#4 & Attended \\
\hline $05 / 11 / 12$ & Atwater FFA Spring Plant Sale & Attended \\
\hline $05 / 12 / 12$ & Atwater FFA Spring Plant Sale & Attended \\
\hline $05 / 17 / 12$ & Atwater FFA Awards Banquet & Participated \\
\hline $09 / 06 / 12$ & FFA Homecoming Float Meeting & Participated \\
\hline $09 / 19 / 12$ & FFA Take Out BBQ \#1 & Participated \\
\hline & & \\
\hline & & \\
\hline & & \\
\hline & & \\
\hline & & \\
\hline & & \\
\hline & & \\
\hline & & \\
\hline & & \\
\hline & & \\
\hline & & \\
\hline & & \\
\hline & & \\
\hline & & \\
\hline & & \\
\hline & & \\
\hline & & \\
\hline & & \\
\hline & & \\
\hline
\end{tabular}




\section{FFA ACTIVITIES (Continued)}

F. FFA Activities above the Chapter Level - List all FFA Activities occurring above the chapter level in which you participated this year which you have NOT recorded in any other section on pages 13-16.

\begin{tabular}{|c|c|c|c|c|c|c|}
\hline \multirow[b]{2}{*}{ Date } & \multirow[b]{2}{*}{ Activity } & \multicolumn{4}{|c|}{ Indicate Level } & \multirow[b]{2}{*}{ Placing or Responsibility } \\
\hline & & Section & Region & State & Nat'l & \\
\hline $02 / 04 / 12$ & Arbuckle FFA Field Day & & & $x$ & & Participated \\
\hline $02 / 17 / 12$ & Modesto MFE/ALA & & $x$ & & & Attended \\
\hline $02 / 18 / 12$ & Modesto MFE/ALA & & $x$ & & & Attended \\
\hline $03 / 03 / 12$ & UC Davis FFA Field Day & & & $x$ & & Participated \\
\hline $03 / 10 / 12$ & Chico State FFA Field Day & & & $x$ & & Participated \\
\hline $03 / 24 / 12$ & CRC FFA Field Day & & & $x$ & & Participated \\
\hline $03 / 31 / 12$ & MJC FFA Field Day & & & $\mathrm{x}$ & & Participated \\
\hline $04 / 14 / 12$ & \multicolumn{2}{|l|}{ Reedley College FFA Field Day } & & $x$ & & Participated \\
\hline $04 / 21 / 12$ & Fresno FFA Field Day & & & $x$ & & Participated \\
\hline $06 / 11 / 12$ & Merced County Fair(6/11-17/20 & $x$ & & & & Participated \\
\hline & & & & & & \\
\hline & & & & & & \\
\hline & & & & & & \\
\hline & & & & & & \\
\hline & & & & & & \\
\hline & & & & & & \\
\hline & & & & & & \\
\hline & & & & & & \\
\hline & & & & & & \\
\hline & & & & & & \\
\hline & & & & & & \\
\hline & & & & & & \\
\hline & & & & & & \\
\hline & & & & & & \\
\hline & & & & & & \\
\hline & & & & & & \\
\hline & & & & & & \\
\hline & & & & & & \\
\hline & & & & & & \\
\hline & & & & & & \\
\hline & & & & & & \\
\hline & & & & & & \\
\hline
\end{tabular}


COMMUNITY SERVICE AND SCHOOL ACTIVITIES

\begin{tabular}{|c|c|c|c|c|c|}
\hline No. & Date & Activity & School & Community Service & $\begin{array}{c}\text { Hours of } \\
\text { Community } \\
\text { Service } \\
\end{array}$ \\
\hline 1 & $1 / 31-12 / 31$ & Link Crew & & $x$ & 94 \\
\hline 2 & $1 / 31-6 / 1$ & Atwater Tennis Team & $x$ & & \\
\hline 3 & $05 / 12 / 13$ & Prom & $\mathrm{x}$ & & \\
\hline 4 & $08 / 31 / 13$ & Back to School Dance & $x$ & & \\
\hline 5 & $08 / 18 / 13$ & Atwater Beautification Day & & $\mathrm{x}$ & 2 \\
\hline 6 & $12 / 19 / 13$ & Canned Food Drive & & $x$ & 2 \\
\hline 7 & & & & & \\
\hline 8 & & & & & \\
\hline 9 & & & & & \\
\hline 10 & & & & & \\
\hline 11 & & & & & \\
\hline 12 & & & & & \\
\hline 13 & & & & & \\
\hline 14 & & & & & \\
\hline 15 & & & & & \\
\hline 16 & & & & & \\
\hline 17 & & & & & \\
\hline 18 & & & & & \\
\hline 19 & & & & & \\
\hline 20 & & & & & \\
\hline 21 & & & & & \\
\hline 22 & & & & & \\
\hline 23 & & & & & \\
\hline 24 & & & & & \\
\hline 25 & & & & & \\
\hline 26 & & & & & \\
\hline 27 & & & & & \\
\hline 28 & & & & & \\
\hline 29 & & & & & \\
\hline 30 & & & & & \\
\hline 31 & & & & & \\
\hline
\end{tabular}

Total of Community Service Hours 


\section{Liquid Measure}

1 tablespoon (level) $=1 / 2$ fluid ounce

3 teaspoons $($ level $)=1$ tablespoon $($ level $)$

2 tablespoons $($ level $)=1$ fluid ounce

8 fluid ounces $=1 / 2$ pint $=1$ cup

2 cups $=1$ pint

2 pints $=1$ quart

4 quarts $=1$ gallon

$71 / 2$ gallons $=1$ cubic foot

1 U.S. gallon $=231$ cubic inches

\section{Solid or Cubic Measure}

1728 cubic inches $=1$ cubic foot

27 cubic feet $=1$ cubic yard

46,656 cubic inches $=1$ cubic yard

128 cubic feet $=1$ cord

4 feet $\times 4$ feet $\times 8$ feet $=1$ cord

1 foot $x 1$ foot $x 1$ inch = 1 board foot

43,560 cubic feet of water $=1$ acre foot

\section{Unit Abbreviations}

$\begin{array}{ll}\text { Acre } & \text { ac } \\ \text { Bale } & \text { bl } \\ \text { Board foot } & \text { bdft } \\ \text { Box } & \text { bx } \\ \text { Cubic } & \mathrm{cu} \\ \text { Cubic Centimeter } & \mathrm{cc} \\ \text { Cubic foot } & \mathrm{cuft} \\ \text { Cubic yard } & \mathrm{cuyd} \\ \text { Dozen } & \mathrm{dz} \\ \text { Each } & \mathrm{ea} \\ \text { Gallon } & \mathrm{gal} \\ \text { Hour } & \mathrm{hr} \\ \text { Hundredweight } & \mathrm{cwt} \\ \text { Liter } & \mathrm{l} \\ \text { Meter } & \mathrm{m} \\ \text { Milliliter } & \mathrm{ml} \\ \text { Month } & \mathrm{mo} \\ \text { Pair } & \mathrm{pr} \\ \text { Pound } & \mathrm{lb} \\ \text { Sack } & \mathrm{sack} \\ \text { Weight } & \text { wt } \\ \text { Yard } & \text { yd }\end{array}$

\section{Square or Surface Measure}

144 square inches $=1$ square foot

9 square feet $=1$ square yard

43,560 square feet $=1$ acre

640 acres $=1$ square mile

36 sections $=1$ township

\section{Linear Measure}

12 inches $=1$ foot

3 feet $=1$ yard

1760 yards $=1$ mile

5280 feet $=1$ mile

\section{Avoirdupois Weight}

16 ounces $=1$ pound $(\mathrm{lb})$

100 pounds $=1$ hundredweight (cwt)

20 hundredweight $=1$ ton

2000 pounds $=1$ ton

\section{Metric Conversion}

1 pound $=.454$ kilogram

1 ounce $=28.35$ grams

1 gallon $=3.785$ liters

$1 \mathrm{fl} . \mathrm{Oz} .=29.573 \mathrm{ml}$

1 mile $=1.609$ kilometers

1 yard $=.9144$ meters

$1 \mathrm{cc}=1 \mathrm{ml}=.061 \mathrm{cu}$ inch 


\section{DRESSING PERCENTAGES/FEED CONVERSION}

\begin{tabular}{|ccc|}
\hline Livestock & Average Percentage & \multicolumn{1}{c|}{ Conversion Rates } \\
\hline Cattle & $62 \%$ & $6-7$ pounds of feed to 1 pound of gain \\
Sheep & $52 \%$ & 5 to 6 pounds of feed to 1 pound of gain \\
Hogs & $72 \%$ & 3 pounds of feed to 1 pound of gain \\
\hline
\end{tabular}

\section{LIVESTOCK BREEDING CHART}

\begin{tabular}{|c|c|c|c|c|c|c|c|}
\hline \multirow[t]{2}{*}{ Animal } & \multirow{2}{*}{$\begin{array}{c}\text { Best age } \\
\text { to Breed } \\
\text { (Mo.) }\end{array}$} & \multicolumn{5}{|c|}{ Heat Period } & \multirow{2}{*}{$\begin{array}{c}\text { Length of } \\
\text { Gestation } \\
\text { Period (days) }\end{array}$} \\
\hline & & Duration & Repeats & $\begin{array}{l}\text { Occurs } \\
\text { After } \\
\text { Delivery }\end{array}$ & $\begin{array}{c}\text { Time to } \\
\text { Breed after } \\
\text { Delivery }\end{array}$ & $\begin{array}{c}\text { Average Body } \\
\text { Temp. } \\
\text { (dearees F.) }\end{array}$ & \\
\hline Mare & 48 & 3-7 days & 18-21 days & 3-17 days & 9th day & 100.5 & 340 \\
\hline Cattle & $15-24$ & $12-18$ hours & 18-21 days & 28 days & $8-12$ weeks & 101.5 & 283 \\
\hline Sow & $8-10$ & 1-3 days & 18-21 days & 3-9 days & $81 / 2$ weeks & 102.6 & 114 \\
\hline Ewe & $18-20$ & $1-2$ days & $13-19$ days & 6-7 mo. & $\begin{array}{l}\text { Summer } \\
\text { and Fall }\end{array}$ & 102.3 & 150 \\
\hline
\end{tabular}

\section{DEPRECIATION SCHEDULE}

\begin{tabular}{|lcll|}
\hline Autos \& Trucks (less than 13,000 5 years & Fences (Agricultural) & 10 years \\
Computers & 5 years & Goats and Sheep (Breeding) & 5 years \\
Cattle (Dairy or Breeding) & 7 years & Hogs (Breeding) & 3 years \\
Farm Buildings & 25 years & Horticulture Structures & 15 years \\
Farm Machinery \& Equipment & 10 years & Trees/Vines & 10 years \\
& & & \\
For all other items - see IRS Publication - Farmers Tax Guide & \\
\hline
\end{tabular}




\section{GREENHAND DEGREE REQUIREMENTS CHECKLIST}

\section{NAME}

1. Be regularly enrolled in a vocational education course for an agricultural

2. Have satisfactory and acceptable plans for a program of supervised agricultural experience.

3. Learn and explain the FFA Creed.

4. Learn and explain the FFA Motto

5. Learn and explain the FFA Salute.

6. Learn and explain the FFA Mission Statement.

7. Describe the FFA emblem.

8. Describe the FFA colors.

9. Describe the FFA symbols.

10 Explain the proper use of the FFA jacket.

11. Have satisfactory knowledge of the history of the organization.

12. Know the duties and responsibilities of FFA members.

13. Personally own or have access to the Official FFA Manual.

14. Submit written application for the degree for chapter records

\begin{tabular}{l}
\hline Applicant Signature \\
\hline Agricultural Teacher 's Signature \\
\hline Date Completed
\end{tabular}

\footnotetext{
* For specific Degree requirements refer to the California State FFA and National FFA Constitutions.
} 
1. Must have held the degree of Greenhand for at least one complete semester of instruction. (A member may not receive both the Greenhand and Chapter FFA Dearees during the same academic vear).

2. Have a record of satisfactory participation in the activities of the local chapt

3. Have satisfactorily completed at least one year of systematic instruction in agriculture education, at or above the ninth grade level.

4. Have in operation an approved supervised farming and/or other supervised agricultural experience program.

5. Have developed plans for continued growth and improvement in a supervised farming and/or other supervised agricultural experience

6. Be regularly enrolled in an agriculture education class.

7. Be familiar with the purposes and programs of activities of the state association and national organization.

8. Be familiar with the provisions of the constitution of the local chapter.

9. Be familiar with Parliamentary Procedure.

10. Must have led a group discussion for fifteen minutes.

11. Must have earned at least $\$ 150$ by his/her own efforts from his/her supervised farming and/or other supervised agricultural experience program and have the $\$ 150$ productively invested or deposited in a bank, or have worked 100 hours on his/her SAEP in excess of scheduled class

12. Have a 2.0 scholastic record in an agricultural course.

13. Participate in activities for community improvement as evidenced by participating in at least two distinctly different activities, to the extent of spending at least 10 hours of personal time, which you seek to serve and/or improve the quality of life in the local community.

\section{Applicant Signature}

Agricultural Teacher 's Signature

\section{Date Completed}

* For specific Degree requirements refer to the California State FFA and National FFA Constitutions. 


\section{STATE DEGREE REQUIREMENTS CHECKLIST}

NAME

1. Must have held the Chapter FFA Degree for at least one year immediately preceding application for the State FFA Degree.

2. Have been an active member of the FFA for at least two years preceding application for the State FFA Degree.

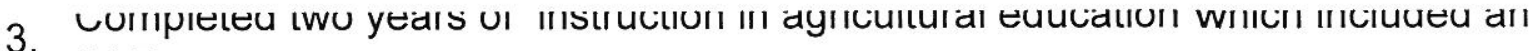
SAE program.

4 Must be regularly enrolled in an agriculture education class at the secondary education level, an agriculture course at the post-secondary education level, or be a graduate of a secondary agriculture education program who is engaged in an agricultural occupation.

5 Worked for a minimum of 500 hours, in excess of scheduled class time, on his/her Supervised Agricultural Experience Program.

6a. Earned by their own efforts from an agricultural enterprise or other agriculturally related work at least $\$ 1000$.

or

$6 \mathrm{~b}$. have an investment of at least $\$ 2,000$ in depreciable property inventory. or

$6 c$. Earned at least $\$ 750$ and have enough unpaid hours in excess of the 500 hours minimum required, so when the excess unpaid hours added to the dollar amount earned the sum equals at least 1000 .

7. Deposited in a bank or otherwise productively invested at least $\$ 1,000.00$.

8. Has performed ten procedures or passed a written test on parliamentary law.

9. Given a six-minute speech OR lead a group discussion for forty-minutes on a topic relating to agriculture or the FFA.

10. Served as an officer, committee chairperson, or participating member of a committee. 
11. Participated in at least five distinctly different FFA activities at the chapter level.

12. Have participated in at least five FFA activities above the chapter level.

13. Participated in at least two distinctly different non-FFA school activities which are conducted outside of normal class time.

14. Participated in activities for community improvement as evidenced by participating in at least two distinctly different activities, to the extent of spending at least 25 hours of personal time.

15. Familiar with the provisions of the State and National Constitutions of the FFA.

16. Have a 2.0 scholastic record.

17. Have participated in the planning and completion of the Chapter Program of Activities.

18. Submit written records of achievement based on the member's own entries in the California Agricultural Education Record Book.

19. Must receive seventy percent $(70 \%)$ of the possible points on his/her Record Book score.

\begin{tabular}{l}
\hline Applicant Signature \\
\hline Agricultural Teacher 's Signature \\
\hline Date Completed
\end{tabular}

* For specific Degree requirements refer to the California State FFA and National FFA Constitutions. 
NAME

1. Have received the State FFA Degree.

2. Have been an active member for the past three years (36 months).

3. Have a record of satisfactory participation in FFA activities on the chapter level.

4. Have a record of satisfactory participation in FFA activities on the state level.

5. Have satisfactorily completed the equivalent of at least three years (540 hours) of systematic secondary school instruction in an agricultural education program or have completed the program of agricultural education offered in the school last attended.

6. Have graduated from high school at least 12 months prior to the national convention at which the degree is to be granted.

7. Have in operation an outstanding supervised agricultural experience program through which a member has exhibited comprehensive planning, managerial and financial expertise.

8. Have maintained records to substantiate the SAEP.

9. Have earned and productively invested at least $\$ 7,500$ or have earned and productively invested at least $\$ 1,500$ and worked 2,250 hours in excess of scheduled class time. Any combination of hours times a factor of 3.33 plus dollars must be equal to, or greater than the number 9,000 . Hours used for the purpose of producing earnings reported as productively invested income shall not be duplicated as hours of credit to meet the minimum requirements for the degree. (Note: starting in 2015, the dollar requirement changes to $\$ 10,000$, productively invested changes to $\$ 2,000$; and the factor changes to 3.56 to equal 10,000)

10. Have a record of outstanding leadership abilities and community involvement and have achieved a high school scholastic record of $\mathrm{C}$ or better as certified by the principal or superintendent.

11. Have participated in at least 50 hours in at least three different community service activities (25 more than State Degree). These hours are in addition to and cannot duplicated as paid or unpaid SAE hours.

\section{Applicant Signature}

Agricultural Teacher 's Signature

Date Completed

* For specific Degree requirements refer to the California State FFA and National FFA Constitutions. 


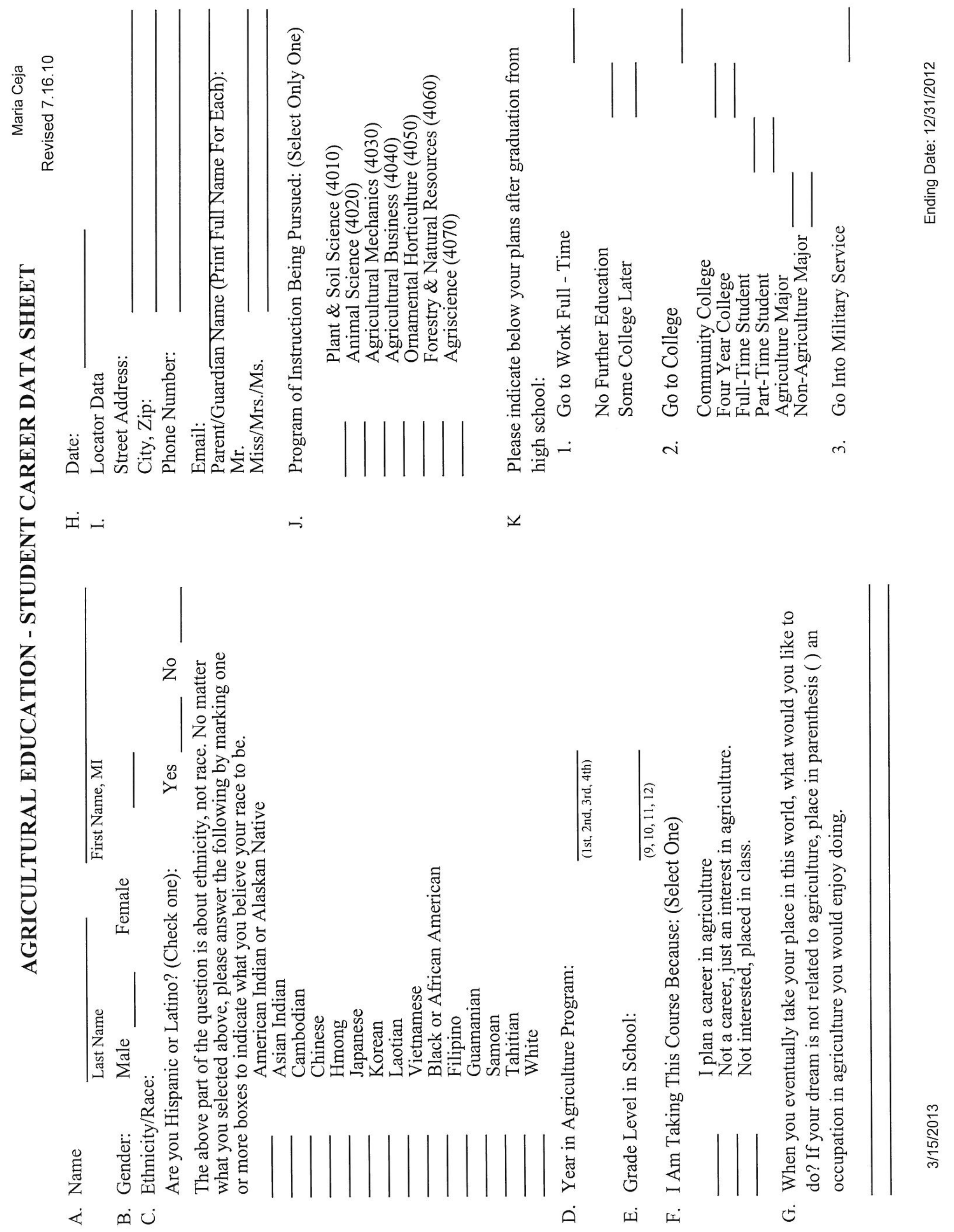




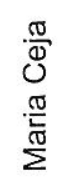

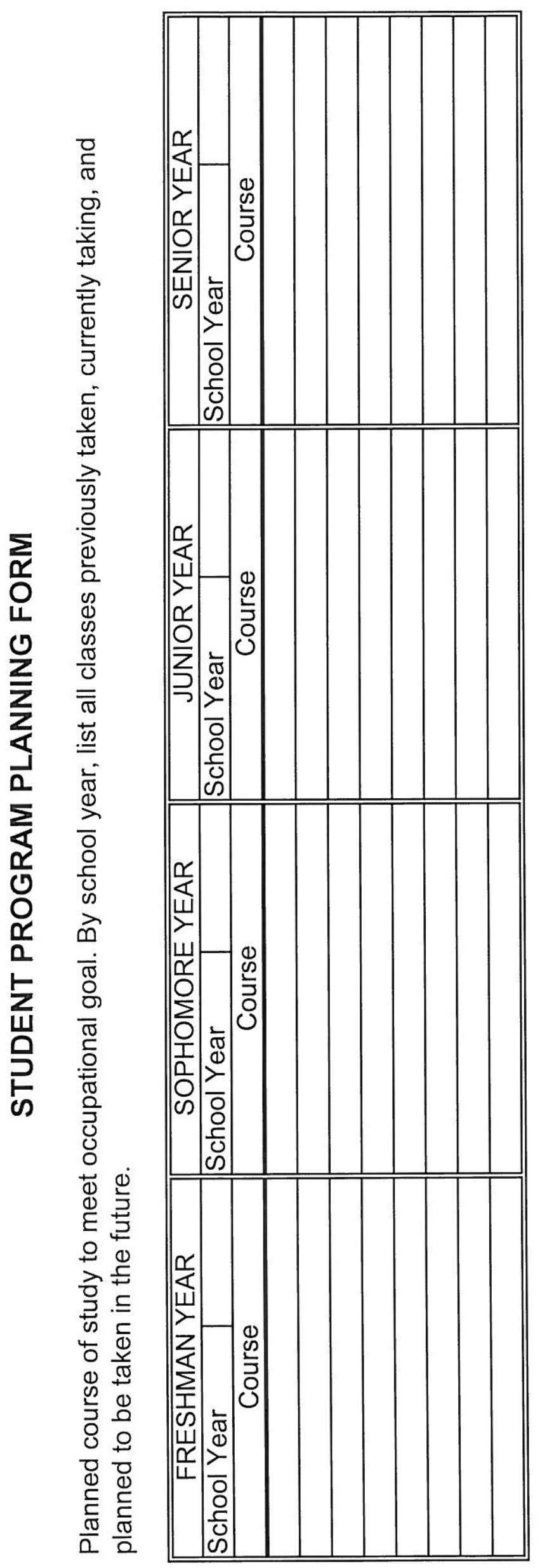

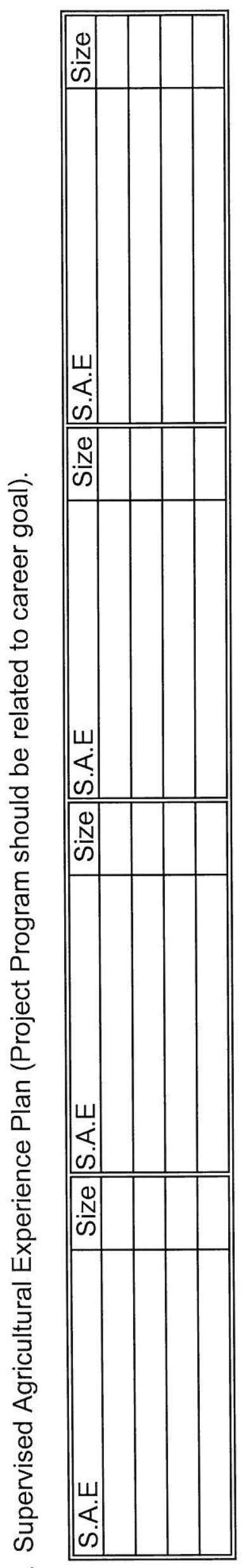

$\Sigma$

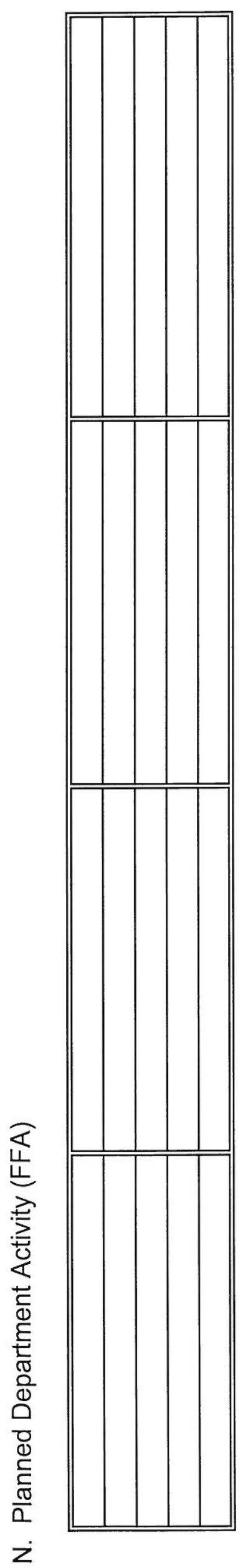

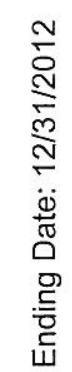

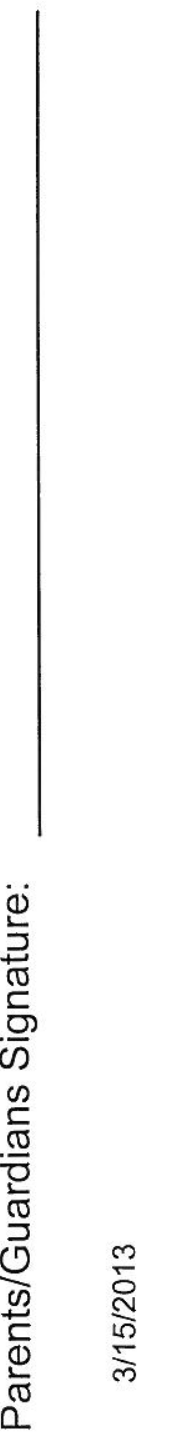




\section{$\underline{\mathbf{C}}$ \\ Course Outlines}

The current course outlines for Ag Biology and Floral Design for this school year at Atwater High School is attached. Other course outlines that are currently offered are available upon request.

\section{Attached you will find:}

- Ag Biology Course Outline

- Floral Design Course Outline 
I. COURSE TITLE AND LEVEL

Department

Course Length

Credit

Prerequisites

Grade Level
AG BIOLOGY

Agriculture

Two Semesters

Life Science (UC/CSU)

None

9-12

\section{BRIEF DESCRIPTION}

To meet the challenges of the future, the scientific community has recognized the importance of uniting efforts in understanding and caring for life and its systems. This course will explain how scientists have found it necessary to share their research across disciplines and try to comprehend life's complexities based on biological studies, including how it is affected by human activities. It brings together the agriculture interactions that occur in the living world, and provides the learner with a solid understanding of the processes that take place within all areas of life on Earth. In addition, learners will gain experience in leadership development, SAE projects, and career exploration in the area of agriculture.

\section{MAJOR GOALS AND OBJECTIVES}

- Students will understand that the fundamental life processes of plants and animals depend on a variety of chemical reactions that occur in specialized areas of the organism's cells.

- Students will understand that mutation and sexual reproduction lead to genetic variation in a population.

- Students will understand that a multicellular organism develops from a single zygote, and its phenotype depends on its genotype, which is established at fertilization.

- Students will understand that genes are a set of instructions encoded in the DNA sequence of each organism that specify the sequence of amino acids in proteins characteristic of that organism.

- Students will understand that the genetic composition of cells can be altered by incorporation of exogenous DNA into the cells.

- Students will understand that stability in an ecosystem is a balance between competing effects.

- Students will understand that the frequency of an allele in a gene pool of a population depends on many factors and may be stable or unstable over time.

- Students will understand that evolution is the result of genetic changes that occur in constantly changing environments.

- Students will understand that as a result of the coordinated structures and functions of organ systems, the internal environment of the human body remains relatively stable (homeostatic) despite changes in the outside environment.

- Students will understand that organisms have a variety of mechanisms to combat disease. 
- Students will understand that scientific progress is made by asking meaningful questions and conducting careful investigations.

\section{CAREER PERFORMANCE STANDARDS}

- Students will understand how personal skill development affects employability.

- Students will understand key concepts in group dynamics, conflict resolution, and negotiation.

- Students will exhibit critical thinking skills, logical reasoning, and problem solving.

- Students will understand the principles of effective communication.

- Students will understand career paths and strategies for obtaining employment within their chosen field.

- Student will understand and adapt to changing technology by identifying, learning, and applying new skills to improve job performance.

\section{COURSE OUTLINE}

\section{SEMESTER 1}

1. Classroom Orientation

a. Class rules

b. Grading policy

2. FFA Leadership Development

a. History of the FFA

b. Local chapter, sectional, regional, state, and national organizations

c. FFA emblem and creed

d. FFA jacket, dress code, code of ethics, motto, and salute

e. FFA chapter officer duties

f. Basic principles of parliamentary procedure

3. Supervised Agriculture Experience Project

a. Introduction to SAE projects

b. Getting a project started

c. Long-range SAE plans

d. Introduction to the FFA record book

4. Investigation \& Experimentation

a. Laboratory safety

b. Laboratory tools and equipment

5. The Science of Biology

a. What is Science?

i. What Science is and is not

ii. Evidence Based on Observation

iii. Interpreting the Evidence

iv. Explaining the Evidence

v. A Scientific View of the World

vi. Science and Human Values

b. How Scientists Work 
i. Designing an Experiment

ii. Publishing and Repeating Investigations

iii. When Experiments are Not Possible

iv. How a Theory Develops

c. Studying Life

i. Characteristics of Living Things

ii. Branches of Biology

iii. Biology in Everyday Life

d. Tools and Procedures

i. A Common Measurement System

ii. Analyzing Biological Data

iii. Microscopes

iv. Laboratory Techniques

v. Working Safely in Biology

6. Chemistry of Life

a. The Nature of Matter

i. Atoms

ii. Elements and Isotopes

iii. Chemical Compounds

iv. Chemical Bonds

b. Properties of Water

i. The Water Molecule

ii. Solutions and Suspensions

iii. Acids, Bases, and $\mathrm{pH}$

c. Carbon Compounds

i. The Chemistry of Carbon

ii. Macromolecules

iii. Carbohydrates

iv. Lipids

v. Nucleic Acids

vi. Proteins

d. Chemical Reactions and Enzymes

i. Chemical Reactions

ii. Energy in Reactions

iii. Enzymes

iv. Enzyme Action

7. Cell Structure and Function

a. Life is Cellular

i. The Cell Theory

ii. Basic Cell Structures

iii. Prokaryotes and Eukaryotes

b. Cell Structures

i. Cell Wall

ii. Nucleus

iii. Cytoskeleton

iv. Organelles in the Cytoplasm 
v. Organelle DNA

vi. The Cell as a Factory

vii. Comparing Cells

c. Movement Through the Membrane

i. Cell Membrane

ii. Diffusion

iii. Osmosis

iv. Facilitated Diffusion

v. Active Transport

d. The Diversity of Cellular Life

i. Unicellular Organisms

ii. Multicellular Organisms

iii. Levels of Organization

8. Photosynthesis

a. Energy and Life

i. Autotrophs and Heterotrophs

ii. Chemical Energy and ATP

iii. ATP and Glucose

b. Photosynthesis: An Overview

i. Investigating Photosynthesis

ii. The Photosynthesis Equation

iii. Light and Pigments

c. The Reactions of Photosynthesis

i. Inside a Chloroplast

ii. NADPH

iii. Light-Dependent Reactions

iv. The Calvin Cycle

v. Factors Affecting Photosynthesis

9. Cellular Respiration

a. Chemical Pathways

i. Chemical Energy and Food

ii. Overview of Cellular Respiration

iii. Glycolysis

iv. Fermentation

b. The Krebs Cycle and Electron Transport

i. The Krebs Cycle

ii. Electron Transport

iii. The Totals

iv. Energy and Exercise

v. Comparing Photosynthesis and Cellular Respiration

10. Cell Growth and Division

a. Cell Growth

i. Limits to Cell Growth

b. Cell Division

i. Chromosomes

ii. The Cell Cycle 
iii. Events of the Cell Cycle

iv. Mitosis

v. Cytokinesis

11. Introduction to Genetics

a. The Work of Gregor Mendel

i. Gregor Mendel's Peas

ii. Genes and Dominance

iii. Segregation

b. Probability and Punnett Squares

i. Genetics and Probability

ii. Punnett Squares

iii. Probability and Segregation

iv. Probabilities Predict Averages

c. Exploring Mendelian Genetics

i. Independent Assortment

ii. A Summary of Mendel's Principles

iii. Beyond Dominant and Recessive Alleles

iv. Applying Mendel's Principles

d. Meiosis

i. Chromosome Number

ii. Phases of Meiosis

iii. Gamete Formation

iv. Comparing Mitosis and Meiosis

e. Linkage and Gene Maps

i. Gene Linkage

ii. Gene Maps

SEMESTER 2

12. DNA and RNA

a. DNA

i. Griffith and Transformation

ii. Avery and DNA

iii. The Hershey-Chase Experiment

iv. The Structure of DNA

b. Chromosomes and DNA Replication

i. DNA and Chromosomes

ii. DNA Replication

c. RNA and Protein Synthesis

i. The Structure of RNA

ii. Types of RNA

iii. Transcription

iv. RNA Editing

v. The Genetic Code

vi. Translation

vii. The Roles of RNA and DNA

viii. Genes and Proteins 
d. Mutations

i. Gene Mutations

ii. Chromosomal Mutations

e. Gene Regulation

i. Gene Regulation: An Example

ii. Eukaryotic Gene Regulation

iii. Regulation and Development

13. Genetic Engineering

a. Changing the Living World

i. Selective Breeding

ii. Increasing Variation

b. Manipulating DNA

i. The Tools of Molecular Biology

ii. Using the DNA Sequence

c. Cell Transformation

i. Transforming Bacteria

ii. Transforming Plant Cells

iii. Transforming Animal Cells

d. Applications of Genetic Engineering

i. Transgenic Organisms

ii. Cloning

14. The Human Genome

a. Human Heredity

i. Human Chromosomes

ii. Human Traits

iii. Human Genes

iv. From Gene to Molecule

b. Human Chromosomes

i. Human Genes and Chromosomes

ii. Sex-Linked Genes

iii. X-Chromosome Inactivation

iv. Chromosomal Disorders

c. Human Molecular Genetics

i. Human DNA Analysis

ii. The Human Genome Project

iii. Gene Therapy

iv. Ethical Issues in Human Genetics

15. Darwin's Theory of Evolution

a. The Puzzle of Life's Diversity

i. Voyage of the Beagle

ii. Darwin's Observations

iii. The Journey Home

b. Ideas That Shaped Darwin's Thinking

i. An Ancient, Changing Earth

ii. Lamark's Theory of Evolution

iii. Population Growth 
c. Darwin Presents His Case

i. Publication of On the Origin of Species

ii. Natural Variation and Artificial Selection

iii. Evolution by Natural Selection

iv. Evidence of Evolution

v. Summary of Darwin's Theory

16. Evolution of Populations

a. Genes and Variation

i. Darwin's Ideas Revisited

ii. Gene Pools

iii. Sources of Genetic Variation

iv. Single-Gene and Polygenic Traits

b. Evolution as Genetic Change

i. Natural Selection on Single-Gene Traits

ii. Natural Selection on Polygenic Traits

iii. Genetic Drift

iv. Evolution Versus Genetic Equilibrium

c. The Process of Speciation

i. Isolating Mechanisms

ii. Testing Natural Selection in Nature

iii. Speciation of Darwin's Finches

17. The History of Life

a. The Fossil Record

i. Fossils and Ancient Life

ii. How Fossils Form

iii. Interpreting Fossil Evidence

iv. Geologic Time Scale

b. Patterns of Evolution

i. Mass Extinctions

ii. Adaptive Radiation

iii. Convergent Evolution

18. Classification

a. Why Classify?

b. Assigning Scientific Names

c. Linnaeus's System of Classification

19. The Nervous System

a. Human Body Systems

i. Organization of the Body

ii. Maintaining Homeostasis

b. The Nervous System

i. Neurons

ii. The Nerve Impulse

iii. The Synapse

20. The Muscular System

a. Types of Muscle

b. Muscle Contraction 
c. Control of Muscle Contraction

d. How Muscles and Bones Interact

21. Bacteria and Viruses

a. Bacteria in Nature

i. Decomposers

ii. Nitrogen Fixers

iii. Bacteria and Disease

iv. Human Uses of Bacteria

v. Controlling Bacteria

b. Viruses

i. What is a Virus?

ii. Viral Infection

iii. Viruses and Disease

iv. Are Viruses Alive?

22. The Immune System and Disease

a. Infectious Disease

i. The Germ Theory of Disease

ii. Koch's Postulates

iii. Agents of Disease

iv. How Diseases are Spread

v. Fighting Infectious Diseases

b. The Immune System

i. Nonspecific Defenses

ii. Specific Defenses

iii. Active Immunity

iv. Passive Immunity

c. Immune System Disorders

i. Allergies

ii. Autoimmune Disease

iii. AIDS

23. Biosphere Energy and Cycles

a. Energy Flow

i. Producers

ii. Consumers

iii. Feeding Relationships

iv. Ecological Pyramids

b. Cycles of Matter

i. Recycling in the Biosphere

ii. The Water Cycle

iii. Nutrient Cycles

iv. Nutrient Limitation

24. Ecosystems and Populations

a. What Shapes an Ecosystem?

i. Biotic and Abiotic Factors

ii. The Niche 
iii. Community Interactions

iv. Ecological Succession

b. How Populations Grow

i. Characteristics of Populations

ii. Population Growth

iii. Exponential Growth

iv. Logistic Growth

c. Limits to Growth

i. Limiting Factors

ii. Density-Dependent Factors

iii. Density-Independent Factors

d. Human Population Growth

i. Historical Overview

ii. Patterns of Population Growth

25. Biodiversity

iii. Future Population Growth

a. Biodiversity

i. The Value of Biodiversity

ii. Threats to Biodiversity

iii. Habitat Alteration and Fragmentation

iv. Demand for Wildlife Products

v. Pollution

vi. Introduced Species

vii. Conserving Biodiversity

b. Charting a Course for the Future

i. Ozone Depletion

ii. Global Warming

iii. The Value of a Healthy Biosphere

\section{INSTRUCTIONAL MATERIALS}

Biology, by Prentice Hall

The Official FFA Manual, by the National FFA Organization

\section{KEY ASSINGNMENTS}

- Laboratory experiments highlight key state standards

- Hands-on activities such as map reading, data analysis, timeline construction, model-making

- Research projects

- Multimedia presentations

- Posters and other types of display presentations related to various topics

VIII. INSTRUCTIONAL METHODS AND/OR STRATEGIES

- Teacher led discussion 
- Hands-on activities

- Lab experiments

- Group projects

\section{ASSESSMENT METHODS}

- Lab practical examinations

- Tests and quizzes

- Group and individual projects/reports

- Lab experiments and activities 
Career and Alternative Education

Merced County Regional Occupational Program

Accredited by Western Association of Schools and Colleges

Approved by California Department of Education

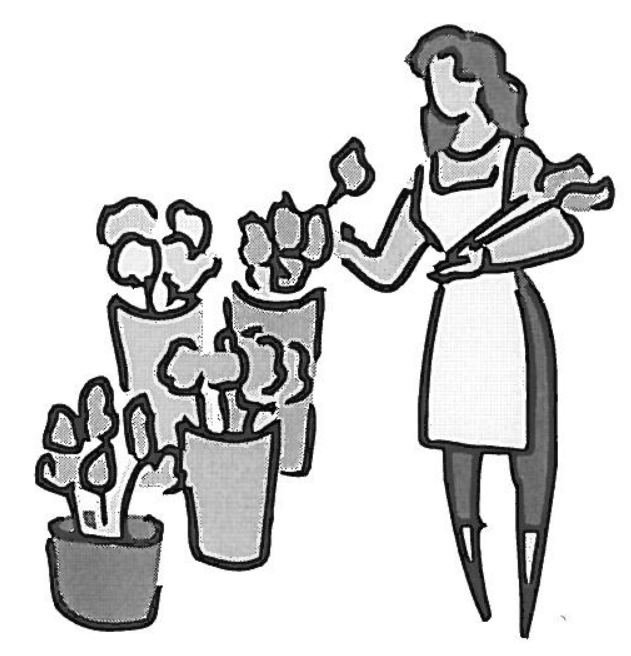

Art \& History of Floral Design I \& II

Course Outline

\section{Every Student a Success}

Lee Andersen, Ph.D.

Merced County Superintendent of Schools

Approved by the Merced County Board of Education - June 14, 2004 


\section{ROP Art \& History of Floral Design I \& II}

\section{PHILOSOPHY}

MCROP delivers innovative educational programs to high school and adult students in preparation for $21^{\text {st }}$ century careers, higher education, and life-long learning.

\section{PROGRAM GOALS}

The goal of the program is to develop students' academic, technical, and interpersonal skills so they will be prepared to:

- Secure employment

- Upgrade skills

- Enter advanced career-technical training

- Pursue college related courses

COURSE TITLE:

ORIGINAL STATE APPROVAL

DATE:

STATE CERTIFICATION DATE: July 13, 2006

STATE ID NUMBER:

ADVISORY COMMITTEE

APPROVAL/REVIEW DATE:

COURSE REVISION DATE:

CBEDS TITLE:

CBEDS NUMBER:

CDE COURSE NUMBER:
603-04 and 74476

The Art \& History of Floral Design I \& II

1995

May 17, 2004

March 2004

Horticulture and the Environment

4050

1361

\section{COURSE DESCRIPTION}

ART \& HISTORY OF FLORAL DESIGN I \& II is designed to introduce students to Floral Design and to provide hands-on training in various entry-level Floriculture positions in their community. Students will be provided the opportunity to explore various aspects of Floral Design. They will complete a final project that will provide an in-depth look at how Floriculture runs and all of the aspects within the scope of career development.

Course instruction

This course is designed to allow students to apply an artistic approach to floral art. The course emphasizes the necessary knowledge and skills to provide the student with a perceptual base leading to understanding artistic perception, creative expression, historical and cultural context(s); aesthetic valuing and connections, relations, applications of the visual arts. Students will derive meaning from artworks through analysis, interpretation, and judgment. Students will connect and apply what is learned in floral art to other art forms, subjects, and post secondary education experiences.

Key instructional methods include direct supervision via lectures and PowerPoint presentations, discussion, cooperative learning, project-based learning, and career development portfolio.

The structure of the course includes students attend class daily for a one period class session for 180 hours of class instruction.

Leadership skills are developed through FFA, or other student organizations. 
Hours: 180 hours/year for one year at one period/day.

A second year at 180 hours/year at one period/day is also available.

Prerequisites:

Helpful Courses/ Experience: Ag Science 1 (LB,G),

Explorations in Agriculture (BC,MGV,A)

Ag. Biology (A, G, BC, MGV,L)

Computer Experience

Articulation: none

Academic Credit: Fine Arts graduation credit (A, BC, L, MGV)

Elective Credit (LB, G)

II. ROP CERTIFICATE AND/OR INDUSTRY LICENSING

To earn an ROP certificate for this course, the student must accomplish the following:

- Achieve a course grade of $\mathrm{C}$ or higher

- Satisfactory completion of student performance objectives

- Demonstrate positive work ethics, attitudes, and attendance

The following industry certification is available for this course:

- N/A

\section{MERCED COUNTY CAREER PATHWAYS AND REPRESENTATIVE JOB TITLES}

Designated Career Pathway: Agriculture/Fine Arts

JOB TITLES:

Retail Floral Shop

- Floral designer assistant

- Floral designer

- Salesperson

- Delivery

- Interior landscape and maintenance

- Cut flower processor

- $\quad$ Office staff

Greenhouse/OH

- Crop production and maintenance

- $\quad$ Grower/Crop manager

- Marketing sales manager

- Greenhouse worker

- Salesperson

- Landscaper/assistant

- Interior designer/assistant

\section{STUDENT PERFORMANCE OBJECTIVES}

Upon successful completion of the course, as aligned with MCROP ESLR's, the student will have:

\section{Common to all Programs:}

- Demonstrated awareness of employment opportunities in careers related to the industry.

- Developed employment literacy to include job readiness skills and technical reading and writing applications demonstrated by completion of an Employability Portfolio.

- Demonstrated safe work habits and attitudes.

- Exhibited leadership skills related to teamwork, communications, human relations, and community responsibility. 
IV. STUDENT PERFORMANCE OBJECTIVES - continued

Common to this ROP Course/ Industry:

- Use senses to perceive work of art, objects in nature, events and the environment.

- Identify visual structures and functions of art using language of visual arts.

- Develop knowledge of an artistic skill in a variety of visual arts and medias.

- Create an original artwork based on personal experiences.

- Select a western line design using one of the major color schemes: monochromatic, complementary, or triadic colors.

- Explore the role of floral design in human history and culture.

- Investigate the universal themes and concepts in historical and contemporary periods.

- Develop a timeline outlining the floral changes and trends of a culture.

- Examine the different artistic works that feature flowers and/or floral displays.

- Derive meaning from artworks through analyzing, interpretations, and judgment by sketching flower arrangements done by one of the great artists of three different historical time periods.

\section{ASSESSMENT OF STUDENT PERFORMANCE}

Assessment of student performance will include but is not limited to:

- Employability Skills Evaluation

- Employability Portfolio and presentation

- Safety awareness in the classroom and/or community classroom setting

- Individual or group Project-Based Learning assignments

- Timely and complete required assignments

- Tests and quizzes

- Classroom participation, punctuality, and attendance

- Presentations/Exhibitions

- Leadership activities

- Supervised floral experience project

\section{TEACHING METHODS, STRATEGIES AND TECHNIQUES}

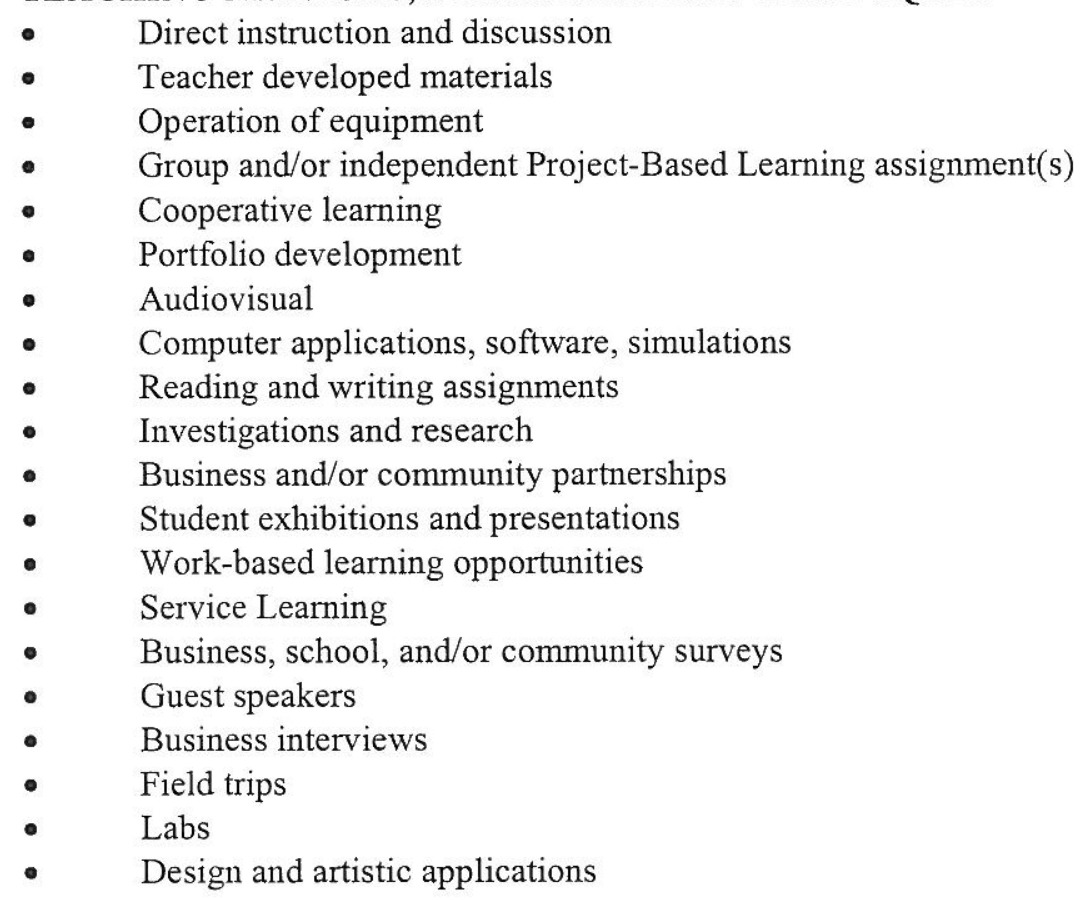




\section{INSTRUCTIONAL MATERIALS AND EQUIPMENT}

This includes, but is not limited to, computer resources, textbooks, video/audiovisual, websites, trade publications, laboratory materials, and specialized equipment.

\section{A. Computer Software}

1. Microsoft Office

\section{B. Required Reading and/or Text}

1. Job Finders Handbook, Merced County ROP

2. Who am I book, Merced County ROP

3. The Art of Floral Design, Norah T. Hunter, Del Mar, USA, 2000

4. Delmar's Handbook of Flowers, Foliage, and Creative Design, Norah T. Hunter, Del Mar, USA, 2000

\section{Student Reading Selection}

1. See \#B above

\section{Instructor Reference Materials $\quad$ (*common to all program areas)}

1. * Merced County ROP ESLR's

2. * Merced County ROP Curriculum Handbook

3. * Merced County Business to Education Resource Guide

4. * California Department of Education Business Education Career Path and Model Curriculum Standards

5. * English-Language Arts Content Standards for California Public Schools

6. * Mathematics Content Standards for California Public Schools

7. * Labor Market Information/Websites

8. Bouquets Floral Arrangements of the Masters; Barrons; 1995

9. The Book of Flowers; Le Livre des Fleurs; 1997

10. Essential Impressionist; Parrgon Publishing Book; 2000

11. The Natural Way to Draw; Kimon Nicolaides

12. California Department of Education Content Standards for Visual and Performing Arts

13. Floriculture... Designing \& Merchandising; Griner, Charles; Delmar Publishing

14. The Retail Florist Business; Hofmann/Pfahl/Behe; Interstate Publishers

15. Landscaping Principles \& Practices; Ingles, Jack E.; Delmar Publishing

16. Introductory Horticulture; Reiley \& Shry; Delmar Publishing

17. Sunset Western Garden Book

18. Teaching Floral Design... A Hands-On Approach; Bigo, Charles and Stringham, Mary Ann; CMA Publications

19. Society of American Florists; www. safnow.org

20. Floral Design CD-ROM (stand alone version); Rankin, Donna; Delmar Publishing

21. Florist Review Magazine

22. The Wreath Book; Rulleyn, Rob; Sterling Publishing Co.

23. Flowers With a Flourish; Lycett, Simon; Laura Glen Publishing

24. Elements of Design Video; Crystal Productions (ISBN 1-56290-158-3 and 1-56290-159-1)

25. Techniques in Flower Judging; VEP Productions \#178

26. Fundamentals of Corsage Making; VEP Productions \#186

27. Horticopia Series CD-ROM; www horticopia.com

28. Flower ID CD-ROM; VEP Productions (ISBN 1-56918-139-X) 
VIII. COURSE OUTLINE

\section{General Workplace Skills:}

Known as Merced County ROP ESLR's, General Workplace Skills are common to all MCROP program areas. They are taught in the specific context of each course. ESLR's are aligned with the National SCANS Competencies, California Department of Education State Career Preparation Standards, and All Aspects of the Industry components. Technical Reading, Writing and Math standards are integrated for the industry specific course when appropriate, and are aligned with the English-Language Arts Content Standards and the Mathematics Content Standards for California Public Schools. All skills are assessed for student certification.

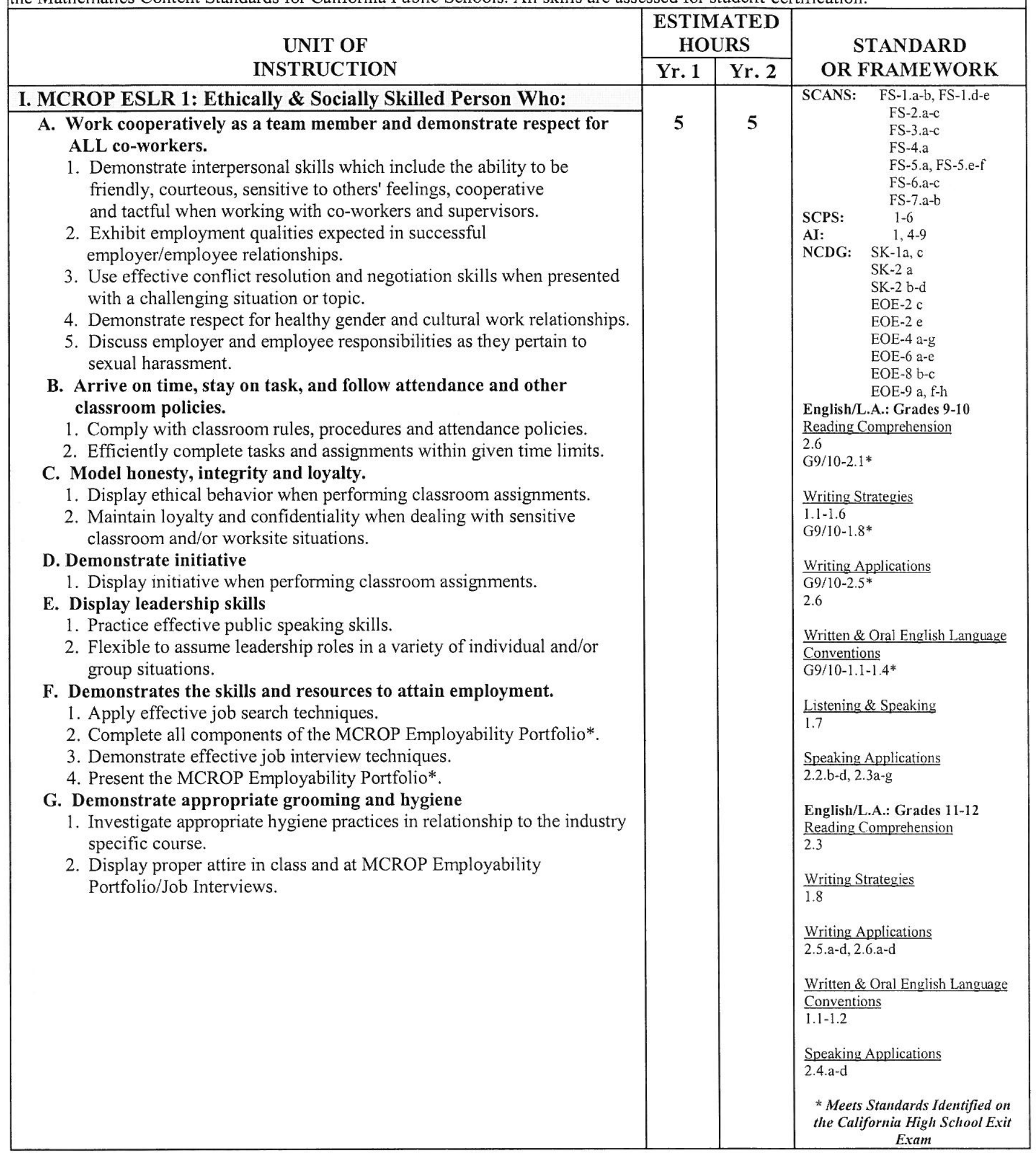




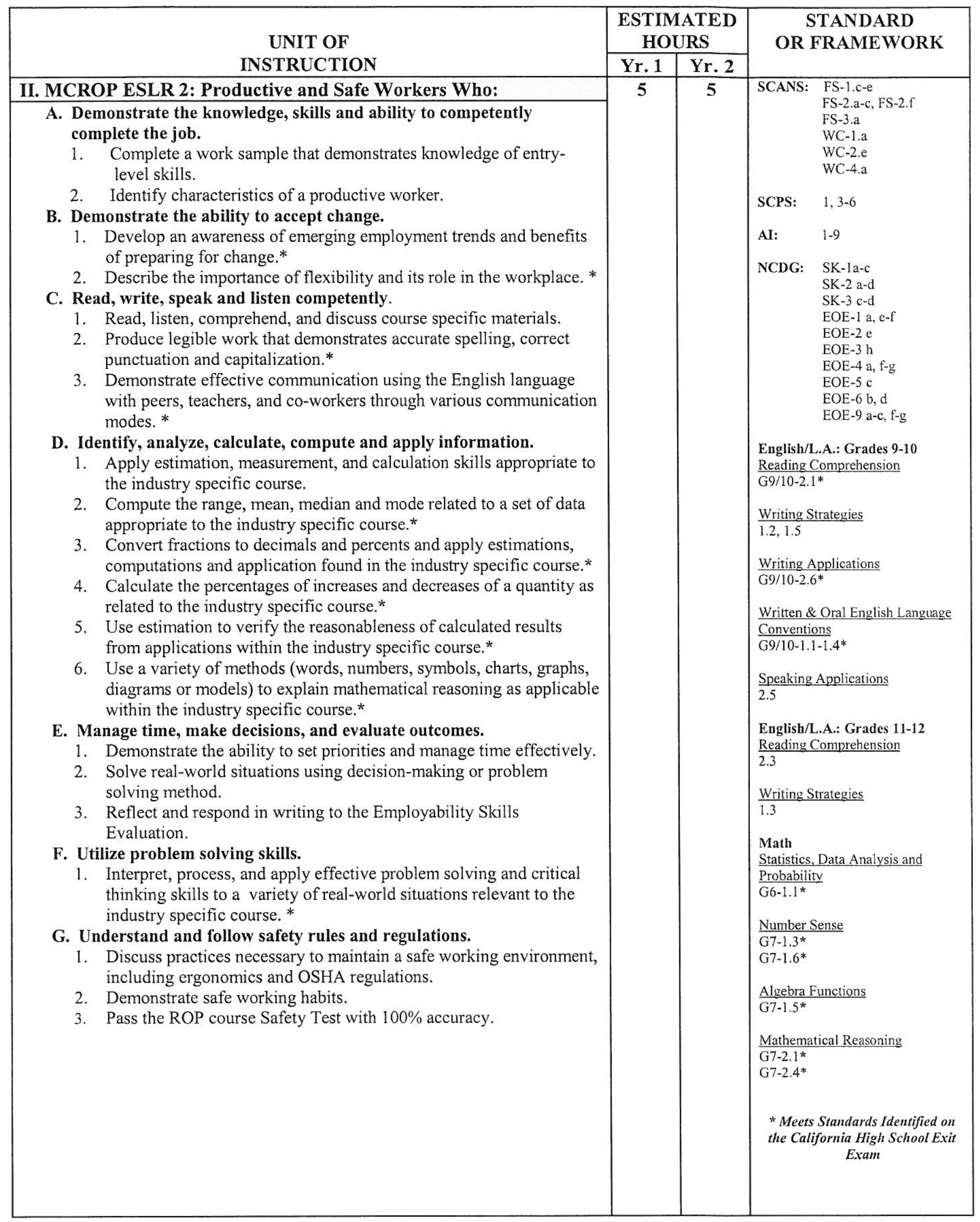




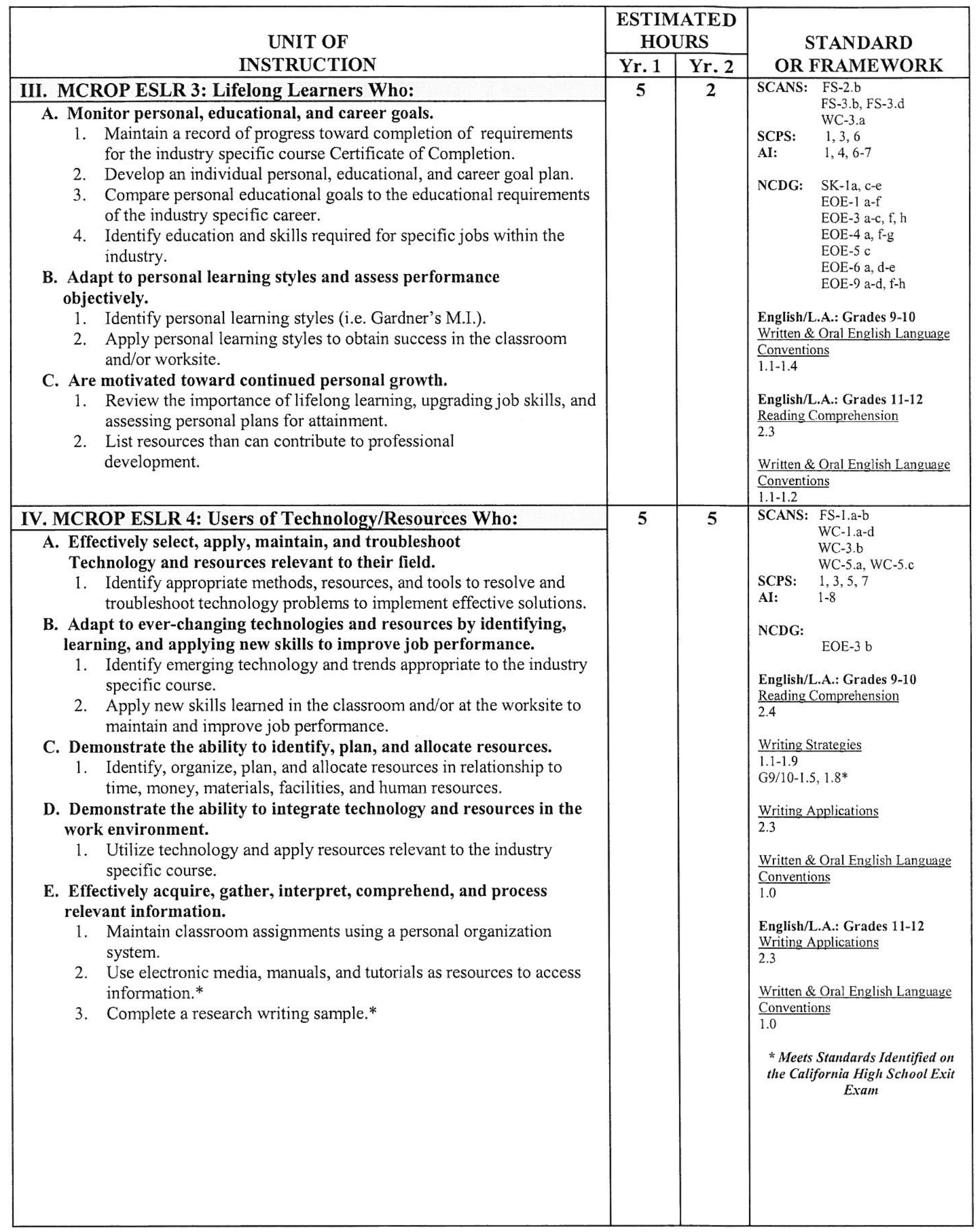




\begin{tabular}{|c|c|c|c|}
\hline \multirow{2}{*}{$\begin{array}{c}\text { UNIT OF } \\
\text { INSTRUCTION }\end{array}$} & \multicolumn{2}{|c|}{$\begin{array}{c}\text { ESTIMATED } \\
\text { HOURS }\end{array}$} & \multirow{2}{*}{$\begin{array}{c}\text { STANDARD } \\
\text { OR FRAMEWORK }\end{array}$} \\
\hline & Yr. 1 & Yr. 2 & \\
\hline V. MCROP ESLR 5: Effective Users of Systems Who: & 5 & 5 & SCANS: FS-l.d-e \\
\hline $\begin{array}{l}\text { A. Understand the social structure and the general function of } \\
\text { the workplace. } \\
\text { 1. Explain the elements of All Aspects of the Industry. } \\
\text { 2. Research the social, organizational and technological systems of a } \\
\text { business. } \\
\text { B. Proficiently use equipment, tools, and terminology. } \\
\text { 1. Utilize a computer and current program applications when } \\
\text { completing the Employability Portfolio. } \\
\text { 2. Practice workplace vocabulary when presenting the Employability } \\
\text { 3. Portfolio. } \\
\text { Demonstrate appropriate care and use of equipment and tools found } \\
\text { in the classroom and/or at the worksite. }\end{array}$ & & & 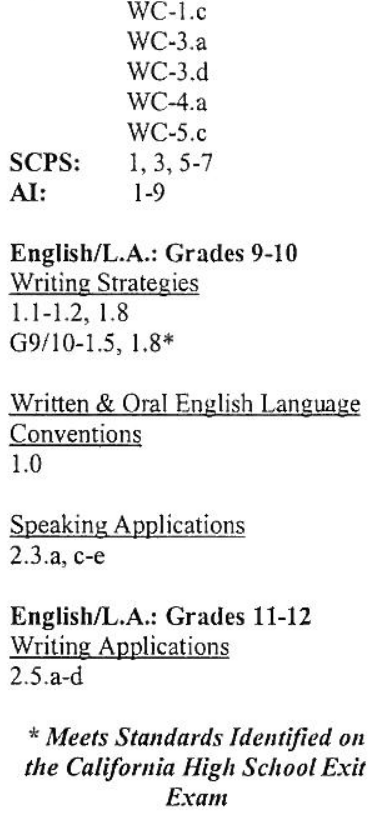 \\
\hline
\end{tabular}




\section{Content Area Skills:}

Content Area Skills contain Occupational Specific Standards aligned with California Department of Education Career Technical Standards and State Frameworks as available. In addition, Industry Specific Standards are aligned with local, state, and national industry standards as available. Technical Reading, Writing and Math standards are integrated for the industry specific course when appropriate, and are aligned with the English-Language Arts Content Standards and the Mathematics Content Standards for California Public Schools. All skills are assessed for student certification.

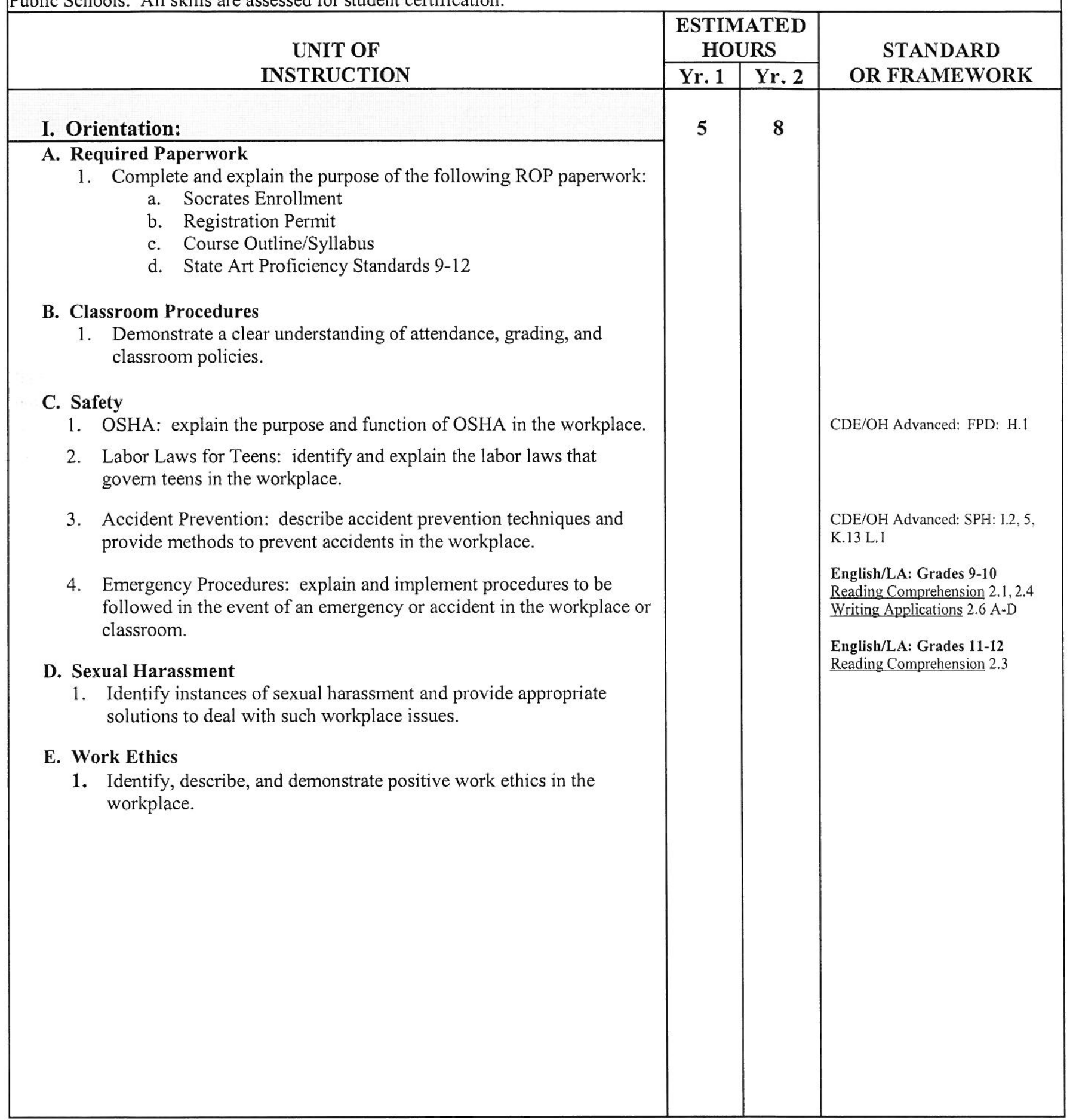




\begin{tabular}{|c|c|c|c|}
\hline \multirow{2}{*}{$\begin{array}{c}\text { UNIT OF } \\
\text { INSTRUCTION }\end{array}$} & \multicolumn{2}{|c|}{$\begin{array}{c}\text { ESTIMATED } \\
\text { HOURS }\end{array}$} & \multirow{2}{*}{$\begin{array}{c}\text { STANDARD } \\
\text { OR FRAMEWORK }\end{array}$} \\
\hline & Yr.1 & Yr. 2 & \\
\hline II. Career Development: & \multirow[t]{2}{*}{10} & \multirow[t]{2}{*}{15} & \\
\hline $\begin{array}{l}\text { A. Floral Design Career Opportunities } \\
\text { 1. Explore, research, and describe the levels of career opportunities } \\
\text { available to individuals in the agriculture floriculture field. } \\
\text { B. Self-Assessment } \\
\text { 1. Complete a self-assessment related to work values and qualities and } \\
\text { complete a plan to improve areas of weakness. } \\
\text { 2. Complete MCROP Employability Skills Evaluation } \\
\text { C. Occupational Goal-Setting } \\
\text { 1. Develop a personal occupational plan that outlines specific career } \\
\text { 2. Coals, and an action plan to achieve these outcomes. }\end{array}$ & & & $\begin{array}{l}\text { CDE/OH Advanced: FPD: A.1,2, } \\
\text { 5, L.1 } \\
\text { CDE/OH Advanced: SPH: P.1-4 } \\
\text { English/LA: Grades 9-10 } \\
\text { Reading Comprehension } 2.5 \text { a-d } \\
\text { Writing App } 2.5 c, 2.6 \text { a-d } \\
\text { Speaking Applications } 2.3 \text { a-f } \\
\text { Listening \& Speaking } 1.7 \\
\text { Grade 11-12: Reading } \\
\text { Comprehension } 2.3\end{array}$ \\
\hline III. Employability: & \multirow[t]{2}{*}{15} & \multirow[t]{2}{*}{15} & \\
\hline $\begin{array}{l}\text { A. Employability Portfolio } \\
\text { 1. Complete an employability portfolio containing the following: } \\
\text { a. Table of Contents } \\
\text { b. Resume } \\
\text { c. Cover Letter } \\
\text { d. Master Application Form } \\
\text { e. Letter of Recommendation } \\
\text { f. Employability Skills Evaluation } \\
\text { g. Work Sample and caption. }\end{array}$ & & & 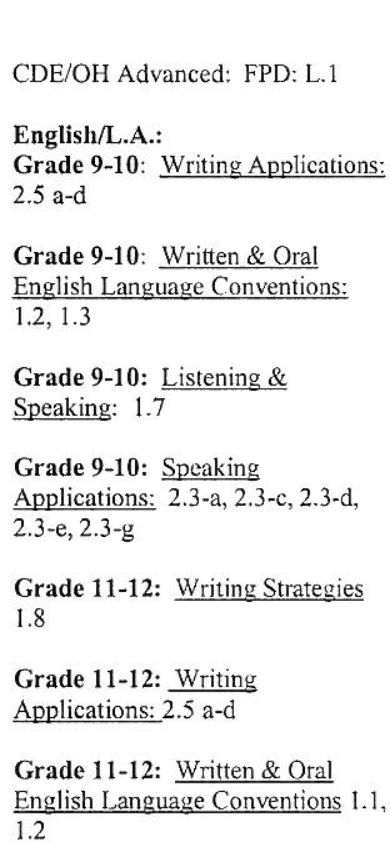 \\
\hline
\end{tabular}




\begin{tabular}{|c|c|c|c|}
\hline \multirow{2}{*}{$\begin{array}{c}\text { UNIT OF } \\
\text { INSTRUCTION }\end{array}$} & \multicolumn{2}{|c|}{$\begin{array}{l}\text { ESTIMATED } \\
\text { HOURS }\end{array}$} & \multirow{2}{*}{$\begin{array}{c}\text { STANDARD } \\
\text { OR FRAMEWORK }\end{array}$} \\
\hline & Yr. 1 & Yr. 2 & \\
\hline IV. Business/Professional Communication: & \multirow[t]{3}{*}{10} & & \multirow{3}{*}{$\begin{array}{l}\text { CDE/OH: Advanced: FPD: } \\
\text { M.1-2 } \\
\text { English/LA: Grades 9-10 } \\
\text { Writing Applications } 2.5 \text { a-d } \\
\text { Writing Strategies } 1.3-1.6,1.8 \\
\text { Speaking Applications } 2.2 \text { b-c } \\
\text { Listening \& Speaking } 1.7 \\
\text { English/LA: Grades } 11-12 \\
\text { Writing Strategies } 1.6,1.8 \\
\text { Written \& Oral English Language } \\
\text { Conventions } 1.1-1.3\end{array}$} \\
\hline $\begin{array}{l}\text { A. Interpersonal Communication } \\
\text { 1. Effective communication: demonstrate the ability to communicate } \\
\text { effectively with co-workers, supervisors, teachers, customers, and } \\
\text { classmates. } \\
\text { 2. Human Relations: demonstrate effective human relation skills while } \\
\text { working with others. } \\
\text { B. Written Communication } \\
\text { 1. Business Correspondence: identify and create business appropriate } \\
\text { memos and letters related to common industry practices. } \\
\text { 2. Writing Sample/Research Paper: create a writing sample or research } \\
\text { paper that demonstrates effective writing and communication skills } \\
\text { used in the workplace. }\end{array}$ & & & \\
\hline $\begin{array}{l}\text { C. Oral Communication } \\
\text { 1. Present Floral Design Research paper to an audience determined by } \\
\text { ROP instructor. }\end{array}$ & & & \\
\hline
\end{tabular}




\begin{tabular}{|c|c|c|c|}
\hline \multirow{2}{*}{$\begin{array}{c}\text { UNIT OF } \\
\text { INSTRUCTION }\end{array}$} & \multicolumn{2}{|c|}{$\begin{array}{l}\text { ESTIMATED } \\
\text { HOURS }\end{array}$} & \multirow{2}{*}{$\begin{array}{c}\text { STANDARD } \\
\text { OR FRAMEWORK }\end{array}$} \\
\hline & Yr. 1 & Yr. 2 & \\
\hline V. Leadership: & \multirow[t]{2}{*}{5} & \multirow[t]{2}{*}{5} & \\
\hline $\begin{array}{l}\text { A. Service Learning } \\
\text { 1. Develop and execute a community service project that will be of } \\
\text { benefit to a specific group, institution, or cause within the } \\
\text { community. } \\
\text { B. Student Organization } \\
\text { 1. Actively participate in the FFA organization. }\end{array}$ & & & $\begin{array}{l}\text { English/Language Arts } \\
\text { Grade 9-10: Speaking } \\
\text { Applications 2.5-d } \\
\text { Grade 9-10: Listening \& } \\
\text { Speaking 1.3, 1.4, 1.7, 1.9 } \\
\text { Grade 9-10: Speaking } \\
\text { Applications 2.6-a, 2.6-b, 2.6-c }\end{array}$ \\
\hline
\end{tabular}




\begin{tabular}{|c|c|c|c|}
\hline \multirow{2}{*}{$\begin{array}{c}\text { UNIT OF } \\
\text { INSTRUCTION }\end{array}$} & \multicolumn{2}{|c|}{$\begin{array}{l}\text { ESTIMATED } \\
\text { HOURS }\end{array}$} & \multirow{2}{*}{$\begin{array}{c}\text { STANDARD } \\
\text { OR FRAMEWORK }\end{array}$} \\
\hline & Yr. 1 & Yr. 2 & \\
\hline VI. Introduction to Art & \multirow[t]{2}{*}{10} & & \\
\hline $\begin{array}{l}\text { A. The variety of art } \\
\text { 1. Describe and interpret artistic perception. } \\
\text { B. When is it Art? } \\
\text { 1. Explain the Philosophy of Arts. } \\
\text { 2. Interpret the Aesthetic Value of Objects. } \\
\text { 3. Develop Artistic Inspirations. } \\
\text { 4. Interpret and understand Art Appreciation. } \\
\text { 5. Explain knowledge of the Art World. }\end{array}$ & & & $\begin{array}{l}\text { CDE /VPA: Aesthetics: } 4.1-4.3 \\
\text { English/LA: Grades 9-10 } \\
\text { Reading/Comprehension } 2.5 \\
\text { Writing Strategies } 1.1-1.3 \\
\text { Listening \& Speaking } 1.7 \\
\text { Speaking Applications } 2.2 \mathrm{~b}, \mathrm{~d} \\
\text { English/LA: Grades } 11-12 \\
\text { Writing Applications 2.6 a-d } \\
\text { Written \& Oral English Language } \\
\text { Conventions } 1.1,1.2 \\
\text { Speaking Applications } 2.4 \text { a-c }\end{array}$ \\
\hline VII. Historical Contributions and Cultural Dimensions & \multirow[t]{2}{*}{15} & & \\
\hline $\begin{array}{l}\text { A. Interpretation } \\
\text { 1. Interpret and describe the meaning of art. } \\
\text { 2. Research and demonstrate elements of Art History. } \\
\text { B. History of Floral Art } \\
\text { 1. Describe the Floral Art of Ancient Civilizations. } \\
\text { 2. Describe the Floral Art of the European Period. } \\
\text { 3. Describe the Floral Art of the Impressionistic Era. } \\
\text { 4. Explain the Oriental Influence of Floral Art. } \\
\text { 5. Explain the American Style of Floral Art. } \\
\text { 6. Demonstrate the current floral arrangement styles and their origination: } \\
\text { C. Research the Influences of floral artists of the } 20^{\text {th }} \text { and } 21^{\text {st }} \text { century } \\
\text { 1. Identify various styles and techniques. } \\
\text { 2. Describe Artistic Inspirations. } \\
\text { 3. Interpret common visual themes used in various cultures. } \\
\text { 4. Explain comparisons of artistic components of various time periods and } \\
\text { cultures: Architecture, Colors, Furniture, Fabrics, and Clothing. } \\
\text { 5. Create a two-dimensional project to represent various periods in floral } \\
\text { art history. } \\
\text { 6. Create a three-dimensional project to represent various periods in floral } \\
\text { art history. } \\
\text { 7. Develop a research project for one historical style. } \\
\text { 8. Explain the research significance of floral materials: Cultures, } \\
\text { 9. Describe Cultural Themes: religious holidays, funerals and weddings. } \\
\text { 10. Create a Cultural Design Practicum using a given theme: two } \\
\text { dimensional layouts, three-dimensional arrangements, fresh and dry cut } \\
\text { techniques. }\end{array}$ & & & $\begin{array}{l}\text { CDE/ VPA: Art Perception: } \\
\text { 1.1-1.5 } \\
\text { CDE/VPA: Hist/Cultural: } \\
3.1-3.5 \\
\text { CDE/VPA: Aesthetics: } 4.1-4.3 \text {, } \\
4.5 \\
\text { English/LA: Grades 9-10 } \\
\text { Writing Strategies } 1.5 \\
\text { Writing Applications } 2.6 \text { a-b } \\
\text { Written \& Oral English Language } \\
\text { Conventions } 1.1-1.4 \\
\text { Listening \& Speaking } 1.7 \\
\text { Speaking Applications } 2.2 \text { b,d } \\
\text { English/LA: Grades } 11-12 \\
\text { Writing Applications } 2.6 \text { a-d } \\
\text { Writing Strategies } 1.6,1.8 \\
\text { Reading Comprehension } 2.3 \\
\text { Written \& Oral English Language } \\
\text { Convention 1.1, } 1.2 \\
\text { Speaking Applications } 2.4 \text { a-c }\end{array}$ \\
\hline
\end{tabular}




\begin{tabular}{|c|c|c|c|}
\hline \multirow{2}{*}{$\begin{array}{c}\text { UNIT OF } \\
\text { INSTRUCTION }\end{array}$} & \multicolumn{2}{|c|}{$\begin{array}{l}\text { ESTIMATED } \\
\text { HOURS }\end{array}$} & \multirow{2}{*}{$\begin{array}{c}\text { STANDARD } \\
\text { OR FRAMEWORK }\end{array}$} \\
\hline & Yr. 1 & Yr. 2 & \\
\hline VIII. Art Elements of Design & \multirow[t]{2}{*}{20} & & \\
\hline $\begin{array}{l}\text { A. Lines } \\
\text { 1. Display actual, implied and expressive use of Line. } \\
\text { 2. Demonstrate vertical, horizontal, and diagonal use of Line. } \\
\text { B. Shapes/Forms } \\
\text { 1. Demonstrate Triangular Floral Art Designs. } \\
\text { 2. Demonstrate Circular Floral Art Designs. } \\
\text { 3. Demonstrate Vertical Floral Art Designs. } \\
\text { 4. Demonstrate Horizontal Floral Art Designs. } \\
\text { C. Colors } \\
\text { 1. Apply the origin of color to Floral Art Designs: hue, primary, } \\
\text { secondary, tertiary, warm, cool, value, tint, tone, and shades. } \\
\text { 2. Apply color harmony to Floral Art Designs: monochromatic, } \\
\text { analogous, complementary, triadic. } \\
\text { D. Textures } \\
\text { 1. Create visual and tactile components in Floral Art: fine, medium, and } \\
\text { course textured media. } \\
\text { 2. Explain various container and material components of Floral Art. } \\
\text { 3. Display knowledge of flower and foliage use. } \\
\text { E. Value } \\
\text { 1. Display light and dark change in Floral Art. } \\
\text { F. Space and Depth } \\
\text { 1. Demonstrate space in two-dimensional and three-dimensional Art. } \\
\text { 2. Interpret space in our environment. } \\
\text { 3. Apply Angling Media in Floral Art. } \\
\text { 4. Create overlapping media for design. } \\
\text { 5. Demonstrate size and color of Media in Floral Art. }\end{array}$ & & & $\begin{array}{l}\text { CDE/VPA: Creative Ex: } 2.3,2.6 \\
\text { CDE/VPA: Aesthetic: } 4.2-4.3 \\
\text { CDE/OH: Advanced: FPD: } \\
\text { E.2, K.5 } \\
\text { CDE/OH: Advanced: SPH: N.2 } \\
\text { English/Language Arts } \\
\text { English/LA: Grades 9-10 } \\
\text { Listening \& Speaking 1.7 } \\
\text { English/LA: Grades 11-12 } \\
\text { Speaking Applications 2.4 a-d } \\
\text { Writing Applications 2.6 a-d }\end{array}$ \\
\hline
\end{tabular}




\begin{tabular}{|c|c|c|c|}
\hline \multirow{2}{*}{$\begin{array}{c}\text { UNIT OF } \\
\text { INSTRUCTION }\end{array}$} & \multicolumn{2}{|c|}{$\begin{array}{l}\text { ESTIMATED } \\
\text { HOURS }\end{array}$} & \multirow{2}{*}{$\begin{array}{l}\text { STANDARD } \\
\text { OR FRAMEWORK }\end{array}$} \\
\hline & Yr. 1 & Yr. 2 & \\
\hline IX. Principles of Art Design & 25 & & \\
\hline $\begin{array}{l}\text { A. Balance } \\
\text { 1. Demonstrate Symmetrical Balance in Floral Art. } \\
\text { 2. Create Asymmetrical Balance in Floral Art. } \\
\text { 3. Create Radial Balance in Floral Art. } \\
\text { 4. Demonstrate Open Balance in Floral Art. } \\
\text { B. Proportion/Scale } \\
\text { 1. Display knowledge of flowers to materials proportion and scale in } \\
\text { Floral Art. } \\
\text { 2. Display knowledge of flower to flower proportion and scale in Floral } \\
\text { Art. } \\
\text { 3. Display knowledge of flower to foliage proportion and scale in Floral } \\
\text { Art. } \\
\text { 4. Demonstrate arrangement to surroundings proportion and scale in } \\
\text { Floral Art. } \\
\text { 5. Demonstrate geometrical techniques in Floral Art. } \\
\text { C. Emphasis } \\
\text { 1. Apply Focal Point to Floral Art Designs. } \\
\text { 2. Demonstrate emphasis in Floral Art Designs. } \\
\text { 3. Create location, size, and pattern of Media for Floral Art Designs. } \\
\text { 4. Create line direction and directional facing in Floral Art Designs. } \\
\text { 5. Display framing and isolation for Floral Art. } \\
\text { D. Rhythm } \\
\text { 1. Interpret Repetition in Floral Art. } \\
\text { 2. Demonstrate Transition in Floral Design. } \\
\text { 3. Create a radiating line in Floral Design. } \\
\text { 4. Apply eye movement to Floral Art Designs. } \\
\text { E. Harmony and Unity } \\
\text { 1. Display color combinations for Artistic Design. } \\
\text { 2. Demonstrate placement in Floral Art. } \\
\text { 3. Apply Proximity to Floral Art Designs. } \\
\text { 4. Interpret Transition in Floral Art Design. } \\
\text { F. Contrast } \\
\text { 1. Create color schemes in Art Design. } \\
\text { 2. Demonstrate Medias Used in Floral Art. }\end{array}$ & & & $\begin{array}{l}\text { CDE/VPA: Art. Perception: 1.1, } \\
1.3 \\
\text { CDE/VPA: Creative Ex.: } 2.3 \\
\text { CDE/VPA: Aesthetics: } 4.2-4.3 \\
\text { English/LA: Grades } 9-10 \\
\text { Listening \& Speaking 1.7 } \\
\text { English/LA: Grades } 11-12 \\
\text { Speaking Applications } 2.4 \text { a-d } \\
\text { Writing Applications } 2.6 \mathrm{a}-\mathrm{d}\end{array}$ \\
\hline
\end{tabular}




\begin{tabular}{|c|c|c|c|}
\hline \multirow{2}{*}{$\begin{array}{l}\text { UNIT OF } \\
\text { INSTRUCTION }\end{array}$} & \multicolumn{2}{|c|}{$\begin{array}{l}\text { ESTIMATED } \\
\text { HOURS }\end{array}$} & \multirow{2}{*}{$\begin{array}{l}\text { STANDARD } \\
\text { OR FRAMEWORK }\end{array}$} \\
\hline & Yr. 1 & Yr. 2 & \\
\hline $\begin{array}{l}\text { X. Creative Expression Through Applying Artistic Processes and } \\
\text { Skills to Original Works of Art }\end{array}$ & \multirow[t]{2}{*}{25} & \multirow[t]{2}{*}{10} & \\
\hline $\begin{array}{l}\text { A. Two-Dimensional Media } \\
\text { 1. Demonstrate knowledge of Basic Drawing and Layout: Simple } \\
\text { Perspective Drawing, Sketching Original Art Works, and Project } \\
\text { Layout. } \\
\text { 2. Display painting techniques for Floral Art: Color Wheel and Still Life. } \\
\text { 3. Create Mosaic Art Designs for Floral Art: Paper and Tile. } \\
\text { 4. Apply Printmaking to Floral Art using pressed flowers. } \\
\text { 5. Demonstrate photograph and graphic design through computer art. } \\
\text { B. Three-Dimensional Sculptures } \\
\text { 1. Create and display flower and foliage media techniques for specific } \\
\text { Floral Art: Mass Flower and Foliage, Filler Flower and Foliage, Line } \\
\text { Flower and Foliage, Form Flower and Foliage, Fresh Flower and } \\
\text { Foliage, Dry Flower and Foliage, and Artificial Flower and Foliage. } \\
\text { 2. Apply mechanics, materials, and media through an introduction to } \\
\text { proper care and proper usage of equipment and media. } \\
\text { 3. Display specific artist styles and techniques using Oriental, European, } \\
\text { and Exhibition Styles: Chinese, Japanese, Vertical, Circular, Triangular, } \\
\text { and Wear and Carry Designs. }\end{array}$ & & & $\begin{array}{l}\text { CDE/VPA: Creative Exp.: } 2.1 \text {, } \\
2.3,2.6 \\
\text { CDE/VPA: Hist./Cultural: } 3.1 \text {, } \\
3.4-3.5 \\
\text { CDE/VPA: Aesthetics: } 4.1-4.3 \\
\text { CDE/OH Advanced: FPD: B.2, } \\
\text { E.1,3, H.1-5, I.1, J.1-7, K.1-6 } \\
\text { CDE/OH: Advanced: LIM: C.1 } \\
\text { CDE/OH: Advanced: SPH: } \\
\text { A.1,2, D.1, N.1, 3-8 } \\
\text { English/LA: Grades 9-10 } \\
\text { Listening \& Speaking 1.7 } \\
\text { English/LA: Grades } 11-12 \\
\text { Speaking Applications } 2.4 \text { a-d } \\
\text { Writing Applications } 2.6 \text { a-d } \\
\text { Math: } \\
\text { Number Sense G7: 1.3, 1.6 } \\
\text { Mathematical Reasoning G7: } 2.1 \text {, } \\
\end{array}$ \\
\hline $\begin{array}{l}\text { XI. Aesthetic Valuing and Making Judgments on Individual Works } \\
\text { of Art }\end{array}$ & \multirow[t]{2}{*}{10} & \multirow[t]{2}{*}{5} & \\
\hline $\begin{array}{l}\text { A. Works of Art and Aesthetic Value } \\
\text { 1. Describe works of art in appropriate terms. } \\
\text { 2. Analyze art works in terms of art elements and design principles. } \\
\text { 3. Identify sensory qualities. } \\
\text { 4. Identify the style and period of viewed art. } \\
\text { 5. Evaluate art elements and art principles used in others and own works } \\
\text { of art. } \\
\text { B. Create Assessments and Methods of Evaluation } \\
\text { 1. Develop a portfolio including two-dimensional drawings, three- } \\
\text { 2. Develop a cultural and historical research paper. } \\
\text { 3. Present student critiques and rubrics. } \\
\text { 4. Interpret teacher critiques and rubrics. } \\
\text { 5. Analyze and interpret art criticisms. } \\
\text { 6. Develop an oral presentation for Floral Art. } \\
\text { 7. Exhibit a Self-Evaluation. } \\
\text { 8. Create verbal and written reflections for Floral Designs. }\end{array}$ & & & $\begin{array}{l}\text { CDE/VPA: Creative Exp: } 2.2 \text {, } \\
2.5-2.6 \\
\text { CDE/VPA: Conn/Re/Apps. } \\
\text { 5.3-5.4 } \\
\text { CDE/OH Advanced: LIM: A.1,3 } \\
\text { English/LA: Grades 9-10 } \\
\text { Reading Comprehension 2.2-2.6 } \\
\text { Writing Strategies 1.1-1.9 } \\
\text { Writing Applications } 2.5 \text { a-d, } 2.6 \\
\text { a-d } \\
\text { Written \& Oral English Language } \\
\text { Conventions 1.1-15 } \\
\text { Listening \& Speaking 1.7 } \\
\text { Speaking Applications } 2.2 \text { b-d, } \\
\text { 2.3 a-g } \\
\text { English/LA: Grades } 11-12 \\
\text { Reading Comprehension } 2.3 \\
\text { Writing Strategies 1.6, } 1.8-1.9 \\
\text { Writing Applications } 2.5 \text { a-d, } \\
\text { 2.6 a-d } \\
\text { Written \& Oral English Language } \\
\text { Conventions 1.1-13 } \\
\text { Speaking Applications } 2.4 \text { a-d }\end{array}$ \\
\hline
\end{tabular}




\begin{tabular}{|c|c|c|c|}
\hline \multirow{2}{*}{$\begin{array}{l}\text { UNIT OF } \\
\text { INSTRUCTION }\end{array}$} & \multicolumn{2}{|c|}{$\begin{array}{l}\text { ESTIMATED } \\
\text { HOURS }\end{array}$} & \multirow{2}{*}{$\begin{array}{l}\text { STANDARD } \\
\text { OR FRAMEWORK }\end{array}$} \\
\hline & Yr. 1 & Yr. 2 & \\
\hline XII. Connections, Relationships, and Applications Learned in Visual Art & \multirow{2}{*}{5} & \multirow{2}{*}{5} & \\
\hline $\begin{array}{l}\text { A. Relationships to Other Disciplines } \\
\text { 1. Compare and Contrast works of art to other discipline areas. } \\
\text { B. Relationships to Careers in Art } \\
\text { 1. Compare and contrast methods demonstrated in art careers. } \\
\text { C. Applications of Artistic Concepts } \\
\text { 1. Visit a local art gallery/museum or apply other floral art field trip. } \\
\text { 2. Design an advertisement using art elements, principles, and techniques } \\
\text { to display student work at an art exhibition. } \\
\text { 3. Create a two-dimensional or three-dimensional design incorporating } \\
\text { elements and principles as applied to a specific theme and culture. }\end{array}$ & & & $\begin{array}{l}\text { CDE/VPA: Creative Exp: } 2.3 \\
\text { CDE/VPA: Hist/Cult. Context: } \\
3.4 \\
\text { CDE/OH Advanced: LIM: } \\
\text { B.1-5 } \\
\text { Math: } \\
\text { Number Sense G7: } 1.3,1.6 \\
\text { Mathematical Reasoning G7:2.1, }\end{array}$ \\
\hline $\begin{array}{l}\text { XIII. Creative Expression Through Advanced Floral Design Arranging for } \\
\text { Entertainment Purposes }\end{array}$ & & \multirow[t]{2}{*}{35} & \\
\hline $\begin{array}{l}\text { A. Demonstrate Floral Art Style and Technique Through Holiday Design } \\
\text { 1. Identify and create types of centerpieces for seasonal and holiday use. } \\
\text { 2. Create accessories for holiday expression: corsages, boutonnieres, } \\
\text { balloon arrangements, wreaths, various container media. } \\
\text { B. Facilitate Creativity and Interactive Arranging Using Party Design } \\
\text { 1. Develop creative arrangements for party occasions. } \\
\text { 2. Organize a party to implement in the community including a Specific } \\
\text { Details Report: Theme, Colors, Invitations, Set-up, and Map. }\end{array}$ & & & $\begin{array}{l}\text { CDE/VPA: Creative Exp: } 2.3 \\
\text { CDE/VPA: Hist/Cult. Context: } \\
3.4 \\
\text { CDE/VPA: Aesthetics: } 4.2-4.3 \\
\text { CDE/VPA: Conn/Rel/Apps: } 5.1 \\
\text { Math: } \\
\text { Number Sense G7: } 1.3,1.6 \\
\frac{\text { Mathematical Reasoning G7: } 2.1 \text {, }}{2.4}\end{array}$ \\
\hline
\end{tabular}




\begin{tabular}{|c|c|c|c|}
\hline \multirow{2}{*}{$\begin{array}{l}\text { UNIT OF } \\
\text { INSTRUCTION }\end{array}$} & \multicolumn{2}{|c|}{$\begin{array}{l}\text { ESTIMATED } \\
\text { HOURS }\end{array}$} & \multirow{2}{*}{$\begin{array}{l}\text { STANDARD } \\
\text { OR FRAMEWORK }\end{array}$} \\
\hline & Yr. 1 & Yr. 2 & \\
\hline $\begin{array}{l}\text { XIV. Advanced Floral Design Techniques for Intricate Arrangements and } \\
\text { Accessories }\end{array}$ & & \multirow[t]{2}{*}{30} & \\
\hline $\begin{array}{l}\text { A. Apply Floral Design Elements and Principles Through Sympathy } \\
\text { Arrangements } \\
\text { 1. Interpret the importance for sympathy flowers in the Floriculture } \\
\text { Industry. } \\
\text { 2. Identify and describe typical sympathy arrangements and accessories. } \\
\text { B. Develop Complete Arrangements and Accessories for Wedding } \\
\text { Ceremony Design } \\
\text { 1. Utilize formal questionnaire for a bridal consultation. } \\
\text { 2. Create bouquets for attendants and other persons. } \\
\text { 3. Develop reception decorations for the wedding party environment. } \\
\text { 4. Create and design accessories for the wedding party ceremony. } \\
\text { 5. Prepare price estimate sheets and formal price sheets for the bridal } \\
\text { C. Apply High-Style and Advanced Floral Designs } \\
\text { 1. Develop individualized floral design projects based upon art and design } \\
\text { 2. techniques. }\end{array}$ & & & $\begin{array}{l}\text { CDE/VPA: Creative Ex.: } 2.3 \\
\text { CDE/VPA: Hist./Cultural: } 3.4 \\
\text { CDE/VPA: Aesthetics: } 4.2-4.3 \\
\text { CDE/VPA: Conn./Rel./Apps.: } \\
5.1-5.2 \\
\text { CDE/OH Advanced: FPD: J.1-7 } \\
\text { English/LA: Grades 9-10 } \\
\text { Listening \& Speaking 1.7 } \\
\text { Speaking Applications 2.2 B-D } \\
\text { English/LA: Grades 11-12 } \\
\text { Language Conventions 1.1-1.3 } \\
\text { Math: } \\
\text { Number Sense G7: 1.3, 1.6 } \\
\text { Mathematical Reasoning G7: 2.1, } \\
2.4\end{array}$ \\
\hline XV. Retail and Wholesale for the Floriculture Industry & & \multirow[t]{2}{*}{30} & \\
\hline $\begin{array}{l}\text { A. Demonstrate Necessary Skills to Manage the Floral Design Retail Shop } \\
\text { 1. Evaluate qualifications to be a Florist. } \\
\text { 2. Develop knowledge of types of floral shops. } \\
\text { 3. Demonstrate pricing methods and use of computers and machines } \\
\text { within the Floriculture Industry. } \\
\text { 4. Apply customer service skills and consultations for the Floriculture } \\
\text { Industry. } \\
\text { 5. Demonstrate knowledge of importance of effective sales skills. } \\
\text { 6. Facilitate marketing and promotion for the Floral Retail Shop. } \\
\text { Management and Facilitation of the Wholesale Floriculture Industry } \\
\text { 1. Apply floral design skills to contribute to the customer sales } \\
\text { management. } \\
\text { 2. Demonstrate cut flower processing techniques and skills for the } \\
\text { floriculture wholesale industry. } \\
\text { 3. Utilize wholesale industry applications to manage floral crop } \\
\text { 4. Exoduction in greenhouses. } \\
\text { Mesigner. } \\
\text { Management and Facilitation of Nursery Production and Sales } \\
\text { 1. Expand plant identification vocabulary, the physiological and } \\
\text { morphological factors affecting identification, and the value of that } \\
\text { knowledge for workers in the nursery production industry } \\
\text { 2. Explain the uses, structural components, advantages and disadvantages } \\
\text { of various horticulture structures used in the industry. } \\
\text { 3. Prepare planting medias and demonstrate approved procedures for the } \\
\text { 5ropagation of nursery plants. }\end{array}$ & & & $\begin{array}{l}\text { CDE/VPA: Aesthetics: 4.1-4.5 } \\
\text { CDE/VPA: Conn./Rel./Apps: } \\
5.1-5.2 \\
\text { CDE/OH: Advanced: SPH: C.1, } \\
\text { E.1-2, 4, F.1-16, G.1-3, 5, 6, 8, } \\
\text { H.5, J.3, 4, 6, K.1, 5, 6, 12-13, } \\
\text { L.1-5, 9, M.1-6, 8-11, N.1-14 } \\
\text { CDE/OH: Advanced: FPD: } \\
\text { A.1-5, B.1-3, C.1-4, D.1-6, F.1-8, } \\
\text { G.1-6, H.4,5, I.I-6, L.1, N.1-14 } \\
\text { CDE/OH : Advanced: LIM: A.2 } \\
\text { CDE/OH: Advanced: NPS: } \\
\text { A.1-5, B.1-6, C.2-7, D.3-13, } \\
\text { G.1-4 } \\
\text { English/LA: Grades 9-10 } \\
\text { Listening \& Speaking 1.7 } \\
\text { Speaking Applications 2.2 B-D } \\
\text { English/LA: Grades 11-12 } \\
\text { Language Conventions 1.1-1.3 } \\
\text { Math: } \\
\text { Number Sense G7: 1.3, 1.6 } \\
\text { Mathematical Reasoning G7: 2.1, } \\
\text { 2.4 }\end{array}$ \\
\hline
\end{tabular}




\section{COURSE HOURS:}

$\begin{array}{ll}\text { Total Classroom Hours Year One: } & 180 \\ \text { Total Classroom Hours Year Two: } & 180 \\ \text { Total Hours: } & 360\end{array}$

\section{STANDARDS REFERENCE CODE:}

\begin{tabular}{|ll|}
\hline & \\
SCANS: & National Career Preparation Standards \\
NCDG: & National Career Development Guidelines \\
AI: & All Aspects of the Industry \\
SCPS: & State Career Preparation Standards \\
CDE English/L.A.: & English/Language Arts Standards \\
CDE Math: & Mathematics Standards \\
CDE Visual \& Performing Arts: & Visual \& Performing Arts Standards: Grades 9-12, \\
& Proficient and Advanced \\
CDE/OH: Advanced SPH: & California Department of Education Agriculture Model \\
& Curriculum Guide: Advanced Core and Specializations: \\
& Specialization in Ornamental Horticulture \\
CDE/OH: Advanced FPD: & California Department of Education Curriculum Guide: \\
& Advanced Specialization in Ornamental Horticulture - \\
& Floriculture in Production and Design \\
CDE/OH: Advanced LIM: & California Department of Education Curriculum Guide: \\
& Advanced Specialization in Ornamental Horticulture - \\
& Landscape Installation and Maintenance \\
CDE/OH: Advanced NPS: & California Department of Education Curriculum Guide: \\
& Advanced Specialization in Ornamental Horticulture, \\
& Nursery Production and Sales \\
&
\end{tabular}

XI. LABOR MARKET INFORMATION:

LMI for local, state, and national data attached.

XII. DEMONSTRATED EFFECTIVENESS

According to the Merced County ROP Follow-Up Report (VE-80C) of June 2002, $73 \%$ of students whose status was known and completed ROP Floral Design in 2001-2002, are either employed or planning to pursue higher education. 
$\underline{D}$

Daily Grade Sheets

Using Aeries, I keep computerized grade book and give printouts to students on a regular basis. Student's grades are posted every Friday in the classroom and can be viewed online by parents and students at any time. This makes it easier for the students to be aware of the assignments that they are missing and assists the parents in making sure their child is doing well in school.

Attached you will find:

- Grade book for each class I teach showcasing students by their high school ID number. 
Page: 1 $<$ Back $>$ 3/14/2013 10:48:59 PM Gradebook Summary 1 - ArtHistFIDsgn1 - Spring Ioimo,J

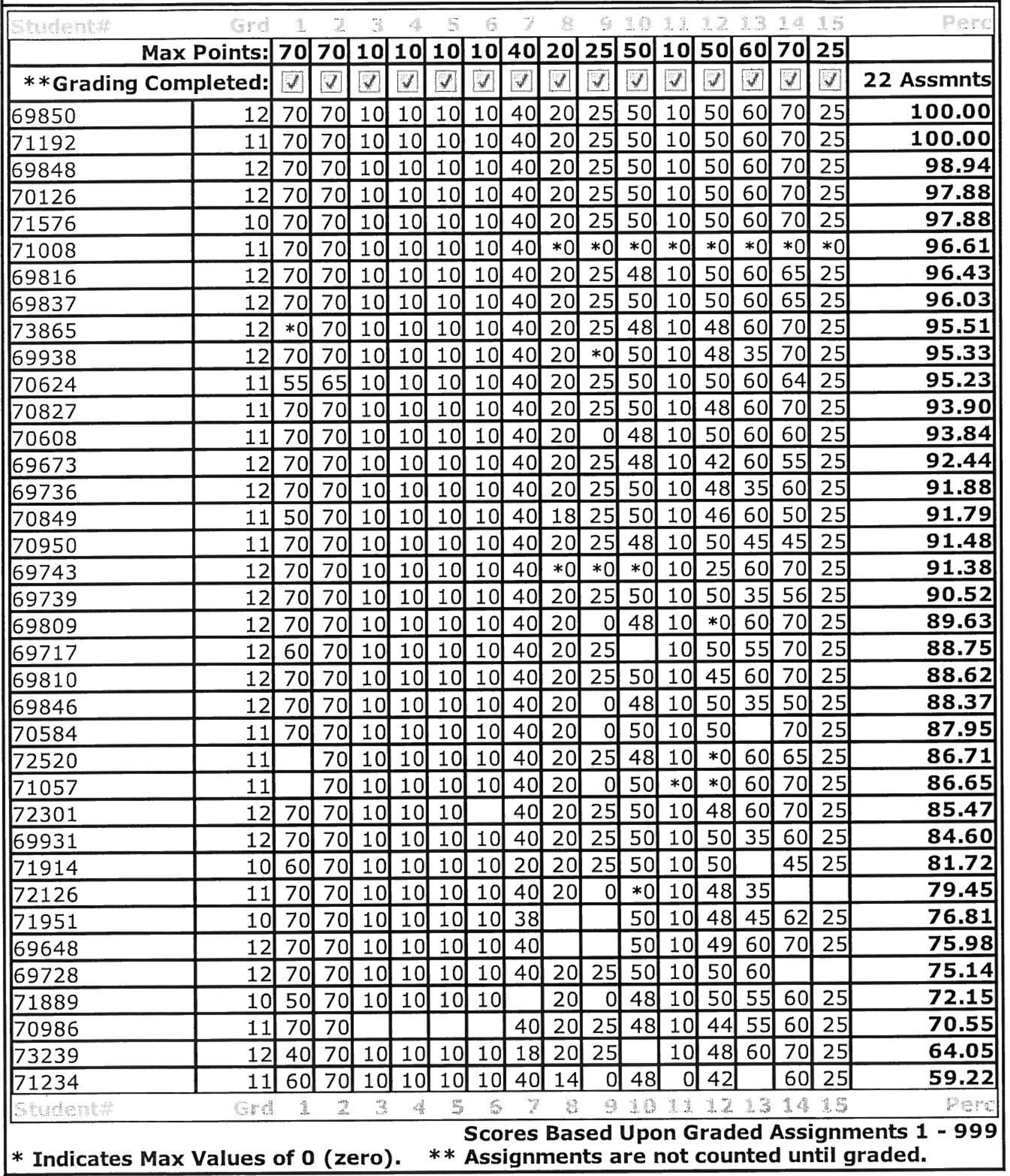


Page: 2

3/14/2013 10:48:59 PM

\begin{tabular}{|c|c|c|c|c|c|c|c|c|c|}
\hline & $1-$ & $\begin{array}{l}\text { rade } \\
\text { rtHis }\end{array}$ & $\begin{array}{l}\text { book } \\
\text { tFID }\end{array}$ & $\begin{array}{l}\text { Sum } \\
\text { gn1 }\end{array}$ & $\begin{array}{l}\text { nary } \\
\text { Sp }\end{array}$ & & & & Ioimo,] \\
\hline Studenity & Eret & 18 & 12 & 1.8 & 19 & 28 & 21 & 22 & pars \\
\hline & Max Points: & 50 & 50 & 20 & 50 & 30 & 12 & 100 & \\
\hline & **Grading Completed: & $\nabla$ & D & 团 & D. & 0 & Q & 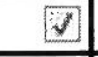 & 22 Assmnts \\
\hline 69850 & \begin{tabular}{|r|r|} 
& 12 \\
\end{tabular} & 50 & 50 & 20 & 50 & 30 & 12 & 100 & 100.00 \\
\hline 71192 & 11 & 50 & 50 & 20 & 50 & 30 & 12 & 100 & 100.00 \\
\hline 69848 & 12 & 50 & 50 & 20 & 50 & 30 & 12 & 92 & 98.94 \\
\hline 70126 & 12 & 45 & 50 & 15 & 50 & 30 & 12 & 93 & 97.88 \\
\hline 71576 & 10 & 50 & 50 & 15 & 50 & 30 & 12 & 88 & 97.88 \\
\hline 71008 & 11 & $* 0$ & $* 0$ & 20 & 50 & 30 & 12 & 89 & 96.61 \\
\hline 69816 & 12 & 41 & 44 & 20 & 50 & 30 & 12 & 94 & 96.43 \\
\hline 69837 & 12 & 41 & 44 & 20 & 50 & 30 & 12 & 89 & 96.03 \\
\hline 73865 & 12 & 40 & 50 & 20 & 50 & 30 & 12 & 80 & 95.51 \\
\hline 69938 & 12 & 50 & 50 & 20 & 50 & 30 & 12 & 87 & 95.33 \\
\hline 70624 & 11 & 50 & 50 & 20 & 50 & 30 & 12 & 85 & 95.23 \\
\hline 70827 & 11 & 35 & 50 & 10 & $* 0$ & 30 & 10 & 86 & 93.90 \\
\hline 70608 & 11 & 44 & 50 & 20 & 50 & 30 & 12 & 93 & 93.84 \\
\hline 69673 & 12 & 43 & 44 & 15 & 50 & 30 & 12 & 82 & 92.44 \\
\hline 69736 & 12 & 43 & 44 & 15 & 50 & 30 & 12 & 86 & 91.88 \\
\hline 70849 & 11 & 41 & 44 & 20 & 50 & 30 & 12 & 91 & 91.79 \\
\hline 70950 & 11 & 35 & 50 & 20 & 50 & 30 & 12 & 85 & 91.48 \\
\hline 69743 & 12 & 40 & 50 & 20 & 50 & 30 & 12 & 79 & 91.38 \\
\hline 69739 & 12 & 35 & 50 & 10 & 50 & 30 & 12 & 83 & 90.52 \\
\hline 69809 & 12 & 41 & 38 & 20 & 50 & 30 & 8 & 79 & 89.63 \\
\hline 69717 & 12 & 45 & 50 & 15 & 50 & 30 & 12 & 86 & 88.75 \\
\hline 69810 & 12 & 40 & 50 & & & 30 & 12 & 95 & 88.62 \\
\hline 69846 & 12 & 41 & 44 & 20 & 50 & 30 & 12 & 89 & 88.37 \\
\hline 70584 & 11 & 38 & 50 & 20 & 50 & 30 & 12 & 93 & 87.95 \\
\hline 72520 & 11 & 35 & 50 & 20 & 50 & 30 & 12 & 83 & 86.71 \\
\hline 71057 & 11 & 50 & 50 & 15 & 50 & 30 & 12 & 87 & 86.65 \\
\hline 72301 & 12 & 50 & 50 & 20 & 50 & 30 & 12 & & 85.47 \\
\hline 69931 & 12 & 43 & 44 & & & 30 & 11 & 92 & 84.60 \\
\hline 71914 & 10 & 35 & 50 & 15 & 50 & 30 & 10 & 76 & 81.72 \\
\hline 72126 & 11 & $* 0$ & $* 0$ & 5 & 50 & 30 & 12 & 91 & 79.45 \\
\hline 71951 & 10 & 35 & 50 & & & & 12 & 92 & 76.81 \\
\hline 69648 & 12 & 41 & 38 & & & & 6 & 76 & 75.98 \\
\hline 69728 & 12 & & & 20 & 50 & 30 & 12 & 92 & 75.14 \\
\hline 71889 & 10 & 41 & 38 & & & 30 & & 74 & 72.15 \\
\hline 70986 & 11 & 43 & 44 & 10 & $* 0$ & & & 0 & 70.55 \\
\hline 73239 & 12 & 38 & 50 & & & 30 & 12 & & 64.05 \\
\hline 71234 & 11 & 45 & 50 & & & & 10 & 0 & 59.22 \\
\hline Stanent & Grov & 15 & 17 & $1 \%$ & 4 & 20 & 21 & 22 & Perre \\
\hline
\end{tabular}


Page: 1 $<$ Back $>$ 3/14/2013 10:59:11 PM

\begin{tabular}{|c|c|c|c|c|c|c|c|c|c|c|c|c|c|c|c|c|c|}
\hline & & & & & $\begin{array}{l}\text { Gra } \\
2-I\end{array}$ & $\begin{array}{l}\text { debc } \\
\text { Int A }\end{array}$ & $\begin{array}{l}\text { oook } \\
\mathrm{Ag} \mathrm{Bi}\end{array}$ & $\begin{array}{l}\text { Sur } \\
\text { io - }\end{array}$ & $\begin{array}{l}\mathrm{mmma} \\
\mathrm{Spr}\end{array}$ & $\begin{array}{l}\text { ary } \\
\text { ring }\end{array}$ & & & & & & & Ioimo,J \\
\hline Studentht & Grd & 1 & 2 & 3 & 4 & 5 & 6 & 2 & 8 & 9 & 10 & 21 & 12 & 28 & 36 & 1.5 & Perd \\
\hline & nts: & 20 & 10 & 20 & 30 & 30 & 15 & 10 & 25 & 15 & 20 & 50 & 10 & 40 & 55 & 10 & \\
\hline$* *$ Gradin & ted: & D & (1) & $\nabla$ & D & 0 & $\checkmark$ & 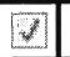 & D & 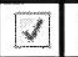 & D & 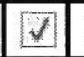 & 0 & (1) & 0 & (N) & 30 Assmnts \\
\hline 72764 & 9 & 20 & 10 & 19 & 30 & 28 & 0 & 10 & 25 & 15 & 20 & 50 & 10 & 40 & 55 & 10 & 105.44 \\
\hline 72735 & 9 & 20 & 10 & 20 & 30 & 30 & 15 & 10 & 25 & 15 & 20 & 50 & 10 & 40 & 55 & 10 & 102.41 \\
\hline 73065 & 9 & 20 & 10 & 20 & 30 & 30 & 15 & 10 & 25 & 15 & 20 & 50 & 10 & 40 & 55 & 10 & 100.70 \\
\hline 72885 & 9 & 20 & 10 & 20 & 30 & 30 & 15 & 10 & 25 & 15 & 20 & 40 & 10 & 40 & \begin{tabular}{|l|}
55 \\
\end{tabular} & 10 & 99.17 \\
\hline 72823 & 9 & 20 & \begin{tabular}{|l|}
10 \\
\end{tabular} & 0 & 30 & 30 & 15 & 10 & 25 & 15 & 20 & 45 & 10 & 40 & 55 & 10 & 96.49 \\
\hline 71799 & 10 & $* 0$ & $* 0$ & $* 0$ & 30 & 30 & 15 & 10 & 25 & 15 & 20 & 50 & 10 & 40 & 55 & 10 & 95.93 \\
\hline 71600 & 10 & 20 & 10 & 20 & 30 & 30 & 15 & 10 & 25 & 15 & 20 & 40 & 10 & 40 & \begin{tabular}{|l|}
55 \\
\end{tabular} & 10 & 95.92 \\
\hline 72247 & 11 & 20 & \begin{tabular}{|l|}
10 \\
\end{tabular} & 15 & 30 & 15 & 0 & $* 0$ & $* 0$ & $* 0$ & 20 & 40 & 10 & 40 & \begin{tabular}{|l|}
55 \\
\end{tabular} & 10 & 5.55 \\
\hline 72761 & 9 & 20 & 10 & 17 & 20 & 20 & 5 & 10 & 25 & 15 & 20 & 40 & 10 & 40 & \begin{tabular}{|l|}
55 \\
\end{tabular} & 10 & 4.58 \\
\hline 72702 & 9 & 20 & 10 & 10 & 30 & 20 & 0 & 10 & 15 & 15 & 20 & 40 & 10 & 40 & 55 & 10 & 3.91 \\
\hline 72854 & 9 & 20 & 10 & 20 & 30 & 30 & 13 & 10 & 25 & 4 & 20 & 42 & 10 & 40 & 55 & 10 & 90.32 \\
\hline 73066 & 9 & 20 & 10 & 20 & 30 & 30 & 5 & 10 & 25 & 15 & 20 & 50 & 10 & 40 & 55 & 10 & 89.41 \\
\hline 71969 & 10 & 20 & 10 & 0 & 30 & 30 & 9 & 10 & 25 & 15 & 20 & 50 & 10 & 40 & \begin{tabular}{|l|}
55 \\
\end{tabular} & 10 & 8.76 \\
\hline 72671 & 9 & 18 & 10 & 10 & 30 & 30 & 15 & 10 & 25 & 15 & 20 & 40 & \begin{tabular}{|l|}
10 \\
\end{tabular} & 40 & 55 & 10 & 8.70 \\
\hline 72697 & 9 & 20 & 10 & 20 & 30 & 30 & 10 & 10 & 25 & 10 & 20 & 50 & 10 & 35 & 55 & 10 & 88.31 \\
\hline 71896 & 10 & 20 & 10 & 20 & 30 & 30 & 15 & 10 & 25 & 15 & 20 & 45 & 10 & 40 & 55 & 10 & 88.28 \\
\hline 72529 & 9 & 20 & \begin{tabular}{|l|}
10 \\
\end{tabular} & 20 & 30 & 30 & 15 & 10 & 25 & \begin{tabular}{|l|}
15 \\
\end{tabular} & 20 & 40 & 10 & 40 & \begin{tabular}{|l|}
55 \\
\end{tabular} & 5 & 83.64 \\
\hline 71742 & 10 & 20 & 10 & 0 & 28 & \begin{tabular}{|l|l|}
33 \\
\end{tabular} & 0 & 10 & 25 & 10 & 20 & 50 & 10 & & & & 3.31 \\
\hline 71548 & 10 & 20 & 10 & 20 & 30 & 30 & 15 & 10 & 25 & \begin{tabular}{|l|}
15 \\
\end{tabular} & 20 & 50 & \begin{tabular}{|l|}
10 \\
\end{tabular} & \begin{tabular}{|l|}
40 \\
\end{tabular} & 55 & 10 & 2.66 \\
\hline 72621 & 9 & 20 & 10 & 20 & 30 & 24 & 7 & 10 & 25 & \begin{tabular}{l|}
15 \\
\end{tabular} & \begin{tabular}{|l|}
20 \\
\end{tabular} & 50 & 10 & 40 & 55 & 10 & 81.92 \\
\hline 72825 & 9 & 20 & 10 & 20 & 30 & 30 & 14 & 8 & 25 & 15 & 20 & 45 & \begin{tabular}{|l|}
10 \\
\end{tabular} & 35 & 55 & 10 & 81.52 \\
\hline 72801 & 9 & 20 & \begin{tabular}{|l|}
10 \\
\end{tabular} & 20 & 30 & 30 & 13 & 10 & 23 & 0 & 20 & 44 & \begin{tabular}{|l|}
10 \\
\end{tabular} & 30 & 55 & 10 & 81.39 \\
\hline 72728 & 9 & 20 & 10 & 0 & 30 & 30 & 15 & 10 & 25 & \begin{tabular}{|l|}
10 \\
\end{tabular} & 20 & 20 & 5 & \begin{tabular}{|l|}
40 \\
\end{tabular} & 55 & 10 & 81.31 \\
\hline 72733 & 9 & \begin{tabular}{|l|l|}
18 & \\
\end{tabular} & \begin{tabular}{|l|}
10 \\
\end{tabular} & 0 & 30 & 15 & 0 & 10 & 25 & 15 & 20 & 40 & 10 & \begin{tabular}{|l|}
40 \\
\end{tabular} & 55 & \begin{tabular}{|l|}
10 \\
\end{tabular} & 81.28 \\
\hline 72551 & 9 & 20 & 10 & 20 & 30 & 30 & 12 & 10 & 25 & 10 & 20 & 45 & \begin{tabular}{|l|}
10 \\
\end{tabular} & 35 & 55 & 10 & 79.75 \\
\hline 72712 & 9 & 17 & 10 & 0 & 20 & 30 & 8 & 2 & 20 & 10 & 14 & 5 & 10 & 40 & 55 & 10 & 79.74 \\
\hline 72879 & 9 & 20 & 10 & 20 & 30 & 23 & 0 & 10 & 25 & 15 & 14 & 10 & 10 & 35 & 55 & 5 & 79.71 \\
\hline 72544 & 9 & 20 & 10 & 20 & 20 & 20 & 15 & 10 & 25 & 15 & 20 & 45 & 10 & 35 & 55 & \begin{tabular}{|l|}
10 \\
\end{tabular} & 78.81 \\
\hline 72848 & 9 & 20 & 10 & 20 & 30 & 20 & 12 & 5 & 23 & 0 & 20 & 25 & 10 & 38 & 55 & 0 & 77.74 \\
\hline 71105 & 11 & 20 & 10 & 20 & 30 & 30 & 7 & 10 & 22 & 5 & 20 & 44 & 10 & 40 & 55 & 10 & 76.88 \\
\hline 72822 & 9 & & & & 30 & 28 & 5 & 8 & 25 & 0 & 20 & 20 & 10 & 40 & 55 & 5 & 75.83 \\
\hline 72596 & 9 & 20 & 10 & 0 & 30 & 24 & 5 & \begin{tabular}{|l|}
5 \\
\end{tabular} & 23 & 0 & 12 & 20 & 2 & 30 & 55 & 10 & 75.81 \\
\hline 72561 & 9 & 20 & 10 & 20 & 23 & 15 & 0 & \begin{tabular}{|l|}
10 \\
\end{tabular} & 25 & 0 & 20 & 30 & 10 & 40 & 55 & \begin{tabular}{|l|}
10 \\
\end{tabular} & 74.48 \\
\hline 72954 & 9 & 20 & 10 & 0 & 30 & 30 & 10 & 10 & 25 & 15 & 20 & 48 & 10 & & & & 73.65 \\
\hline 72914 & 9 & 20 & 10 & 20 & 30 & 25 & 0 & & & & 14 & 9 & 0 & 35 & 55 & 10 & 72.79 \\
\hline 71645 & 10 & 20 & 10 & 0 & 28 & 30 & 0 & 10 & 20 & 5 & 18 & 20 & 0 & 40 & 55 & 10 & 72.44 \\
\hline 70966 & 11 & 20 & 10 & 0 & 30 & 30 & 7 & 10 & 13 & 10 & 20 & 30 & 10 & 40 & 35 & 10 & 71.32 \\
\hline 72771 & 9 & 20 & 10 & \begin{tabular}{|l|}
20 \\
\end{tabular} & 30 & 30 & 5 & 10 & 25 & 4 & 20 & 43 & 10 & 40 & 55 & 10 & 70.17 \\
\hline 72103 & 10 & 20 & 10 & 0 & & & & 8 & 23 & 0 & 20 & 30 & 10 & 40 & 55 & 0 & 65.18 \\
\hline 72708 & 9 & 20 & 10 & 0 & 30 & 20 & 0 & 10 & 15 & 0 & 20 & 40 & 10 & 40 & 55 & 10 & 56.23 \\
\hline \begin{tabular}{|l}
72554 \\
\end{tabular} & 9 & \begin{tabular}{|l|}
20 \\
\end{tabular} & 10 & 0 & 30 & 30 & 5 & \begin{tabular}{|l|}
10 \\
\end{tabular} & 25 & 3 & 20 & 43 & 10 & & & & 54.51 \\
\hline Srudentut & rest & 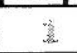 & 2 & 3 & 4 & 5 & 6 & 7 & है & 9 & 10 & 12 & 12 & 等落 & 14 & 15 & wert \\
\hline
\end{tabular}


Page: 2 3/14/2013 10:59:11 PM

\begin{tabular}{|c|c|c|c|c|c|c|c|c|c|c|c|c|c|c|c|c|c|}
\hline \multicolumn{17}{|c|}{$\begin{array}{l}\text { Gradebook Summary } \\
2 \text { - Int Ag Bio - Spring }\end{array}$} & \multirow{2}{*}{$\frac{\text { Ioimo,J }}{2 \mathrm{p}}$} \\
\hline Standenter & Stot & 26 & 17 & 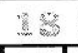 & $29:$ & 25 & In & 22 & 23 & 24 & 25 & 25 & 23 & 28 & 29 & 30 & \\
\hline & Max Points: & $21:$ & 50 & 30 & $35:$ & 20 & 15 & 15 & 10 & 16 & 25 & 40 & 20 & 20 & 30 & 20 & \\
\hline \multicolumn{2}{|c|}{$* *$ Grading Completed: } & 0 & 0 & D & (⿴) & (1) & D & (1) & V] & (1) & Q & 0 & D & D & Q & 四 & 30 Assmnts \\
\hline 72764 & \begin{tabular}{r|r|} 
& 9 \\
\end{tabular} & 19 & 44 & 30 & 33 & 12 & 15 & 15 & 10 & 16 & 25 & 39 & 20 & 125 & 19 & 18 & 105.44 \\
\hline 72735 & 9 & 26 & 46 & 30 & 25 & 20 & 15 & 15 & 10 & 16 & 25 & 38 & 20 & 20 & 27 & 17 & 102.41 \\
\hline 73065 & 9 & 23 & 42 & 30 & 35 & 20 & 14 & 15 & 10 & 16 & 25 & 40 & 20 & 20 & 26 & 20 & 100.70 \\
\hline 72885 & 9 & 26 & 50 & 30 & 25 & 20 & 15 & 15 & 10 & 16 & 15 & 20 & 20 & 20 & 30 & 20 & 99.17 \\
\hline 72823 & 9 & 22 & 32 & 30 & 35 & 20 & 15 & 15 & 10 & 16 & 25 & 40 & 20 & 20 & 20 & 18 & 96.49 \\
\hline 71799 & 10 & 18 & 50 & 30 & 25 & 20 & \begin{tabular}{|l|}
15 \\
\end{tabular} & 15 & 10 & 16 & 25 & 40 & 20 & 20 & 28 & 20 & 95.93 \\
\hline 71600 & 10 & 21 & \begin{tabular}{|l|}
40 \\
\end{tabular} & \begin{tabular}{|l|}
30 \\
\end{tabular} & \begin{tabular}{|l|}
35 \\
\end{tabular} & 20 & 15 & 15 & 10 & 16 & 20 & 40 & 20 & 20 & 20 & 10 & 95.92 \\
\hline 72247 & 11 & 22 & 45 & 30 & \begin{tabular}{|l|}
35 \\
\end{tabular} & 20 & 15 & 15 & 10 & 16 & 25 & 40 & 20 & 18 & 27 & 20 & 95.55 \\
\hline 72761 & 9 & 21 & 35 & 30 & \begin{tabular}{|l|}
35 \\
\end{tabular} & 20 & 14 & 15 & 10 & 16 & 25 & 40 & 20 & 20 & 30 & 18 & 94.58 \\
\hline 72702 & 9 & 22 & 50 & 25 & \begin{tabular}{|l|}
25 \\
\end{tabular} & 20 & 15 & 15 & 10 & 16 & 25 & 39 & 20 & 19 & 28 & 20 & 93.91 \\
\hline 72854 & 9 & 26 & & 30 & \begin{tabular}{|l|}
15 \\
\end{tabular} & 0 & 15 & 15 & 0 & 14 & 20 & 40 & 20 & 20 & 18 & 5 & 90.32 \\
\hline 73066 & 9 & 20 & & 30 & \begin{tabular}{|l|}
25 \\
\end{tabular} & 10 & 15 & 15 & 0 & 14 & 25 & 40 & 20 & 20 & 22 & 15 & 89.41 \\
\hline 71969 & 10 & 19 & & 30 & 25 & 0 & 7 & 15 & 7 & 16 & 25 & 40 & 20 & 20 & 26 & 18 & 88.76 \\
\hline 72671 & 9 & 18 & 32 & 30 & \begin{tabular}{|l|}
15 \\
\end{tabular} & 12 & 15 & \begin{tabular}{|l|}
15 \\
\end{tabular} & 8 & 16 & 25 & 38 & 20 & 20 & 15 & 10 & 38.70 \\
\hline 72697 & 9 & 17 & 34 & 26 & \begin{tabular}{|l|}
25 \\
\end{tabular} & 0 & 14 & 15 & 0 & 14 & 25 & 38 & 20 & 20 & 30 & 20 & 88.31 \\
\hline 71896 & 10 & 17 & & 30 & \begin{tabular}{|l|}
25 \\
\end{tabular} & 10 & 15 & 15 & 4 & 16 & 20 & 40 & 20 & 20 & 24 & 10 & 38.28 \\
\hline 72529 & 9 & 14 & 50 & 30 & \begin{tabular}{|l|}
15 \\
\end{tabular} & 10 & 15 & 13 & 0 & \begin{tabular}{|l|}
12 \\
\end{tabular} & 23 & 40 & 20 & 10 & 30 & 20 & 83.64 \\
\hline 71742 & 10 & 27 & 32 & 28 & \begin{tabular}{|l|}
25 \\
\end{tabular} & 0 & 11 & 15 & 10 & 16 & 25 & 40 & 20 & 19 & 25 & 0 & 83.31 \\
\hline 71548 & 10 & 18 & 50 & 30 & 35 & 20 & 15 & 15 & 10 & & 25 & 40 & 20 & 20 & 28 & 20 & 82.66 \\
\hline 72621 & 9 & 17 & & 30 & 25 & 10 & 15 & 15 & 0 & 10 & 25 & 35 & 20 & 20 & 20 & 16 & 81.92 \\
\hline 72825 & 9 & 16 & 50 & 30 & 35 & 20 & 14 & 15 & 10 & 4 & 25 & 35 & 20 & 19 & 20 & 20 & 81.52 \\
\hline 72801 & 9 & \begin{tabular}{|l|}
23 \\
\end{tabular} & \begin{tabular}{|l|}
0 \\
\end{tabular} & 20 & 25 & 10 & 15 & 15 & 0 & \begin{tabular}{|l|}
14 \\
\end{tabular} & & & & 19 & \begin{tabular}{|l|}
30 \\
\end{tabular} & 20 & 81.39 \\
\hline 72728 & 9 & 14 & & 30 & 35 & 20 & 13 & 15 & 5 & 16 & 20 & 40 & 20 & 20 & 20 & 0 & 81.31 \\
\hline 72733 & 9 & 18 & 45 & 30 & 21 & 15 & & & & 16 & 25 & 30 & 20 & 18 & \begin{tabular}{|l|}
7 \\
\end{tabular} & 8 & 81.28 \\
\hline 72551 & 9 & 20 & & 28 & 25 & 0 & 14 & 15 & 0 & 6 & 25 & 35 & 20 & 19 & 20 & 20 & 79.75 \\
\hline 72712 & 9 & \begin{tabular}{|l|}
17 \\
\end{tabular} & 50 & 30 & 35 & \begin{tabular}{|l|}
10 \\
\end{tabular} & 15 & 15 & 10 & \begin{tabular}{|l|}
14 \\
\end{tabular} & 22 & 35 & 20 & 16 & 14 & 10 & 79.74 \\
\hline 72879 & 9 & \begin{tabular}{|l|}
18 \\
\end{tabular} & 34 & 25 & \begin{tabular}{|l|}
35 \\
\end{tabular} & 20 & 15 & 15 & 0 & \begin{tabular}{|l|}
8 \\
\end{tabular} & 25 & 40 & 20 & 17 & \begin{tabular}{|l|}
29 \\
\end{tabular} & 20 & 79.71 \\
\hline 72544 & 9 & 20 & 50 & 28 & 25 & 0 & 4 & 7 & 0 & 6 & 25 & 35 & 20 & 20 & 10 & 20 & 78.81 \\
\hline 72848 & 9 & 21 & 22 & 11 & 10 & 0 & 11 & 5 & 0 & 14 & 25 & 40 & 20 & 20 & 10 & 0 & 77.74 \\
\hline 71105 & 11 & \begin{tabular}{|l|}
22 \\
\end{tabular} & & & & & 15 & 15 & 0 & 10 & 25 & 28 & 20 & 14 & 12 & 20 & 76.88 \\
\hline 72822 & 9 & 14 & 35 & 30 & 35 & 20 & 15 & 15 & 10 & 10 & 25 & 32 & 20 & 18 & 30 & 20 & 75.83 \\
\hline 72596 & 9 & 13 & 50 & 30 & \begin{tabular}{|l|}
25 \\
\end{tabular} & 0 & 15 & 12 & 10 & 16 & \begin{tabular}{|l|}
20 \\
\end{tabular} & 40 & 20 & 14 & 17 & 0 & 75.81 \\
\hline \begin{tabular}{|l}
72561 \\
\end{tabular} & 9 & \begin{tabular}{|l|}
18 \\
\end{tabular} & 48 & 30 & 25 & \begin{tabular}{|l|}
0 \\
\end{tabular} & 15 & 15 & 2 & 6 & 25 & 32 & 20 & 18 & 10 & 8 & 74.48 \\
\hline 72954 & 9 & 18 & & 30 & 10 & 20 & 15 & 15 & 2 & 14 & 20 & 40 & 20 & 20 & 20 & 10 & 73.65 \\
\hline 72914 & 9 & 19 & 50 & 30 & 30 & 20 & 15 & 15 & 10 & 10 & 25 & 39 & 20 & & & & 72.79 \\
\hline 71645 & 10 & 16 & 30 & 30 & 25 & 0 & & & & 14 & 13 & 25 & 20 & 10 & 29 & 0 & 72.44 \\
\hline 70966 & 11 & 16 & 50 & & & & 15 & 15 & 0 & 16 & 20 & 40 & 20 & & & & 71.32 \\
\hline 72771 & 9 & 14 & & & & & & & & 14 & 20 & 40 & 20 & 20 & 13 & 0 & 70.17 \\
\hline 72103 & 10 & 16 & & 28 & 25 & 0 & 14 & 15 & 0 & 14 & 15 & 35 & 20 & & & & 65.18 \\
\hline 72708 & 9 & 19 & 26 & & & & 15 & 15 & 5 & & & & & 15 & 17 & 17 & 56.23 \\
\hline 72554 & 9 & 22 & & & & & 15 & 9 & 0 & 2 & 5 & 40 & 10 & 20 & 13 & 0 & 54.51 \\
\hline Student & grat & 16 & 17 & 1.8 & 29 & 20 & 21 & 22 & 23 & 24 & 35 & 26 & 27 & 28 & 29 & 30 & tores \\
\hline
\end{tabular}


Page: 1 $<$ Back > 3/14/2013 10:59:39 PM

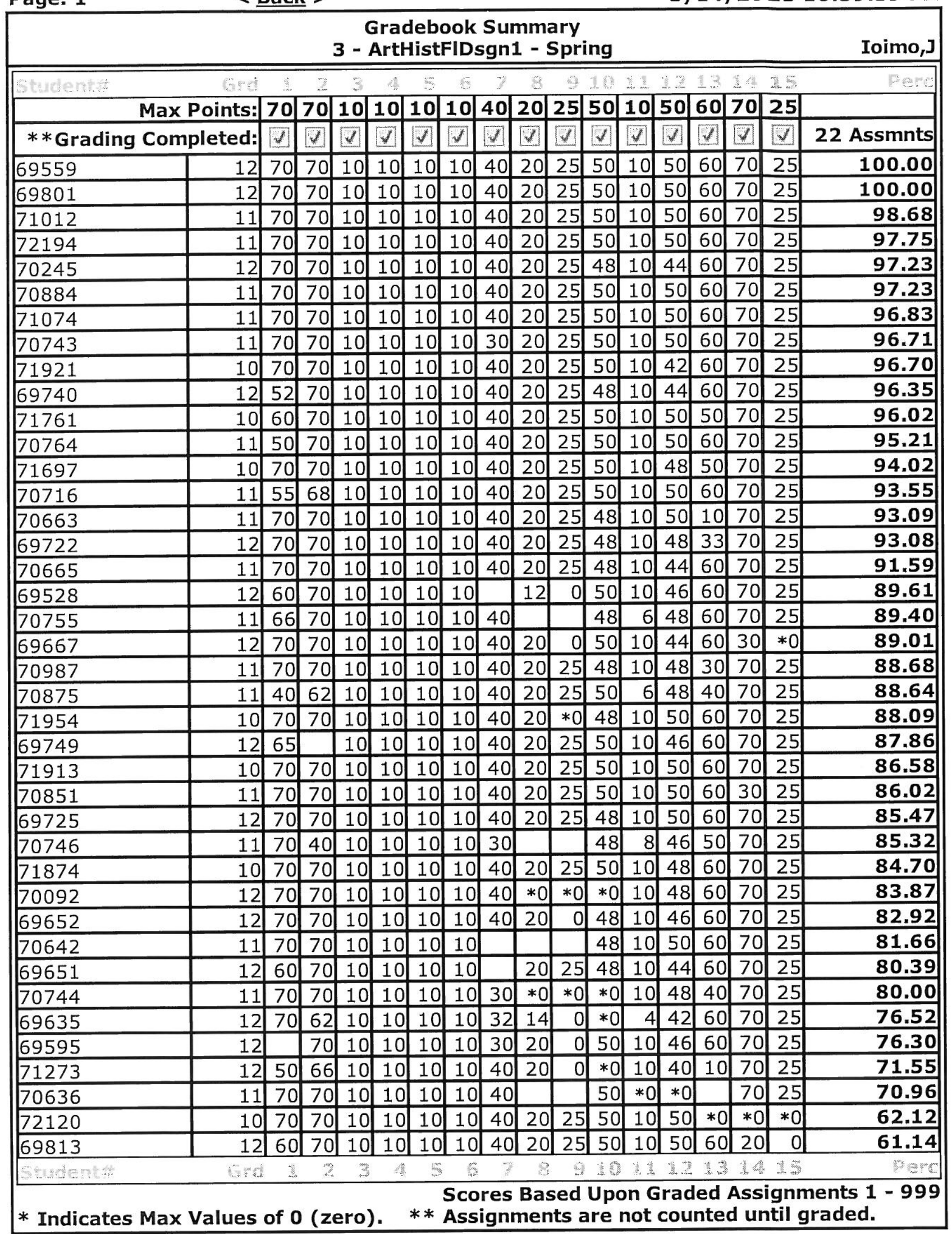


Page: 2

3/14/2013 10:59:39 PM

\begin{tabular}{|c|c|c|c|c|c|c|c|c|c|}
\hline & $3-$ & $\begin{array}{l}\text { Arade } \\
\text { ArtHis }\end{array}$ & $\begin{array}{l}\text { book } \\
\text { stFIDs }\end{array}$ & $\begin{array}{l}\text { Sum } \\
\text { gnn1 }\end{array}$ & $\begin{array}{l}\text { mary } \\
-\mathrm{Spr}\end{array}$ & & & & [oimo,] \\
\hline Students & 58 & 16 & b & $2 \mathrm{~g}$ & 19 & 20 & 21 & 22 & perte \\
\hline & Max Points: & 50 & 50 & 20 & 50 & 30 & 12 & 100 & \\
\hline & **Grading Completed: & 0 & D & 0 & 0 & Q & D & 回 & 22 Assmnts \\
\hline 69559 & \begin{tabular}{r|r|} 
& 12 \\
\end{tabular} & 50 & 50 & 20 & 50 & 30 & 12 & 100 & 100.00 \\
\hline 69801 & 12 & 50 & 50 & 20 & 50 & 30 & 12 & 100 & 100.00 \\
\hline 71012 & 11 & 50 & 50 & 20 & 50 & 30 & 12 & 90 & 98.68 \\
\hline 72194 & 11 & 50 & 50 & 20 & 50 & 30 & 12 & 83 & 97.75 \\
\hline 70245 & 12 & 50 & 50 & 20 & 50 & 30 & 12 & 87 & 97.23 \\
\hline 70884 & 11 & 45 & 50 & 20 & 50 & 30 & 12 & 84 & 97.23 \\
\hline 71074 & 11 & 46 & 50 & 20 & 50 & 30 & 12 & 80 & 96.83 \\
\hline 70743 & 11 & 50 & 50 & 20 & 50 & 30 & 8 & 87 & 96.71 \\
\hline 71921 & 10 & 44 & 50 & 20 & 50 & 30 & 12 & 89 & 96.70 \\
\hline 69740 & 12 & 50 & 50 & 20 & 50 & 30 & 12 & 95 & 96.35 \\
\hline 71761 & 10 & 46 & 50 & 20 & 50 & 30 & 10 & 92 & 96.02 \\
\hline \begin{tabular}{|l}
70764 \\
\end{tabular} & 11 & 44 & 50 & 20 & 50 & 30 & 12 & 86 & 95.21 \\
\hline 71697 & 10 & 48 & 45 & 10 & 50 & 30 & 12 & 80 & 94.02 \\
\hline 70716 & 11 & 40 & 49 & 20 & 50 & 30 & 12 & 76 & 93.55 \\
\hline 70663 & 11 & 50 & 40 & 20 & 50 & & 8 & 91 & 93.09 \\
\hline 69722 & 12 & 48 & 48 & 10 & 50 & 30 & & 97 & 93.08 \\
\hline 70665 & 11 & 46 & 50 & 20 & 50 & & & 84 & 91.59 \\
\hline 69528 & 12 & 50 & 49 & 20 & 50 & 30 & 12 & 97 & 89.61 \\
\hline 70755 & 11 & 44 & 50 & 20 & 50 & 30 & 12 & 76 & 89.40 \\
\hline 69667 & 12 & 46 & 50 & 20 & 50 & 30 & & 85 & 89.01 \\
\hline 70987 & 11 & 40 & 50 & 20 & 50 & 0 & 12 & 77 & 88.68 \\
\hline 70875 & 11 & 44 & 50 & 18 & 50 & 30 & 12 & 74 & 88.64 \\
\hline 71954 & 10 & 44 & 50 & & & 30 & 12 & 84 & 88.09 \\
\hline 69749 & 12 & 40 & 40 & 20 & 50 & 30 & 12 & 93 & 87.86 \\
\hline 71913 & 10 & 44 & 50 & & & & 12 & 95 & 86.58 \\
\hline 70851 & 11 & 44 & 50 & 20 & 50 & 30 & 12 & & 86.02 \\
\hline 69725 & 12 & 50 & 50 & 10 & 50 & 30 & 12 & 0 & 85.47 \\
\hline 70746 & 11 & 45 & 50 & 10 & 50 & 30 & 12 & 90 & 85.32 \\
\hline 71874 & 10 & 44 & 50 & & & & & 94 & 84.70 \\
\hline 70092 & 12 & 50 & 50 & & & & & 100 & 83.87 \\
\hline 69652 & 12 & 50 & 50 & 20 & 50 & 30 & 12 & & 82.92 \\
\hline 70642 & 11 & 44 & 50 & 20 & 50 & & & 77 & 81.66 \\
\hline 69651 & 12 & 50 & 50 & 20 & 50 & 30 & 12 & & 80.39 \\
\hline 70744 & 11 & 44 & 50 & 20 & 50 & 30 & 12 & & 80.00 \\
\hline 69635 & 12 & 50 & 50 & & & & 12 & 80 & 76.52 \\
\hline 69595 & 12 & 44 & 50 & & & 30 & 8 & 89 & 76.30 \\
\hline 71273 & 12 & 50 & & & & 30 & 12 & 80 & 71.55 \\
\hline 70636 & 11 & 46 & 50 & & & & & 88 & 70.96 \\
\hline 72120 & 10 & $* 0$ & $* 0$ & & & & & & 62.12 \\
\hline 69813 & 12 & 44 & & & & 30 & 12 & & 61.14 \\
\hline \begin{tabular}{|l|} 
Studentlt \\
\end{tabular} & 63 & 16 & 12 & 18 & 29 & 28 & 21 & 22 & Pere \\
\hline
\end{tabular}


Page: 1 $<$ Back $>$ 3/14/2013 10:50:48 PM

\begin{tabular}{|c|c|c|c|c|c|c|c|c|c|c|c|c|c|c|c|c|c|}
\hline & & & & 4- & Ar & His & s. & sgn1 & $1-9$ & & ing & & & & & & [oimo,] \\
\hline Gturd & $6 \mathrm{met}$ & 1 & 2 & 3 & 4 & 5 & 6 & 7 & 8 & 6 & 10 & 11 & 12 & $\mathrm{~B}$ & 14 & 35 & Peso \\
\hline & Max Points: & 70 & 70 & 10 & 10 & 10 & 10 & 40 & 20 & 25 & 50 & 10 & 50 & 60 & 70 & 25 & \\
\hline$* *$ Gradin & Completed: & $\checkmark$ & D. & U & 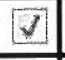 & $D$ & $D$ & 1 & D & $\Delta$ & $D$ & $\sqrt{ }$ & 7 & $\checkmark$ & $d$ & U & 22 Assmnts \\
\hline 70816 & 11 & 70 & 70 & 10 & 10 & 10 & 10 & 40 & 20 & 25 & 50 & 10 & 50 & 50 & 70 & 25 & 98.46 \\
\hline 70786 & 11 & 70 & 70 & 10 & 10 & 10 & 10 & 40 & 20 & 25 & 50 & 10 & 50 & 60 & 70 & 25 & 98.28 \\
\hline 71854 & 10 & 70 & 70 & 10 & 10 & 10 & 10 & 40 & 20 & 25 & 50 & 10 & 50 & 60 & 70 & 25 & 97.49 \\
\hline 70666 & 11 & 70 & 70 & 10 & 10 & 10 & 10 & 40 & 20 & 25 & 48 & 10 & 48 & 60 & 20 & 25 & 96.97 \\
\hline 71143 & 11 & 70 & 70 & 10 & 10 & 10 & 10 & 40 & 20 & 25 & 48 & 10 & 48 & 60 & 70 & 25 & 96.57 \\
\hline 72411 & 11 & 70 & 70 & 10 & 10 & 10 & 10 & 40 & 20 & 25 & 45 & 10 & 48 & 60 & 70 & 25 & 96.57 \\
\hline 69659 & 12 & 60 & 70 & 10 & 10 & 10 & 10 & 40 & 20 & 25 & 50 & 10 & 50 & 60 & 70 & 25 & 95.89 \\
\hline 70704 & 11 & 70 & 70 & 10 & 10 & 10 & 10 & 40 & $* 0$ & $* 0$ & $* 0$ & 10 & 50 & 60 & 70 & 25 & 95.69 \\
\hline 70898 & 11 & 70 & 70 & 10 & 10 & 10 & 10 & 40 & 20 & 25 & 50 & 10 & 50 & 40 & 70 & 25 & 95.34 \\
\hline 70692 & 11 & 70 & 70 & 10 & 10 & 10 & 10 & 40 & 20 & 25 & 50 & 10 & 50 & 60 & 60 & 25 & 94.44 \\
\hline 69594 & 12 & 70 & 70 & 10 & 10 & 10 & 10 & 40 & 20 & 25 & 50 & 10 & 44 & 35 & 20 & 25 & 94.19 \\
\hline 70880 & 11 & 70 & 70 & 10 & 10 & 10 & 10 & 40 & 20 & 0 & 50 & 10 & 50 & 60 & 60 & 25 & 93.58 \\
\hline 70626 & 11 & 70 & 70 & 10 & 10 & 10 & 10 & 40 & 20 & 25 & 50 & 10 & 48 & 60 & 70 & 25 & $93 \times 18$ \\
\hline 70843 & 11 & 70 & 70 & 10 & 10 & 10 & 10 & 40 & $* 0$ & $* 0$ & $* 0$ & 10 & 46 & 60 & 70 & 25 & 92.00 \\
\hline 71119 & 11 & 70 & 70 & 10 & 10 & 10 & 10 & 40 & $* 0$ & $* 0$ & $* 0$ & 10 & 50 & 60 & 30 & 25 & 88.08 \\
\hline 70970 & 11 & 70 & 70 & 10 & 10 & 10 & 10 & & 10 & 25 & $* 0$ & 10 & 45 & 50 & 60 & 25 & 87.10 \\
\hline 73254 & 12 & $* 0$ & $* 0$ & 10 & 10 & 10 & 10 & $* 0$ & 20 & 25 & 50 & 10 & 50 & 60 & 60 & 25 & 84.70 \\
\hline 69746 & 12 & 50 & 70 & 10 & 10 & 10 & 10 & 30 & 20 & 0 & 50 & 10 & 48 & 60 & 60 & 25 & 84.50 \\
\hline 70693 & 11 & 70 & 70 & 10 & 10 & 10 & 10 & & 20 & 25 & 50 & 10 & 48 & 50 & 70 & 25 & 84.44 \\
\hline 70730 & 11 & 70 & 70 & 10 & 10 & 10 & 10 & 40 & 20 & 25 & 50 & 10 & 50 & 60 & 60 & 25 & 84.29 \\
\hline 70655 & 11 & 70 & 70 & 10 & 10 & 10 & 10 & 40 & 20 & 0 & 50 & 10 & 46 & 35 & 60 & 25 & 84.22 \\
\hline 70158 & 12 & 70 & 70 & 10 & 10 & 10 & 10 & 40 & 20 & 25 & 50 & 10 & 50 & 60 & 45 & 25 & 83.96 \\
\hline 73208 & 12 & 70 & 70 & 5 & 10 & 10 & 5 & 40 & & & 50 & 10 & 50 & 60 & 70 & 25 & 79.34 \\
\hline 70858 & 11 & 70 & 70 & 10 & 10 & 10 & 10 & & & & 50 & 10 & 50 & 60 & 70 & 25 & 75.29 \\
\hline 70864 & 11 & 70 & 70 & 10 & 10 & 10 & 10 & 40 & 20 & 25 & 45 & 10 & 46 & & 10 & $* 0$ & 74.43 \\
\hline 70086 & 12 & 48 & 70 & 10 & 10 & 10 & 10 & 20 & 20 & 0 & 50 & 10 & 46 & 60 & 20 & 0 & 73.86 \\
\hline 71105 & 11 & 55 & 70 & 10 & 10 & 10 & 10 & 40 & & & 50 & 10 & 48 & & 70 & 25 & 72.64 \\
\hline 71320 & 12 & 70 & 70 & 10 & 10 & 10 & 10 & 40 & 20 & 25 & 48 & 10 & 48 & 60 & 60 & 25 & 70.31 \\
\hline 73211 & 12 & 60 & 70 & 10 & 10 & 10 & 10 & 40 & 20 & 25 & 50 & $* 0$ & $* 0$ & 60 & & & 55.73 \\
\hline 69752 & 12 & 70 & 70 & 10 & 10 & 10 & 10 & 40 & $* 0$ & $* 0$ & $* 0$ & 10 & 44 & & 60 & 25 & 54.61 \\
\hline 70461 & 12 & 40 & 70 & 10 & 10 & 10 & 10 & 40 & 20 & $* 0$ & 48 & 10 & 48 & 10 & & & 52.19 \\
\hline 71221 & 11 & 70 & 70 & & & & & 30 & 20 & 25 & 40 & 10 & 50 & 54 & & & 42.23 \\
\hline 69531 & 12 & & & & & & & & & & 45 & 10 & 10 & & 60 & 25 & 26.43 \\
\hline Growenth & xyra & is & 2 & 3 & 4 & the & 5 & 7 & 8 & 9 & 20 & 12 & 12 & 2.3 & 2.4 & 1,5 & 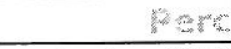 \\
\hline
\end{tabular}


Page: 2

3/14/2013 10:50:48 PM

\begin{tabular}{|c|c|c|c|c|c|c|c|c|c|}
\hline & 4- & $\begin{array}{l}\text { radel } \\
\text { rtHis }\end{array}$ & $\begin{array}{l}\text { book } \\
\text { tFIDs }\end{array}$ & $\begin{array}{l}\text { Sum } \\
\text { gn1 }\end{array}$ & $\begin{array}{l}\text { nary } \\
- \text { Spr }\end{array}$ & & & & Ioimo,J \\
\hline Student: & ard & 26 & 37 & 18 & 29 & 20 & 28 & 22 & Pers \\
\hline & Max Points: & 50 & 50 & 20 & 50 & 30 & 12 & 100 & \\
\hline & $* *$ Grading Completed: & 0 & $\nabla$ & $\nabla$ & 1 & 1 & D & 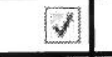 & 22 Assmnts \\
\hline 70816 & \begin{tabular}{r|r|} 
& 11 \\
\end{tabular} & 50 & 50 & 20 & $* 0$ & 30 & 12 & 97 & 98.46 \\
\hline 70786 & 11 & 40 & 50 & 20 & 50 & 30 & 12 & 97 & 98.28 \\
\hline 71854 & 10 & 50 & 50 & 20 & 50 & 30 & 12 & 81 & 97.49 \\
\hline 70666 & 11 & $* 0$ & 50 & 20 & 50 & 30 & & 94 & 96.97 \\
\hline 71143 & 11 & 41 & 50 & 20 & 50 & 30 & 12 & 87 & 96.57 \\
\hline 72411 & 11 & 46 & 50 & 20 & 50 & 30 & 12 & 85 & 96.57 \\
\hline 69659 & 12 & 44 & 50 & 20 & 50 & 30 & 12 & 83 & 95.89 \\
\hline 70704 & 11 & 40 & 50 & 20 & 50 & 30 & 12 & 82 & 95.69 \\
\hline 70898 & 11 & 44 & 50 & 20 & 50 & 30 & 12 & 87 & 95.34 \\
\hline 70692 & 11 & 40 & 49 & 20 & 50 & 30 & 12 & 77 & 94.44 \\
\hline 69594 & 12 & $* 0$ & 50 & 20 & 50 & 30 & 12 & 88 & 94.19 \\
\hline 70880 & 11 & 40 & 50 & 20 & 50 & 30 & 12 & 93 & 93.58 \\
\hline 70626 & 11 & 48 & 50 & 20 & 50 & & & 88 & 93.18 \\
\hline 70843 & 11 & 35 & 30 & 20 & 50 & 30 & 12 & 87 & 92.00 \\
\hline 71119 & 11 & 44 & 50 & 20 & 50 & & & 96 & 88.08 \\
\hline 70970 & 11 & 40 & 50 & 20 & 50 & 30 & 12 & 80 & 87.10 \\
\hline 73254 & 12 & 40 & 49 & & & 30 & $* 0$ & 87 & 84.70 \\
\hline 69746 & 12 & 50 & 50 & & $* 0$ & 30 & & 73 & 84.50 \\
\hline 70693 & 11 & 49 & 50 & & & 30 & 12 & 92 & 84.44 \\
\hline 70730 & 11 & 46 & 49 & & & & & 96 & 84.29 \\
\hline 70655 & 11 & 49 & $* 0$ & 10 & $* 0$ & & & 88 & 84.22 \\
\hline 70158 & 12 & 35 & 50 & & & 30 & 12 & 80 & 83.96 \\
\hline 73208 & 12 & 48 & 50 & & & & 12 & 84 & 79.34 \\
\hline 70858 & 11 & 35 & 50 & 20 & 50 & 30 & 12 & & 75.29 \\
\hline 70864 & 11 & 0 & $* 0$ & 20 & $* 0$ & 30 & 12 & 86 & 74.43 \\
\hline 70086 & 12 & 46 & 49 & & & 30 & 12 & 99 & 73.86 \\
\hline 71105 & 11 & 48 & 50 & & & 30 & & 75 & 72.64 \\
\hline 71320 & 12 & 40 & 49 & & & & & 0 & 70.31 \\
\hline 73211 & 12 & & & & & & & 85 & 55.73 \\
\hline 69752 & 12 & 35 & 30 & & & & & & 54.61 \\
\hline 70461 & 12 & & & & & & & 88 & 52.19 \\
\hline 71221 & 11 & & & & & & & 0 & 42.23 \\
\hline 69531 & 12 & 35 & 30 & & & & & 0 & 26.43 \\
\hline Gturentit & crat & 13 & 17 & 18 & 10 & 20 & in & 22 & perce \\
\hline
\end{tabular}


Page: 1 $<$ Back $>$

3/14/2013 11:00:02 PM

Gradebook Summary

6 - Int Ag Bio - Spring

Ioimo,]

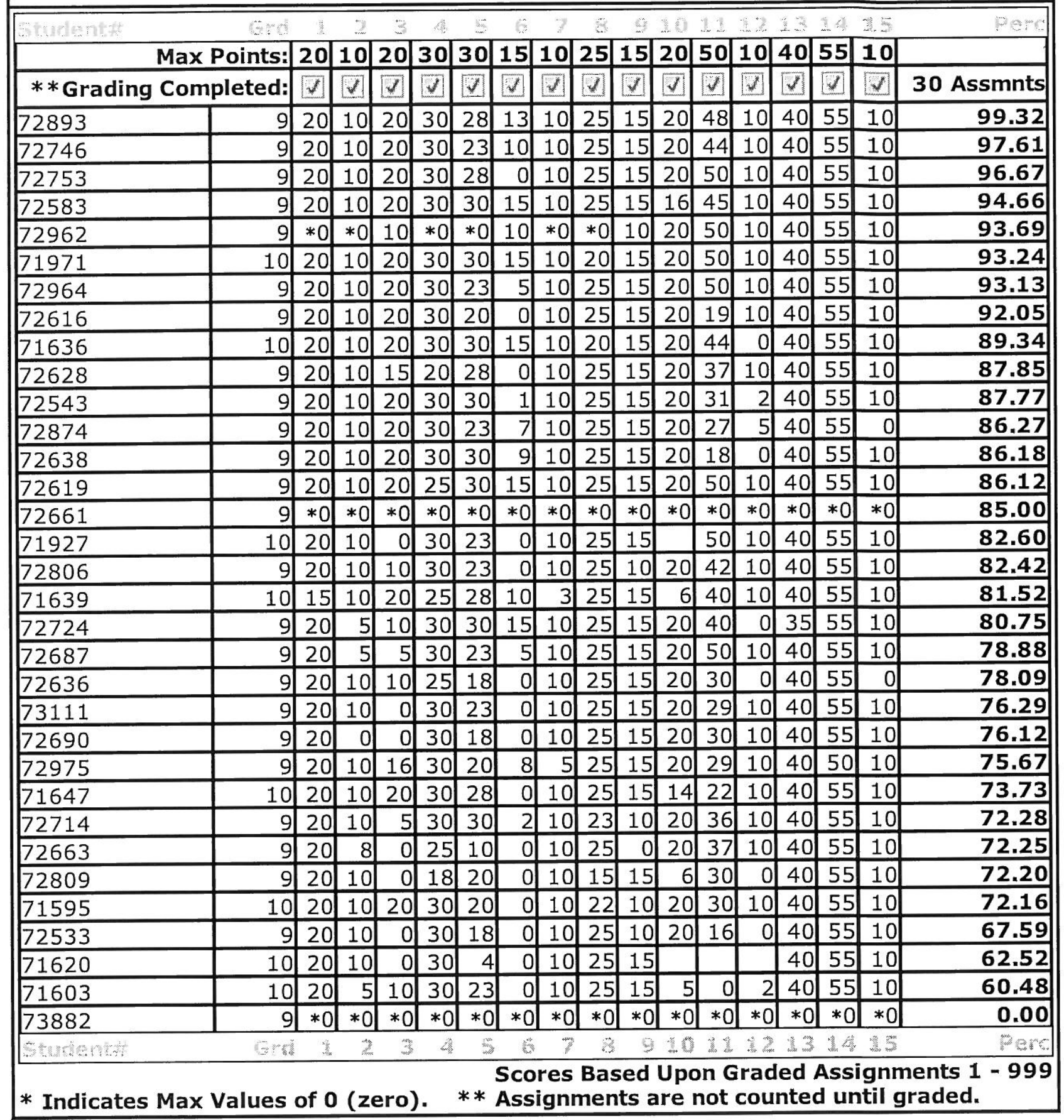


Page: 2

3/14/2013 11:00:02 PM

\begin{tabular}{|c|c|c|c|c|c|c|c|c|c|c|c|c|c|c|c|c|c|}
\hline \multicolumn{17}{|c|}{$\begin{array}{l}\text { Gradebook Summary } \\
6 \text { - Int Ag Bio - Spring }\end{array}$} & \multirow{2}{*}{ Ioimo,J } \\
\hline \multirow[t]{2}{*}{ Standenter } & Grd & 46 & 27 & 1 恼 & 29 & 20 & 21 & 22 & 23 & 248 & 25 & 26 & 37 & 28 & 24 & 30 & \\
\hline & Max Points: & 21 & 50 & 30 & 35 & 20 & 15 & 15 & 10 & 16 & 25 & 40 & 20 & $20:$ & 30 & 20 & \\
\hline \multicolumn{2}{|c|}{ ** Grading Completed: } & 圆 & D & 国 & D & 口] & Q & D & 团 & D & D & N & 0 & \begin{tabular}{|l|}
0 \\
\end{tabular} & D & 0 & 30 Assmnts \\
\hline 72893 & \begin{tabular}{l|r|} 
& 9 \\
\end{tabular} & 23 & 50 & 30 & 35 & 20 & 14 & 15 & 10 & 14 & 25 & 40 & 20 & 20 & 30 & 20 & 99.32 \\
\hline 72746 & 9 & 22 & 48 & 30 & 35 & 0 & 15 & 15 & 10 & 16 & 25 & 40 & \begin{tabular}{|l|}
20 \\
\end{tabular} & 20 & 30 & 20 & 97.61 \\
\hline 72753 & 9 & 22 & 50 & 30 & \begin{tabular}{|l|}
35 \\
\end{tabular} & 18 & 13 & 14 & 10 & 14 & 25 & 40 & \begin{tabular}{|l|}
20 \\
\end{tabular} & 20 & \begin{tabular}{|l|}
30 \\
\end{tabular} & 10 & 96.67 \\
\hline 72583 & 9 & 21 & 35 & 25 & 35 & 10 & 15 & 15 & 10 & 14 & 25 & 40 & \begin{tabular}{|l|}
20 \\
\end{tabular} & \begin{tabular}{|l|}
20 \\
\end{tabular} & \begin{tabular}{|l|}
30 \\
\end{tabular} & 16 & 94.66 \\
\hline 72962 & 9 & 14 & $* 0$ & 30 & 35 & 20 & 15 & 15 & 10 & 16 & 25 & 40 & \begin{tabular}{|l|}
20 \\
\end{tabular} & \begin{tabular}{|l|}
20 \\
\end{tabular} & \begin{tabular}{|l|}
30 \\
\end{tabular} & 20 & 93.69 \\
\hline 71971 & 10 & 20 & 45 & \begin{tabular}{|l|}
30 \\
\end{tabular} & 35 & 10 & 10 & 10 & 0 & 14 & 25 & 40 & \begin{tabular}{|l|}
20 \\
\end{tabular} & \begin{tabular}{|l|}
20 \\
\end{tabular} & 30 & 10 & 93.24 \\
\hline 72964 & 9 & 18 & 50 & 30 & 35 & 12 & 15 & 15 & 10 & 14 & 25 & 40 & 20 & 20 & 30 & 15 & 93.13 \\
\hline 72616 & 9 & 23 & \begin{tabular}{|l|}
50 \\
\end{tabular} & 30 & 35 & 0 & 10 & 15 & 1 & 16 & 25 & 40 & \begin{tabular}{|l|}
0 \\
\end{tabular} & 20 & 30 & \begin{tabular}{|l|}
15 \\
\end{tabular} & 92.05 \\
\hline 71636 & 10 & 18 & 40 & 30 & 25 & 10 & 15 & 15 & 10 & 12 & 25 & 40 & 20 & 20 & 30 & 20 & 89.34 \\
\hline 72628 & 9 & 16 & \begin{tabular}{|l|}
45 \\
\end{tabular} & 29 & 35 & 0 & 14 & 0 & 10 & 16 & \begin{tabular}{|l|}
25 \\
\end{tabular} & 40 & 20 & 20 & \begin{tabular}{|l|}
30 \\
\end{tabular} & 20 & 87.85 \\
\hline 72543 & 9 & 17 & 35 & 30 & 20 & 0 & 15 & 15 & 10 & 16 & 19 & 40 & 20 & 20 & \begin{tabular}{|l|}
30 \\
\end{tabular} & 15 & 87.77 \\
\hline 72874 & 9 & 18 & 50 & 30 & 20 & 0 & 15 & 15 & 0 & 14 & 25 & 40 & 20 & 20 & \begin{tabular}{|l|}
30 \\
\end{tabular} & 10 & 86.27 \\
\hline 72638 & 9 & 15 & 35 & 30 & 25 & 0 & 15 & 15 & \begin{tabular}{|l|}
5 \\
\end{tabular} & 16 & 25 & 40 & 20 & 20 & \begin{tabular}{|l|}
30 \\
\end{tabular} & 20 & 86.18 \\
\hline 72619 & 9 & 17 & 35 & & & & 15 & 15 & 10 & 16 & \begin{tabular}{|l|}
25 \\
\end{tabular} & 40 & 20 & 20 & 30 & \begin{tabular}{|l|}
15 \\
\end{tabular} & 86.12 \\
\hline 72661 & 9 & $* 0$ & $* 0$ & $* 0$ & $* 0$ & $* 0$ & $* 0$ & $* 0$ & $* 0$ & $* 0$ & \begin{tabular}{|l|}
$* 0$ \\
\end{tabular} & $* 0$ & $* 0$ & 20 & \begin{tabular}{|l|}
30 \\
\end{tabular} & \begin{tabular}{|l|}
5 \\
\end{tabular} & 85.00 \\
\hline 71927 & 10 & 21 & & & & & 13 & 15 & 10 & 16 & 25 & 40 & 20 & 20 & 30 & 20 & 82.60 \\
\hline 72806 & 9 & 19 & 43 & 28 & 35 & 0 & 15 & 15 & 5 & 12 & 15 & 20 & 0 & 20 & 30 & 0 & 82.42 \\
\hline 71639 & 10 & 18 & 30 & \begin{tabular}{|l|}
23 \\
\end{tabular} & 35 & 10 & 4 & 15 & 0 & 10 & \begin{tabular}{|l|}
25 \\
\end{tabular} & 40 & 20 & 20 & 30 & 10 & 81.52 \\
\hline 72724 & 9 & $* 0$ & 35 & & & & 15 & 15 & 10 & 14 & 21 & 37 & 20 & 20 & 30 & 0 & 80.75 \\
\hline 72687 & 9 & 15 & 44 & 27 & 35 & 10 & 15 & 15 & 10 & 4 & 25 & 40 & \begin{tabular}{|l|}
20 \\
\end{tabular} & 20 & 30 & 14 & 78.88 \\
\hline 72636 & 9 & 11 & 45 & 28 & 35 & 0 & 14 & 15 & 0 & 16 & 25 & 15 & 20 & 20 & 30 & 15 & 78.09 \\
\hline 73111 & 9 & 22 & 46 & 24 & 30 & 0 & 10 & 15 & 0 & 16 & & & & & & & 76.29 \\
\hline 72690 & 9 & 17 & 50 & 28 & 35 & 0 & 6 & 15 & 5 & 6 & 25 & 40 & 20 & \begin{tabular}{|l|}
20 \\
\end{tabular} & 30 & 0 & 76.12 \\
\hline 72975 & 9 & 13 & & 30 & 35 & 0 & 15 & 10 & 1 & 10 & 25 & 40 & 20 & \begin{tabular}{|l|}
20 \\
\end{tabular} & \begin{tabular}{|l|}
30 \\
\end{tabular} & 13 & 75.67 \\
\hline 71647 & 10 & 22 & & 19 & 35 & 0 & 15 & 15 & 0 & & 25 & 30 & 20 & \begin{tabular}{|l|}
20 \\
\end{tabular} & \begin{tabular}{|l|}
30 \\
\end{tabular} & 20 & 73.73 \\
\hline 72714 & 9 & 7 & 50 & 28 & 35 & 10 & 5 & 15 & 2 & 14 & 25 & 40 & 20 & & & & 72.28 \\
\hline 72663 & 9 & 13 & & & & & 15 & 15 & 2 & 16 & 25 & 40 & 20 & 20 & 30 & 15 & 72.25 \\
\hline 72809 & 9 & 10 & & 30 & 20 & 0 & 15 & 10 & 10 & 16 & 19 & 40 & 20 & 20 & 30 & 20 & 72.20 \\
\hline 71595 & 10 & 19 & 50 & \begin{tabular}{|l|}
28 \\
\end{tabular} & 32 & 0 & 15 & 15 & 3 & 12 & & & & & & & 72.16 \\
\hline 72533 & 9 & 18 & 50 & 28 & 27 & 0 & 15 & 15 & 8 & 12 & & & & & & & 67.59 \\
\hline 71620 & 10 & $* 0$ & & & & & & & & 12 & 25 & 40 & 20 & \begin{tabular}{|l|}
20 \\
\end{tabular} & 30 & 20 & 62.52 \\
\hline 71603 & 10 & $* 0$ & & 30 & 35 & 0 & 13 & 5 & 2 & 6 & 25 & 40 & 20 & 20 & 30 & 0 & 60.48 \\
\hline 73882 & 9 & $* 0$ & $* 0$ & $* 0$ & $* 0$ & $* 0$ & $* 0$ & $* 0$ & $* 0$ & *0 & $* 0$ & $* 0$ & $* 0$ & \begin{tabular}{|l|}
$* 0$ \\
\end{tabular} & \begin{tabular}{|l|}
$* 0$ \\
\end{tabular} & $* 0$ & 0.00 \\
\hline Sturderter. & Gyth & 26 & 8 & 13 & 39 & 27 & 21 & 22 & 2 & 24 & 25 & 26 & $2 y$ & 28 & 29 & 34 & werc \\
\hline
\end{tabular}




\section{$\underline{\mathbf{E}}$}

\section{SAE Supervision Form}

The project supervision form currently used for Atwater FFA is attached. There are current examples of how the form is used for SAE projects. I supervise the market lambs / breeding ewe projects and the Floral Design projects. Currently, I have over 50 floral projects, 15 market lambs, and one breeding ewe going to the Merced County Fair. The following sheets are copies of $S A E$ project supervision visits.

\section{Attached you will find:}

- $S A E$ project visit forms 
Atwater High School - Agriculture Department

Sur.ervision Record of Supervised Project

Name

roject(s)

Account Book: Yes No Parent Contact Yes No

\section{Conditions found at time of visit}

1. General condition of project: Poor Fair Average Above Average

2. Recommendations

3. Miscellaneous information

4. The student has attained or learned the following as a result of this project:

\begin{tabular}{ll}
\hline & \\
\hline Parent's Signature _ & Date \\
5. Student's Signature & Date \\
Agricultural Instructor's Signature &
\end{tabular}

WHITE: Student Copy YELLOW: Ag. Dept. PINK: Supt. Copy 


\section{F \\ Wall Chart of SAE Visits}

Currently, Atwater FFA does not have a wall chart of project visits in our department. When our students have possession of their SAE project, the supervising instructor makes regular visits and documents them individually. In the future, our department would like to implement a wall chart as a visual reminder of visits that need to be made. 


\section{$\underline{\mathbf{G}}$ \\ SAE Student Summary}

Students summarize their SAE projects through their business agreements in their record books for Atwater FFA. Students are required to complete their business agreements before they start their SAE projects. These business agreements are either created in a paperback FFA record book or on the electronically record book. The following is a current student sample of their SAE summary. Also a general list is kept by each teacher that shows each student has an SAE by listing name, project area, project, hours, and costs.

\section{Attached you will find:}

- $S A E$ business agreement (Market Lamb)

- SAE business agreement (Floral Design) 


\section{OWNERSHIP ENTERPRISE AGREEMENT}

(Each enterprise requires a separate agreement)

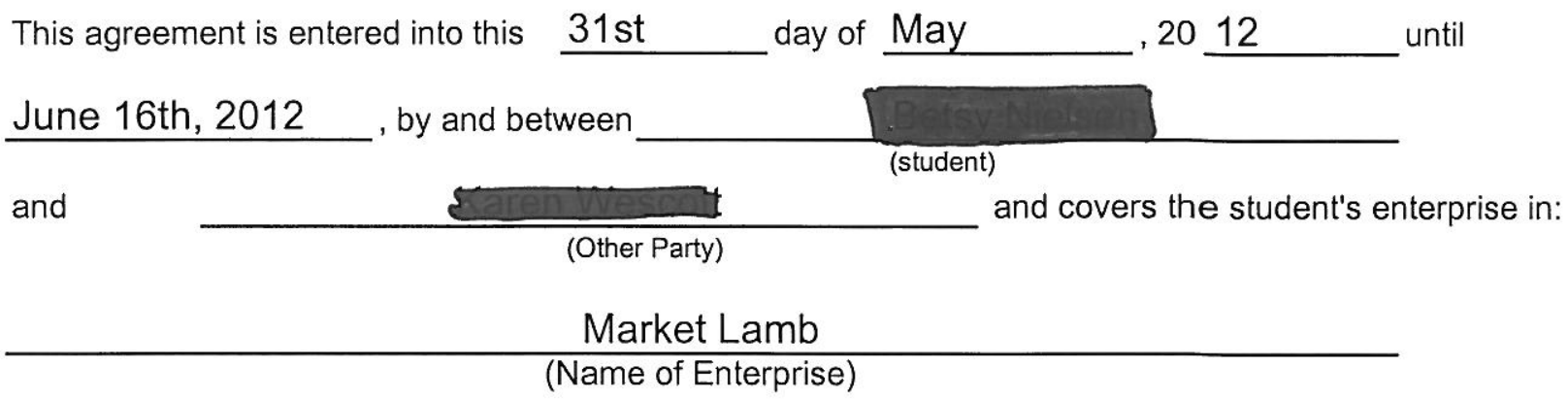

This agreement must contain statements concerning what each party is responsible to provide and/or benefits he/she will receive. Items that must be addressed are: equipment, land, buildings, capital (money), management, and profit or loss.

\section{Please use complete sentences and be specific with details.}

will work with the FFA advisor, Ms. loimo, to locate a quality lamb to be purchased at least sixty days prior to the Merced County Fair. W will also purchase insurance for the lamb. Once the lamb has been purchased, it will be kept at will maintain the pens and shelter that will serve as the home of the lamb. will provide free of charge: shelter, lamb pen, electricity, and maintenance equipment. also agrees to provide access to clean water and an automatic waterer at no charge. with the assistance from the FFA advisor, will make decisions relative to the lamb project. will determine and cover the costs for feed, medicine, entry fees, grooming supplies, and show equipment. will provide the scale to weigh the lamb. The FFA advisor will conduct regular on site visits with and will assist in weighing the lamb. At the end of the project, $\square$ agrees to provide the buyer a thank you letter and a record book. Once the thank-you letter and record book have been approved, $\square$ will be given her fair check. — Will receive $100 \%$ of the profit or loss associated with this project.

Signatures

of Parties

Involved 


\section{PLACEMENT ENTERPRISE AGREEMENT}

(Paid and Unpaid Work Experience)

1 To provide a basis of understanding and to promote sound business relationships, this written agreement is established

on

January 1,2012

This work/training will start on

January 1,2012

and will end on or about December 31,2012 unless the arrangement becomes unstisfactory to either party.

2 Business name and type

Atwater FFA Floral Department

3 Person (employer/trainer) responsible for training:

Ms. Ioimo

4 Wages: $\quad 30 \%$ of the Retail Cos $\quad$ Frequency of Payment

One week after the event

5 Agricultural Job Skills to be Performed:

The student needs to perform the basic skills in floral arranging such as bow making, wiring and taping, floral ID, tool ID, and floral care. The student also needs to be able to create the basic floral designs such as: round arrangements, symmetrical arrangements, vase arrangements, corsages, boutonnieres, presentation bouquets and modern style table centerpieces.

\section{IT IS UNDERSTOOD THAT THE EMPLOYER WILL:}

The Atwater FFA Floral Department will provide the student with the proper materials, supplies and facility to create and construct arrangements. Atwater FFA will pay for the supplies, flowers, and materials that go into the arrangements and will provide the cooler to store the flowers. Atwater FFA will purchase the necessary supplies and equipment to cover the initial costs/investment of the project. The Atwater FFA will provide free of charge: floral cooler, floral materials, floral supplies and flowers / foliage. Atwater FFA will pay $30 \%$ of the retail costs one week after the event has occurred.

\section{THE STUDENT AGREES TO:}

Student will design, create and construct arrangements for various events held throughout the school year. Student will create arrangements for weddings, school dances, community events, and funerals. Student agrees to create floral arrangements such as corsages, boutonnieres, table centerpieces, presentation bouquets, wedding bouquets, and vase arrangements.

8 STUDENT'S SIGNATURE:

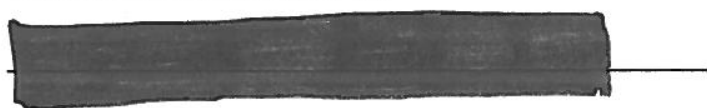

EMPLOYER/TRAINER'S SIGNATURE:

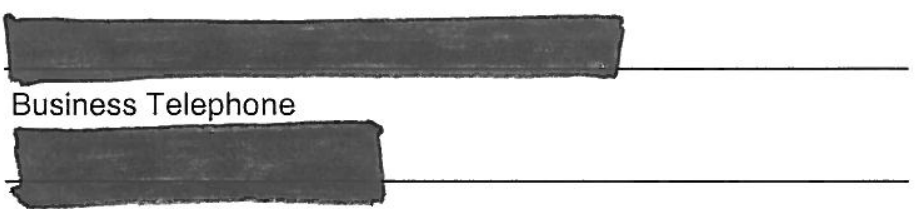




\section{$\underline{\mathrm{H}}$ \\ Board Approved SAE Policy}

Atwater High School follows and supports this educational code. A copy of the board-approved department SAE policy was not located, although contact with administration was made. Following is a copy of the education code stating the requirement for $S A E$ to be in place for any student in an agriculture program.

\section{Attached you will find:}

- Educational code for SAE projects 


\section{EDUCATION CODE SECTION 52450-52454}

52454. (a) The curriculum of school districts that choose to participate in the state program of agricultural career technical education shall include all of the following components:

(1) Organized classes in the study of agricultural science and technology.

(2) A student-supervised occupational experience program in agriculture.

(3) A program of leadership, organization, and personal development.

(b) Student learning activity developed to supplement these components shall be considered curricular and shall contribute to the grade of the participating student when those activities are integral to assisting the student to achieve the career objective of the class or course.

It is the intent of the Legislature that opportunities are provided for teachers to be employed on a 12-month basis in order to maintain supervised occupational experience on a year-round basis for students enrolled in agricultural career technical programs. 


\section{$\underline{I}$ \\ Program of Work}

The Atwater FFA Program of Work is developed each year with information for students, administrators, and community members about our Agriculture Program. It covers the pertinent information for fair projects, program goals and Agriculture/ FFA education.

A Chapter Program of Works is developed annually and a copy is furnished to the Regional Supervisor by December $15^{\text {th }}$.

The currently copy of the 2012-2013 Program of works is attached.

\section{Attached you will find:}

- Program of Work for 2012-2013 


\section{Atwater High School FFA}

Atwater High School Agriculture Department

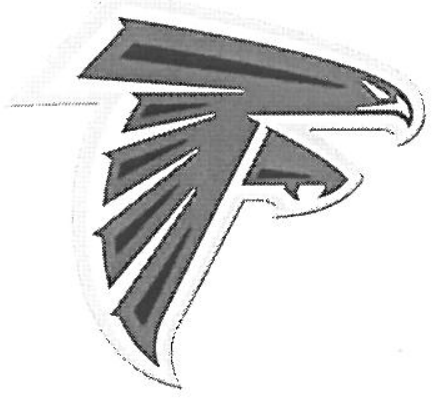

$2012-2013$

Program of Activities

Overview / Budgets

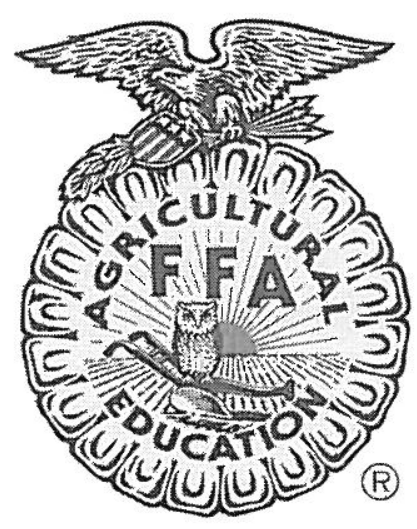




\section{Table of Contents}

President's Message $\quad$ _.............

Officer's Message $\quad$..............

Advisor's Message $\quad$............. 4

2012 - 2013 Chapter Goals $\quad$............

Calendar of Activities $\quad$.............

FFA and Agricultural Education $\quad$............

FFA Mission and Strategies $\quad$............ 12

FFA Emblem $\quad \ldots \ldots \ldots \ldots \ldots \ldots$

FFA Creed $\quad \ldots \ldots \ldots \ldots \ldots \ldots$

FFA Colors and Motto $\quad \ldots \ldots \ldots \ldots \ldots$

FFA Official Dress $\quad \ldots \ldots \ldots \ldots \ldots \ldots$

FFA Code of Ethics $\quad$.............

SAE

……... 18

Cooperation $\quad \ldots \ldots \ldots \ldots \ldots . . . .20$

Community Service $\quad \ldots \ldots \ldots \ldots \ldots \ldots . . . .21$

Leadership / Committees $\quad$............ 22

Earnings and Savings $\quad$............ 24

Conduct of Meetings $\quad$............

Scholastic Achievements and Scholarships $\quad$............ 26

Recreation $\quad \ldots \ldots \ldots \ldots . . . . .27$

Public Relations $\quad$............. 28

Alumni Relations $\quad$............. 29

Fairs and Official Show Uniforms $\quad$............. 30

Merced County Fair SAE Budgets $\quad$............ 31

Point Awards System $\quad$............ 33

Chapter Constitution $\quad$ _........... 37

Atwater FFA History- State FFA Degrees $\quad$ ….........

Atwater FFA History- State/National Recognition $\quad$............. 50

Atwater High School Enrollment History $\quad$...........

Atwater High School Course Enrollment Data $\quad$........... 55

Atwater High School Agriculture Department / FFA Budgets $\quad$........... 56

Department Staff Assignments and Responsibilities $\quad$............

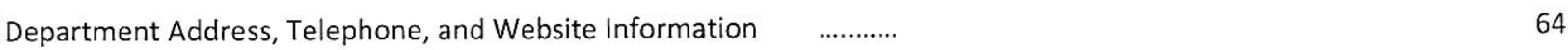

1 ) Pase 


\section{President's Message}

Dear Chapter Members,

The school year is in full swing and off to a great start as we begin another year of FFA excellence. The Atwater High School FFA has a long history of promoting students' success and character development. As we continue to exceed expectations, we can look forward to a school year full of teamwork, dedication, and success. With the addition of many new agriculture courses, members, teams and ideas we are ready to begin the school year with excitement and many new opportunities.

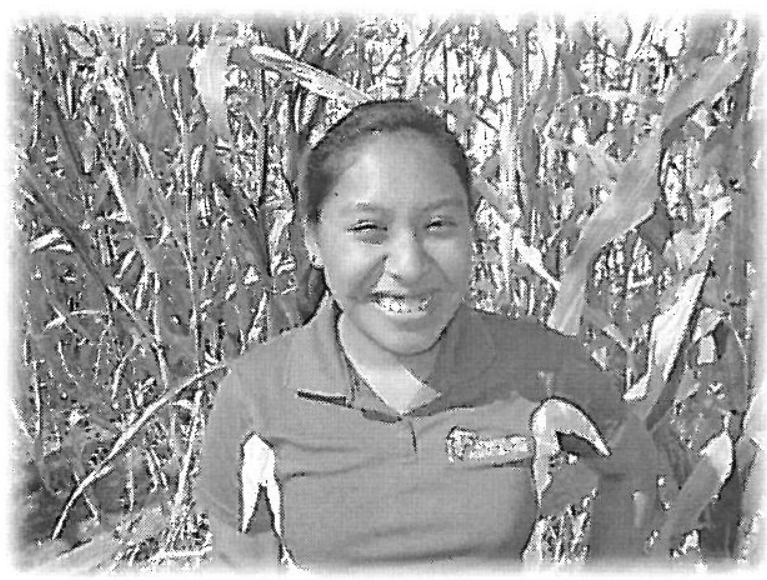

This year's officer team is ready to face the many challenges and obstacles put in their way throughout the year. I speak for the officer team when I say that we look forward to guiding each member in every way possible so they can have the greatest experience possible in the FFA. Our organization is over 850 members strong. We hold the power to make a difference in our school and our community while upholding the traditions that are so rich within the FFA organization.

This year, our goals are many, but with the support of our incredible membership, we will triumph and succeed in the spirit that only FFA can uphold. As quoted by legendary football coach Vince Lombardi, "The achievements of an organization are the results of the combined effort of each individual."

The future of our organization will be shaped by the visions that we share with our advisors. I look forward to working with my officer team and fellow FFA members to preserve and enhance our contributions to our school and our community.

Sincerely,

Mayratternandez

Mayra Hernandez

2012-2013 Chapter President

2 lorage 


\section{Officer's Message}
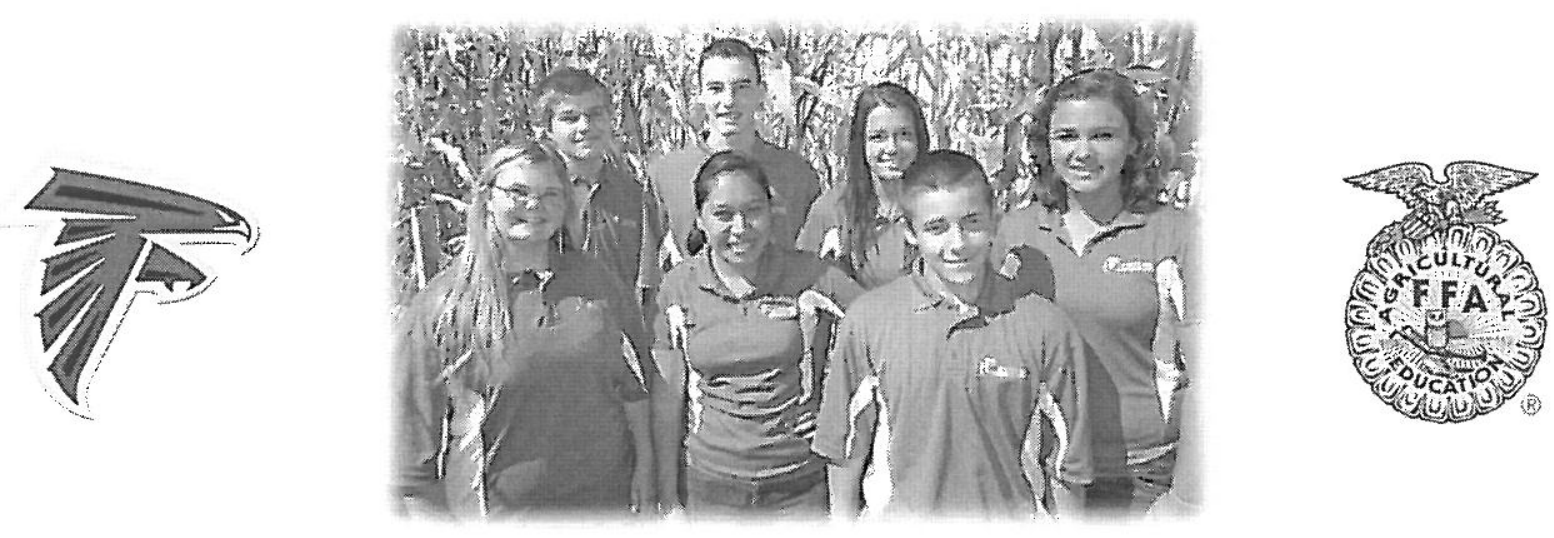

Left to Right:

Heather Lewandowski (Secretary), Jesse Tafoya (Treasurer), Mayra Hernandez (President), Taylor Ferreira (Vice President), Susana Brasil Historian), Michael Marcilino (Sentinel), and Makala Navarro (Reporter).

Dear Members,

Our 2012-2013 Atwater FFA theme is "The Lead is Yours, So Keep Calm and Farm On". All of you continue to take advantage of the opportunities FFA and agriculture education have to offer. So, the leadership is in your hands .... Keep calm, and continue to farm on!

Your 2012-2013 Atwater FFA chapter officer team would like to welcome you to the Atwater High School Agriculture program. We are beginning what is going to be another year of entertainment and production! You're invited to learn, grow, and develop in agriculture and FFA through chapter meetings, judging teams, community service activities, fundraisers, team competitions, recreational activities and much, much more! Everything we execute will be enjoyable, enlightening and dynamic. So FFA Members...get ready to "farm on"!

It is our goal to make sure that others are aware of the agriculture industry and its importance in our everyday life. There is so much to explore in the agriculture industry such as agriculture mechanics, animal science, horticulture, agriculture business, biotechnology, agronomy, floriculture, and computer technology. Our chapter goals for this year include maintaining our involvement in the community and their awareness of our program, activities, and making sure that more and more students are continuing to get involved in the FFA program.

We encourage students to get involved and take the many opportunities the FFA and the agriculture industry offer.

\section{Mayra Hernandez, Taylor Ferreira, Heather Lewandowski, Jesse Tafoya, Makala Navarro, Michael Marcílino, and Susana Brasit}




\section{Advisor's Message}

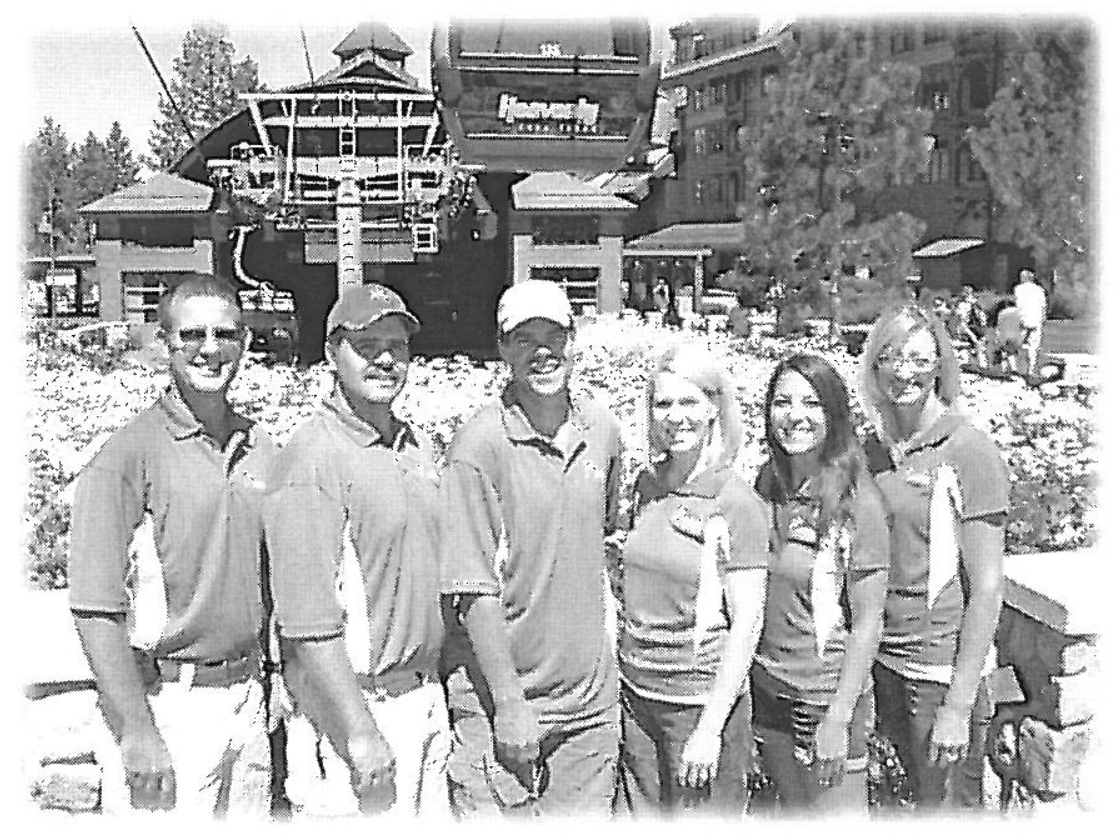

Dave Gossman, Sam Meredith, Dan Flatt, Beth Williams, Jackie loimo, and Natalie Kirschner

Dear Chapter Members,

The Advisors of the Atwater FFA would like to welcome each and every new and old member alike to the Atwater FFA and Agriculture program for the 2012-2013 school year.

The mission of the Atwater FFA and Atwater High School Agriculture Department is to lead, assist, and motivate the members of the FFA in providing high quality agricultural education that is equitable and efficient, that prepares students for higher education, employment, and citizenship, and promotes students' intellectual, ethical and cultural growth.

We are committed to make a positive difference in the lives of young people through the variety of resources and opportunities agriculture education and the FFA have to offer. We believe we have something of academic, personal, or career value for all of our students and we encourage all of you to take advantage of the opportunities that have made the Atwater High School agriculture program one of the most productive programs in the state!

We look forward to working with all of you and experience all the successes and adventures that the 2012-2013 school year has ahead!

Sincerely,

$$
\text { NatalieKirschner BethKnapp SamMeredith Jackie Ioimo Dan Flatt DaveGossman }
$$

The Atwater FFA Advisors

4 | Page 


\section{Chapter Goals}

Our 2012-2013 FFA officer team created the following chapter goals during our annual FFA Chapter Officer Retreat held at South Lake Tahoe in August 2012:

\section{Develop Strong and Effective Chapter Leadership}

- Develop and strengthen communication skills

- Increase student involvement \& participation

- $\quad$ Expand leadership classroom resources / supplies

- Improve scrapbook efficiency, development, and equipment

- Improve secretary \& treasurer record keeping

- Increase \& improve agriculture leadership curriculum \& resources

- Expand technology communication with student-made video announcements

2. Develop and Strengthen Agriculture Resources and Curriculum

- Increase large and medium ag mechanics projects

- $\quad$ Expand curriculum technology resources - teaching/learning tools

- $\quad$ Expand and develop wood SAE projects

- $\quad$ Expand and develop horticulture SAE projects

\section{Expand Student Involvement and Participation}

- Increase student attendance and participation at chapter meetings

- Increase SAE projects (animal, plant, and ag mech)

- $\quad$ Expand and strengthen FFA competition opportunities / teams

- Improve organization and planning of events/activities

- Increase state and improve development of national FFA applications (National Chapter Award)

\section{Develop Strong Recruitment \& Retention Program}

- Strengthen and expand middle school relationships \& communication

- Maintain / improve recruitment presentations \& education

- $\quad$ Strengthen advanced Ag Welding and Ag Wood enrollment \#'s

- Maintain/strengthen agriculture "foundation" $\left(9^{\text {th }}\right.$ grade) courses 


\title{
Chapter Goals
}

\section{Expand \& Develop Agriculture Facilities / Resources}

\author{
Horticulture
}

- $\quad$ Acquire plant labeling system

- Install new (concrete) walkway and gate in-between pole barn and storage sheds

- Expand plant SAE/projects/sales with perennials, shrubs, and trees

- Install new brick walkway area at NW corner of ag department driveway

\section{Arnold's Farm}

- $\quad$ Explore need for swine water antibiotic system

- Improve/upgrade swine pump/septic system

- Install eye-bolts in each pen so feeders can be connected to walls

- Improve cleaning/operation efficiency

- $\quad$ Explore new/improved sheep pens (facility upgrade opportunities)

\section{$\underline{\text { Pole Barn }}$}

- Install new storage (Tuff) shed for goat/rabbit supplies \& equipment

- $\quad$ Pour new concrete slabs (example - shed)

- Install "above ground" Popper storage rack

Agriculture Mechanics / Shops

- $\quad$ Create/install TIG welding lab / work area

- Build/create new cylinder storage area

- Remove storage container in-between shop buildings

- Paint new storage containers 


\section{Callendar of Activities}

June

13-19

20-24

July

11-16

Merced County Fair

CATA Conference

Merced

San Luis Obispo

Sacramento

Ag Staff

\section{August}

8-10

20

22

27

TBA

\section{September}

3

6

7

5

11

25

21

20

19

TBA

TBA

\section{October}

3

6-7

12

12-13

3

17

18

26

19

22-26

24

$7 \mid$ Page
Chapter Officer Retreat

First Day of School

Chapter Officer Meeting

Placemat Ads Fundraiser

Open Shop Night \#1

Labor Day Holiday

Homecoming Float Meeting

Placemat Ads Fundraiser Ends

Chapter Officer Meeting

Merced-Mariposa CATA \& FFA SOLC

Central Region SOLC

FFA "Pool Party" Mtg

AHS Football Game BBQ

Take-Out BBQ \#1

Chapter Officer Meeting

Open Shop Night \#2

Open Shop Night \#3

Greenhand Leadership Conference.

FFA COLC

AHS Homecoming Game Parade/BBQ

FFA Fall Plant Sale

Chapter Officer Meeting

Opening and Closing Ceremonies

Atwater Beautification Day

AHS Football Game BBQ

End of $1^{\text {st }}$ Quarter

National FFA Finals (Agronomy)

Chapter Officer Mtg
Lake Tahoe

Ag Dept.

Ag Class

Ag Shops

Ag Dept.

AHS

Ag Dept.

Merced College

Merced College

AHS

AHS

AHS

Ag Dept.

Ag Shops

Ag Shops

(no school)

Meredith

Gossman

Knapp

Ag Staff

Ag Staff

Ag Staff

Ag Staff

Knapp/Meredith

Knapp

Meredith

Meredith

Modesto

Denair

AHS

AHS Ag Dept.

Ag. Dept.

Gustine

Atwater

AHS

Indiana / Wash DC

AHS
Kirschner

Knapp

Ag Staff

Gossman

Knapp

5:00 PM Ag Staff

Ag. Staff

Ag Staff

Knapp

Knapp 


\section{Calendar of Activities}

\section{November}

\section{7}

3

7

6

12

13-14

16-17

17

19-23

28

29

TBA

TBA

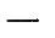

December

\section{5}

6

8

18

20

21

24-31

TBA

TBA

\section{January}

$1-4$

7

15

$8 \mid$ l'a
FFA "Corn Maze" Chapter Meeting MJC Cotton FFA Field Day

Open Shop Night \#4

Open Shop Night \#5

CATA Section Mtg

Cotton Judging State Finals

Chapter Officer Mtg

Greenhand / Chapter Degree Ceremony

Veterans Day

Local Project Competition

CATA Road Show

CATA Regional Meeting

Thanksgiving Break

Chapter Officer Mtg

Sectional Project Competition

Open Shop Night \#6

Open Shop Night \#7

Chapter Officer Mtg

Take-Out BBQ \#2

Mariposa Creed Speaking Contest

FFA Morning Wave Chapter Mtg

AHS End of Semester

FFA "Basketball" Trip

AHS Winter Break

Open Shop Night \#8

Open Shop Night \#9

AHS Winter Break

$2^{\text {nd }}$ Semester Starts

FFA M/M Section Manuscripts Due
Ag Dept.

AHS

Ag Shops

Ag Shops

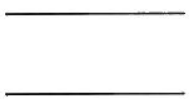

Ag Staff

Kirschner

Meredith

Meredith

Ag. Staff

$\mathrm{Ag}$ Staff

Knapp

Ag Staff

BCHS Theater

(no school)

AHS

Cosumnes River College

Cosumnes River College

AHS

Ag. Dept.

Ag Shops

Ag Shops

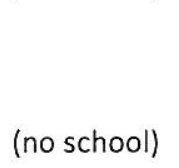

Meredith

Ag Staff

Ag Staff

Knapp

Meredith

Meredith

Meredith

AHS

AHS

Mariposa HS

Ag Dept.

6:00 AM

Oakland

Ag Shops

Ag Shops

(no school)

(no school)

AHS Ag Dep.
Ag Staff

Meredith

Meredith

Knapp
Knapp/Meredith
Ag Staff
Ag Staff
Ag Staff
Meredith
Meredith

Ag Staff 


\section{Calendar of Activities}

9
$17-18$
21
16
26
23
23
$28-31$
TBA
TBA

\section{February}

$$
6
$$$$
1
$$$$
2
$$

\section{March}

\section{2}

13

14

15

9

26

16

27

19

23

TBA
Chapter Officer Mtg

CATA Governing Board Mtg

Martin Luther King Jr. Holiday

FFA "Movie Night" Chapter Meeting

FFA "Super Saturday"

Chapter Officer Mtg

Merced Fair Student Parent Exhibitor Mtg

Merced Fair Deposit Week

Open Shop Night \#10

Open Shop Night \#11

Project Comp. Banquet

Merced Fair Deposit Week (cont.)

Arbuckle Field Day

Chapter Officer Mtg

Presidents Weekend Holiday

FFA MFE/ALA Conference

Presidents Weekend Holiday

Chapter Officer Mtg

FFA Week Basketball Tourney

FFA Week Ag Olympics

FFA Week "Kiss the Pig"

FFA / CATA Regional Meeting

Ag Booster Dinner

Open Shop Night \#12

Open Shop Night \#13

UC Davis Field Day

Chapter Officer Mtg

FFA Take-Out Dinner \#3

End of $3^{\text {rd }}$ Quarter (AHS)

Chico State Field Day

Central Region (south) State Degrees

Merced College Field Day

Chapter Officer Mtg

FFA "Bowling" Chapter Meeting

Modesto JC Field Day

Open Shop Night \#14
AHS

Galt

AHS

Merced College

AHS

Ag Dept.

Ag Shops

Ag Shops

Merced Fairgrounds

Arbuckle

AHS

Modesto

AHS

TBD

AHS

AHS

Merced College

APC Hall

Ag Shops

AG Shops

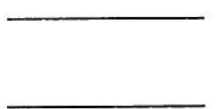

UC Davis

AHS

Ag Dept.

Chico

Merced College

AHS

Bellevue Bowl

MJC

Ag Shops
Knapp

Gossman

(No school)

Ag Staff

Ag Staff

Knapp

Ag Staff

Ag Staff

Meredith

Meredith

Ag Staff

Ag Staff

Ag. Staff

Knapp

(no school)

Knapp

(no school)

Knapp

Ag Staff

Gossman

Gossman

Ag Staff

Meredith

Meredith

Ag Staff

Knapp

Knapp/Meredith

Ag Staff

Ag Staff

Ag Staff

Knapp

Ag Staff

Ag Staff

Meredith 


\section{Calendar of Activities}

TBA

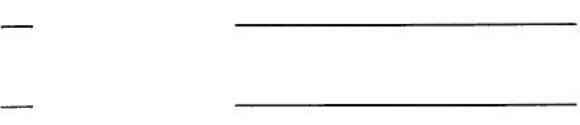

April

1-5

10

6

11

13

16

20

20-23

24

TBA

TBA

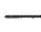

May

1

4

7

23

10-11

8

14

27

TBA

TBA

June

6

20

9-16

23-27

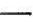

$-$
AHS Spring Recess

Chapter Officer Mtg

Cosumnes River College Field Day

Sectional CO/OP \& CATA Mtg

Reedley College Field Day

FFA "Burrito Bingo" Chapter Meeting

Fresno State Field Day

FFA State Leadership Conference

Chapter officer mtg

Open Shop Night \#16

Open Shop Night \#17

Chapter Officer Mtg

Cal-Poly SLO State Finals Field Day

'13-'14 Chapter Officer Apps Due

FFA Take-Out Dinner \#4

FFA Spring Plant Sale

Chapter Officer Mtg

Chapter Awards Banquet

School Holiday

Open Shop Night \#18

Open Shop Night \#19

Last Day of School / Graduation

Point Award Trip

Merced County Fair

CATA Conference
Ag Shops

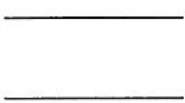

$\longrightarrow$

AHS

Cosumnes River College

Livingston

Reedley College

AHS Gym

Fresno State

Fresno State

Ag Shop

Ag Shop

(no school)

Knapp

Ag Staff

Ag Staff

Ag Staff

Ag Staff

Ag Staff

Ag Staff

Meredith

Meredith

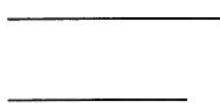

AHS

San Luis Obispo

Ag Dept.

Ag Dept.

Ag Dept.

AHS

TBA

TBA

Ag Shop

Ag Shop

TBA

Merced

Cal Poly, SLO
Knapp

Ag Staff

Ag Staff

Knapp/Meredith

Gossman

Knapp

Ag Staff

Meredith

Meredith

Ag Staff

Ag Staff

Ag Staff

$\left.10\right|^{p}$ a $g e$ 


\section{FFA and Agricultural Education}

When you put on an FFA jacket, you become part of a total agriculture education program that will connect you to exciting careers in the science, business and technology of agriculture. FFA is only one of three essential components of this system, all of which work together to provide you with the personal, academic and career experiences essential for your success. Get to know the "three circles" that make this possible.

Classroom/Laboratory Instruction- Agriculture is rooted in science, math, business and technology. The time you spend in the classroom and school lad with you teacher will help you explore and master the information necessary to move forward with you career development. Get ready for exciting hands-on opportunities that make textbooks come alive!

Supervised Agricultural Experience (SAE)- Nothing takes your skills to highest level faster than putting them into practice. Through an SAE, you can create your own landscaping business, conduct a scientific research project that could change the world, grow crops or raise livestock, secure a meaningful job that provides insider experience related to your career choice, or learn how to make a difference in your community though civic engagement. Best of all, you can earn while you learn.

FFA- As an FFA member, you'll work on developing your potential for premier leadership, personal growth and career success. By participating in competitions, degree programs, state and national conventions, community service projects, summer camps and chapter committees, you'll grow in ways that take advantage of your talents and help you become the leader you were meant to be. The key to success in FFA is to get involved!

Make sure you're getting a complete Agricultural Education experience, and remember that it all works together. Talk with you agricultural teacher today and make plans to perform in all three arenas. Don't just settle for a high school diploma when you can get set for life.

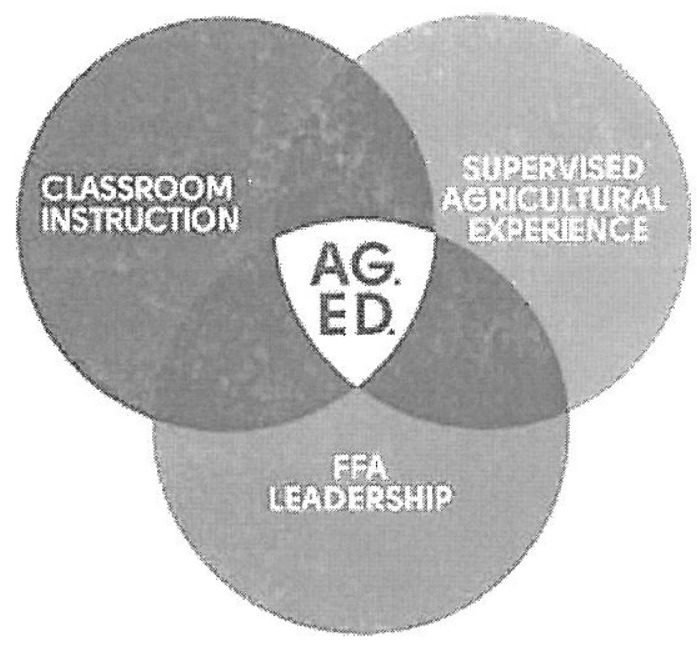

$11 \mid P$ Pag 


\section{FFA Mission and Strategies}

FFA makes a positive difference in the lives of students by developing their potential for premier leadership, personal growth and career success through agriculture education.

To accomplish this mission, FFA:

$>$ Develops competent and assertive agriculture leadership

$>$ Increases awareness of the global and technological importance of agriculture and its contribution to our well-being.

Strengthens the confidence of agriculture students in themselves and their work.

Promotes the intelligent choice and establishment of an agricultural career

$>$ Encourages achievement in supervised agricultural experience programs

$>$ Encourages wise management of economic, environmental and human resources of the community

$>$ Develops interpersonal skills in teamwork, communications, human relations and social interaction.

$>$ Builds character and promotes citizenship, volunteerism and patriotism.

y Promotes cooperation and cooperative attitudes among all people.

$>$ Promotes healthy lifestyles.

$>$ Encourages excellence in scholarship.

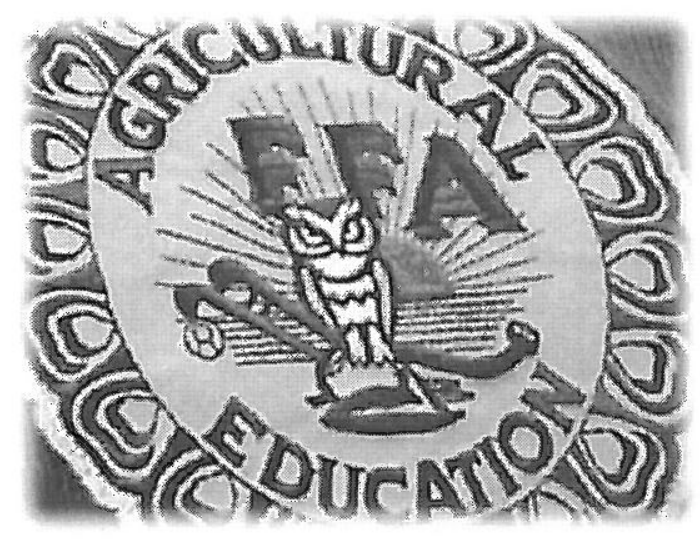

12 Page 


\section{$\underline{\text { FFA Emblem }}$}

Many organizations have logos they use as part of their identity. As with most logos, the FFA emblem is symbolic. It contains five separate elements. Each element represents items or ideals that are important to the organization and its members.

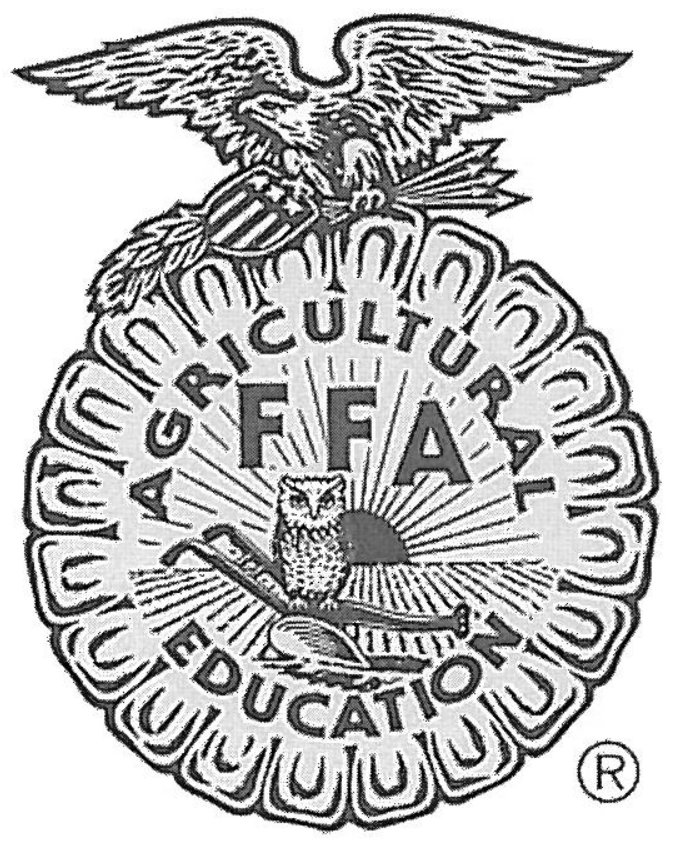

The cross-section of an ear of corn serves as the emblem's foundation, just as corn has historically served as a foundation crop in American agriculture. Corn is also a symbol of unity because it is native to America and it is grown in every state.

The rising sun appears in the center of the emblem and symbolizes progress in agriculture and the confidence FFA members have in the future.

The plow is a symbol of labor and tillage of the soil.

The owl represents knowledge and wisdom.

The eagle is perched on top of the emblem and served as a reminder of our freedom and ability to explore new horizons for the future of agriculture.

Finally, the words, "Agriculture Education" surrounding the letters "FFA" indicate that the FFA is an important part of the agricultural education program. 


\section{FFA Creed}

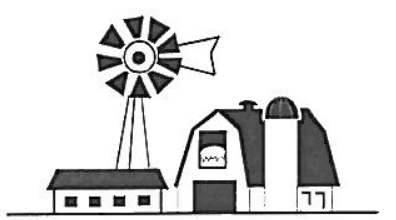

The FFA Creed is a basic statement of beliefs and a common bond between members. The creed was written by E.M. Tiffany and adopted at the $3^{\text {rd }}$ National FFA Convention. It was revised at the $38^{\text {th }}$ and $63^{\text {rd }}$ conventions to reflect changes in FFA members and the agricultural industry.

\section{The FFA Creed}

I believe in the future of agriculture, with a faith born not of words but of deeds-achievements won by the present and past generations of agriculturists; in the promise of better days through better ways, even as the better things we now enjoy have come to us from the struggles of former years.

I believe that to live and work on a good farm, or to be engaged in other agricultural pursuits, is pleasant as well as challenging; for I know the joys and discomforts of agricultural life and hold an inborn fondness for those associations which, even in hours of discouragement, I cannot deny.

I believe in leadership from ourselves and respect from others. I believe in my own ability to work efficiently and think clearly, with such knowledge and skill as I can secure, and in the ability of progressive agriculturists to serve our own and the public interest in producing and marketing the product of our toil.

I believe in less dependence on begging and more power in bargaining; in the life abundant and enough honest wealth to help make it so--for others as well as myself; in less need for charity and more of it when needed; in being happy myself and playing square with those whose happiness depends upon me.

I believe that American agriculture can and will hold true to the best traditions of our national life and that I can exert an influence in my home and community which will stand solid for my part in that inspiring task.

\footnotetext{
$14 \mid$ P a
} 
FFA Colors and Motto

\title{
Colors
}

The National FFA Organization chose national blue and corn gold as its official colors in 1929. As the blue field of our nation's flag and the golden fields of ripened corn unify our country, the FFA colors give unity to the organization.

\section{Motto}

Many important things come in small containers. Although a diamond ring takes up a little space, it is extremely valuable. So it is with the FFA motto. The motto has just 12 words, but those words are powerful.

\section{Learning to Do,}

\author{
Doing to Learn,
}

Earning to Live,

Living to Serve

$15 \mid P^{2} \operatorname{age}$ 


\section{FFA Official Dress}

One of the most unifying elements for any group is its uniform. In FFA, the uniform members wear to local, state and national functions is called official dress. It provides identity and gives the organization a distinctive and recognizable image.

\section{Proper Use of the FFA Jacket}

- The jacket is to be worn only by members.

- The jacket should be kept clean and neat at all times.

- The back of the jacket includes only: a large official FFA emblem, the name of the state association and the name of the local chapter, district or area. The front of the jacket includes only: a small official FFA emblem, the name of the individual, one office or honor and the year of that office or honor.

- The jacket should be worn on official occasions with the zipper fastened to the top. The collar should be turned down and the cuffs buttoned.

- The jacket should be worn by members and officers on all official FFA occasions, as well as other occasions where the chapter or state association is represented. It may be worn to school and other appropriate places.

- The jacket should only be worn to places that are appropriate for members to visit.

- School letters and insignia should not be attached to or worn on the jacket.

- When the jacket becomes too faded and worn to wear in public, it should be discarded or the emblems and lettering should be removed.

- The emblems and lettering should be removed if the jacket is given or sold to a non-member.

- A member should act professionally when wearing the official FFA jacket.

- Members should refrain from use of tobacco and alcohol when underage and at all times when representing the FFA. In addition, members should exhibit their leadership qualities when they encounter substances including tobacco and alcohol and serve to discourage others from inappropriate behavior.

- All chapter degree, officer pins, and other award medals should be worn beneath the name on the right side of the jacket, with the exception that a single State FFA charm and American FFA key should be worn above the name or attached to a standard key chain. No more than three medals should be worn on the jacket; these should represent the highest degree earned, the highest office held and the highest award earned by the member.

\section{Official FFA Dress}

- Official dress for female members is a black skirt, white blouse with blouse with official FFA scarf, black shoes, and official jacket zipped to the top. Black slacks may be worn for traveling and outdoor activities.

- The official dress for male members is black slacks, white shirt, official FFA tie, black shoes, black socks and the official jacket zipped to the top. 


\section{FFA Code of Ethics}

People are always observing you. Your actions when you wear the FFA jacket or represent the organization become part of the organization's image. To keep the image of the FFA and members sharp, delegates at the 1952 National FFA Convention adopted a Code of Ethics for FFA members to follow. The FFA Code of Ethics still protects the FFA image. It also guides members to make positive, healthy choices - and not only during FFA activities. The code of ethics guidelines are good to follow during all occasions and functions.

\section{The FFA Code of Ethics}

FFA Members conduct themselves at all times to be a credit to their organization, chapter, school, community and family. I pledge to:

\footnotetext{
Develop my potential for premier leadership, personal growth and career success

Make a positive difference in the lives of others.

$>$ Dress neatly and appropriately for the occasion.

$>$ Respect the rights of others and their property.

$>$ Be courteous, honest and fair with others.

$>$ Communicate in an appropriate, purposeful and positive manner.

$>$ Demonstrate good sportsmanship be being modest and winning and generous in defeat.

$>$ Make myself aware of FFA programs and activities and be an active participant.

$>$ Conduct and value a supervised agricultural experience program.

Strive to establish and enhance my skills through agricultural education in order to enter a successful career.

Appreciate and promote diversity in our organization.
}

17||$^{3} a g$ 
What if you could get classroom credit and FFA awards for doing what you like: experimenting with careers, earning money, building a resume and having fun? You can - with a Supervised Agricultural Experience (SAE) program. An SAE is a program you design to gain hands-on experience and develop skills in agricultural career areas that interest you.

You choose an SAE program that lets you discover, explore, experience and excel in careers. In the meantime, you gain skills and experience that pay off in areas of life. Your SAE program can lead you toward personal growth, premier leadership, and career success.

An SAE program is not just another class assignment or graduation requirement. You are truly in charge of your $\mathrm{SAE}$ ! Although your agriculture teacher will help you learn related information and keep good records, the success or failure of your SAE is up to you. It's an exciting opportunity to prove your abilities to future employers - and to yourself.

\section{Atwater FFA SAE Program}

* The Chapter will encourage all members to maintain a Supervised Agriculture Experience (SAE) program.

* The Chapter will encourage members to compete at shows with their SAE.

$>$ All Chapter members are expected to work as a team at all fairs and shows

- The Chapter will conduct an Exhibitors / Parent evening to inform parents and members of a member's responsibilities.

- The Chapter will require parents of all first time exhibitors to attend a meeting conducted by the Chapter Advisors. This meeting will serve as an informal session to allow parents / exhibitors to become aware of the expectations and responsibilities placed on the Chapter exhibitor.

All projects exhibited at fairs and shows by members of the Chapter must be entered in the FFA division and only with Advisor approval and supervision.

$>$ Members exhibiting at fairs must maintain academic requirements set forth by Atwater High School and the Atwater Agriculture Program and FFA. In order to participate in any activity beyond the chapter level, an individual must maintain at least a $2.0 \mathrm{GPA}$, cannot have more than one $\mathrm{F}$, and cannot have received less than a $\mathrm{C}$ grade in any Agriculture class the last eligibility period to the event. 
Additional eligibility rule - Students will be given one chance for scholastic ineligibility for showing at fairs. If a student becomes ineligible to show at a fair that they had planned to show, the student will receive a warning. If the same student should become ineligible again to show at a fair that they had planned to show at, the student will no longer be eligible to show with Atwater FFA.

- Members are encouraged to apply for local, regional and state proficiency awards.

- Members are encouraged to apply for advanced degrees (i.e. State FFA Degree)

- Members are encouraged to compete in the Local and Sectional Project Competition.

- Members are required to follow project Advisor's recommendations concerning their SAE.

- Members are encouraged to strive to improve and develop their SAE each year.

- Encourage members to develop skills within their SAE through participation and appropriate judging teams.

- Members are encouraged to attend demonstrations, breeding shows, and equipment shows which will enable them to increase their efficiency and knowledge of their SAE.

Members are encouraged to provide support and help their fellow Chapter members.

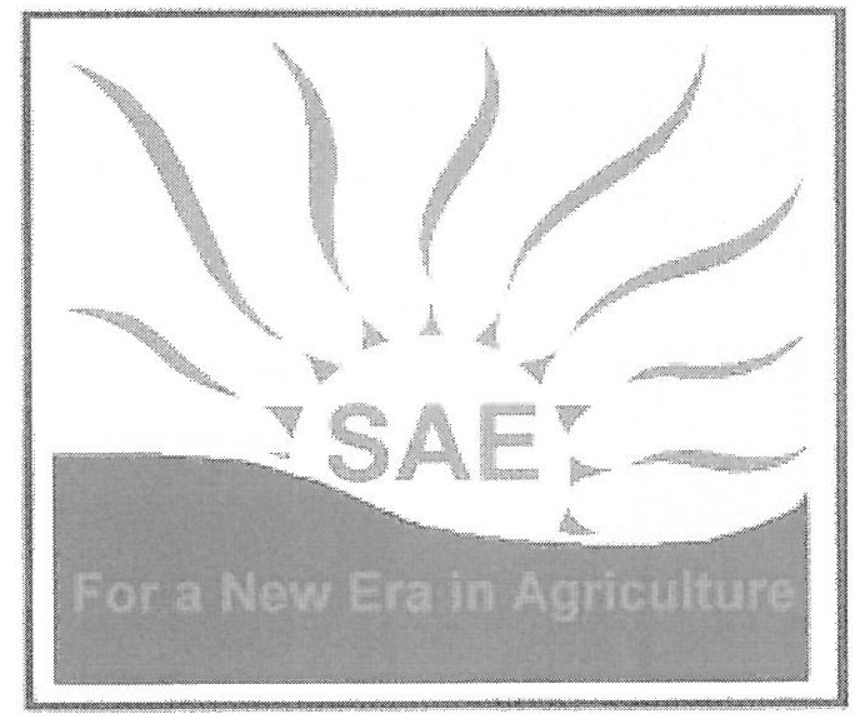

19 Pla $^{3}$ a 


\section{Cooperation}

The Atwater FFA chapter will develop a sense of cooperation among the entire membership.

- The Atwater Chapter will cooperate with other FFA chapters.

- Participation in Sectional, Regional, and State activities.

- Hosting Sectional activities as needed.

- Serving the awards banquet for Livingston FFA

- The Chapter will cooperate with Atwater High School.

- BBQ during home AHS football games and AHS BBQ functions.

- Participation in school functions and events

- Chapter representation during school sponsored activities and functions

- Cooperation and support with other AHS youth organizations

- The Chapter will participate in community cooperation.

- Participating and working with Merced County Office of Education's ROP program and awards ceremony.

- Participating and cooperating with local elementary schools in various agriculture projects (example: school gardens)

- Providing local middle schools with an informative recruitment presentation.

- Participation in a local city beautification project(s).

- Participation in Merced County and the American Cancer Society's Relay for Life

- Members exhibiting at fairs and shows will cooperate together and compete as a team. 


\section{Community Service}

The primary objective towards community service is for FFA members to establish an attitude of service towards the community in which they live.

The Atwater FFA will develop a sense of community service among the entire membership.

- Our chapter will conduct food and toy drives during the Thanksgiving and Christmas holidays to help those in need.

- We will assist with community projects and activities when called upon by the Chamber of Commerce.

- We will participate in the Atwater Beautification Day.

- We will take advantage of opportunities to form partnerships with community organizations in working with agricultural education and agricultural projects.

- Our chapter continues to strive towards participating in various community outreach programs
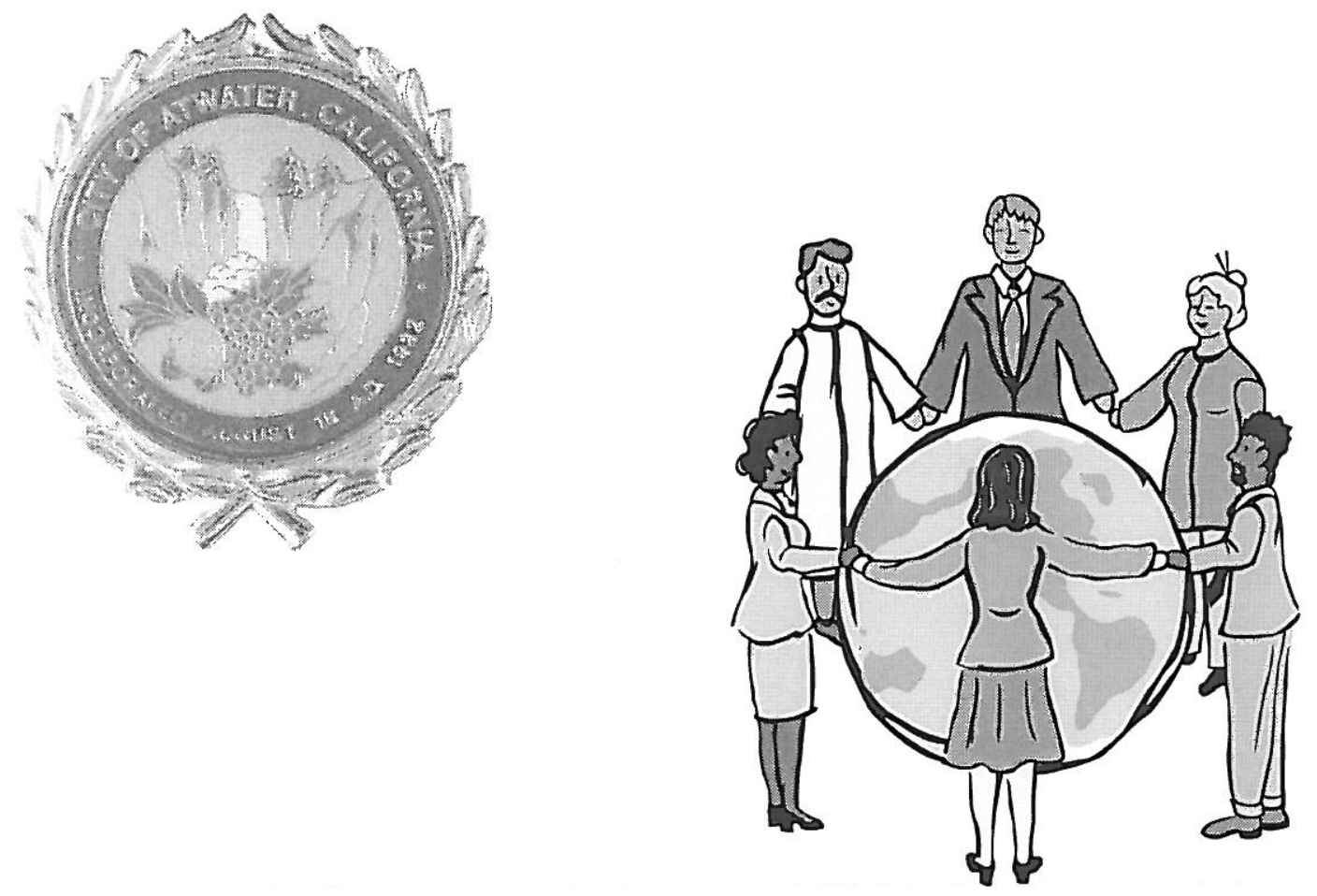


\section{Leadership}

Leadership is the ability to guide or influence others to work towards a meaningful goal while helping each to develop themselves as group members. Leadership is the ability in a well-adjusted person to handle people, to inspire or influence the actions of others, to make decisions or to move a group to action. Leadership is a contribution to the establishment and attainment of group processes. Therefore, leadership is a quality of group action.

\section{Public Speaking}

- Prepared Public Speaking

- Extemporaneous Public Speaking

- Parliamentary Procedure

- Job Interview

- Opening and Closing Ceremonies Speaking Contest

\section{Committees}

- Every member on at least one committee or involved in some kind of activity. The objective of each committee and committee chair(s) is to plan, prepare, organize, and implement each activity/event.

Annual FFA Awards Banquet - Overall

- Annual FFA Awards Banquet - Awards

- Annual FFA Awards Banquet - Decorations

- Annual FFA Awards Banquet - Food

- Annual FFA Awards Banquet - Music

- Annual FFA Awards Banquet - Script / Program

- Annual FFA Awards Banquet - Tickets

- Annual FFA Awards Banquet - Video / Flyers

- Atwater Beautification

- Canned Food Drive

- Drive-thru BBQ's (4)

- FFA "Basketball" or "Hockey" Trip

- FFA Homecoming Float

- FFA Jackets )Ordering / Organization)

- FFA "Bowling" Meeting

- FFA "Burrito Bingo" Meeting

- FFA "Morning Wave" Meeting

- FFA "Movie Night" Meeting

- FFA "Point Awards" - Tabulations/Recording

- FFA "Pool Party" Meeting

- FFA State Officer Visits

- Floral Christmas Arrangements

- Greenhand / Chapter Degree Ceremony 


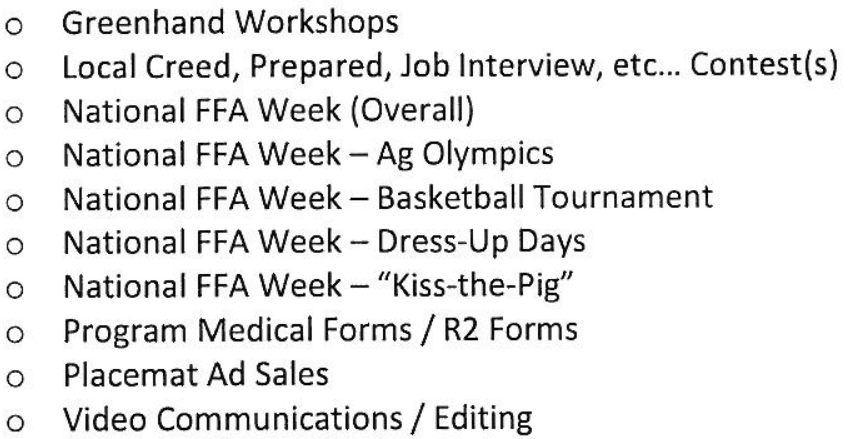

- Select Chapter members as Chairpersons for Committees

\section{Degrees and Awards}

- Encourages every member to apply for Greenhand and Chapter Farmer FFA Degree Encourage every qualified member to apply for the State and American FFA degree

- Encourage members to apply for State Proficiency Awards

\section{Officer / Leadership Training}

- Annual Chapter Retreat for new officers

- Leadership Training Conference for all officers

- Sectional \& Regional Officer Training

- Made for Excellence Leadership Training / Advanced Leadership Academy / Sacramento Leadership / Washington DC Leadership Conference

\section{Meetings}

- Conduct meetings in an orderly fashion by utilizing Parliamentary Procedures

- Have regularly scheduled Chapter Officer and Chapter Meetings

- Encourage every member to attend and participate at all meetings

- Send delegates to all Sectional, Regional, State, and National Meetings

\section{Offices}

- Encourage local members to run for local, sectional, regional, and state offices

- Invite Sectional, Regional, and State Officers to speak to your chapter

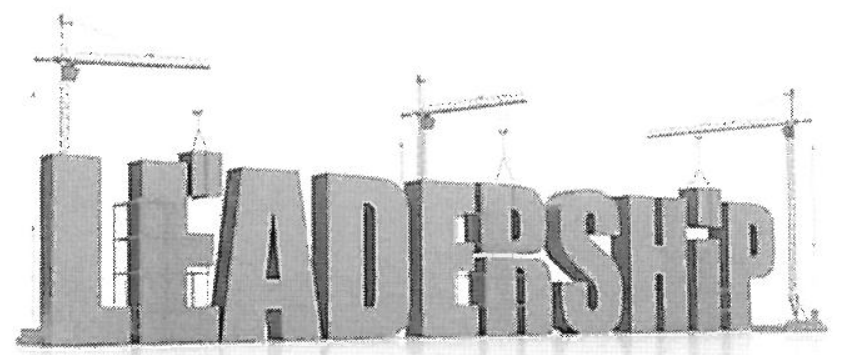




\section{Earnings and Savings}

As a self-supporting, non-profit organization, the earnings and savings aspect of our chapter is very important towards the success and productivity of our 2012-2013 school year.

The chapter earns money in various ways in order to finance FFA events and activities throughout the year. Some of these activities include:

- $\quad$ Atwater Ag Booster Dinner

- $\quad$ Atwater FFA "Fall Fest" Dinner / Auction

- $\quad$ Atwater FFA Plant Sales (2)

- $\quad$ AHS Ag Mechanics Wood/Metal Project Sales

- $\quad$ BBQ Take-Out Dinners (4)

- $\quad$ Milk Vending Machine

- $\quad$ Placemat Ad Fundraiser

- $\quad$ Save Mart S.H.A.R.E.S. Program

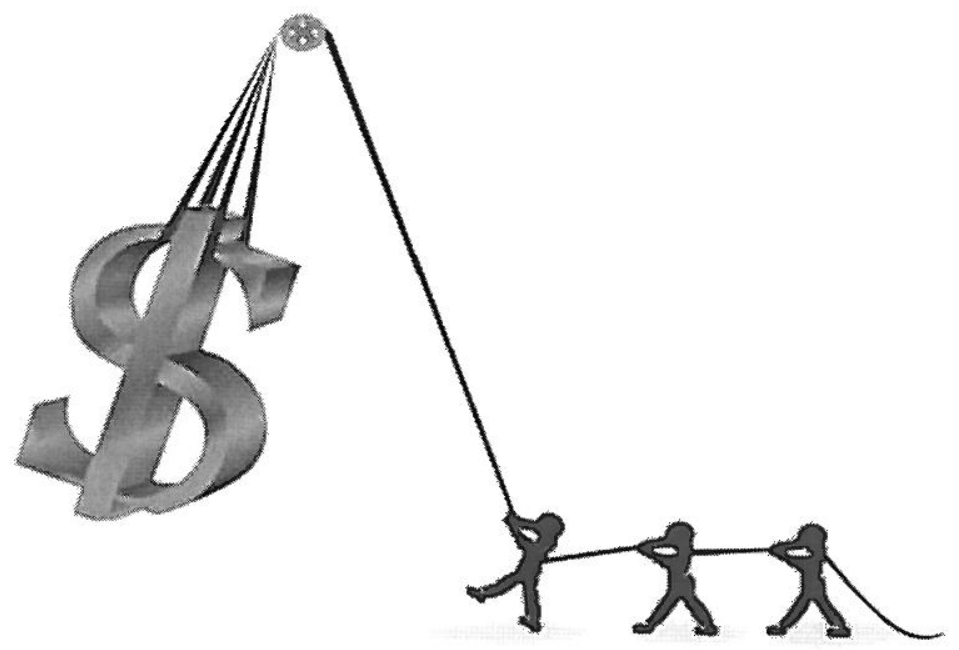




\section{Conduct of Meetings}

\section{Hold Regular, Well-Planned Meetings that Capture the Chapter's Interest and Participation}

- Have weekly Chapter Officer Meetings

- Have regular month Chapter Meetings

- Call special meetings when necessary

- Conduct regular Executive Meetings in order to maintain solid Chapter communications

- Prepare a well-planned program before meetings

- Provide refreshments for Chapter Meetings

- Have frequent and informative committee reports

- Invite parents and the community leaders to the Chapter Meeting

- The duty of the Sentinel is to set the proper paraphernalia out for the Chapter Meeting and to help the President in maintaining order.

- The goal of the Chapter is to have a least $50 \%$ attendance at each Chapter Meeting

- Have an activity after every Chapter Meeting

Special Meetings Should be Held as Necessary

- A special potluck dinner meeting will be held for the Greenhand/Chapter FFA Degree Installation Banquet

- A very special Awards Banquet will be held in May to wrap up the year.

The Official Ceremonies will be used at all Meetings

- All officers are required to learn their part.

- The officers will wear the official uniform at all meetings

- The necessary paraphernalia will be used at all meetings.

$25 \mid P\{g e$ 


\section{$\underline{\text { Scholastic Achievement and Scholarships }}$}

The chapter will encourage students to strive for academic excellence.

1. Improve scholarship of FFA members in all academic subjects

A. Encourage members to strive for C.S.F. standards

B. Strive to have all FFA members on the honor roll

C. Award points on the Chapter Point Awards system for good grades

D. Require that all Chapter Officers maintain at least a B in all agriculture classes.

E. Members participating in competitive events shall not fall below a $\mathrm{C}$ or 2.0 average on a 4.0 scale or have less than a $\mathrm{C}$ in any agriculture class. Eligibility for all competitive events will be suspended if any of the above shall occur.

2. Will strive to improve home technology, reading and library use.

A. Encourage each member to subscribe and read at least one agriculture publication.

B. Encourage each member to use school and county libraries for agriculture research projects.

3. Will encourage Seniors to apply for scholarships available to them in order to continue their education.

A. Twelfth grade members are encouraged to apply for scholarships including the Bloss, Fancher, Winton Grange, Farm Bureau, and Atwater Ag Booster Scholarship which are available to agriculture students.

B. Twelfth grade members are encouraged to apply for any scholarships which are available to them for the school they are planning to attend.

C. Twelfth grade chapter members are encouraged to talk with their counselors about other scholarships which may be available to them as a result of their parent's affiliation with a lodge or places of employment.

4. Scholastic Awards

A. Award trophies to the Agriculture students in each grade level with the highest GPA. 


\section{$\underline{\text { Recreation }}$}

The purpose of recreation is to create an opportunity for FFA members to participate in recreational activities and develop one's social and team building skills. It's also an opportunity to have some fun!

Here's a list of recreational activities scheduled for the $2012-2013$ school year:

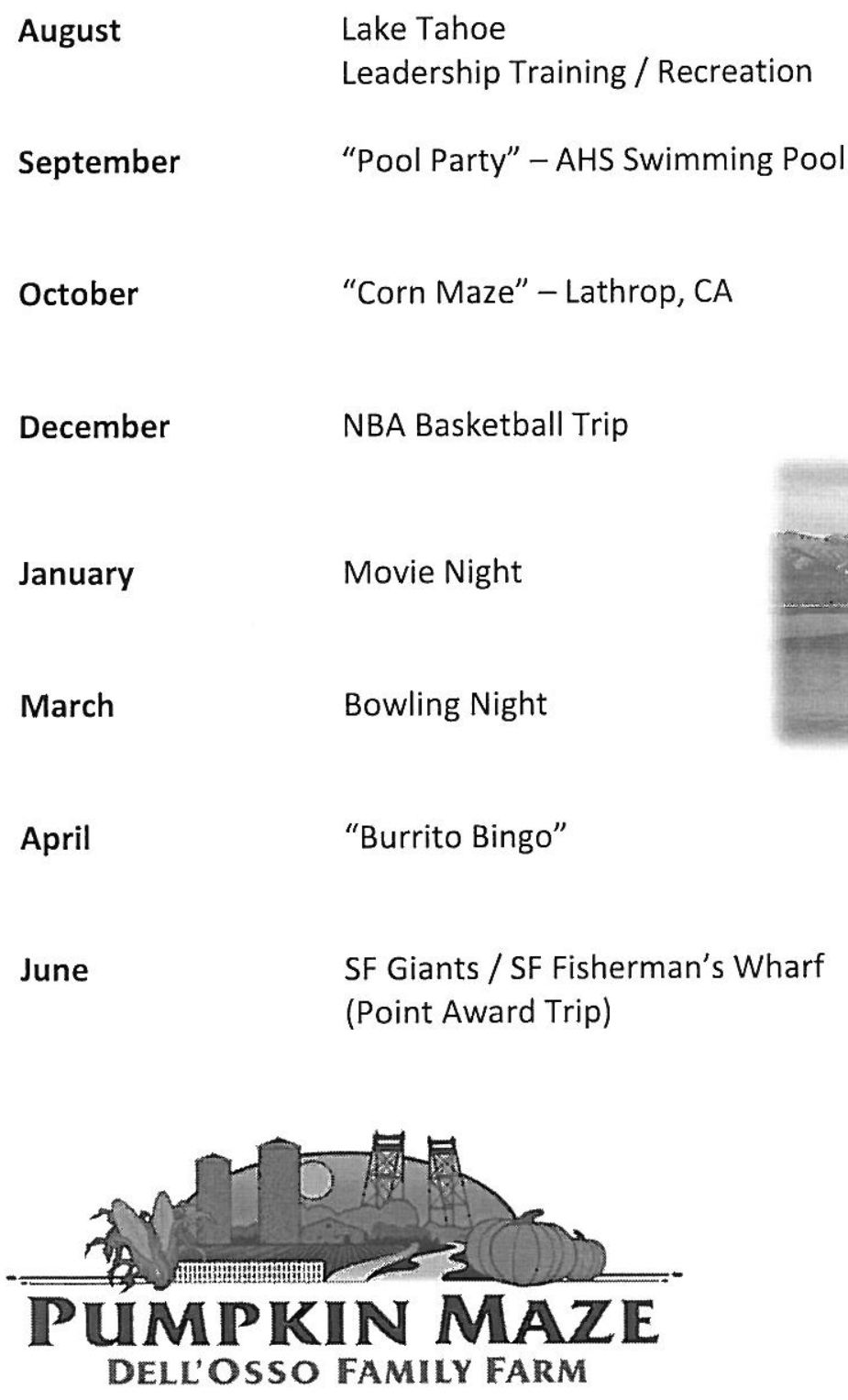
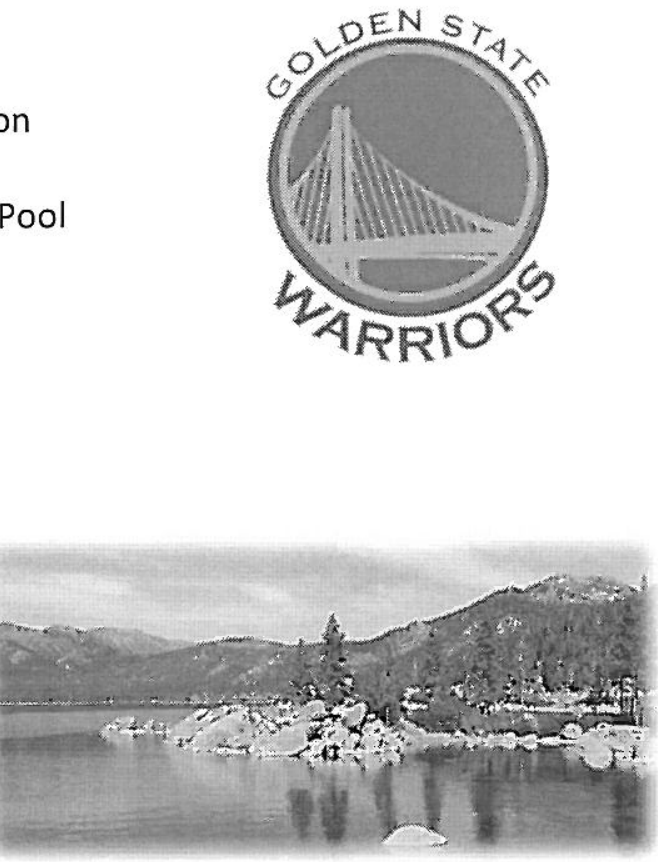


\section{Public Relations}

The purpose of public relations is to inform our chapter members and the general public about the activities of our local chapter as well as the overall benefits of the FFA.

\section{Media}

- Establish, strengthen, and maintain relationships with media contacts

- Submit articles and photos to various local, regional and state media publications

- Extend media coverage beyond newspapers and publications (i.e. radio, tv, etc...)

- Continue to develop and promote the www.AtwaterFFA.org website as an information resource

- Extend and participate in new communication technology resources such as Facebook

\section{FFA Week}

- Use various forms of media to keep the public informed during FFA Week

- Conduct school and community activities throughout FFA Week

\section{Various FFA Events and Activities}

- Select worthy persons as Honorary Chapter farmers

- Recognize worthy individuals to receive Certificates of Appreciation

- Provide community advertisements through Placemat Ad fundraiser

- Host various award recognition ceremonies for parents and families of FFA members

- Sponsor a parent / member banquet

- Maintain a chapter scrapbook

- Chamber of Commerce and other community service clubs

- Serve at the Livingston FFA Awards Banquet

\section{Atwater High School}

- Regular communication sessions with AHS administration and counselors

- Assist and support various school activities 


\section{$\underline{\text { Alumni Relations }}$}

The Chapter will encourage graduating seniors to keep membership affiliation for the following year.

- As graduate members, the chapter will encourage these members to:

- Exhibit at fairs until eligibility membership expires

- Apply for advanced degrees such as the American FFA Degree

- Apply for proficiency awards in their SAE area

- Continue an active role in participation in local activities

- Attend all chapter meetings

- The Chapter will utilize the expertise of alumni members when needed by the Chapter.

- To help coach judging teams

- To serve as judges of local FFA contests

- To assist in money raising activities such as ad sales, BBQ's, etc.

- Provide facilities for SAE projects

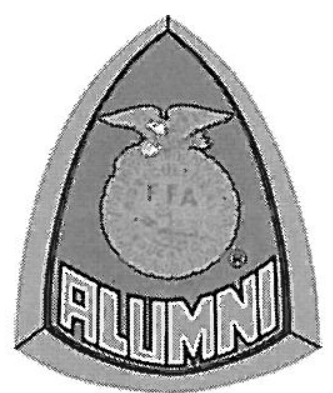




\section{Fairs and Official Show Uniforms}

\section{Official Show Uniform}

The official Show Uniform for FFA members consists of:

White shirt or blouse, white pants, FFA tie, and FFA jacket. Shoes should be appropriate for what you are showing.

\section{Fairs}

The Atwater FFA Chapter is involved in many fairs throughout the year. The livestock and agricultural mechanics projects are exhibited throughout the state, where the chapter wins many awards and honors. The animals that are exhibited include market and breeding sheep, market and breeding beef, market and breeding swine, dairy cattle, rabbits, market, breeding, and dairy goats.

The Fairs that are attended are:

$$
\begin{array}{ll}
- & \text { (Summer) Merced County Fair } \\
-\quad & \text { (Summer) California State Fair }
\end{array}
$$
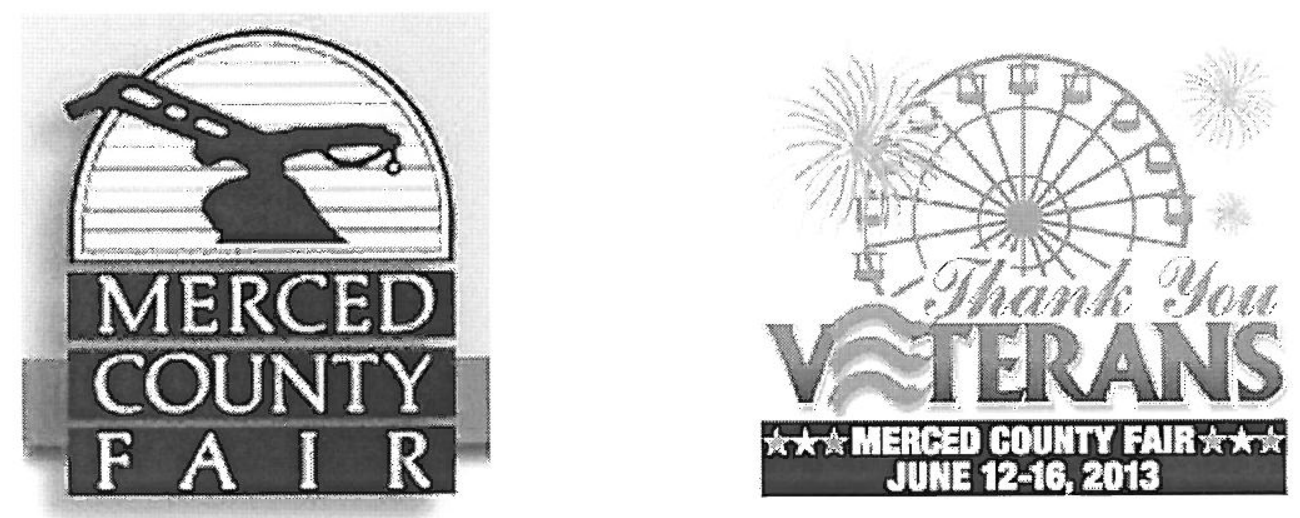

$30 \mid$ Page 


\section{Merced County Fair SAE Budgets}

\begin{tabular}{|c|c|c|c|c|}
\hline Expenses & Market Hog & Market Lamb & Market Goat & Market Steer \\
\hline Purchase of animal & & & & \\
\hline Livestock Insurance & 225 & 225 & 200 & 800 \\
\hline Veterinary Supplies & 15 & 15 & 10 & 50 \\
\hline Fair Bedding & 10 & 5 & 5 & 20 \\
\hline Feed & 10 & 15 & 15 & 30 \\
\hline Show Supplies & 190 & 100 & 100 & 20 \\
\hline Income & 15 & 20 & \\
\hline
\end{tabular}
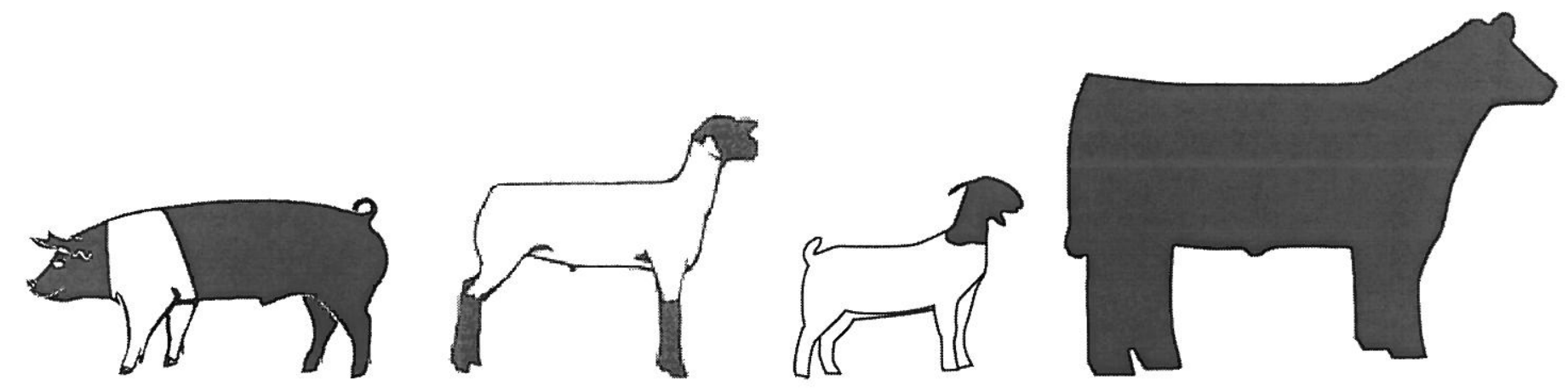

31 |P 


\section{Merced County Fair SAE Budgets}

\begin{tabular}{|c|c|c|c|c|}
\hline & Bred Heifer & Dairy Heifer & Fryer Rabbit & $\begin{array}{l}\text { Rabbit Meat } \\
\text { Pen }\end{array}$ \\
\hline \multicolumn{5}{|l|}{ Expenses } \\
\hline Purchase of animal(s) & 800 & 1200 & 20 & 60 \\
\hline Livestock Insurance & 60 & 60 & & \\
\hline Veterinary Supplies & 60 & 75 & & \\
\hline Fair Bedding & 20 & 40 & & \\
\hline Feed & 650 & 500 & 10 & 10 \\
\hline Show Supplies & 30 & 75 & 25 & 25 \\
\hline Breeding Fees & 125 & & & \\
\hline \multicolumn{5}{|l|}{ Income } \\
\hline Sale of beef bred heifer & 1800 & & & \\
\hline Sale of dairy replacement heifer & & 2000 & & \\
\hline Sale of rabbit(s) & & & 70 & 130 \\
\hline \multicolumn{5}{|l|}{ Sale of steer $(1200 \mathrm{lbs} @ \$ 1.30 / \mathrm{lb})$} \\
\hline Total Estimated Recipts & 1800 & 2000 & 70 & 130 \\
\hline Total Estimated Expenses & 1620 & 1950 & 55 & 95 \\
\hline Estimated Net Profit & 180 & 50 & 15 & 35 \\
\hline
\end{tabular}
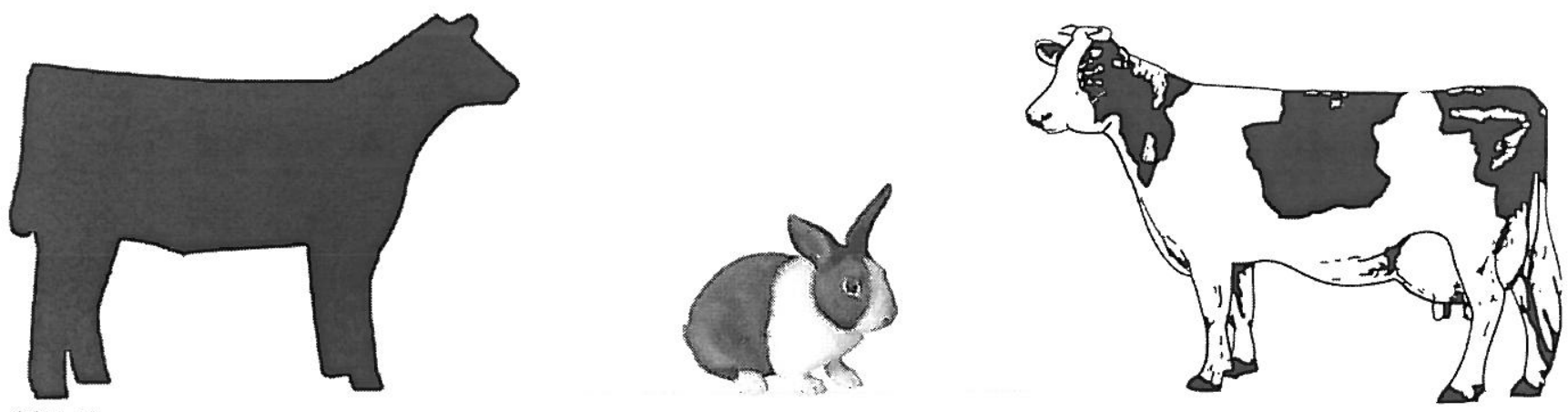


\section{Point Awards System}

The Point Award System was developed in order to recognize and award those members who are most active in various FFA activities throughout the year. The top twenty individuals will receive an award and recognition at our awards banquet in May. The top twenty members were invited to participate in a Point Award trip sponsored by the Atwater FFA. In 2012, the Point Award members went to on a river rafting trip.
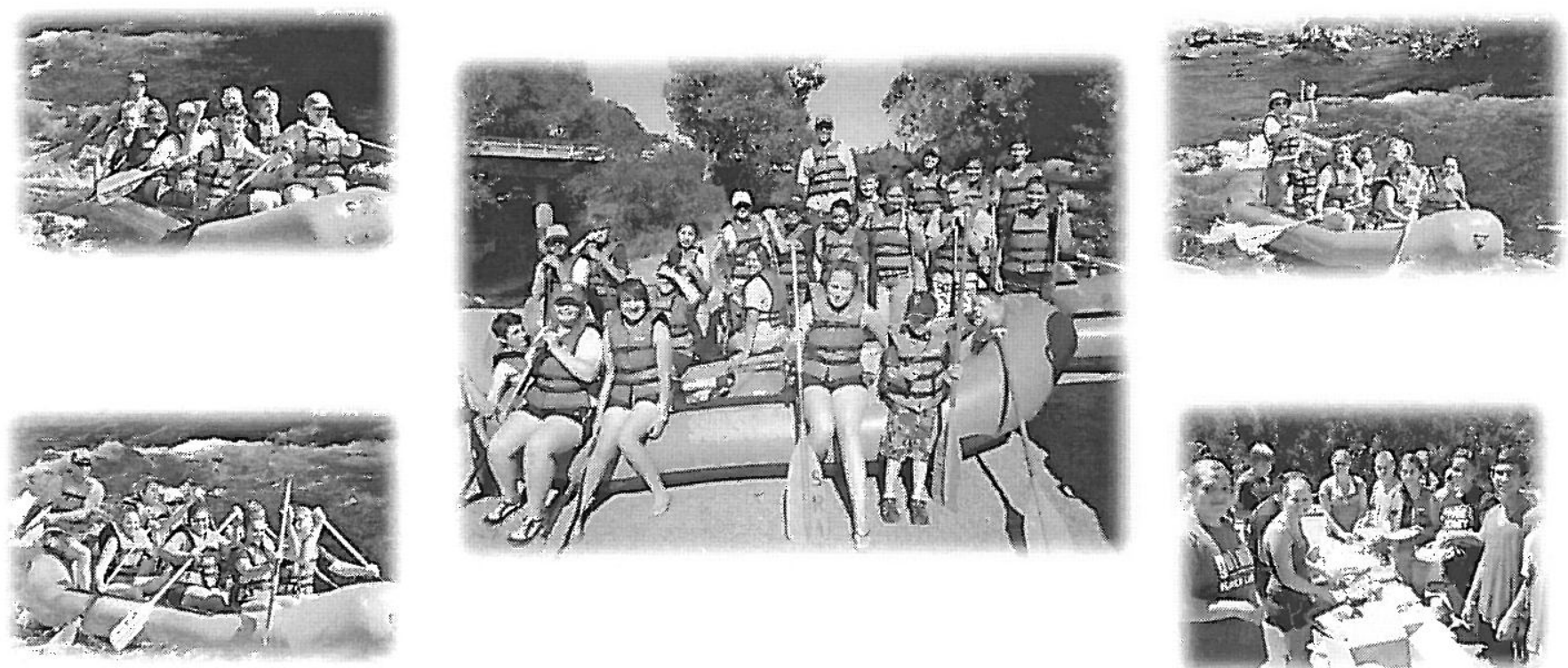

2011 - 2012 Point Award Winners

\begin{abstract}
Carolyn Schiber
Cheyenne Schoonover Donald Moles

Giancarlo Kamesch Hans vanWarmerdam Heather Lewandowski James Bray
\end{abstract}

\author{
Jesse Tafoya \\ Joana Pena \\ Joy Wilcox \\ Luis Favela \\ Makala Navarro \\ Maria Ceja \\ Mayra Hernandez
}

Mekayla Coughran

Morgan Briner

Noemy Escamilla

Sandra Flores

Sandy Xiong

Taylor Ferreira

For June 2013, the officer team selected a trip to a San Francisco Giants game and Fisherman's Wharf. The Point Award System is an evaluation resource used by the Advisors towards selecting each year's Star Chapter Greenhand and Star Chapter Farmer award recipient 


\section{Point Awards System}

\section{Atwater FFA Point Awards List}

\section{FFA Leadership / Community Service / Work Day Activities}
A Ag Dept. Work Day
20
B Chairman
1. Over-all Chairman (Upon Completion Of Report)
20
C Chapter FFA Degree (Year Received)
D Community Service Work
E Greenhand Degree (Year Received)

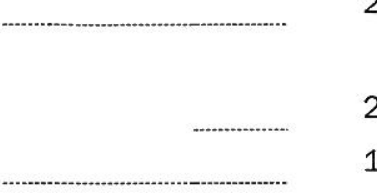
15
$5 /$ Hour
30
F Homecoming Float
$15 /$ day
$G \quad$ Meetings
1. Attendance At Each Chapter Meeting
2. $100 \%$ Attendance At Chapter Meetings

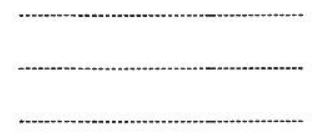
3. Representing The Chapter At Sectional Meetings

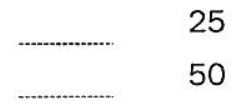
4. Representing The Chapter At Regional Meetings
15
5. Representing The Chapter At State Meetings
………...
20
6. Representing The Chapter At National Meetings
H Officers
1. Chapter Officer
2. Sectional Officer
3. Regional Officer
4. Student Body Officer
5. Class Or Club Officer
30
100
65
75
35
25
Official FFA Jacket
25
60
J Star Chapter Farmer
50
K Star Greenhand
100
L Star Regional Farmer
50
Star Sectional Farmer

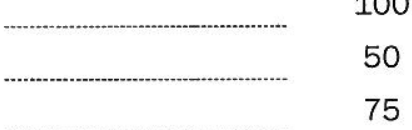
N Star State Farmer
75
State FFA Degree (Application Submitted)
100
$P \quad$ State FFA Degree (Year Awarded)
Q Wear FFA Jacket Or Apparel To School On Designated Day
10

\section{Fundraisers}


B FFA Plant Sale

C Placement Ad Sales

D Take-Out BBQ Tickets

\section{Supervised Occupational Experience Program (SAE)}
A Agriculture Mechanics Project(s)
25
B Beef / Dairy Cattle Fair Project
C Landscape Project at Merced / Madera County Fair
50
D Large Ag Mech Project(s) - Instructor's Approval
75
E Plant/ Horticulture Project(s)
25
F Swine / Goat / Sheep Fair Project
G Project Competition
1. Local Competitions
50
2. Sectional Competition
a. Gold Award Winner
b. Silver Award Winner

$\mathrm{H} \quad$ Exhibition At Fairs And Shows

1. Animal Projects
a. Class Winner $\left(1^{\text {st }}\right.$ or $\left.2^{\text {nd }}\right)$
10
b. Breed Champion
c. Overall Champion (Grand or Reserve)

2. Agriculture Mechanics / Horticulture Projects

a. Outstanding Project

4. Showmanship
a. Top 10 Showmanship
b. Showmanship Champion
c. Round Robin Winner

25

50

\section{Scholarship (Based On Semester Grade Only)}

$\begin{array}{ll}\text { A } & 3.5-4.0+\text { Overall School Year GPA (all AHS classes) } \\ \text { B } & 3.0-3.49 \text { Overall School Year GPA (all AHS classes) } \\ \text { C } & 2.5-2.99 \text { Overall School Year GPA (all AHS classes) }\end{array}$

\section{Judging Teams}

A Participation (Official FFA Contest) 


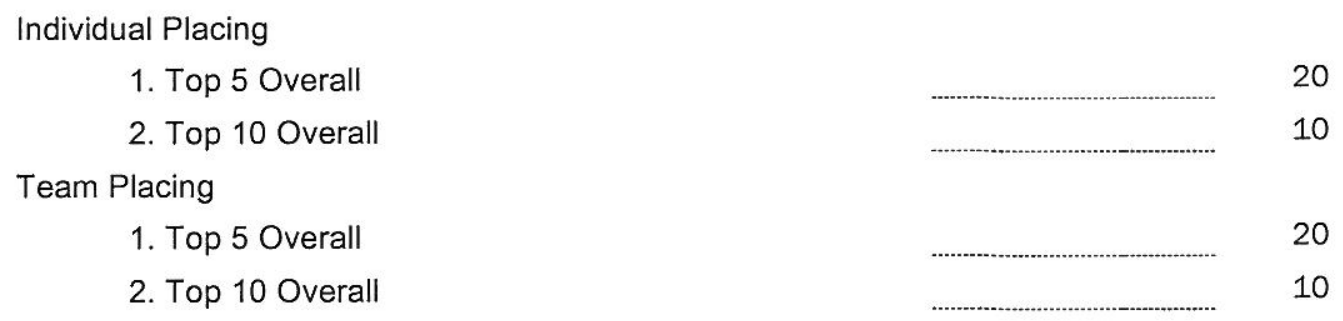

(Double All Of The Judging Team Point For State Finals)

The Coach Of Each Individual Team Will Award Each Time Member That He Feels Is Deserving A One Time Award Of 150 Point At The End Of The Year.

V Best Informed Greenhand, Co-Op Quiz, Public Speaking, Parliamentary Procedure, Creed And Opening And Closing Ceremonies Contest
A Chapter Competition
20
B Sectional Competition
25
C Regional Competition
30
D State Competition
50

VI National Competitions (Participation)
A Judging Teams
200
B Parliamentary Procedures
200

\section{Proficiency Awards}
A Local
25
B Submitting Regional Application
35
C Region State
50
D Nation
75
E Final Four 


\section{Chapter Constitution}

\section{Constitution}

of the

\section{Atwater FFA Chapter}

Revised September 2004

\section{Article I: Names and Purposes}

Section A. The name of this organization shall be the Atwater Chapter FFA (Future Farmers of America) \#CA0344

Section B. The Purposes for which this Chapter is formed are as follows:

1. To improve agriculture conditions and practices in and about Merced County

2. To develop agricultural skills or prepare for leadership, cooperative attitudes and rural responsibility, in individuals preparing to enter an agricultural occupation.

3. To advance the cause of agriculture education and to encourage the FFA.

4. FFA makes a positive difference in the lives of students by developing their potential for: premier leadership, personal growth and career success through agriculture education.

\section{Article II: Organization}

Section A. The Chapter of the Future Farmers of America is a charted local entity of the Merced-Mariposa Section of the California Association, made up of local members. 


\section{Article III: Membership Organization}

Section A. Membership in this organization shall be active and honorary.

Section B. Membership is limited to students enrolled in Agriculture education at Atwater High School.

Section C. Membership of graduates is limited to students that were active members their Senior year and graduated from high school.

Section D. The Atwater FFA is a $100 \%$ affiliation Chapter with every student becoming a member of the FFA when they enroll in an agriculture class.

Section E. No students may participate in any FFA activities unless they are members in good standing.

Section F. The FFA Advisors at their own discretion have the right to dismiss any member from the Atwater FFA organization at any time.

Section G. Active work in this chapter shall be carried on by active members.

Section $\mathrm{H}$. Award recipients must attend Chapter awards banquet to receive any awards.

Section I. All members exhibiting livestock at fairs and shows must attend the fair awards ceremony with official uniform; jacket only.

Section J. High School members exhibiting at fairs and shows must attend 6 chapter meetings to be eligible to show. All graduates are strongly encouraged to attend 6 agricultural related meetings or activities.

\section{Article IV: Officers}

Section A. The chapter officers for the Atwater FFA shall be President, Vice President, Secretary, Treasurer, Reporter, Sentinel, and Historian.

Section B. All elective chapter officers shall hold office for one year after election or until successors are selected as described in Article IV, Section G.

Section C. Application for chapter office shall be available two weeks prior to selection of officers via the Nominating Committee. All applications will be screened by the nominating committee.

Section D. Members holding the FFA Greenhand Degree, or higher, are eligible to hold office.

Section E. All officers must be enrolled in the Agriculture Leadership class that meets daily during the term of their office.

Section F. All officers must have all of their SAE projects in the FFA. 
Section G. Officers who cannot fulfill their duties or who are impeached will be replaced by the first alternate selected by the Nominating Committee.

Section $\mathrm{H}$. No officer may be impeached without due process as defined in Article VII.

Section I. The Nominating Committee shall select the chapter officers.

Section J. The Nominating Committee shall be composed of two student representatives from the $9^{\text {th }}$ grade, $10^{\text {th }}$ grade, $11^{\text {th }}$ grade, $12^{\text {th }}$ grade, the retiring $12^{\text {th }}$ grade FFA chapter president, and advisors. Nominating Committee members are not eligible to run for chapter office. In the event the current FFA chapter president is not in the $12^{\text {th }}$ grade, their spot on the Nominating Committee will remain vacant. The Nominating Committee will review officer applications, conduct interviews of prospective candidates, and select each chapter officer via a unanimous vote within the Nominating Committee.

Section K. The time for Nominating Committee selection shall be set by the FFA Officer Team, and the Advisors.

Section L. All FFA chapter officers who fall below a 3.0 grade average in the Agriculture class(es), or become academically ineligible, will be put on probation for six week period. If by the end of the next six week period, the grade average has not improved to a 3.0 or above, or does not become academically eligible, they will be replace by the manner described in Article IV, Section G.

Section M. All newly elected officers are required to attend the Chapter Officer Leadership Retreat to be held the summer prior to the school year that they service as an officer as well as the fall Chapter Officer Leadership Conference (COLC). Officers which do not attend the conference, except for reasons beyond their control, i.e. sever illness, death in the family, will be replace in the manner described in Article IV, Section G.

\section{Article V: Duties of Officers}

Section A. The duties and responsibilities of Chapter Officer shall be:

1. Attend all Chapter and Chapter Officer meetings.

2. Attend Chapter and Regional Officer Leadership Training Conference

3. Cooperate with advisors on all activities.

4. Be able to lead by example. Act and perform in a manner which is becoming of an FFA Chapter officer at all times. 
5. Be willing to memorize their parts as prescribed in the Official FFA Manual for all official ceremonies.

6. Have a genuine interest in being part of a leadership TEAM.

7. Be familiar with the Chapter constitution and bylaws.

8. Be willing to accept responsibility.

9. Be familiar with parliamentary procedure.

Section B. The duties and responsibilities of the President shall be:

1. Preside over and conduct meetings according to accepted parliamentary procedure.

2. Call special meetings if needed.

3. Keep members on the subject and within time limits.

4. Appoint committees and serve as a non-voting member of them.

5. Call other offices to the chair as necessary or desirable.

6. Represent the Chapter and speak on occasions.

7. Coordinate Chapter efforts by keeping in close touch with the other Officers and members, and the advisors.

8. Follow up Chapter activities and check on progress being made.

9. Keep Chapter activities moving in a satisfactory manner.

10. Prepare agenda for Executive and Chapter meetings with the secretary.

11. Coordinate the activities of the Chapter and keep in touch with the progress of activities.

Section C. The duties of and responsibilities of the Vice-President shall be:

1. Assist the president.

2. Preside at meetings in absence of the president.

3. Be prepared to assume duties and responsibilities of the president.

4. In charge of insuring that all committee work of the Chapter is completed satisfactorily.

5. Responsible for the invocation at the Greenhand/Chapter Farmer awards ceremony, annual awards banquet and at other times when needed.

Section D. Duties and responsibilities of the Secretary shall be:

1. Prepare and read the minutes of the past meetings.

2. Have available for the President the list of business for each meeting.

3. Attend to office correspondence of the Chapter.

4. Prepare Chapter reports. 
5. Keep the permanent records of the Chapter in the agriculture office.

6. Cooperate with the treasure in keeping an accurate membership role and issue membership cards.

7. Call meetings to order in the absent of a presiding officer.

8. Read communication at meetings.

9. Have on hand for each meeting the following:

a. Secretary's book and minutes of previous meeting.

b. Lists of committee and committee reports.

c. Copy of the Program of Activities.

d. The Official FFA Manual.

e. Copies of the Chapter Constitution and Bylaws.

10. Prepare, post and distribute motions.

11. Prepare Point Award cards and distribute to advisors by the $27^{\text {th }}$ of the presiding month.

Section E. Duties and Responsibilities of the Reporter shall be:

1. Gather and classify Chapter news.

2. Prepare news notes and articles for publication or broadcast.

3. Send news notes to the state reporter and to the FFA New Horizons.

4. Arrange for FFA participation in local radio and/or TV Programs.

5. Work closely with the advisors to maintain a log of FFAer's of the month for monthly publication.

6. Prepare a Chapter newsletter to be sent to members and alumni.

7. All news releases and articles must be approved by the Chapter Advisors prior to being released.

8. Prepare Monthly Newsletter to Chapter members.

Section F. Duties and responsibilities of the Treasure shall be:

1. Receive and act as custodian of Chapter funds.

2. Assist in preparing an annual budget of estimated receipts and expenditures.

3. Keep the financial records of the Chapter.

4. Devise appropriate ways and means of financing chapter activities.

5. Pay out Chapter funds as authorized by the student body.

6. Prepare financial statements and reports.

7. Encourage systematic saving-individual and Chapter thrift.

8. Build up chapter's financial standing. 
9. Required to prepare a written report monthly.

Section G. Duties and responsibilities of a Sentinel shall be:

1. Set-up the meeting room and care for chapter paraphernalia and equipment.

2. Attend to the door during meetings and welcome visitors.

3. See that the meeting room is kept comfortable.

4. Take charge of candidates for degree ceremonies.

5. Assist with entertainment features and refreshments.

6. Keep an accurate roll of those present at Chapter meetings.

7. Make arrangements with the custodial staff for microphones and audio equipment prior to their need.

Section $\mathrm{H}$. Duties and responsibilities of the Historian shall be:

1. Keep and maintain the Chapter scrapbook.

2. Be in charge of the Chapter camera and make certain it is available for use at each and every FFA activity during the year.

3. Take pictures of contest winners for the newspaper and make them available to the Chapter reporter as soon as possible after the contest.

\section{Article VI: Impeachment}

Section A. Immediate Impeachment

The FFA advisors may at any time at their own discretion remove an officer who has repeatedly disregarded his/her duties by not fulfilling them to his/her best ability.

Section B. Steps of Impeachment

Step 1. Any FFA Chapter officer not fulfilling the duties as described by this constitution will be required to meet with fellow officers and two Advisors to discuss a plan for improvement.

Step 2. A written plan of improvement will be drawn by the advisor based on the conversation of the meeting in Step 1, and will be confirmed and signed by the FFA President, Vice-President, and by the Officer in question.

Step 3 . If the Officer in question still does not fulfill his/her duties, then a $2 / 3$ vote of the Chapter officers and advisors will remove that Officer from office. 


\section{Article VII: Committees}

Section A. A member may serve on not more than two committees at any one time and may only one committee if he/she is a chairperson of that committee.

Section B. The committee chairperson is responsible to call committee meetings and to see that all work that committee is assigned is performed.

Section C. That committee chairperson shall cooperate with the Chapter advisors and Chapter officers on all committee work.

Section D. That committee chairperson's report to the Chapter in writing will be the result of all work performed by his/her committee including financial implications for the Chapter.

Section E. No person having been chairperson on any committee shall be eligible to work on another committee until the written report is made by the committee.

\section{Article XIII: Meetings}

Section A. Meetings shall be held once a month.

Section B. The president shall have the power to call special meetings as the need arises.

\section{Article IX: Dues}

Section A. As long as incentive grant funds are available, dues shall be paid for all members through that source.

\section{Article X: Eligibility to Participate at Fairs and Judging Contests}

Section A. Eligibility of members exhibiting at fairs and shows will be based on the Advisor's discretion.

Section B. Members must maintain a 2.0 GPA with no F's in an Agriculture class to be eligible to exhibit at fairs and judging events.

Section C. Members must comply with rules and guidelines set forth by the Chapter committee on fairs and shows.

Section $\mathrm{D}$. In the event that a student becomes academically ineligible to participate 
at a fair at which they planned to exhibit livestock, he/she will be placed on academic probation by the Agriculture Department. If that student becomes ineligible again, he/she will lose his/her privilege to exhibit at all fairs with the Atwater FFA Chapter for the next semester.

\section{Article XI: Amendments}

Section A. To amend the Constitution, a 2/3 vote of the active members is required.

Section B. To become effective, the amendment must be posted for two weeks previous to the vote of the active members.

\section{Article XII: Ratification of Constitution}

Section A. The Constitution should be come effective when passed by $2 / 3$ vote of the members voting. 


\section{Atwater FFA History - State FFA Degrees}

The Atwater FFA became an official chapter (\#281) with the California FFA Association during the 1957-1958 school year. The following pages showcase state and national chapter and individual recognition.

\section{California State FFA Degree Recipients}

The California State FFA Degree is the highest degree a student can earn at the state level. A State FFA Degree recipient has taken FFA involvement beyond the chapter level and had a successful SAE program. The following names are individuals who have earned their California State FFA Degree through the Atwater FFA:

1979-1980

Kerwin Grissom

1980-1981

Rich DeSousa

Kandace Heller

Tom Schmidt

Kevin Sorensen

Andrew Todd

1981-1982

Chris Beutel

Scott Clamp

Matt Machado

Paul Machado

Kathy Pareira

Jon Schmidt

Robbie Stanford

Andy Taylor

Sonya Veldhuis

John White

Ryan Williams

1982-1983

Stacy McDowell

Greg Rieke

Eric Sorensen

Fred Souza

Ramie Stone

Laura Terra
Roslynn Williams

1983-1984

Monica Bairos

Monique Bolcao

Loren Freitas

Sharee Lemas

Derick Locke

James Pacheco

Catherine Schmidt

Trent Sherman

Stan Souza

Joseph Vierra

1984-1985

Jessica Brooks

Greg Cardey

Scott Cortinas

Danny Dutra

Jeff Hammar

Amber Houska

Troy Lindenberg

Rick Little

Tina Nichols

Jimmy Pitcock

Todd Rinkenberger

John Sexauer

Fatima Silva

Toni Teixeira

Manual Whitaker
1985-1986

Scott Chatham

David Ferroni

Victoria Freitas

Tony Homen

Todd Lemas

Justin Pareira

Troy Rinkenberger

Scot Sherman

John Silva

Kelly Vierra

Tony Wilson

1986-1987

Mike Barry

Chester Bradley

Melissa Brown

David Bryson

James Butrym

Allen Cline

Justin Covert

Liz Escobar

Tammy Farmer

Angela Grandov

Richard M. Gresio Jr.

Shirley Harrison

Beatrice Hildreth

Scott Koehn

Michelle Lemmon

Marco Leaon

Elder Lopes

Robert Lunsford

45 Page 
Kaci Childers

Norbet S. Duarte

Mal Machado

David McDowell

Katherine Meadows

Eileen Miller

Sayf Munir

Dayna Nachtigal

Joseph Pacheco

David Pearce

David Pisacco

Paul Stone

Michelle Toconis

Melissa Vieria

Christie Wood

1987-1988

John Blevins

Duarte Borges

Danielle Buzbee

Chris Cardey

Marc Haywood

Scott Hosburgh

Chris Kowalski

Stefanie Prine

Tracey Row

Annette Stanford

Melanie Toews

Katrina Watson

1988-1989

Mike Burdick

Lisa Cabral

Nathan Cabral

Ronda Codd

Margaret Crawford

Richard Freitas Jr.

Jacklin Gamble

Chris Hernandez

James Lencioni

Tony Lunsford

Stayci Maddox

Alicia McGrath

Venita Sherrell

Denise Strauss
Jeanna Alves

Don Benordon

Frank Cardenas

Debra Cardoza

David Corvelo

Jared Covert

Zak deBoer

Tammy Fraguglia

Lynette McGill

Jaime Macias

Sean D. Mounts

Chris O'Gara

Jason Plagenza

Bruce M. Santos

Steve Santos

Frank Shaw

Wade A. Shaw

Cherie Steck

Joey Wren

Jose A. Zarate

1990-1991

Ed Agueda

Michelle Armas

Nelly Barcelos

Jennifer Clark

Paul Garcia

Kevin Hammon

Jose Hernandez

Adam Johnston

Brian Laranjo

Jaime Leon

Lesa Prine

Desiree Romero

Jennifer Romero

Shane Roppoli

Stefanie St. John

Tina White

1991-1992

Tony D. Agueda

Richard Alvernaz

Tony Avila

Edward Casaday
John Jimenez

Jason Latronica

Joseph F. Martin

Ed Mello

John Mendes

Mary Nichols

Shane D. Patterson

Diahann J. Selkow

David J. Souza

Allison Tassey

Mark Walker

1992-1993

David Avelar

Matt Baptista

Kory Billings

Michelle Duarte

Noel Nunes

Mandy Rommel

Jenny Silva

1993-1994

Danny Agueda

Dario Avila

Benjamin Bese

Gerald Borba

Joseph Burroughs

Travis Cox

Elia DelToro

Gus DelToro

Melissa Diaz

Kathleen Dores

Levi Dukes

Joey Dutra

Luis Garaveto

Paula Gonzales

Joshua Hanson

Jeremy Johnson

Brian Keiser

Cody Kingston

Summer Lentz

Anthony Lucich

Manuel Machado

Desi McComb 
1993-1994

(continued)

Michelle Mello

Richard Mello

Horacio Oliveira

Tim Petersen

Jason Rider

Tara Rocha

Mark Sherman

Jeff Tucker

Sarah Walker

Libby Weathers

Randy White

1994-1995

John Anderson

Benina Burroughs

James Burroughs

Robin Gamble

Michelle Giordano

Samantha Guenther

Lee Lancaster

Richard Lancaster

Gina Lucich

Sean Martin

Jacob Martinez

Andy McMurry

Stacey Mello

Mark Pimentel

Abbi Plagenza

Gabriel Santos

David Sullivan

1995-1996

Leslie Avila

Spence Beckstead

Heather Carter

Adam Casso

Eric Harcksen

Goretti Machado

Isabel Madruga

Sage Miekle

Dave Nunes

Zach Plagenza

Sandy Richardson
Bryan Tassey

Janine Xavier

1996-1997

Gina Armas

Christina Avila

Holly Baker

Brian Baptista

Amy Bauer

Nicole Bettencourt

Mary F. Burroughs

Anthony Cabral

Janeffer Caetano

Kelly Etheridge

Tricia Fowler

Robert Fragulia

Erin Fucillo

Robert Gamble

Heather R. Gibson

Maria Hendrickson

Kari Loewen

Miguel Lopez

Matthew Migliazzo

Sara Miller

Patricia Johnson

Christina Parreira

Jarrod Pimentel

Stephanie Powers

Khyla Smith

Tait Tezo

Addie Trip

1997-1998

Elizabeth Avila

Craig Arnold

Suzanne Baker

Elizabeth Bristow

Shauna Brown

Angela Cabrera

Vanessa Carter

Karen Corvelo

April Frank

Jennifer Gallaway

Karie Haygood

Joey Horta

Rhett Kennedy

Laurie Lucich
Danny Machado

Frank Machado

Junior Machado

Jeremy Mancebo

Jeni McClesky

Bobbie Nelson

Alan Olivera

Shane Pack

Alan Oliveira

Shane Pack

Ryan Passadori

April Perry

Ramianne Plagenza

Katie Rommel

Kristi Rommel

Kristi Sliva

Allison Smith

Eric Souza

Corrie Stone

Jennifer Thomas

Jennifer Trinadale

1998-1999

Alex Alvarez

Stephanie Avila

Lindsey Buendia

Candice Burrola

Zebulon Borrough

Cory Condren

Kenneth Correia

Annie Fagundes

Molly Fagundes

Justin Ferreira

Gary Goucher

Jason Haygood

Amber R. Huff

Amanda Johnson

Brad Kessler

Greg Kessler

Benjamin Migliazzo

David Nelson

Christopher Oliveria

LeeAnne Painter

Sarina Rocha

Cari Sedgwick

Kyle J Pimentel

Chris Smith

Nina Trindade

47| Page 
Debby Akers

Dann Ambriz

Garland Austin Jr.

Trista Condren

Tony Dores

Matt Freeman

Jenette LaMere

Rosewitha Lancaster

Chor Moua

Bryan Ray

Ashley Regalo

Jennifer Sandford

Anthony Santos

Anthony Sodini

Steven Wolff

Jessica Trindade

2000-2001

Katie A. Arnold

Heather Barnes

Molly Bettencourt

Ryan Burnthorne

Meggie Fagundes

Linda Garcia

Denita Howard

LeAnne Lindenberg

Todd Machado

James Oliveria

Rianna Xavier

2001-2002

Cesar Avila

Leoterio Borges

Jenny Correia

Brandon Fullerton

Travis Hosburgh

Cynthia Machado

Jill Mclver

Chris Migliazzo
John Migliazzo

Danny Royer

Tiffany Sheppa

Felipe Sousa

Shane Waterman

2002-2003

Tara Albrecht

Patricia Pimentel

Cesar Sanchez

2003-2004

Jason Dores

Jacquelyn Grande

Bobby Lax

Sarah Magneson

Jessica McAdams

Cody Ratley

Amy Wright

2004-2005

Christy Copeland

Brandon Johnson

Christina Menezes

Jessica Mooneyham

Ryan Pimentel

Cece Villasenor

Rudy Ybarra

2005-2006

Denee Choquette

Kylie Lax

Julia Pedro

Eric Wunder

2006-2007

Javier Garcia

Caryn Granger

Richardo Luna

Annalysa Pimentel
Alys Scoggins

Rebbie Shelton

Brittini Wagner

2007-2008

Hector Ayala

Jake Baraldi

Jose Cardona

Kristelle Choquette

Shawn Conour

Ali Copeland

Bryce Dibble

Ceicali Kuykendall

Saul Lua

Milissa Payne

Catherine Payton

John Pedro

Brock Pisacco

Jorge Pulido

Katheline Reyes

Brenae Royal

Kaylyn Schiber

Lauren Thomas

Brogin Wagner

Lacey Wilcox

Donovan Woodward

2008-2009

Joslyn Apodaca

Kellie Bergstrom

Adam Cruz

Jenna Cruz

Stefani Dias

Amber Dutra

Jesus Gonzales

Briana Hamamoto

Curtis Kelly

Lauren Navarro

Matiana Rivera

Grant Rose

Amada Sevilla

Jenna Shelton 
$2009-2010$

Guadalupe Ayala

Terilyn Bettencourt

Keziah Brigham

John Brownwood

Sasha Del Muro

Laura Gonzalez

Elani Goodhart

Ricky Ornelas

Paul Ortiz

Ashely Payton

Lilly Reyes

Nikki Schiber

William Thomas

Collette Wilcox
$2010-2011$

Emily Beresford

Timothy Demma

Brian Dennis

Marisa Jorge

Samuel Lord-Huff

Corey Mesa

Jacob Minor

Richard Ornelas

Stephanie Quintana

Mason Rose

Vanessa Sevilla

Nicole Sharafian

Tawny Smith

Amanda Solis

James Summerton

Christina Willman
Matt Woods

$2011-2012$

Brandy Benefield

Vanessa Del Toro

Mayra Hernandez

Nayeli Hernandez

Chuck Lord-Huff

Hilliary Junsay

Brie Mansker

Courtney Miscione

Sarah Rogers

Carolyn Schiber

Cheyenne Schoonover

Cailyn Yerrick

Jasmine Zapien 


\section{Atwater FFA History - State/National Recognition}

\section{American FFA Degree Recipients}

As the highest degree achievable in the National FFA Organization, receiving the American FFA Degree shows an FFA member's dedication to his or her chapter and state FFA associations. American FFA Degree recipients show promise for their future and have gone above and beyond to achieve excellence.

\section{$\underline{\text { State Champion CDE Teams }}$}

Career development events (CDE's) are opportunities to develop skills that can be used in a future career. There are 24 different career development events available for team/individual competition at the state and national level.

\section{Proficiency Award Recipients}

Supervised Agriculture Experience (SAE) proficiency areas are programs where students are working for an individual or business for the experience or for pay. There are 51 proficiencies recognized at the state and national level.

The following is a history of state and national awards/accomplishments recognizing the Atwater FFA Chapter and Atwater FFA individuals:

$\underline{1979-1980}$

Superior Chapter

$\underline{1980-1981}$

Superior Chapter

$\underline{1981-1982}$

Star Advisor - Stan Mollart

$\underline{1982-1983}$

Superior Chapter

$\underline{1983-1984}$

Star Reporter - JoAnn Lourenco

Superior Chapter

$\underline{1984-1985}$

Central Region President - Monique Bolaco Specialty Animal Production - Jessica Brooks Star Advisor - Ray Munir $\underline{1985-1986}$

American Degree - Chris Sumpter Star Farmer - Todd Rinkenberger

$\underline{1986-1987}$

Honorary American Farmer - Ray Munir National Scholoarship - Greg Cardey State Treasurer - Todd Rinkenberger

$\underline{1987-1988}$

American Degree- Greg Cardey, Loren E. Freitas, Victoria A. Freitas, Todd Rinkenberger Central Region President-Sayf Munir National Scholarships-Sayf Munir Proficiency Award in Swine Production- Joseph Pacheco

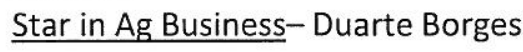

$\underline{1988-1989}$

Honorary American Farmer- Mark Anglin Proficiency Award in Agricultural Mechanics- Doug Cameron II 
$\underline{1989-1990}$

American Degree- Duarte Borges, David Bryson, Scott Koehn, Sayf Munir, Dayna Nachtigal, Joseph Pacheco, Scot Sherman

Proficiency Award in Horse Production- Lynnette McGill

State Champion CDE- Parliamentary Procedure

Novice

\section{0-1991}

American Degree-Chris Cardey

State Champion CDE-Parliamentary Procedure

Advanced

\section{1-1992}

Agriscience Teacher of the Year- Ray Munir Proficiency Award in Placement in Agricultural Production-Bruce Santos State Champion CDE- Light Horse Superior Chapter

\section{$\underline{1992-1993}$}

American Degree- Lynnette McGill, Bruce Santos Superior Chapter

\section{$\underline{1993-1994}$}

National Scholarship- Noel Nunes Proficiency Award in Horse Production- Mandy Rommel Proficiency Award in Placement in Agricultural Production- Norbert Duarte Superior Chapter

\section{4-1995}

American Degree-Eduard Mello, Shane Patterson, David Souza

National Scholarships-Libby Weathers

Proficiency Award in Swine Production- John

Anderson

Star Farmer- Noel Nunes

State Scholarships-Allison Tassey

Superior Chapter

\section{$\underline{1995-1996}$}

American Degree- Mandy Rommel, Allison Tassey State Champion CDE- Fruit Judging, Marketing Plan Superior Chapter

$\underline{1996-1997}$

American Degree- John Anderson, Dario Avila, Anthony A. Lucich, Manuel Machado, Mark Sherman, Libby Weathers

Central Region President- Bryan Tassey

National Convention Delegate- Bryan Tassey

Proficiency Award in Pomolgy Production

Placement- Eric Harcksen

Star Advisor-Mark Anglin

State Champion CDE-Milk Quality and Dairy Foods

Superior Chapter

\section{7-1998}

American Degree- Benina Burroughs, Gabriel Santos National Proficiency Award in Fruit and Vegetable Production- Eric Harcksen Proficiency Award in Soil and Water ManagementEric Harcksen Proficiency Award in Specialty Crop ProductionAllison Smith

Proficiency Award in Wildlife Management- Suzanne Baker

Superior Chapter

\section{$\underline{1998-1999}$}

American Degree- Eric Harcksen, Bryan Tassey, Janine Xavier

National Proficiency Award in Wildlife ManagementSuzanne Baker

Proficiency Award Olericulture Production

Entrepreneurship-Craig Arnold

Star Reporter-Molly Fagundes

Superior Chapter

\section{$\underline{1999-2000}$}

American Degree- Christina Avila, Holly Baker, Adam Casso, Tricia Fowler, Jennifer Galalway, Patricia

$51 \mid$ P多e 
Johnson, Rhett Kennedy, Frank Machado, Matthew Migliazzo, Bobbie Nelson, Jenni McCleskey, Shane

Peck

National Convention Delegate- Molly Fagundes

National Scholarship- Molly Fagundes

Proficiency Award in Ag Communications- Elizabeth

Avila

Proficiency Award in Dairy Production Placement-

Danny Machado

National FFA Chapter Award - Gold Recipient

\section{0-2001}

American Degree- Craig Arnold, Karie Haygood, Christina Hendrickson, Joey Horta, Brad Kessler, Danny Machado, Alan Oliveira Jr., Katie Rommel, Kristi Silva, Carrie Stone, Jennifer Trindade, Joey Xavier

Proficiency Award in Beef Production Placement-

Zeb Burroughs

Proficiency Award in Food Science and Technology-

Molly Fagundes

State Champion CDE- Prepared Speaking; Meggie

Fagundes

State Star Reporter-Meggie Fagundes

Superior Chapter

\section{$\underline{2001-2002}$}

Central Region President- Meggie Fagundes

State Vice President- Molly Fagundes

\section{$\underline{2002-2003}$}

State Scholarship-Molly Fagundes

Superior Chapter

$\underline{2003-2004}$

Superior Chapter

$\underline{\text { 2004-2005 }}$

American Degree- Meggie Fagundes

Star State Reporter-Mai Chia Yang

State Band-Jorge Pulido, Brenae Royal

State Champion CDE-Milk Quality and Dairy Foods
Superior Chapter

\section{$\underline{2005-2006}$}

American Degree- Bobby Lax, John Migliazzo

National Convention Delegate-Christina Menezes

State Champion CDE- Floriculture

State Scholarship- Christina Menezes

Superior Chapter

\section{$\underline{2006-2007}$}

Star State Reporter-Kaylyn Schiber

State Band-Katheline Reyes, Brenae Royal

Superior Chapter

\section{7-2008}

Star Administrator- Linda Lucas

State Band-Jorge Pulido, Brenae Royal, Katheline

Reyes

Superior Chapter

\section{8-2009}

State Reporter - Kaylyn Schiber

Star State Reporter - Lilly Reyes

State Champion CDE - Nursery and Landscape

State Champion CDE Scrapbook - Atwater FFA

State Band - Elani Goodhart, Stefani Dias

Superior Chapter

$$
\underline{2009-2010}
$$

American Degrees - Kaylyn Schiber and Lauren Navarro

Star State Reporter - Mekayla Coughran

State Champion CDE - Light Horse

State Band - Elani Goodhart

State Nominating Committee - Terilyn Bettencourt

CATA/NAAE - 2010 Outstanding California

Middle/Secondary High School Agriculture Program

Superior Chapter

$$
\underline{2010-2011}
$$

Star State Reporter - Carolyn Schiber State Champion CDE - Agronomy

$52 \mid$ Page 
Star Agriscience Teacher - Beth Knapp

Superior Chapter

$\underline{2011-2012}$

National FFA Chapter Award - Gold Recipient

State Champion CDE - Agronomy

State Champion CDE - Milk Quality and Dairy Foods

CATA Teacher of Excellence - Dave Gossman

$53 \mid$ Page 


\section{Atwater High School Agriculture / FFA Enrollment History}

California Agriculture Education - R-2 Enrollment (Individual students enrolled in agriculture courses)

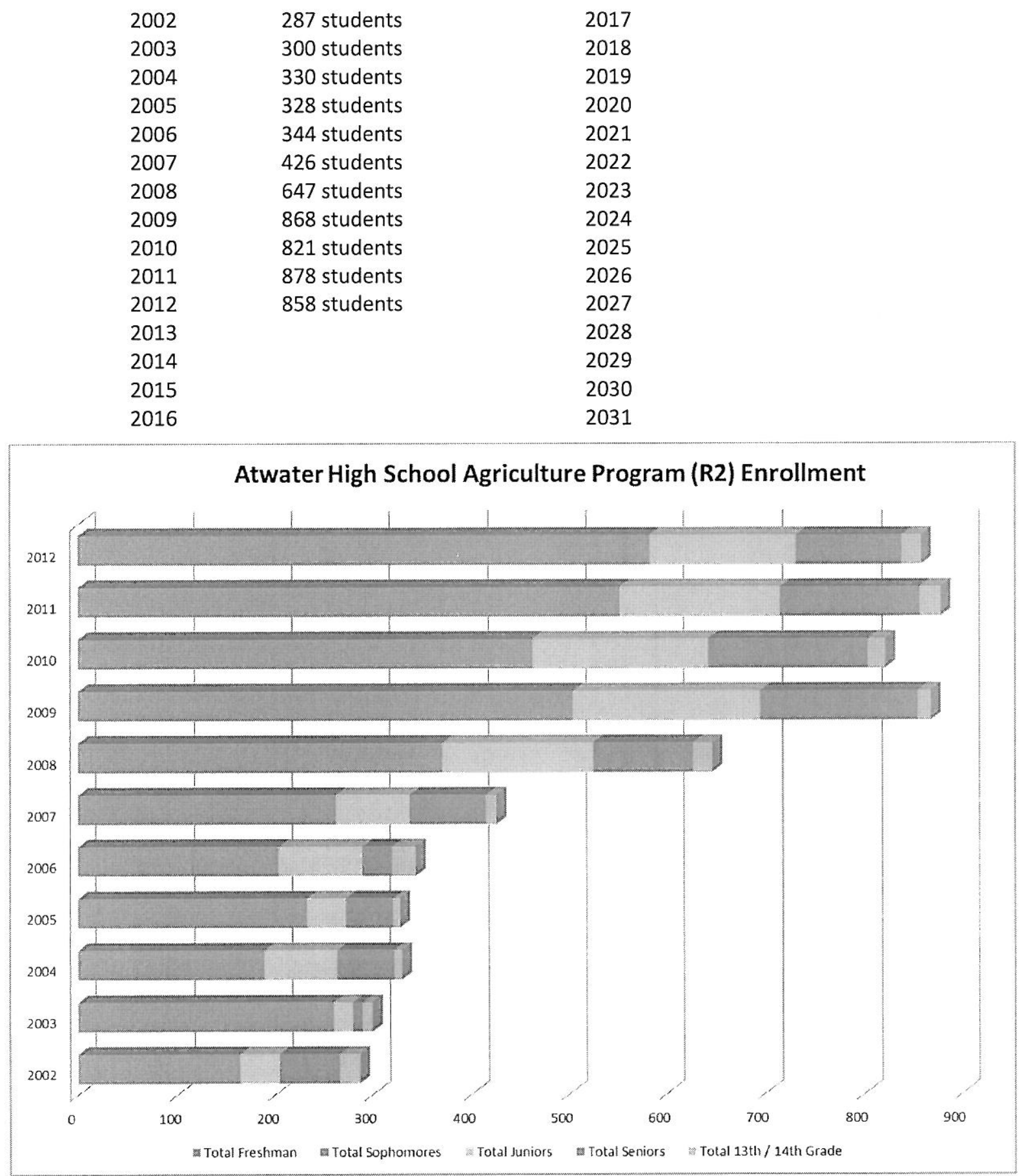




\section{Atwater High School Agriculture Department Course Enrollment Data}

\begin{tabular}{|c|c|c|c|c|c|c|c|c|c|c|c|c|}
\hline Course & Enrollment & 2002 & 2003 & 2004 & 2005 & 2006 & 2007 & 2008 & 2009 & 2010 & 2011 & 2012 \\
\hline \multirow{4}{*}{$\begin{array}{l}\text { 1st Year } \\
\text { Courses }\end{array}$} & ** $\mathrm{Ag}$ Biology & 26 & 44 & 50 & 78 & 114 & 147 & 211 & 332 & 191 & 265 & 227 \\
\hline & " Ag Life Science & $n / a$ & $n / a$ & $\mathrm{n} / \mathrm{a}$ & $n / a$ & $n / a$ & $n / a$ & 90 & 76 & 110 & 111 & 107 \\
\hline & * Ag Shop Skills & 28 & 22 & 57 & 55 & 52 & 27 & 92 & 126 & 56 & 86 & 106 \\
\hline & - Exploration in Agriculture & $\mathrm{n} / \mathrm{a}$ & 15 & 55 & 56 & 52 & 51 & $n / a$ & $n / a$ & $n / a$ & $\mathrm{n} / \mathrm{a}$ & $n / a$ \\
\hline \multirow{5}{*}{$\begin{array}{c}\text { 2nd / 3rd } \\
\text { Year }\end{array}$} & $* \quad$ Ag Earth Science & $n / a$ & 65 & 60 & 93 & 61 & 63 & 96 & 146 & 104 & 115 & 152 \\
\hline & $* \quad$ Ag Environmental Science & n/a & $n / a$ & $n / a$ & $\mathrm{n} / \mathrm{a}$ & $n / a$ & $n / a$ & $\mathrm{n} / \mathrm{a}$ & 34 & 65 & 72 & 35 \\
\hline & Small Engines & 13 & $* m 56$ & 11 & $\mathrm{n} / \mathrm{a}$ & $\mathrm{n} / \mathrm{a}$ & 33 & 11 & 27 & 27 & 26 & 24 \\
\hline & Welding Tech 1 & 11 & 15 & 14 & 32 & 23 & 56 & 33 & 40 & 53 & 57 & 65 \\
\hline & Wood Construction I & $n / a$ & $\mathrm{n} / \mathrm{a}$ & $n / a$ & $\mathrm{n} / \mathrm{a}$ & $\mathrm{n} / \mathrm{a}$ & $\mathrm{n} / \mathrm{a}$ & 19 & 31 & 59 & 18 & 26 \\
\hline \multirow{10}{*}{$\begin{array}{c}\text { 3rd / 4th } \\
\text { Year } \\
\text { Courses }\end{array}$} & Ag Economics / Govemment & $\mathrm{n} / \mathrm{a}$ & n/a & $\mathrm{n} / \mathrm{a}$ & $\mathrm{n} / \mathrm{a}$ & $n / a$ & $\mathrm{n} / \mathrm{a}$ & $\mathrm{n} / \mathrm{a}$ & $\mathrm{n} / \mathrm{a}$ & 38 & 38 & 34 \\
\hline & Ag Leadership & 16 & 26 & 22 & 23 & 22 & 24 & 19 & 29 & 26 & 28 & 35 \\
\hline & Equipment Construction & 13 & $\mathrm{n} / \mathrm{a}$ & $\mathrm{n} / \mathrm{a}$ & $n / a$ & $\mathrm{n} / \mathrm{a}$ & 20 & 10 & 10 & 8 & 4 & 5 \\
\hline & Floral Design V/II & 20 & 43 & 51 & 17 & 11 & $\mathrm{n} / \mathrm{a}$ & 79 & 80 & 128 & 122 & 116 \\
\hline & Horticulture & $n / a$ & $n / a$ & $\mathrm{n} / \mathrm{a}$ & $\mathrm{n} / \mathrm{a}$ & n/a & 22 & 12 & 34 & 16 & 35 & 31 \\
\hline & Power Mechanics & $\mathrm{n} / \mathrm{a}$ & $n / a$ & $\mathrm{n} / \mathrm{a}$ & $\mathrm{n} / \mathrm{a}$ & $\mathrm{n} / \mathrm{a}$ & $n / a$ & 0 & 31 & 19 & 26 & 31 \\
\hline & Veterinary Science & $n / a$ & $\mathrm{n} / \mathrm{a}$ & $n / a$ & $\mathrm{n} / \mathrm{a}$ & $\mathrm{n} / \mathrm{a}$ & $\mathrm{n} / \mathrm{a}$ & 34 & 32 & 59 & 36 & 37 \\
\hline & Welding Tech II & 6 & 4 & 2 & 6 & 17 & 12 & 18 & 14 & 14 & 19 & 22 \\
\hline & Wood Construction II & $\mathrm{n} / \mathrm{a}$ & $n / a$ & $n / a$ & $\mathrm{n} / \mathrm{a}$ & $n / a$ & $n / a$ & 13 & 20 & 23 & 25 & 6 \\
\hline & Wood Construction III & $\mathrm{n} / \mathrm{a}$ & $n / a$ & $\mathrm{n} / \mathrm{a}$ & $\mathrm{n} / \mathrm{a}$ & $\mathrm{n} / \mathrm{a}$ & $n / a$ & 3 & 5 & 13 & 3 & 12 \\
\hline \multirow{7}{*}{$\begin{array}{l}\text { Courses } \\
\text { Closed }\end{array}$} & $\approx \quad$ Ag Science I & 86 & $\mathrm{n} / \mathrm{a}$ & $n / a$ & $n / a$ & $n / a$ & $n / a$ & $n / a$ & $\mathrm{n} / \mathrm{a}$ & $n / a$ & $n / a$ & $n / a$ \\
\hline & $\star \quad$ Ag Science $/ /$ & 22 & $\mathrm{n} / \mathrm{a}$ & $\mathrm{n} / \mathrm{a}$ & $\mathrm{n} / \mathrm{a}$ & $n / a$ & $n / a$ & $\mathrm{n} / \mathrm{a}$ & $\mathrm{n} / \mathrm{a}$ & $n / a$ & $n / a$ & $n / a$ \\
\hline & Animal Anatomy \& Physiology & 16 & $n / a$ & $\mathrm{n} / \mathrm{a}$ & $\mathrm{n} / \mathrm{a}$ & $\mathrm{n} / \mathrm{a}$ & $n / a$ & $\mathrm{n} / \mathrm{a}$ & $n / a$ & n/a & $n / a$ & $n / a$ \\
\hline & Internships in Ag I/II & 18 & 14 & 23 & 16 & 13 & 22 & $\mathrm{n} / \mathrm{a}$ & $\mathrm{n} / \mathrm{a}$ & $n / a$ & $n / a$ & $\mathrm{n} / \mathrm{a}$ \\
\hline & Total Course Enrollment: & 275 & 248 & 345 & 376 & 365 & 477 & 740 & 1067 & 1009 & 1086 & 1071 \\
\hline & & \multicolumn{11}{|c|}{ * Freshman entry course } \\
\hline & & \multicolumn{11}{|c|}{$\begin{array}{l}\text { ** Science Graduation Credit } \\
* * * \text { Primarily non-Ag students. Covered Industrial Tech students }\end{array}$} \\
\hline
\end{tabular}

\begin{tabular}{|c|c|c|c|c|c|c|c|c|c|c|c|}
\hline R-2 Information (Individual Entry) & 2002 & 2003 & 2004 & 2005 & 2006 & 2007 & 2008 & 2009 & 2010 & 2011 & 2012 \\
\hline Freshman Year $1 \mathrm{Ag}$ & 83 & 76 & 140 & 122 & 116 & 136 & 214 & 296 & 276 & 294 & 308 \\
\hline Sophomores Year $1 \mathrm{Ag}$ & 54 & 45 & 23 & 28 & 24 & 45 & 75 & 72 & 34 & 64 & 24 \\
\hline Juniors Year $1 \mathrm{Ag}$ & 14 & 23 & 29 & 13 & 21 & 25 & 64 & 78 & 48 & 26 & 28 \\
\hline Seniors Year $1 \mathrm{Ag}$ & 21 & 21 & 25 & 7 & 13 & 17 & 51 & 56 & 43 & 41 & 34 \\
\hline Sophomores Year $2 \mathrm{Ag}$ & 27 & 59 & 26 & 83 & 64 & 80 & 82 & 136 & 153 & 194 & 251 \\
\hline Juniors Year $2 \mathrm{Ag}$ & 12 & 30 & 16 & 14 & 18 & 16 & 35 & 62 & 53 & 26 & 19 \\
\hline Seniors Year $2 \mathrm{Ag}$ & 6 & 6 & 12 & 9 & 6 & 12 & 18 & 41 & 36 & 24 & 9 \\
\hline Juniors Year $3 \mathrm{Ag}$ & 14 & 13 & 30 & 13 & 47 & 34 & 55 & 52 & 74 & 111 & 101 \\
\hline Seniors Year $3 \mathrm{Ag}$ & 6 & 7 & 14 & 8 & 5 & 10 & 10 & 21 & 35 & 27 & 10 \\
\hline Seniors Year $4 \mathrm{Ag}$ & 29 & 10 & 7 & 24 & 6 & 38 & 23 & 40 & 44 & 49 & 64 \\
\hline Continuing FFA Enrolled Graduates & 21 & 10 & 8 & 7 & 24 & 11 & 20 & 14 & 18 & 15 & 20 \\
\hline & 2002 & 2003 & 2004 & 2005 & 2006 & 2007 & 2008 & 2009 & 2010 & 2011 & 2012 \\
\hline Total Freshman & 83 & 165 & 140 & 122 & 116 & 136 & 214 & 296 & 276 & 294 & 308 \\
\hline Total Sophomores & 81 & 95 & 49 & 111 & 88 & 127 & 157 & 208 & 187 & 258 & 275 \\
\hline Total Juniors & 40 & 20 & 75 & 40 & 86 & 75 & 154 & 192 & 180 & 163 & 148 \\
\hline Total Seniors & 62 & 10 & 58 & 48 & 30 & 77 & 102 & 158 & 160 & 141 & 107 \\
\hline Total AHS Ag Enrollment & 266 & 290 & 322 & 321 & 320 & 415 & 627 & 854 & 803 & 856 & 838 \\
\hline Total 13th / 14th Grade & 21 & 10 & 8 & 7 & 24 & 11 & 20 & 14 & 18 & 22 & 20 \\
\hline Total AHS FA (R-2) Enrollment & 287 & 300 & 330 & 328 & 344 & 426 & 647 & 868 & 821 & 878 & 858 \\
\hline
\end{tabular}

This chart reflects our numbers that are tabulated each fall for our annual "Fall Ag Advisory Committee Meeting" where we invite the local feeder school counselors \& principals, AHS adminsitration, School Board, District personnel, Ag Advisory Board, Ag Booster representatives, AHS counselors, and community representatives to present a "State of the Union" presentation to share (1) Where We Are and (2) Where We Are Going. The meeling provides valubale insight and communication to our programs "vision" and goals. It also provides an opportunity to share ideas, concerns, and current events Additional charts, packets, marketing/promotional material is presented each year. This annual meeting has proven very beneficial and productive. 


\section{Atwater High School Agriculture Department / FFA Budgets}

\section{2-2013 FFA General Account Budget}

$\underline{\text { Revenue }}$

Ag Booster Donation

$\$ 11,000$

Fall Fest Fundraiser

$\$ 6,000$

National Finals Trip Donations

$\$ 9,000$

Placemat Ad Sales

$\$ 5,500$

Save Mart SHARES Program

$\$ 2,000$

Take-Out BBQ's (4)

$\$ 10,000$

Total Revenue

$\$ 43,500$

\section{Expenses}

Fair Equipment/Supplies

$\$ 2,000$

FFA Field Day Registrations

$\$ 3000$

FFA Greenhand Conference

$\$ 800$

FFA Meetings (Food, Supplies, etc..)

$\$ 3,500$

FFA National Finals Trip

$\$ 13,000$

FFA Recreational Trip(s) Transportation

$\$ 2,200$

FFA Student Fundraising Incentives

$\$ 4,000$

FFA Supplies

$\$ 2,000$

Office/Operation Supplies

$\$ 3,000$

Promotion/Marketing

$\$ 4,500$

Staff iPads / Computers

$\$ 5,500$

Total Expenses

$\$ 43,500$

\section{2-2013 FFA Horticulture Account Budget}

\section{Revenue}

$\begin{array}{lr}\text { Fall Fest Fundraiser } & \$ 1,000 \\ \text { Fall Plant Sale } & \$ 2,000 \\ \text { Floral Projects } & \$ 5,000 \\ \text { Merced County Fair Projects } & \$ 5,000 \\ \text { Spring Plant Sale } & \$ 2,000\end{array}$




\section{Expenses}

Facility Concrete / Fencing Projects $\$ 1,500$

FFA Activities / Events

$\$ 1,000$

FFA Judging Teams (Nationals)

$\$ 2,000$

Floral Supplies / Equipment

$\$ 3,000$

Horticulture Equipment

$\$ 2,000$

Horticulture Facility Projects

$\$ 1,500$

Horticulture Supplies

$\$ 4,000$

Total Expenses

$\$ 15,000$

\section{2-2013 Wood Shop / Small Engines Account Budget}

\section{$\underline{\text { Revenue }}$}

Atwater Ag Boosters

$\$ 500$

District Funds

$\$ 6,500$

Fall Fest Fundraiser

$\$ 1,500$

Sale of Mowers / Engine Repair

$\$ 250$

Sale of Wood Projects

$\$ 1,500$

Total Revenue

$\$ 10,250$

\section{Expenses}

Classroom/Lab Supplies Student Projects

$\$ 6,500$

Equipment Repair

$\$ 1,000$

General Shop Supplies / Materials

$\$ 2,750$

Total Expenses

$\$ 10,250$

\section{2-2013 Welding/Metal Fabrication Account Budget}

\section{Revenue}

Atwater Ag Boosters 
Donations from Repairs $\$ \$ 1,400$

Fall Fest Fundraiser $\$ \$ 1,500$

Merced County Fair Projects $\$ 1,200$

Metal Art Sales (During Plant Sales) $\$ 2,000$

Project Payments $\$ \$ 8,500$

Scrap Metal Recycling $\$ \$ 1,500$

Total Revenue $\quad \$ 17,800$

\section{Expenses}

Equipment Repairs

$\$ 600$

Freshman Ag Shop Skills Projects

$\$ 3,500$

General Shop Supplies / Materials

$\$ 1,200$

Misc. Supplies / Equipment

$\$ 2,500$

Modesto Steel / Custom Metal (Material)

$\$ 8,500$

Powder Coating Projects

$\$ 500$

Welding Supplies / Airgas

$\$ 1,000$

Total Expenses

$\$ 17,800$

\section{2-2013 ROP Account Budget}

Revenue

Veterinary Science

$\$ 1,098$

Horticulture

$\$ 981$

Floral Design

$\$ 2,772$

Total Revenue

$\$ 4,851$

\section{Expenses}

Flowers / Supplies

$\$ 1,200$

Nasco (Lab Supplies)

$\$ 400$

$\$ 300$

CVE (Curriculum Materials)

$\$ 1,861$

Chico State Field Day Transportation

$\$ 1,090$

Total Expenses

$\$ 4,851$ 


\section{2-2013 Ag Incentive Grant Account Budget}

\section{Revenue}

Incentive Grant Disbursement

$\$ 20,451$

Total Revenue

$\$ 20,451$

\section{Expenses}

Airgas (Shop)

$\$ 2,000$

CATA Memberships

$\$ 840$

Davis Digital (Office Services)

$\$ 900$

FFA Membership Dues

$\$ 7,530$

FFA State Conference Lodging

$\$ 2,300$

FFA State Finals Lodging

$\$ 2,100$

FFA Supplies

$\$ 2,000$

$\$ 250$

New Professionals Conference

$\$ 1,000$

Team Wear - Officer Supplies

$\$ 1,531$

Total Expenses

$\$ 20,451$

\section{2-2013 Carl Perkins Account Budget}

\section{$\underline{\text { Revenue }}$}

2012-2013 Disbursement

$\$ 33,893$

Total Revenue

$\$ 33,893$

\section{Expenses}

All Data Subscription (Wood)

$\$ 1,000$

Biology Lab Equipment

$\$ 600$

CATA Road Show / Conference

$\$ 1,266$

CATA Summer Conference (SLO)

$\$ 3,700$

FFA Leadership Conference (Fresno State)

$\$ 3,000$

FFA Leadership Conferences (MFE / ALA)

$\$ 2,200$

Indianapolis Car Rentals (National FFA)

$\$ 1,200$

$59 \mid$ P a 
Indianapolis Hotel (National FFA)

$\$ 2,000$

Pole Barn Shed

$\$ 3,182$

Shop/Classroom Computers

$\$ 13,745$

Welding Shop Tools

$\$ 1,000$

Wood Shop Tools

$\$ 1,000$

Total Expenses

$\$ 33,893$

\section{2-2013 AHS Site Account Budget}

Revenue

Site Disbursement

$\$ 2,000$

Total Revenue

$\$ 2,000$

Expenses

Office Depot (Office/Operation Supplies)

$\$ 1,400$

Nasco (Lab Supplies)

$\$ 600$

Total Expenses

$\$ 2,000$

\section{2-2013 MUHSD Transportation Account Budget}

Revenue

Site Disbursement

$\$ 7,050$

Total Revenue

$\$ 7,050$

\section{Expenses}

FFA Judging Contests

$\$ 4,500$

FFA Leadership/Professional Conferences

$\$ 1,750$

FFA Officer/Staff Retreat

$\$ 800$

Total Expenses

$\$ 7,050$

Total 2012-2013 Atwater High School Revenue/Expense Budget -

$\$ 154,795$

$60 \mid P a g e$ 


\section{Atwater High School Agriculture Department 2012-2013 Staff Assignments/Responsibilities}

\begin{tabular}{|c|c|c|c|c|c|c|}
\hline Ag Department & Flatt & Gossman & loimo & Kirschner & Williams & Meredith \\
\hline Department Chair & & $\mathrm{x}$ & & & & \\
\hline \multicolumn{7}{|l|}{ Accounting } \\
\hline CATA Regis tration & & & & & $\mathrm{x}$ & \\
\hline Departmental / District Accounting / PO's & & & & & $\mathrm{X}$ & \\
\hline FFAAccounting / PO's & & & & & $\mathrm{x}$ & \\
\hline Hotel Reservations & & & & & $x$ & \\
\hline Office Supplies Orders & & & & & $\mathrm{x}$ & \\
\hline Perkins Funding Application & & $\mathrm{X}$ & & & & \\
\hline ROP Accounting/PO's & & & & & $x$ & \\
\hline ROP/Site/Incentive Budget & & & & & $\mathrm{x}$ & \\
\hline Warehouse Orders & & & & & $\mathrm{x}$ & \\
\hline
\end{tabular}

General Program / Facility

5-year Equipment Allocation

Advis ory Committee Roster \& Minutes

Ag Advisory Committee Planning and Agenda

Ag Boos ter Committee

Chart of Staff Responsibilities

Comprehensive Program Plan

Department Marketing / PR / Liason

Graduate Follow-Up

Incentive Grant

Incentive Grant Reviews

In-Service Activities List

Maintain Comprehensive Progrom Plan Binder

Maintain Program Management Binder

Maintenance Requests

Quarterly / Yearly CATA Meetings / Events

R2 Report \& Roster

Recruitment

Report of Expenditures

Transportation Requests/Requisitions

\begin{tabular}{|c|c|c|c|c|c|}
\hline & & & & $x$ & \\
\hline & $x$ & & & & \\
\hline & $x$ & & & & \\
\hline & $x$ & & & & \\
\hline & $x$ & & & & \\
\hline & & & & $x$ & \\
\hline & $x$ & & & & \\
\hline & & & & $x$ & \\
\hline & & & & $x$ & \\
\hline & & & & $x$ & \\
\hline & & & & $x$ & \\
\hline & & & & $x$ & \\
\hline & & & & $x$ & \\
\hline & $x$ & & & & \\
\hline$x$ & $x$ & $x$ & $x$ & $x$ & $x$ \\
\hline & & & & $x$ & \\
\hline & $x$ & & & & \\
\hline & & & & $x$ & \\
\hline & $x$ & & & & \\
\hline
\end{tabular}

\section{FFA Advisor}

Advance Leaders hip Academy Conference

American FFA Degree Applications

Chapter Officer Leadership Conference

Chapter Reportor

Greenhand Conference

Made for Excellence Leadership Conference

Organize Local Project Competition

Organize Sectional Project Competition

Oversee Planning for FFA Meetings

Quarterly FFA Activities List for Class Grading

Regional Officer Leadership Conference

Registration for CDE Contest

Registration for Conferences

Scrapbook

Sectional Officer Leadership Conference

State FFA Degree Applications

State FFA Lea dership Conference

\begin{tabular}{|c|c|c|c|c|c|}
\hline & & & $x$ & & \\
\hline & $x$ & & $x$ & & \\
\hline \multirow[t]{14}{*}{$x$} & $x$ & $x$ & $x$ & $x$ & $x$ \\
\hline & & & $x$ & & \\
\hline & $x$ & & & & \\
\hline & & & $x$ & & \\
\hline & $x$ & & $x$ & & \\
\hline & & & & & $x$ \\
\hline & & & & & $x$ \\
\hline & & & $x$ & & \\
\hline & & & $x$ & & \\
\hline & & & $x$ & & \\
\hline & $x$ & & & & \\
\hline & & & $x$ & & \\
\hline & & $x$ & & & \\
\hline & & & $x$ & & \\
\hline$x$ & $x$ & $x$ & $x$ & $x$ & $\underline{x}$ \\
\hline$x$ & $x$ & $x$ & $x$ & $x$ & $x$ \\
\hline
\end{tabular}




\begin{tabular}{|c|c|c|c|c|c|c|}
\hline & Flatt & Gossman & loimo & Kirschner & Knapp & Meredith \\
\hline \multicolumn{7}{|l|}{ Animal / Lives tock } \\
\hline Fair Supplies & & $x$ & $\mathrm{X}$ & $\mathrm{x}$ & $x$ & $\mathrm{x}$ \\
\hline Dairy Cattle Facility & & & & & $\mathrm{X}$ & \\
\hline Pole Barn - Goats / Rabbits / Vet Science Lab & & & & $\mathrm{X}$ & & \\
\hline School Farm (sheep) & & & $\mathrm{X}$ & & $\mathrm{x}$ & \\
\hline School Farm (swine) & & $x$ & & & & \\
\hline \multirow[t]{2}{*}{ Veterinary Supplies } & & $x$ & & $\mathrm{x}$ & & \\
\hline & Flatt & Gossman & loimo & Kirschner & Knapp & Meredith \\
\hline \multicolumn{7}{|l|}{ Horticulture Facility } \\
\hline Floriculture / Outside Floral Fridge & & & $\mathrm{X}$ & & & \\
\hline General Care and Maintenance & & $\mathrm{x}$ & & & & \\
\hline Grape Vineyard & & & $\mathrm{x}$ & & & \\
\hline Greenhouse & & $\mathrm{X}$ & & & & \\
\hline Horticulture Plots & & $\mathrm{x}$ & & & & \\
\hline Lathe House & & $\mathrm{x}$ & & & & \\
\hline Mini-Orchard Lab & & $x$ & & & & \\
\hline Nursery Facility / Gardens & & $x$ & & & & \\
\hline OH Storage Containers & & $\mathrm{x}$ & & & & \\
\hline Pole Barn & & $x$ & & & & \\
\hline \multirow[t]{2}{*}{ Rose Lab } & & $\underline{x}$ & & & & \\
\hline & Flatt & Gossman & loimo & Kirschner & Knapp & Meredith \\
\hline \multicolumn{7}{|l|}{ Shop / Equipment / Machinery } \\
\hline Ag Shop Maintenance - Welding & & & & & & $\mathrm{x}$ \\
\hline Ag Shop Maintenance - Wood \& Power Mechanics & $x$ & & & & & \\
\hline Ag Trucks & & & & & & $x$ \\
\hline BBQ Trailers & & & & & & $x$ \\
\hline Forklift Maintenance & $\mathrm{x}$ & & & & & \\
\hline Livestock Trailers & & & & & & $x$ \\
\hline School Shop and Equipment & & & & & & $x$ \\
\hline Shop Nights & $x$ & & & & & $x$ \\
\hline \multirow[t]{2}{*}{ Storage Buildings } & & & & & & $\mathrm{x}$ \\
\hline & Flatt & Gossman & loimo & Kirschner & Knapp & Meredith \\
\hline \multicolumn{7}{|l|}{ Facility } \\
\hline \multirow[t]{2}{*}{ BBQ - Cooking } & & & & & & $\mathrm{X}$ \\
\hline & Flatt & Gossman & loimo & Kirschner & Knapp & Meredith \\
\hline \multicolumn{7}{|l|}{ Project Supervision } \\
\hline Ag Mechanics & $x$ & & & & & $x$ \\
\hline Beef Projects & & & & & & $\mathrm{X}$ \\
\hline Dairy Cattle Projects & & & & & $x$ & \\
\hline Goat Projects & & & & $\mathrm{x}$ & & \\
\hline Horse Projects & & & & & $\mathrm{x}$ & \\
\hline Floriculture Projects & & & $x$ & & & \\
\hline Horticul ture Projects & & $\mathrm{x}$ & & & & \\
\hline Rabbits & & & & $\mathrm{X}$ & & \\
\hline Sheep Projects & & & $\mathrm{x}$ & & & \\
\hline Swine Projects & & $\mathrm{X}$ & & & & \\
\hline Work Experience Projects & & $x$ & $x$ & $\mathrm{x}$ & $x$ & $x$ \\
\hline
\end{tabular}




\begin{tabular}{|c|c|c|c|c|c|c|}
\hline & Flatt & Gossman & loimo & Kirschner & Knapp & Meredith \\
\hline \multicolumn{7}{|l|}{ FFA Judging Teams / Contests } \\
\hline Ag Mechanics & & & & & & $x$ \\
\hline Agronomy & & & & & $x$ & \\
\hline BIG (Consult/Assist Student Teacher) & & & & $\mathrm{x}$ & & \\
\hline Cotton & & & & $\mathrm{x}$ & & \\
\hline Creed Speaking & & & & & $\mathrm{x}$ & \\
\hline Dairy Products & & $\mathrm{x}$ & & & & \\
\hline Extemporaneous Speaking & & & & & $\mathrm{x}$ & \\
\hline Floriculture & & & $\mathrm{x}$ & & & \\
\hline Grapevine & & & $\mathrm{x}$ & & & \\
\hline Job Interview & & & & & $\mathrm{x}$ & \\
\hline Land & & & & & & $\mathrm{x}$ \\
\hline Livestock & & & $\mathrm{x}$ & & & \\
\hline Meats & & & & $\mathrm{x}$ & & \\
\hline Nursery and Landscape (Horticul ture) & & $\mathrm{x}$ & & & & \\
\hline Opening and Closing Advanced & & & & $x$ & & \\
\hline Opening and Closing Novice & $x$ & $\mathrm{x}$ & $\mathrm{x}$ & $x$ & $x$ & $\mathrm{x}$ \\
\hline \multirow[t]{2}{*}{ Prepared Public Speaking } & & & & & $x$ & \\
\hline & Flatt & Gossman & Ioimo & Kirschner & Knapp & Meredith \\
\hline \multicolumn{7}{|l|}{ Awards } \\
\hline Awards Banquet & $\mathrm{x}$ & $\mathrm{X}$ & $\mathrm{x}$ & $\mathrm{X}$ & $\mathrm{X}$ & $\mathrm{X}$ \\
\hline Greenhand / Chapter Farmer Awards Ceremony & $\mathrm{x}$ & $\mathrm{X}$ & $\mathrm{x}$ & $\mathrm{x}$ & $\mathrm{X}$ & $\mathrm{X}$ \\
\hline National Chapter Award Application & & & & $\mathrm{X}$ & & \\
\hline Scholarships & & & & & $\mathrm{x}$ & \\
\hline POA Tabulations & & & & $\mathrm{x}$ & & \\
\hline \multirow[t]{2}{*}{ Proficiency Awards } & $\mathrm{x}$ & $\mathrm{x}$ & $\mathrm{x}$ & $\mathrm{x}$ & $\mathrm{X}$ & $\mathrm{X}$ \\
\hline & Flatt & Gossman & loimo & Kirschner & Knapp & Meredith \\
\hline \multicolumn{7}{|l|}{ Fundraisers } \\
\hline$\underline{\text { Ag Mechanics Projects (Plasma Art, Wood, and Engines) }}$ & $x$ & & & & & $\mathrm{x}$ \\
\hline Drive Thru BBQ & $\mathrm{X}$ & & $x$ & $\mathrm{X}$ & $\mathrm{x}$ & $x$ \\
\hline "Fall Fest" Fundraiser & & $x$ & & & $x$ & \\
\hline (Yearly) Floral Projects & & & $x$ & & & \\
\hline Plant Sales (Fall and Spring) & & $x$ & & & & \\
\hline Placement Ads & & $x$ & & & & \\
\hline Save Mart S.H.A.R.E.S. Program & & $x$ & & & & \\
\hline
\end{tabular}

$63 \mid P$ 蜘然 


\section{Atwater High School Agriculture Department Atwater FFA \\ 2201 Fruitland Ave \\ Atwater, CA 95301 \\ 209-357-6025 \\ www.AtwaterFFA.org}

$64 \mid$ Page 


\section{J \\ Board Approved FFA Policy}

A copy of board-approved FFA as an integral part of the Ag program policy was not located, although contact with administration was made. Following is a copy of the education code stating the requirement for an FFA to be an integral part for any student in an agriculture program. Atwater High School follows and supports this education code.

\section{Attached you will find:}

- Educational code for FFA 


\section{EDUCATION CODE SECTION 52450-52454}

52454. (a) The curriculum of school districts that choose to participate in the state program of agricultural career technical education shall include all of the following components:

(1) Organized classes in the study of agricultural science and technology.

(2) A student-supervised occupational experience program in agriculture.

(3) A program of leadership, organization, and personal development.

(b) Student learning activity developed to supplement these components shall be considered curricular and shall contribute to the grade of the participating student when those activities are integral to assisting the student to achieve the career objective of the class or course.

It is the intent of the Legislature that opportunities are provided for teachers to be employed on a 12-month basis in order to maintain supervised occupational experience on a year-round basis for students enrolled in agricultural career technical programs. 


\section{$\underline{\mathbf{K}}$ \\ Recruitment Program}

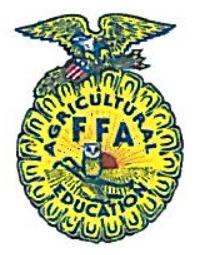

The recruitment program at Atwater High School starts before students enroll for the $9^{\text {th }}$ grade year. There are two high schools within Atwater and the district has outlined our high school to have the "inner-city" students. This makes many of our students agriculturally unaware. Starting the recruitment process before our students enroll as $9^{\text {th }}$ graders has helped our program grow and thrive in the last 6 years. By coordinating with the middle schools principals and counselors, we are finding opportunities to visit the students and promote our program to the agriculturally unaware.

There are many recruitment activities and materials that we have developed the promote agriculture courses. Presentations at the middle schools, flyers, and $8^{\text {th }}$ grade parent night are just the few things we do in order to promote our program. The flyers are available to all middle school students which discuss our program and explain the courses offered. We encourage them to develop an area of interest so that they can easily fall into a specific agriculture pathway as they enter high school. These flyers have "check boxes" that makes it easier for our counselors when the students turn in their paperwork. The brochures are in both English and Spanish as well.

We also recruit at $8^{\text {th }}$ grade parent night and set up tables showcasing our Ag Science classes and Ag Shop Skills classes. FFA students assist us by explaining to the parents and students about our program and we also pass out more flyers to students that did not receive them at their middle school. 


\section{Attached you will find:}

- English and Spanish broachers of courses

- Letter sent to incoming freshman parents

- Handout on Ag as an integral part of education 

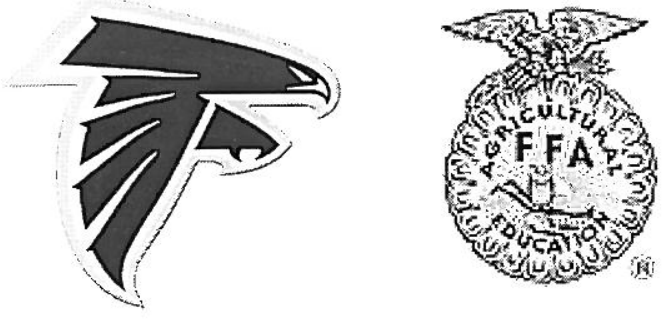

\section{$2013-2014$ \\ Agriculture Science Classes ( $\underline{\text { Ag Life Science and Ag Biology) }}$}

- BOTH Ag Life Science and Ag Biology are the exact same academic courses as regular Life Science and Biology.

- BOTH courses mirror the same California State Educational Standards, textbooks/resources, district pacing guides, and material. The difference is when your son/daughter is enrolled in one of the Ag Science classes, they are automatically a member of FFA and are eligible to participate and get involved in all aspects of FFA, leadership, and agriculture events/ activities.

- BOTH life science courses emphasize laboratory "hands-on" learning and problem solving skills. Course content includes cells, energy, genetics, DNA, evolution, human systems and ecology. The Ag Biology course meets UC/CSU “D” credit for admissions.

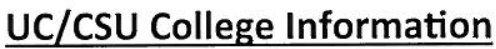

The above course are designed to provide students with the opportunity to explore and develop agricultural career interests, FFA involvement, leadership skills, and scholastic \& personal growth.

\section{Students CAN be enrolled in an ag science and/or ag elective course and STILL follow a UC/CSU graduation requirement pathway.}

If you have any questions/concerns, please contact an AHS counselor and/or the AHS Agriculture Department at 357-6025$$
2013-2014
$$

\section{Agriculture Elective Classes}

\section{( $\underline{A g}$ Shop Skills and Exploration in Agriculture )}

- $\quad \mathrm{Ag}$ Shop Skills is specifically designed for 9th grade students interested in gaining skills in electrical, plumbing, wood working, welding, metal fabrication, job safety, tool identification and a variety of "hands-on" project development. THIS COURSE IS THE ONLY SHOP COURSE AVAILABLE FOR 9TH GRADE STUDENTS .

- Exploration in Agriculture is especially designed for 9th grade students interested in being involved, exploring and developing skills in California Agriculture, FFA / Leadership / Public Speaking, Record Keeping / Ag Business, Horticulture / Plant Science, and Animal \& Veterinary Science. This course serves as the foundation course towards advanced courses in ag business, plant science, horticulture, and animal science and compliments the Ag science courses. Course content focuses on "hands-on" application in speaking, writing, record keeping, horticulture, and animal science skills. This course also qualifies students to participate in all FFA activities throughout the year and is for 9th graders only.

To participate in agriculture / FFA activities, students MUST BE Enrolled in at least 1 agriculture class (Ag Life, Ag Bio, $\mathrm{Ag}$ Shop and/or Exploration in Ag).

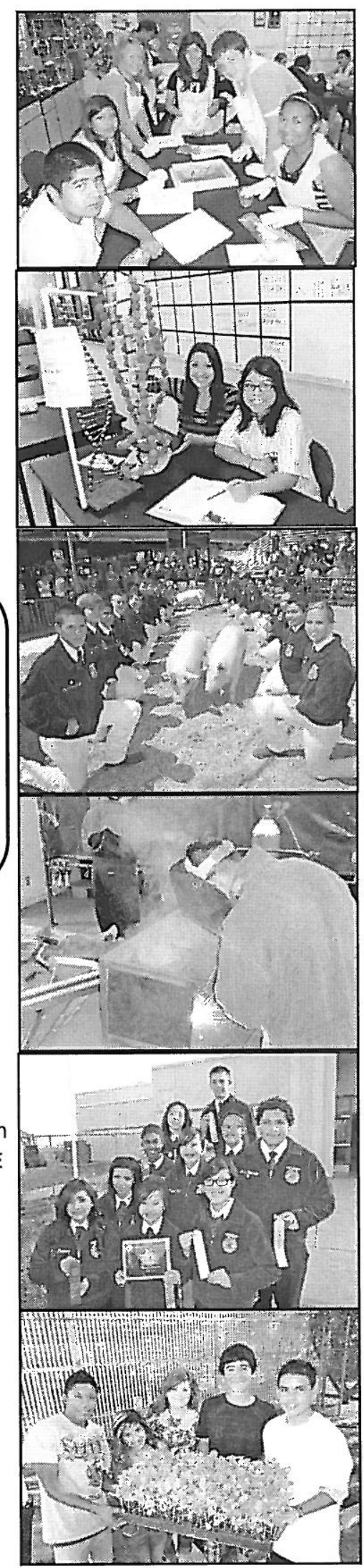



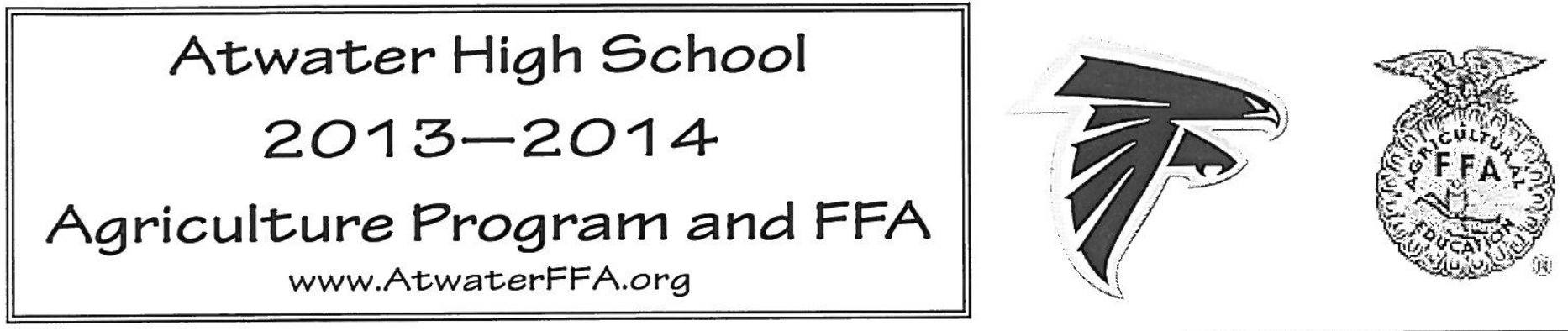

\section{$2013-2014$ \\ Cursos de Ciencia Agrícola (Vida de Ciencias Agy Biología Ag)}

- $\quad$ AMBOS Vida de Ciencias Ag y Biología de Ag son exactamente los mismos cursos académicos que Vida de Ciencias y Biología regular.

- $\quad$ AMBOS cursos siguen los mismos Estándares Educativos del Estado de California, libros de texto/recursos, guías de aprendizaje del distrito, y material. La diferencia es cuando su hijo/ a está inscrito en una de las clases de Ciencias Agrícolas, se convierte automáticamente en miembro de la FFA y es elegible para participar e involucrarse en todos los aspectos de la FFA, el liderazgo, los eventos y_actividades de la agricultura.

- $\quad$ AMBOS cursos de Vida de Ciencias enfatizan el laboratorio "hands-on" prácticas de aprendizaje y habilidades para resolver problemas. El contenido del curso incluye las células, la energía, la genética, el ADN, la evolución, los sistemas humanos y la ecología. El curso de Biología de Ag cumple con el requisito de créditos de admisión "D” para UC/CSU.

\section{UC/CSU Información Colegial}

El curso anterior se ha diseñado para proporcionar a los estudiantes la oportunidad de explorar y desarrollar los intereses de carreras agrícolas, la participación de la FFA, habilidades de liderazgo, y el crecimiento académico y personal.

Los estudiantes PUEDEN matricularse en uno de los cursos de arriba y todavía siguen cumpliendo con el requisito de graduación de UC / CSU.

Si tiene cualquier pregunta o duda, póngase en contacto con un consejero de AHS o al Departamento Agrícola de AHS al 357-6025

\section{$2012-2013$}

\section{Talleres de Atwater High School}

\section{(Habilidades de talleres Agrícola y Exploración en la Agricultura)}

- Este curso está diseñado específicamente para estudiantes del 9 @ grado interesados en adquirir conocimientos en electricidad, plomería, carpintería, soldadura, fabricación de metal, seguridad en el trabajo, la identificación de herramientas y una variedad de "hands-on" prácticas de desarrollo del proyecto. Este curso es el único curso de taller disponible para estudiantes del 9 ㅇado.

- Exploración en la Agricultura está especialmente diseñado para estudiantes del noveno grado interesados en participar, en explorar y desarrollar habilidades en la Agricultura de California, FFA/ Liderazgo/Hablar en Público, Mantenimiento de Registros / Negocios, Horticultura / Ciencias de las plantas, Animales y Veterinaria. Este curso sirve como base para los cursos de colocación avanzada en Negocios de ag (agricultura), ciencia de las plantas, Horticultura, y la ciencia animal y se complementa con los cursos de ciencias Ag. El contenido del curso se enfoca en el ejercicio de "práctica" en el habla, la escritura, el mantenimiento de registros, horticultura, y las habilidades de ciencia animal Este curso también califica a los estudiantes a participar en todas las actividades de FFA durante todo el año.

Para participar en las actividades de Agricultura/ FFA, los estudiantes DEBEN estar inscritos por lo menos en una clase de agricultura ( $\mathrm{Ag}$ Vida, $\mathrm{Ag}$ Bio, $\mathrm{Ag}$ Shop y/o Exploración en Ag).

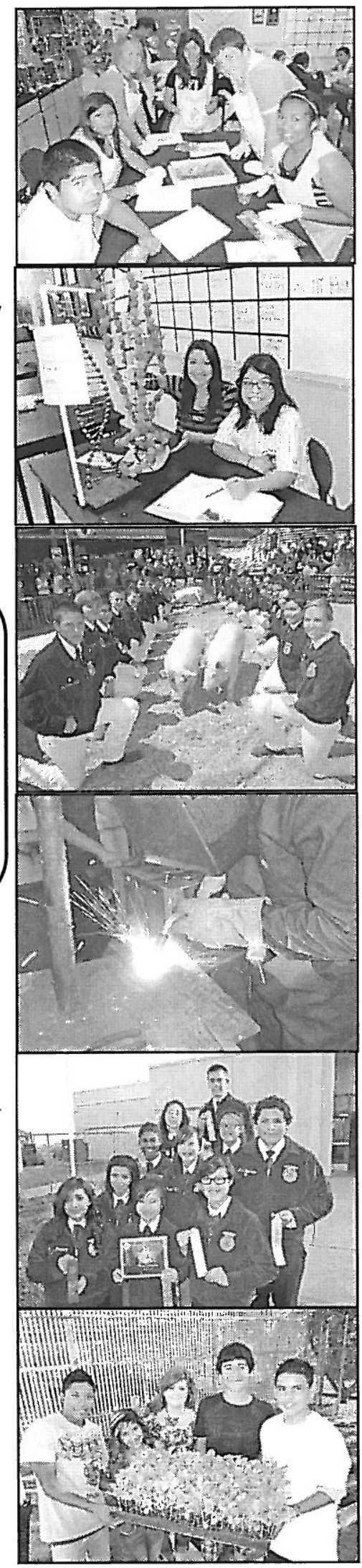




\section{ATWATER HIGH SCHOOL}

FRESHMAN

COURSE SELECTION FORM 2013-14

357-6009

Freshman Counselor, Mr. Joel Dickson
Name:

Birthdate:

Current School:

\section{All 9th grade students will be enrolled in the following 5 core classes.}

Placement will be determined by reading levels/state test scores.

ENGLISH

MATH

HEALTH.GEOGRAPHY

SCIENCE

$\underline{\mathrm{PE}}$
I would like my science class to be an Ag Science class

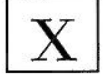

Date

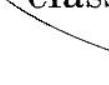

I would be interested in taking PE 0 period (before school, 6:45 am)

9th Grade Elective Choices: Indicate 1st choice (1), \& Alternates $(2,3)$

*Students who fail to refurn this registration form will be placed in electives based on openings

\section{AGRICULTURE}

0111 Explorations in Ag

0112 Ag Shop Skills

AVID

0764. AVID (application/

interview process)

\section{BUSINESS}

0602.1 Computer Keyboarding

0629 Computer Applications 1

(recommended typing speed of $30 \mathrm{wpm}$ )

\section{FAMILY AND CONSUMER SCIENCE} 0662 Foods and Nutrition 1
FINE ARTS

0202 Art 1

0232 Theatre Arts 1

0234 Theatre Arts 2 (WMS only)

0240 Photography 1

0221 Computer Graphics

0252 Band 1 (w/0 period Band/PE)

0272 Guitar

\section{WORLD LANGUAGES}

0701 French 1

0719 Reading/W riting for Spanish Speakers*

0720 Spanish for Spanish Speakers 1* 0731 Spanish 1

* Students will be tested during the first week of school to determine proper placement. 


\section{$2013-2014$ \\ Atwater High School \\ Agriculture Department}

Dear Atwater High School Parent / Guardian,

"FFA makes a positive difference in the lives of students by developing their potential for premier leadership, personal growth and career success" - This is the mission statement of agricultural education.

Nearly $50 \%$ of all AHS students are currently enrolled in at least one AHS agriculture class! No matter what your child's future objectives may be, the Atwater High School Agriculture Program can provide your son/daughter skills, resources, and experience that will benefit any personal, educational (college/university), and career goals. In order to be eligible for any of the agriculture, FFA, and SAE (supervised educational experience - "projects") opportunities, your son/daughter must be enrolled in at least 1 agriculture class. The following is a list of classes available to your son/daughter based on your/their interests:

\#1 If you son/daughter has an interest in a "shop class" in the areas of electrical, wood, welding, and metal fabrication:

\section{Ag Shop Skills (Elective)}

Introduction to Shop Skills is specifically designed for 9th grade students interested in gaining skills in engines, power mechanics, electrical, plumbing, wood working, welding, and metal fabrication. This course serves as the foundation course towards Small Engines, Power Mechanics, Welding Technology and Wood Construction courses offered to $10^{\text {th }}-12^{\text {th }}$ grade students. Content areas in job safety and tool identification are included with "hands-on" learning and various projects to build and take home. This course also qualifies students to participate in all FFA activities throughout the year. The shops and shop equipment were part of a recent $\$ 1.7$ million dollar upgrade.

\#2 If your son/daughter has as interest in animal science, plant/horticulture science, leadership, "handson" learning, outside projects, etc...:

\section{Exploration in Agriculture (Elective)}

Exploration in Agriculture is especially designed for 9th grade students interested in being involved, exploring and developing skills in California Agriculture, FFA / Leadership / Public Speaking, Record Keeping / Ag Business, Horticulture / Plant Science, and Animal \& Veterinary Science. This course serves as the foundation course towards advanced courses in ag business, plant science, horticulture, and animal science and compliments the Ag science courses. Course content focuses on "hands-on" application in speaking, writing, record keeping, horticulture, and animal science skills. This course also qualifies students to participate in all FFA activities throughout the year. 


\section{Ag Biology (Ag Science)}

Ag Biology is a one year, laboratory science course, designed for the college bound student. The curriculum is the exact same as (science course) Biology, however it provides the students eligibility to participate in all FFA activities.

\section{This course meets AHS Life Science graduation credit and UC/CSU credit for admissions.}

\section{Ag Life Science (Ag Science)}

Ag Life Science is a one year life science course for students not enrolled in Ag Biology or Biology. The curriculum is the exact same as (science course) Life Science, however it provides the students eligibility to participate in all FFA activities. Course material from "Exploration in Agriculture" (FFA, Leadership, Public Speaking, etc..) will also be integrated.

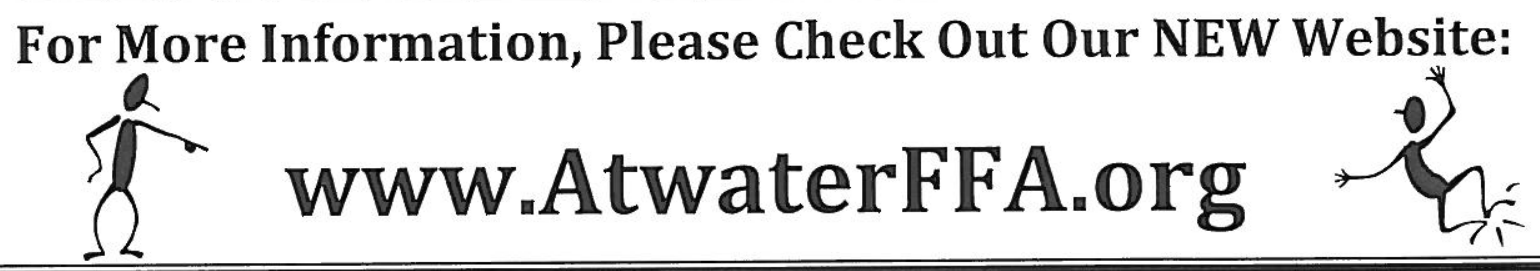

\section{Commonly Asked Questions}

My son/daughter has an interest in taking an agriculture class. Which one do you recommend?

First, we recommend your son/daughter enroll in an "Ag Science" class (Ag Life Science or Ag Biology- see above). This will fulfill their $9^{\text {th }}$ grade science requirement. If your son/daughter has in interest in working in the shop (wood construction, electrical, welding, etc..), you will want to enroll them in the Introduction to Shop Skills class (this is the ONLY shop class available for $9^{\text {th }}$ graders). If they would like to focus on plants, animals, etc... (non-shop), you will want to enroll them in Exploration in Ag. To be eligible to participate in any agriculture / FFA activities, your son/daughter must be enrolled in at least one agriculture class.

Can my son/daughter get into a major university (UC / CSU) by taking an agriculture class each year?

YES! We have students who have taken at least 1 agriculture class each year and have been accepted/enrolled in community colleges, California State Universities, and Universities of California campuses.

Our goal is to provide your son/daughter the skills and resources to be successful in life!
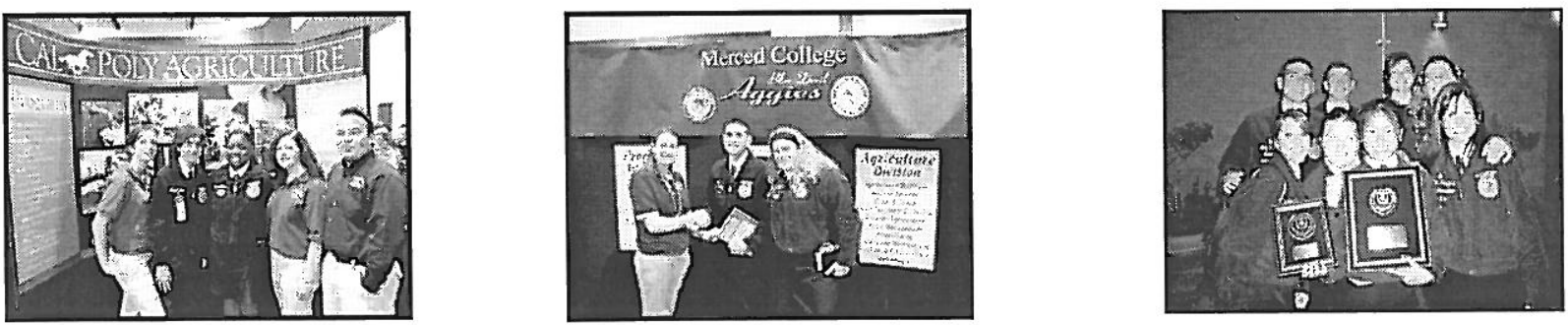


\section{$\underline{\mathbf{L}}$ \\ Chapter Scrapbook}

The Atwater FFA Historian maintains our chapter scrapbook and an advisor oversees the process of the book being created. Our scrapbook and all the materials are located in the AG1 classroom. The scrapbook includes pictures, newspaper articles, social media screen captures, and explanations of each event. The book includes memorabilia from our chapter's SAE events, leadership conferences, FFA events, and community service for the current year. When completed, our scrapbook is entered in the regional competition.

\section{Attached you will find:}

- Sample pages from our scrapbook 
One portion of the Scrapbook is dedicated to SAE Projects. Here is an example of a couple of our SAE Project pages.

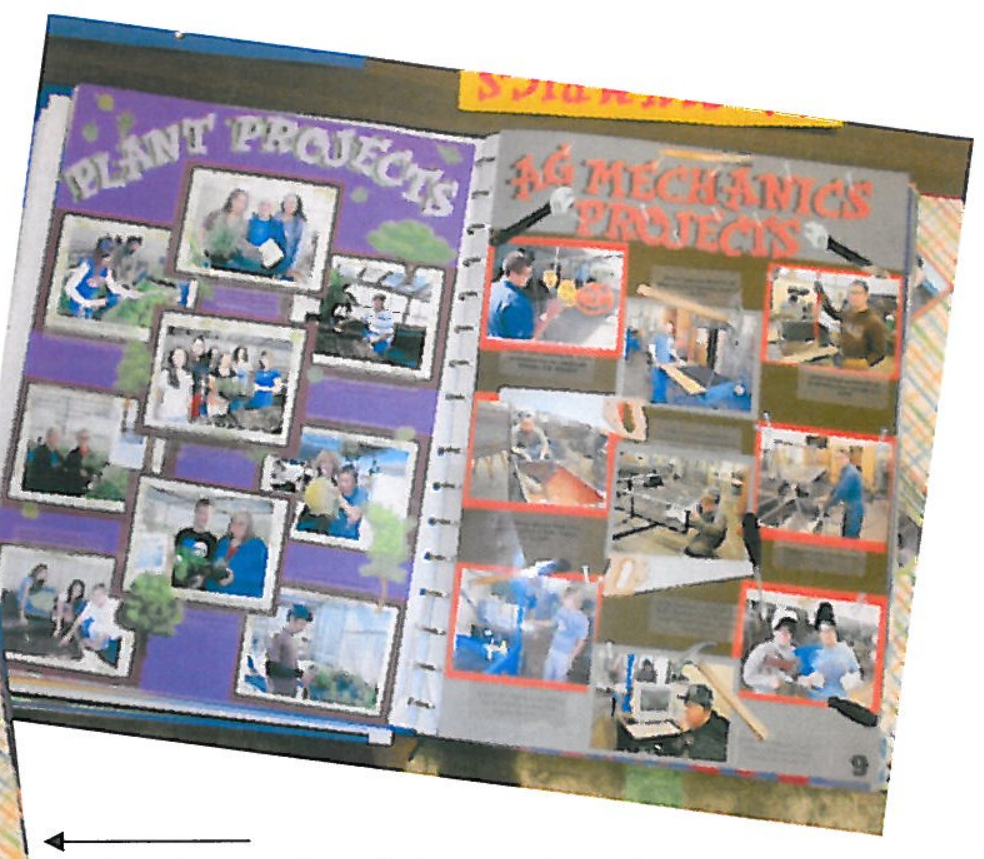

Another portion of the Scrapbook is dedicated to Leadership Activities . Here is an example of a couple of our Leadership pages.

A list of FFA Activities is required in the scrapbook. These pages depict some of those activities.
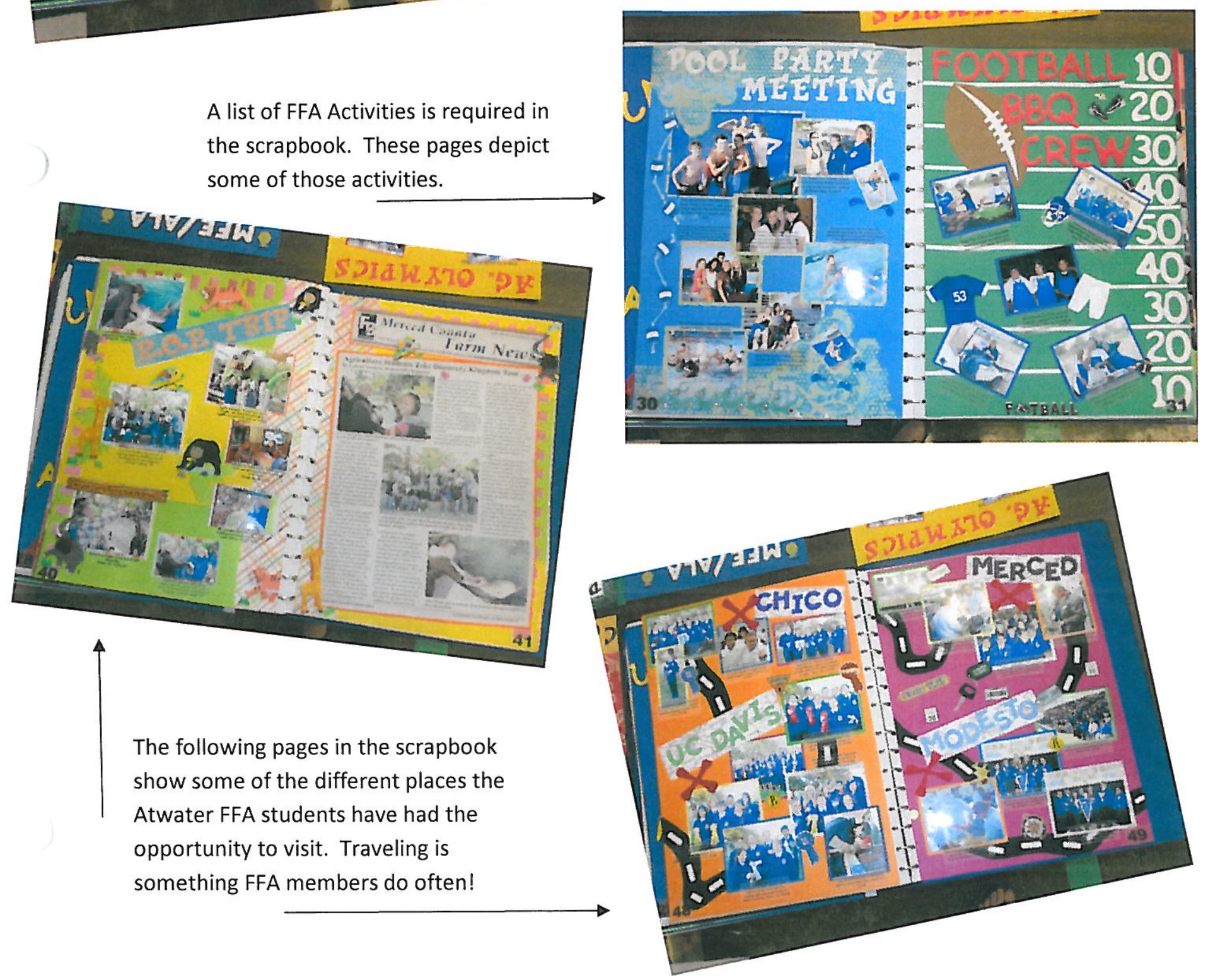


\section{$\underline{\text { M }}$ \\ Summer Activities Schedule}

Atwater FFA keeps its summer activities schedule on our chapter calendar and web page, which is available to all students and advisors. All activities for student participation are entered into the calendar.

The agreement between the Merced Union High School District Teacher Association and Merced Union High School District does not state that vocational agricultural instructor keep track of their summer hours on the extended contract. A simple log can be filled out by each agriculture instructor to keep track of extra hours spend during summer activities such as CATA summer conference and Merced County Fair.

\section{Attached you will find:}

- 2012 Summer Activities

- Ag Teacher Time Card 

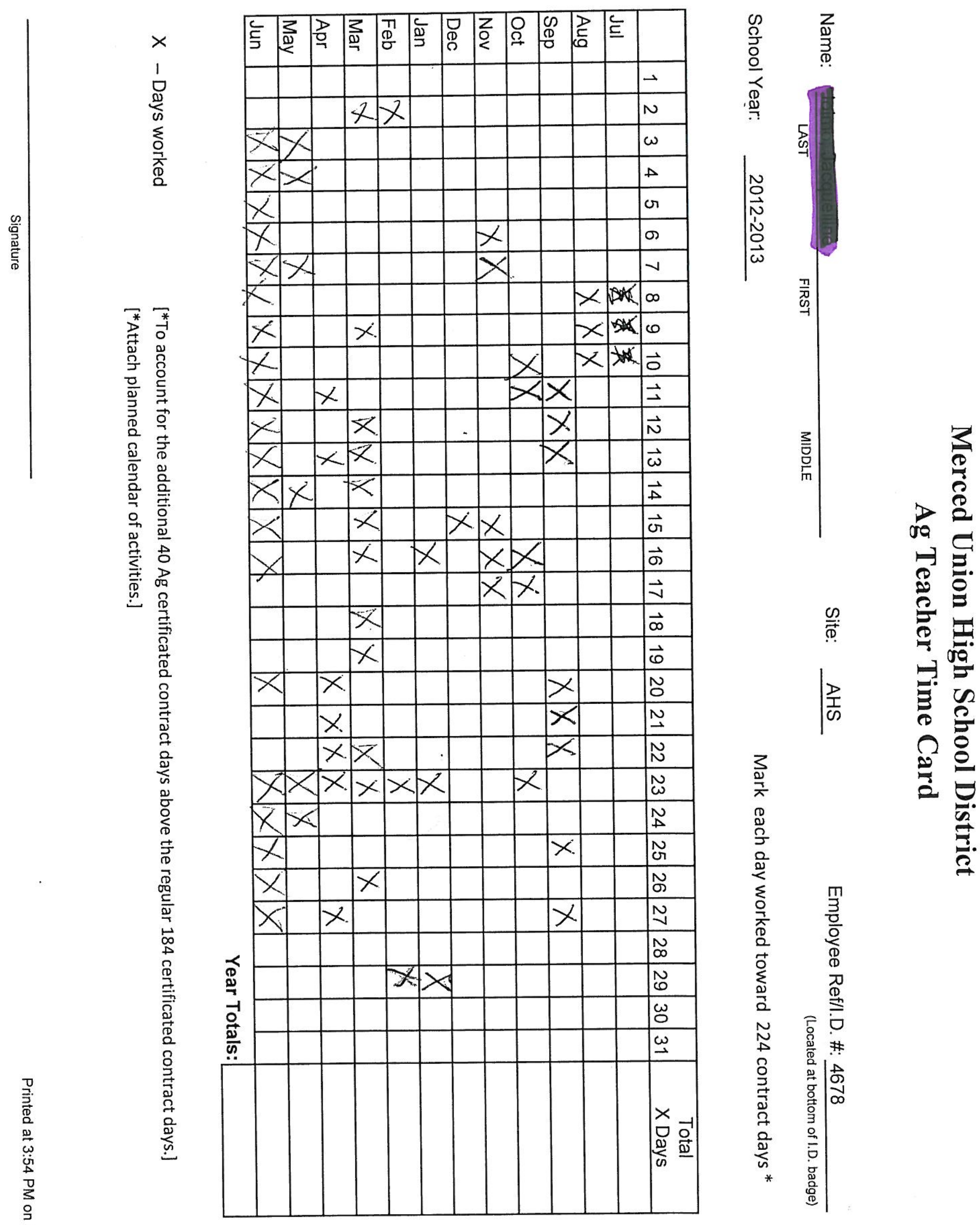


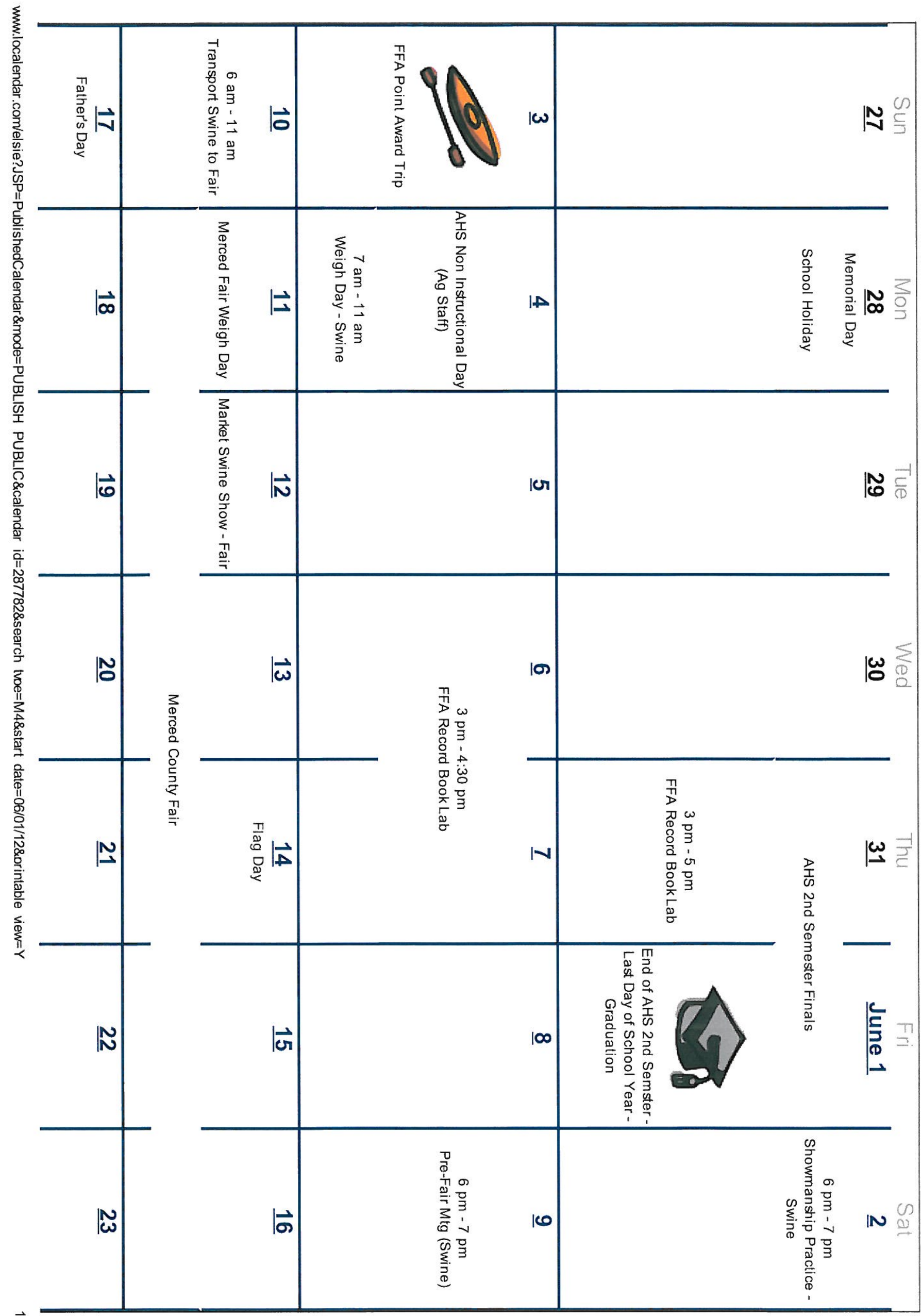




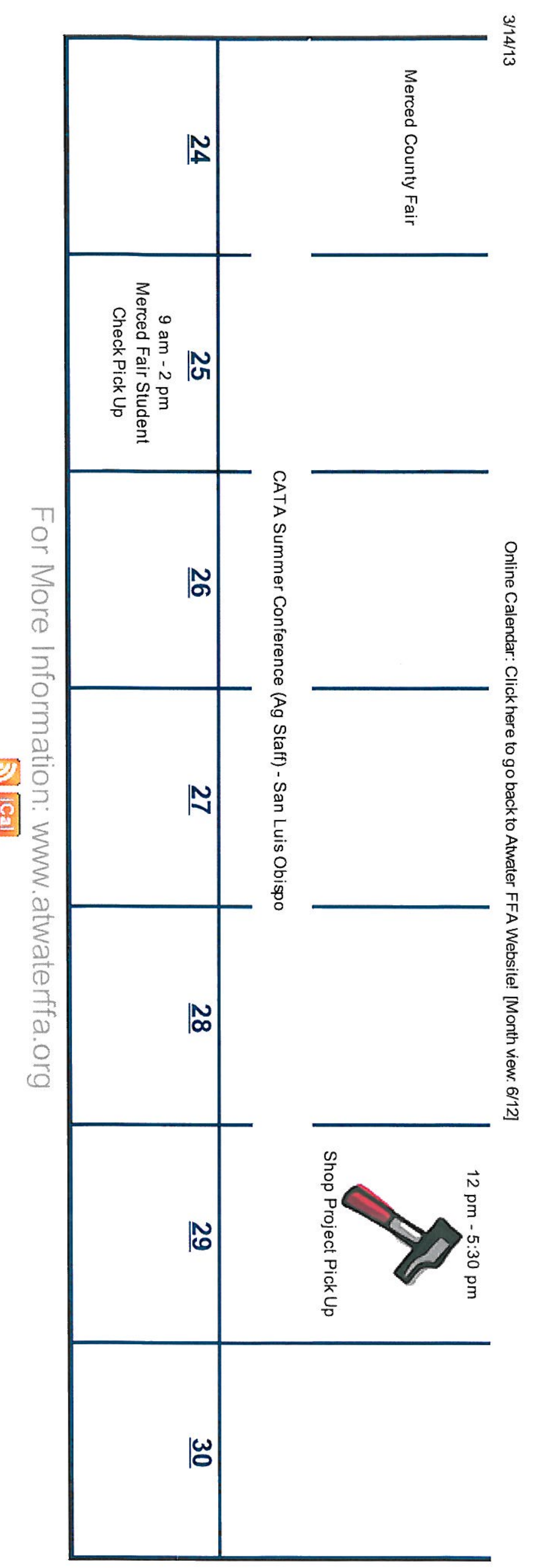




\section{$\underline{\mathbf{N}}$ \\ Graduate Follow-Up Survey}

A follow-up system is used which gathers the following information from program completers:

- Status of employment or school enrolled within

- Option regarding the value and relevance of the agriculture program

- Suggestions for improving the agriculture program

Each year, every student graduated senior fills out a graduate follow-up survey. From the information on the survey, the students are contacted the following year to gather information and feed-back. Each follow-up survey will be placed in the appropriate program completer's file within the agriculture department.

\section{Attached you will find:}

- Graduate Follow-Up Survey 


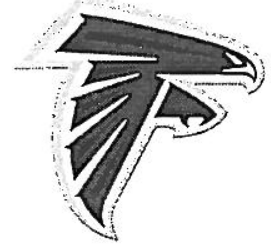

\section{Atwater High School \\ Agriculture Department \\ Graduate Follow-up}

Name

Address

Phone \#

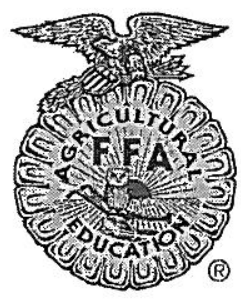

Phone \#

Email

1. Years in Atwater FFA Ag Program $\quad \begin{array}{lllll}1 & 2 & 3 & 4\end{array}$

2. Area of Agriculture Study in Atwater FFA

3. What are your future plans for next year?
a. Attend 2-year college
major:
b. Attend 4-year college
major:
c. Work part-time agriculture related non-ag related
d. Work full-time agriculture related non-ag related
e. Join Military
f. Other

4. What are your career goals?
a. (no college)
b. During college
c. After college 


\section{$\underline{0}$ \\ Graduate Status}

The Atwater FFA does not have the most accurate and up to date graduate records. It is hard many times to locate a make contact with a majority of our students.

We have used the Vo-Ag graduate follow-up for California to keep track of the past year's graduates. Atwater FFA plans to continue using the California FFA graduate follow-up to keep a good record of our graduates.

\section{Attached you will find:}

- Graduate Status 


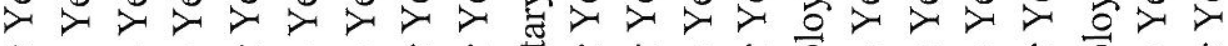

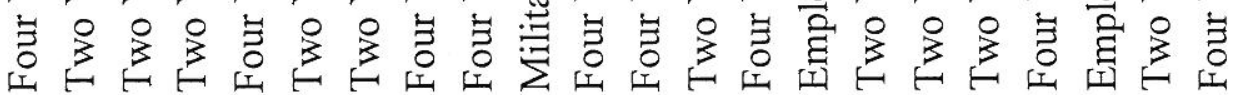

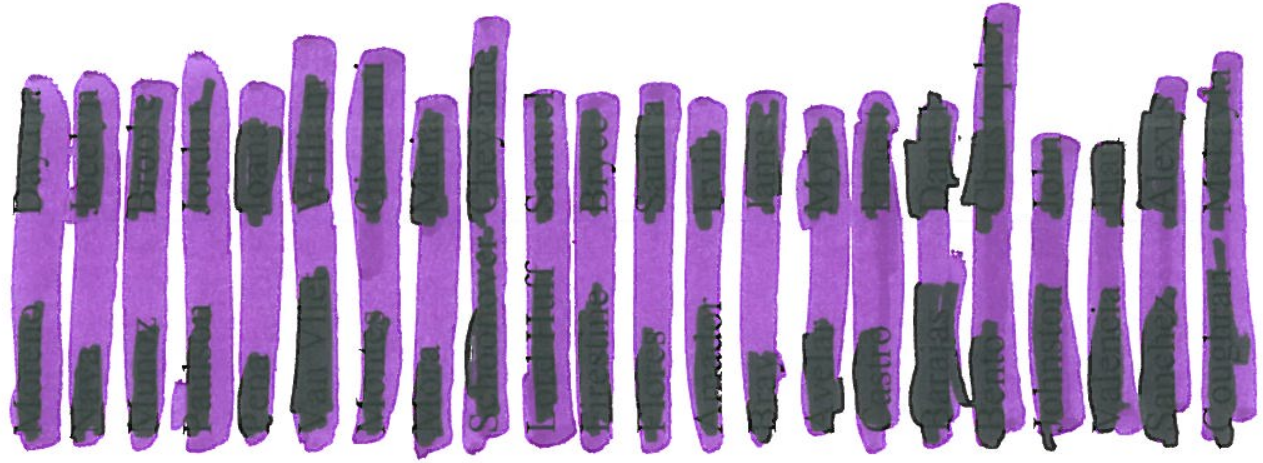




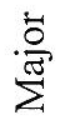

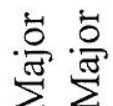

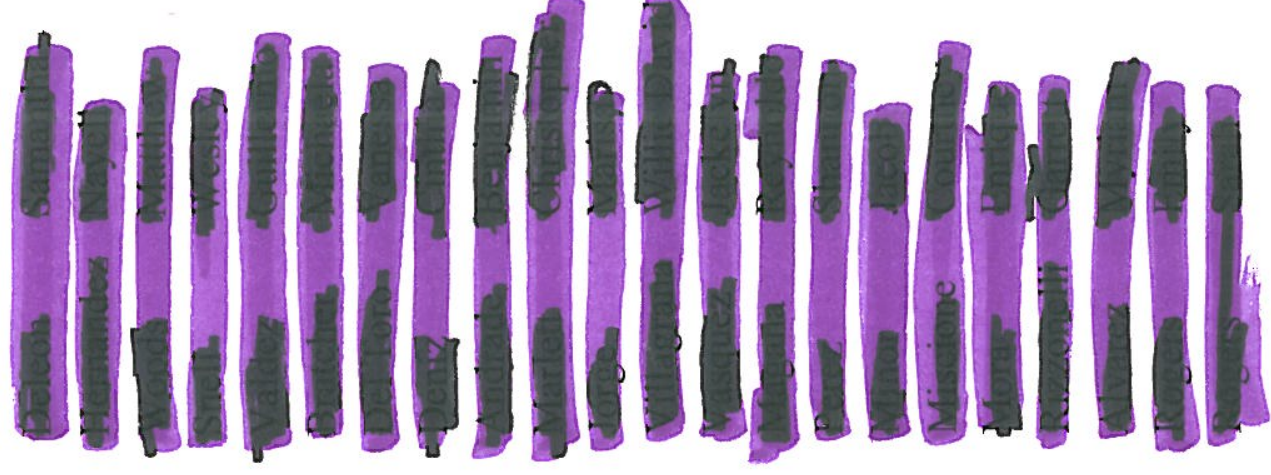




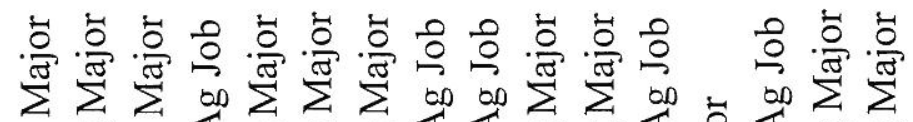




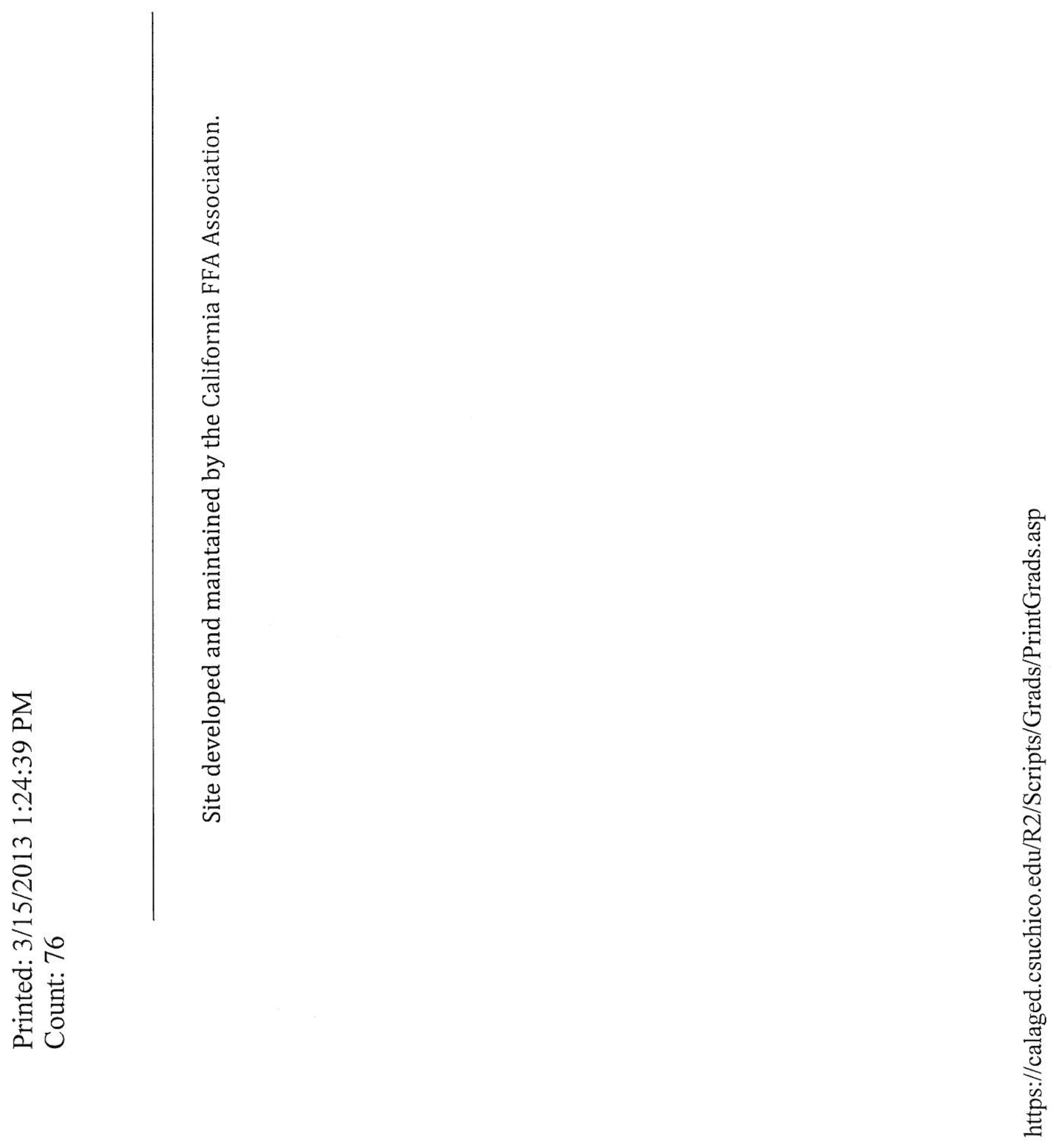




\section{$\underline{\mathbf{P}}$ \\ Comprehensive Plan}

A copy of the comprehensive plan for Atwater High School can be found is a separate binder labeled "Comprehensive Program Plan." This binder is updated annually and had received approval from the state to maintain program certification and incentive grant funds. 


\section{Q \\ Advisory Committee Minutes}

The Atwater FFA Advisory Committee meets twice a year. Here we discuss and ROP business, and other business relevant to our program's success for the upcoming year. Those invited to participate in the fall meeting are Agriculture instructors, committee members, ROP career technicians, and other special guests.

Our spring advisory committee meeting focuses on recruitment, summary of the year's success thus far, and proposals for future changes to better our department. This meeting includes Agriculture instructors, committee members, $8^{\text {th }}$ grade principals, administration, and counselors, AHS administration and counselors, and other special guests.

\section{Attached you will find:}

- Advisory Committee Meeting Minutes 


\section{Atwater High School Agriculture Department}

\section{Fall 2012 Ag Advisory Meeting Minutes}

October 30, 2012 


\section{Atwater High School \\ Agriculture Department Advisory Committee Meeting \\ Tuesday, October 30, 2012 \\ 6:00 PM}

Meeting Called to Order by

Welcome by

Roll Call and Introductions:

2011-2012 Advisory Committee Members

TERM: $2012-2015$

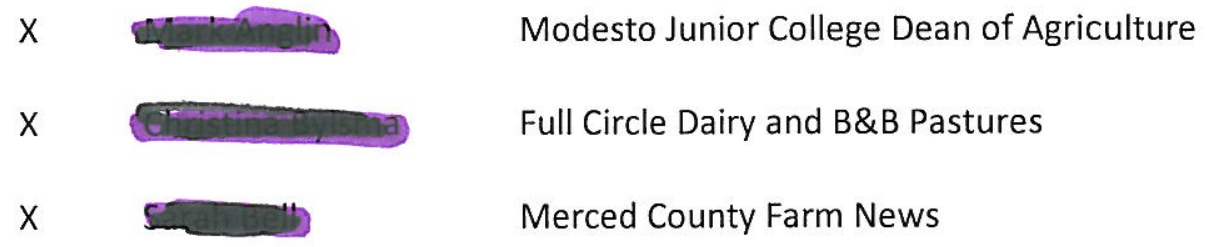

TERM: $2011-2014$

X Community Agriculturalist

$x$ Merced College - Horticulture

TERM: $2010-2013$

$x$

$x$

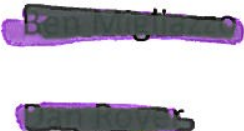

Invited Special Guest(s)

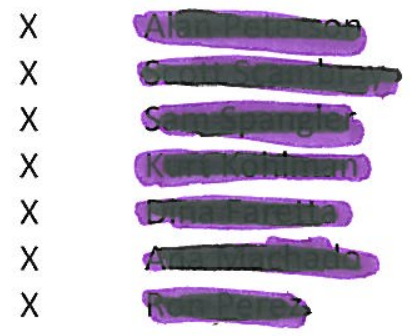

Sierra Cascade Nursery

Vista Livestock, Inc.
Atwater High School Principal

MUHSD Superintendent

MUHSD Board of Trustees

MUHSD Board of Trustees

MUHSD CTE Coordinator

MUHSD Program Administrator

MUHSD Maintenance/Operations Director 


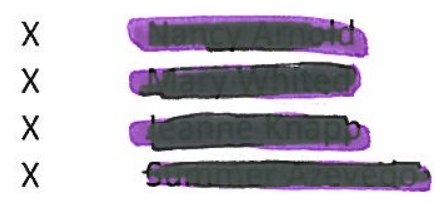

Winton Middle School Counselor

Merced County ROP

Merced County ROP

Fresno State University - Student Teacher

$\begin{array}{lllll}\text { AHS Ag Department } & \text { Instructors } & & \\ X & X & \text { Sam Meredith } & \text { Dave Gossman } \\ X & X & \text { Datt } & \text { Natie Kirschner }\end{array}$

I. Dinner

II. Introduction of Committee, Guests and Instructors

III. Minutes from the Previous Meeting

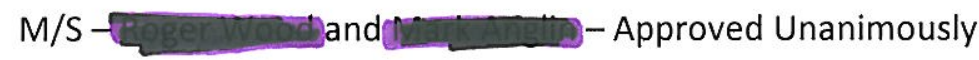

IV. Recognition of Term Ending Members and Election of Committee Officers

V. Review of 2011-2012 Goals (Presented bylDann

Highlights -

- Completed NEW long term horticulture facility and grapevine (viticulture) facility

- Constructed a NEW organic compost area

- Constructed a NEW rabbit facility (pole barn)

- Constructed a NEW goat / small livestock facility (pole barn)

VI. Program of Activities Presentation (Presented by tur

- 2012-2013 Goals

Highlights -

- Maintain/strengthen program recruitment

- Strengthen advanced welding and wood enrollment \#'s

- Repair/revise Farm Swine facility

- Explore and identify Farm Sheep facility upgrade/expansion

- Continue to expand technology/communication resources

- Add new concrete walkway near new nursery area

- Add new concrete pad around rabbit facility

- Construct a new supply/equipment shed in pole barn 
- Calendar of Activities (available on www.AwaterFFA.org) - New POA will be mailed when completed

VII. 2012-2013 Budget Overview (General 2012-2013 Operational Budget)

MUHSD Transportation Budget

Revenue

Site Disbursement

$\$ 7,046$

Total Revenue $\$ \$ 7,050$

Expenses

FFA Judging Contests $\$ \$ 4,500$

FFA Leadership/Professional Conferences $\quad \$ 1,750$

FFA Officer/Staff Retreat $\$ \$ 800$

Total Expenses $\quad \$ 7,050$

AHS Site Budget

Revenue

Site Disbursement

$\$ 2,000$

Total Revenue $\$ \mathbf{\$ 2 , 0 0 0}$

Expenses

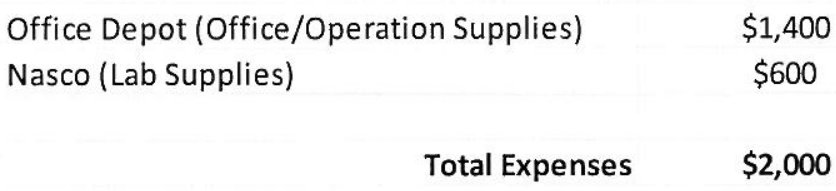

Ag Incentive Grant Budget 
Revenue

Incentive Grant Disbursement

$\$ 20,451$

Total Revenue

$\$ 20,451$

Expenses

$\begin{array}{lc}\text { Airgas (Shop) } & \$ 2,000 \\ \text { CATA Memberships } & \$ 840 \\ \text { Davis Digital (Office Services) } & \$ 900 \\ \text { FFA Membership Dues } & \$ 7,530 \\ \text { FFA State Conference Lodging } & \$ 2,300 \\ \text { FFA State Finals Lodging } & \$ 2,100 \\ \text { FFA Supplies } & \$ 2,000 \\ \text { New Professionals Conference } & \$ 250 \\ \text { Team Wear - Officer Supplies } & \$ 1,000 \\ \text { UC Davis Field Day Transportation } & \$ 1,531 \\ & \\ & \text { Total Expenses }\end{array}$

Funding Budget

Revenue

2012-2013 Disbursement

$\$ 33,893$

Total Revenue

$\$ 33,893$

\section{Expenses}

All Data Subscription (Wood) $\$ 1,000$

Biology Lab Equipment $\$ 600$

CATA Road Show / Conference \$1,266

CATA Summer Conference (SLO) $\$ 3,700$

FFA Leadership Conference (Fresno State) \$3,000

FFA Leadership Conferences (MFE / ALA) \$2,200

Indianapolis Car Rentals (National FFA) \$1,200

Indianapolis Hotel (National FFA) \$2,000

Pole Barn Shed \$3,182

Shop/Classroom Computers \$13,745

Welding Shop Tools \$1,000

Wood Shop Tools $\$ \$ 1,000$

Total Expenses $\quad \$ 33,893$

\section{ROP Funding Budget}


Revenue

Veterinary Science

$\$ 1,098$

Horticulture

$\$ 981$

Floral Design

$\$ 2,772$

Total Revenue

$\$ 4,851$

Expenses

Flowers / Supplies $\quad \$ 1,200$

Nasco (Lab Supplies) $\$ \$ 400$

CVE (Curriculum Materials) $\$ 300$

Chico State Field Day Transportation \$1,861

Promo Direct (Project Promotional Supplies) $\quad \$ 1,090$

Total Expenses $\quad \$ 4,851$

AHS Ag Mechanics (Welding) - FFA Metal Shop Budget

Revenue

Atwater Ag Boosters $\$ 500$

Custom Plasma Projects $\$ \$ 1,200$

Donations from Repairs $\$ 1,400$

Fall Fest Fundraiser $\$ \$ 1,500$

Merced County Fair Projects $\$ 1,200$

Metal Art Sales (During Plant Sales) $\$ \$ 2,000$

Project Payments $\$ \$, 500$

Scrap Metal Recycling $\$ 1,500$

Total Revenue $\quad \$ 17,800$

Expenses

Equipment Repairs $\$ 600$

Freshman Ag Shop Skills Projects $\$ 3,500$

General Shop Supplies / Materials $\$ 1,200$

Misc. Supplies / Equipment $\$ \$ 2,500$

Modesto Steel / Custom Metal (Material) $\$ \$ 8,500$

Powder Coating Projects $\$ 500$

Welding Supplies / Airgas $\quad \$ 1,000$

Total Expenses $\quad \$ 17,800$

AHS Ag Mechanics (Wood / Engines) - FFA Wood/Engines Shop Budget 
Revenue

Atwater Ag Boosters $\$ 500$

District Funds $\$ \$ 6,500$

Fall Fest Fundraiser $\$ \$ 1,500$

Sale of Mowers / Engine Repair \$250

Sale of Wood Projects $\$ 1,500$

Total Revenue $\quad \$ 10,250$

Expenses

Classroom/Lab Supplies Student Projects $\quad \$ 6,500$

Equipment Repair $\$ 1,000$

General Shop Supplies / Materials $\$ 2,750$

Total Expenses $\quad \$ 10,250$

\section{AHS Horticulture / Floral Design Budget}

\section{Revenue}

Fall Fest Fundraiser $\quad \$ 1,000$

Fall Plant Sale $\$ 2,000$

Floral Projects $\quad \$ 5,000$

Merced County Fair Projects $\quad \$ 5,000$

Spring Plant Sale $\$ 2,000$

Total Revenue $\quad \$ 15,000$

\section{Expenses}

Facility Concrete / Fencing Projects $\$ 1,500$

FFA Activities / Events $\$ 1,000$

FFA Judging Teams (Nationals) $\$ 2,000$

Floral Supplies / Equipment $\$ 3,000$

Horticulture Equipment $\$ 2,000$

Horticulture Facility Projects $\$ \$ 1,500$

Horticulture Supplies $\$ \$ 4,000$

Total Expenses $\quad \$ 15,000$ 


\section{AHS General FFA Budget}

Revenue

$\begin{array}{lc}\text { Ag Booster Donation } & \$ 8,000 \\ \text { Fall Fest Fundraiser } & \$ 6,000 \\ \text { National Finals Trip Donations } & \$ 9,000 \\ \text { Placemat Ad Sales } & \$ 5,500 \\ \text { Save Mart SHARES Program } & \$ 2,000 \\ \text { Take-Out BBQ's (4) } & \$ 10,000\end{array}$

Total Revenue $\quad \$ 40,500$

\section{Expenses}

Fair Equipment/Supplies

$\$ 1,000$

FFA Field Day Registrations

$\$ 2,500$

FFA Greenhand Conference

$\$ 800$

FFA Meetings (Food, Supplies, etc..) $\$ 2,000$

FFA National Finals Trip

$\$ 13,000$

FFA Recreational Trip(s) Transportation $\$ 2,200$

FFA Student Fundraising Incentives $\$ 4,000$

FFA Supplies $\$ 2,000$

Office/Operation Supplies $\$ \$ 3,000$

Promotion/Marketing $\$ 4,500$

Staff iPads / Computers $\$ \$ 5,500$

Total Expenses $\quad \$ \mathbf{4 0 , 5 0 0}$

TOTAL 2012-2013 Revenue/Expense Budget - \$151,795.00

VII. Program / Agriculture Courses / R - 2 Data

A. Overall Program Objectives

1. Provide students the resources and opportunities for personal growth, educational development, and career success.

2. Get students involved

3. Maximize the agricultural education model

- Classroom

- $\quad$ FFA

- $\quad$ SAE (apply classroom/FFA experience through "hands-on" application)

B. 2012-2013 Program Status/Update

1. 858 Individual Agriculture Students 
2. Primary Reasons for Overall Sustained Growth

- Organized/Established Pathways and Courses

* Ag Mechanics

* Agricultural Sciences (Horticulture and Animal Science)

- $\quad 9^{\text {th }}$ Grade Ag/FFA "Foundation" Courses/Enrollment

- Quality of Ag Biology / Environmental Ag Science / Earth Science Curriculum and Test Results

- $\quad$ Expanded opportunities with "advanced" agriculture courses including Floral Design (UC " $F$ " Credit), Ag Economics/Government, and Horticulture.

- $\quad$ Students have "bought" into program - Students are involved in/out of the classroom

3. Enrollment Comparisons ('11-12 vs '12-'13)

$20112012 \quad \%$ Change

\section{Largest Growth}

$\begin{array}{lccc}\text { Wood Construction III } & 3 & 12 & 75 \% \\ \text { Wood Construction I } & 18 & 26 & 31 \% \\ \text { Ag Earth Science } & 115 & 152 & 24 \% \\ \text { Ag Shop Skills } & 86 & 106 & 19 \%\end{array}$

\section{Relatively Steady}

Equipment Construction

Ag Leadership

Welding Tech 1

Welding Tech II

Power Mechanics

Veterinary Science

Ag Life Science

$\begin{array}{ccc}4 & 5 & 20 \% \\ 28 & 35 & 20 \% \\ 56 & 65 & 14 \% \\ 19 & 22 & 14 \% \\ 26 & 31 & 16 \% \\ 36 & 37 & 3 \% \\ 111 & 107 & -4 \% \\ 122 & 116 & -5 \% \\ 26 & 24 & -8 \% \\ 38 & 34 & -12 \% \\ 35 & 31 & -13 \%\end{array}$

Floral Design I/II

Small Engines

Ag Economics / Government

Horticulture

$-13 \%$

\section{Largest Decrease}

$\begin{array}{lccc}\text { Ag Biology } & 265 & 227 & -17 \% \\ \text { Ag Environmental Science } & 72 & 35 & -106 \% \\ \text { Wood Construction II } & 25 & 6 & -317 \%\end{array}$

\section{Highlight Summary of Enrollment Data}

- $\quad$ Ag Shop Skills course enrollment increased for second straight year after major decrease 2 years ago. Issues that affect enrollment in this course include:

1. $9^{\text {th }}$ graders faced with limited "elective" opportunities based on academic needs/requirements 
2. Course conflicted with other interests (athletics, band, etc..)

- Welding Tech I / Wood Construction I-Slight increase due to last years Ag Shop Skills foundation numbers (increased last year from year before)

- $\quad$ Ag Biology-Decrease was due to eliminating a section (over-enrolled). Last year's \#'s are based on an extra prep period.

- Environmental Ag Science - Similar to "Ag Biology". Section closed to accommodate higher Earth Science \#'s.

- Ag Economics / Government - Very popular with students. Could have easily filled 2 sections if available (over 110 students enrolled).

- Wood II / III, Welding Tech II / Equipment Construction - Steady decrease correlates with decrease in opportunities for students due to other conflicts (required courses, remediation, etc...)

4. Program / Facility Updates

- Long Term Horticulture Growing Area Completed - 80'x50' fenced growing area is located behind the county building. Vineyard (Grapes) is in place for viticulture lab. New garden plots installed for MCOE special education students. Area landscaped.

- Pole Barn Rabbit and Goat Facility - New rabbit and goat facility project has been completed in the pole barn. A new storage shed for supplies/equipment is scheduled to be installed later this Fall.

- Positive Impact of School, District, Community, and Industry Support - Direct correlation towards support of the agriculture program and production in student involvement/achievement.

\section{Program Priorities for 2012-2013}

A. Continue Establishing Opportunities for Students to Complete 4 Year Agriculture Pathway

1. Maintain strong student enrollment in "Foundation" courses Year \#1. (see attached Pathway/Course list)

- $\quad$ Ag Shop Skills (Ag Mech Pathway)

- Ag Biology

- $\quad$ Ag Life Science

2. Maintain / expand enrollment in "advanced" agriculture pathway courses

- Floral Design

- Horticulture

- Veterinary Science

- Ag Economics / Government 
3. Benefits / Advantages to Four Year Pathway Students

- Increase school involvement

- Increase motivation/desire towards academics/careers

- Increase college / university / trade school enrollment

- 75\%+ of 2011-2012 3-4 year ag pathway students currently enrolled in $2 \mathrm{yr} / 4 \mathrm{yr}$ college/universities or military.

- LARGE increase of 3-4 year ag pathway students going directly into a 4 year university

\section{Vision for Future Growth / Opportunity}

\section{A. Encourage District Towards Expansion of Class Periods / Opportunities}

- Recognizing today's budget challenges and the state/federal requirements pertaining to standardized testing, we cannot overlook the need to provide students the opportunity to explore interests, "life skill" classes, career pathway courses that extend beyond core academic classes.

- Students are extremely limited with today's 6 period schedule/format

- A recommendation towards the future is to have a plan in place to expand and/or reformat current schedule when economic opportunities become available.

- Current pathway/classes hardest hit is the Ag Mechanics (Shop).

B. Explore opportunities in Ag Business pathway courses and Food Science pathway courses as staff CTE retirement(s) loom ahead.

C. Expand Student SAE (agriculture projects) Opportunities and Project \#'s

\section{Program Needs / Inquiries / Concerns}

A. If you ask a senior $\left(12^{\text {th }}\right.$ grade) student what they plan to do after graduation, the most common answer is "I don't know". Are we really meeting the needs of our students/community?

B. Primary focus last few years has been on A-G and "API / Scores", the opportunities for students in APPLICABLE education courses, SKILL development, and the ability to explore and identify a "direction" in one's future has decreased and/or been ignored. As required graduation / CST test courses increased, career tech and "life" courses have decreased.

C. Solution to "B" would take all parties involved (DTA, District, community, etc...), but with a common vision of expanding opportunities for ALL students that focus on all avenues of post high school education opportunities. Goal should be to add a $7^{\text {th }}$ class/period to a student's schedule.

\section{Ag Incentive Grant Review}

Motion to Approve / Seconded - Ben Migliazzo and Sarah Bell (approved unanimously) 
XIII. Discussion Items

* reinforced the magnitude of opportunities regarding agriculture education and the productivity and accomplishments of Atwater High School Agriculture / FFA.,

\section{Motion to Adjourn}

$M / S=0$-Approved

6:58 PM 


\section{$\underline{\mathbf{R}}$ \\ Student Program Plan}

At Atwater FFA, students complete their program plan at the beginning of every year when the $R-2$ is completed. The student program plan assists with students choosing their career pathways as well as assists with planning out their agriculture plans and goals.

Following is a copy of a freshman students plan for the next 4 years as well as a copy of Atwater FFA's Agriculture Careers Pathways

\section{Attached you will find:}

- R2 Program Plan

- Agricultural Pathways 
Address: (PO Box or Mailing Address)

City: State: Zip: (Atwater 95301 or Winton 95388)

Hispanic: Yes No (Check One)

Race: (Check One or more) White

$\square$ Asian Indian

$\square$ Cambodian $\square$ Chinese

$\square$ Hmong

$\square$ Japanese $\quad \square$ Korean

$\square$ Laotian

$\square$ Vietnamese

$\square$ Black

$\square$ American Indian/Alaska Native

$\square$ Native Hawaiian/Pacific Island

$\square$ Filipino

$\square$ Guamanian

Samoan

$\square$ Tahitian

Year in Ag: (Circle One) $\begin{array}{lllll}1 & 2 & 3 & 4\end{array}$

Grade: (Circle One) $\begin{array}{llll}9 & 10 & 11 & 12\end{array}$

Gender: (Circle One) Male Female

Pathway: (Check One)
$\square$ Ag Business Management
$\square$ Agriscience
$\square$ Forestry
$\square$ Plant / Soil Science

$\square$ Ag Mechanics

$\square$ Animal Science

$\square$ O.H. (Plants)

\section{I am taking this course because: (Check One)}

I plan a career in Agriculture

Not a career in Agriculture

$\square$ Not interested, placed in class

Please indicate your plans after graduation: Pick one column and then check all that apply.

Go to Work Full-Time

_No Further Education

Some College Later
Go to College

_Community College

Four Year College

_Full-Time Student

_Part-Time Student

_Agriculture Major

_Non-Agriculture Major

_Go into Military 


\section{AGRICULTURAL EDUCATION - PLANNING SHEET| 2012* 2013}

Planned course of study to meet occupational goal. By school year, list all classes previously taken, currently being taken, and planned to be taken in the future.

\begin{tabular}{|c|c|c|c|}
\hline FRESHMAN YEAR & SOPHOMORE YEAR & JUNIOR YEAR & SENIOR YEAR \\
\hline$(20-)$ & $(20-\ldots)$ & $(20-\quad)$ & $(20-\quad)$ \\
\hline CLASS & CLASS & CLASS & CLASS \\
\hline English 9 & English 10 & English 11 & English 12 \\
\hline & World Hist. & US History & Govt / Econ \\
\hline & & & \\
\hline & & & \\
\hline & & & \\
\hline & & & \\
\hline & & & \\
\hline
\end{tabular}

Supervised Agricultural Experience Project Plan (Project program should be related to career goal.)

\begin{tabular}{l} 
FRESHMAN YEAR \\
\begin{tabular}{|c|c|c|c|c|c|c|c||}
\hline \hline SAE (Project Title) & SIZE & SAE (Project Title) & SIZE & SAE (Project Title) & SIZE & SAE (Project Title) & SIZE \\
\hline & & & & & & & \\
\hline & & & & & & & \\
\hline
\end{tabular} \\
\hline
\end{tabular}

Planned Departmental Activities (List the FFA Activities you would like to or have participated in by school year.)

\begin{tabular}{|c|c|c|c|}
\hline FRESHMAN YEAR & SOPHOMORE YEAR & JUNIOR YEAR & $\underline{\text { SENIOR YEAR }}$ \\
\hline & & & \\
\hline & & & \\
\hline & & & \\
\hline & & & \\
\hline & & & \\
\hline
\end{tabular}




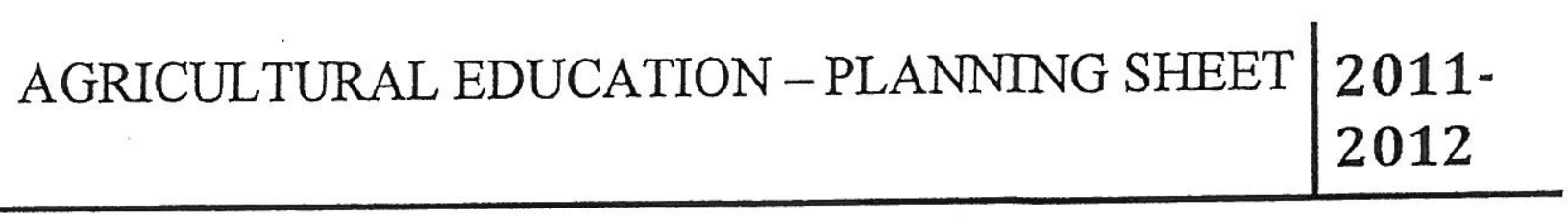

Planned course oof study to meet occupational goal. By school year, list all classes previously taken, currently being taken, and planned to be taken in the future.

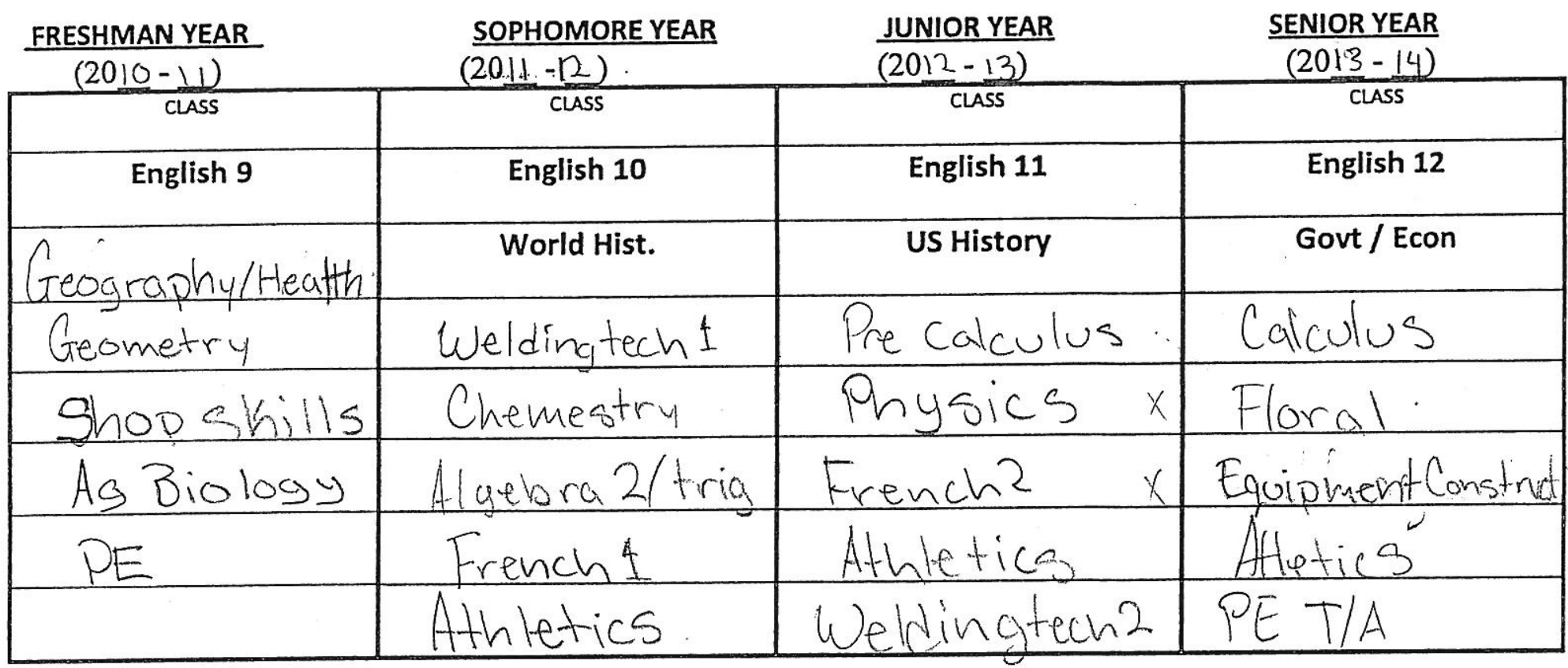

Supervised Agricultural Experience Project Plan (Project program should be related to career goal.).

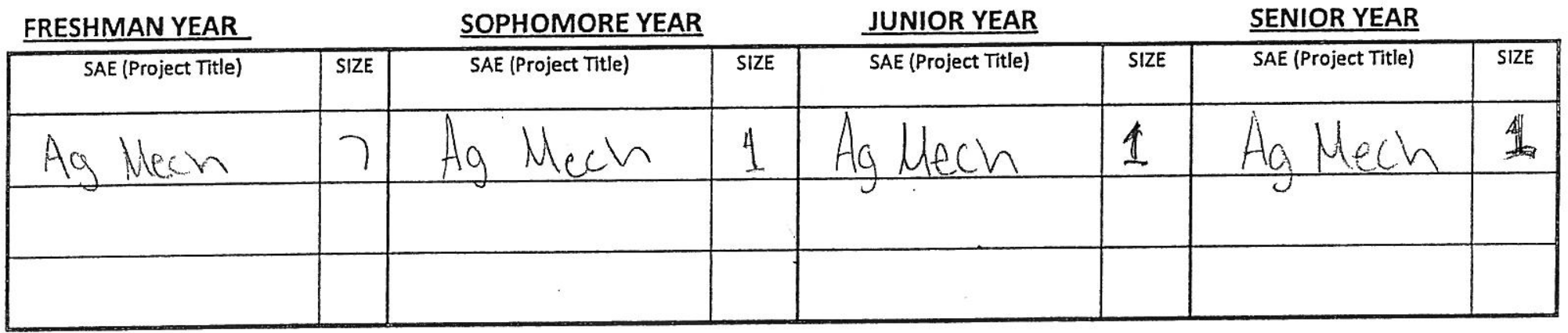

Planned Departmental Activities (List the FFA Activities you would like to or have participated in by school year.)

FRESHMAN YEAR

SOPHOMORE YEAR

JUNIOR YEAR

SENIOR YEAR

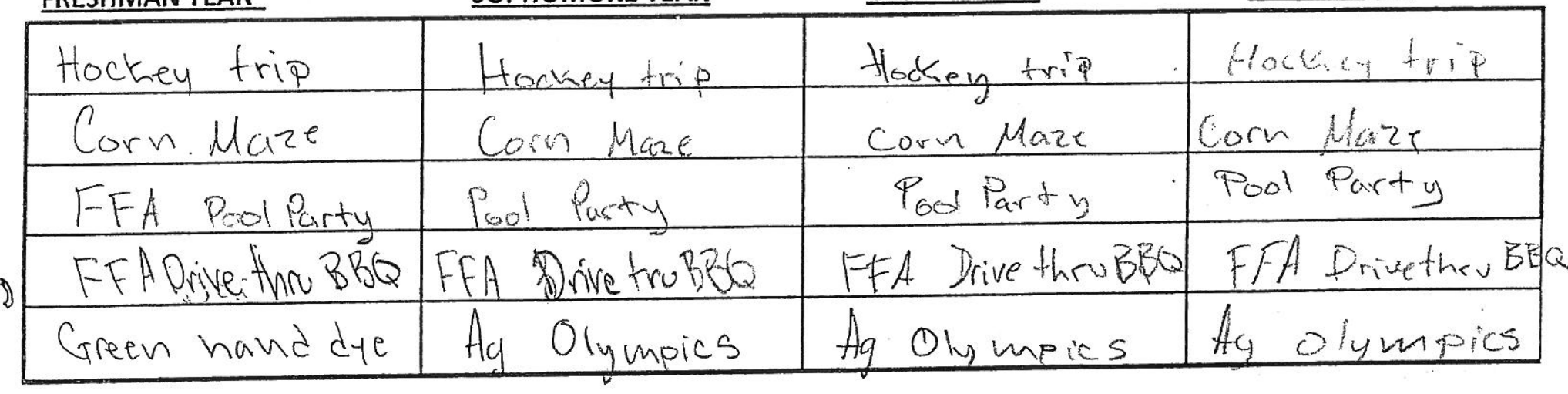




\section{AGRICULTURAL EDUCATION - STUDENT DATA $\mid 2011$ - \\ 2012}

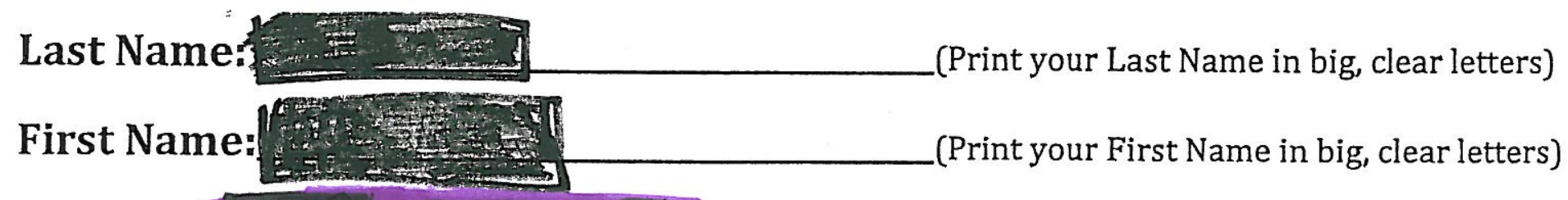
Address: (PO Box or Mailing Address)

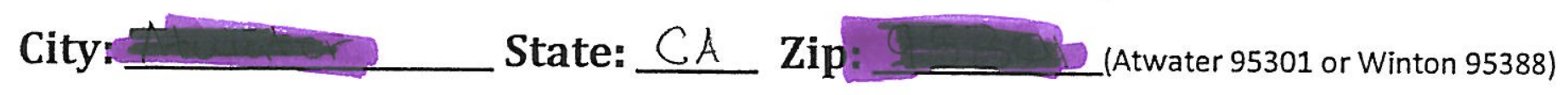

Hispanic: $X$ Yes No (Check One)

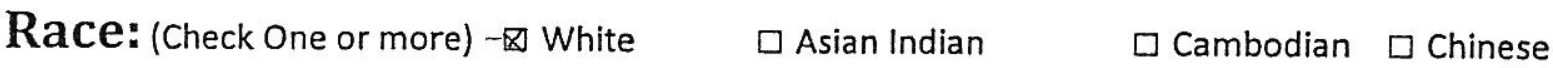
$\square$ Hmong
$\square$ Japanese $\square$ Korean
Laotian
$\square$ Vietnamese
$\square$ Black
$\square$ American Indian/Alaska Native
Native Hawaiian/Pacific Island
$\square$ Filipino
$\square$ Guamanian
Samoan
$\square$ Tahitian

Year in Ag: (Circle One) 1 (2) 34

Grade: (Circle One)

9 (10) $11 \quad 12$

Gender: (Circle One)

(Male Female

Pathway: (Check One)
$\square$ Ag Business Management
冈 Ag Mechanics
Agriscience
$\square$ Animal Science
$\square$ Forestry
O.H. (Plants)
$\square$ Plant/Soil Science

\section{I am taking this course because: (Check One)}

I plan a career in Agriculture

$\square$ Not a career in Agriculture

$\square$ Not interested, placed in class

\section{Please indicate your plans after graduation: Pick one column and then check all that apply.}

Go to Work Full-Time

_No Further Education

_ Some College Later
$X$ Go to College

_Community College

XFour Year College

_Full-Time Student

X Part-Time Student

_Agriculture Major

$\not{\triangle}$ Non-Agriculture Major

_Go into Military 


\section{Agriculture Career Pathways 2012-2013}

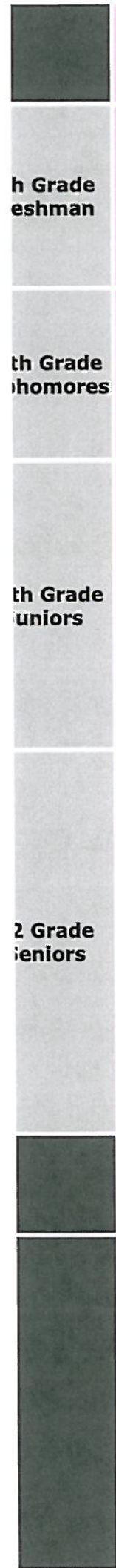

Animal Science

Ag Life Science

Ag Biology *

Ag Biology *

Ag Environmental Science

Ag Earth Science *

Veterinary Science

Junior Ag Electives (see below)

Veterinary Science

Internships in Agriculture I

Senior Ag Electives (see below)

\section{Junior / Senior Ag} Electives

Ag Economics

Ag Government

Ag Leadership

Floral Design

Horticulture

Internships in Agriculture I/II

Small Engines

Wood Construction I

Welding Technology I

\begin{tabular}{|c|c|}
\hline $\begin{array}{c}\text { Ornamental } \\
\text { Horticulture }\end{array}$ & $\begin{array}{c}\text { Ag Business \& } \\
\text { Communications }\end{array}$ \\
\hline Ag Life Science & Ag Life Science \\
\hline Ag Biology* & Ag Biology * \\
\hline
\end{tabular}

Ag Biology *

Ag Environmental Science

Ag Earth Science *

Ag Biology *

Ag Environmental Science

Ag Earth Science *

Internships in Agriculture I

Horticulture

Floral Design *

Junior Ag Electives

(see below)

Horticulture

Floral Design *

Senior Ag Electives (see below)

Junior / Senior Ag Electives

Ag Economics

Ag Government

Ag Leadership

Internships in Agriculture I/II

Small Engines

Veterinary Science

Wood Construction I

Welding Technology I

\section{Ag Leadership \\ Junior Ag Electives \\ (see below)}

Internships in Agriculture I

or

Internships in Agriculture II

Ag Leadership

Senior Ag Electives

(see below)

\section{Junior / Senior Ag} Electives

Ag Economics Ag Government

Ag Leadership

Floral Design

Horticulture

Internships in Agriculture I/II

Small Engines

Veterinary Science

Wood Construction I

Welding Technology I
(A) Power Mechanics

Agriculture Mechanics

\section{Introduction to Shop Skills}

$\mathrm{A}=$ Engines/Mechanics

$\mathrm{B}=$ Welding $/$ Metal

$C=$ Wood Construction

- C= Wood Construction
(A) Small Engines
(B) Welding Tech I

(C) Wood Construction I

(B) Welding Technology II

(C) Wood Construction II

(A) Internships in $\mathrm{Ag}$

(B) Ag Welding Fabrication

(C) Wood Construction III

Senior Ag Electives (see below)

(ROP Automotive I - Off Campus - Non Ag

\section{Agriculture Mechanics Pathway Notes}

"It is recommended to take at least Ag Mech course each year. If you a unable (due to required AHS courses is recommended that you take an agriculture science course or an agriculture course that meets graduation requirement to maintai ag/FFA eligibility"

Taking an Ag Life, Bio, Environment and/or Earth Science course at thi same time as a shop class is highl encouraged. 


\section{$\underline{\mathbf{S}}$ \\ Proficiency Standards}

Atwater High Agriculture has proficiency standards, also called program completion standard.

These standards are assessed through exams, coursework, FFA, SAE, and student demonstration. There are separate proficiency standards for ROP courses, which are assessed at the same manner.

Atwater Agriculture program also implements the California State Standards into our courses. Attached you will find the standards used for the Ag Biology and Floral Design courses.

\section{Attached you will find:}

- Program Completion Standards 


\section{PROGRAM COMPLETION STANDARDS}

\section{Agriculture Biology}

- Students will understand the basic concepts of scientific inquiry and critical thinking.

a Students will develop an understanding of the basic structural unit of life and cellular activities.

* Students will develop a basic understanding of animal physiology and function such as reproduction, digestion, and animal health.

- Students will develop a basic understanding of plant physiology and anatomy such as photosynthesis and respiration, germination, nutrition, and reproduction.

- Students will understand the role of soil, fertilizer, irrigation, and pest control in plant growth and development.

* Students will develop a basic understanding of social structure and characteristics.

- Students will develop a basic understanding of animal behavior. 
ATWATER AGRICULTURE DEPARTMENT

ROP PROGRAM COMPLETION STANDARDS

1. Personal Skills

Students will understand how personal skill development affects employability. They will exhibit positive attitudes, self-confidence, persevering, and self-discipline. They will manage time and balance priorities, as well as demonstrate a capacity for life long learning.

2. Interpersonal Skills

Students will understand key concepts in group dynamics, conflict resolution, and negotiation. They will work cooperatively, share responsibilities, and assume leadership roles. They will demonstrate cooperative working relationships across gender and cultural groups.

3. Thinking and Problem Solving Skills

Students will exhibit critical and creative thinking skills, logical reasoning, and problem solving. They will apply numerical estimation, measurement, and calculation. They will recognize problem situations, identify, locate, and organize needed information or data and the purpose, evaluation, and selection of alternate solutions.

4. Communication Skills

Students will understand the principles of effective communicators. They will communicate both written and orally. They will listen attentively to instructions and request clarification or additional information as needed.

5. Occupational Skills

Students will understand occupational safety issues, including avoidance of physical hazards in the work environment. They will operate equipment safely as not to endanger themselves or others. They will demonstrate proper handling of hazardous materials.

6. Employment Skills

Students will understand career paths and strategies for obtaining employment within their chosen fields. They will assume responsibility for professional growth. They will understand and promote the role of their field within a productive society, including professional organizations.

7. Technology Skills

Students will understand and adapt to changing technology by identifying, learning, and applying new skills to improve job performance. They will effectively employ technologies relevant to their field. 
T

Credentials

All agriculture teachers at Atwater High School are appropriately credentialed for the courses that they instruct. Each instructor has his or her agriculture specialist credential in addition to their clear credential and single subject credential in agriculture. As to date, three out of the five teachers have their Master's in Agriculture Education. The other two advisors are in the process of completing their Master's program in the next year.

Attached you will find:

- Copy of my credentials 


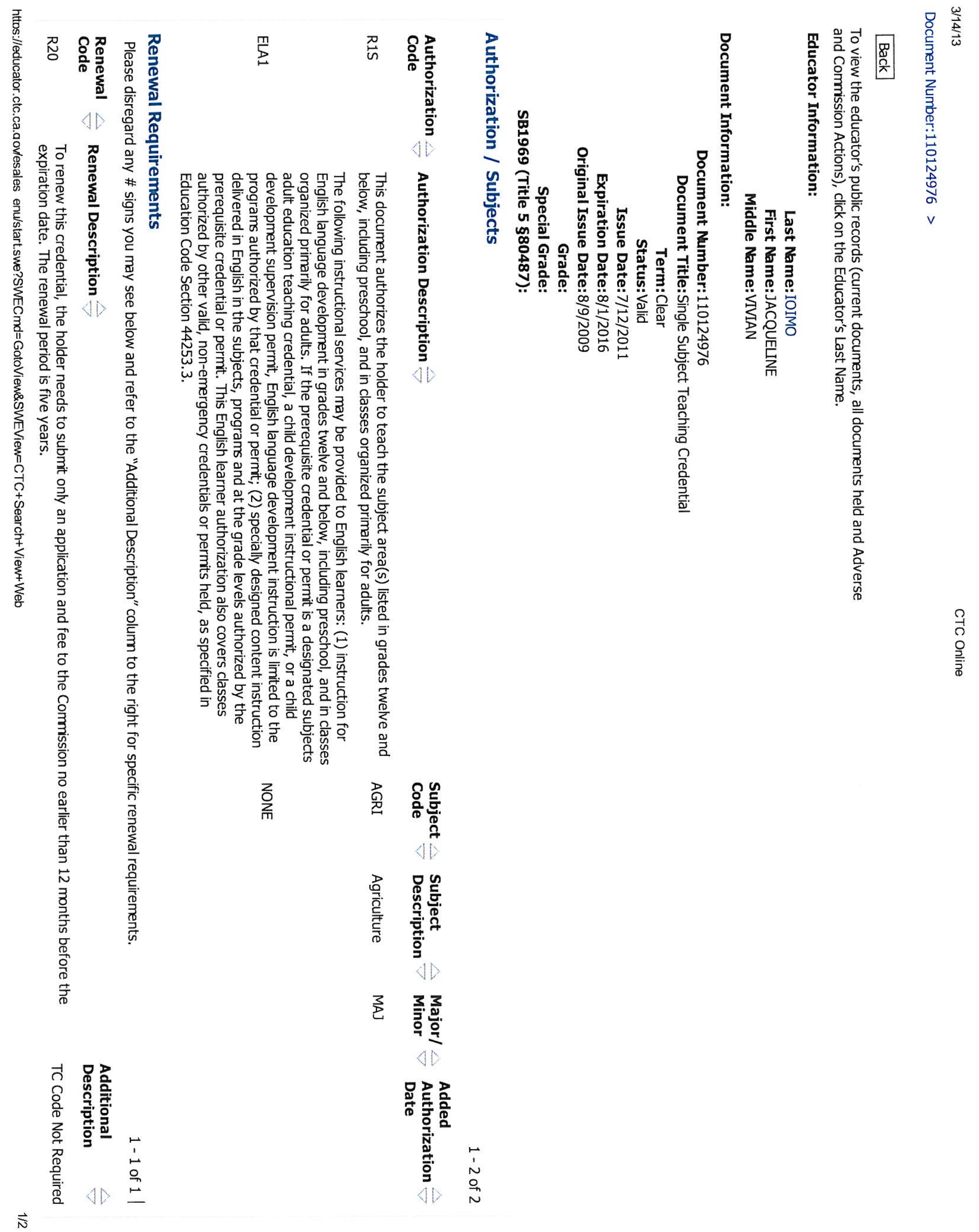




\section{$\underline{\mathrm{U}}$ \\ Department \& Chapter Activities}

Atwater FFA participates in many activities throughout the year. Atwater FFA participates in events such as public speaking, judging, leadership conferences and chapter meetings. These students participate in events that are held at the chapter, sectional, regional, state and national level.

\section{Attached you will find:}

- 2012-2013 Calendar of Activities

- 2012 Chapter Activities Checklist

- 2012 Department Activities 


\section{Calendar of Activities}

June

Merced

Ag Staff

20-24

CATA Conference

San Luis Obispo

Ag Staff

July

11-16

California State Fair

Sacramento

Ag Staff

August

8-10

20

22

27

TBA

\section{September}

3

6

7

5

11

25

21

20

19

TBA

TBA

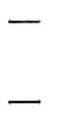

\section{October}

\section{3}

6-7

12

12-13

3

17

18

26

19

22-26

24

$7 \mid$ Page
Chapter Officer Retreat

First Day of School

Chapter Officer Meeting

Placemat Ads Fundraiser

Open Shop Night \#1

Labor Day Holiday

Homecoming Float Meeting

Placemat Ads Fundraiser Ends

Chapter Officer Meeting

Merced-Mariposa CATA \& FFA SOLC

Central Region SOLC

FFA "Pool Party" Mtg

AHS Football Game BBQ

Take-Out BBQ \#1

Chapter Officer Meeting

Open Shop Night \#2

Open Shop Night \#3

Greenhand Leadership Conference.

FFA COLC

AHS Homecoming Game Parade/BBQ

FFA Fall Plant Sale

Chapter Officer Meeting

Opening and Closing Ceremonies

Atwater Beautification Day

AHS Football Game BBQ

End of $1^{\text {st }}$ Quarter

National FFA Finals (Agronomy)

Chapter Officer Mtg
Lake Tahoe

Ag Dept.

Ag Class

Ag Shops

Ag Dept.

AHS

Ag Dept.

Merced College

Merced College

AHS

AHS

AHS

Ag Dept.

Ag Shops

Ag Shops

(no school)

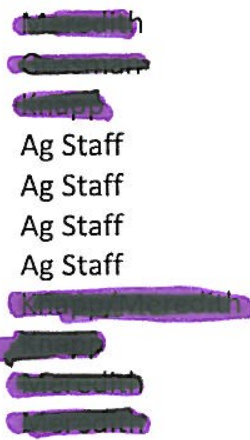

Modesto

Denair

AHS

AHS Ag Dept.

Ag. Dept.

Gustine

Atwater

AHS

5:00 PM

Indiana / Wash DC

AHS

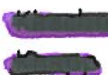

Ag Staff

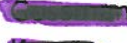

Ag Staff

Ag. Staff

Ag Staff

Ag Staff

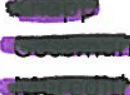

and

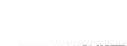

Ag Staff

Ag Staff

Ag Staff

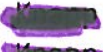




\section{Calendar of Activities}

\section{November}

7

3

7

6

12

13-14

16-17

17

\section{December}

\section{5}

6

8

18

20

21

24-31

TBA

TBA

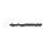

\section{January}

\section{1-4}

7

15
FFA “Corn Maze” Chapter Meeting MJC Cotton FFA Field Day

Open Shop Night \#4

Open Shop Night \#5

CATA Section Mtg

Cotton Judging State Finals

Chapter Officer Mtg

Greenhand / Chapter Degree Ceremony

Veterans Day

Local Project Competition

CATA Road Show

CATA Regional Meeting

Thanksgiving Break

Chapter Officer Mtg

Sectional Project Competition

Open Shop Night \#6

Open Shop Night \#7

Chapter Officer Mtg

Take-Out BBQ \#2

Mariposa Creed Speaking Contest

FFA Morning Wave Chapter Mtg

AHS End of Semester

FFA "Basketball" Trip

AHS Winter Break

Open Shop Night \#8

Open Shop Night \#9

AHS Winter Break

$2^{\text {nd }}$ Semester Starts

FFA M/M Section Manuscripts Due
Ag Dept.

AHS

Ag Shops

Ag Shops

Woolgrowers

Fresno State

AHS

BCHS Theater

AHS

Cosumnes River College

Cosumnes River College

AHS

Ag. Dept.

Ag Shops

Ag Shops

AHS

AHS

Mariposa HS

Ag Dept.

Oakland

Ag Shops

Ag Shops

(no school)

Ag. Staff

Ag Staff

Ag Staff

Ag Staff

Ag Staff

(no school)
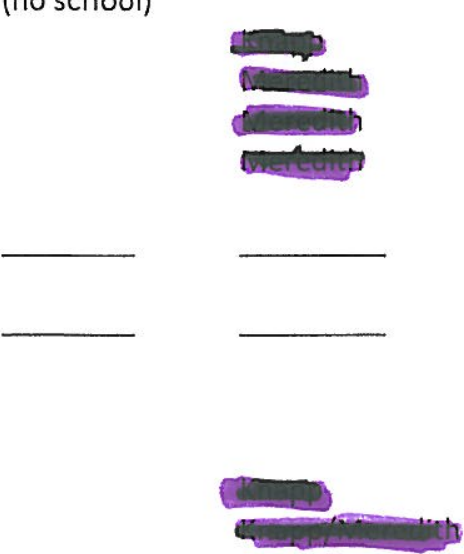

Ag Staff

Ag Staff

Ag Staff

(no school)

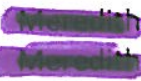

(no school)

AHS Ag Dep.

Ag Staff 


\section{Calendar of Activities}

9

$17-18$

21

16

26

23

23

28-31

TBA

TBA

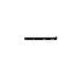

\section{February}

6

1

2

13

15-18

15-16

18

27

20

21

22

23

TBA

TBA

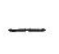

\section{March}

\section{2}

13

14

15

9

26

16

27

19

23

TBA
Chapter Officer Mtg

CATA Governing Board Mtg

Martin Luther King Jr. Holiday

FFA "Movie Night" Chapter Meeting

FFA "Super Saturday"

Chapter Officer Mtg

Merced Fair Student Parent Exhibitor Mtg

Merced Fair Deposit Week

Open Shop Night \#10

Open Shop Night \#11

Project Comp. Banquet

Merced Fair Deposit Week (cont.)

Arbuckle Field Day

Chapter Officer Mtg

Presidents Weekend Holiday

FFA MFE/ALA Conference

Presidents Weekend Holiday

Chapter Officer Mtg

FFA Week Basketball Tourney

FFA Week Ag Olympics

FFA Week "Kiss the Pig"

FFA / CATA Regional Meeting

Ag Booster Dinner

Open Shop Night \#12

Open Shop Night \#13

UC Davis Field Day

Chapter Officer Mtg

FFA Take-Out Dinner \#3

End of $3^{\text {rd }}$ Quarter (AHS)

Chico State Field Day

Central Region (south) State Degrees

Merced College Field Day

Chapter Officer Mtg

FFA "Bowling" Chapter Meeting

Modesto JC Field Day

Open Shop Night \#14
AHS

Galt

AHS

Merced College

AHS

Ag Dept.

Ag Shops

Ag Shops

(No school)

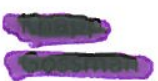

Ag Staff

Ag Staff

Ag Staff

Ag Staff
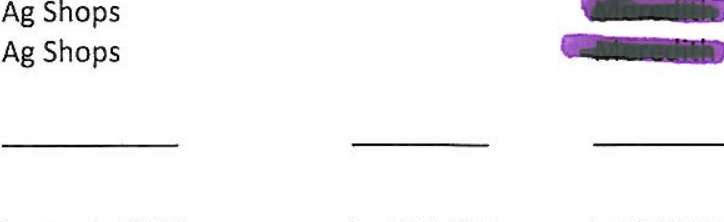

Merced Fairgrounds

Ag Staff

Ag Staff

Arbuckle

AHS

Modesto

(no school)

Ag. Staff

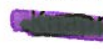

(no school)

AHS

TBD

AHS

AHS

Merced College

APC Hall

Ag Shops

AG Shops

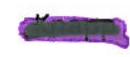

Ag Staff

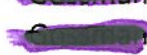

Ag Staff

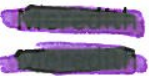

Ag Staff

UC Davis

AHS

Ag Dept.

Chico

Ag Staff

Ag Staff

Ag Staff

Merced College

AHS

Bellevue Bowl

Ag Staff

Ag Staff

Ag Shops 


\section{Calendar of Activities}
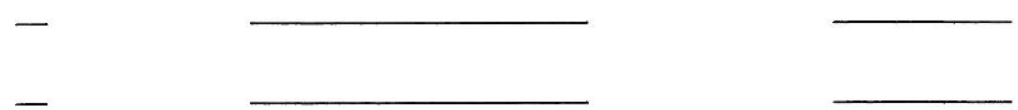

April

AHS Spring Recess

Chapter Officer Mtg

Cosumnes River College Field Day Sectional CO/OP \& CATA Mtg

Reedley College Field Day FFA "Burrito Bingo" Chapter Meeting Fresno State Field Day FFA State Leadership Conference Chapter officer mtg Open Shop Night \#16 Open Shop Night \#17

\section{AHS}

(no school)

Cosumnes River College

Livingston

Reedley College

AHS Gym

Fresno State

Fresno State

Ag Shop

Ag Shop

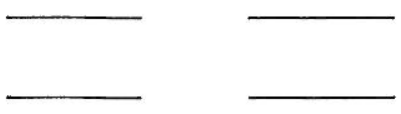

Ag Staff Ag Staff Ag Staff Ag Staff Ag Staff Ag Staff
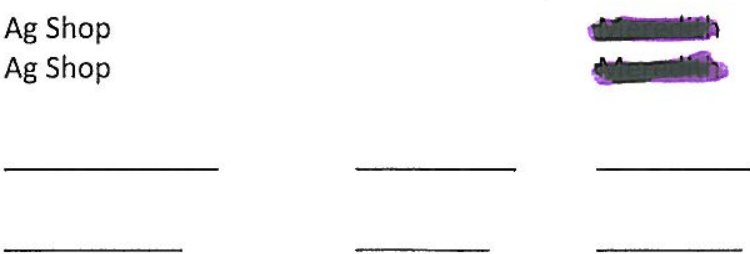

May

1

4

7

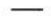

June

6

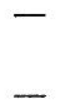

Chapter Officer Mtg

Cal-Poly SLO State Finals Field Day

'13-'14 Chapter Officer Apps Due

FFA Take-Out Dinner \#4

FFA Spring Plant Sale

Chapter Officer Mtg

Chapter Awards Banquet

School Holiday

Open Shop Night \#18

Open Shop Night \#19

Last Day of School / Graduation

Point Award Trip

Merced County Fair

CATA Conference
TBA

Merced

Cal Poly, SLO
AHS

San Luis Obispo

Ag Dept.

Ag Dept.

Ag Dept.

AHS

TBA

Ag Shop

Ag Shop

TBA

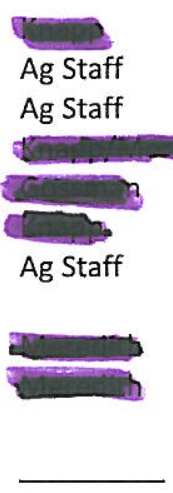

Ag Staff

Ag Staff

Ag Staff 


\begin{tabular}{|c|c|c|}
\hline \multicolumn{3}{|c|}{ ANNUAL FFA CHAPTER ACTIVITIES CHECK SHEET } \\
\hline \multicolumn{3}{|l|}{ Must meet at least 12 areas } \\
\hline LEADERSHIP ACTIVITY & YES & NO \\
\hline Attended State Leadership Conference & $\mathbf{x}$ & \\
\hline Attended Regional Meeting & $\mathbf{x}$ & \\
\hline Attended Regional Leadership Conference & $\mathbf{x}$ & \\
\hline Attended Greenhand Conference & $\mathbf{x}$ & \\
\hline Attended Made for Excellence Conference & $\mathbf{x}$ & \\
\hline Attended Advanced Leadership Academy & $\mathbf{x}$ & \\
\hline Attended Sacramento Experience & & $\mathbf{x}$ \\
\hline Participated in Opening-Closing Contest - Sectional & $\mathbf{x}$ & \\
\hline Participated in Best Informed Contest - Sectional & $\mathbf{x}$ & \\
\hline Participated in Parliamentary Pro Contests - Sectional & & $\mathbf{x}$ \\
\hline Participated in Prepared Public Speaking - Sectional & $\mathbf{x}$ & \\
\hline Participated in Extemporaneous Speaking - Sectional & & $\mathbf{x}$ \\
\hline Participated in Creed Recitation - Sectional & $\mathbf{x}$ & \\
\hline Participated in Job Interview Contest - Sectional & $\mathbf{x}$ & \\
\hline Participated in Agricultural COOP Quiz Contest - Sectional & $\mathbf{x}$ & \\
\hline Submitted State FFA Degree Application & $\mathbf{x}$ & \\
\hline Submitted American FFA Degree Application & $x$ & \\
\hline Submitted Proficiency Application - Sectional or Regional & $\mathbf{x}$ & \\
\hline Submitted Chapter Award Application - Sectional or Regional & $\mathbf{x}$ & \\
\hline Participated in Project Competition - Sectional & $\mathbf{x}$ & \\
\hline Participated in any FFA Judging Activity (other than above) & $\mathbf{x}$ & \\
\hline Participated in any other FFA Sectional Activity & $\mathbf{x}$ & \\
\hline Participated in Local Leadership Activities (3 maximum - list below) & $\mathbf{x}$ & \\
\hline 1 FFA Offficer Training & $\mathrm{x}$ & \\
\hline 2 Atwater Beautification & $\mathrm{x}$ & \\
\hline 3 8th Grade Tour & $\mathbf{x}$ & \\
\hline TOTAL AREAS MET & 23 & \\
\hline
\end{tabular}




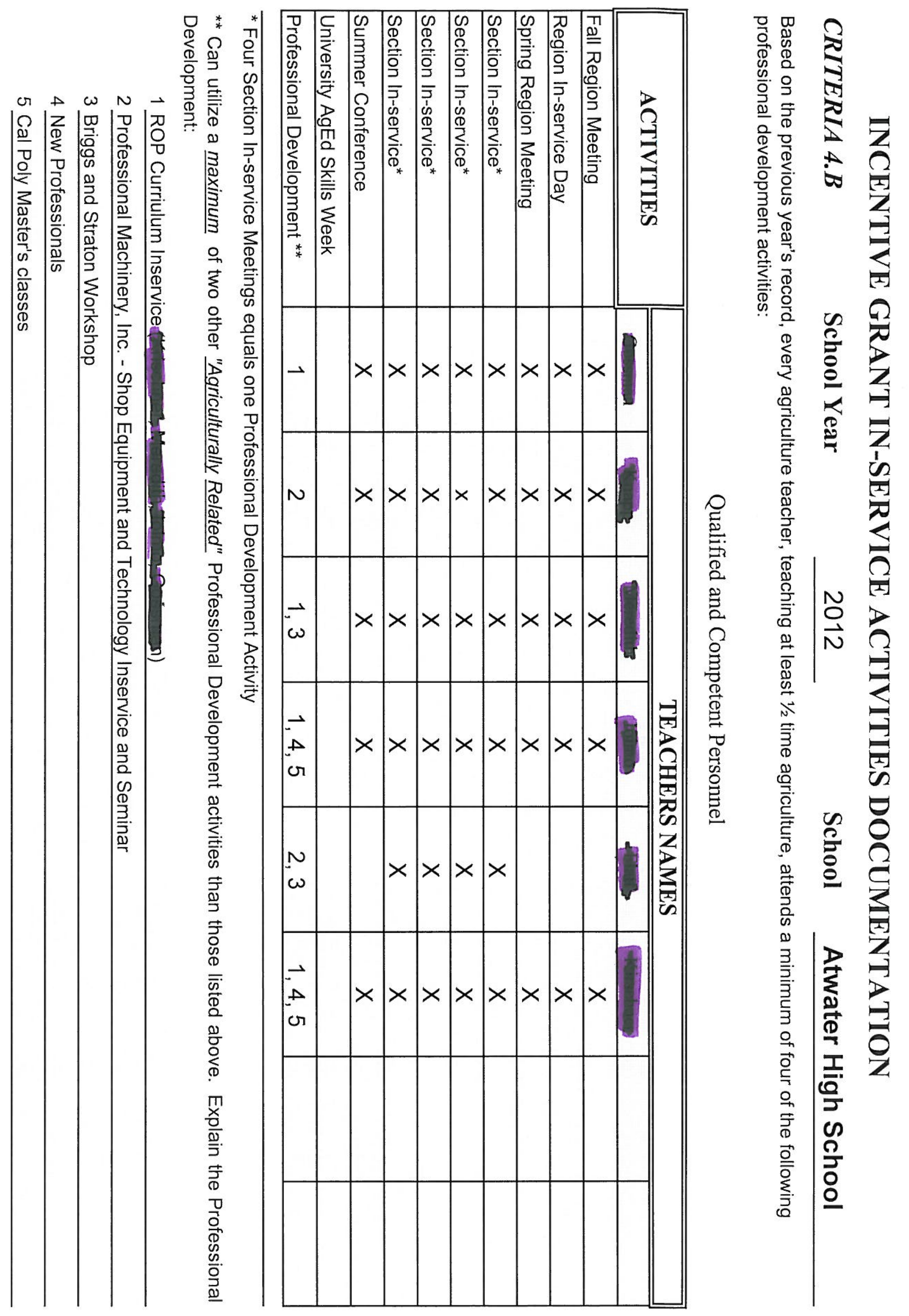




\section{$\underline{\mathbf{V}}$ \\ Daily Log}

I keep a desk top calendar, a wall calendar, and a personal planner where I write down department, collaboration or any other meetings that I might need to attend. I also keep track of $S A E$ visits and FFA activities via my smart phone.

I do log in my extra hours on our Ag Teacher Time Card that our district provides us that tracks the extra 40 hours of work.

\section{Attached you will find:}

- Picture of wall calendar

- Ag Teacher Time Card 


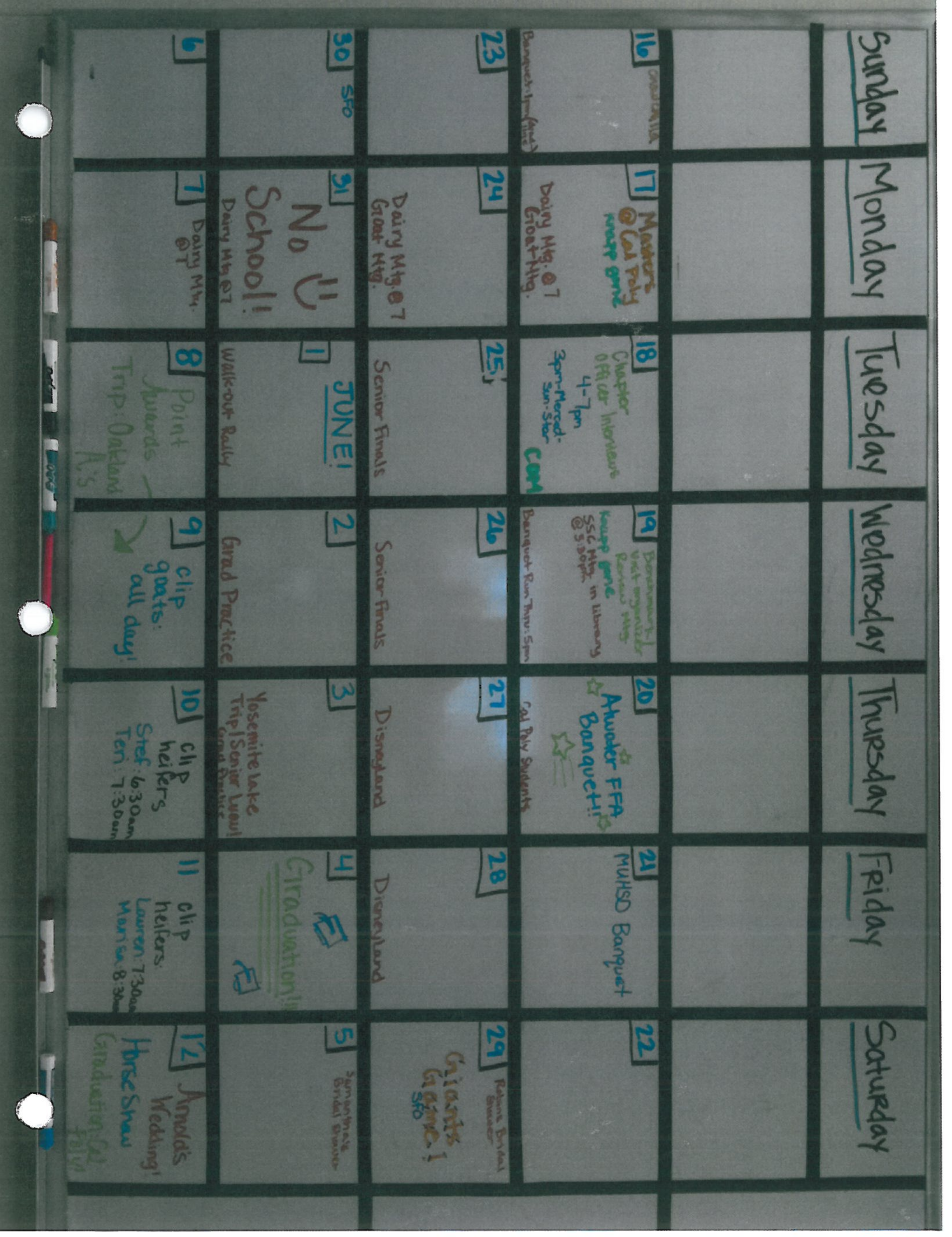



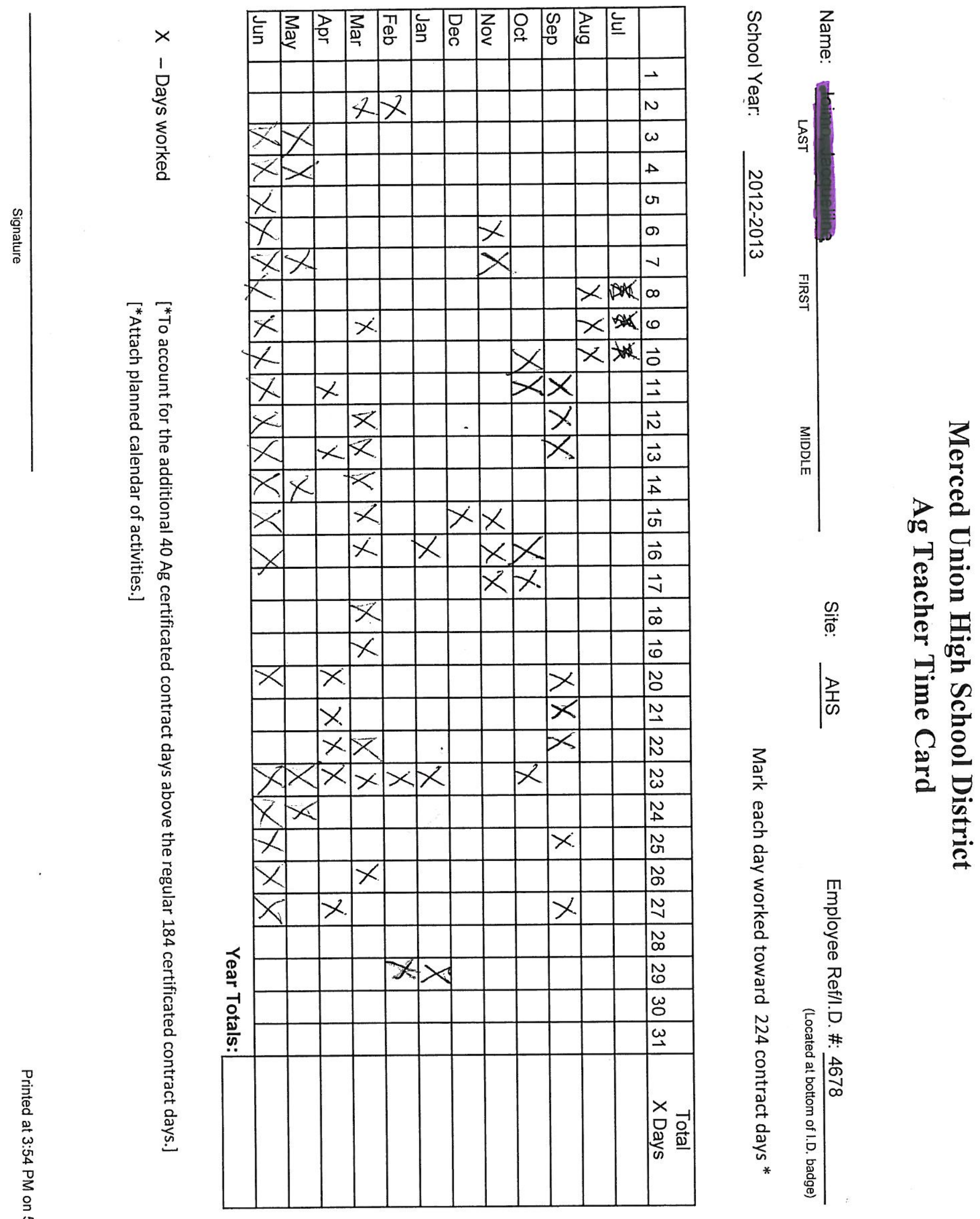


\section{$\underline{\mathbf{W}}$ \\ Professional Development}

Professional growth and in-service activities is key for new teachers. Each year the instructors at Atwater High are keep track of their professional development. The information is used in the completion of the Incentive Grant In-service Activities Documentation. It is kept on file with the state as well as our department. Everyone in the department attends professional development events whenever they are given (Regional "Road Shows", Regional Meetings, CATA Summer Skills, etc.)

Listed Below is the Profession Development I have attended / plan on attending for the 2012-2013 School Year:

- Early Adopters Meeting for the Common Core

- Fall Regional Meeting

- Regional In-service Day "Road Show"

- Early Adopters for the Common Core Leadership Conference

- Spring Regional Meeting

- Sectional In-services

- CATA Summer Conference

- AIFD Floral Design Certification Meeting 


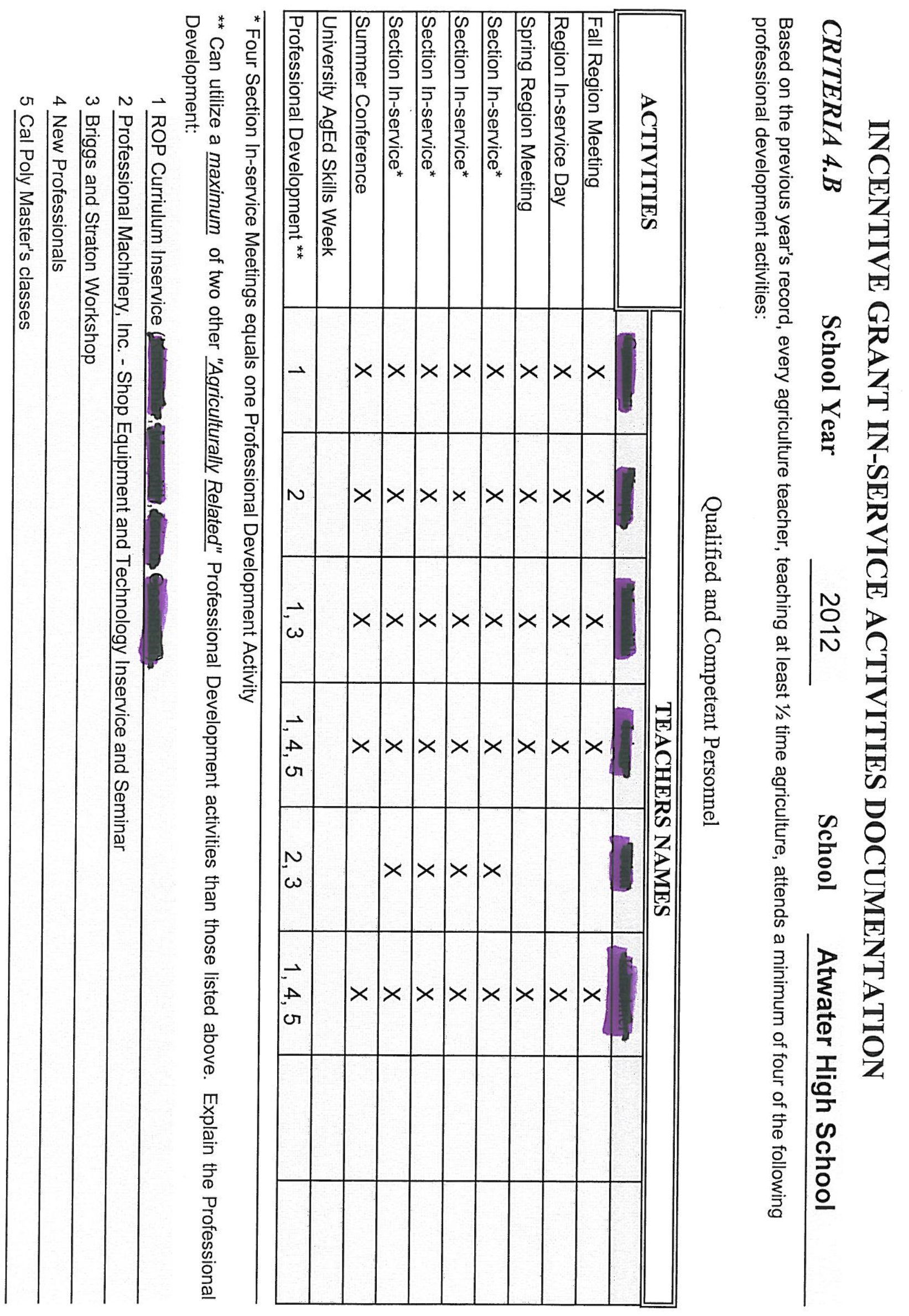




\section{$\underline{\mathbf{X}}$ \\ $\underline{\text { R-2 Report }}$}

Atwater FFA is well integrated considering demographics for our area. For the 2012-2013 school year we had 858 students enrolled in our agriculture program. In the past four years, Atwater has hired one new teacher and will possibly hire another instructor for the 2013-14 year.

Retention is increasing due to recruitment, marketing of program and overall program improvement. We look forward to have continual success in the Atwater FFA Program.

\section{Attached you will find:}

- R2 Data Chart 


\section{R2 Teacher Information Atwater HS,Atwater Year: 2012}

\begin{tabular}{|l|l|l|l|l|c|c|c|c|c|c|c|}
\hline $\begin{array}{l}\text { Last } \\
\text { Name }\end{array}$ & $\begin{array}{l}\text { First } \\
\text { Name }\end{array}$ & MI & Gender & Ethnicity & $\begin{array}{c}\text { Total } \\
\text { Years } \\
\text { Teaching } \\
\text { Ag. }\end{array}$ & Credential Type & $\begin{array}{c}\text { 9-Month } \\
\text { Salary }\end{array}$ & $\begin{array}{c}\text { Extended } \\
\text { Contract } \\
\text { Stipend }\end{array}$ & $\begin{array}{c}\text { FFA } \\
\text { Stipend }\end{array}$ & $\begin{array}{c}\text { Department } \\
\text { Head } \\
\text { Stipend }\end{array}$ & $\begin{array}{c}\text { SOE } \\
\text { Period }\end{array}$ \\
\hline & Female & White & 3 & $\begin{array}{c}\text { Agriculture } \\
\text { Specialist }\end{array}$ & 49516 & 9903 & 0 & 0 \\
\hline & L & Male & White & 11 & $\begin{array}{c}\text { Agriculture } \\
\text { Specialist }\end{array}$ & 83960 & 13993 & 0 & 1220 & $\mathrm{~N}$ \\
\hline & $\mathrm{J}$ & Male & White & 9 & $\begin{array}{c}\text { Agriculture } \\
\text { Specialist }\end{array}$ & 63832 & 12766 & 0 & 0 \\
\hline
\end{tabular}

\begin{tabular}{|l|l|l|l|l|l|}
\hline \hline Schedule & Period & Beginning Time & Course Title & Enrollment & Type \\
\hline 1 & 1 & $8: 00$ & Advanced Sm Eng/Power & 31 & Ag Mechanics \\
\hline 1 & 2 & $8: 57$ & Ag Wood 1 & 29 & Ag Mechanics \\
\hline 1 & 3 & $9: 54$ & Ag Wood 2/3 & 18 & Ag Mechanics \\
\hline 1 & 4 & $10: 51$ & Smlengs/pwreq & 24 & Ag Mechanics \\
\hline 1 & 5 & $12: 49$ & Weld Ag Shop Skills & 36 & Ag Mechanics \\
\hline
\end{tabular}

\begin{tabular}{|l|l|l|l|l|l|}
\hline Schedule & Period & Beginning Time & Course Title & Enrollment & Type \\
\hline 1 & 1 & $8: 00$ & Horticulture & 31 & O.H./Floral \\
\hline 1 & 2 & $8: 57$ & Ag Earth Science & 39 & Plant/Soil Science \\
\hline 1 & 3 & $9: 54$ & Ag Earth Science & 37 & Plant/Soil Science \\
\hline 1 & 4 & $10: 51$ & Ag Earth Science & 37 & Plant/Soil Science \\
\hline 1 & 5 & $12: 59$ & Ag Enviromental Science & 34 & Plant/Soil Science \\
\hline 1 & 6 & $1: 46$ & Ag Earth Science & 38 & Plant/Soil Science \\
\hline
\end{tabular}

\begin{tabular}{|l|l|l|l|l|l|}
\hline \multicolumn{5}{|l|}{} \\
\hline Schedule & Period & Beginning Time & Course Title & Enrollment & Type \\
\hline
\end{tabular}




\begin{tabular}{|l|l|l|l|l|l|}
1 & 1 & $8: 00$ & Art History Floral Design & 36 & O.H./Floral \\
\hline 1 & 2 & $8: 57$ & Ag Biology & 36 & Ag Biology \\
\hline 1 & 3 & $9: 54$ & Art History Floral Design & 36 & O.H./Floral \\
\hline 1 & 4 & $10: 51$ & Art History Floral Design & 36 & O.H./Floral \\
\hline 1 & 5 & $12: 49$ & Prep & 0 & Prep \\
\hline 1 & 6 & $1: 46$ & Ag Biology & 35 & Ag Biology \\
\hline
\end{tabular}

\begin{tabular}{|l|l|l|l|l|l|}
\hline Schedule & Period & Beginning Time & Course Title & Enrollment & Type \\
\hline 1 & 0 & $7: 00$ & Ag Leadership & 34 & Other Ag \\
\hline 1 & 1 & $8: 00$ & Ag Life Science & 37 & Agriscience I \\
\hline 1 & 2 & $8: 57$ & Ag Life Science & 33 & Agriscience I \\
\hline 1 & 3 & $9: 54$ & Prep & 0 & Prep \\
\hline 1 & 4 & $10: 51$ & ROP Vet Science & 37 & Animal Science \\
\hline 1 & 5 & $12: 49$ & Ag Life Science & 37 & Agriscience I \\
\hline
\end{tabular}

\begin{tabular}{|l|l|l|l|l|l|}
\hline Schedule & Period & Beginning Time & Course Title & Enrollment & Type \\
\hline 1 & 1 & $8: 00$ & Ag Biology & 41 & Ag Biology \\
\hline 1 & 2 & $8: 57$ & Ag Econ Govt & 36 & Other Ag \\
\hline 1 & 3 & $9: 54$ & Ag Biology & 41 & Ag Biology \\
\hline 1 & 4 & $10: 51$ & Ag Biology & 40 & Ag Biology \\
\hline 1 & 5 & $12: 49$ & Prep & 0 & Prep \\
\hline 1 & 6 & $1: 47$ & Ag Biology & 33 & Ag Biology \\
\hline
\end{tabular}

\begin{tabular}{|l|l|l|l|l|l|}
\hline Schedule & Period & Beginning Time & Course Title & Enrollment & Type \\
\hline 1 & 1 & $8: 00$ & Ag Shop Skills & 34 & Ag Mechanics \\
\hline 1 & 2 & $8: 57$ & Weld Tech 1 & 34 & Ag Mechanics \\
\hline 1 & 3 & $9: 54$ & Equip Const/Weld 2 & 26 & Ag Mechanics \\
\hline 1 & 4 & $10: 51$ & Ag Shop Skills & 33 & Ag Mechanics \\
\hline 1 & 5 & $12: 49$ & Prep & 0 & Prep \\
\hline 1 & 6 & $1: 46$ & Weld Tech 1 & 31 & Ag Mechanics \\
\hline
\end{tabular}

Printed: 3/15/2013 1:22:38 PM 


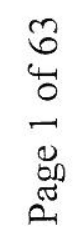

$\sum_{2}^{ \pm} x \times x \times x \times x$

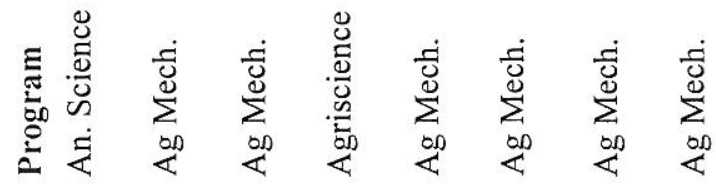

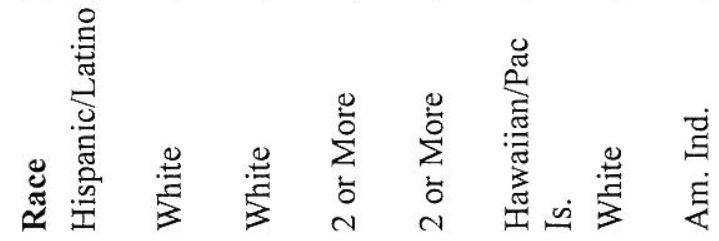
营x $x \quad x \quad x$

$\frac{2}{\overline{1}}$

重

莺山 $\Sigma \Sigma \Sigma \Sigma \Sigma \Sigma \Sigma \Sigma \Sigma$

윤의 =의 의

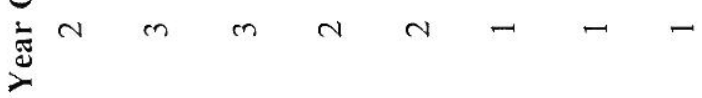

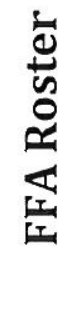

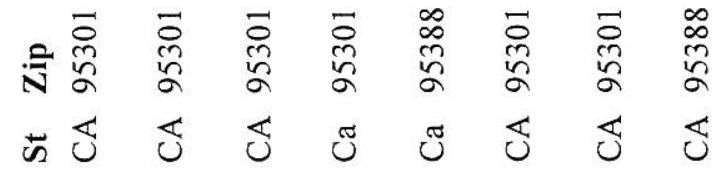

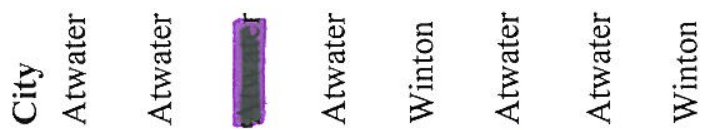

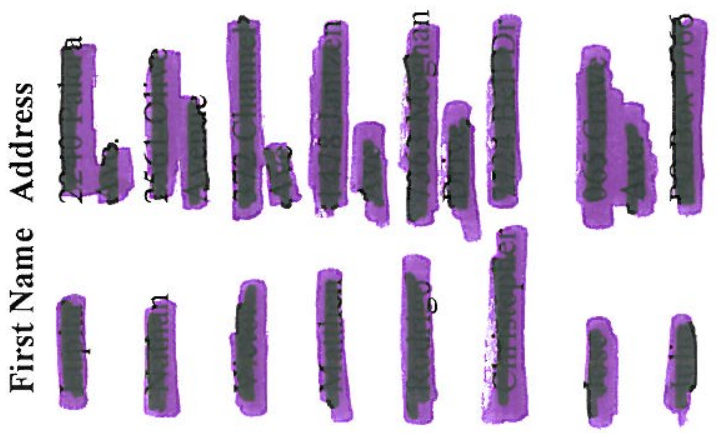

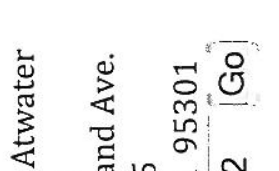

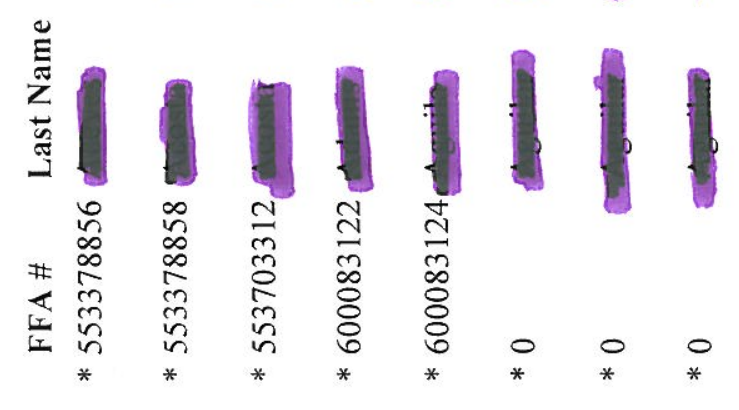




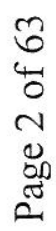

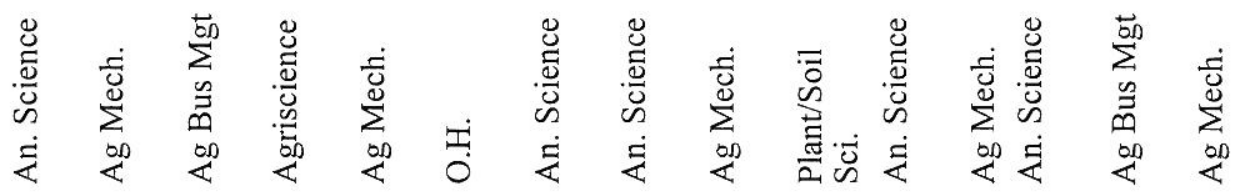

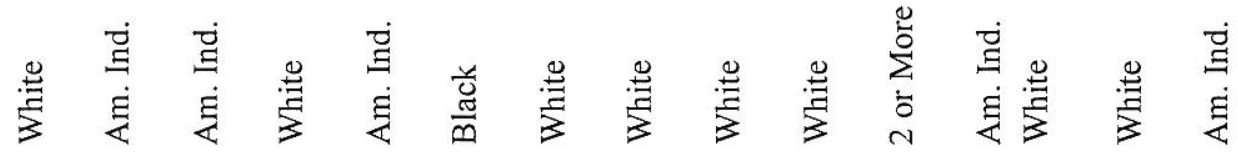

$x \times x \times x \times x \times x \times x \times x \times$

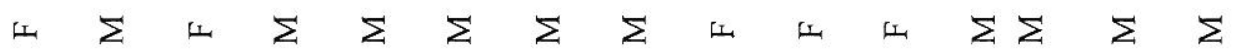

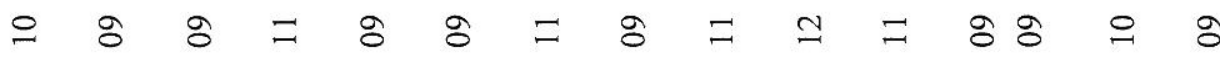

$4--4-m-m-m-4-$

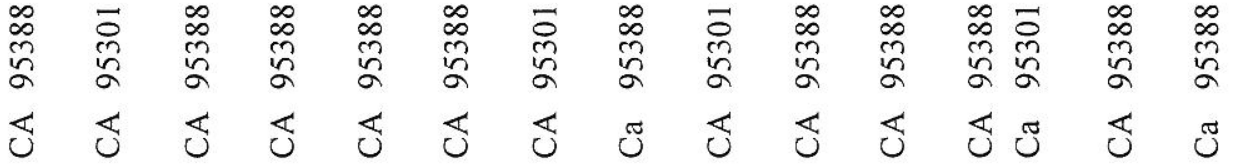

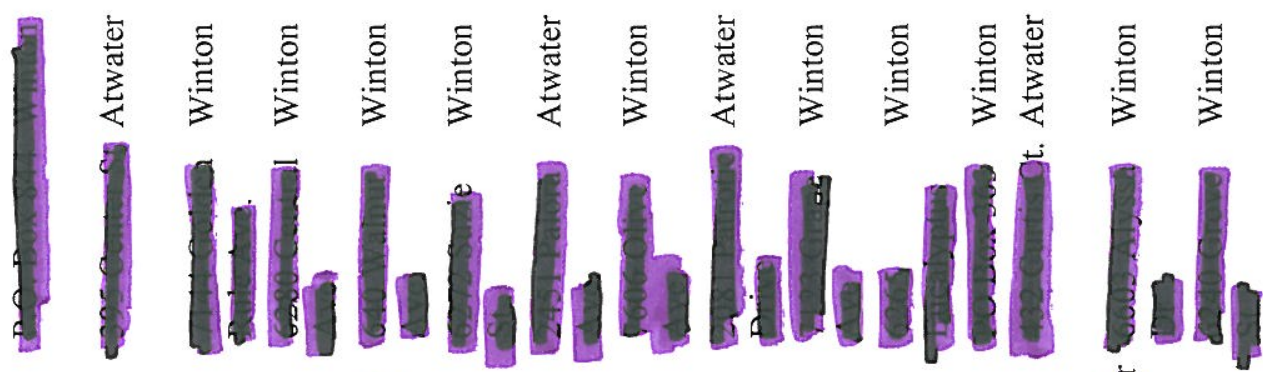
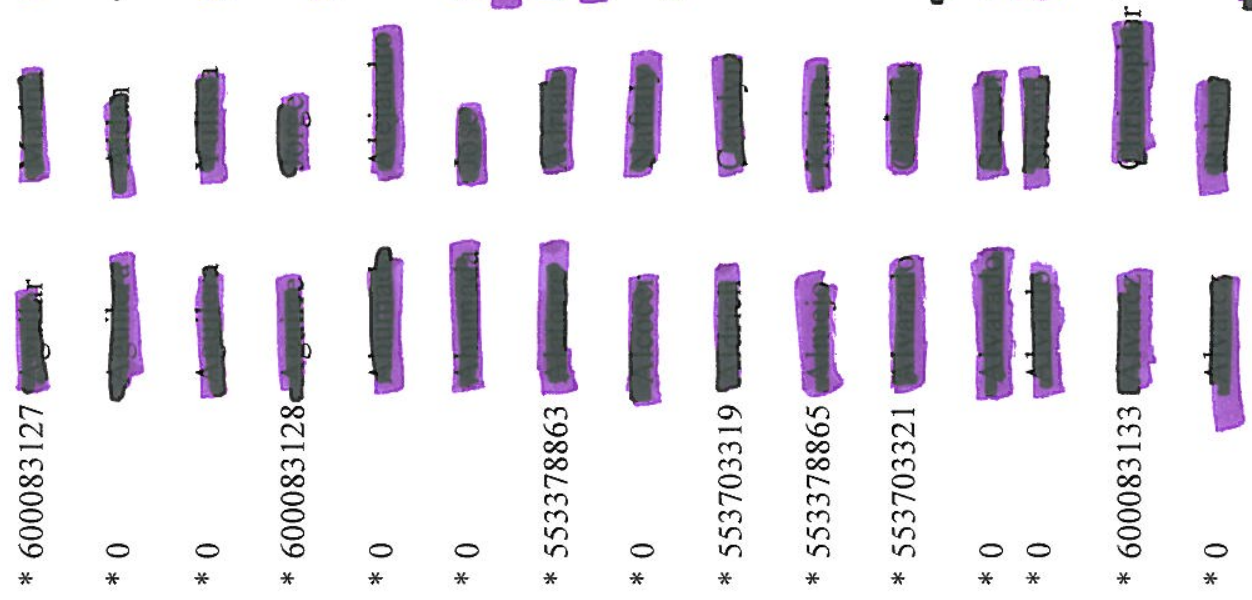


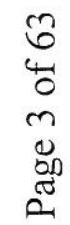

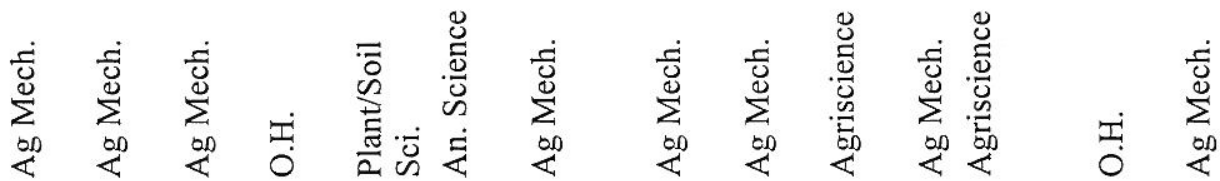

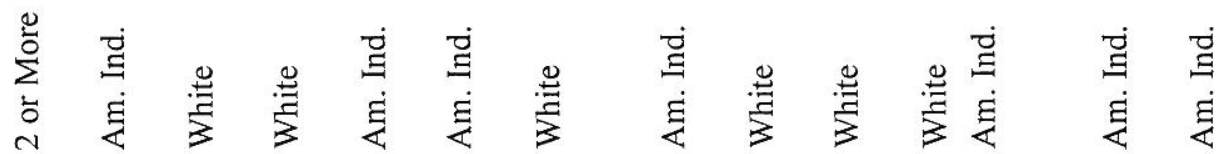

$\times \times \quad \times \quad \times \quad \times \quad \times \quad \times \quad \times \quad x \times \quad x \times$

$\Sigma \Sigma \Sigma \Sigma \omega \Sigma \Sigma \Sigma \Sigma \Sigma \Sigma \Sigma \Sigma 山 山 山 \Sigma$

$=8 \circ \simeq 8$ $8 \simeq g=8$ 8 g 8

$n-4-4-4-4-4-4$

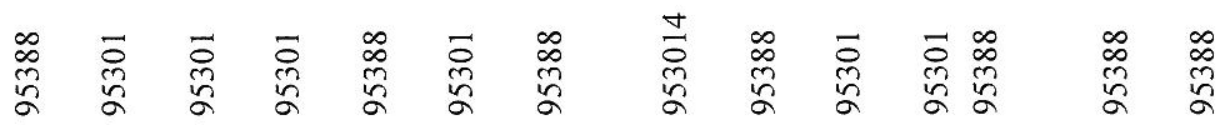

త

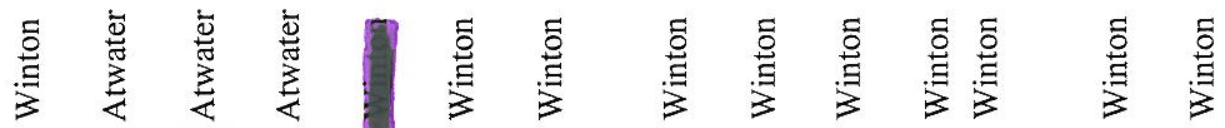

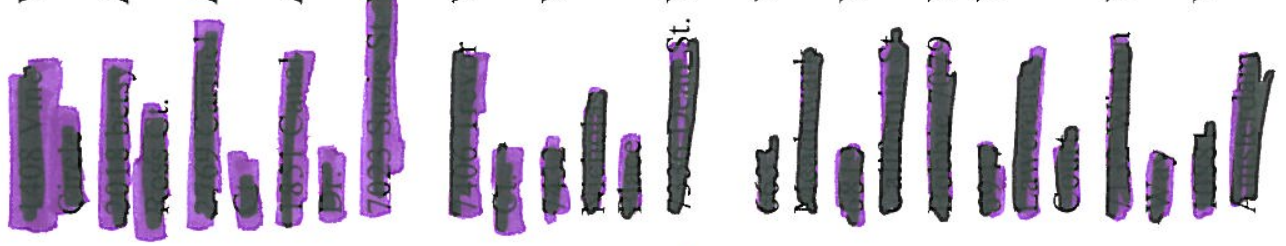

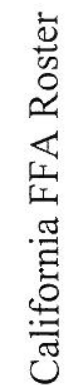




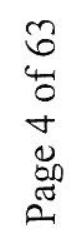

$x \quad x \quad x \quad x \quad x \quad x \quad x \quad x \quad x \quad x \quad x \quad x \quad x \quad x$

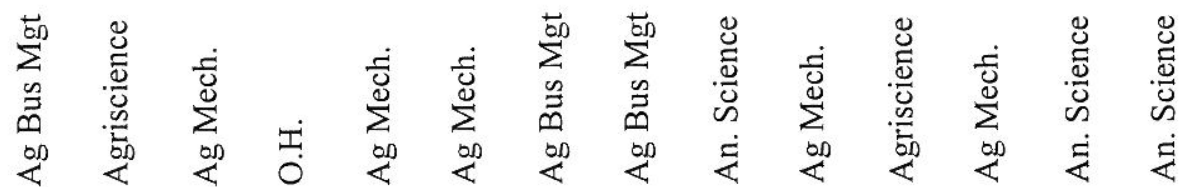

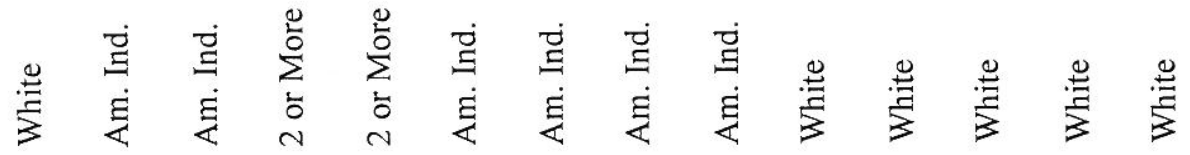

$\begin{array}{llllllllllllllll} & \times & \times & \times & \times & \times & \times & \times & \times & \times & \times\end{array}$

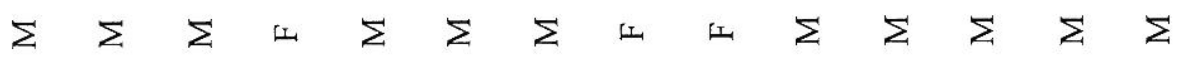

응ㅇㅇ 8 \& 8 \& 8 으응 8

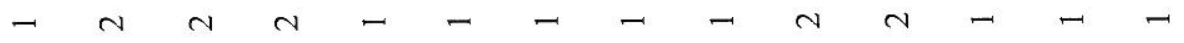

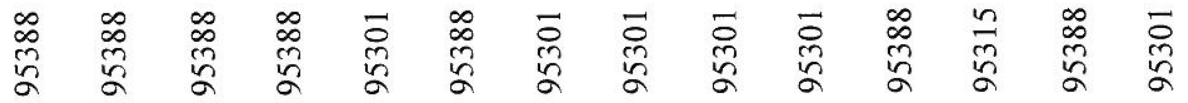

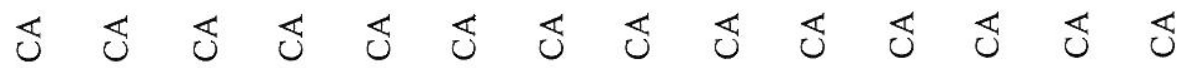

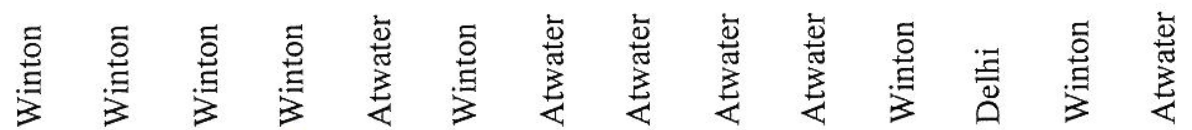

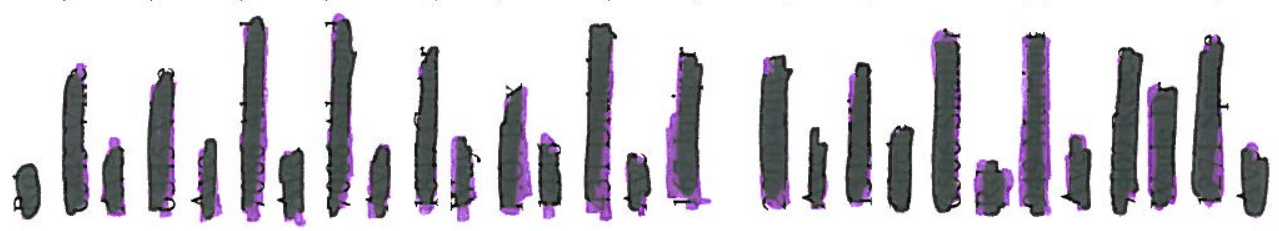

$|1,1||1||||||| 1$

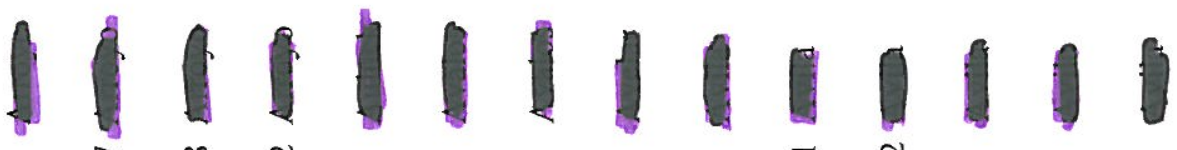

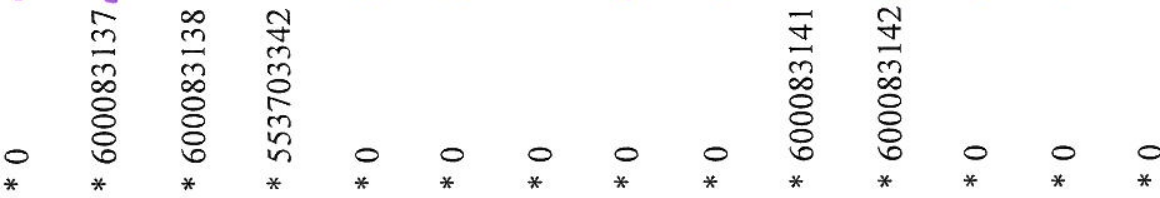




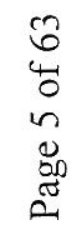

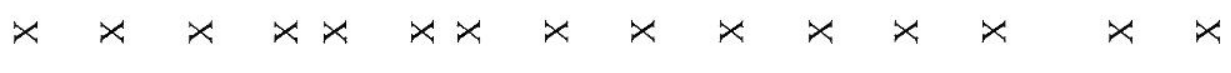

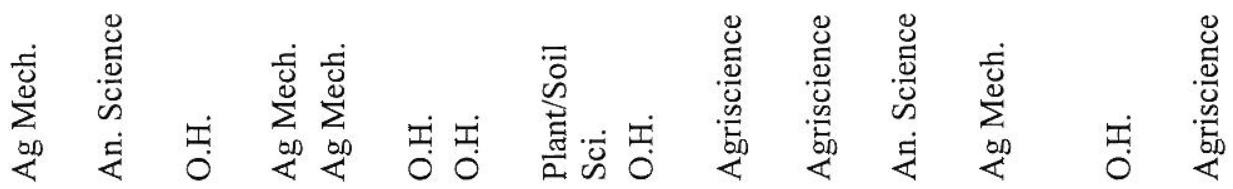

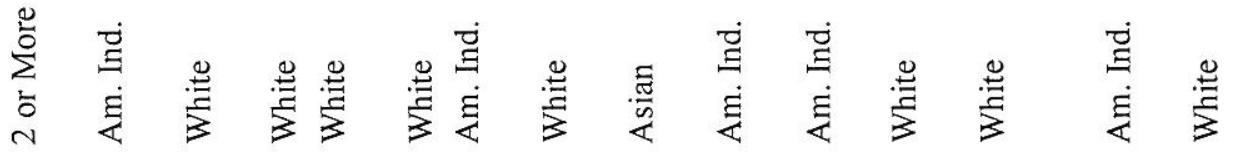

$x \times x \times x \times \quad \times \quad x \times x \quad x \times$

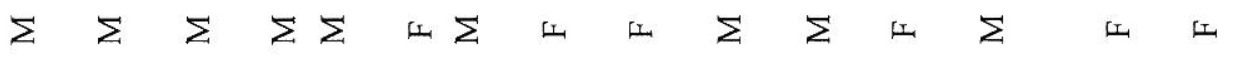

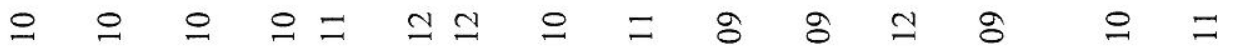

$4444 m+4-4,4-4 m$

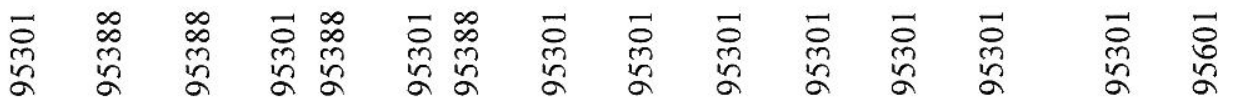

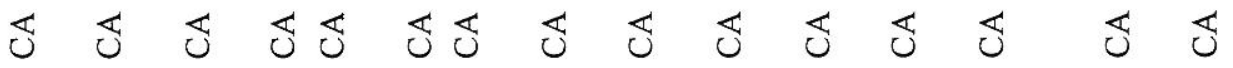

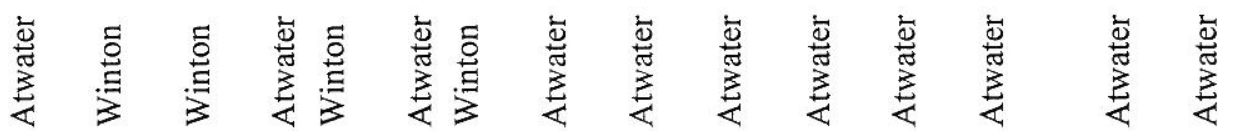

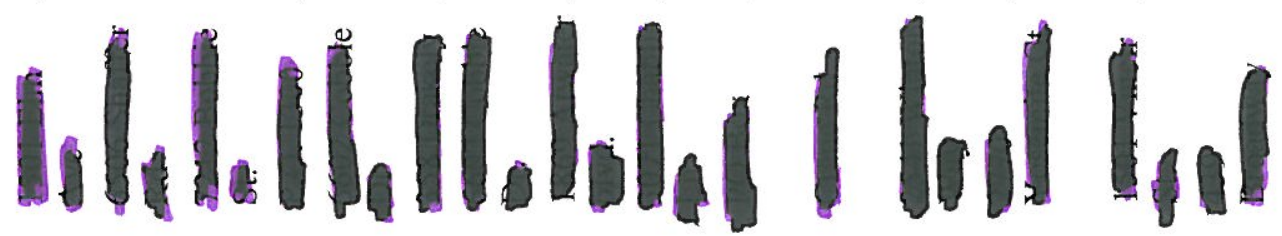

I | len || || | | | | | |

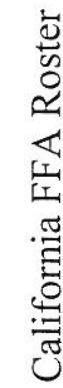

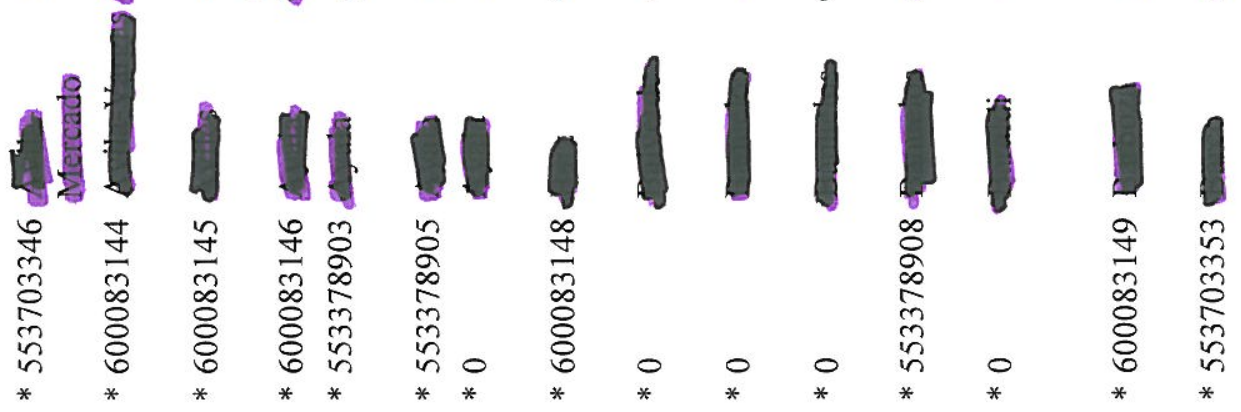


3
3
4
0
0
0
0
0
0
0

$x \times x \quad x \quad x \quad x \quad x \quad x \quad x \quad x \quad x \quad x \quad x \quad x$

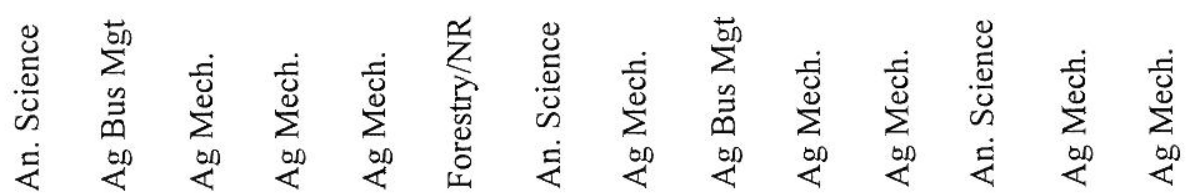

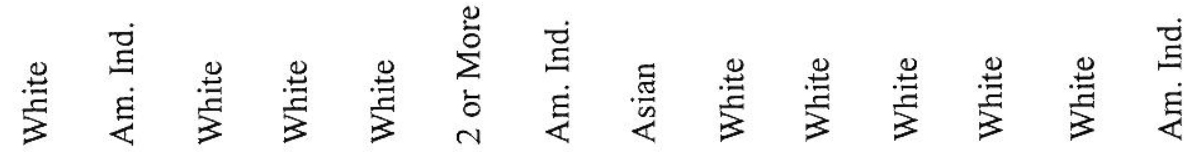
$\times \quad x \quad \times \quad x \quad x \quad x \quad x \quad x \quad x \quad x$

$\Sigma \Sigma \Sigma \Sigma \Sigma \Sigma \Sigma \Sigma \Sigma \Sigma \Sigma \Sigma \Sigma 山 \Sigma \Sigma$

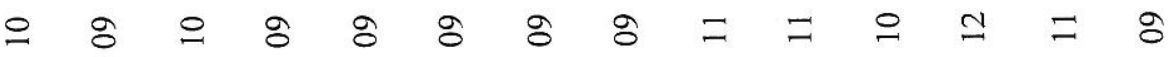

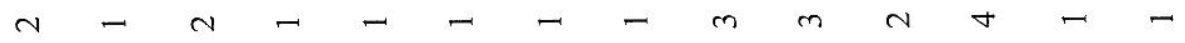

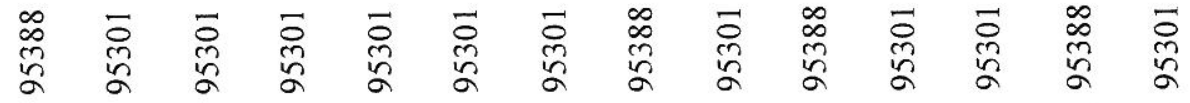

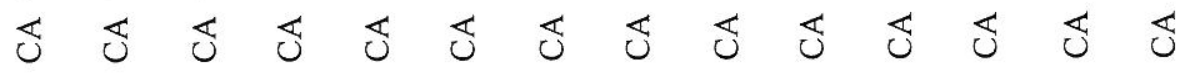

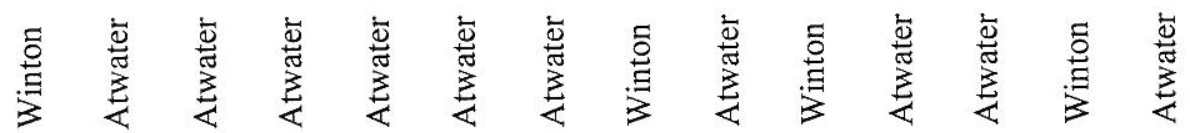
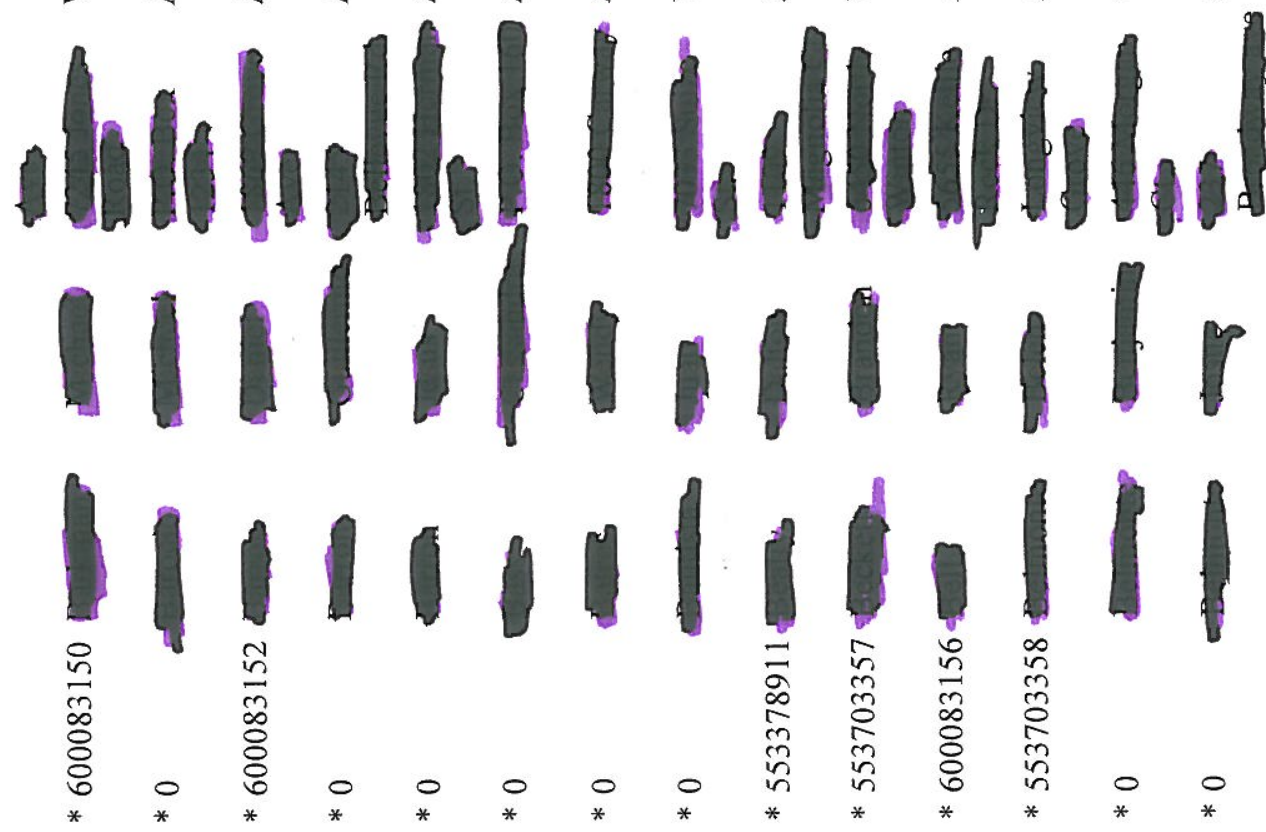


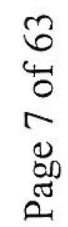

$x \times x \times x \times x \times x \times x \quad x \quad x \quad x \quad x \quad x$

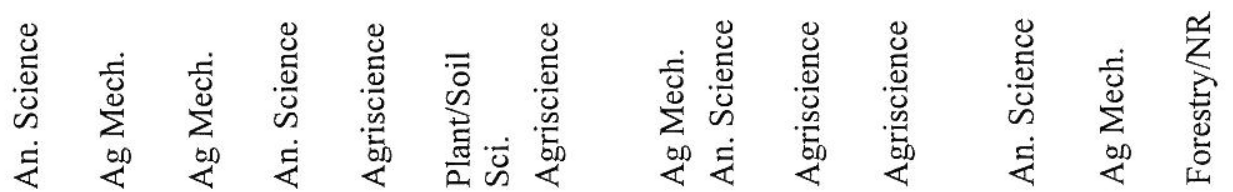

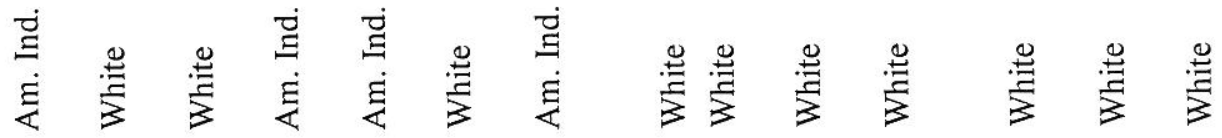

$x \times x \quad x \quad x$

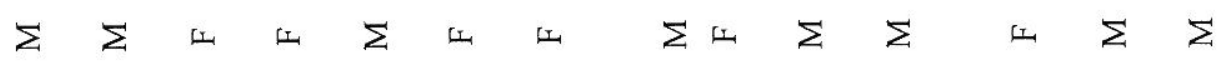

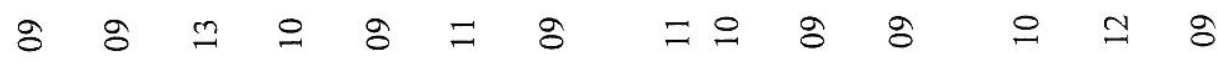

$-\quad m+n-m+n-4+$

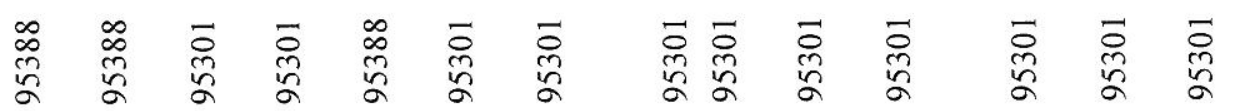

త

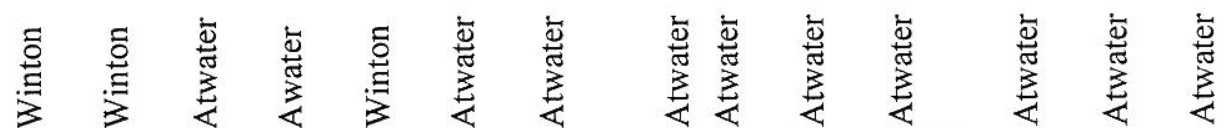

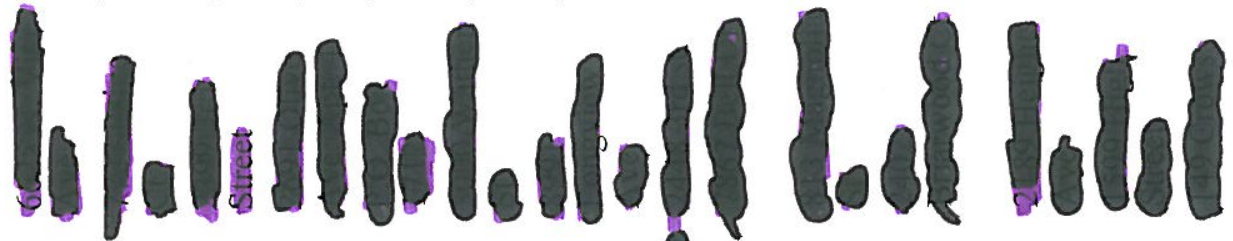

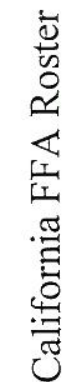
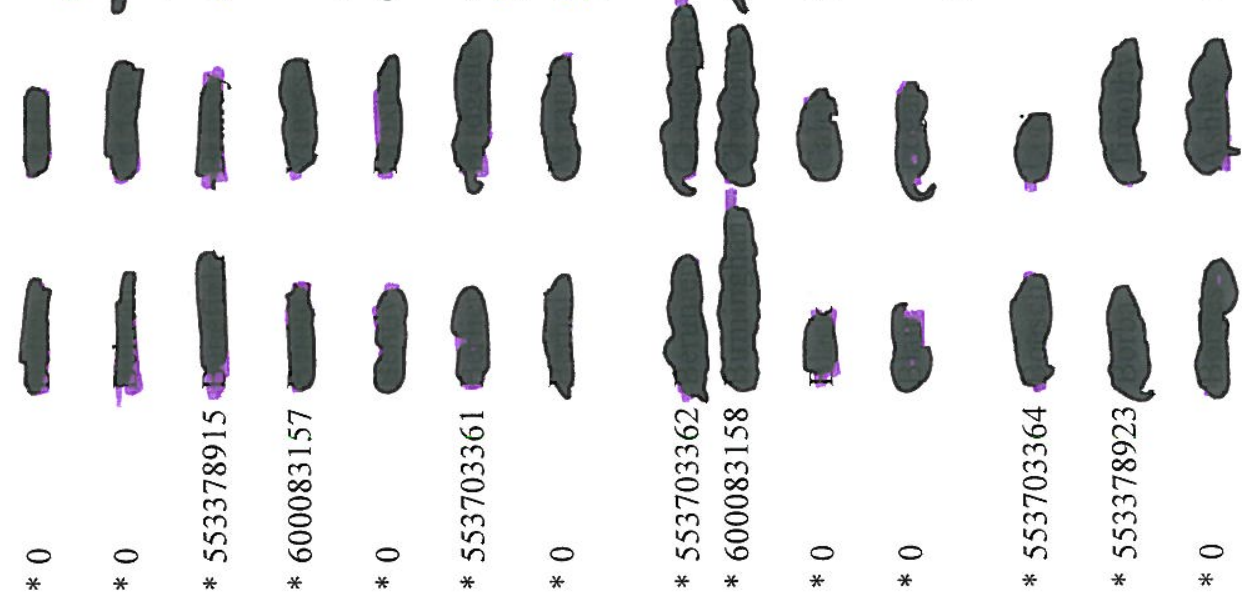
30
4
0
$\infty$
0
0
0
0

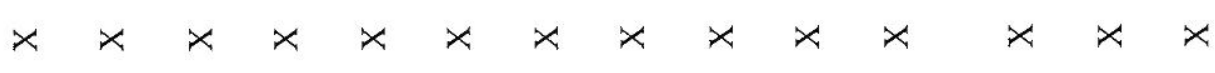

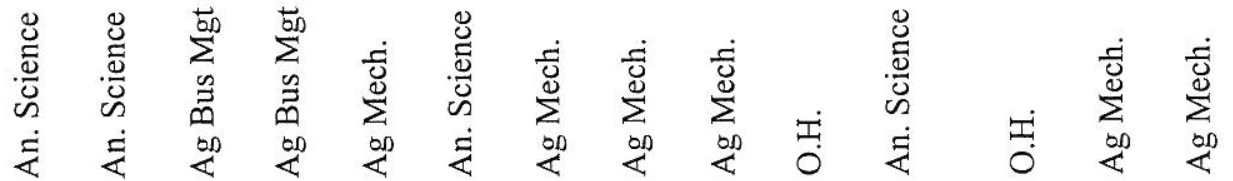

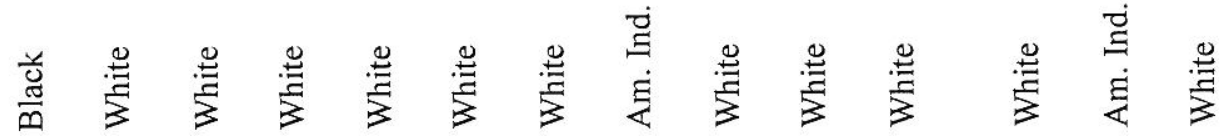
$x \quad x \quad x \quad x$

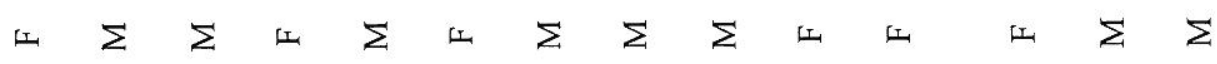

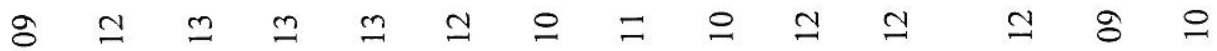

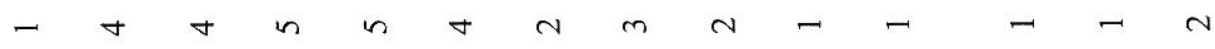

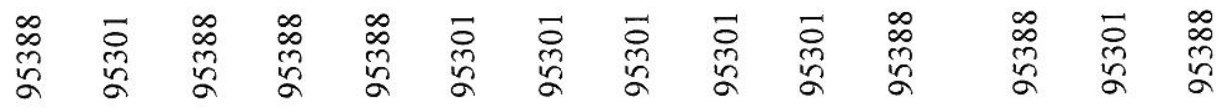

仙

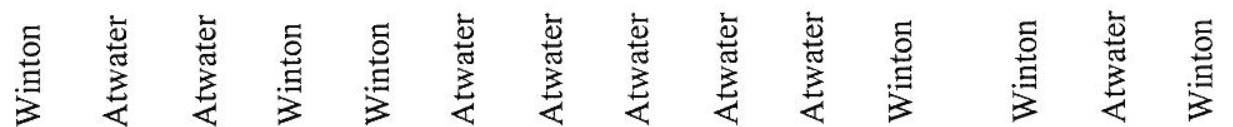
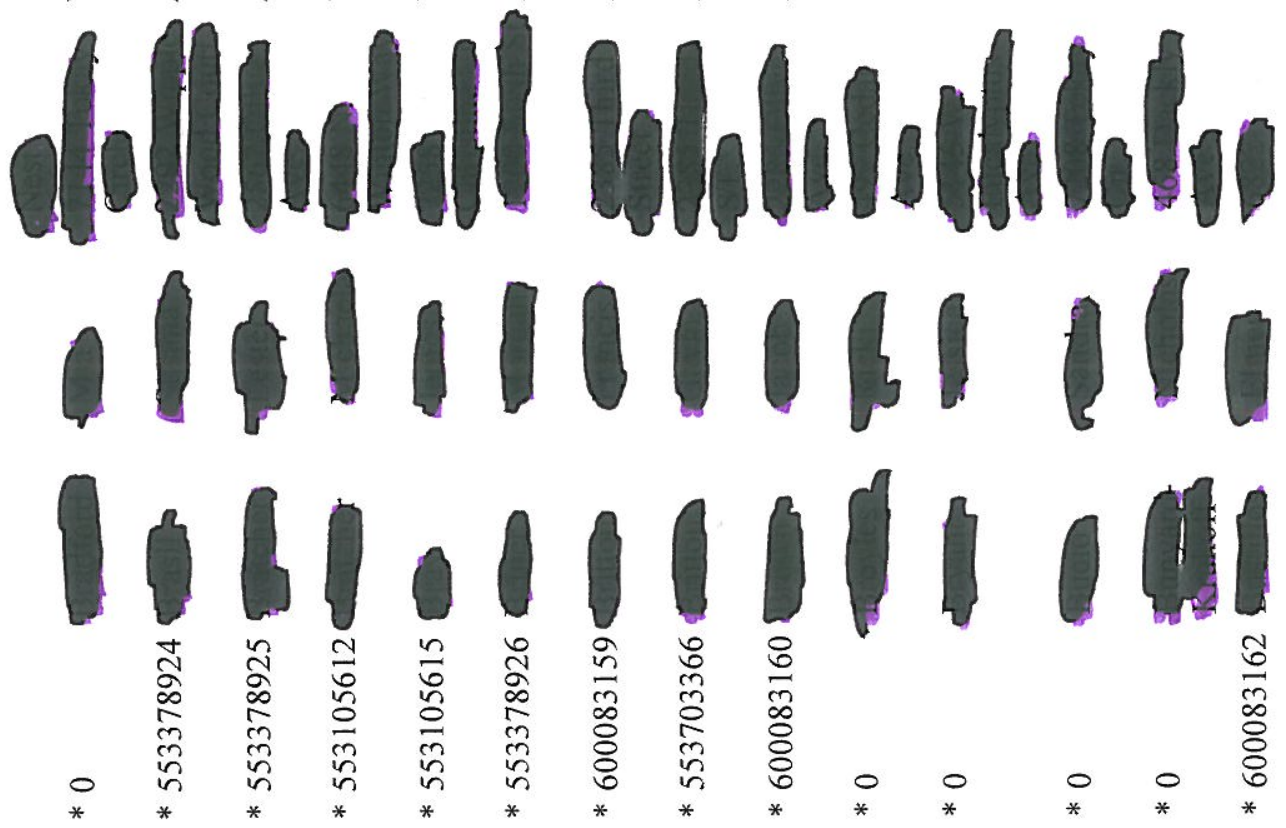


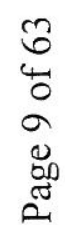

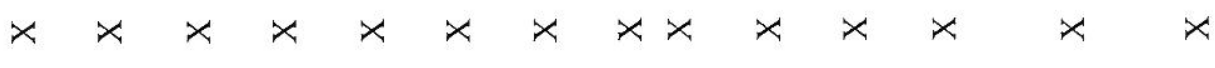

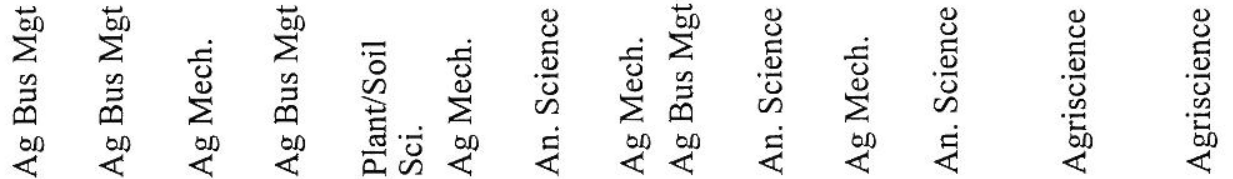

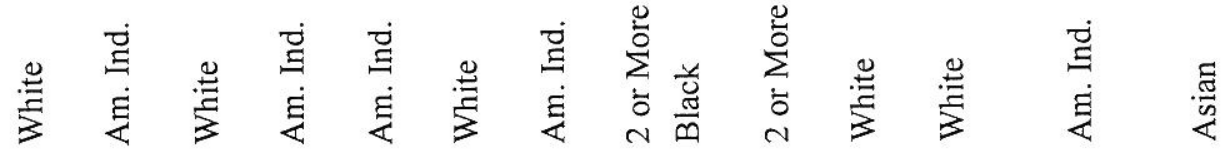

$\begin{array}{llllllllll}x & x & \times & x & x & x & x\end{array}$

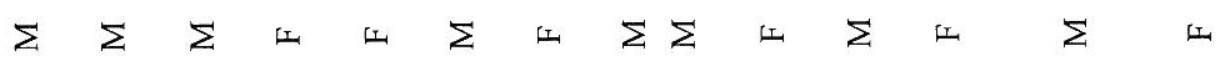

\& $8 \simeq 8$ 의 $=$ o 으으의 8

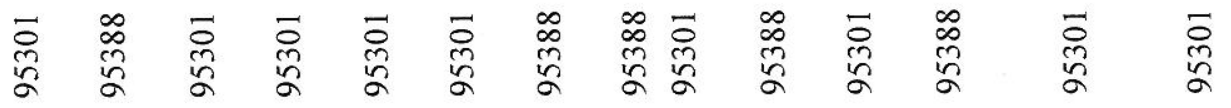

仙

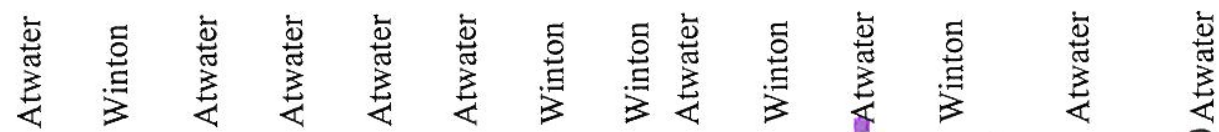

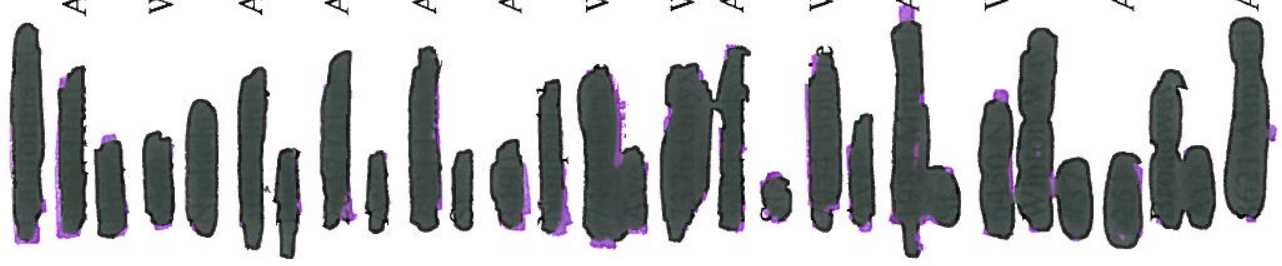

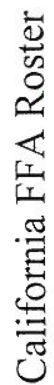
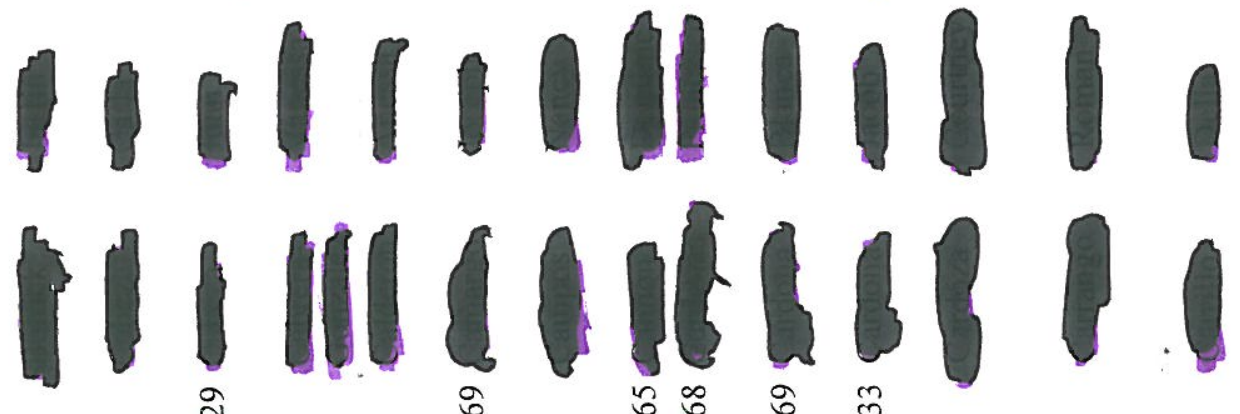

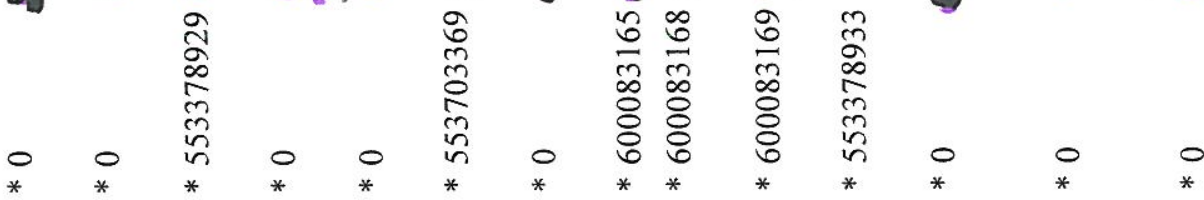

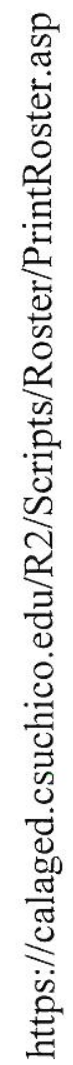




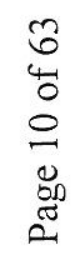

$\times \quad \times \quad \times \quad \times \quad \times \quad x \times \quad x \quad x \quad x \quad x \quad x \quad x \quad x \quad x$

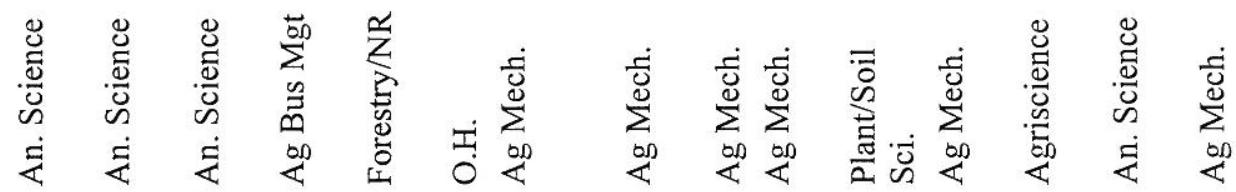

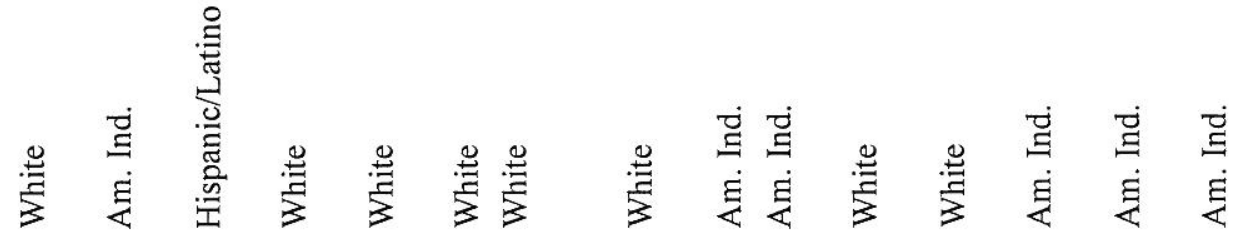
$x \times x \times x \times x \times x \quad x \quad x \quad x \quad x \quad x$

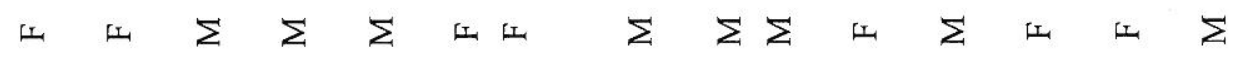

으으으으요용ㅇㅇㅇ

$-\rightarrow 4+4,4-4-4-4$

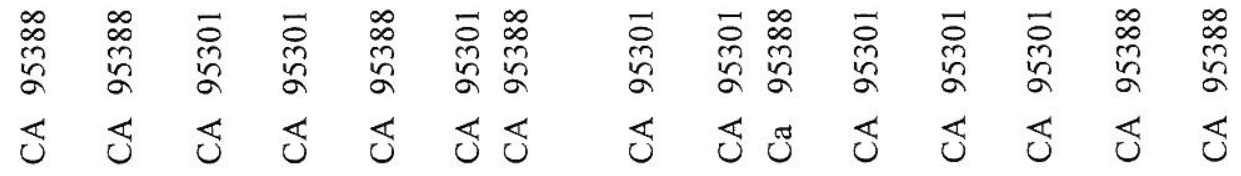

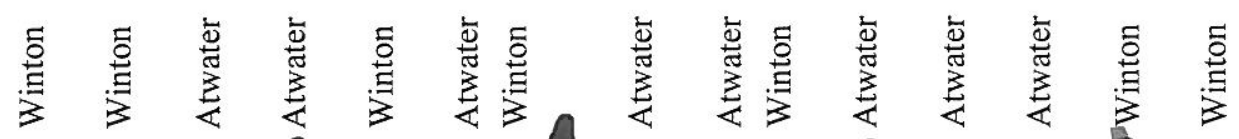

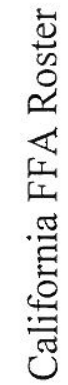
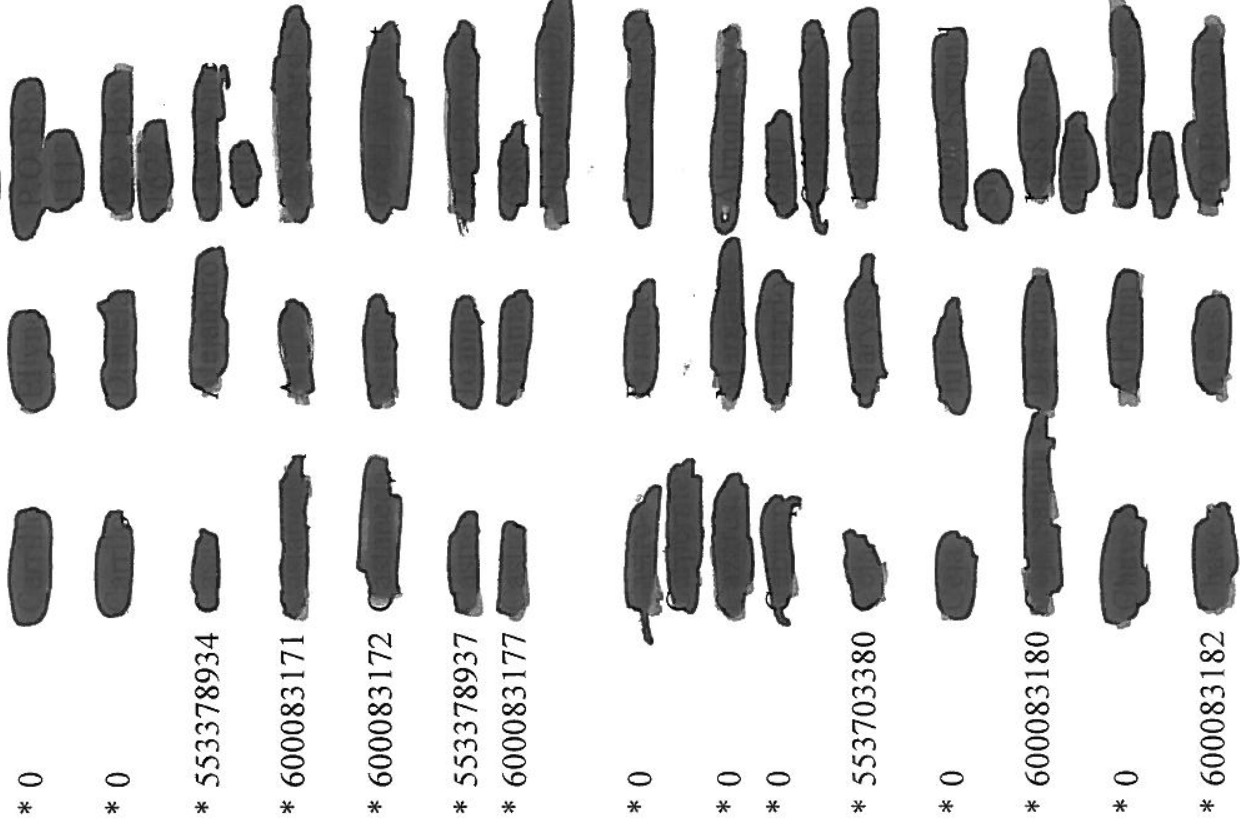


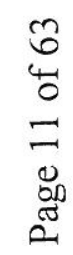

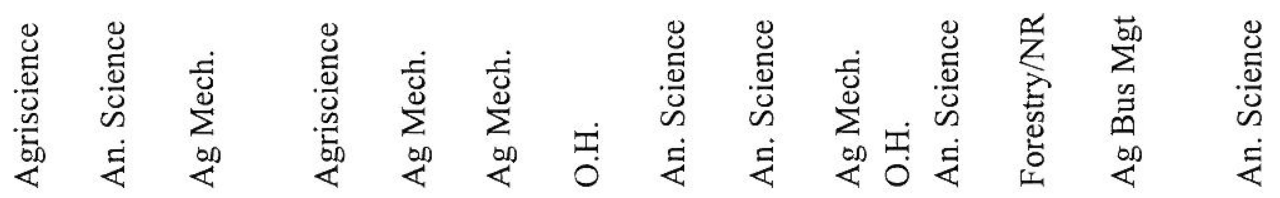

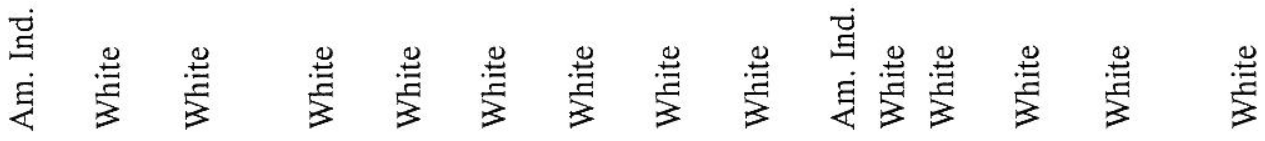
$x x x+x x \quad x x \quad x$

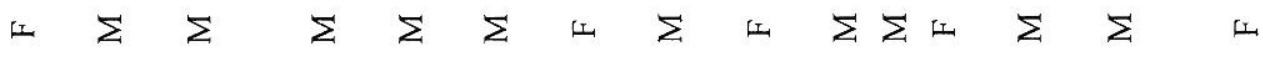

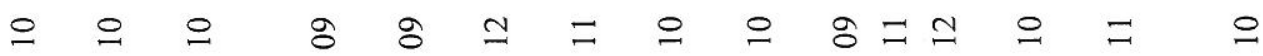

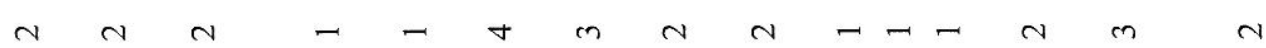

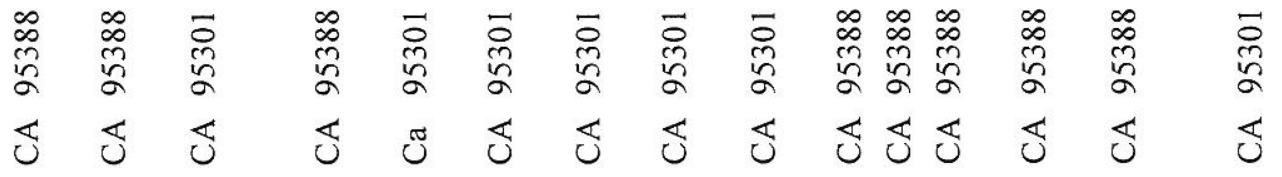

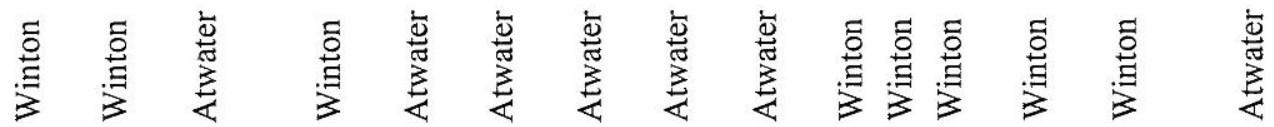

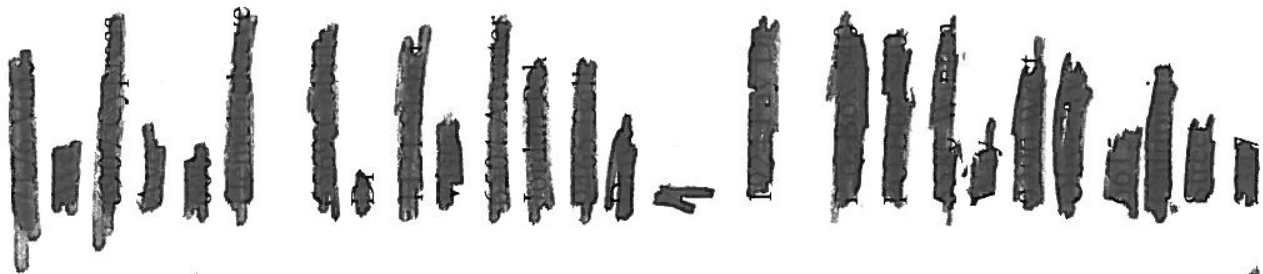

$|1||| \||||||| \mid$

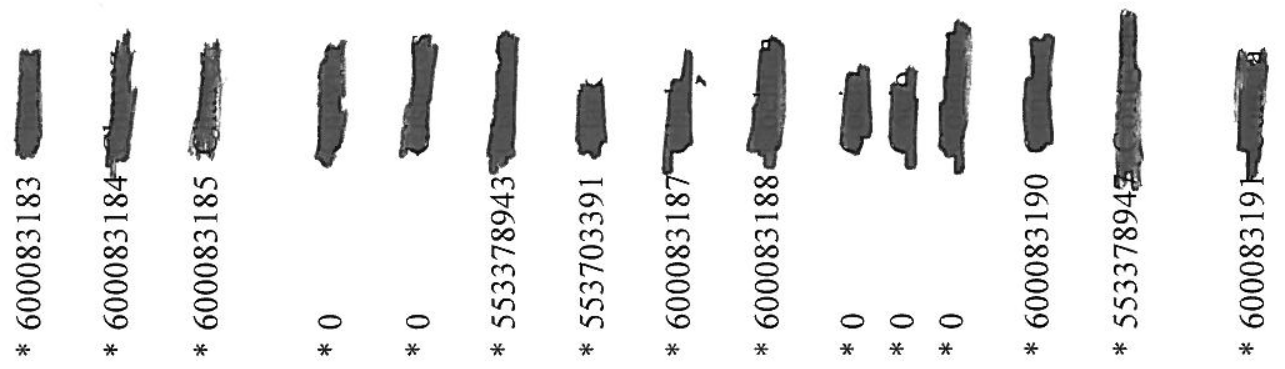




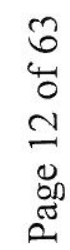

$x \quad x \quad x \quad x \quad x \quad x \quad x \quad x \quad x \quad x \quad x \quad x$

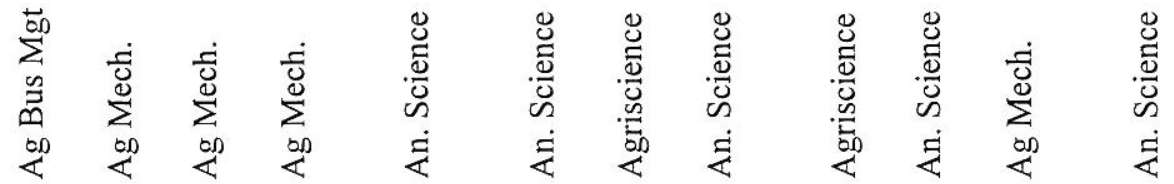

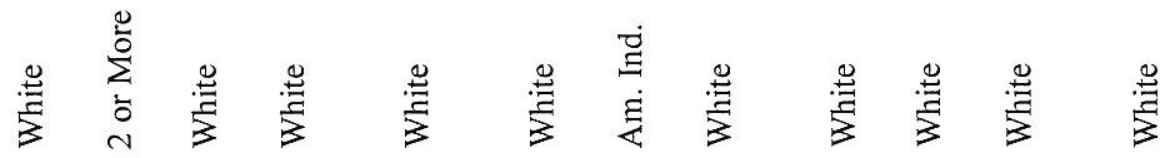

$\times \times x$

$x \times x \times$

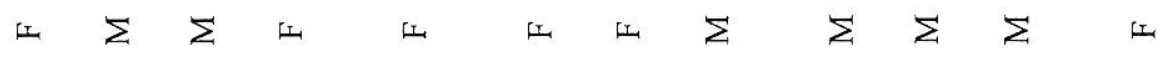

요응 $ㅇ ㅇ=$

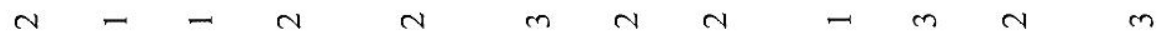

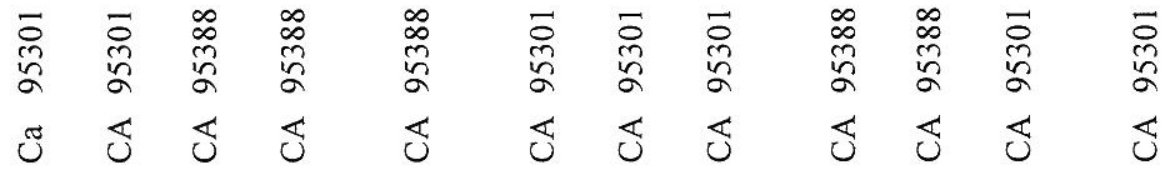

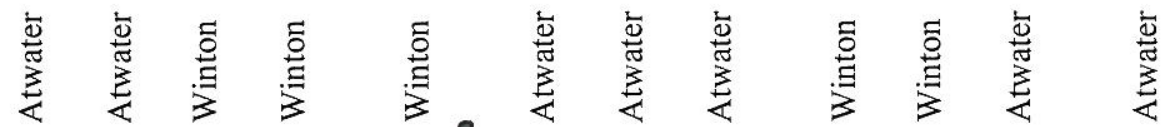

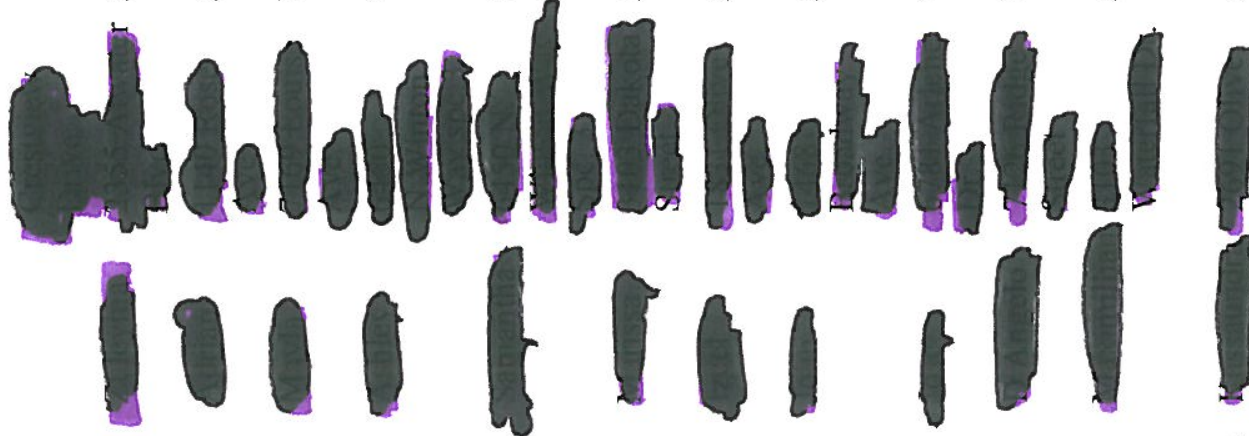

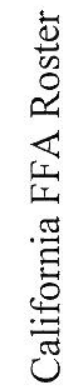

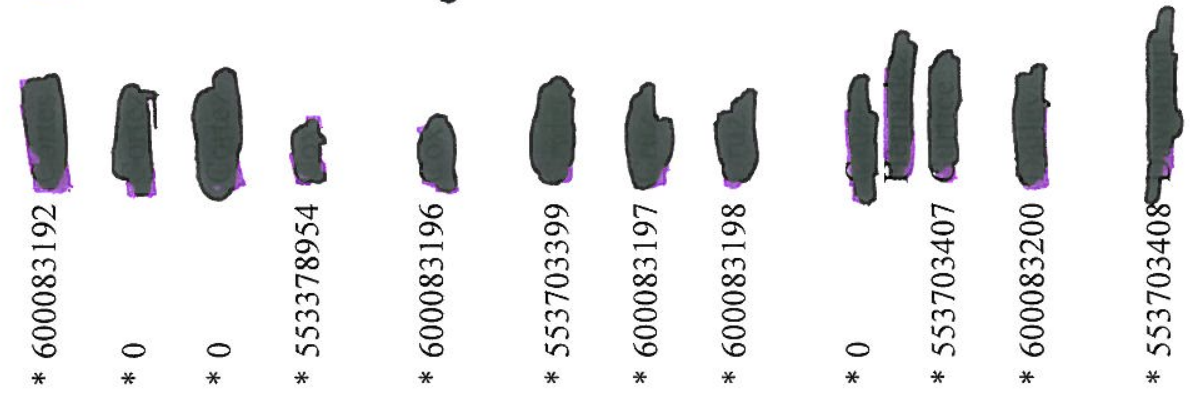


$\hat{\sigma}$
4
0
0
0
0
0

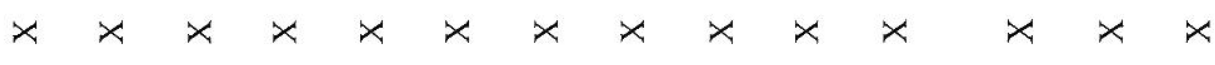

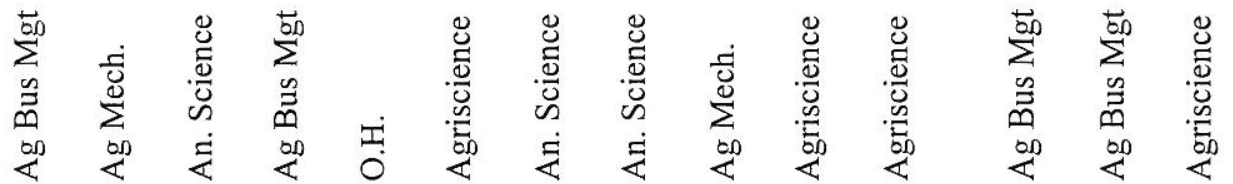

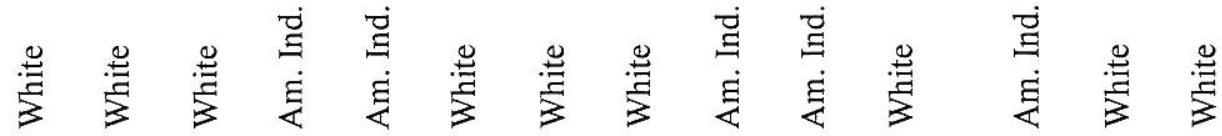
$x \times x \times x \quad x \quad x \quad x$

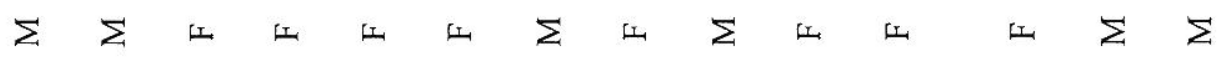

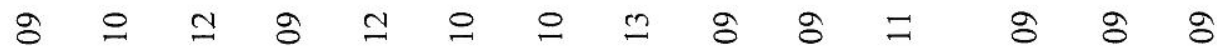

$-4 \rightarrow-4,-4,-\pi-$

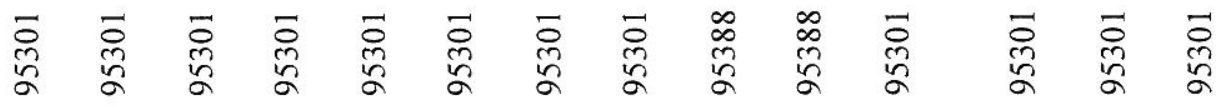

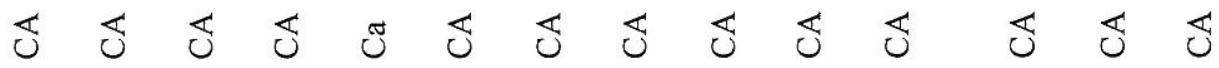

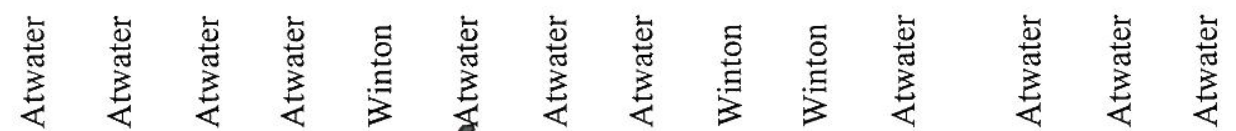

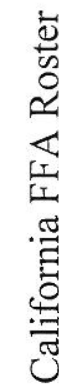
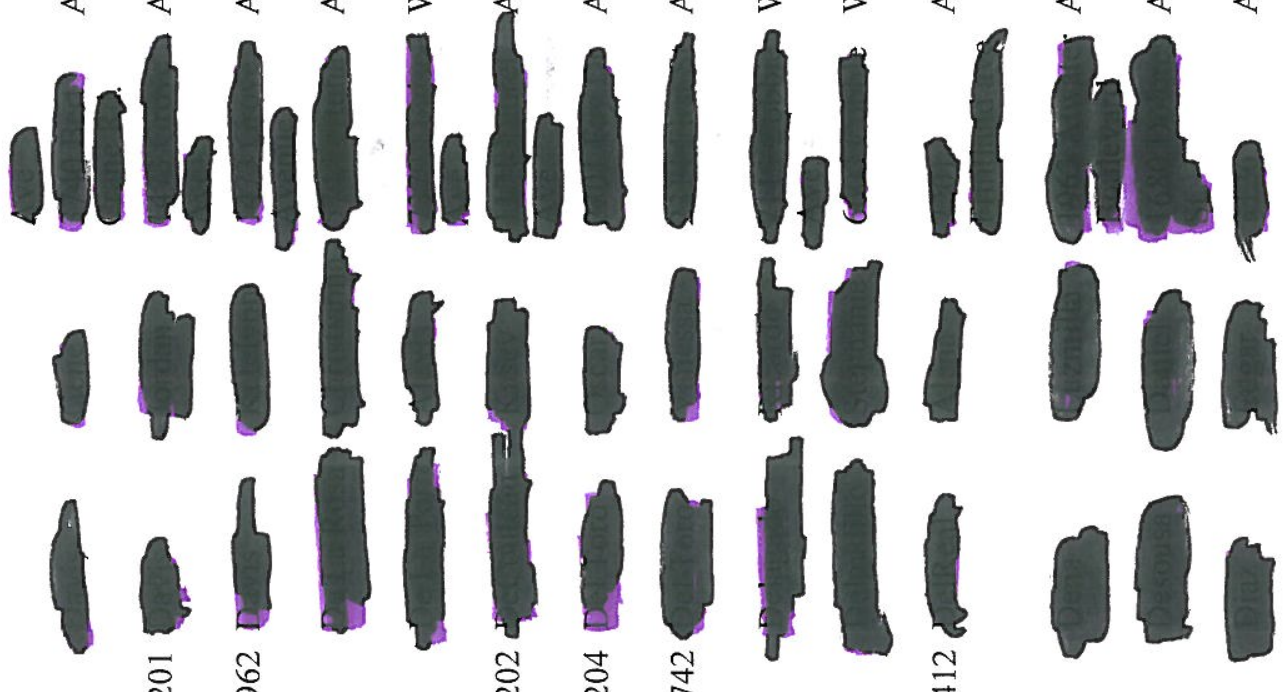


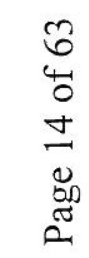

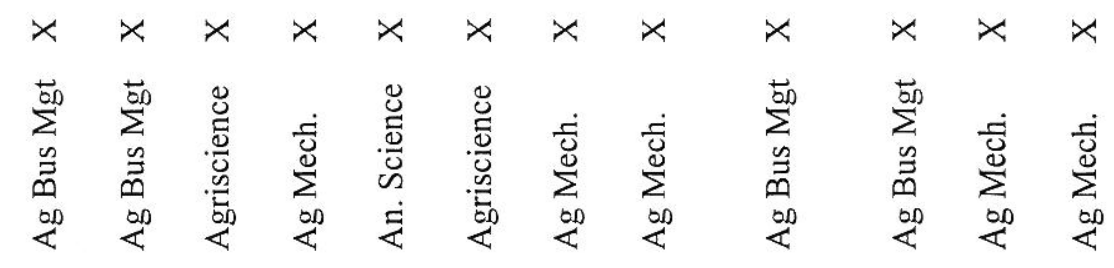

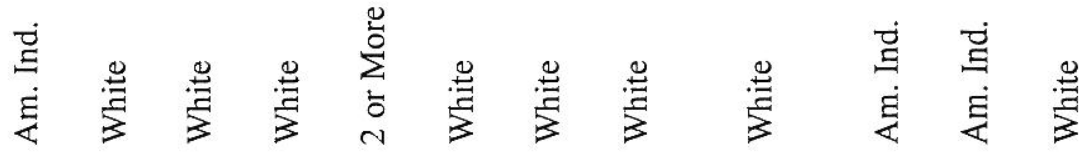

$x \times \times \times \times \times x \times x$

$\Sigma \Sigma \omega \Sigma 山 山 \Sigma 山 \Sigma 山 山 \Sigma 山$

$g \circ \circ=8 \circ 9 \subseteq$ g 9

- $-4 a 4-4 m a-4$

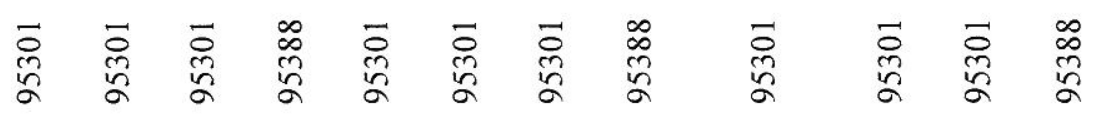

త

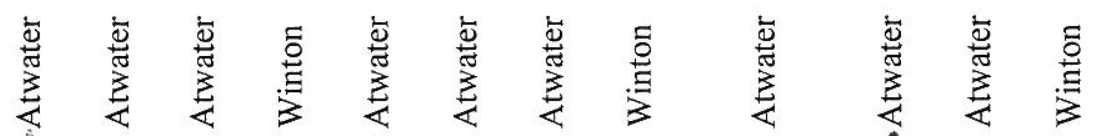

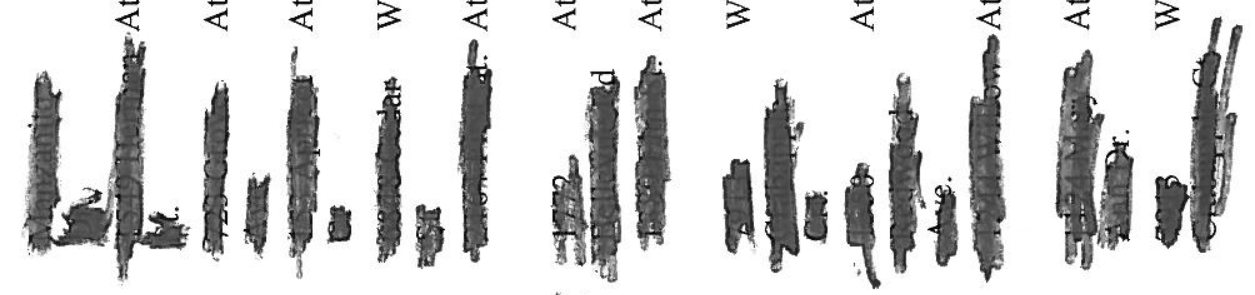

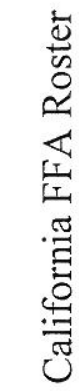

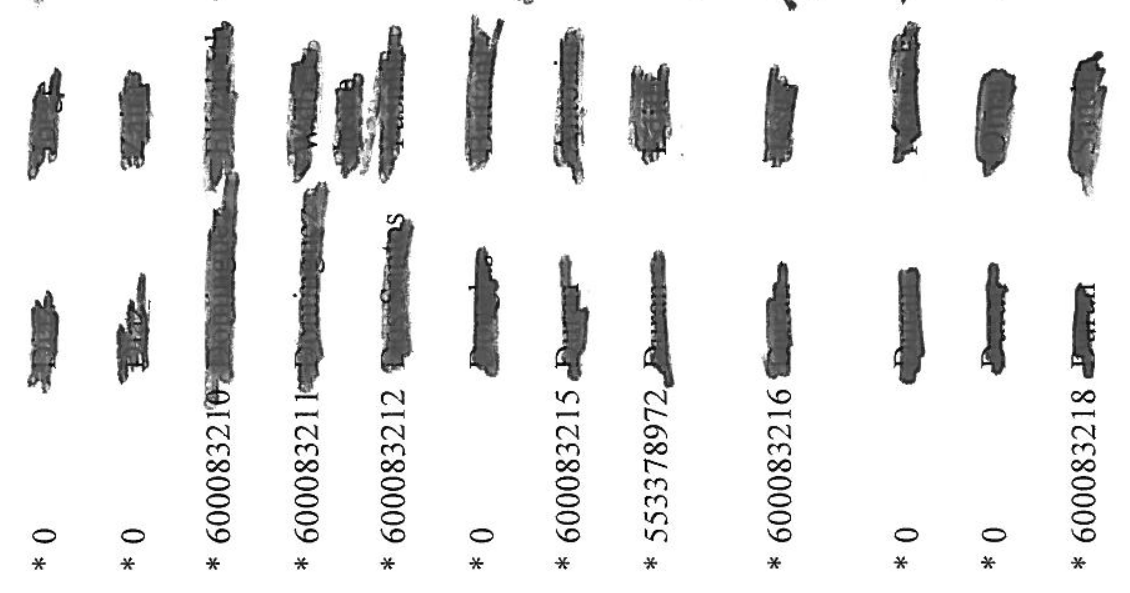




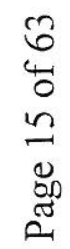

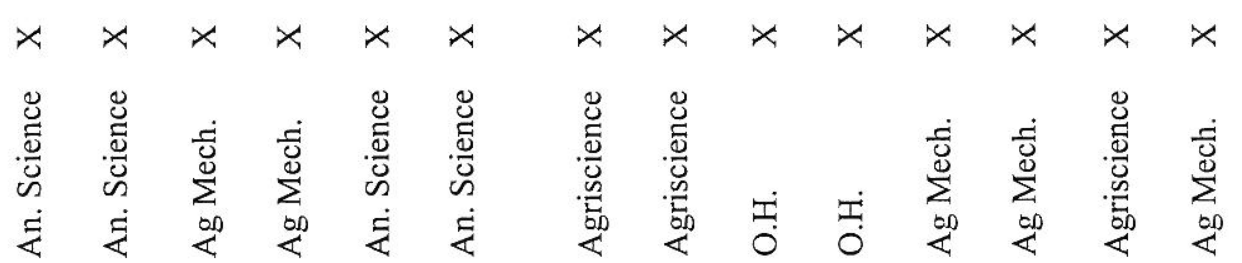

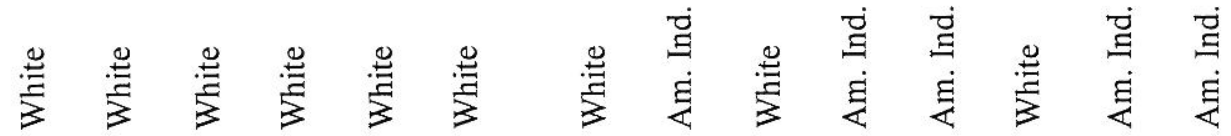
$x \quad x \quad x \quad x \quad x \quad x$

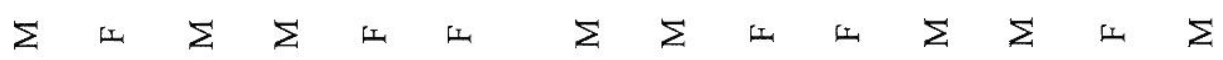

$\subseteq=\simeq==8$ \& $\simeq 8$ g $=\subseteq=$

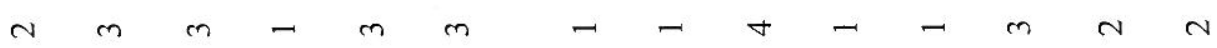

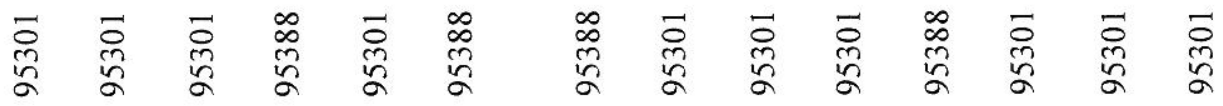

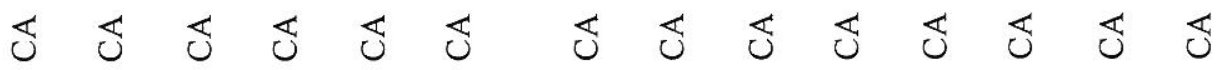

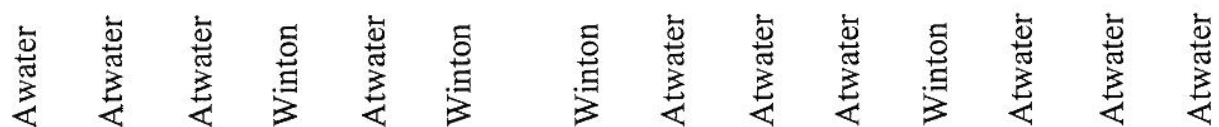

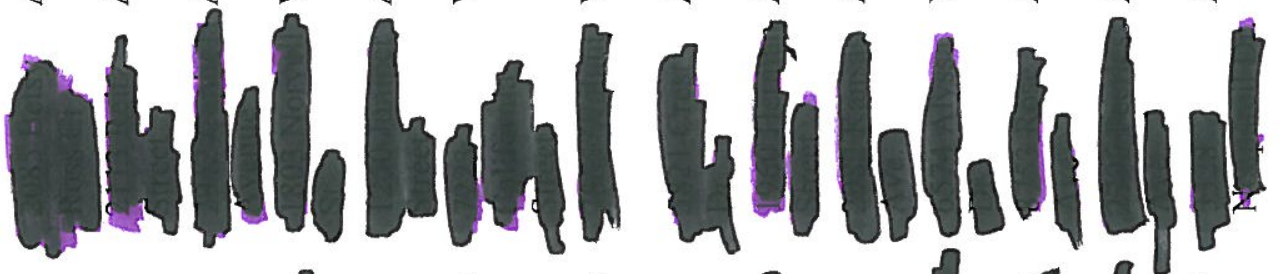

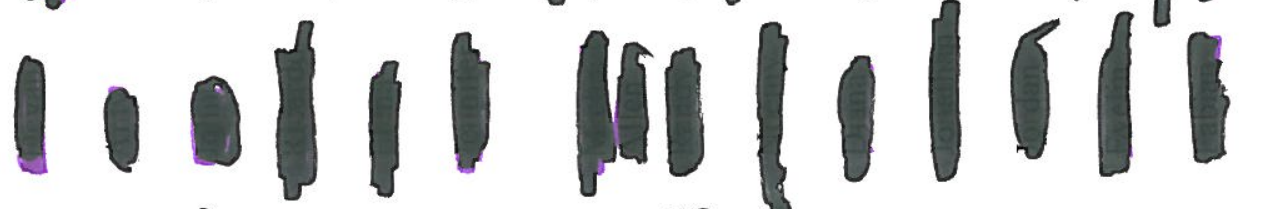

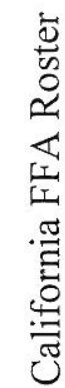

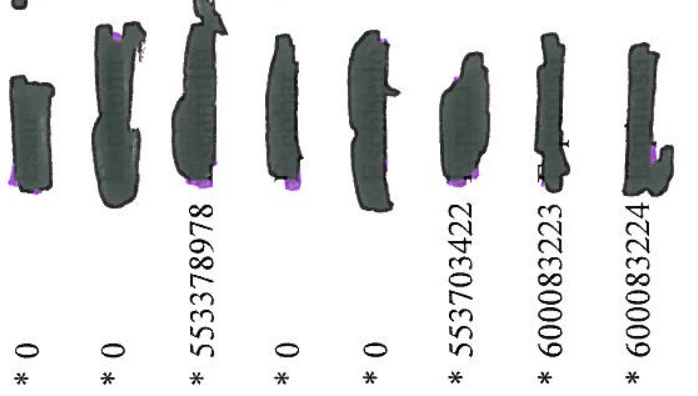


3
6
4
0
0
0
$\mathbb{8}$
$\approx$
$\approx$

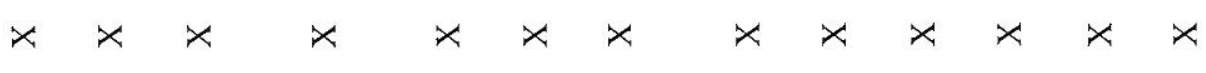

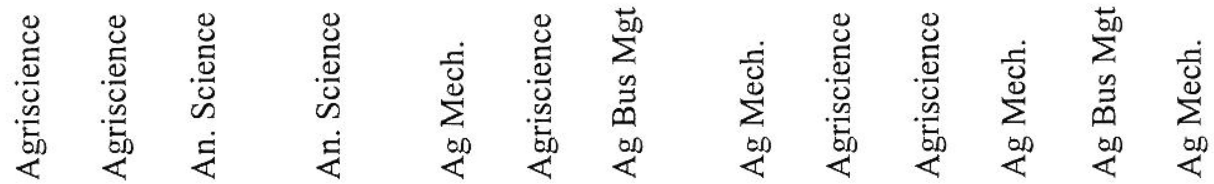

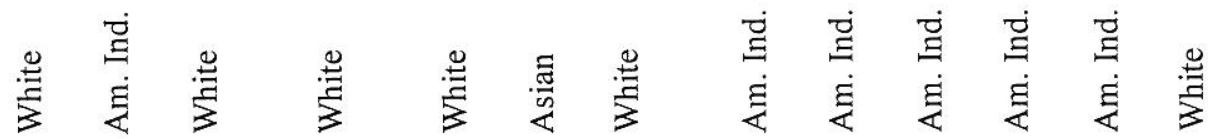
$x \times x \times x \times x \times x \times x \times x \times$

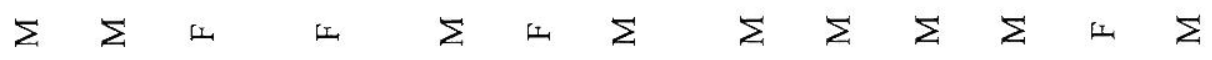

으의 $ᄋ \circ 8$ \& $8=8=$

$-4 n-4-4 \rightarrow-m-m$

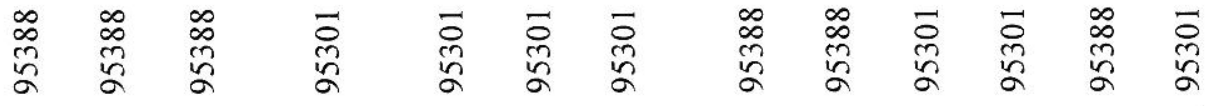

范

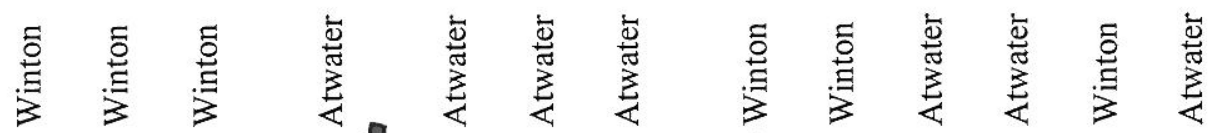
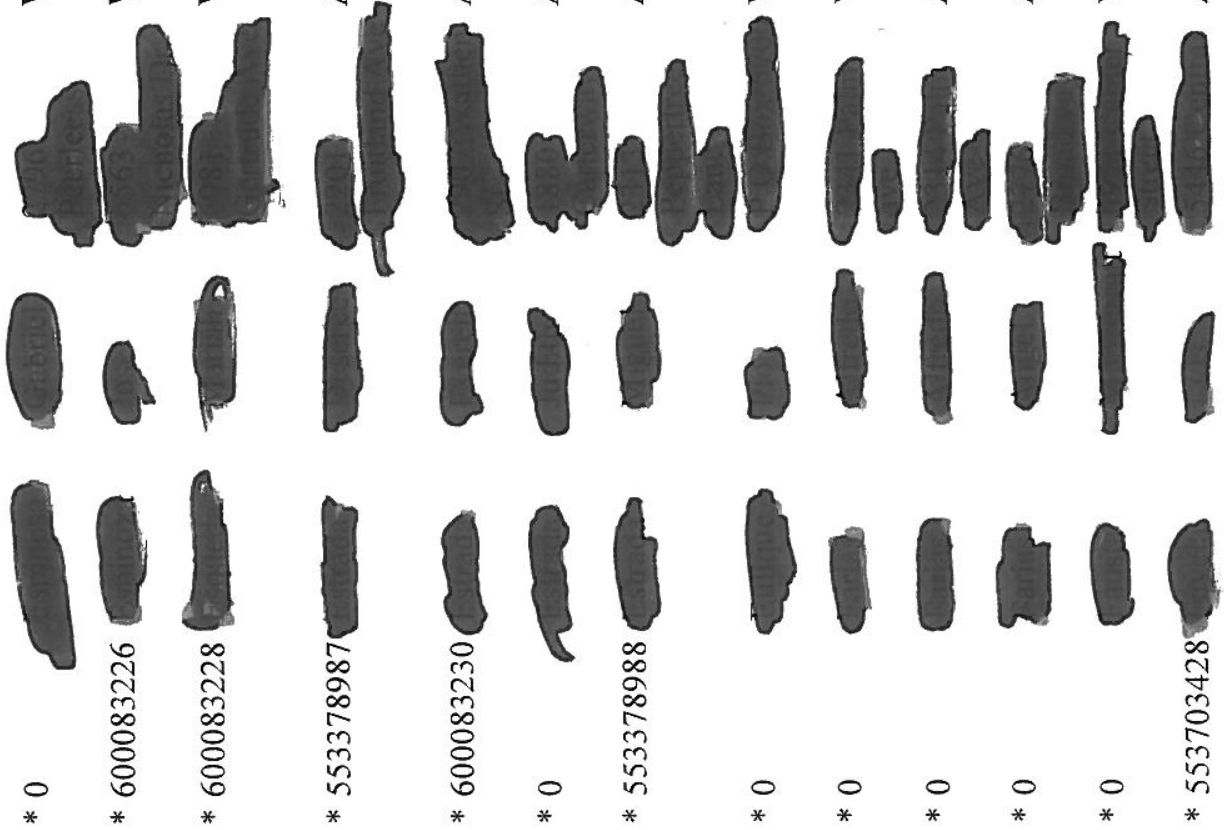


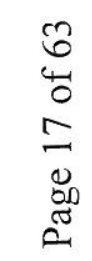

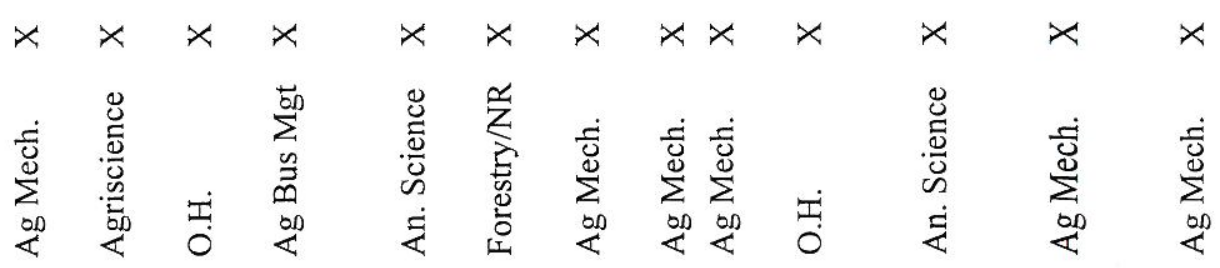

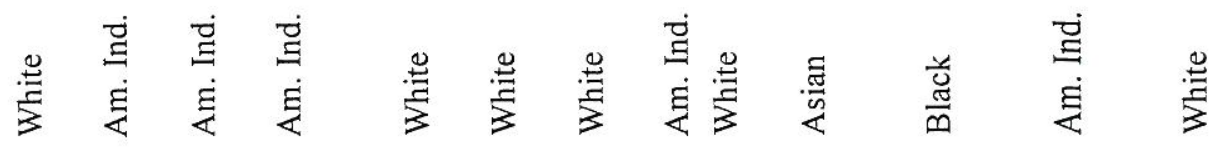
$x \times x \times x \quad x \quad x \quad x$

$\Sigma$ 山 山 $\Sigma$ 山 $\Sigma \Sigma \Sigma \Sigma \Sigma \Sigma$ 山 $\Sigma \Sigma \Sigma$

$\simeq$ \& 8 o $\simeq$ g $8=8$ o $8=$

$+--\rightarrow+-m--b m$

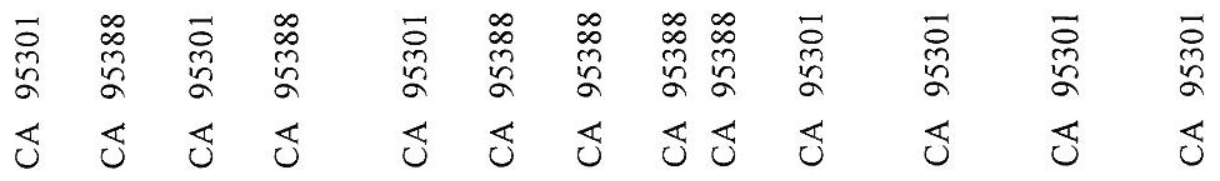

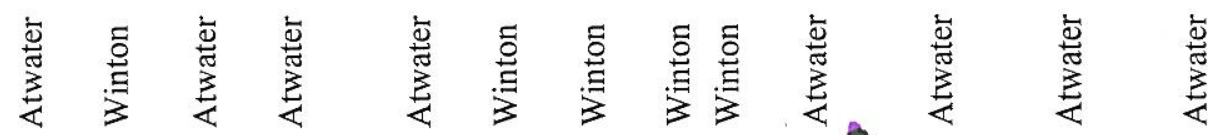

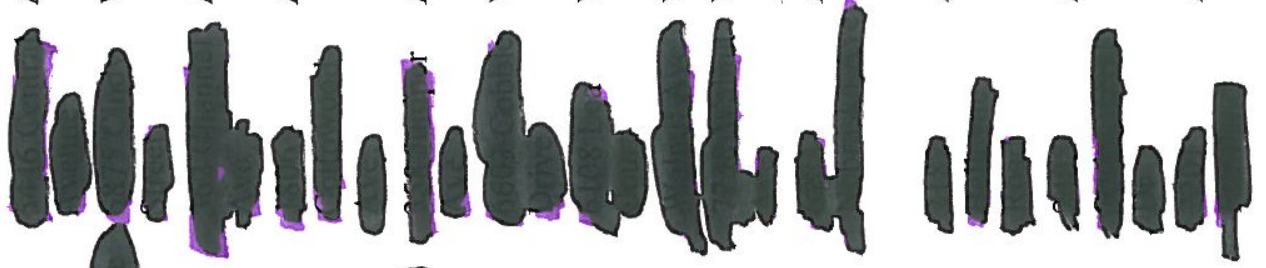

㐫
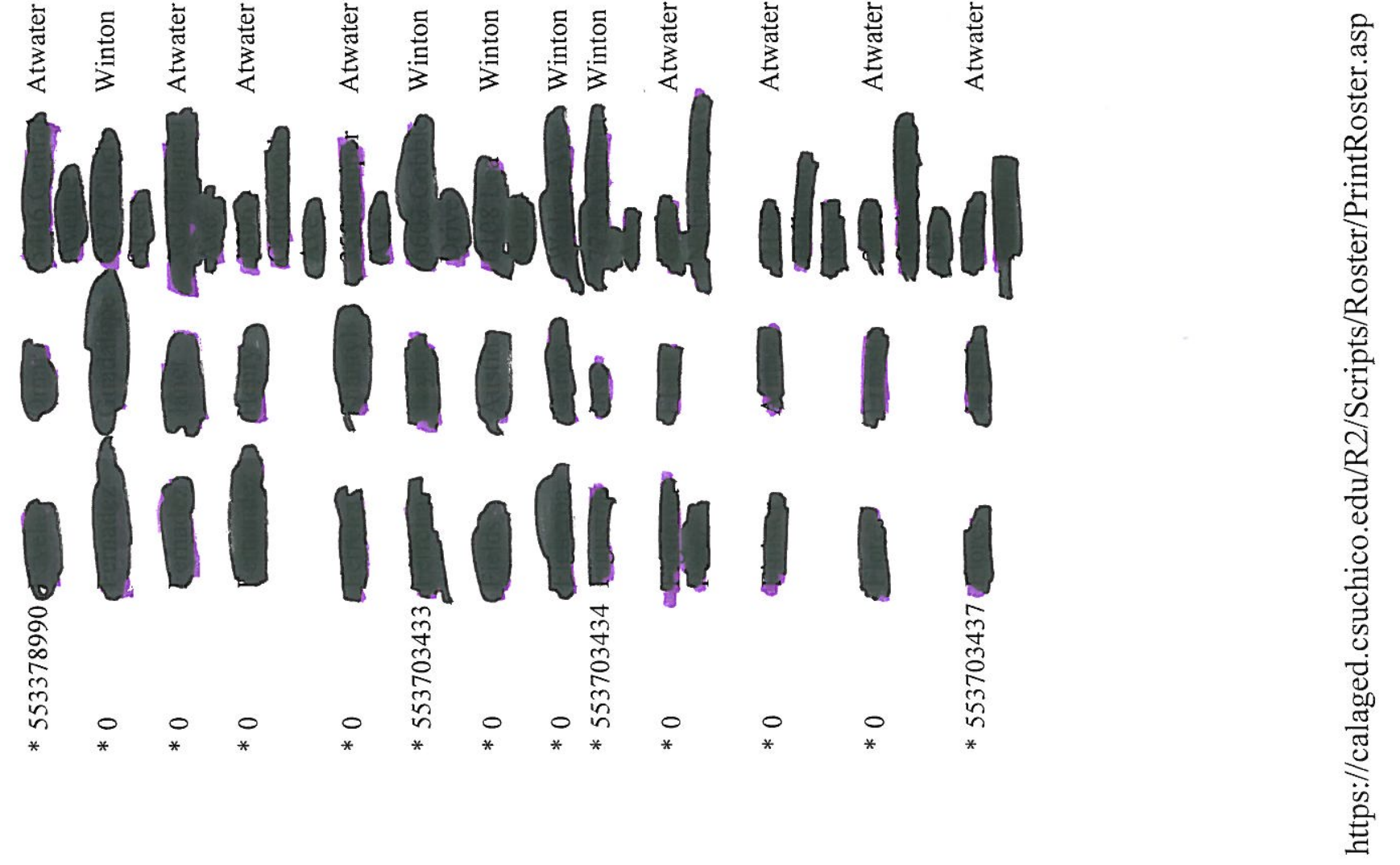


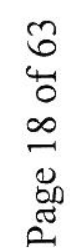

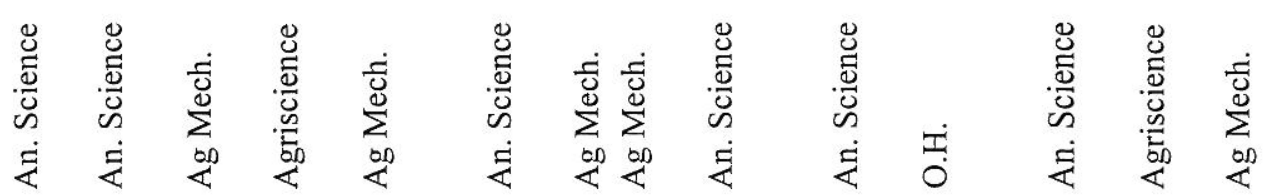

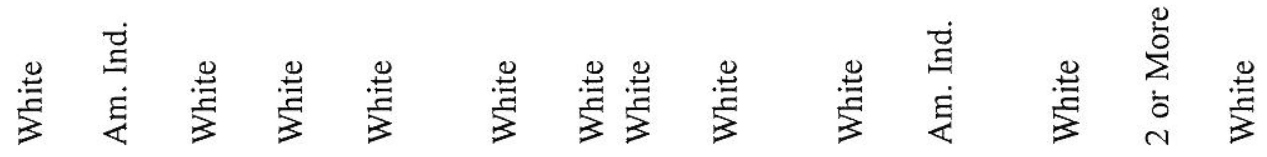
$\times \times x$

$x \quad x \quad x \quad x$

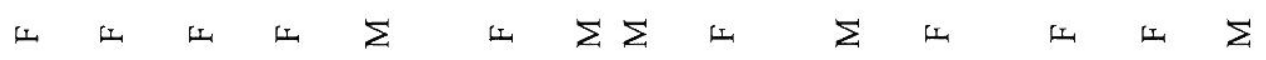

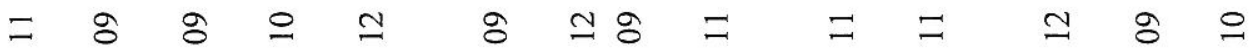

$m-\rightarrow+N \rightarrow m-m-N$

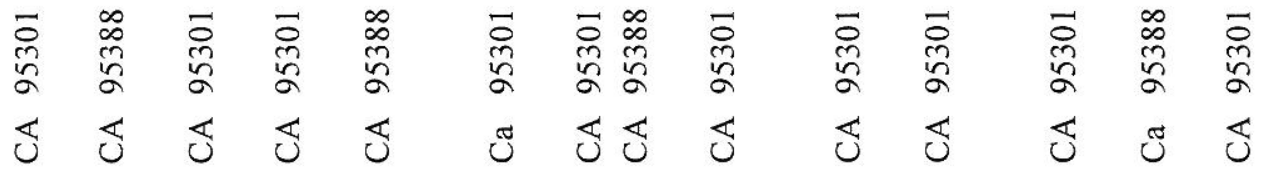

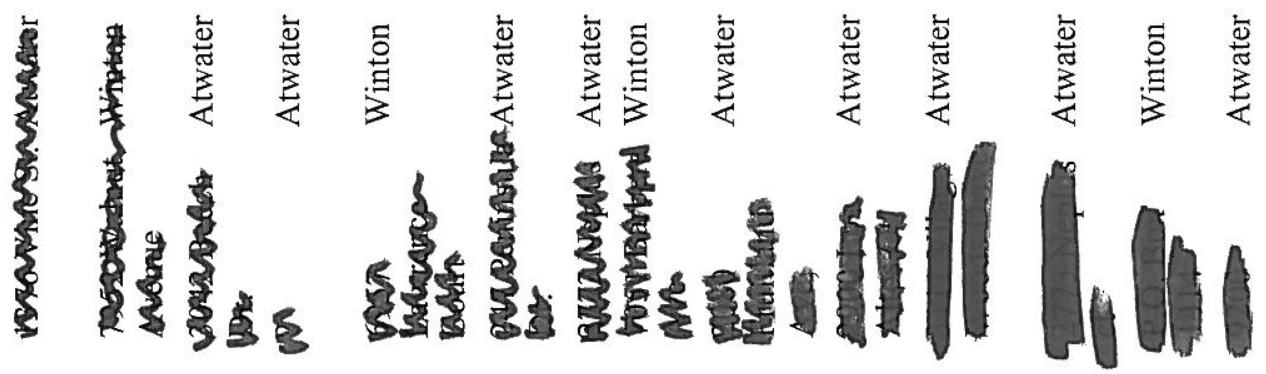

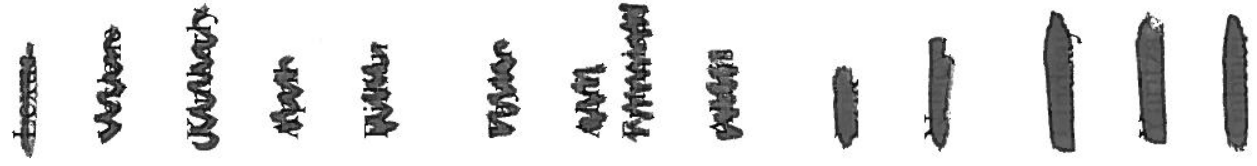

可

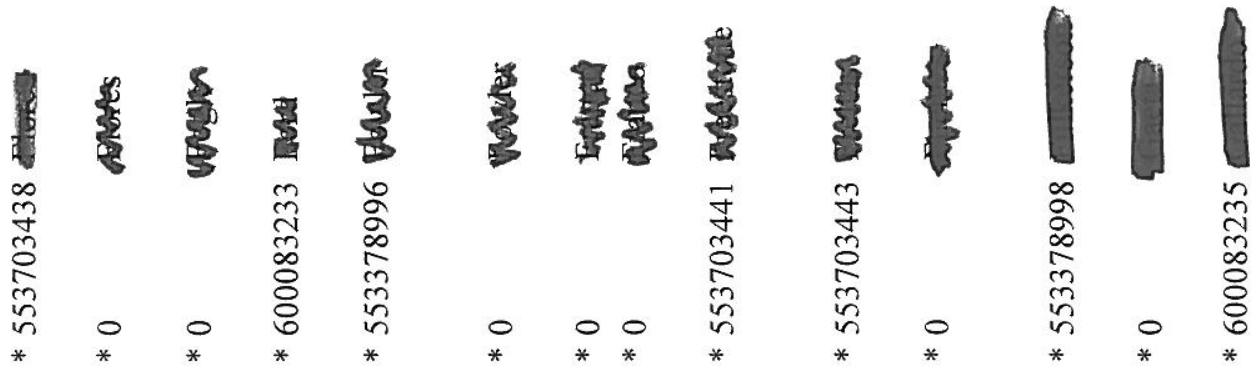




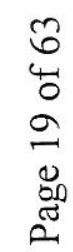

$$
\begin{aligned}
& x \times x \quad x \quad x \quad x \quad x \quad x \quad x \quad x \quad x \quad x \quad x
\end{aligned}
$$

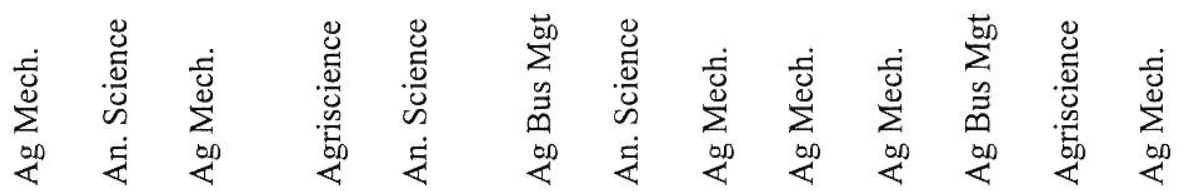

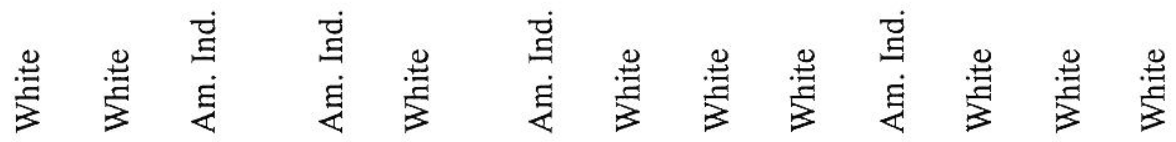
$x \times x \times x \times x \times x \times x \times x \times$

$\Sigma \Sigma \Sigma \Sigma \Sigma 山 \Sigma \Sigma \Sigma \Sigma \Sigma \Sigma \Sigma \Sigma \Sigma 山 \Sigma$

의 $8=g=\simeq=8=0$

$4 m-m-m+m-m 44$

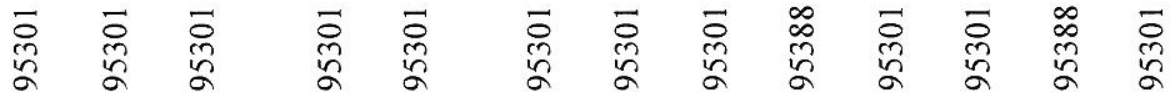

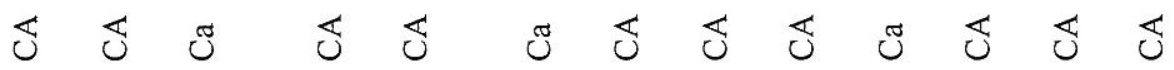

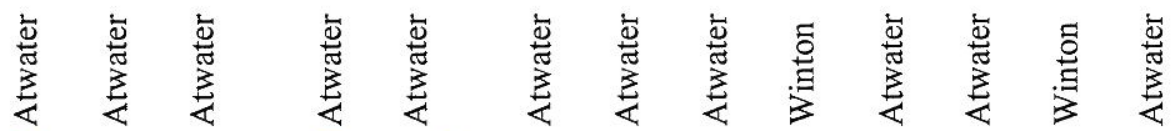
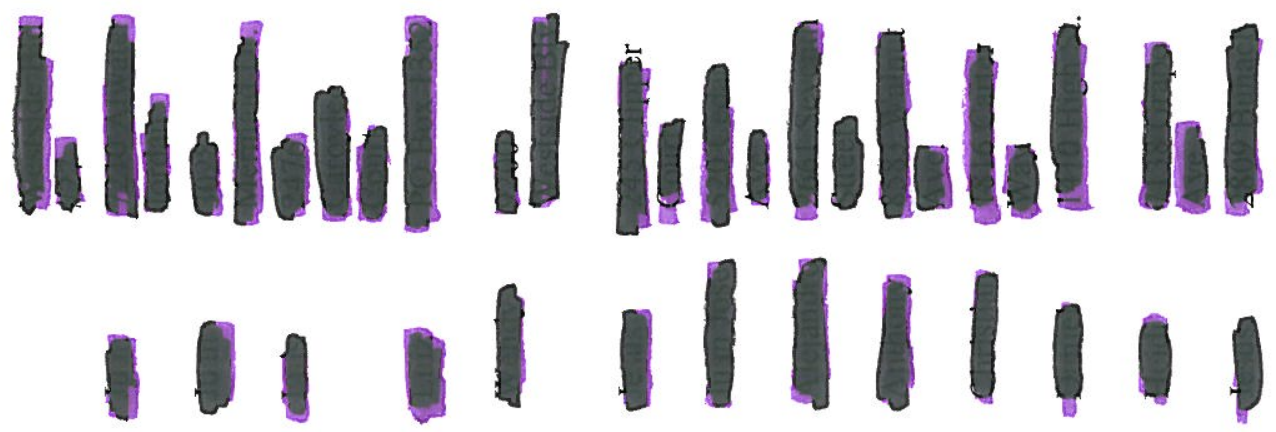

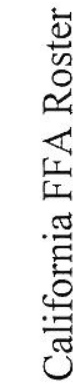

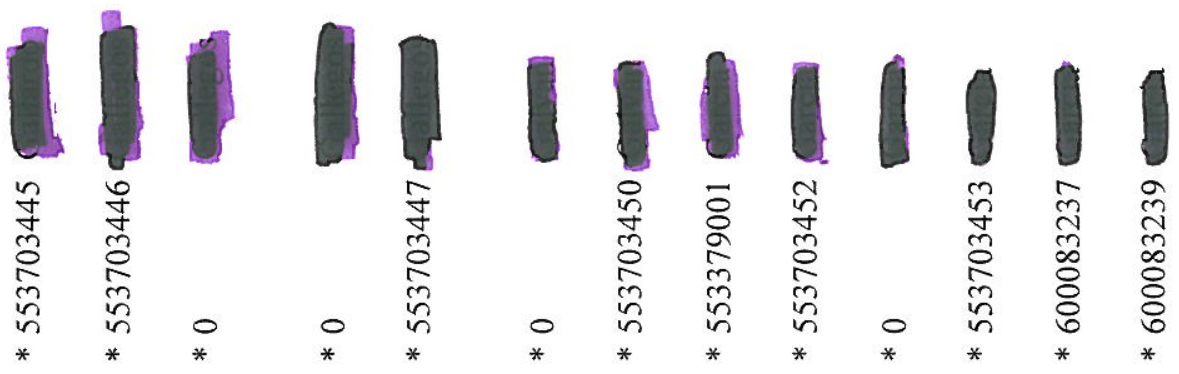




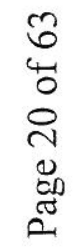

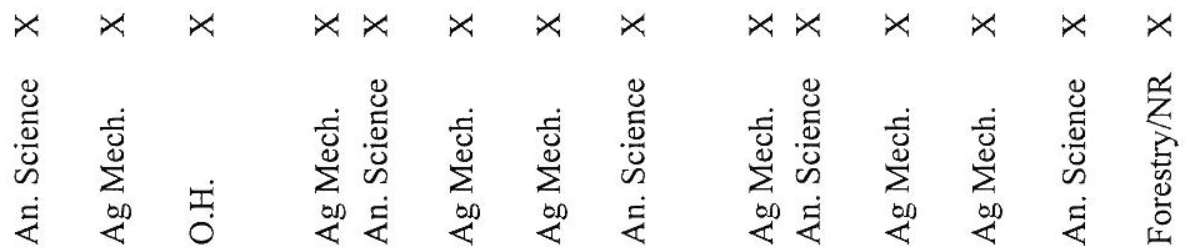

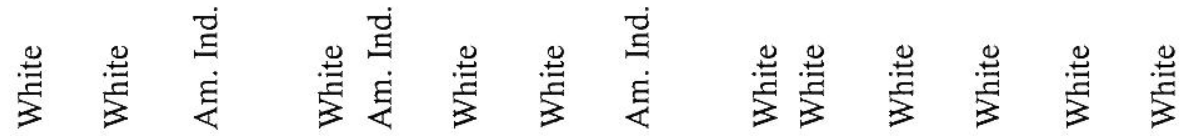

$\times \quad x \quad x \quad x \times x \times x \quad x \quad x \quad x$

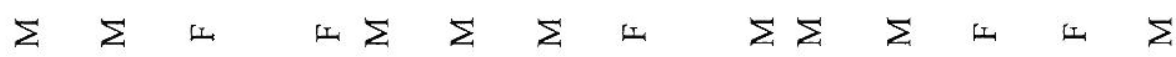

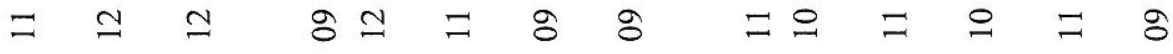

$m--4 m-4-4 m n-4$

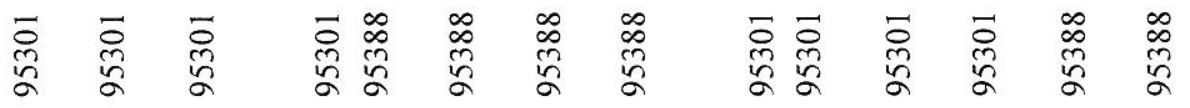

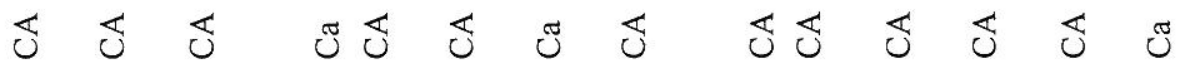

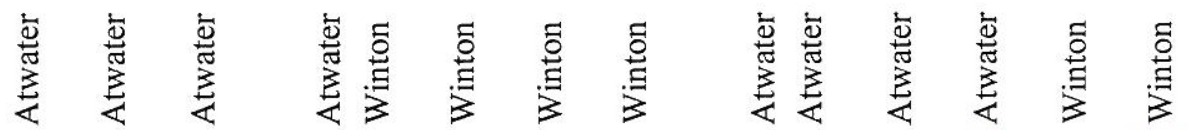
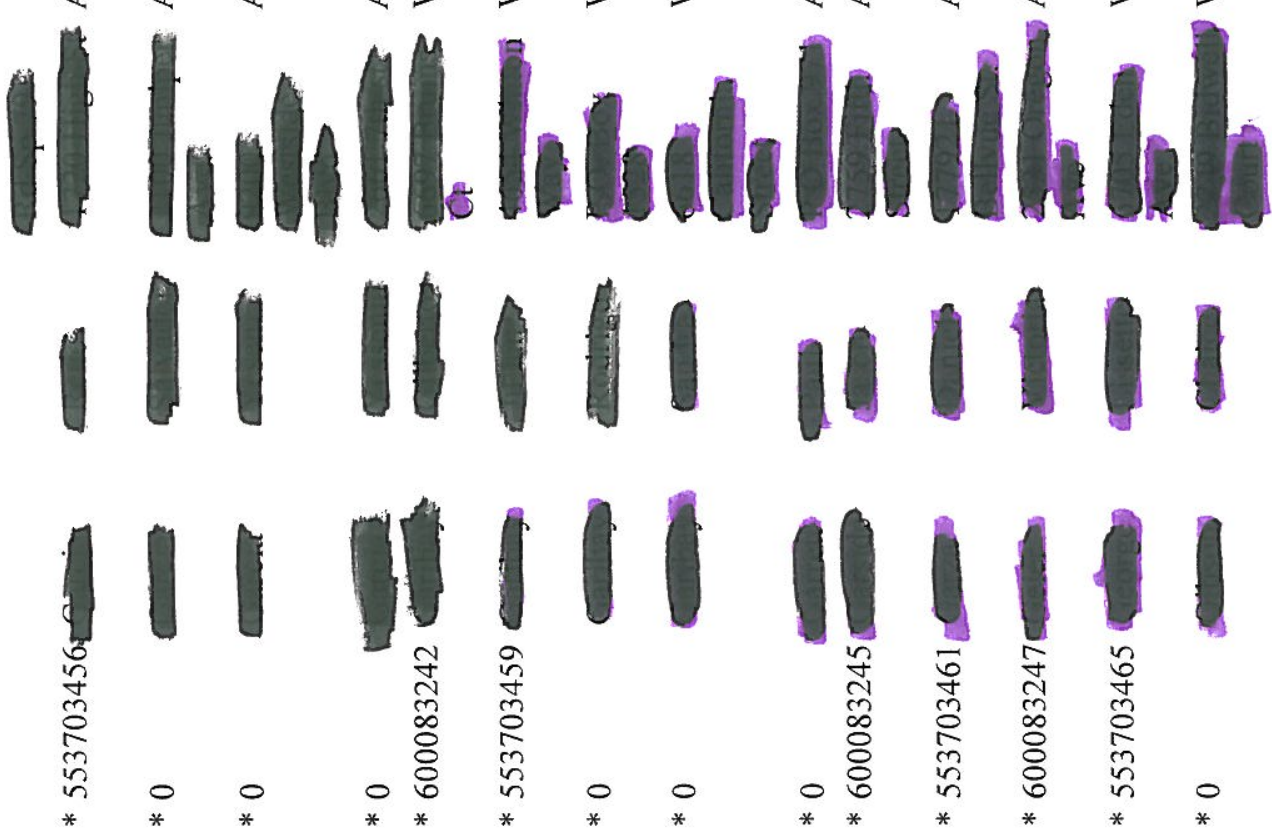
$\beta$
$\delta$
4
$\vec{N}$
0
$\infty$
0
0

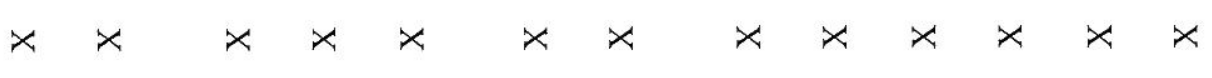

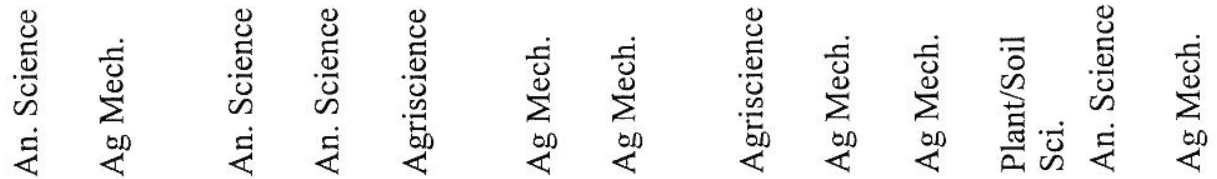

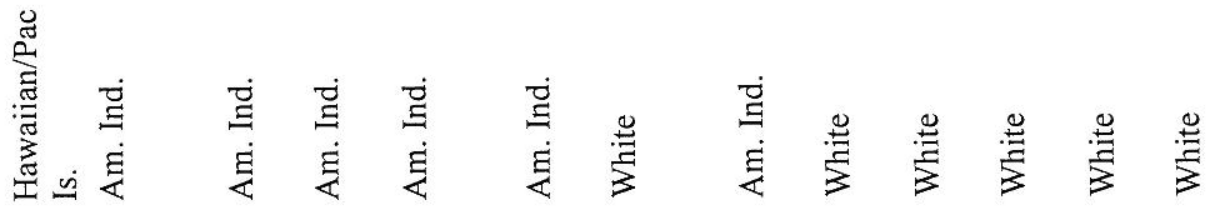
$x \times x \times x \times x \quad x \quad x \quad x$

$\Sigma \Sigma \Sigma \Sigma \Sigma \Sigma \Sigma \Sigma \Sigma \Sigma \Sigma \Sigma \Psi \Sigma$

요 8 \& $=\simeq \therefore \simeq$

$--4 \pi m-4 \pi N$

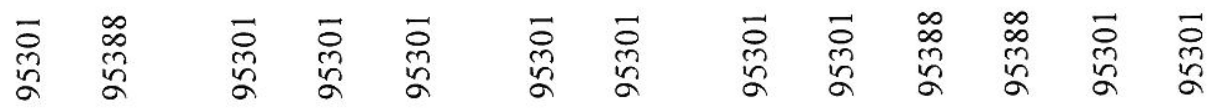

త
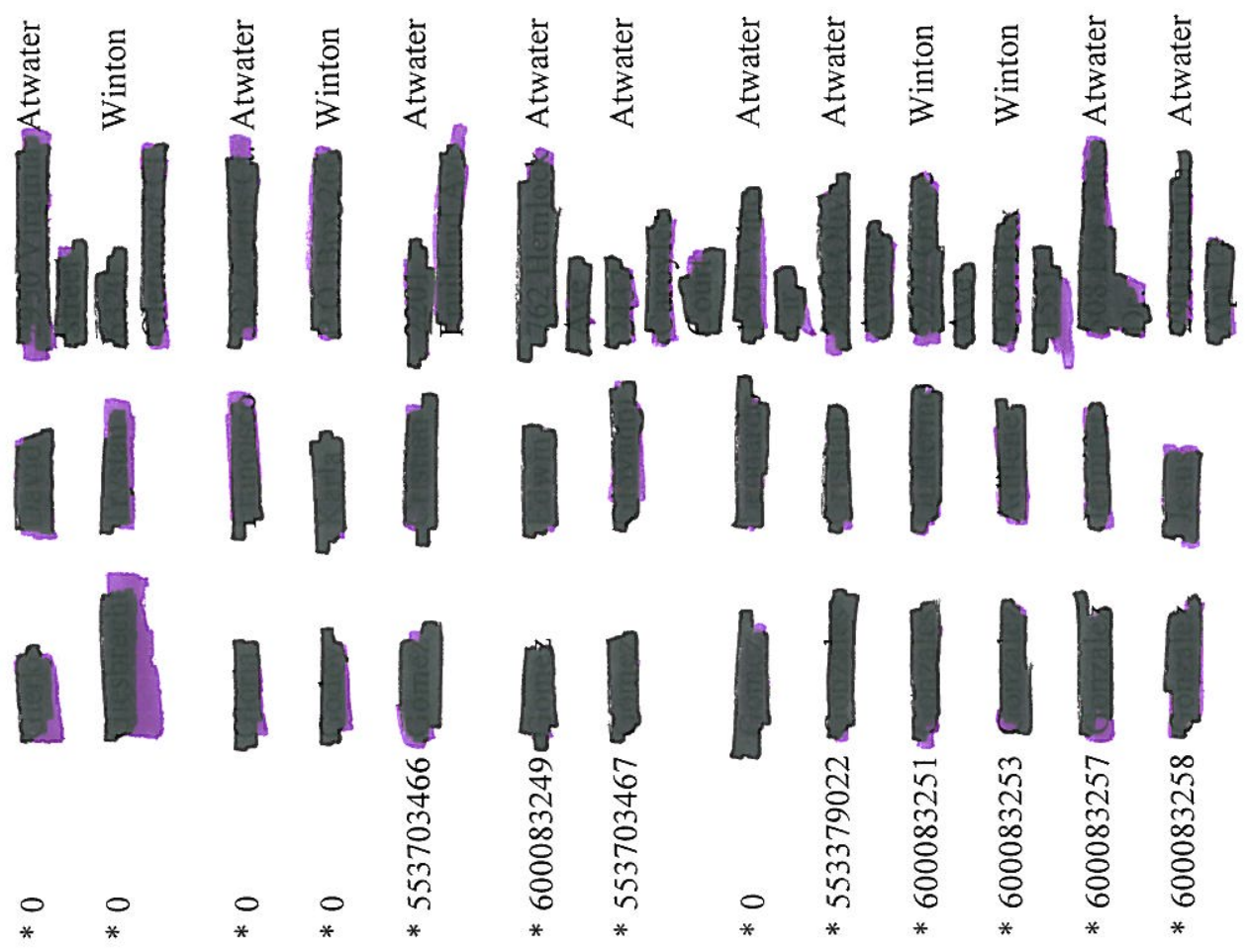


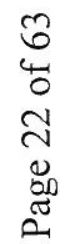

$x \quad x \quad x \quad x \quad x \quad x \quad x \quad x \quad x \quad x \quad x \quad x \quad x$

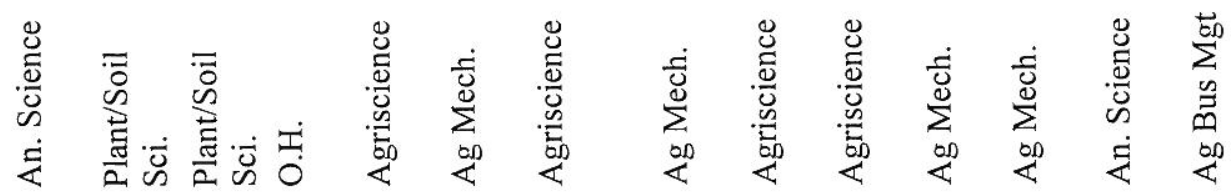

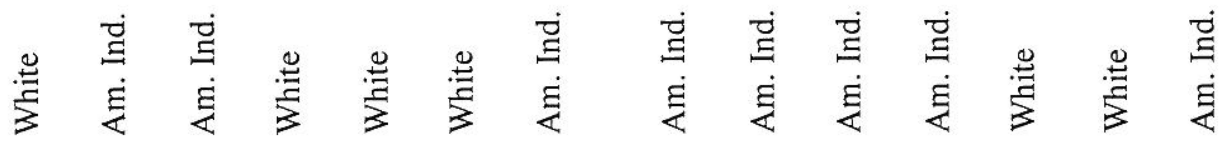
$x \quad x \quad x \quad x \quad x \quad x \quad x \quad x \quad x \quad x \quad x$

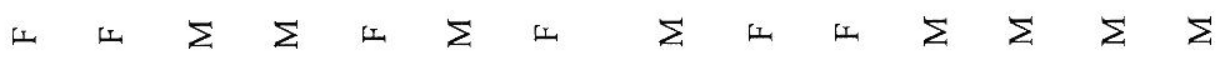

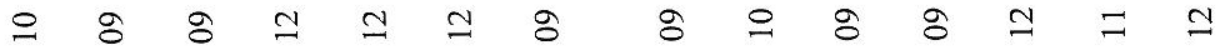

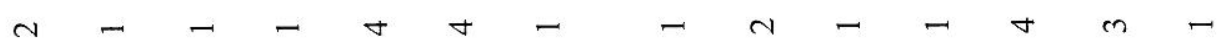

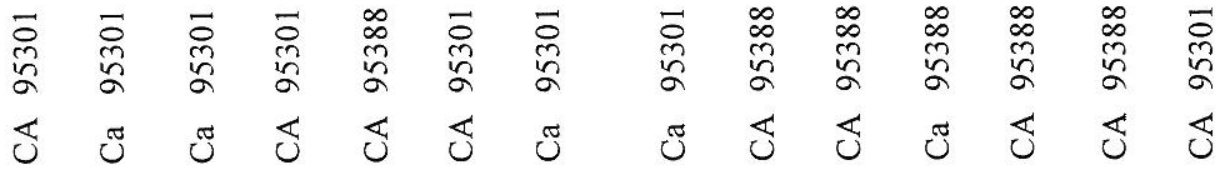

离离离离

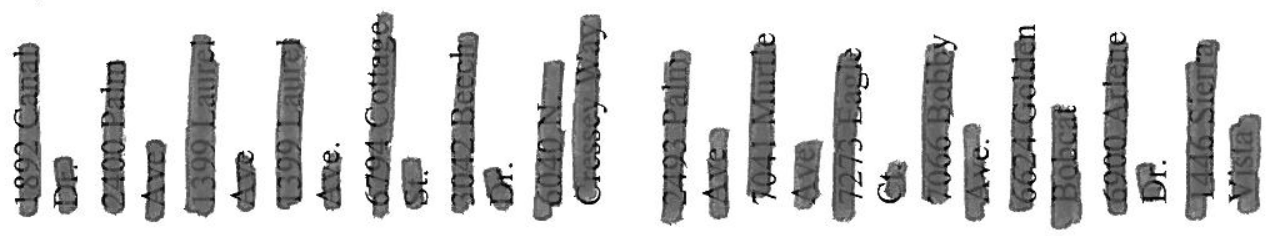

\|\|\|\|\|\|\|\|$\|$

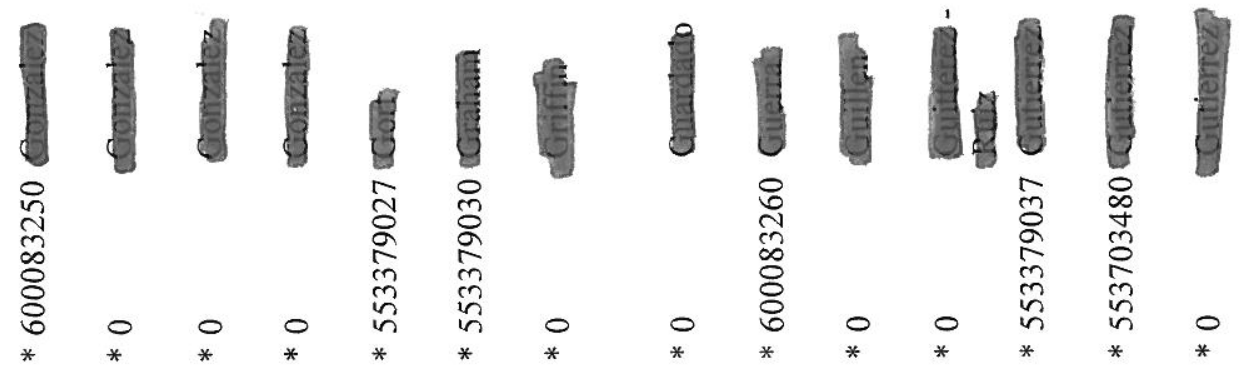




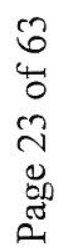

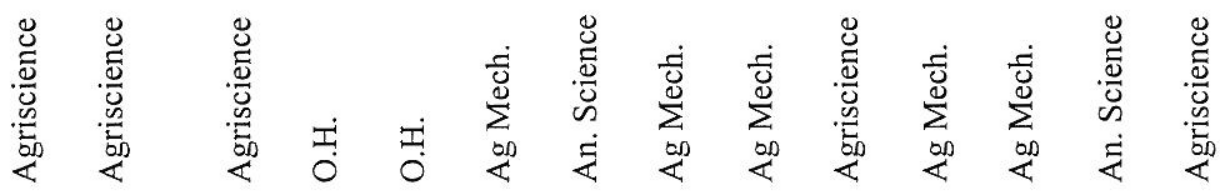

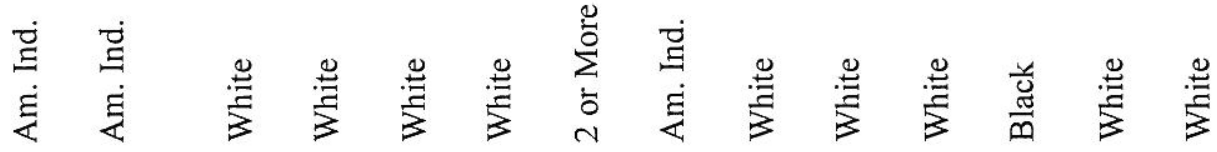
$x \times x \times x \times$

$x$

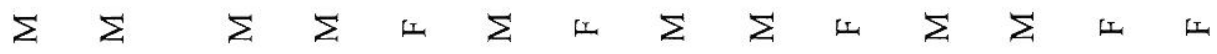

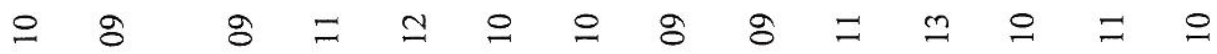

$4-4-4-4-m$ n -4

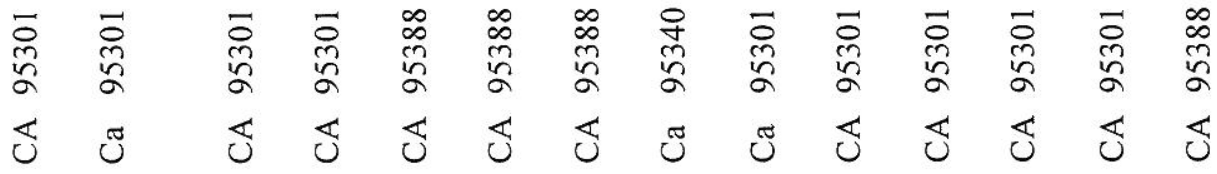

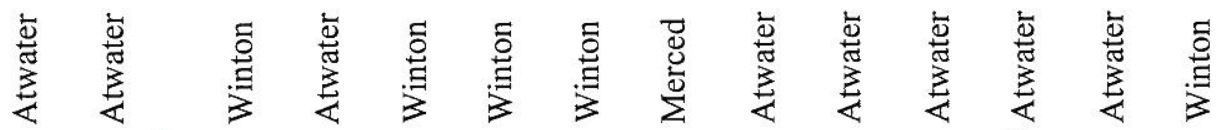

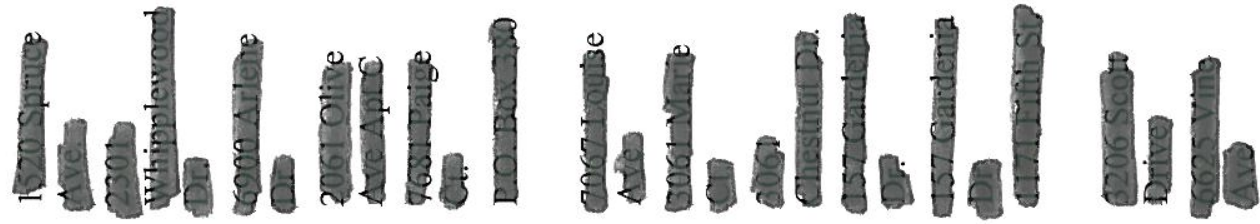

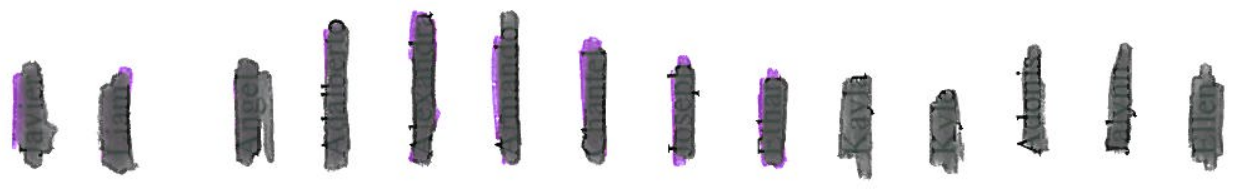

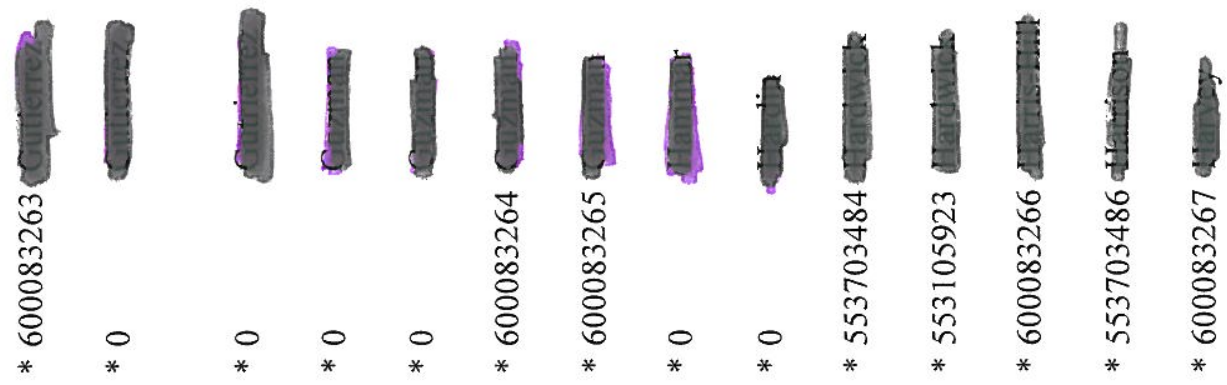




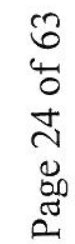

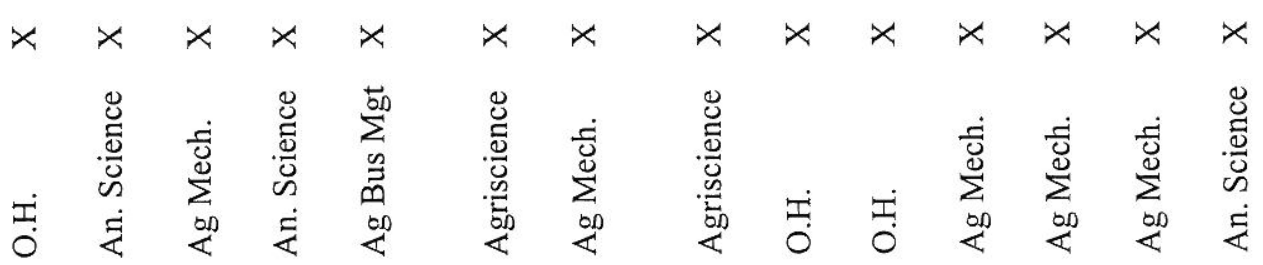

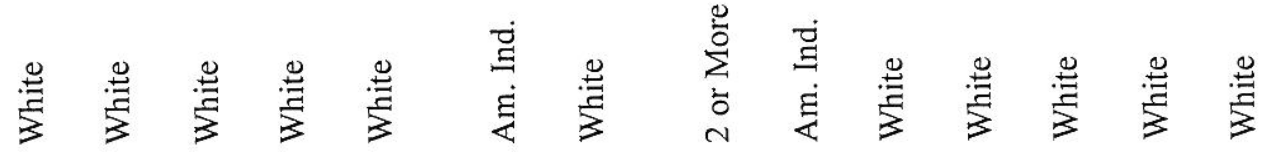
$\times \quad \times \quad x \quad x \quad x \times x$

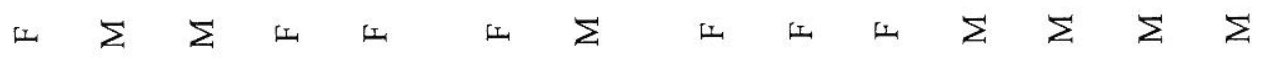

$\simeq 8=\simeq \simeq \therefore \simeq \simeq \therefore$

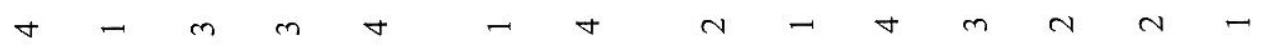

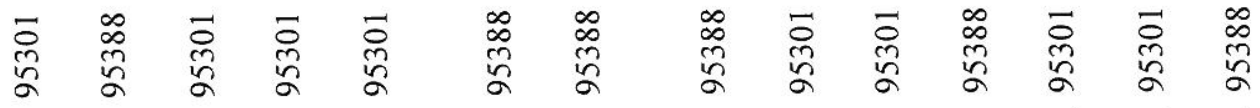

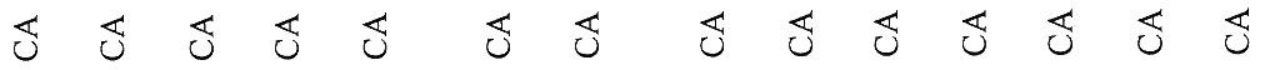

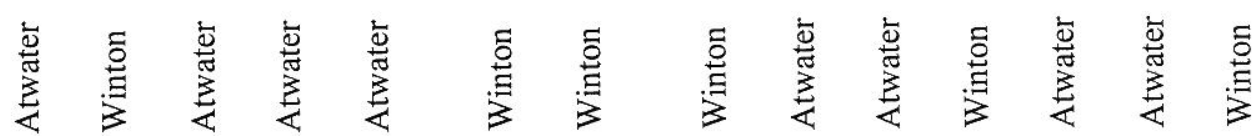
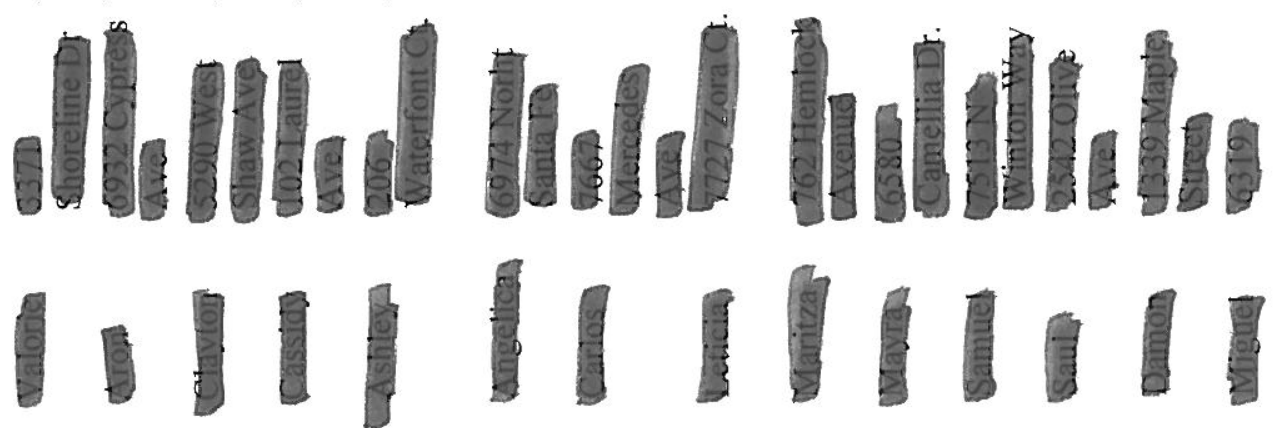

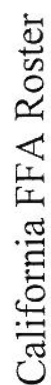

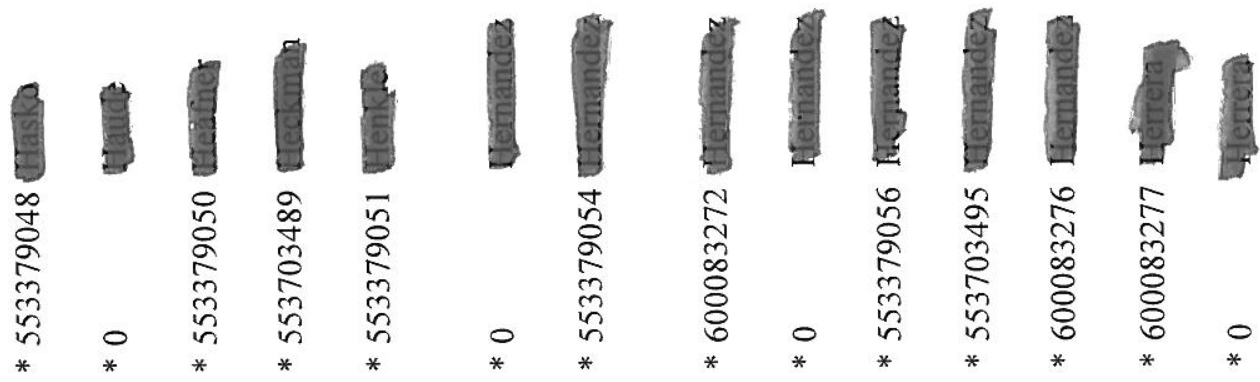




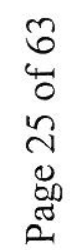

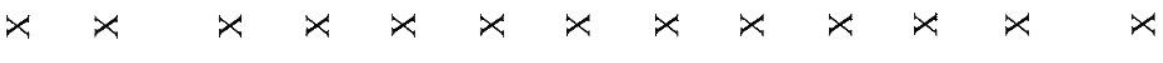

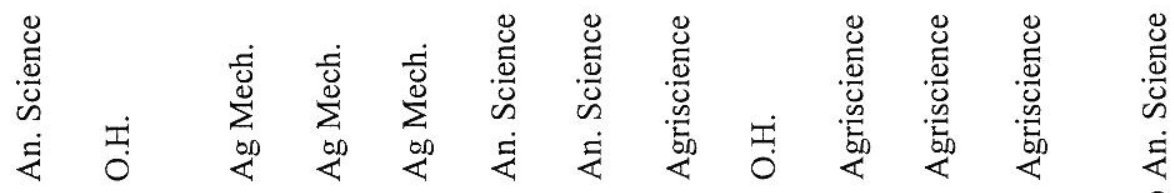
$\times \quad \times \quad \times \quad \times \quad \times \quad \times \quad x$

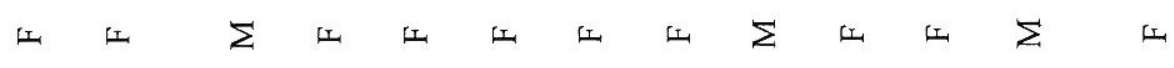

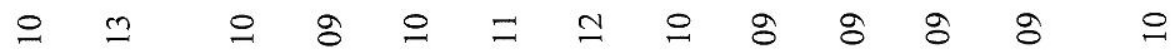

$44 h-4 m \pi n-4-4$

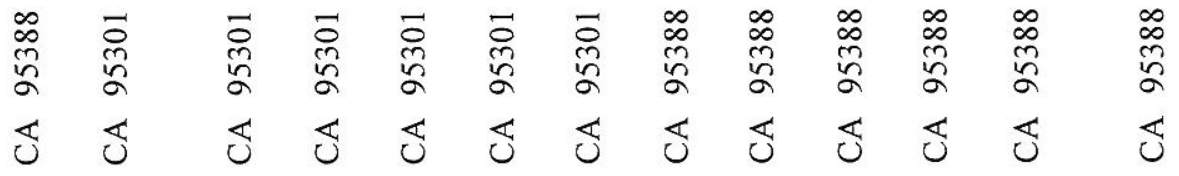

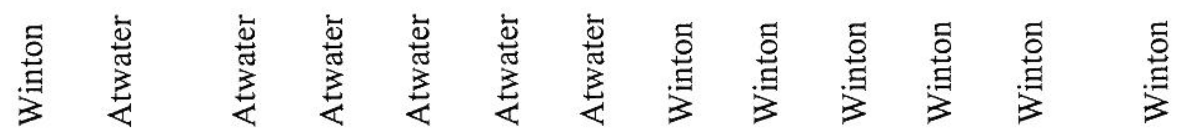

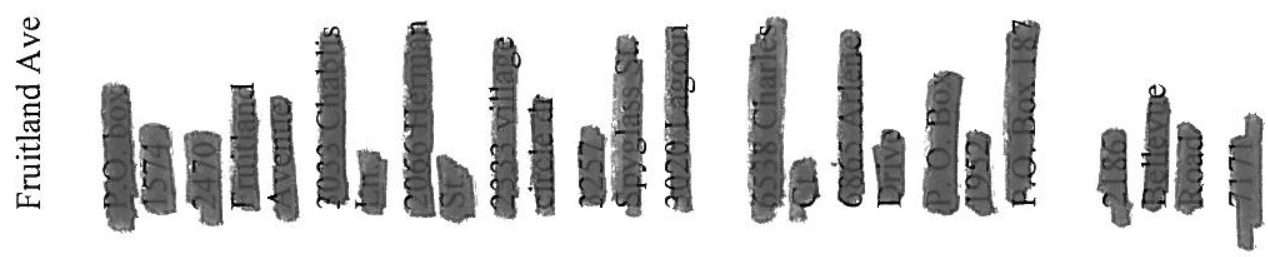

|| ||||$|111|$ |

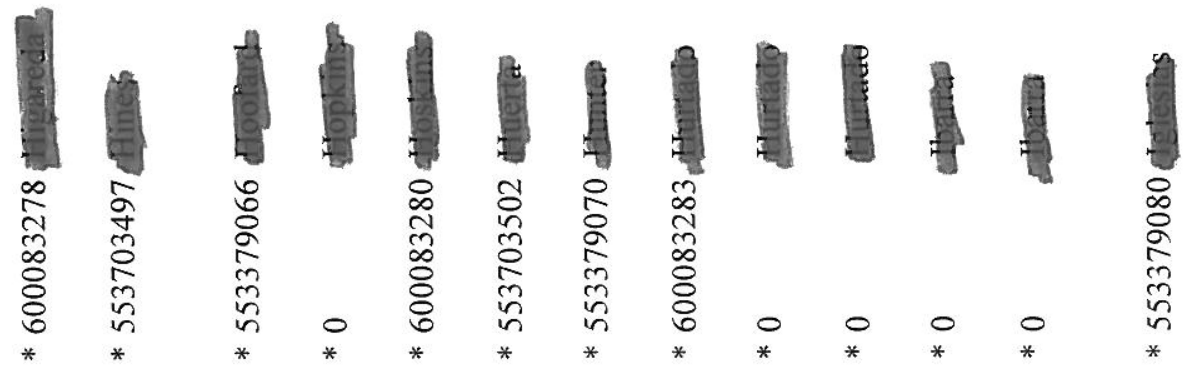


3
4
+
0
1
0
0
0
0

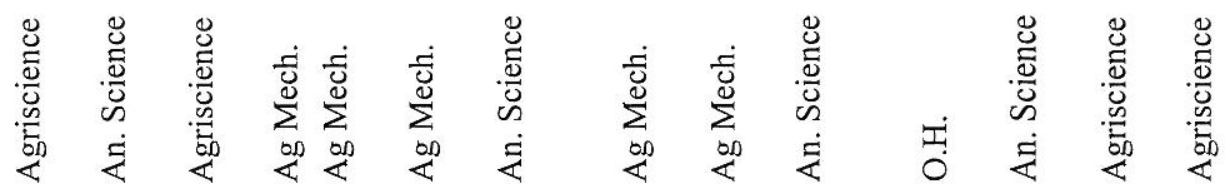

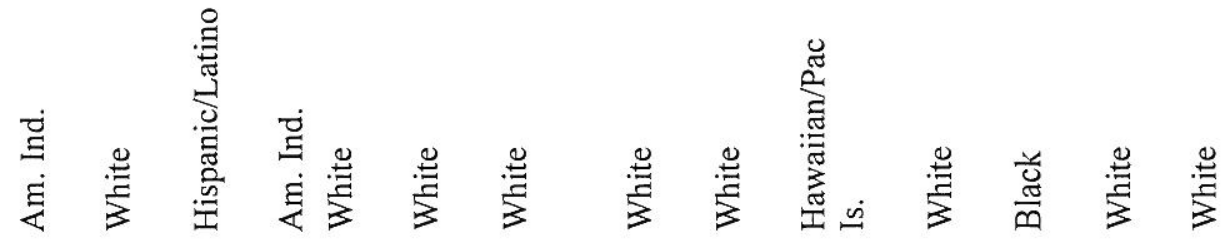

$x \times x \times x \times x \times x$

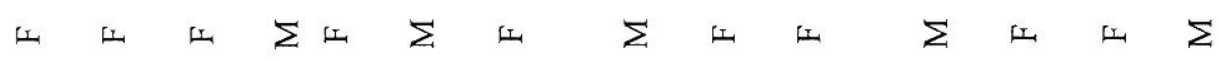

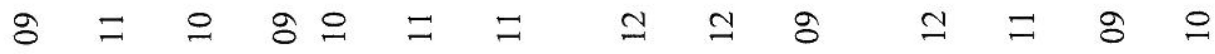

$-m a-4 m \pi n-4-4$

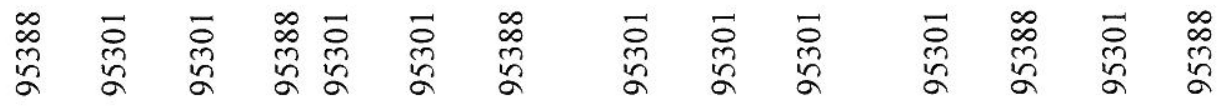

తు

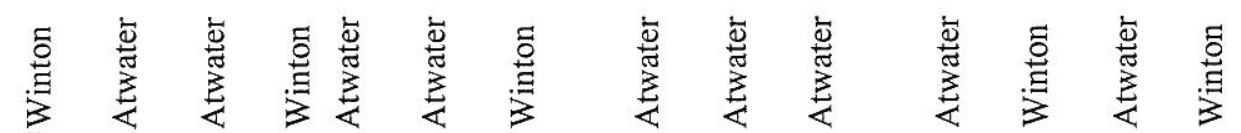

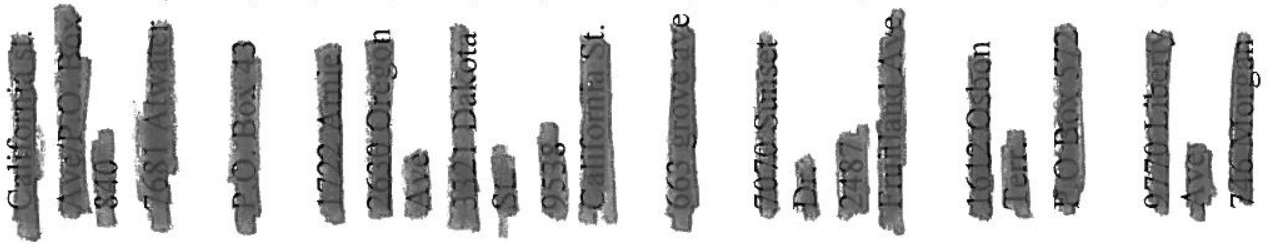

\|\|\|\|\|\|\|\|

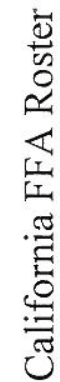

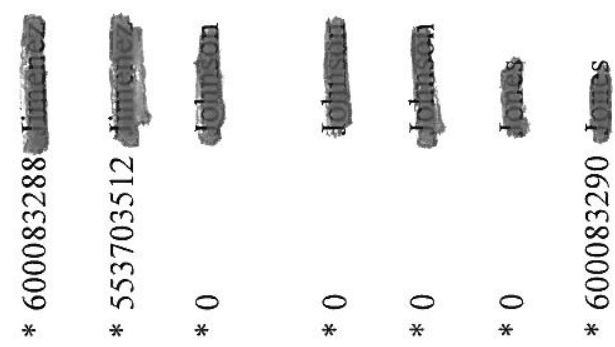




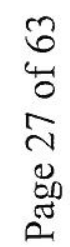

$x \times x \times x \times x \quad x \quad x \quad x \quad x$

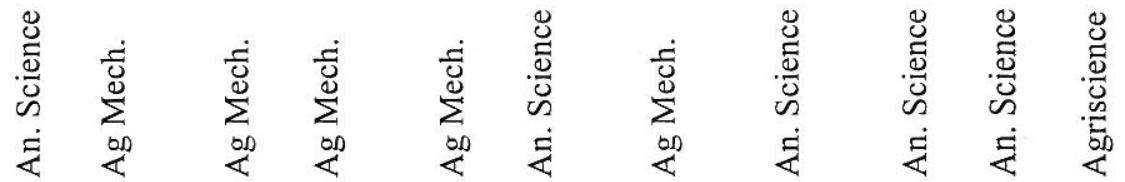

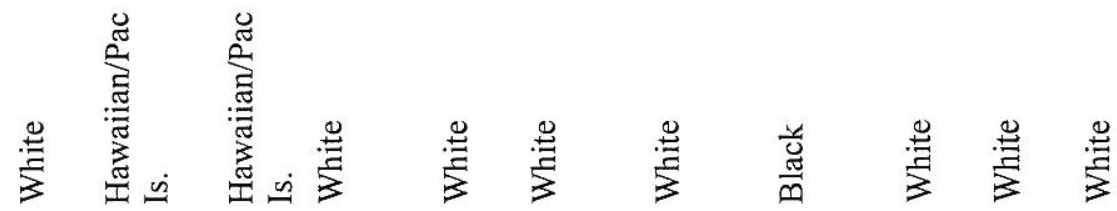

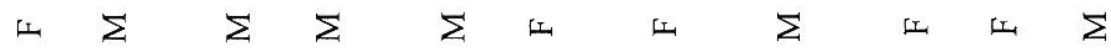

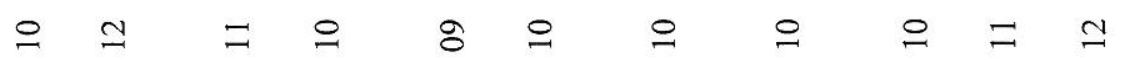

$4 \rightarrow \pi n-4,4 \quad 4 \quad 4 \quad 4 \quad 4-7$

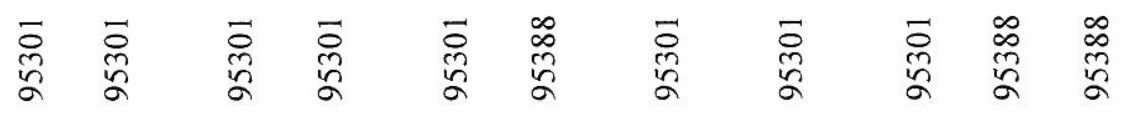

త゙

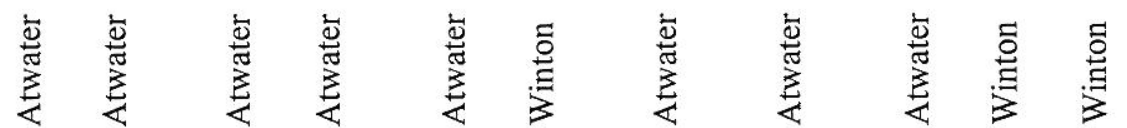

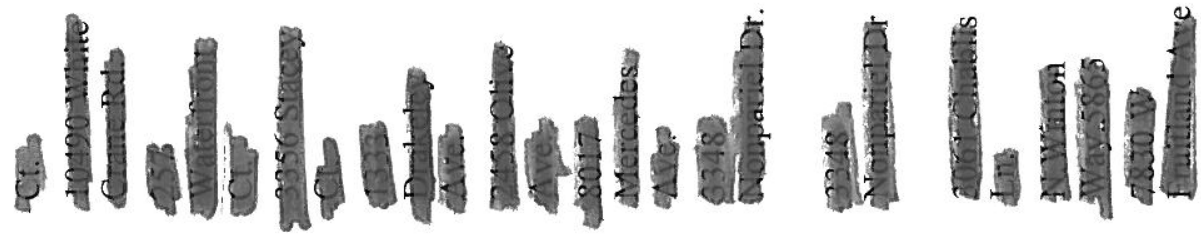

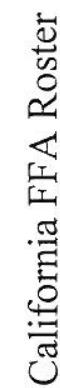

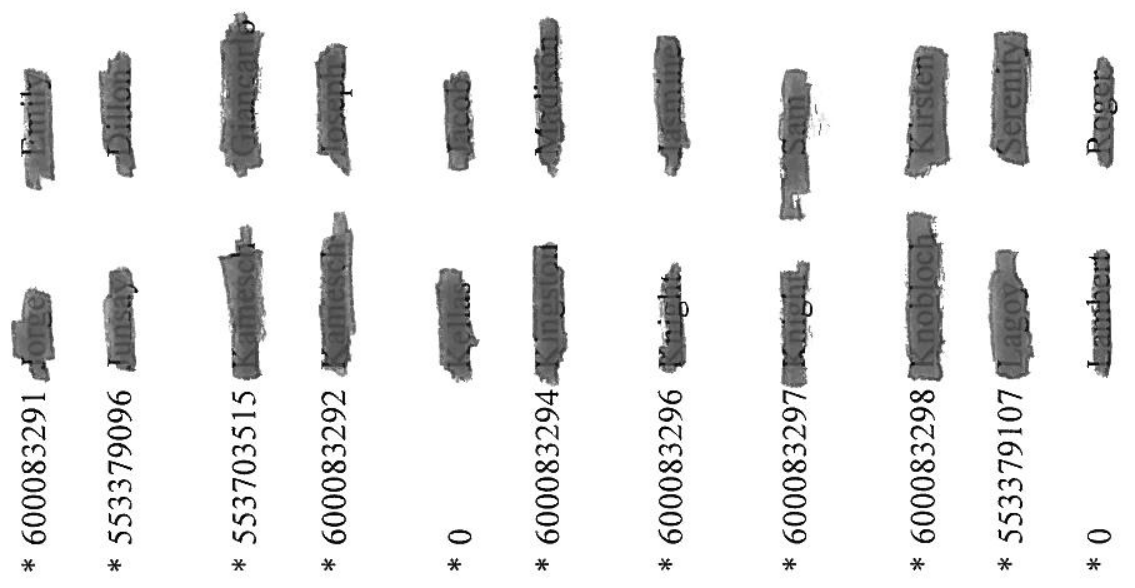




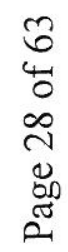

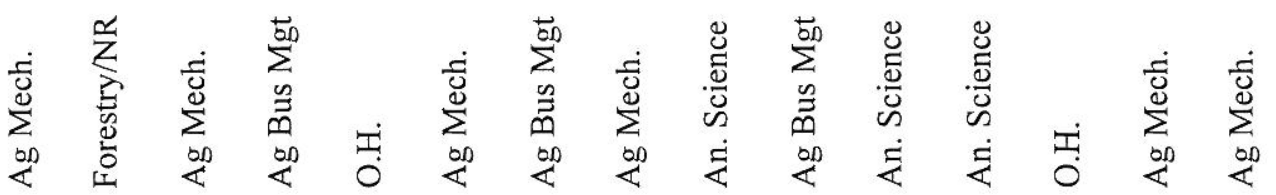

荧 $x \quad x \quad x \quad x \quad x \quad x$

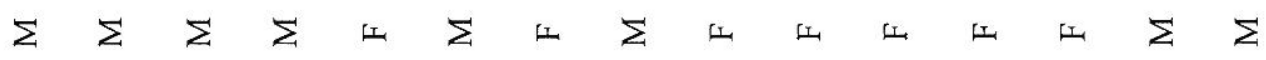

드드으의

$\mathrm{N} \rightarrow-m-\mathrm{N}-\mathrm{N}-\mathrm{n}-\mathrm{n}-\mathrm{n}$

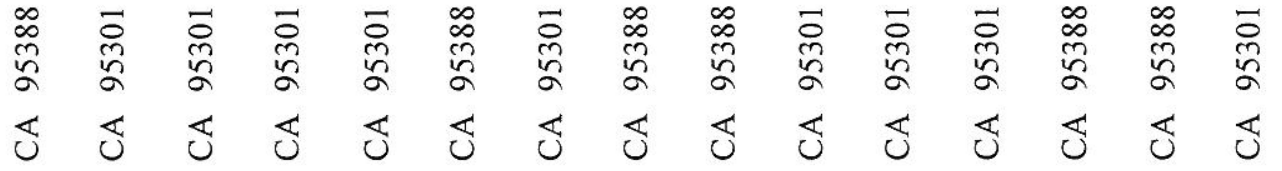

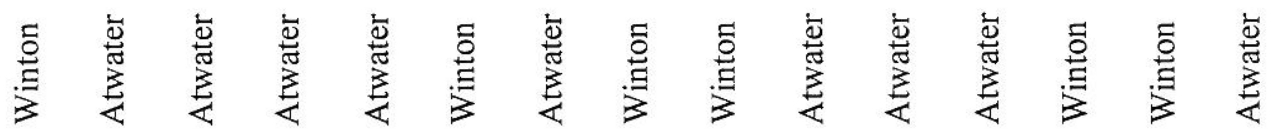

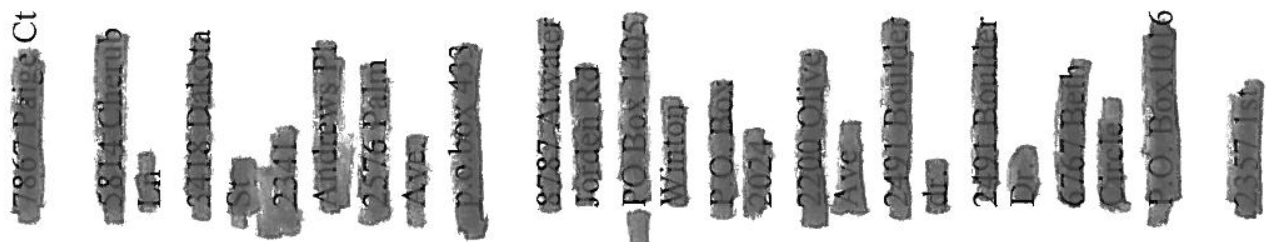

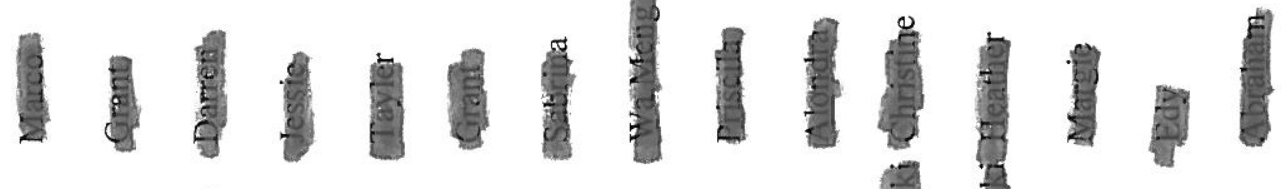

西 


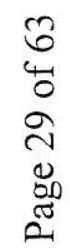

$x \quad x \quad \times \quad \times \quad x \quad \times \quad x \quad x \quad \times \quad x \quad x \quad \times \quad x \quad x$

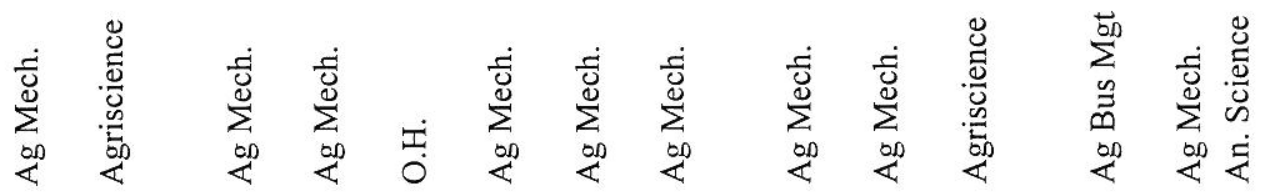

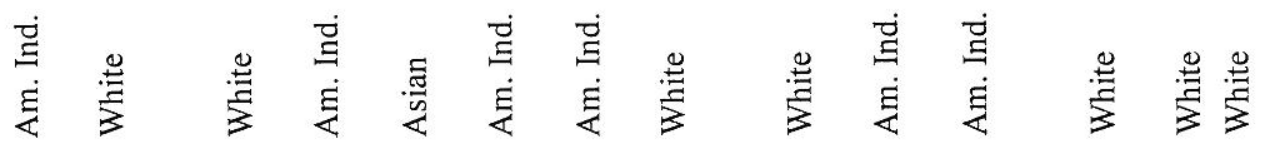

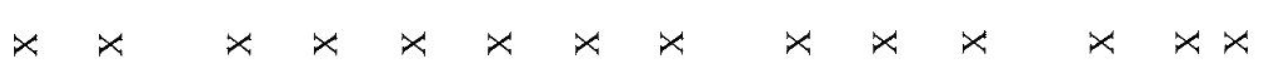

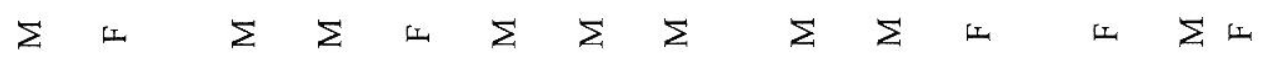

$8=\simeq \approx \therefore \therefore \therefore \therefore ㅇ ㅡ ㅇ ㅡ$

$-m+4-4-464$

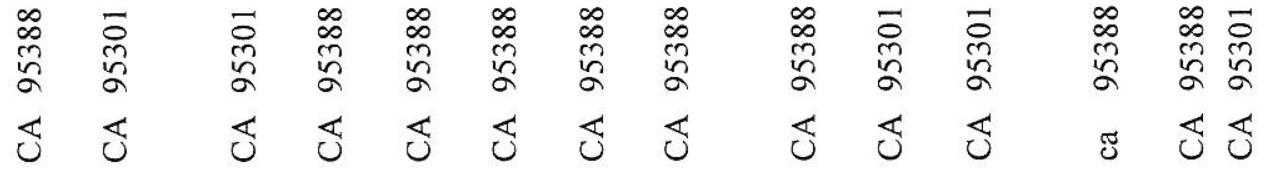

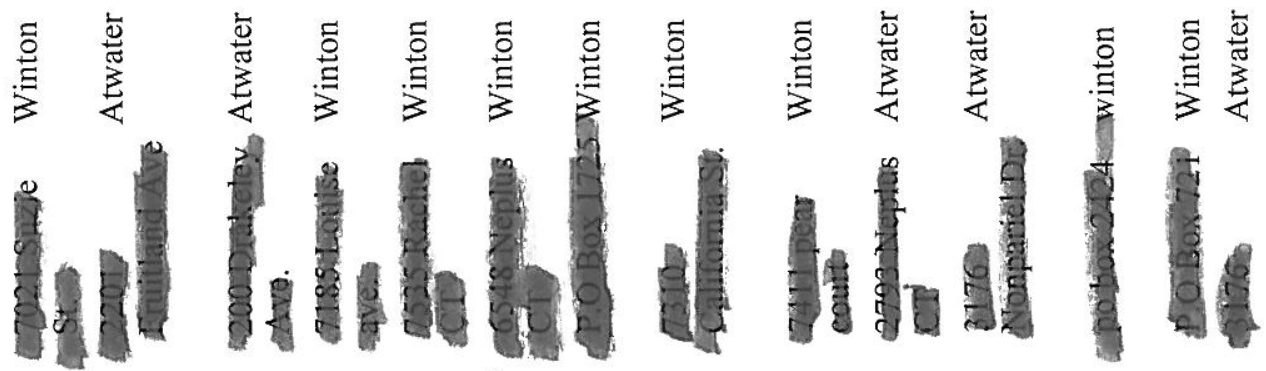

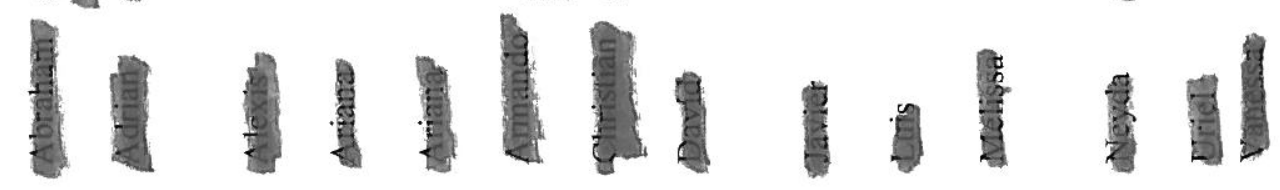

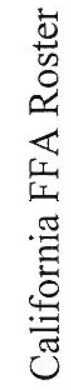

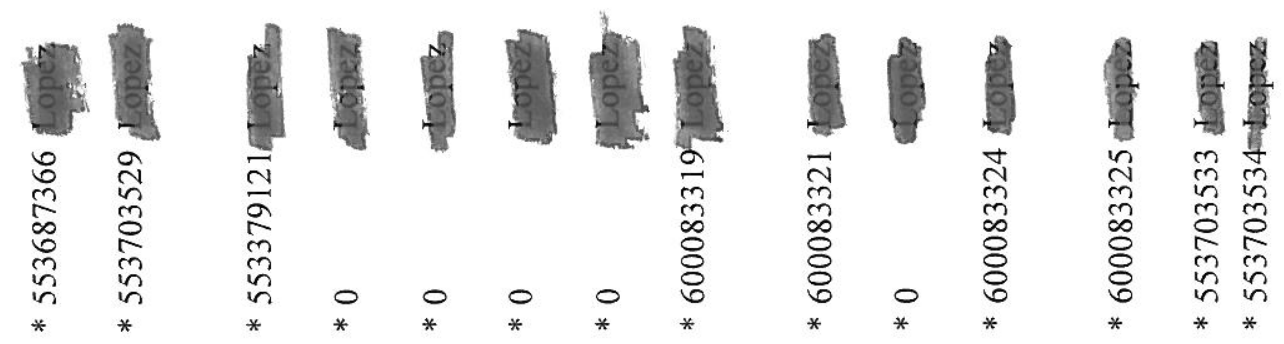




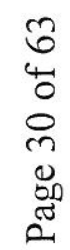

$x \quad x \quad x \quad x \quad x \quad x \quad x \quad x \quad x \quad x \quad x \quad x$

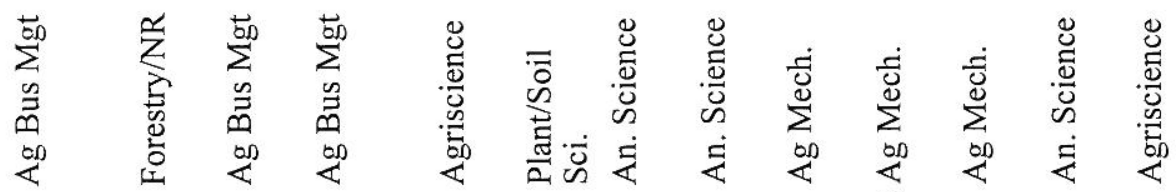

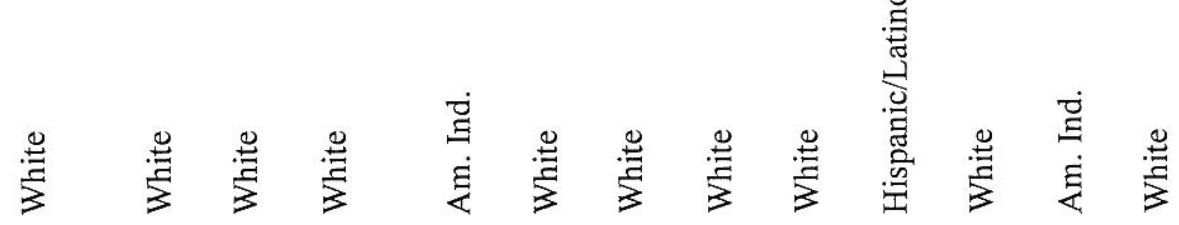
$x \quad x \quad x \quad x \quad x \quad x \quad x \quad x$

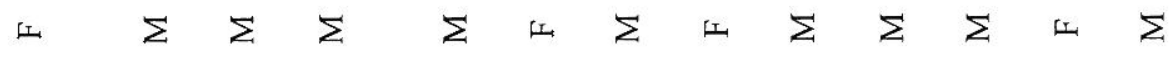

응 $28=0=0$ 용

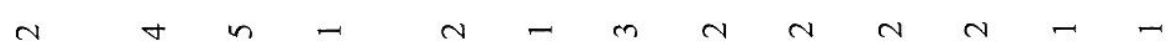

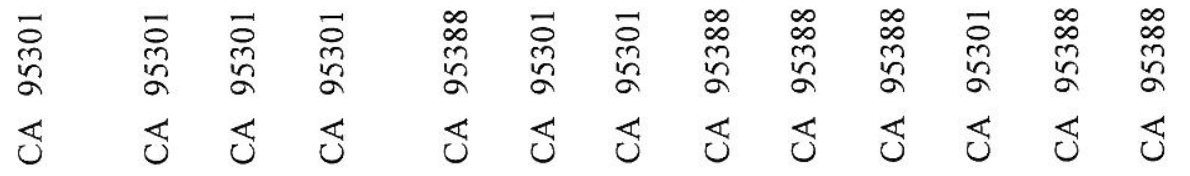

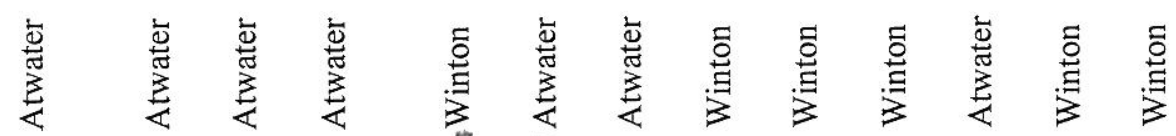
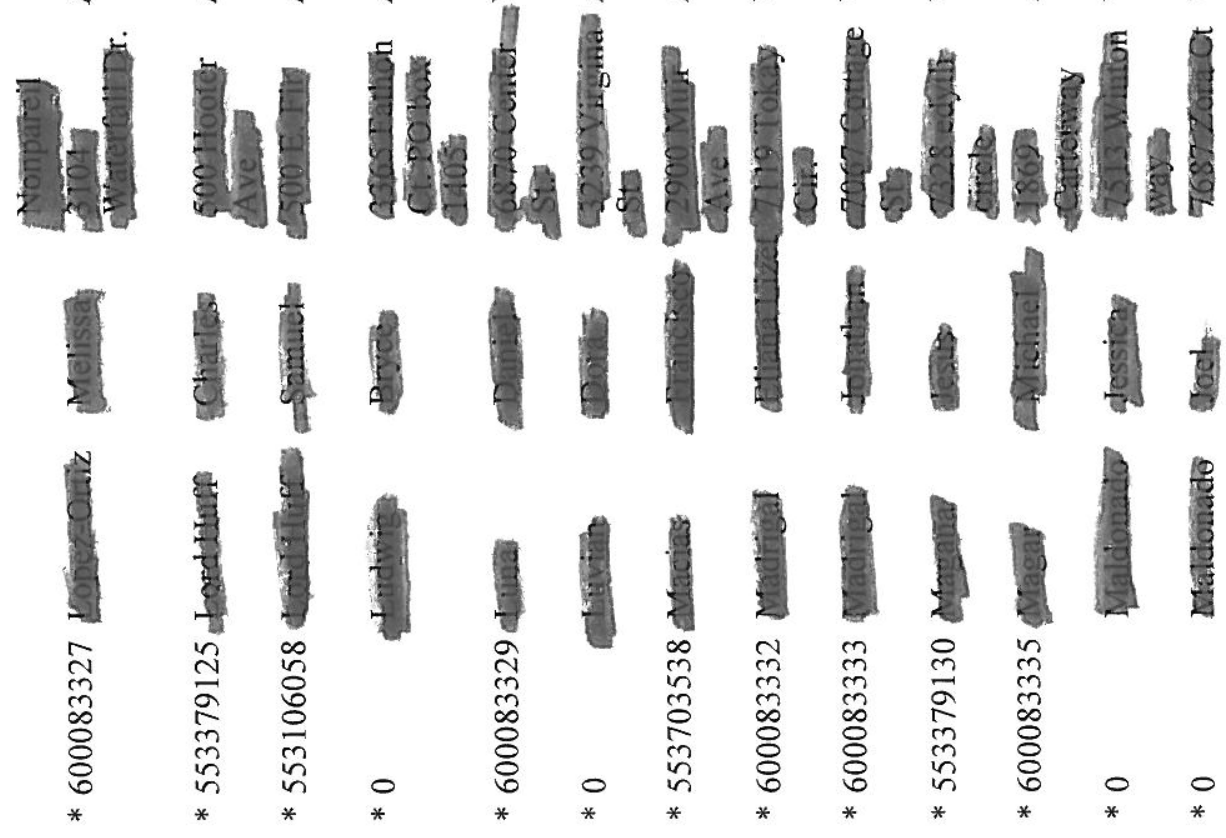


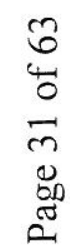

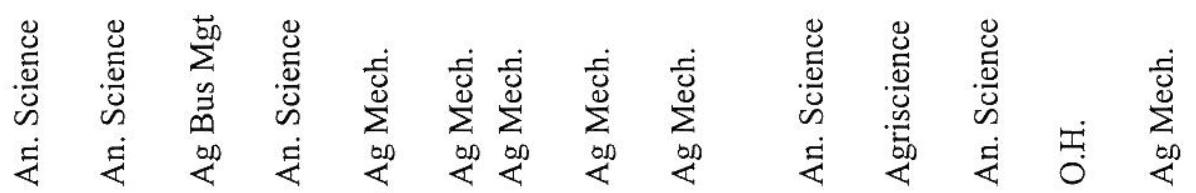

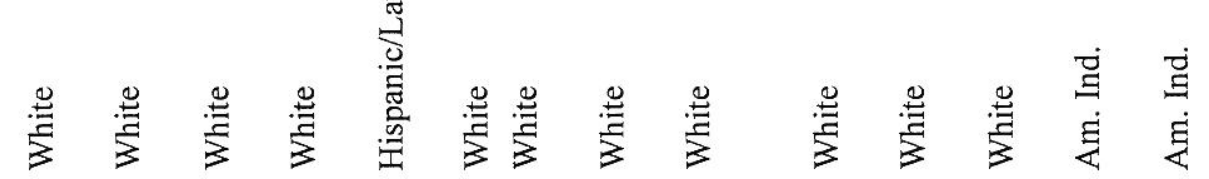
$x \quad x \quad x \quad x \quad x \quad x \quad x \quad x$

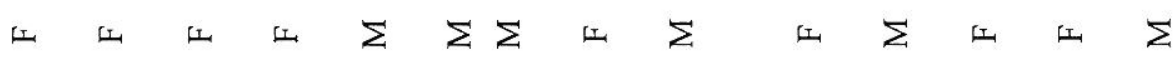

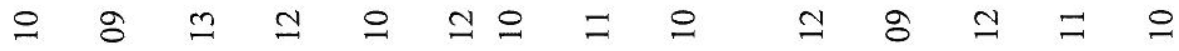

$4 \rightarrow+4-4-4 \rightarrow-4-4$

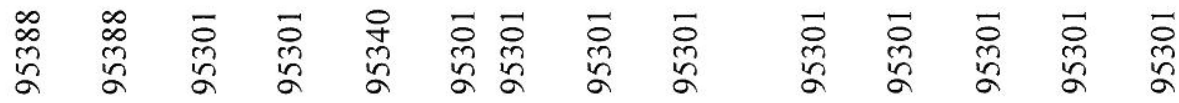

范

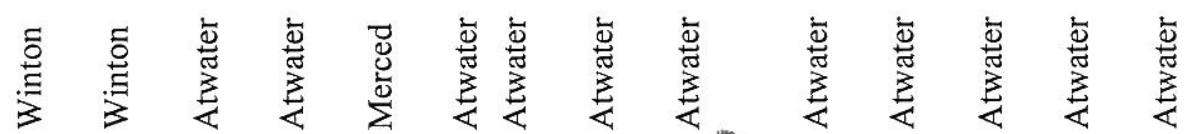
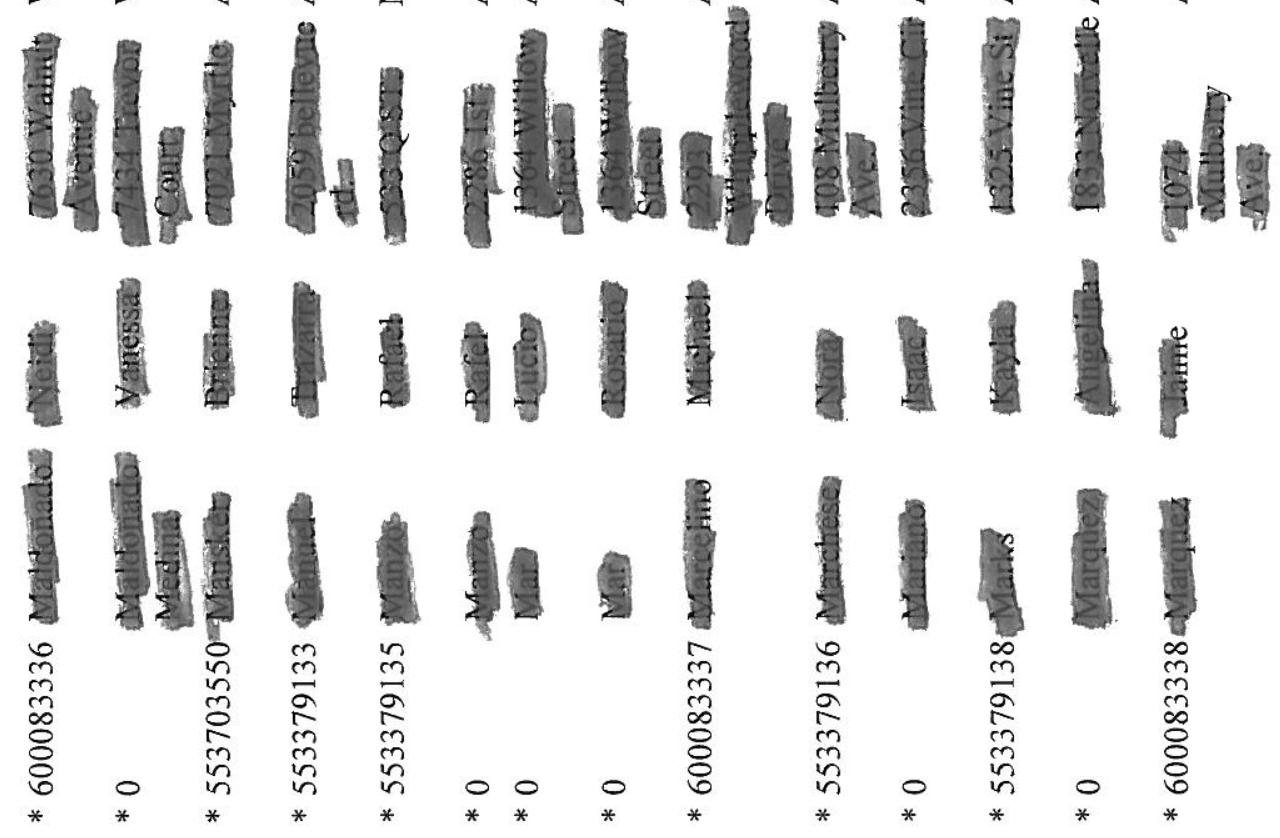


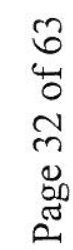

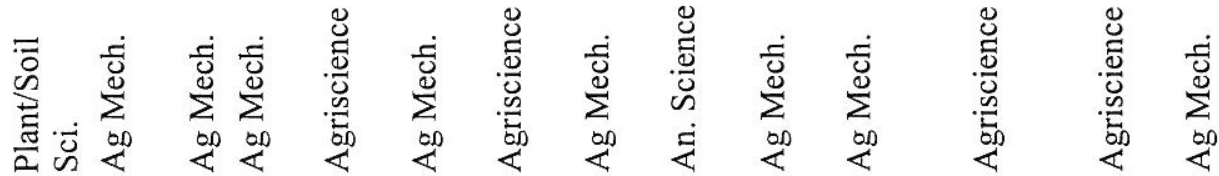

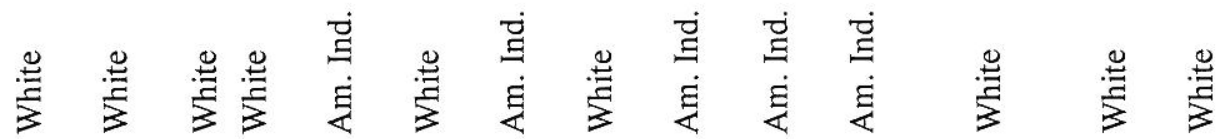
$x \quad x \quad x \quad x \quad x \quad x \quad x \quad x \quad x \quad x \quad x \quad x$

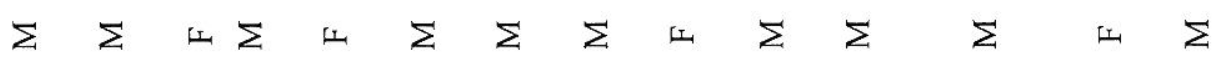

응ㅇㅇㅇㅇㅇㅇㅇ 8 의

$m-4 \rightarrow-4 \rightarrow-4 \rightarrow-4$

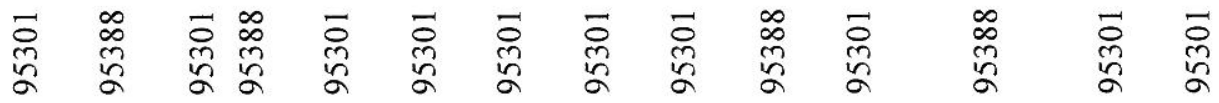

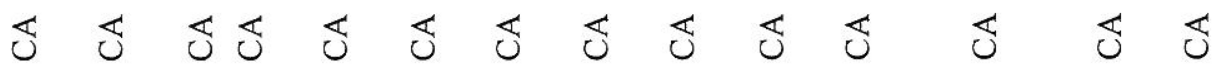

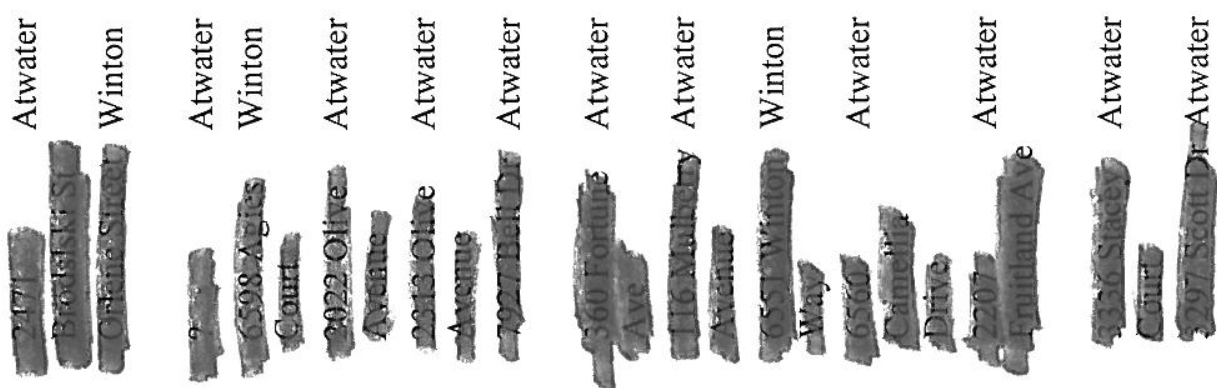

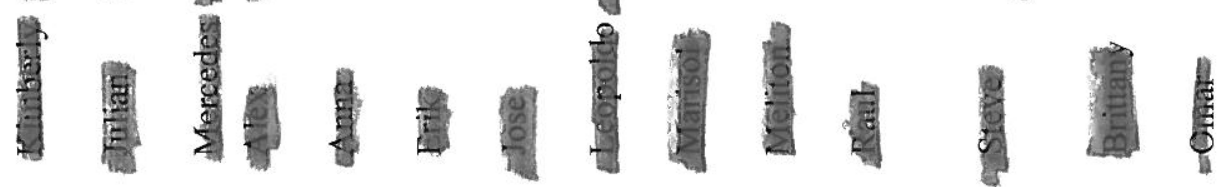

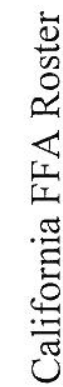

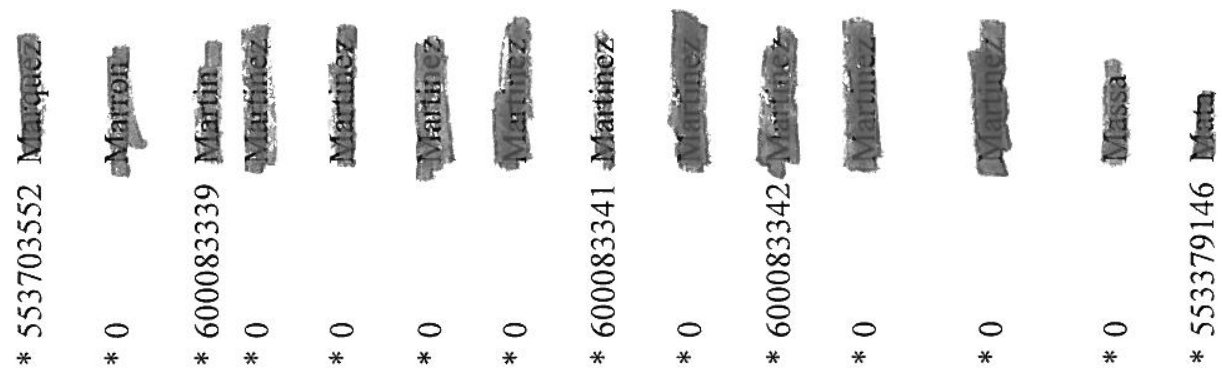


$\hat{6}$
+
0
$\infty$
$\infty$
$\infty$
$\approx$
$\approx$

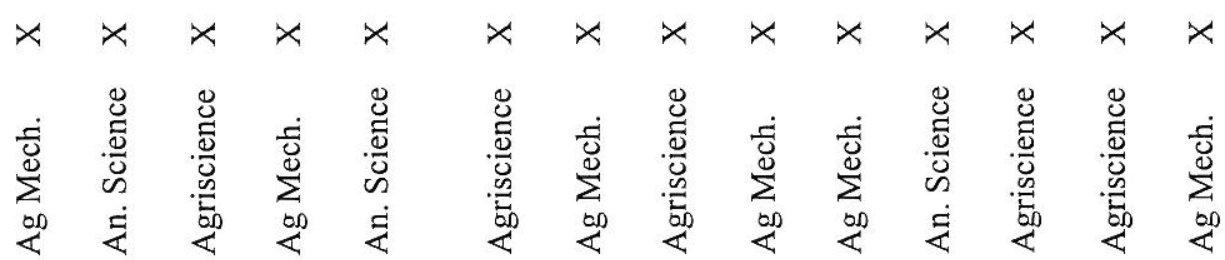

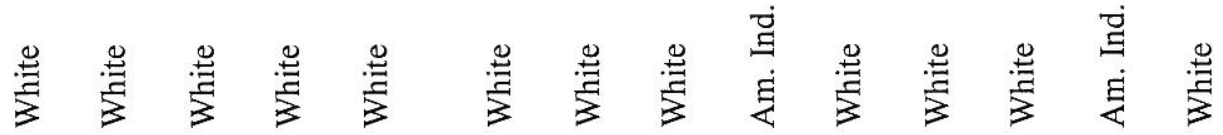
$x \times x \times x$

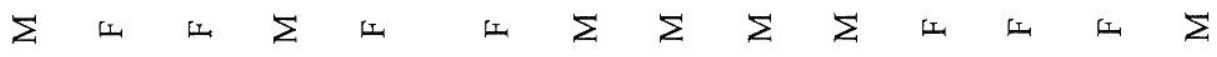

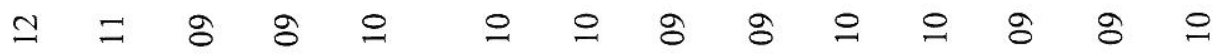

$m-n-N-4-4-4$

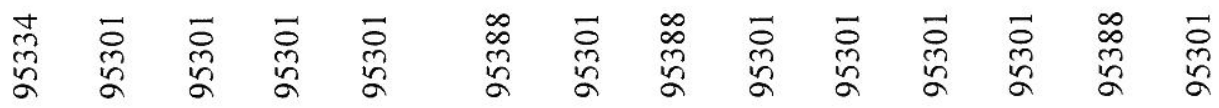

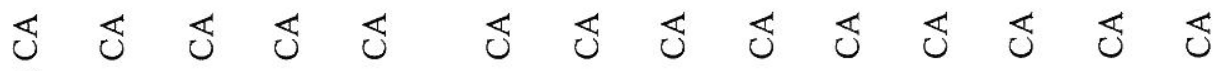

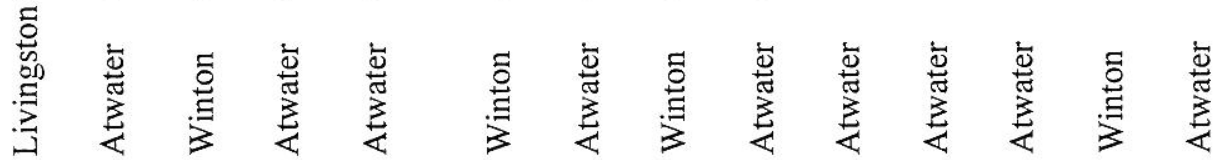
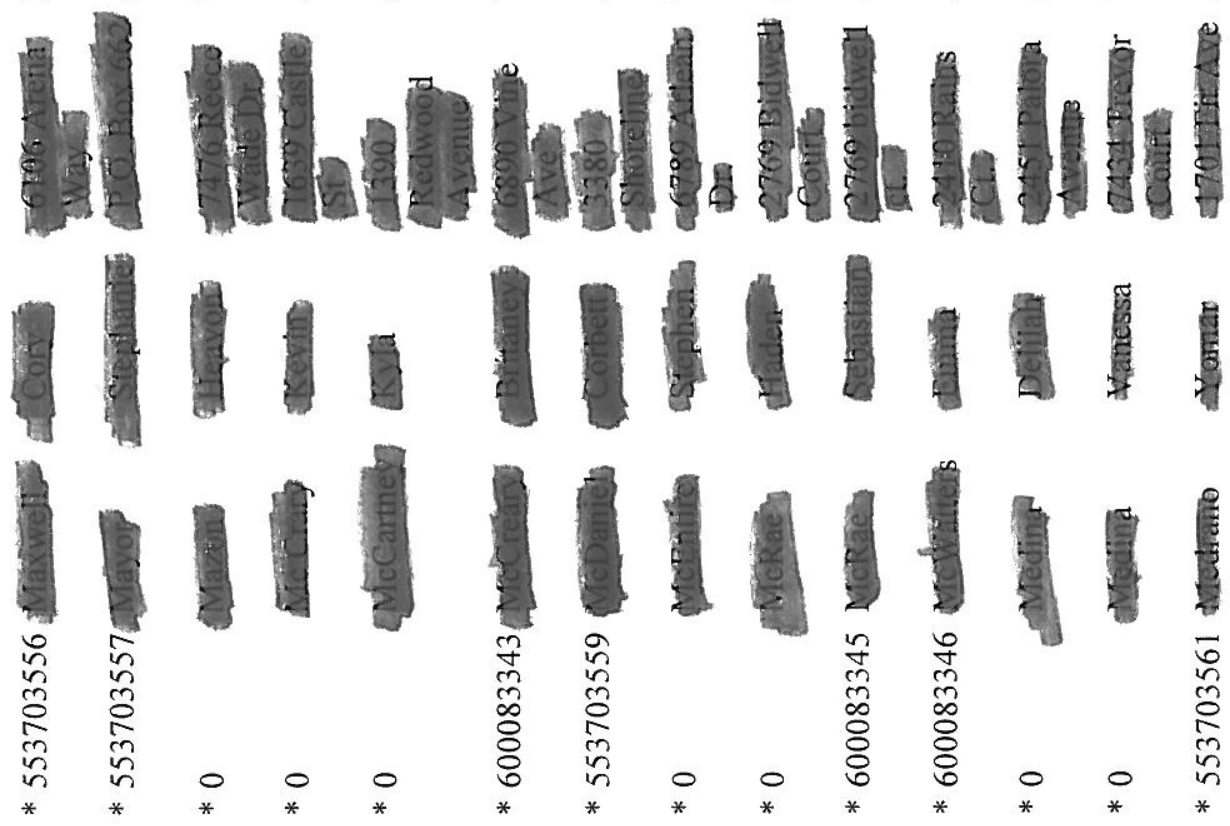
$\hat{6}$
4
0
+
$\infty$
$\infty$
$\approx$
$\approx$

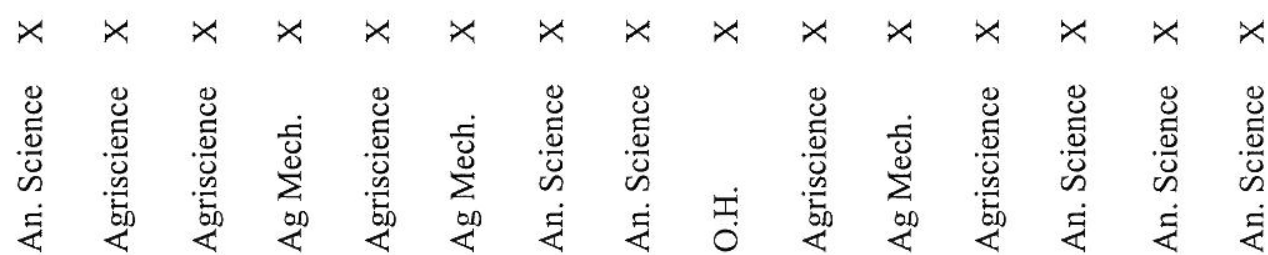

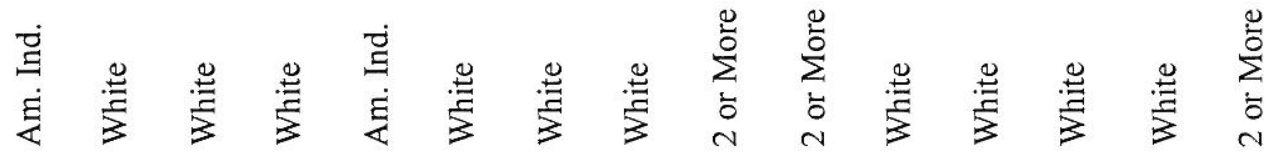

$x \quad x \quad x \quad x \quad x \quad x \quad x \quad x \quad x \quad x$

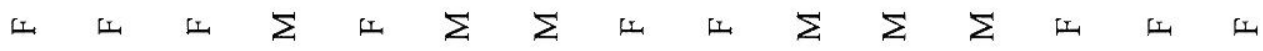

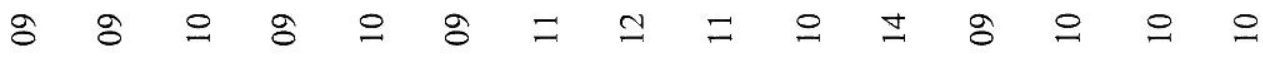

$-4-4-4-4-4,4-4$

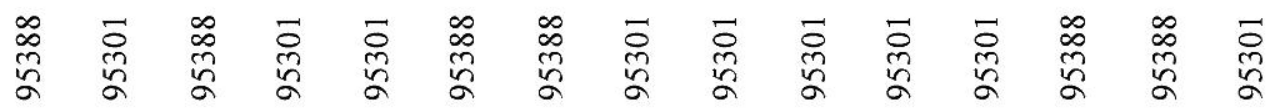

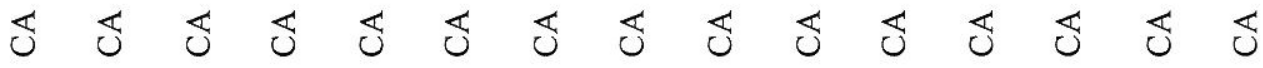

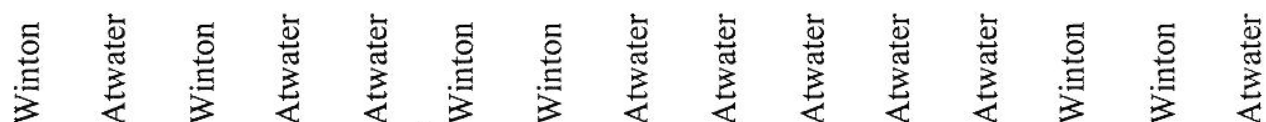

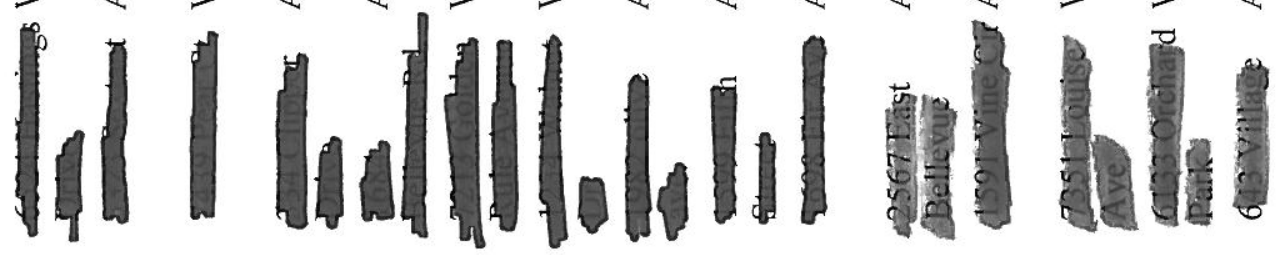

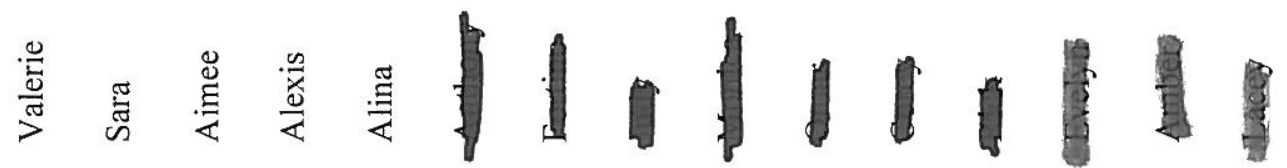

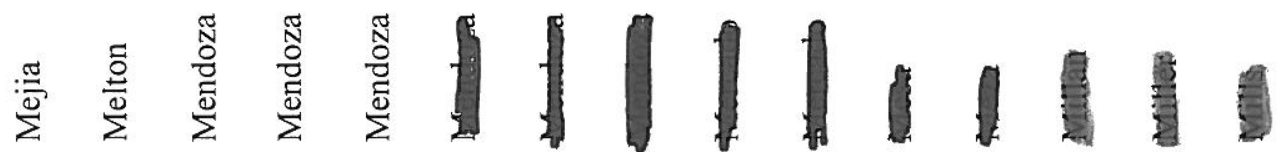

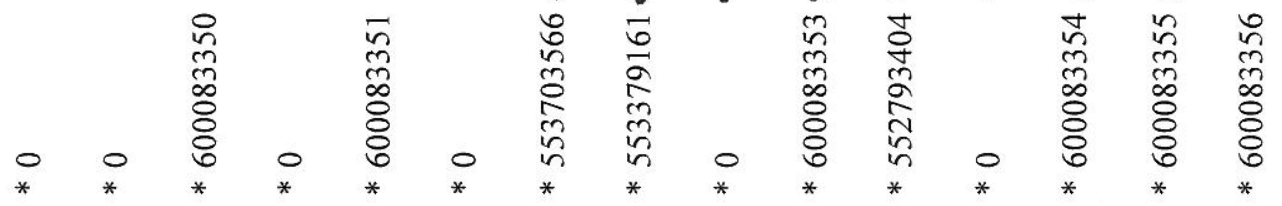


3
6
4
$n$
$n$
0
0
$\Xi$
$\tilde{\sigma}$

$\times \quad x \quad x \quad x \quad x \quad x \quad x \quad x \quad x \quad x \quad x \quad x \quad x \quad x$

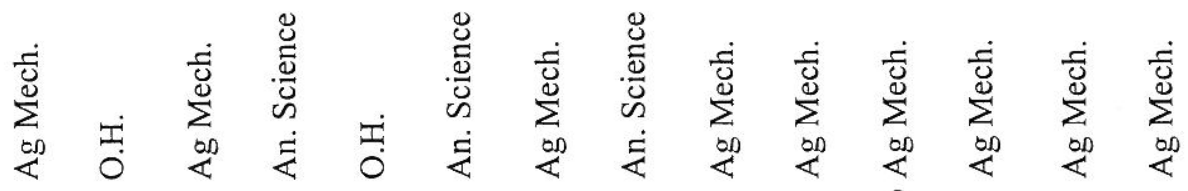

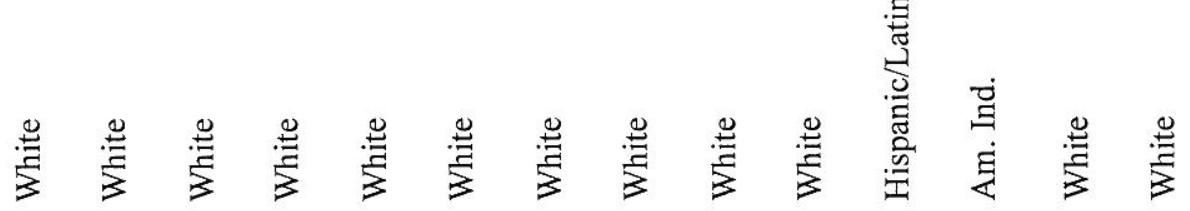
$\times x$

$x \times x \times x$

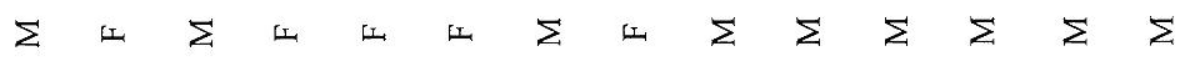

$\cong=\Xi \cong 8=\subseteq \circ \simeq \exists \circ \circ \circ=$

$n-4 n-m+4+4+4-4 m$

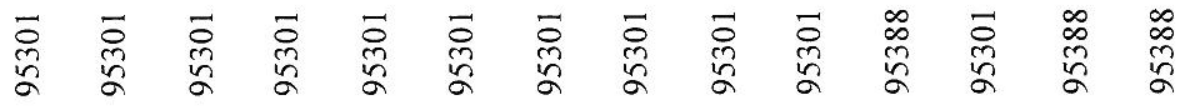

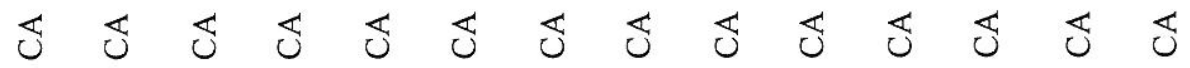

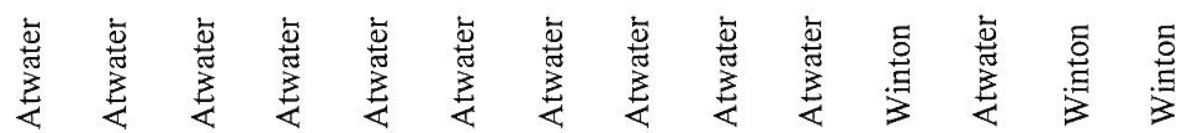

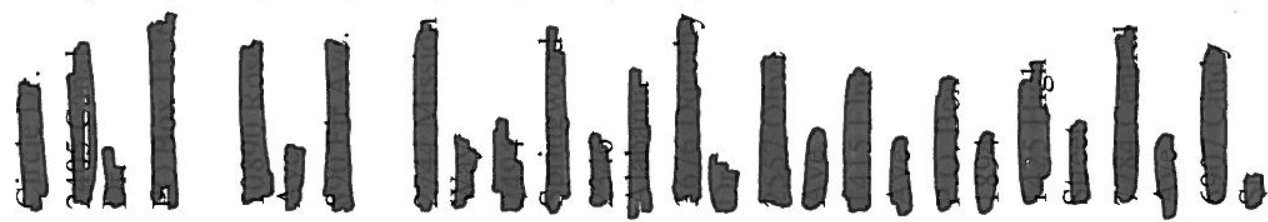

\|\|\|\|\|\|\|\|$\|$

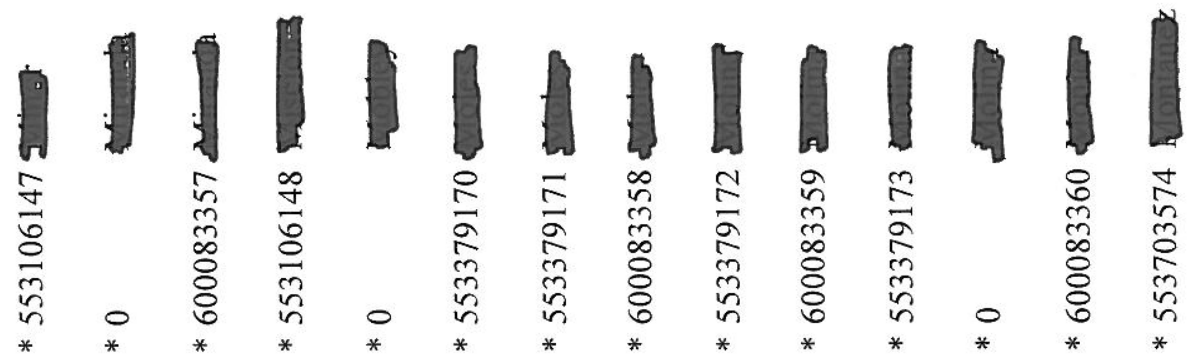




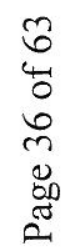

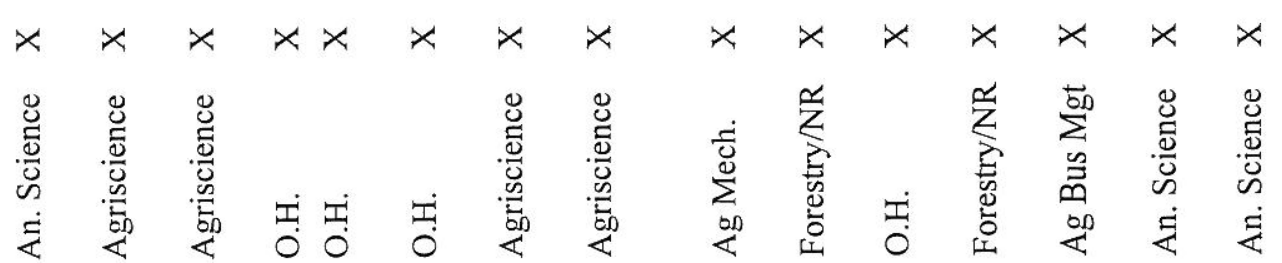

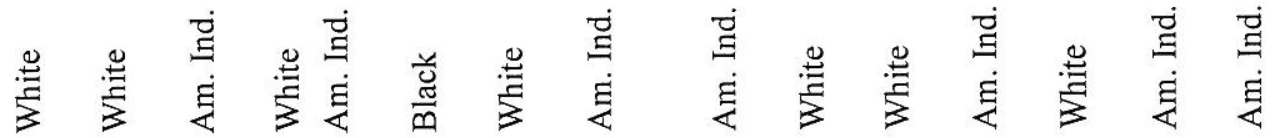
$x \quad x \times x \times x \times x \times x$

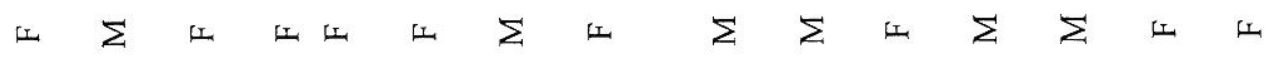

$8=0=8 \circ \circ \therefore=8 \circ 8=8=$

$-m--4 N-4-4-4-$

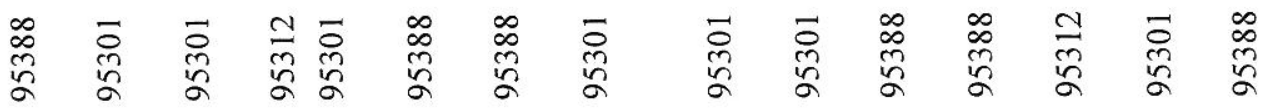

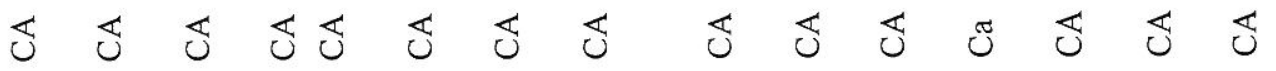

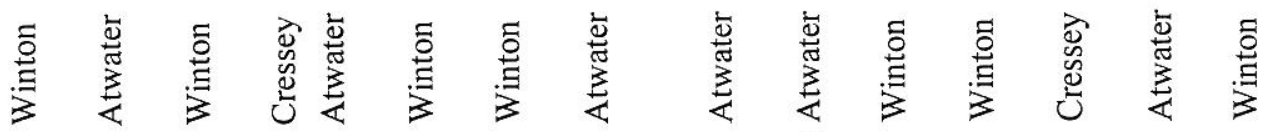

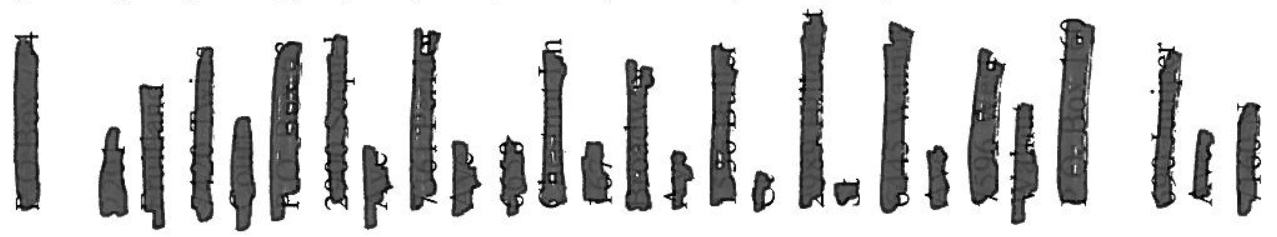

| \|\|\|\|||||||||

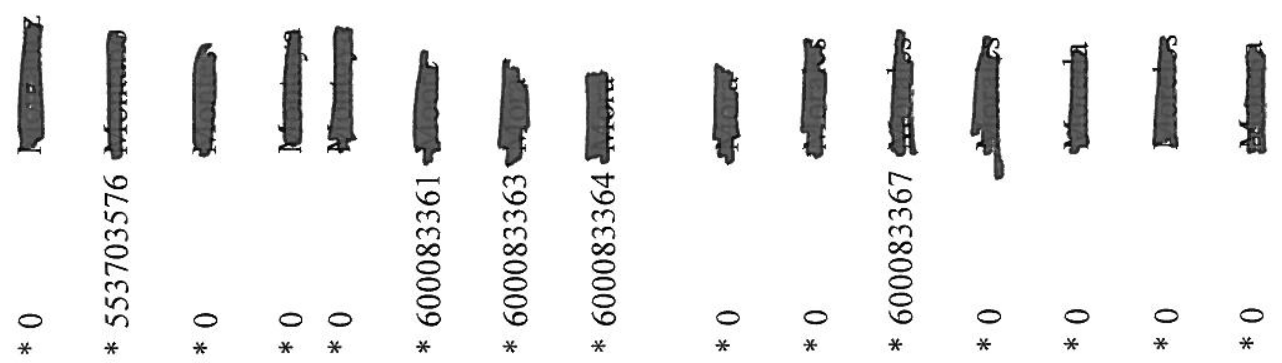


$\hat{6}$
4
0
0
0
0
0
$\approx$

$x \times x \times x \times x \quad x \quad x \quad x \quad x \quad x \quad x \quad x$

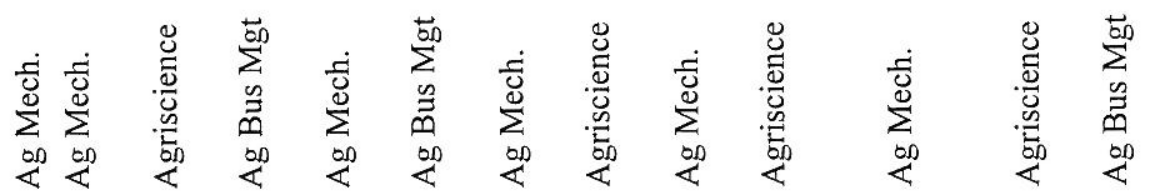

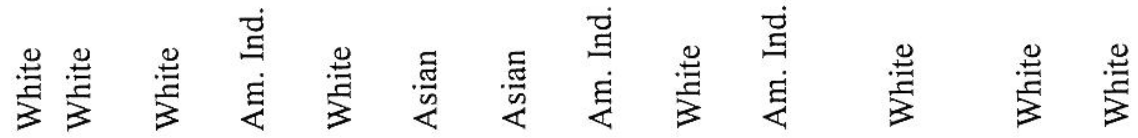
$x \times x \times x \times x \quad x \quad x$

$\Sigma \Sigma \Sigma \omega \Sigma \Sigma \Sigma \Sigma \Sigma \Sigma \Sigma \Sigma \Sigma \Sigma \Sigma \Sigma 山 \Sigma$

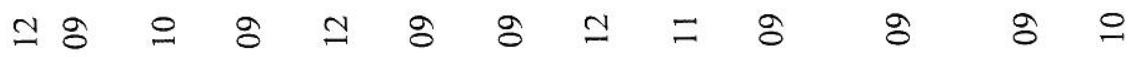
$n-4-\rightarrow-m-\rightarrow-4$

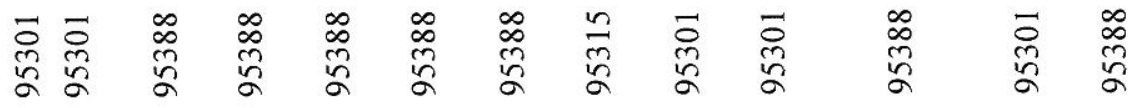

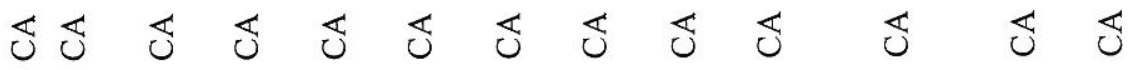

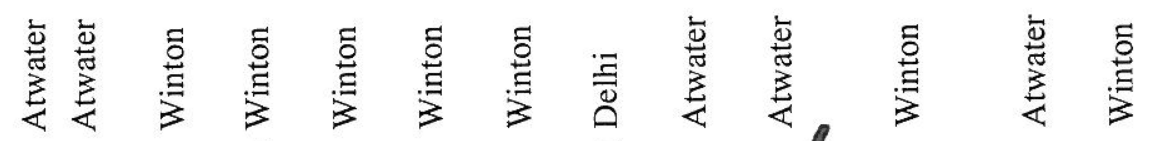
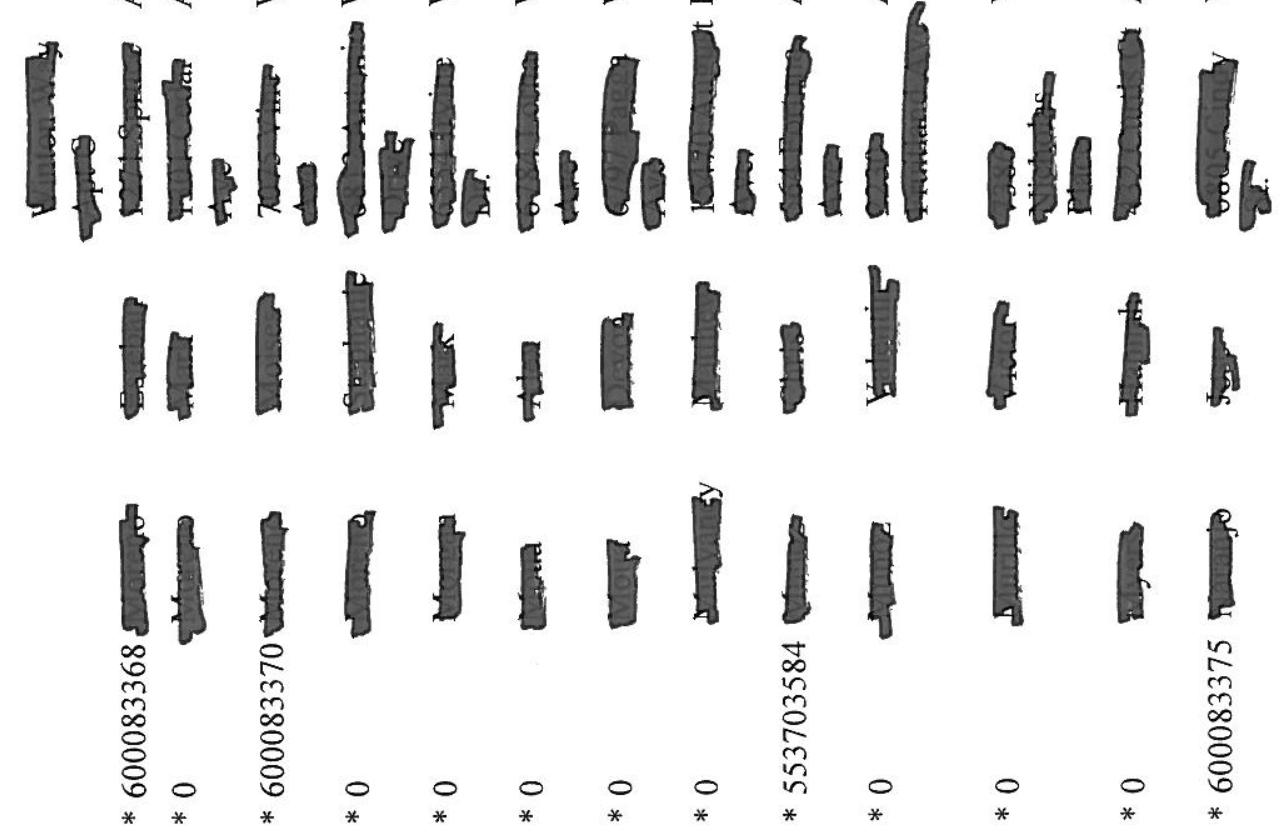


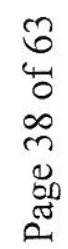

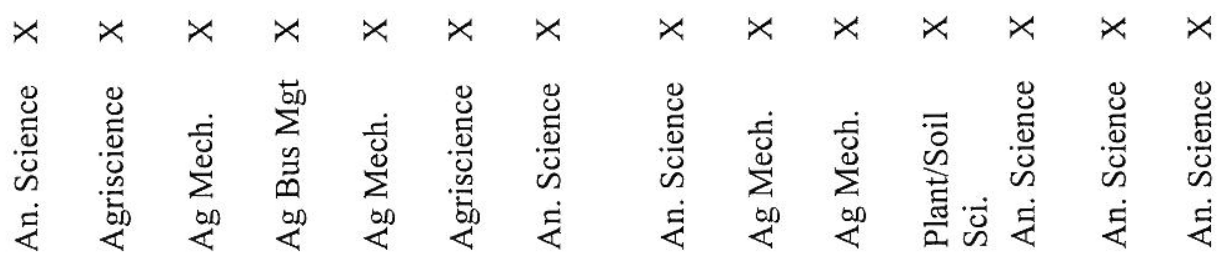

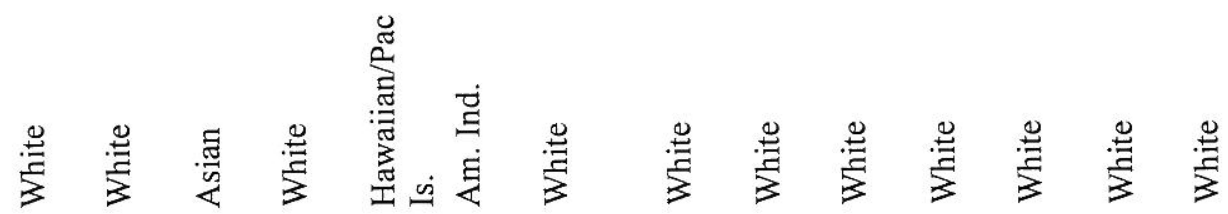
$\times \quad \times \quad \times \quad x \quad \times \quad x \times$

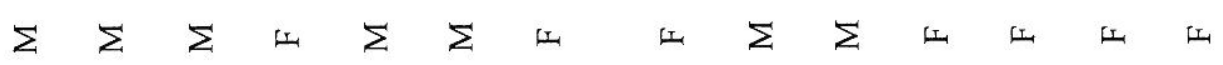

\& 8 \& $=\simeq 8 \circ \simeq 8$ $\circ=0 \simeq$

$---m--N+-m N N m$

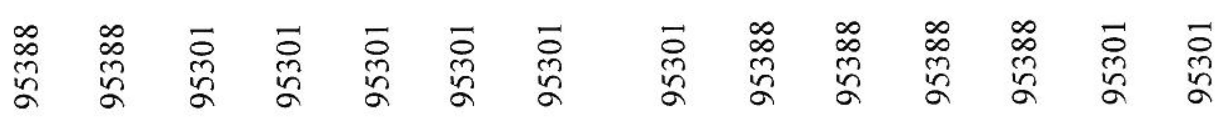

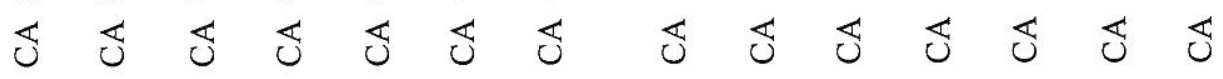

营总离

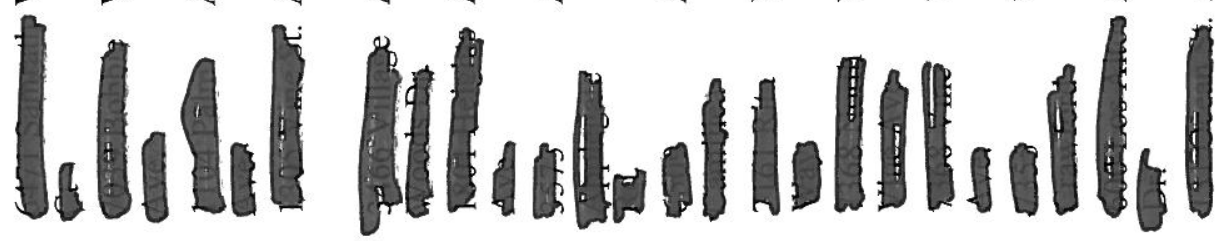

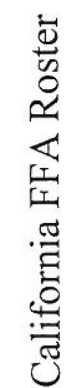
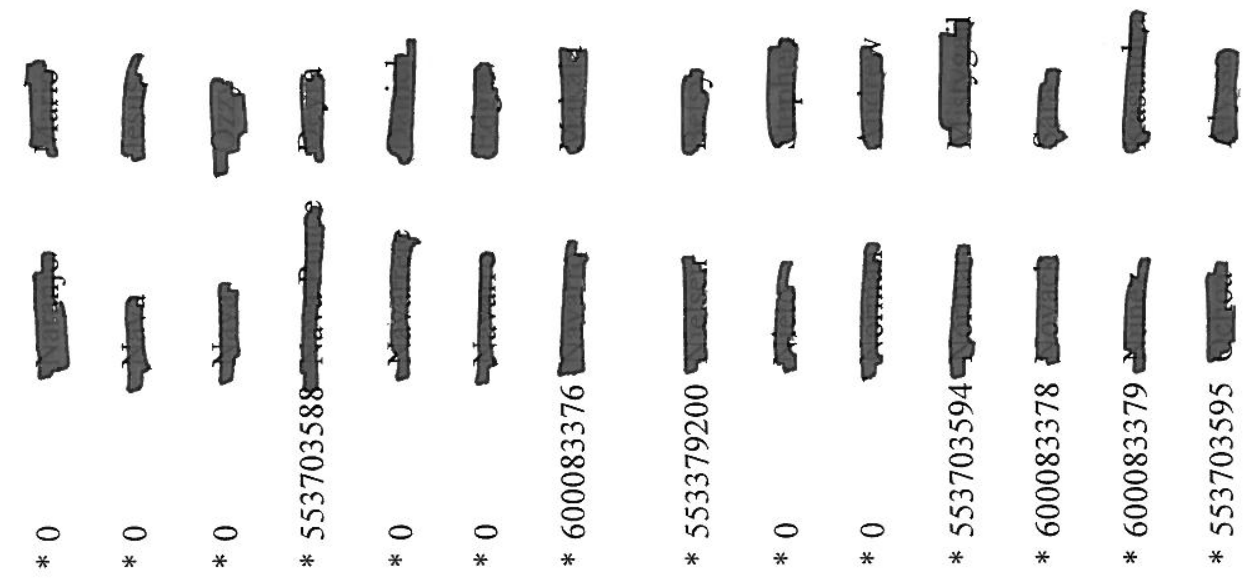
3
6
4
0
0
0
0
0
0

$x \quad x \quad x \quad x \quad x \quad x \quad x \quad x \quad x \quad x \quad x$

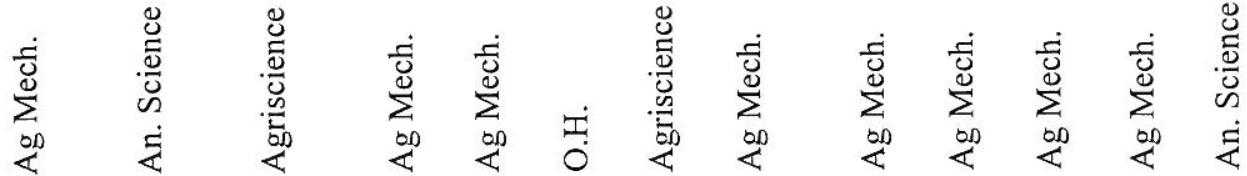

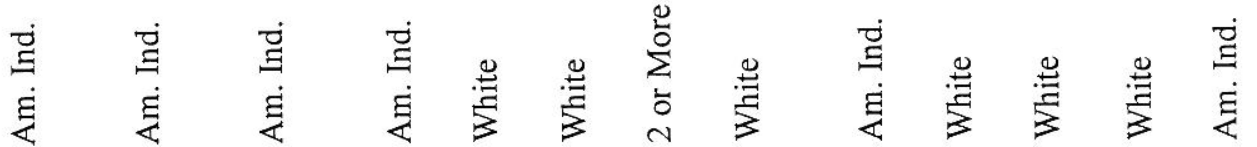

$x \quad x \quad x \quad x \quad x \quad x \quad x \quad x \quad x$

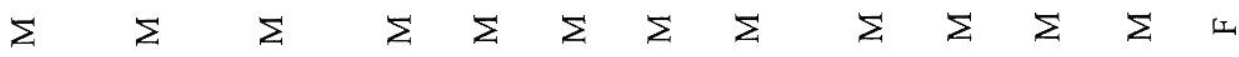

으 8 \& 8 의 의 8 으

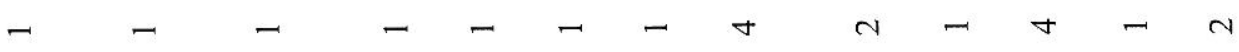

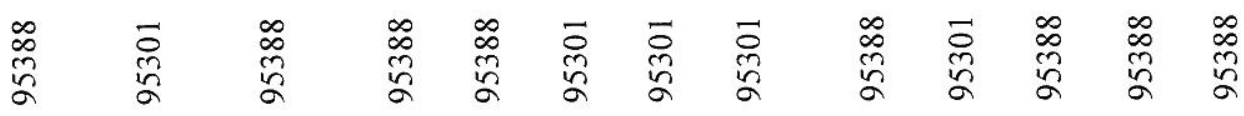

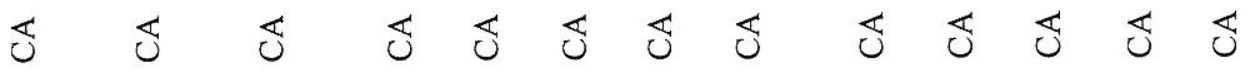

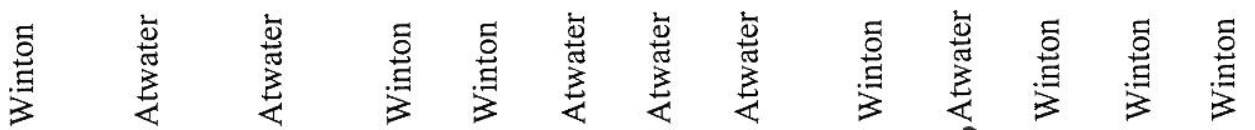

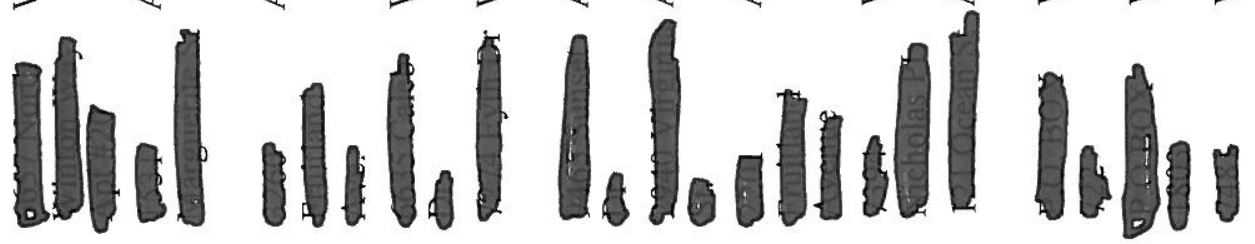

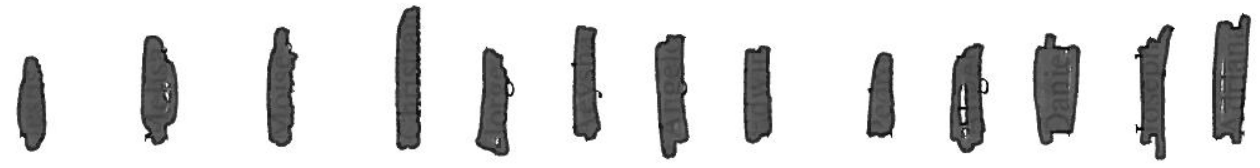

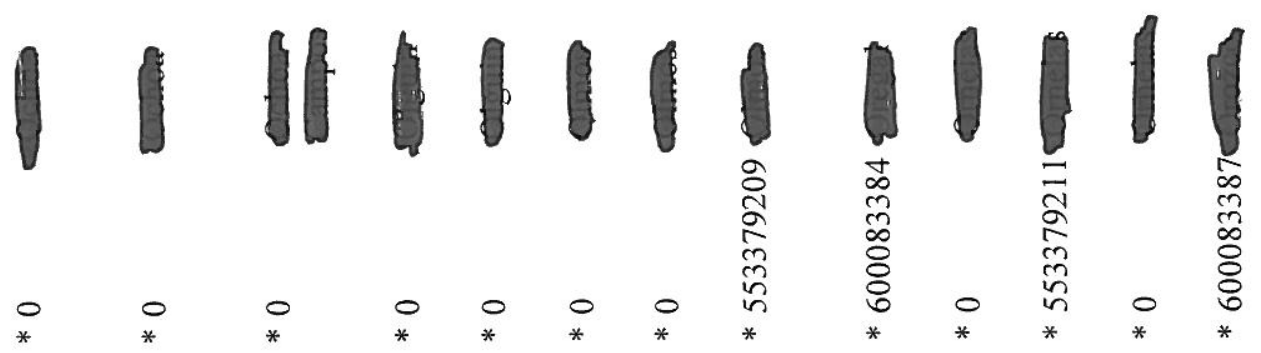


0
8
4
4
+
0
80
0
0
0

$x \times x \times x \times x \times x \times x \times x \times x$

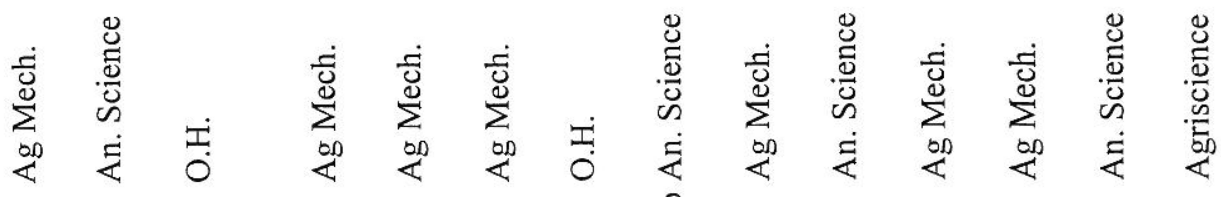

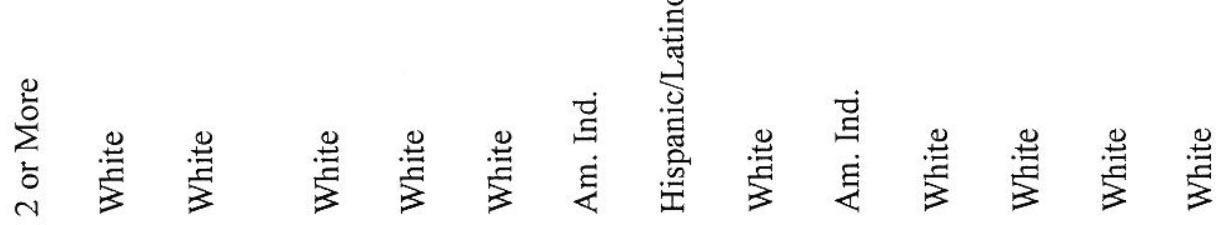
$x \times x \times x \times x \times x \times x$

$\Sigma$ 山 山 $\Sigma \Sigma \Sigma \Sigma$ 山 $\Sigma \Sigma$ 山 $\Sigma \Sigma$ 山 $\Sigma$

$8 \circ \simeq \therefore \simeq \circ \circ \circ=\circ \therefore \simeq=8$

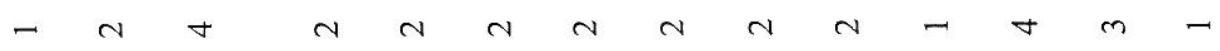

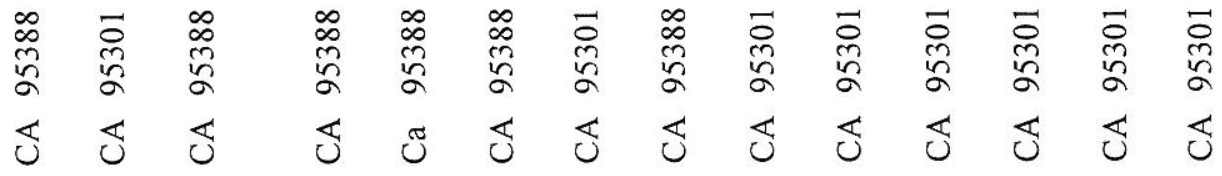

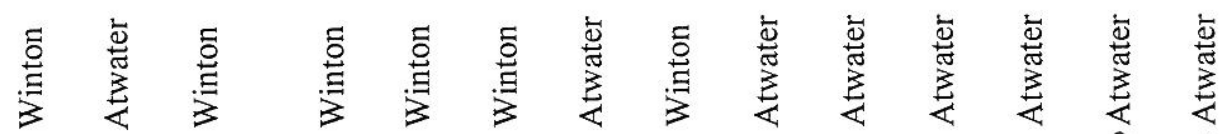
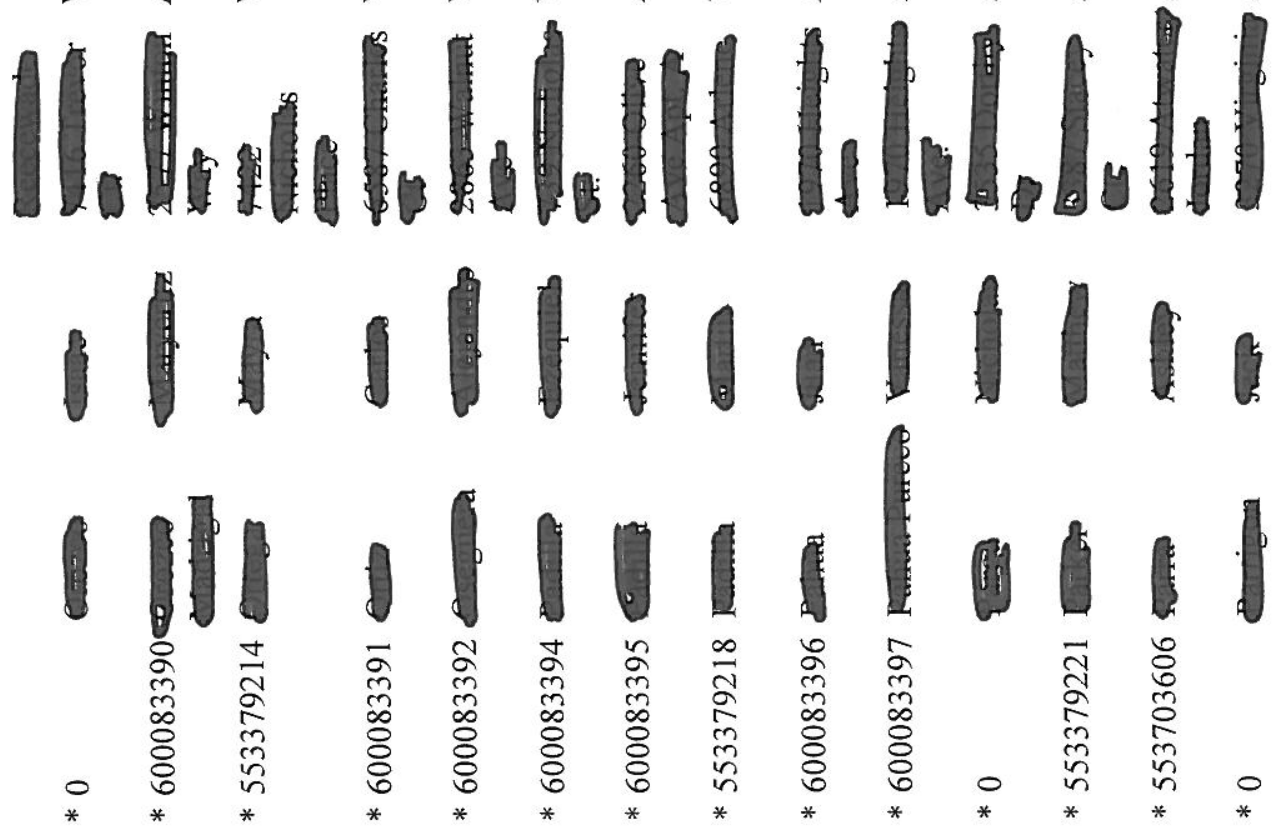


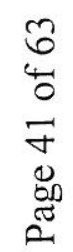

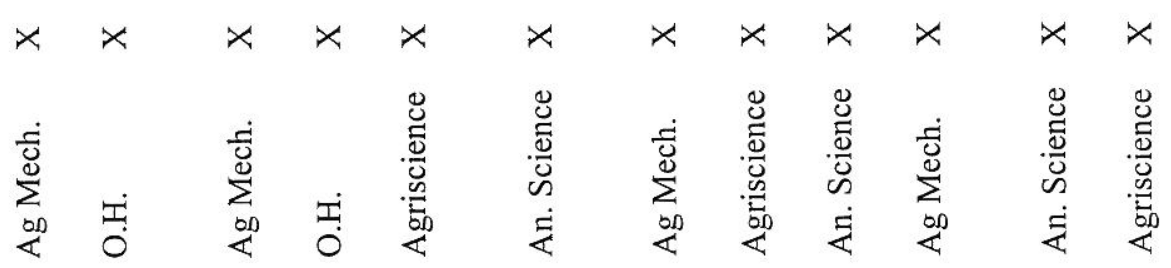

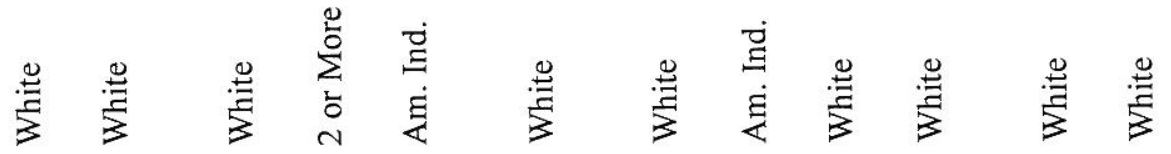
$x \quad x \quad x \quad x \quad x \quad x \quad x \quad x \quad x \quad x$

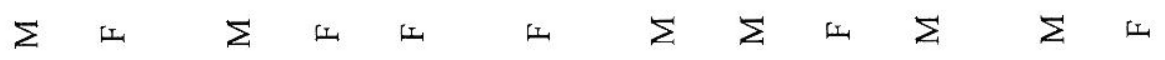

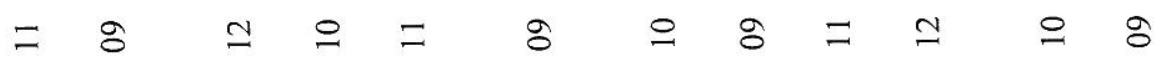

$m-\nabla N-N-m+m_{-}$

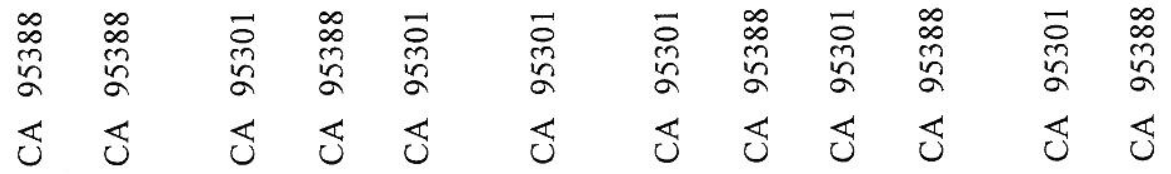

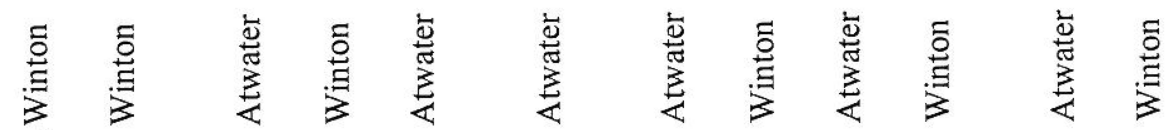

a 6 (1)

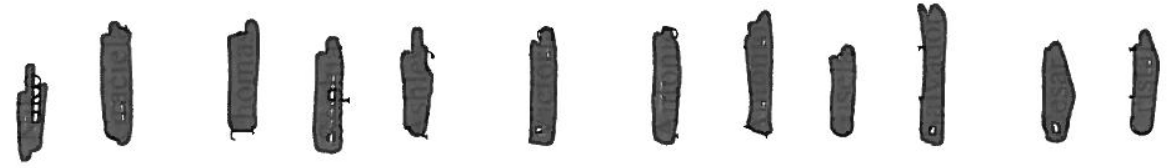

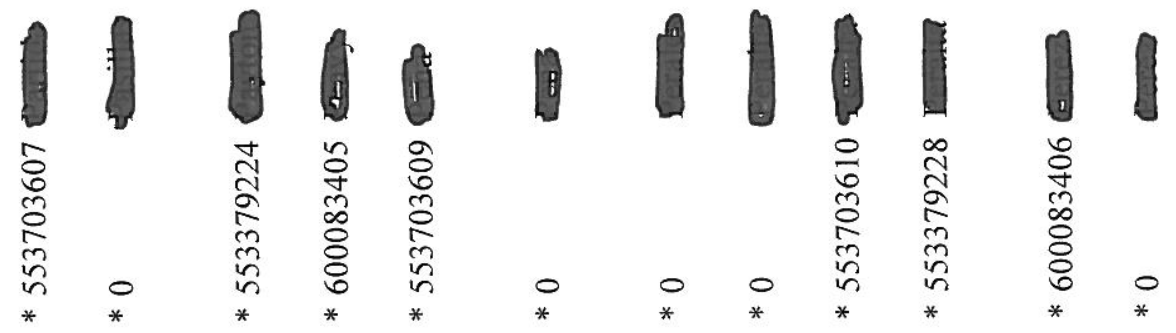




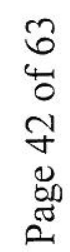

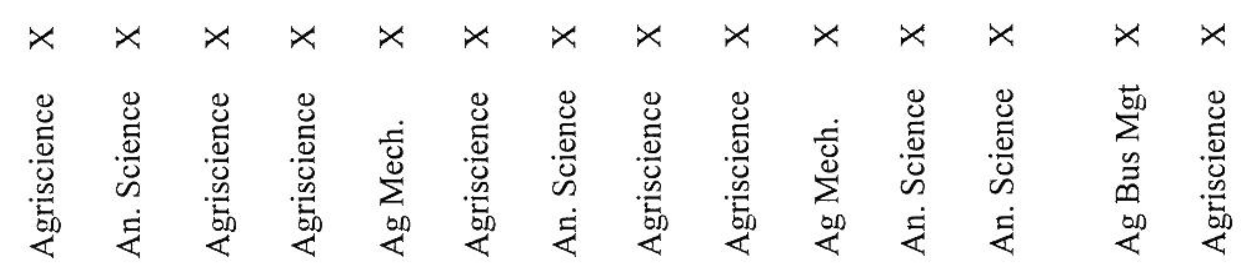

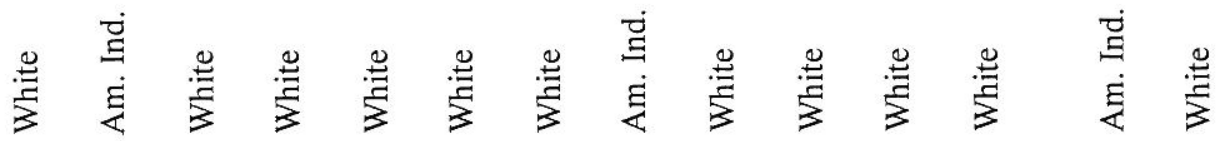
$x \times x \times x \quad x \quad x \quad x \quad x \quad x \quad x \quad x \quad x$

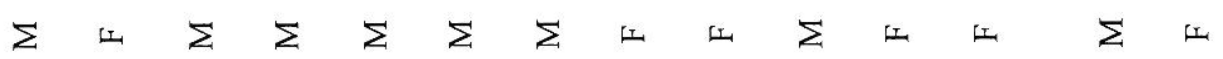

$g=g \circ=g \circ g$ o $=m=\cong$

$--\infty-n-m n m-$

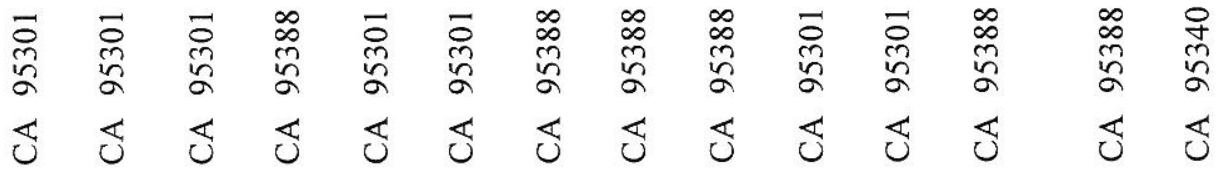

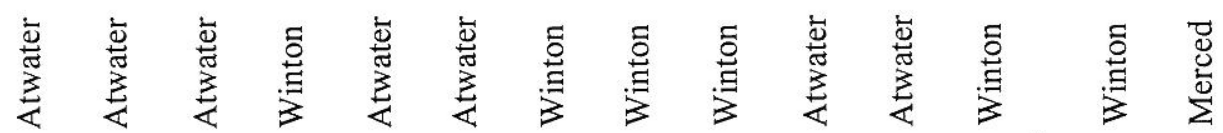

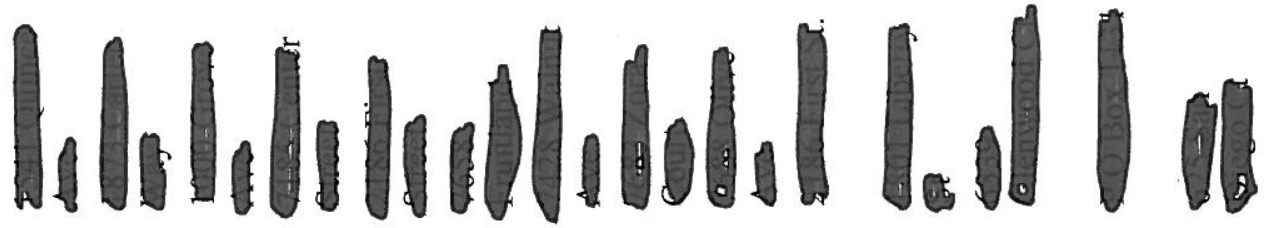

| | || | | | | || ||

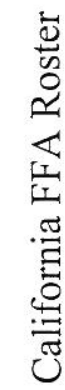

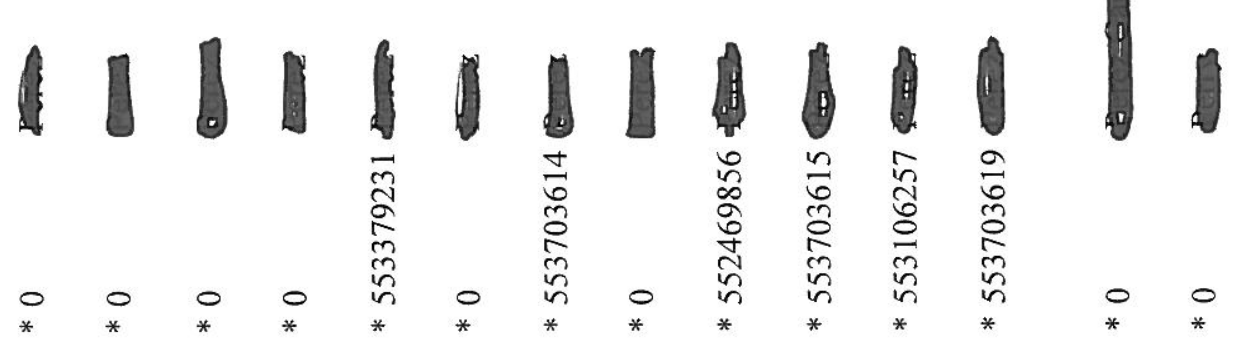




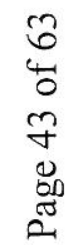

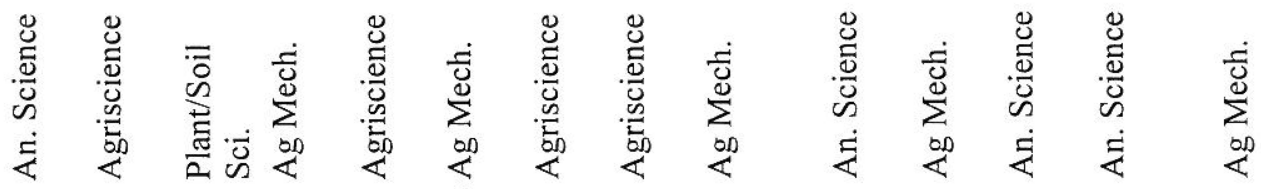

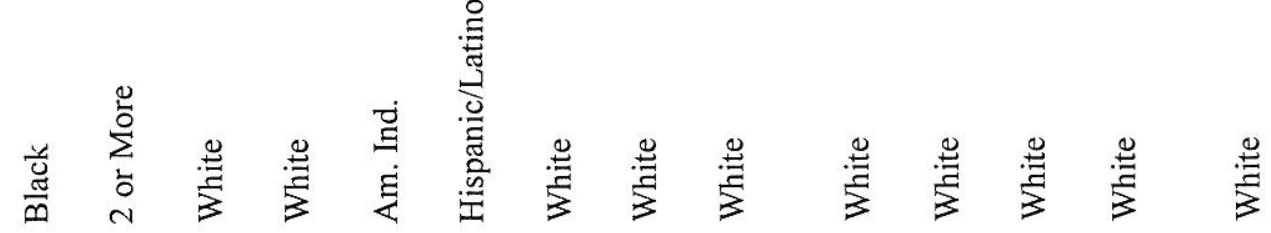
$x \times x+x \times x$

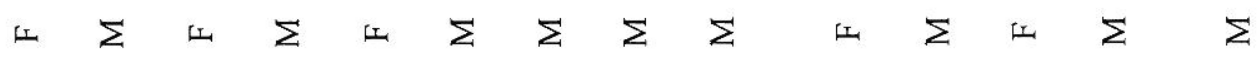

으으응 8 의 $=$ ㅇ

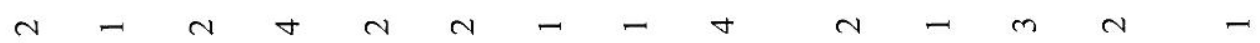

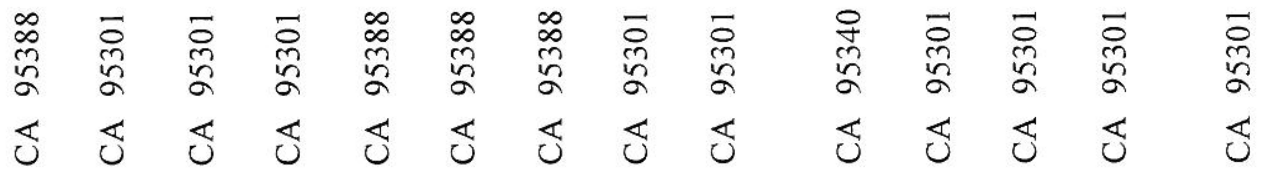

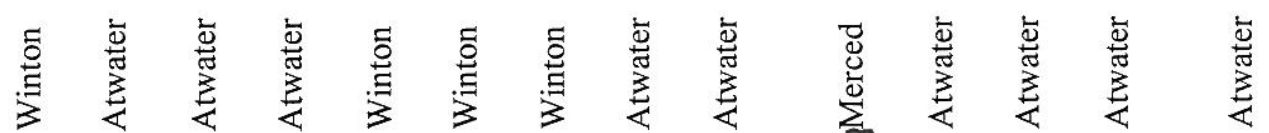

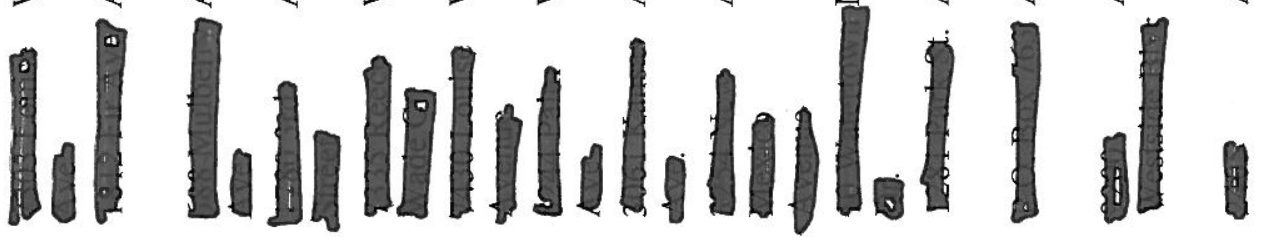

|||||\|||||||||

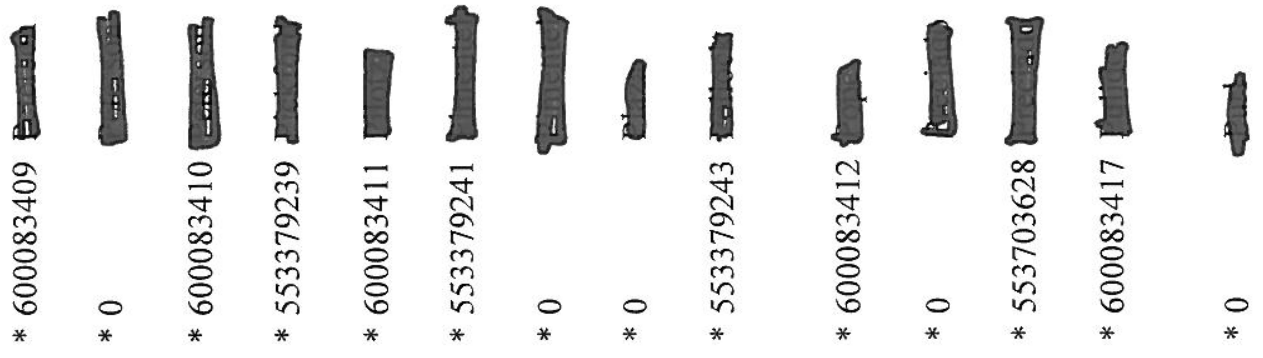


\[ \]
6
+
+
+
0
0
0

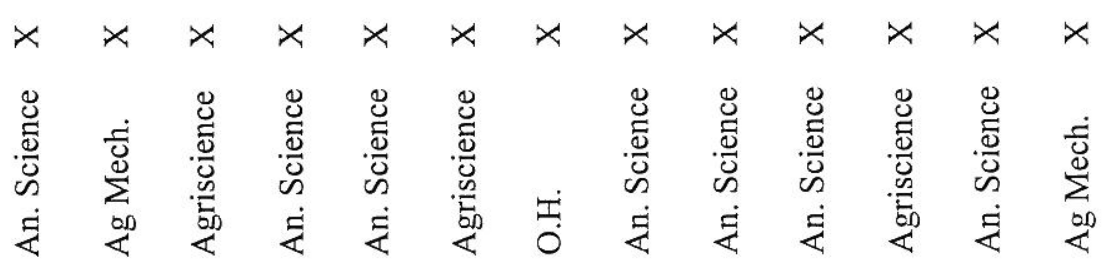

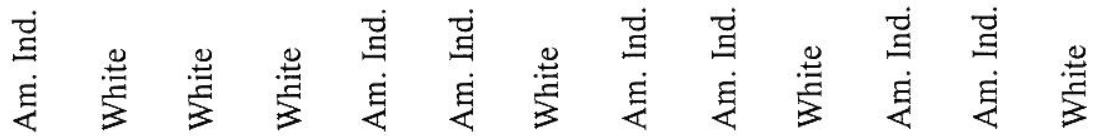
$\times \quad \times \quad x \quad x \quad x \quad x \quad x \quad x \quad x \quad x \quad x$

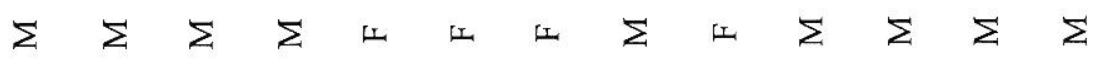

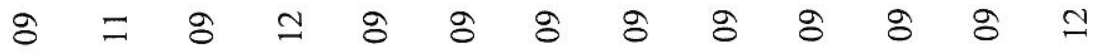

$\neg m-\neg-\neg-\neg-\neg-\neg$

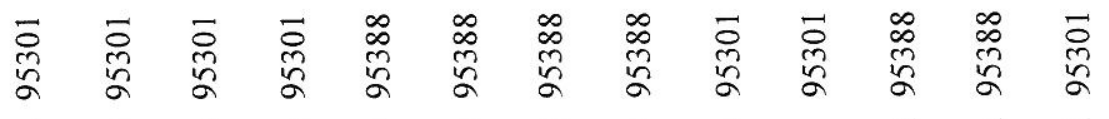

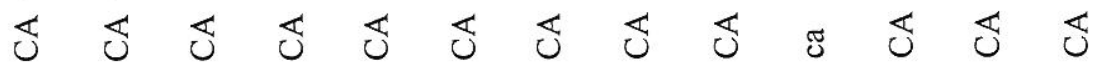

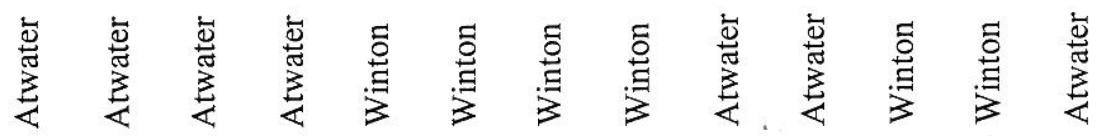

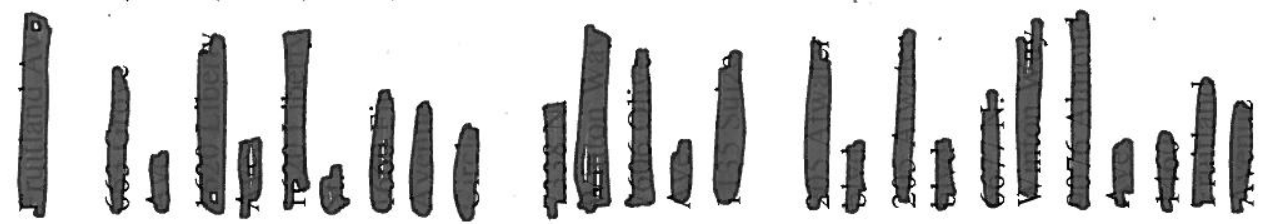

$11,11 \| 111111$

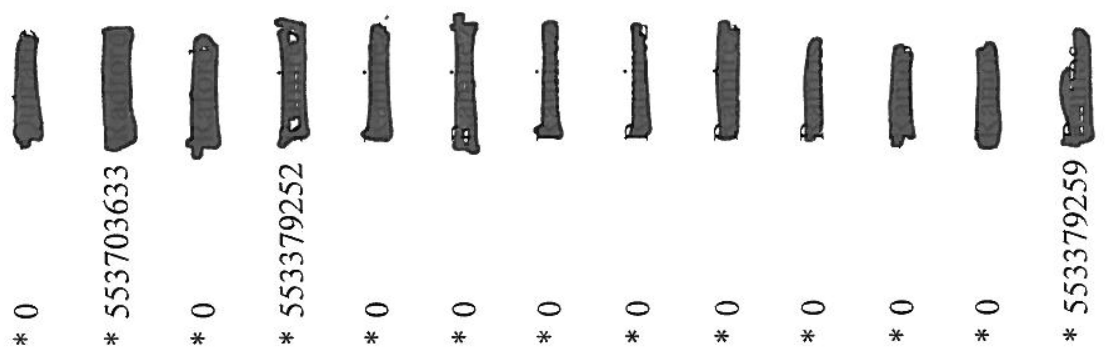




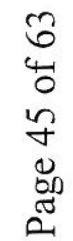

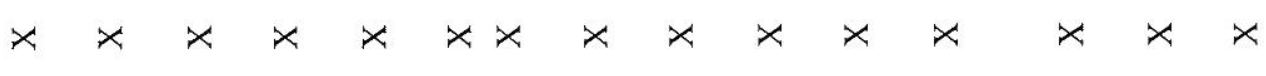

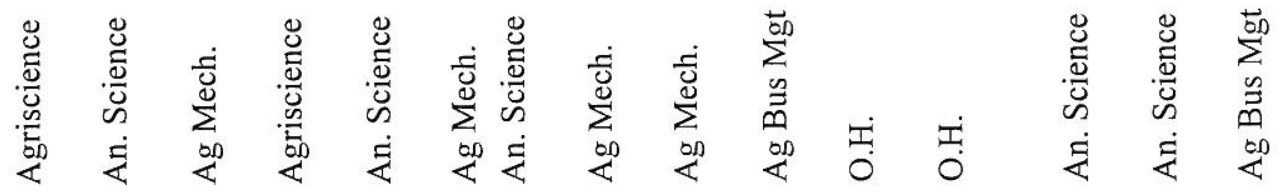

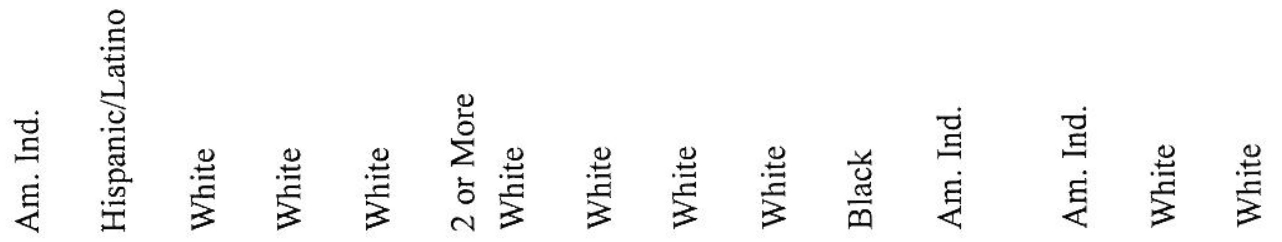
$x \times x \quad x \quad x \quad x \quad x \quad x \quad x \quad x \quad x \quad x \quad x$

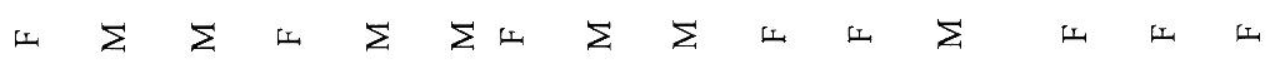

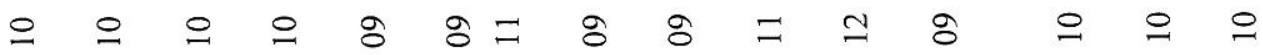

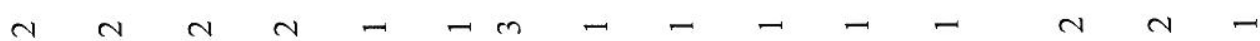

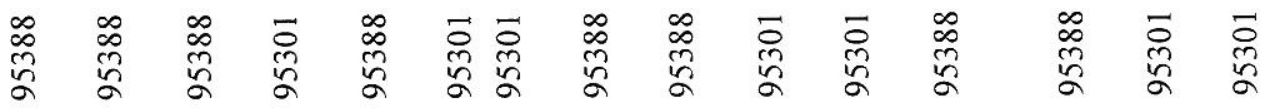

తు

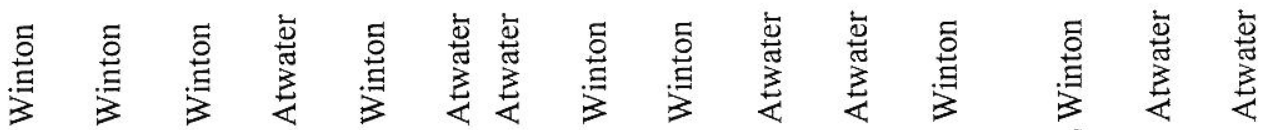

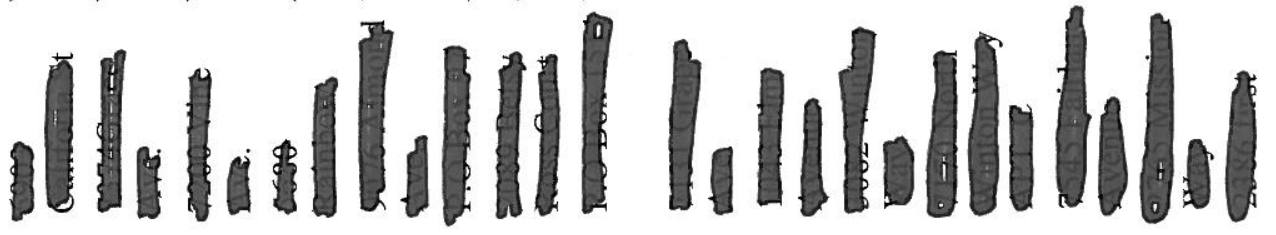

$\|1\|\|\| 1\|1\| 1\|\|$

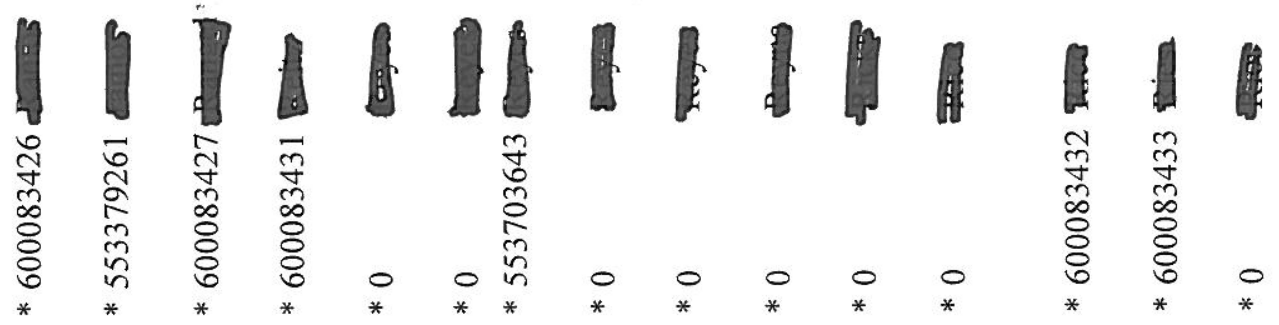


$\widehat{0}$
4
0
0
+
0
0
0
0

$x \times x \times x \times x \times x \times x \times$

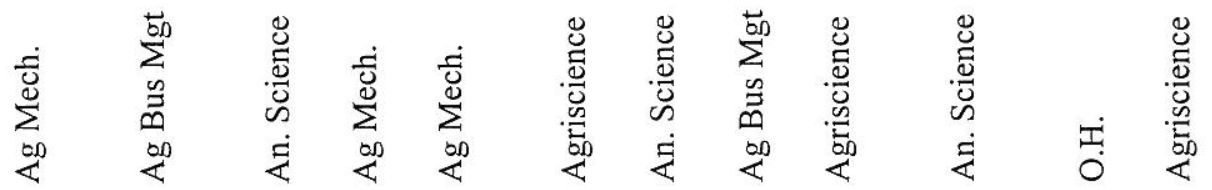

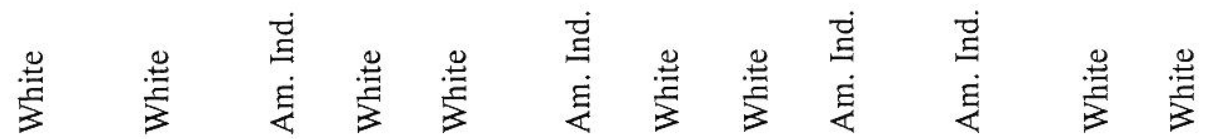
$x \times x \times x \times x \times x \quad x \quad x$

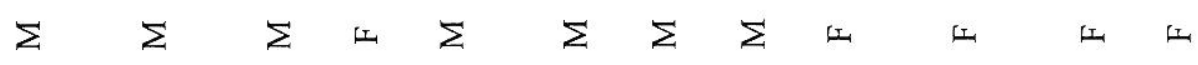

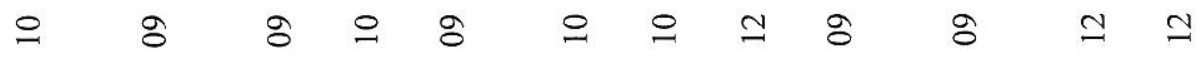

$4-4-4-4,-4-4$

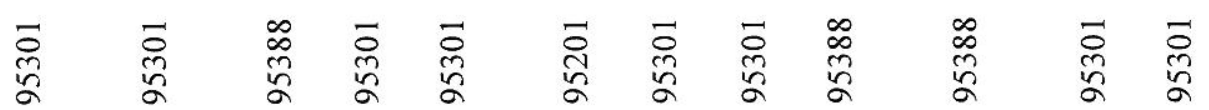

త

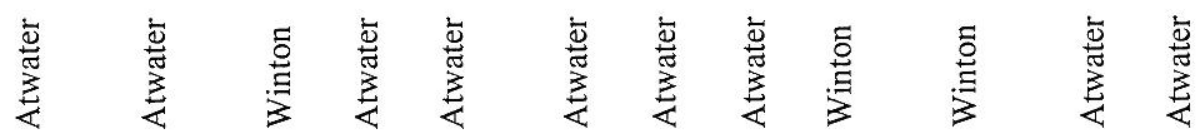

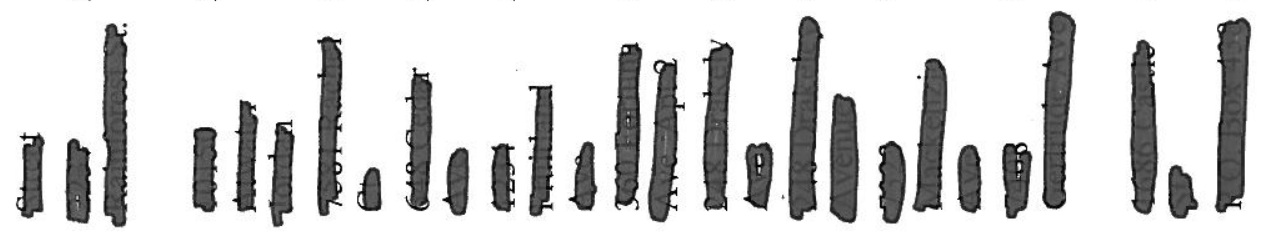

$1|1,1| 1,1,111$

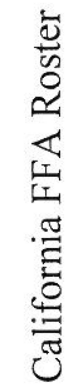

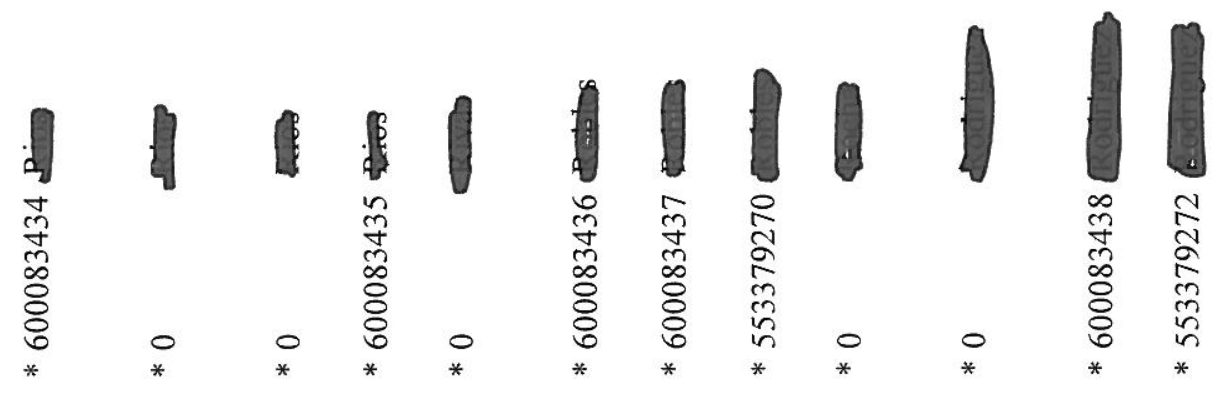


3
6
4
0
+
0
8
0
0

$x \times x \times x \times x \times x \times x \quad x \quad x \quad x \quad x$

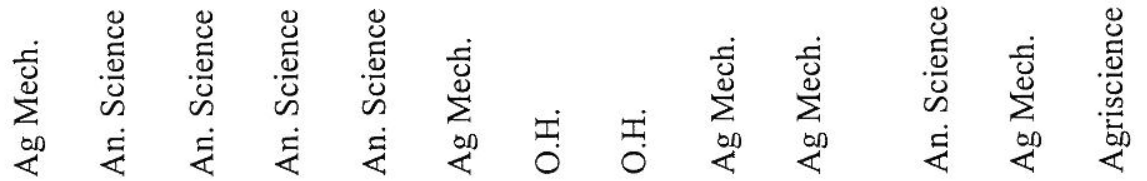

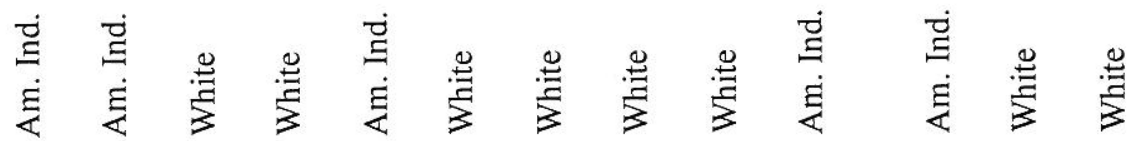

$\times \quad x \quad x \quad x \quad x \quad x \quad x \quad x \quad x \quad x \quad x \quad x \quad x$

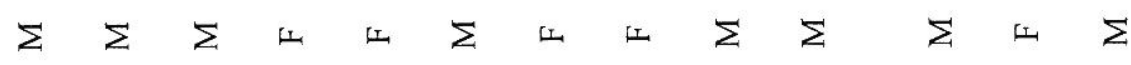

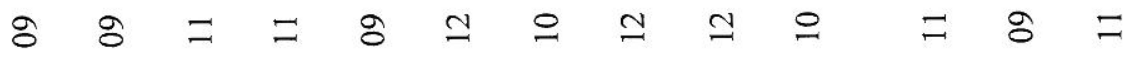

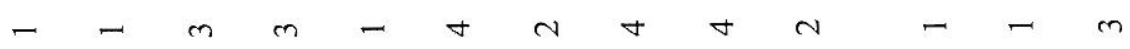

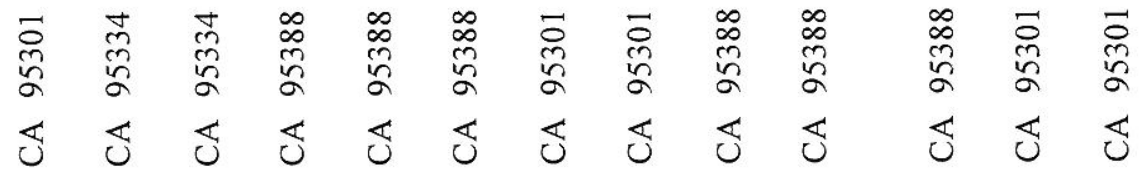

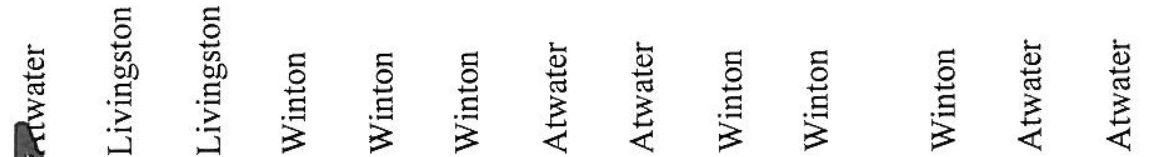

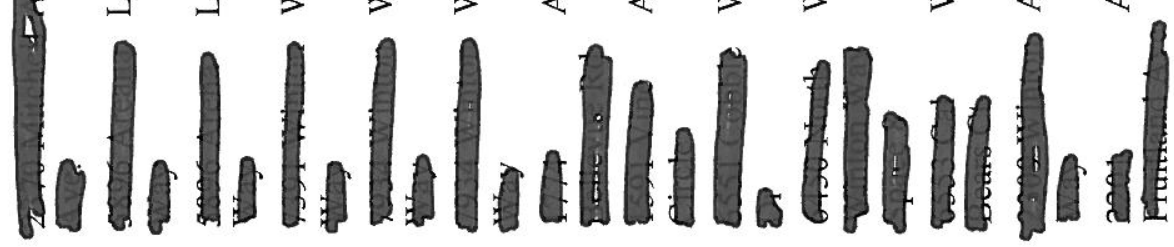

$111\|1\|\|11\| 111$

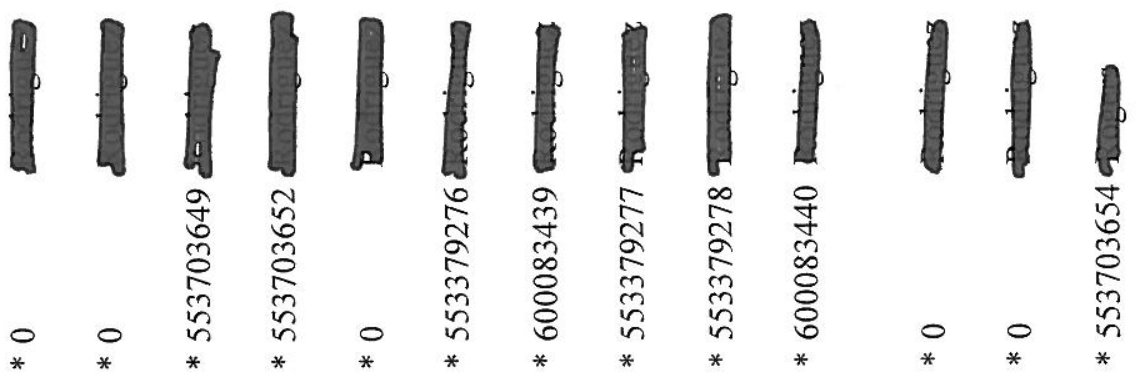




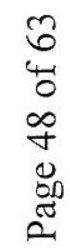

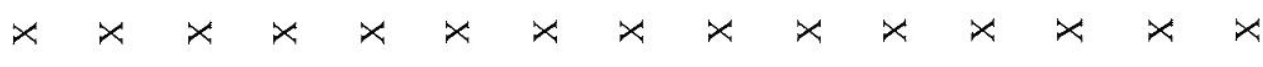

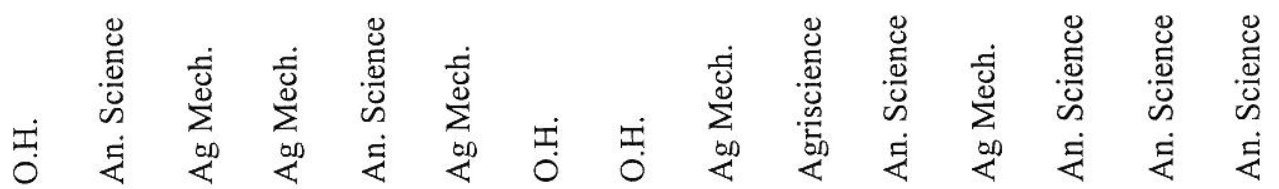

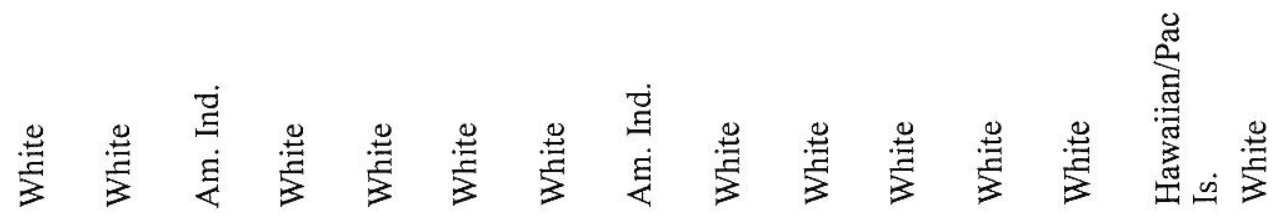
$x \times x \times x \times x \times$

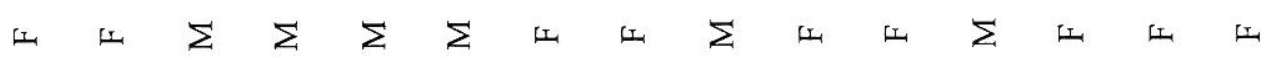

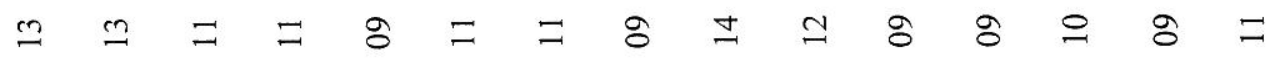

$n n-m-m--0 m-N-m$

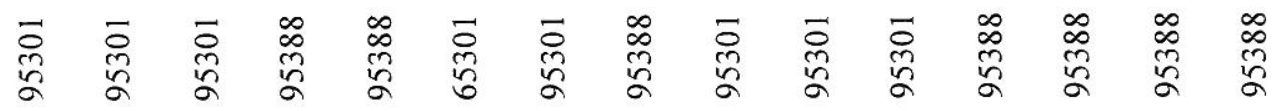

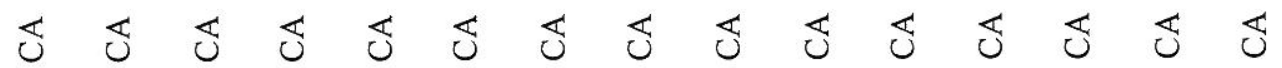

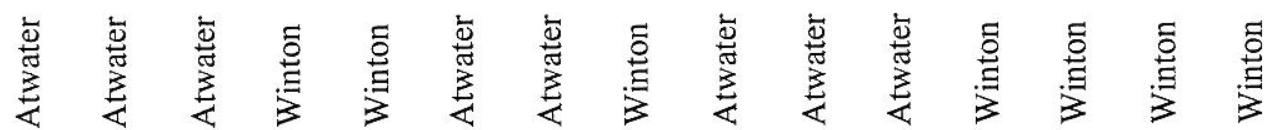

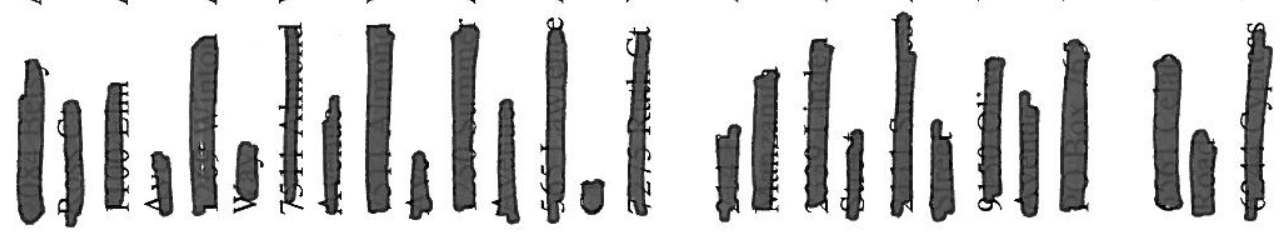

111111111111111

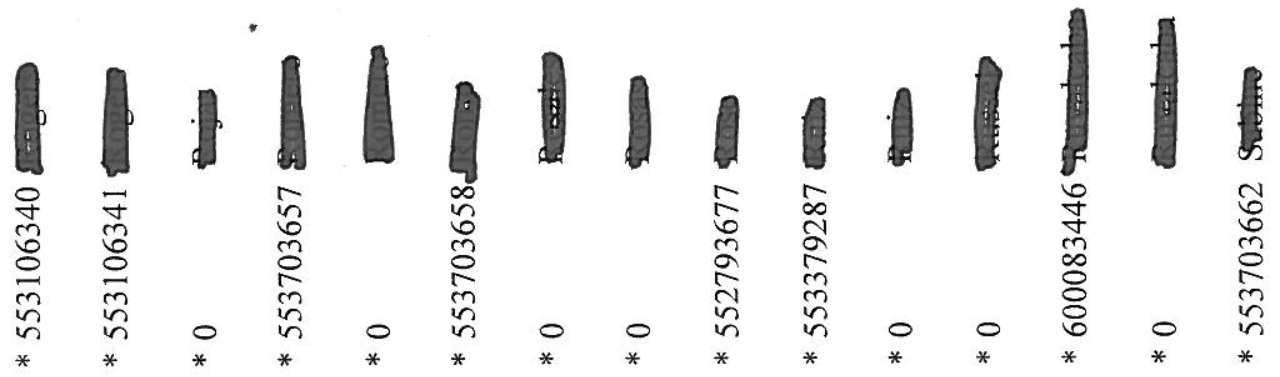




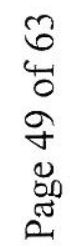

$x \times \times \quad \times \quad \times \quad \times \quad \times \quad x \quad x \quad x \quad x \quad x$

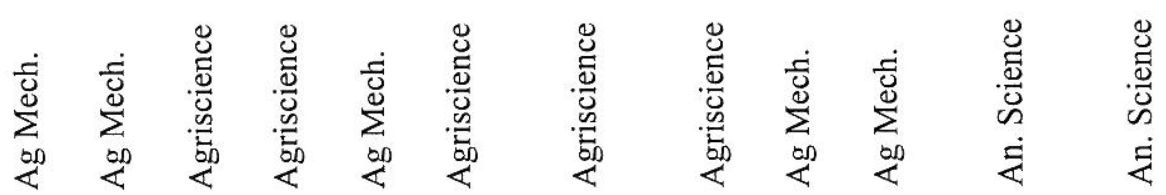

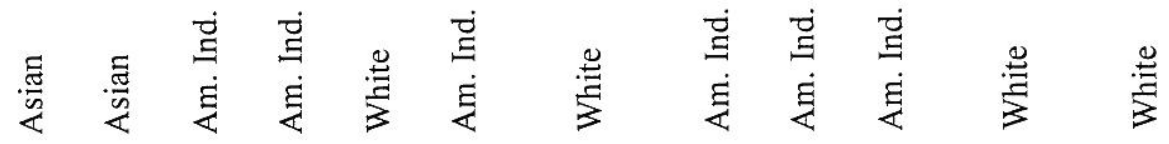
$x \times x \times x \times x \times x \times$

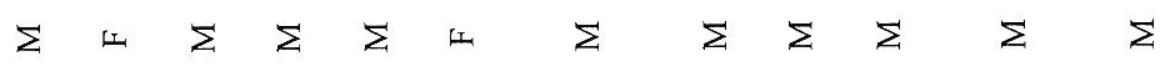

$\simeq 8 \circ 8=\subseteq \circ \therefore \simeq=$

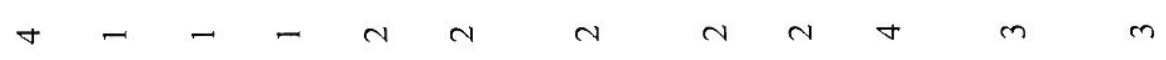

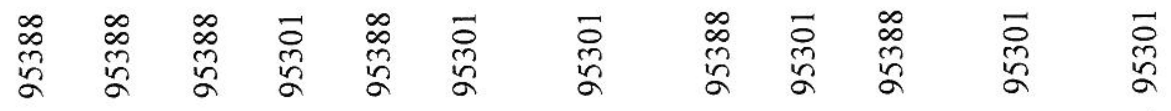

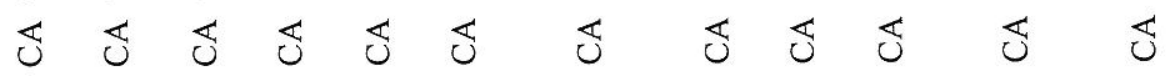

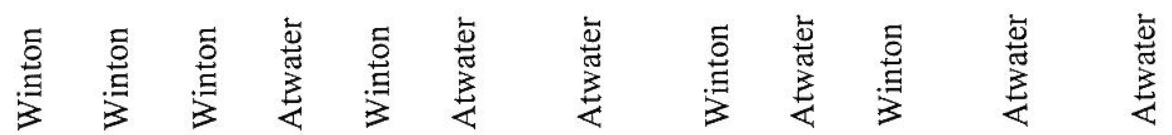

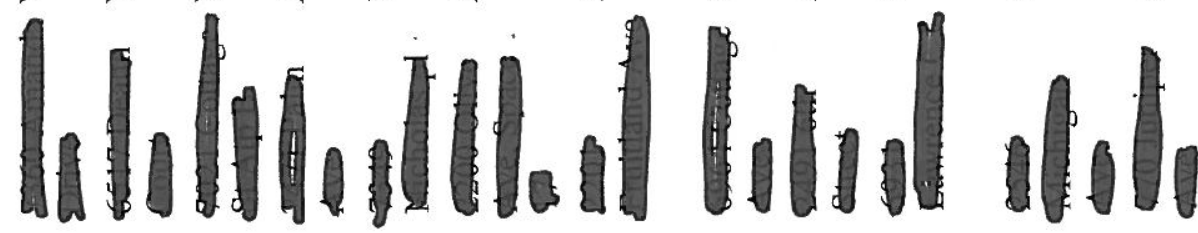

$11,111 \mid 111+11$

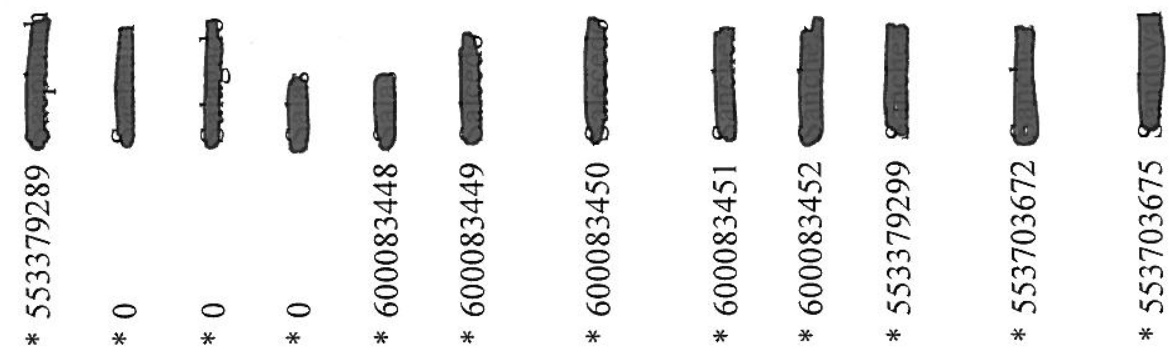


3
+
+
0
0
$\infty$
0
0
0

$$
\begin{aligned}
& \times \quad x \quad x \quad x \quad x \quad x \quad x \quad x \quad x \quad x \quad x \quad x \quad x \quad x \quad x
\end{aligned}
$$

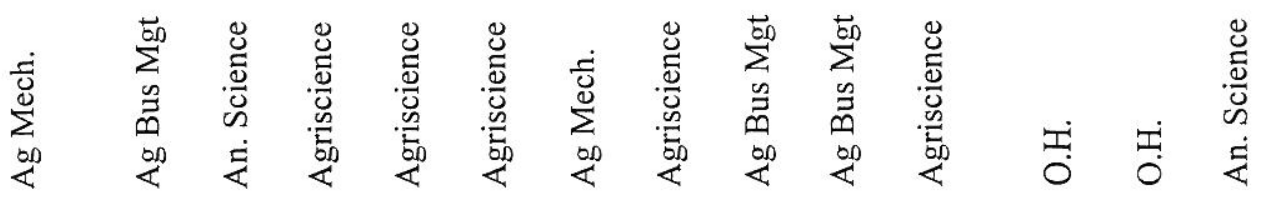

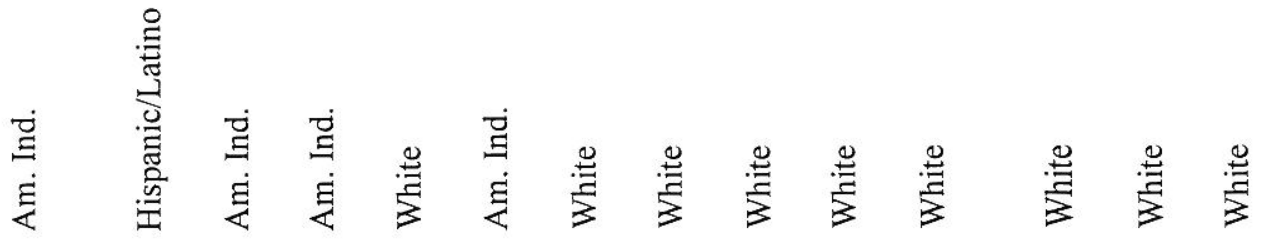$$
x \times x \times x \times x
$$

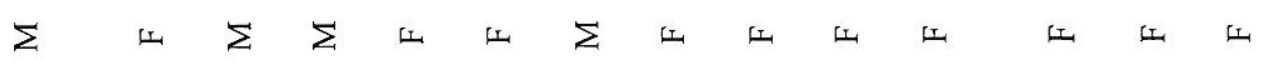

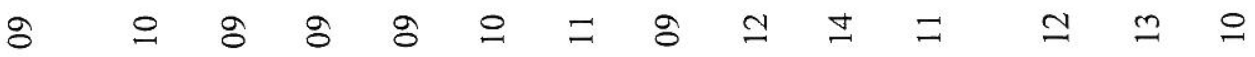

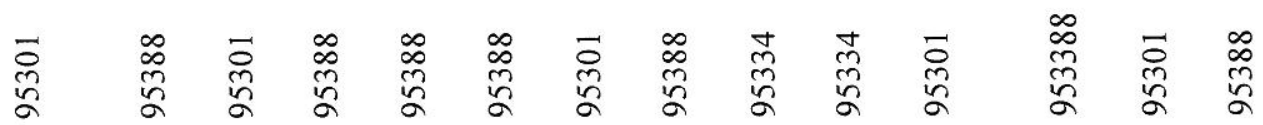

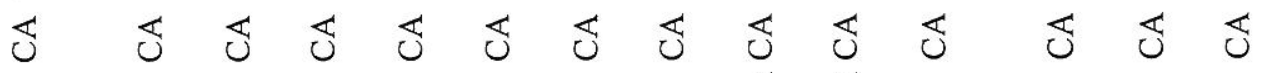

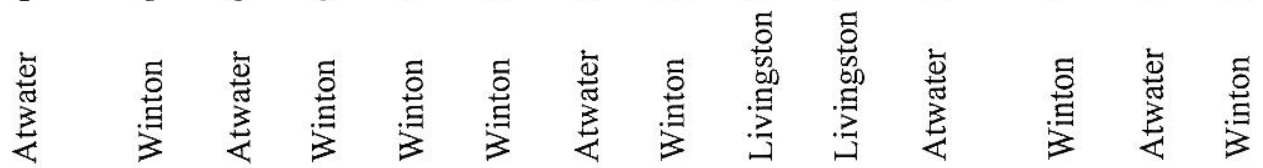
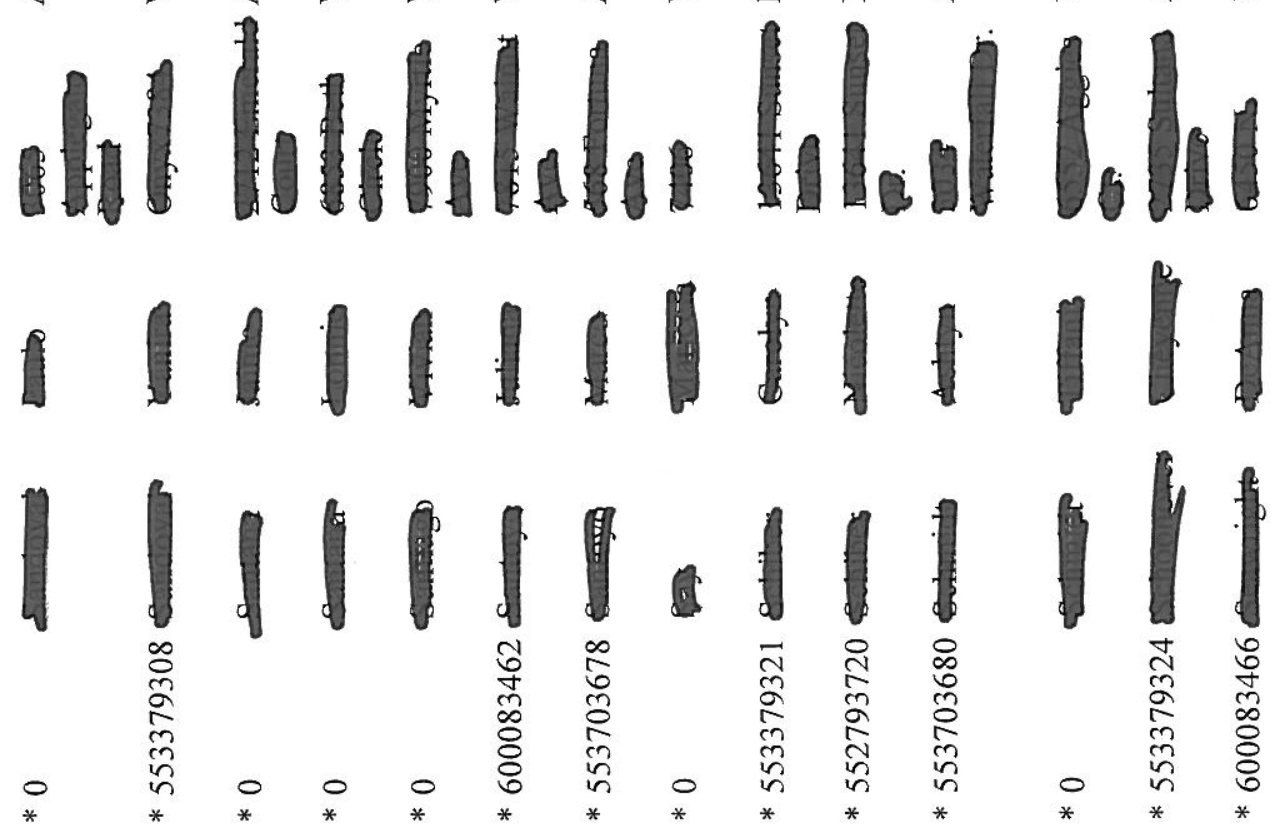


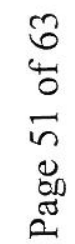

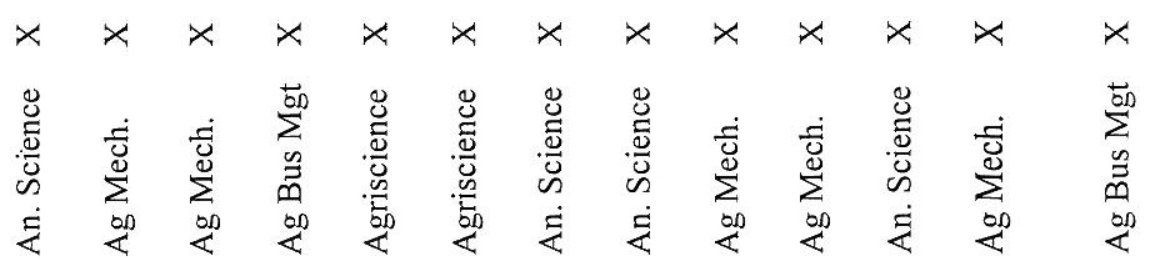

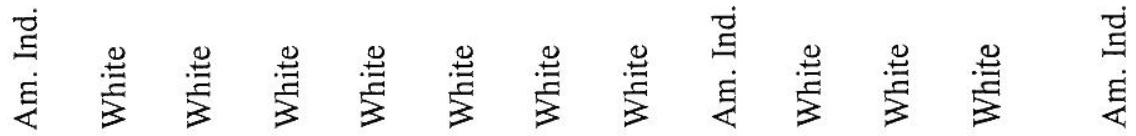

$x \quad x \times x \times x \times$

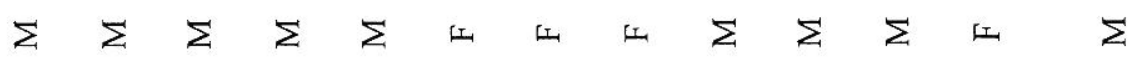

의 $=\therefore 8= \pm \therefore \circ \circ \simeq$ ㅇ

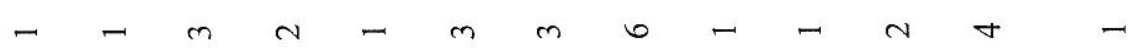

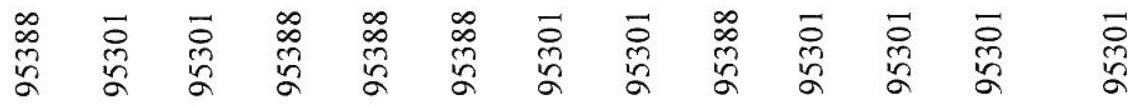

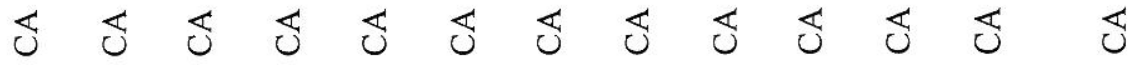

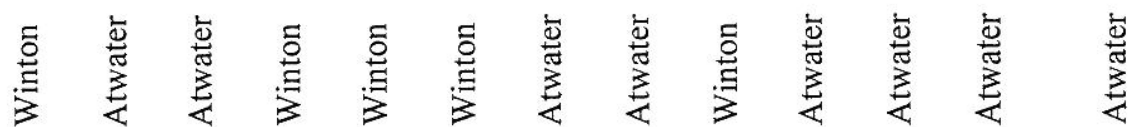

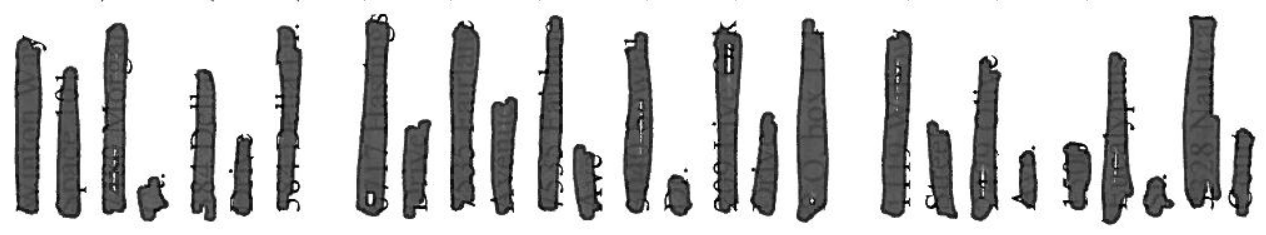

$1111,11,11,11$

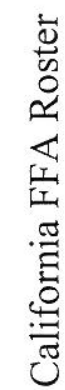

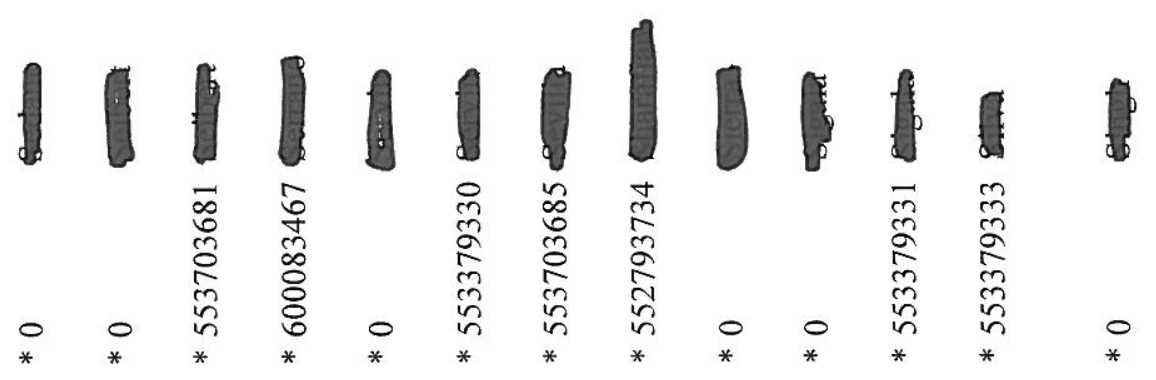




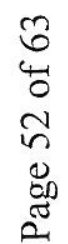

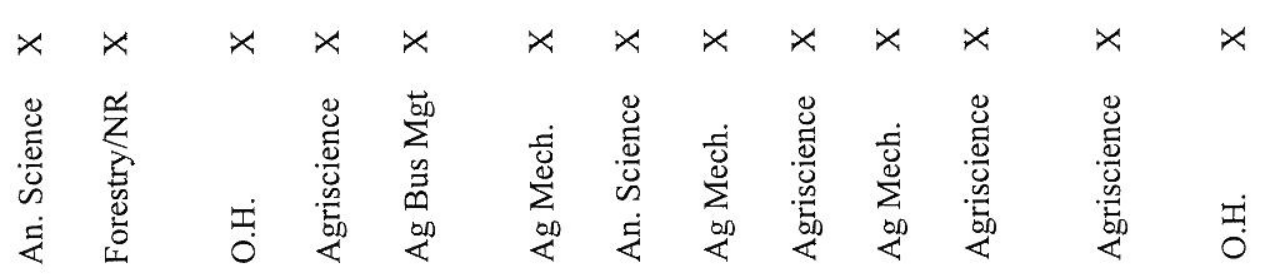

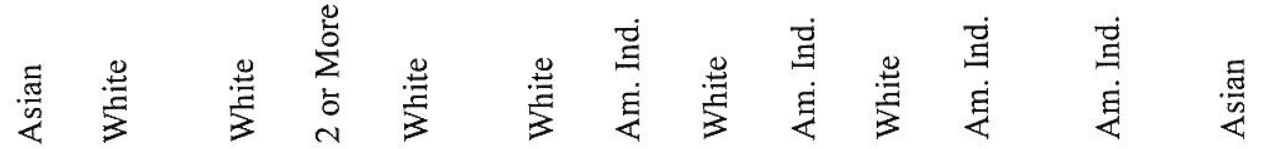
$\times \times \times \times \times x$

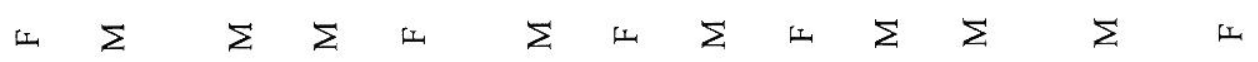

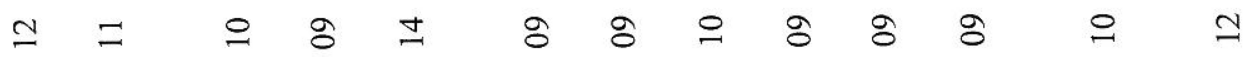

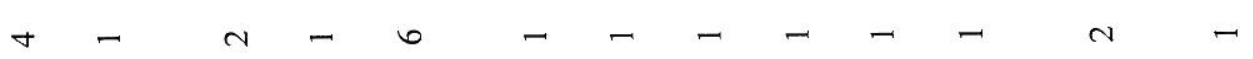

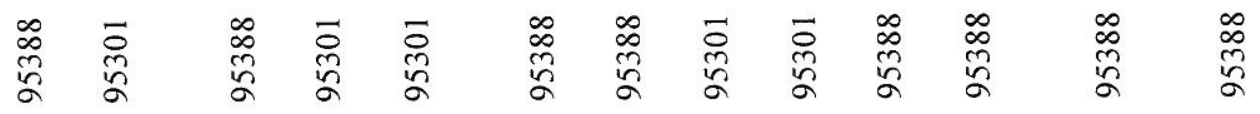

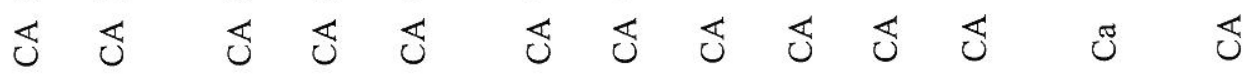

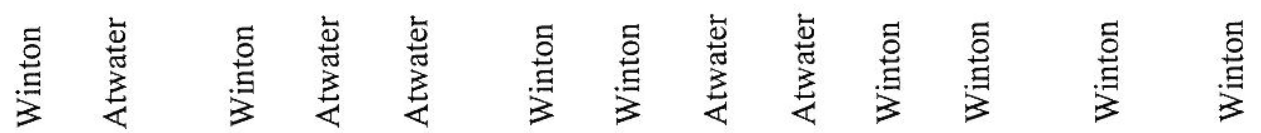

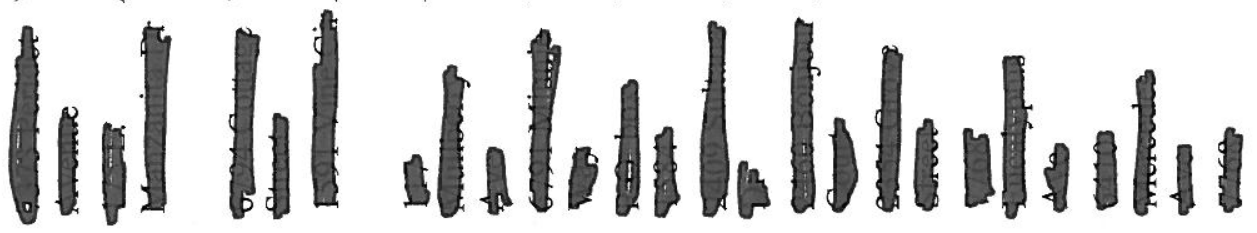

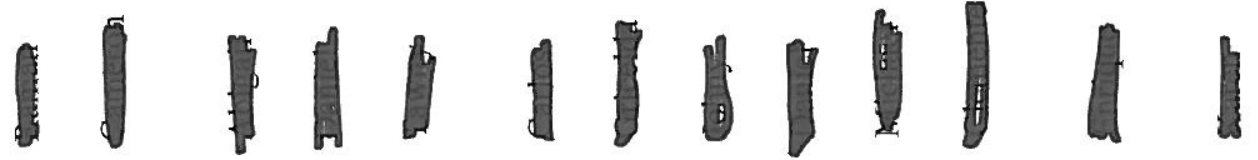

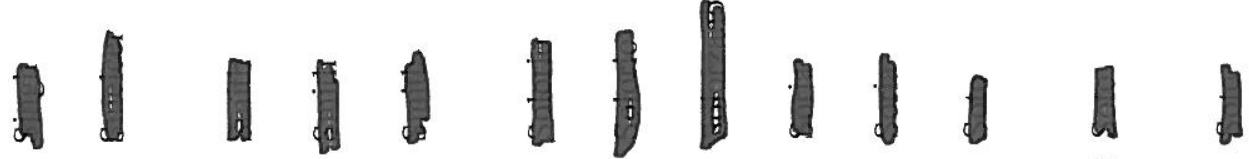

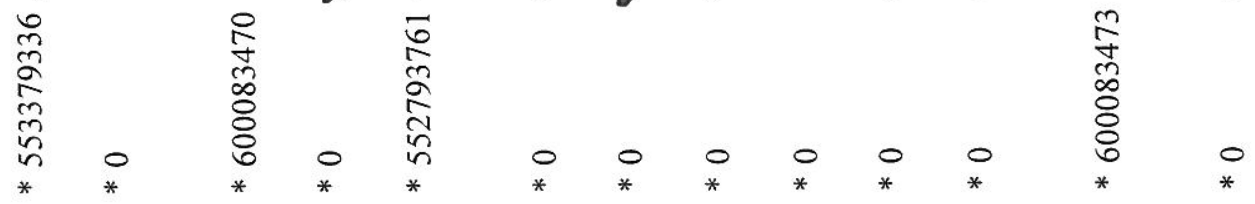




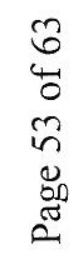

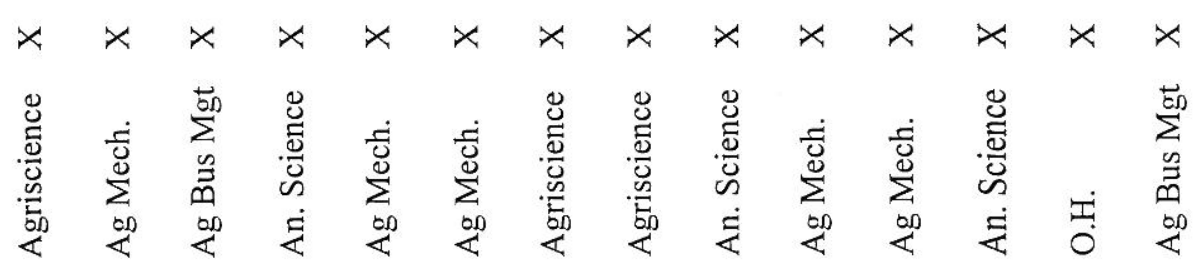

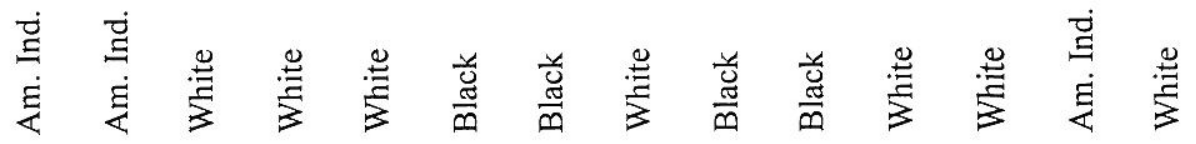

$x \quad x$

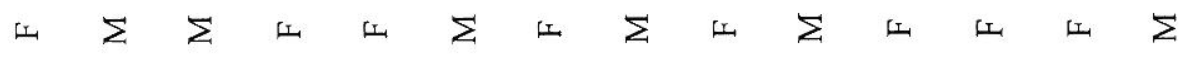

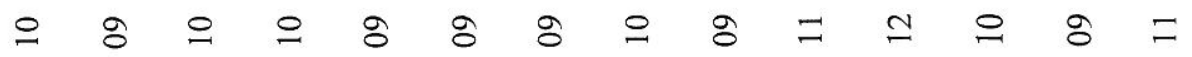

$4-4 n-\rightarrow-m+n-m$

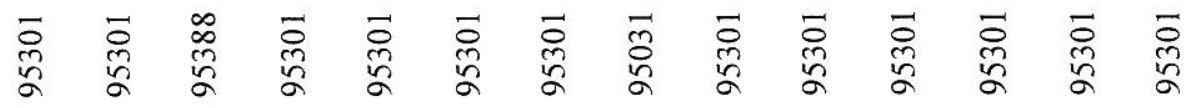

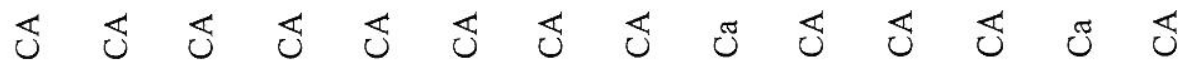

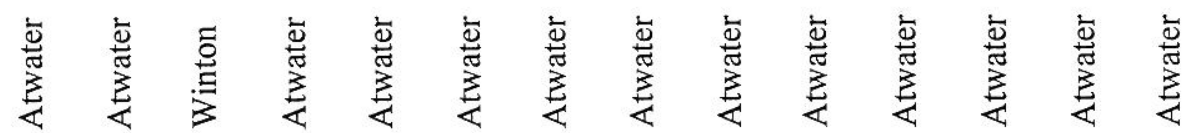

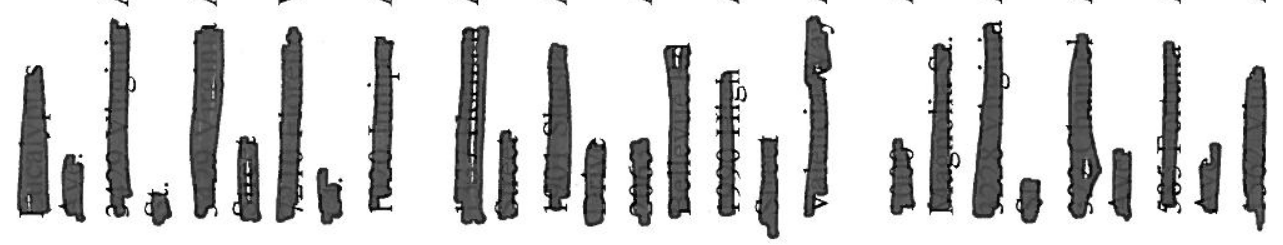

\|\|\|\|\|\|\|\|\|\|$_{1}$

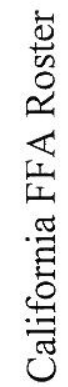

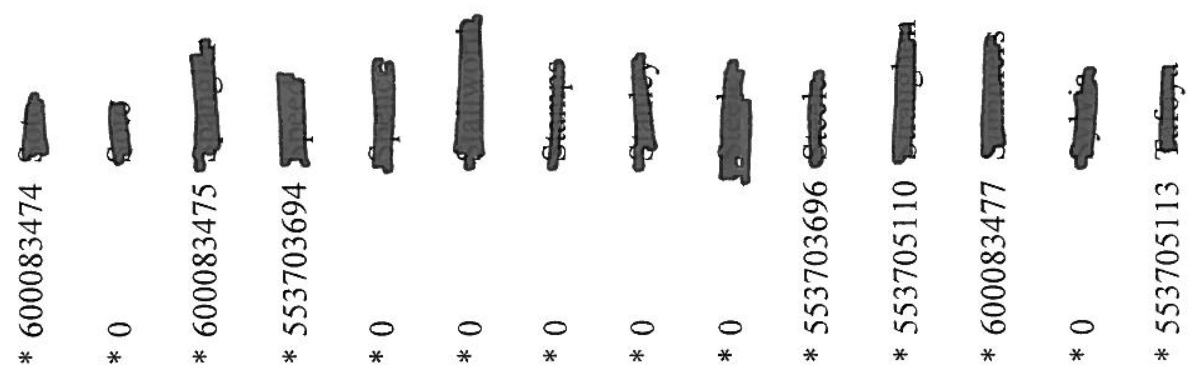




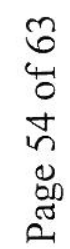

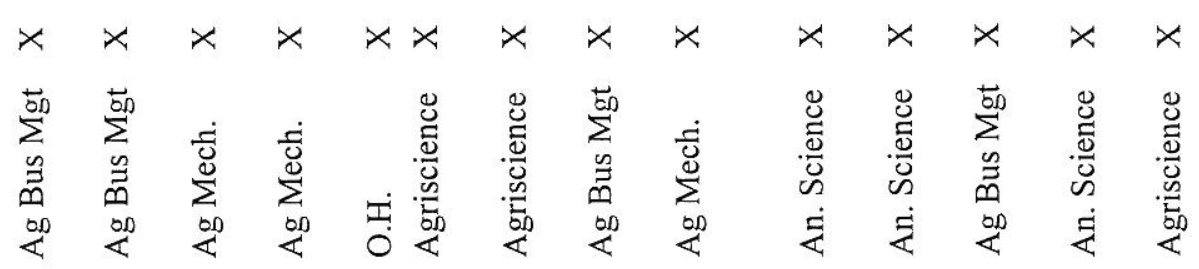

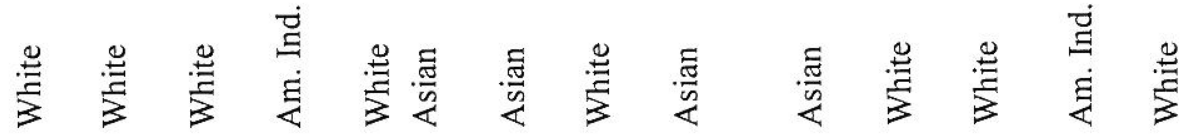

$\int_{x=x} y_{x} x_{x}$

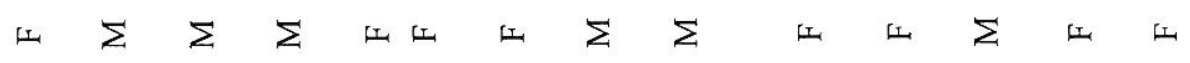

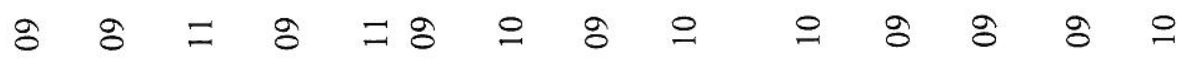

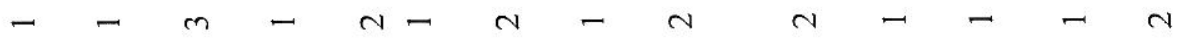

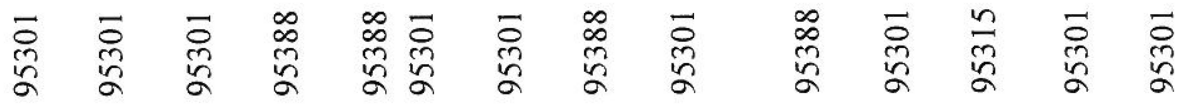

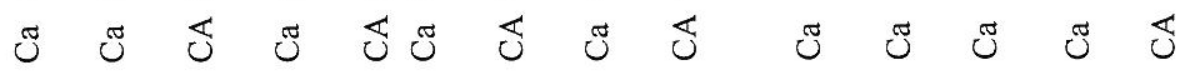

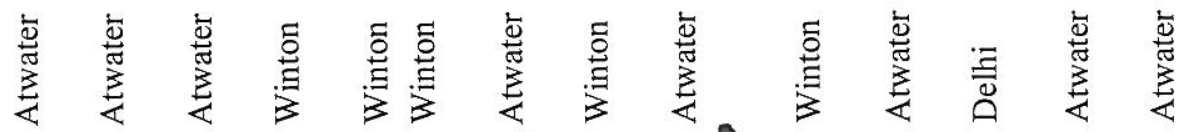

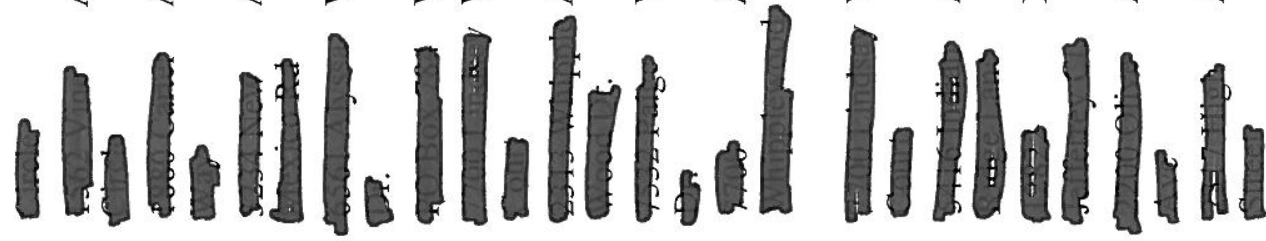

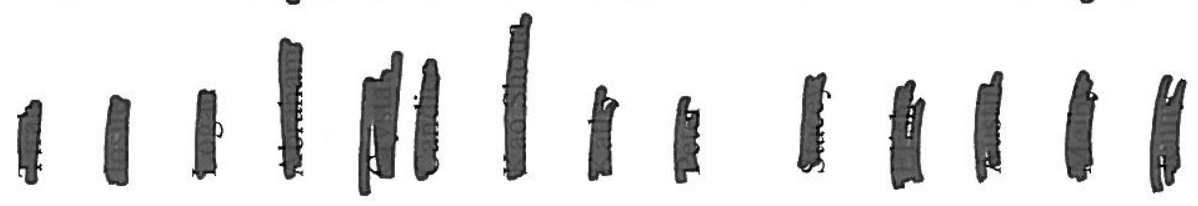

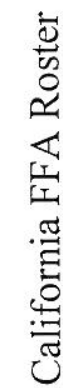

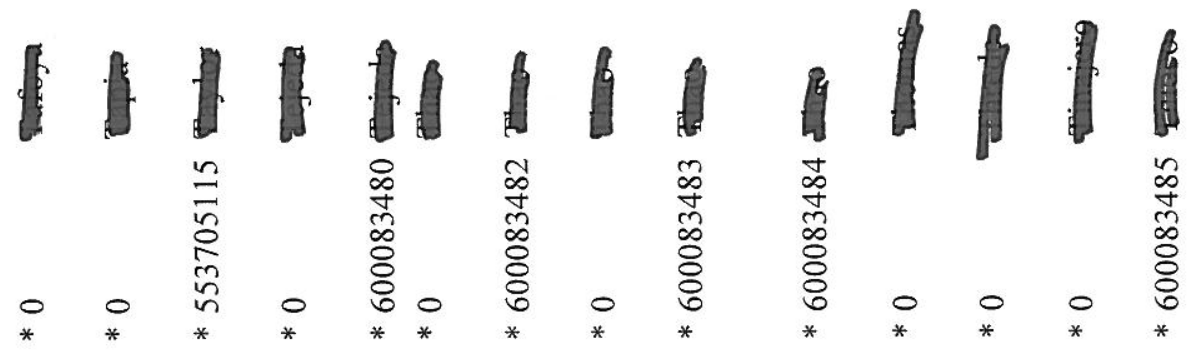




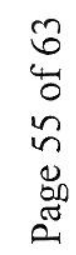

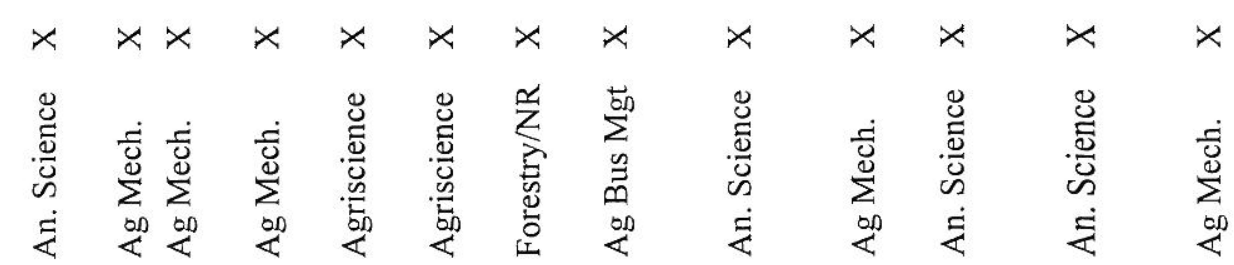

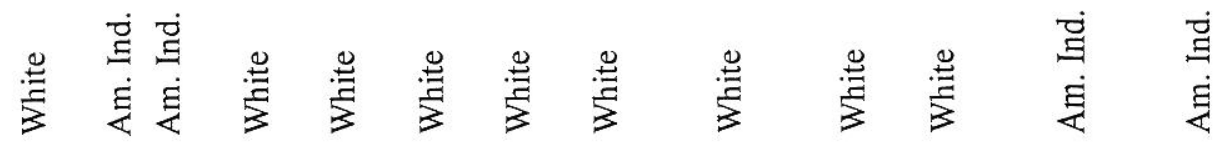
$\times x \times \quad \times \quad \times \quad \times \quad x \quad \times \quad x \quad x$

山 $\Sigma \Sigma \Sigma \Psi 山 \Sigma \Sigma$ 山 $\Sigma \Sigma \Sigma$ 山 $\Sigma$

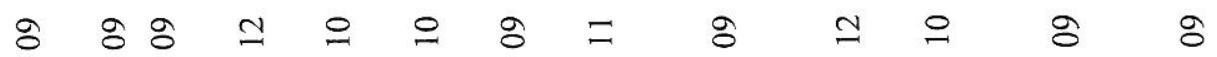

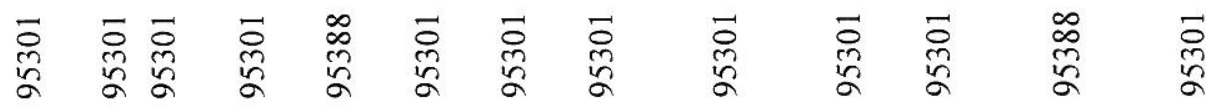

ฮீ ฮீ

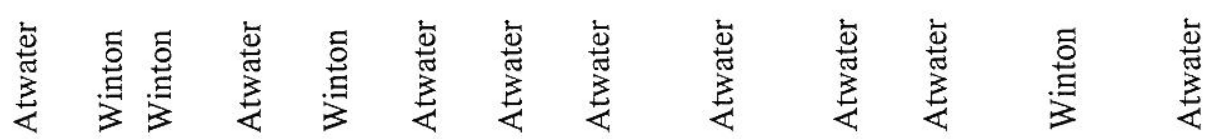

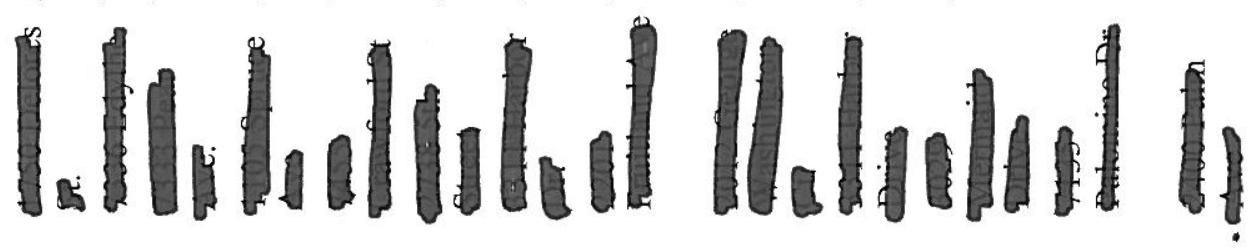

\|\|$,\|\|||||||$

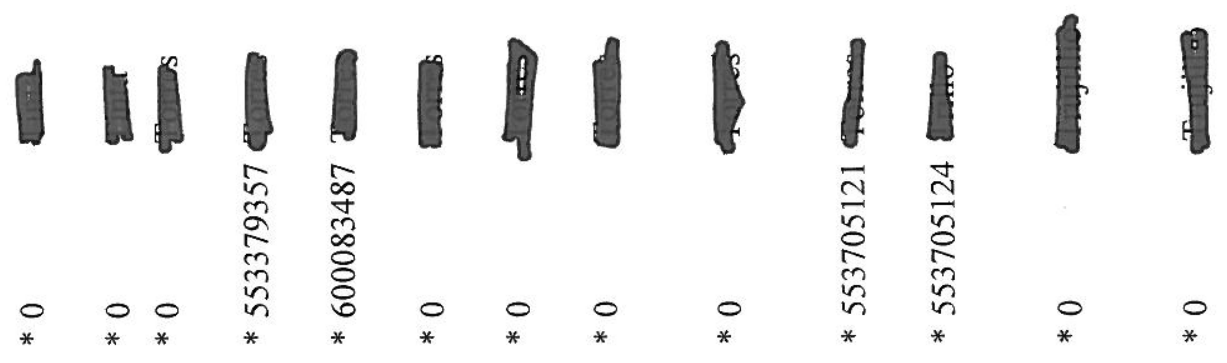




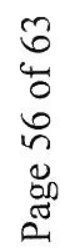

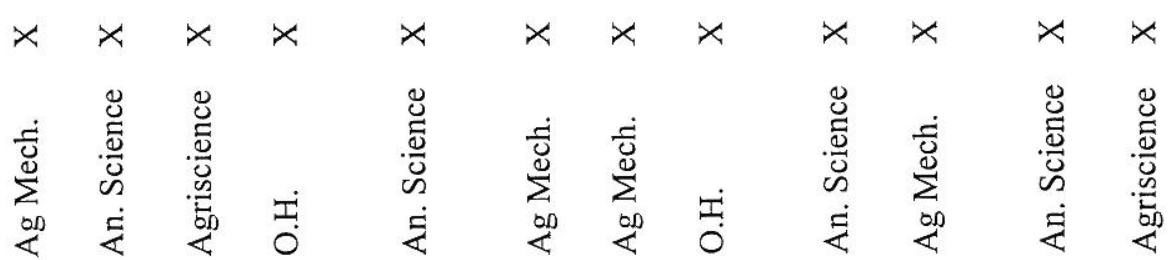

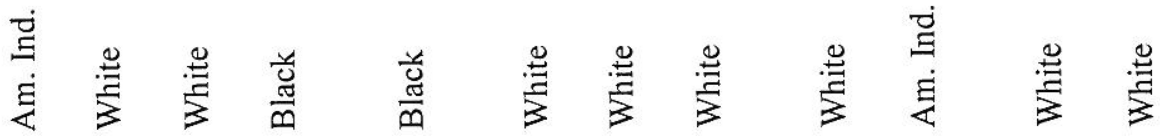
× $\times x \times x \times x \quad x \quad x \quad x \quad x \quad x$

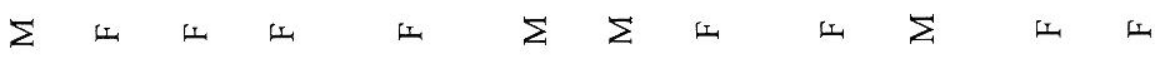

$8 \circ \circ 8$ o $=\exists=\circ$ o 8 o

$-4 N-m-m-4-$

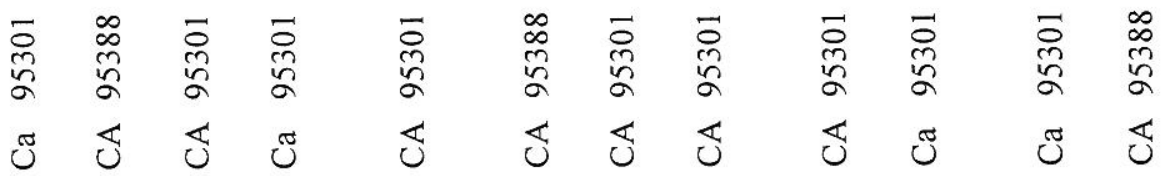

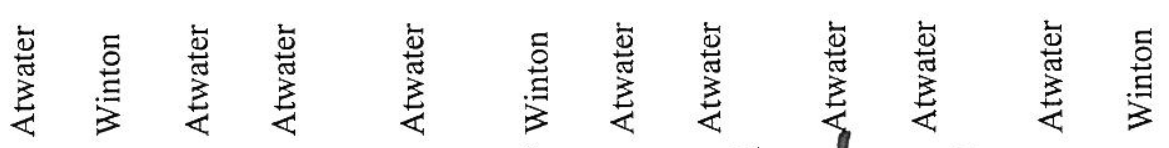

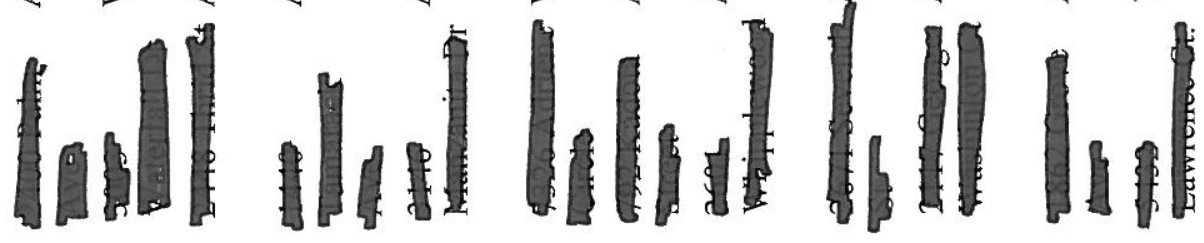

$11111 \| 111111$

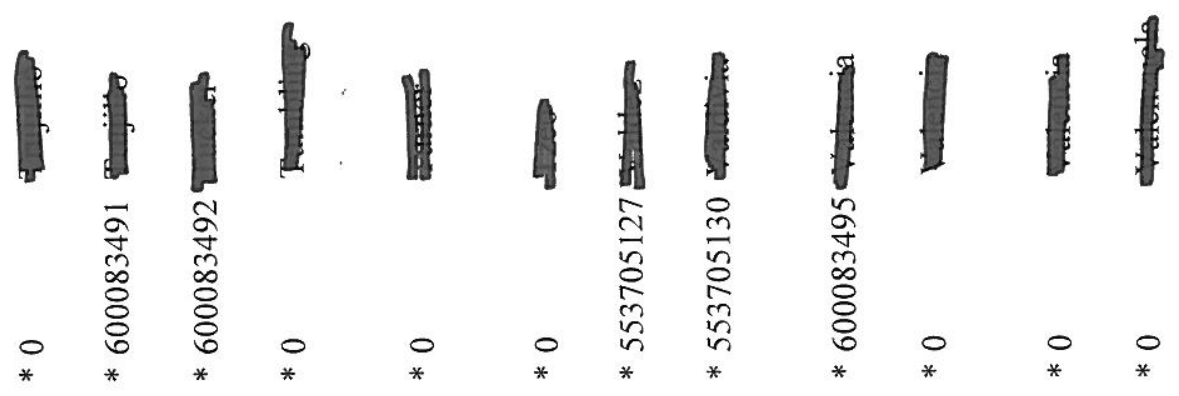




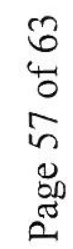

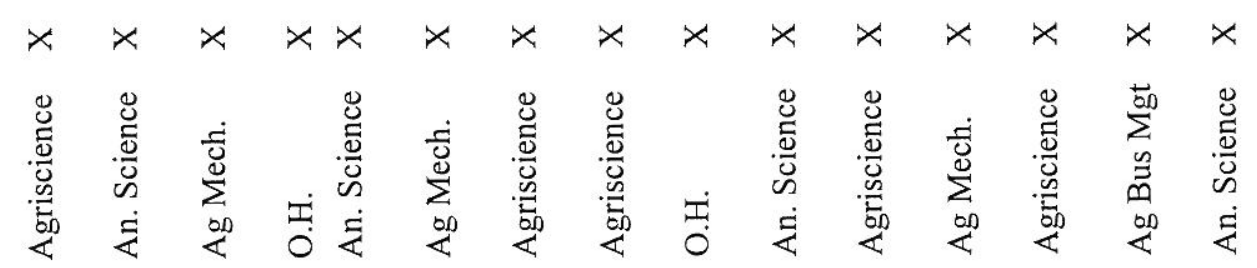

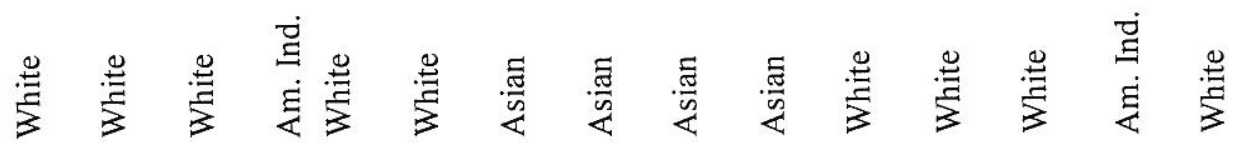
$x \quad x \quad x \quad x \quad x \quad x \quad x$

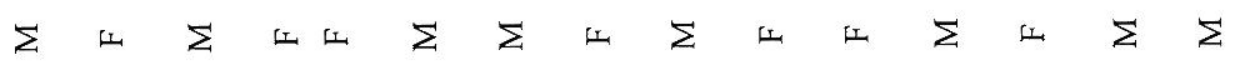

으응ㅇㅇㅢ

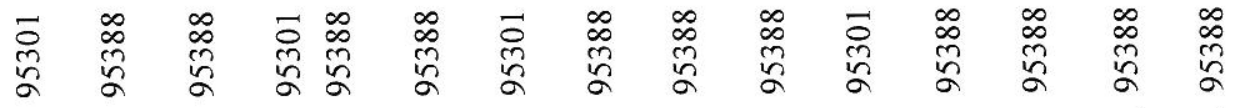

క

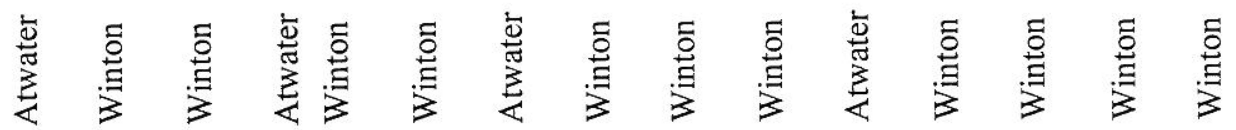

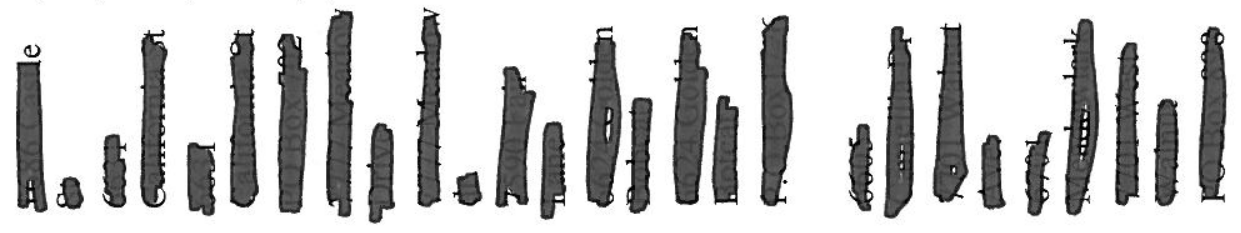

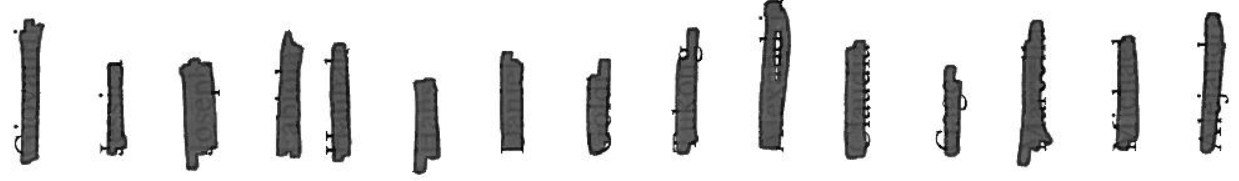

\|nilin || |||||

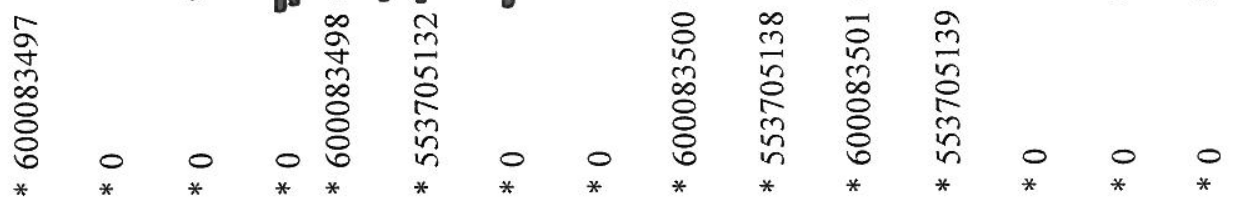


$\hat{0}$
+
$\infty$
$\infty$
$\infty$
$\infty$
0
0
0

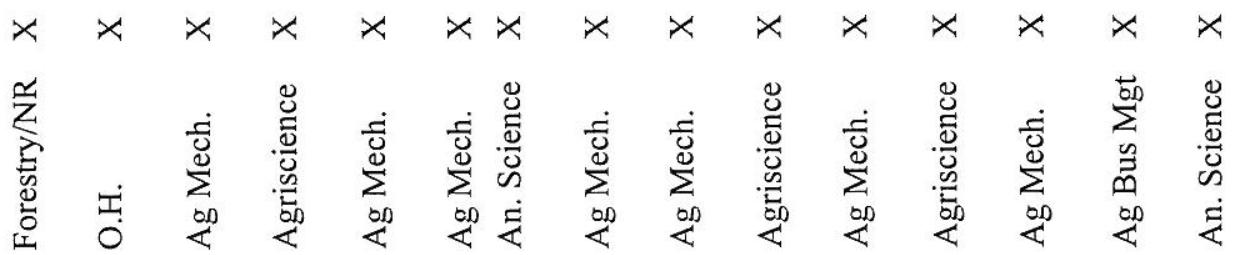

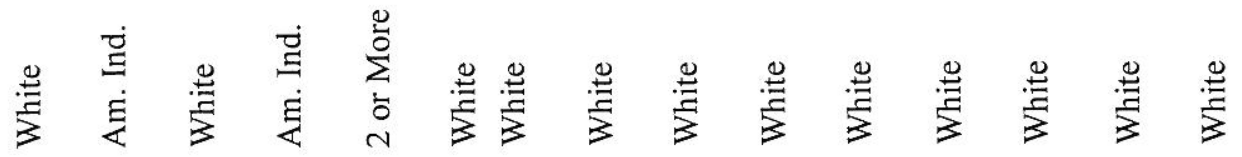
$\times \quad x \quad x \quad x \quad x \quad x \quad x \quad x \quad x \quad x \quad x$

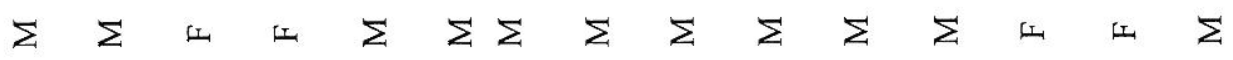

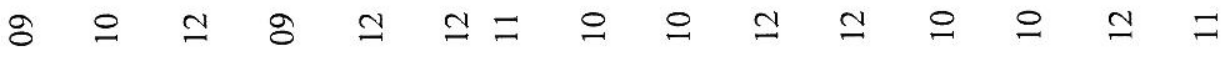

$-4 \nabla-4 \nabla m-4-4-4$

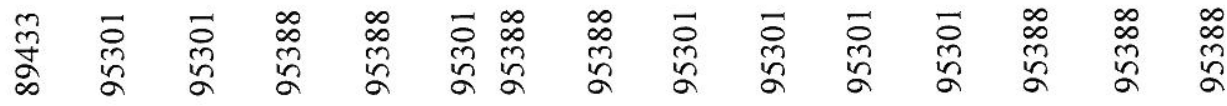

之

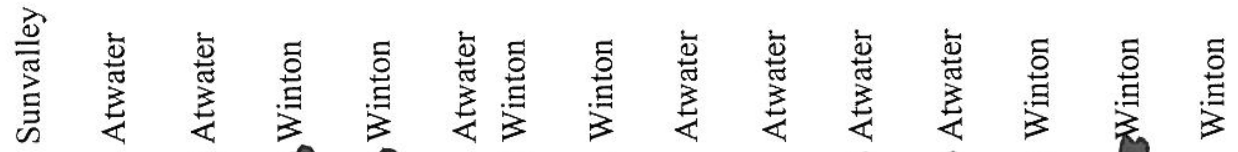

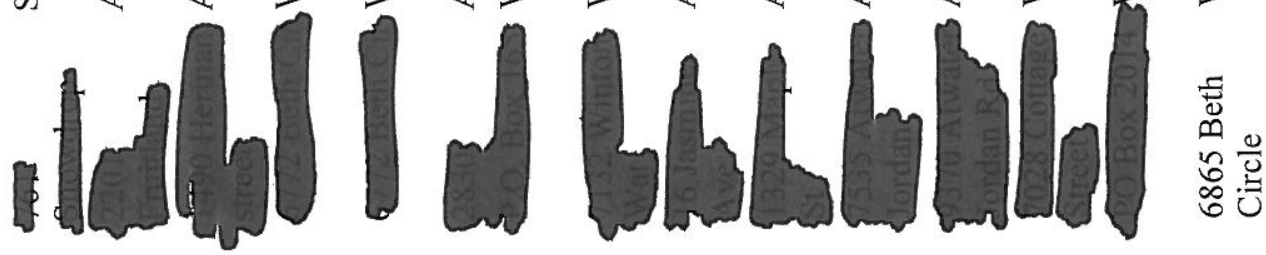

औ

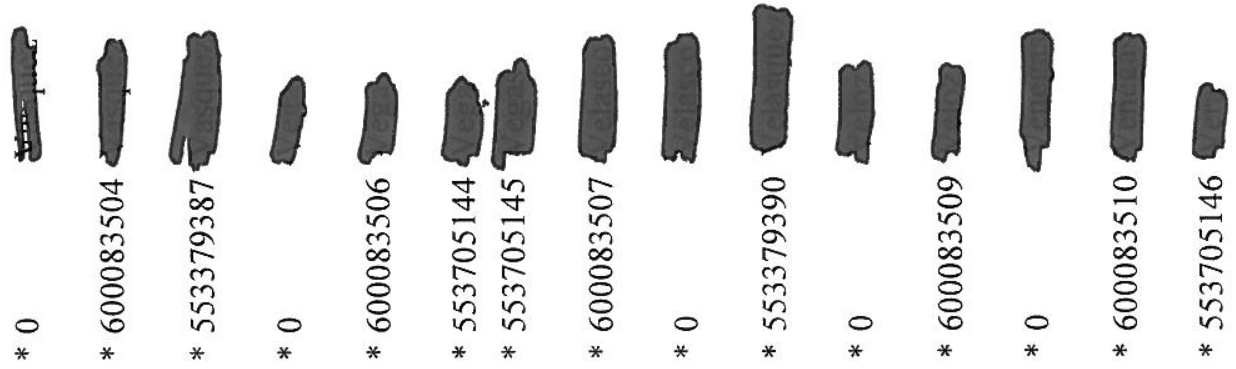




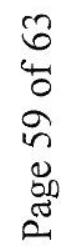

$$
\begin{aligned}
& \times \times x \times x \times x \times
\end{aligned}
$$

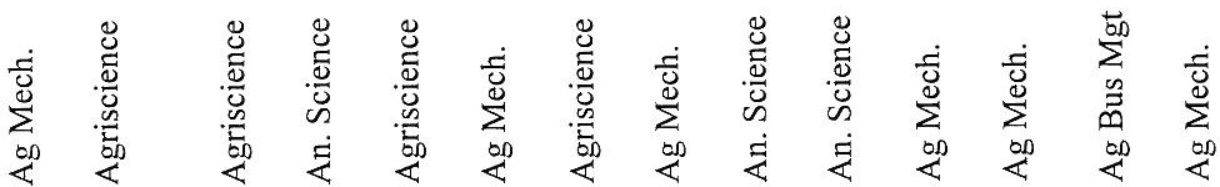

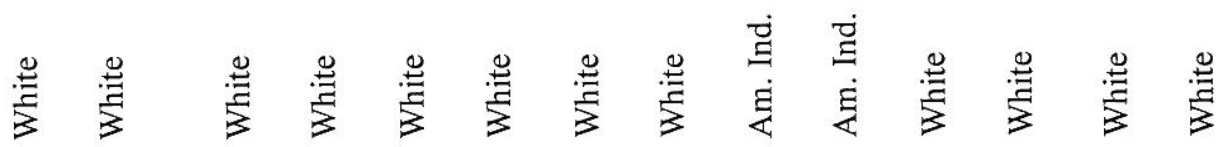
$\times \quad x \quad x \quad x \quad x \quad x \quad x \quad x \quad x \quad x \quad x \quad x \quad x$

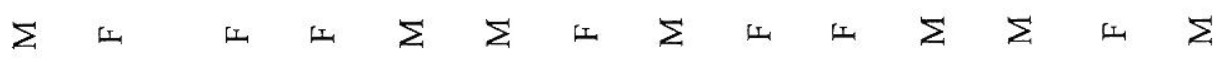

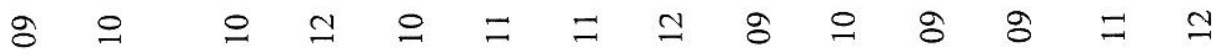

$-4 a+4,4-4,4$

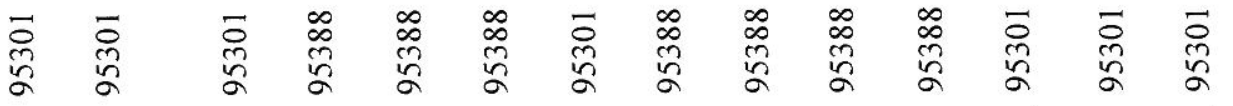

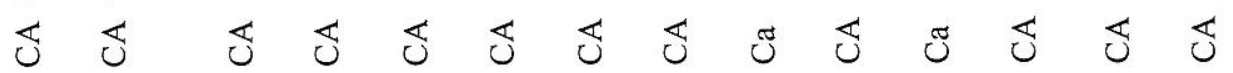

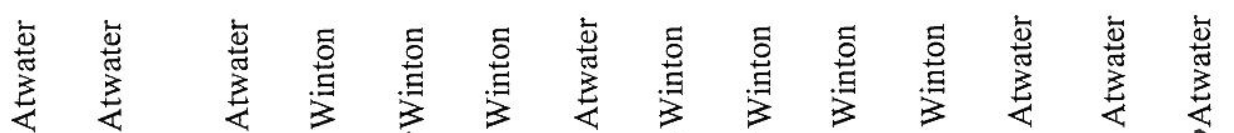

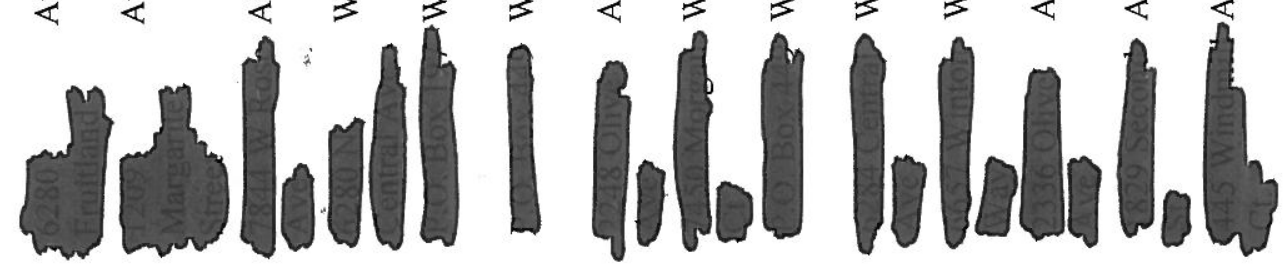

II

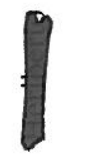

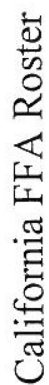

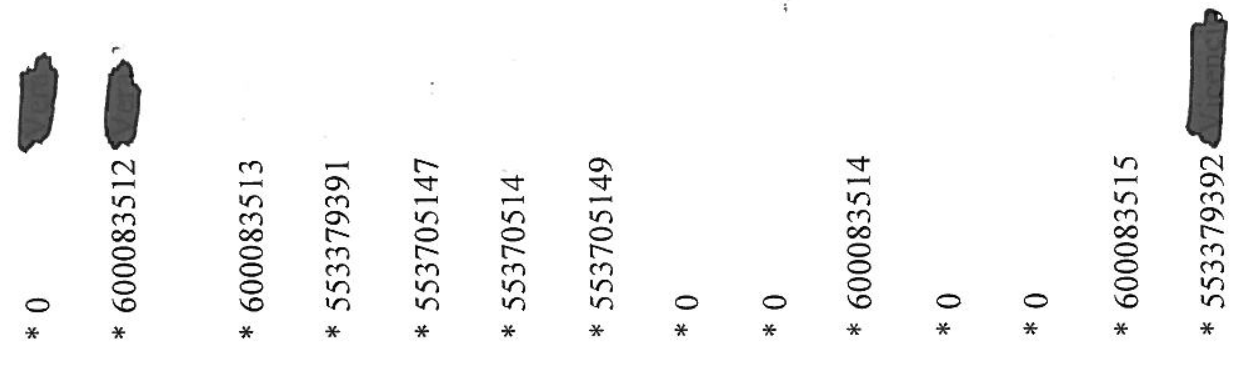




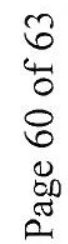

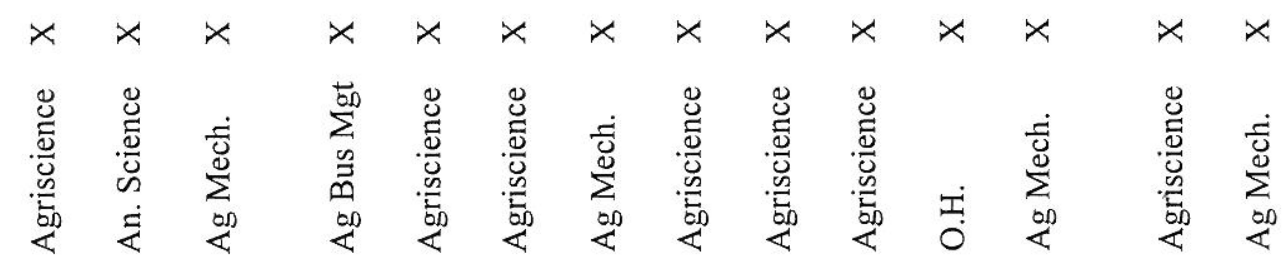

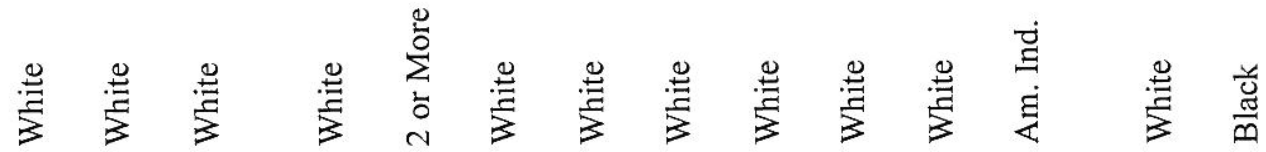
$x \times x \times x \quad x \quad x \quad x$

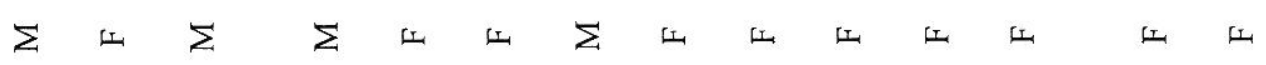

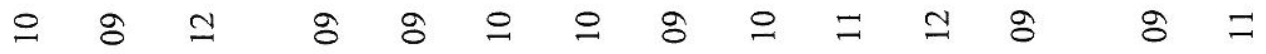

$4-+4-4-4-4-4$

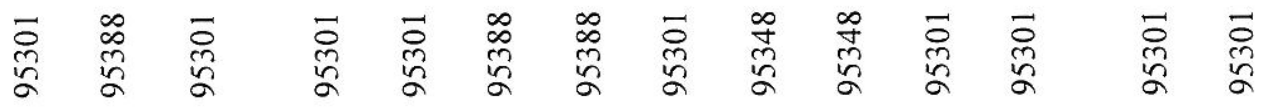

它

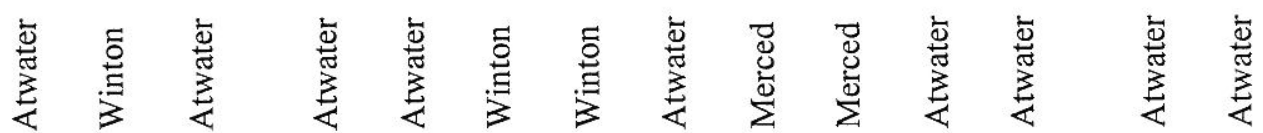

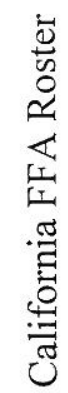

\|\|\|\| $\mid$

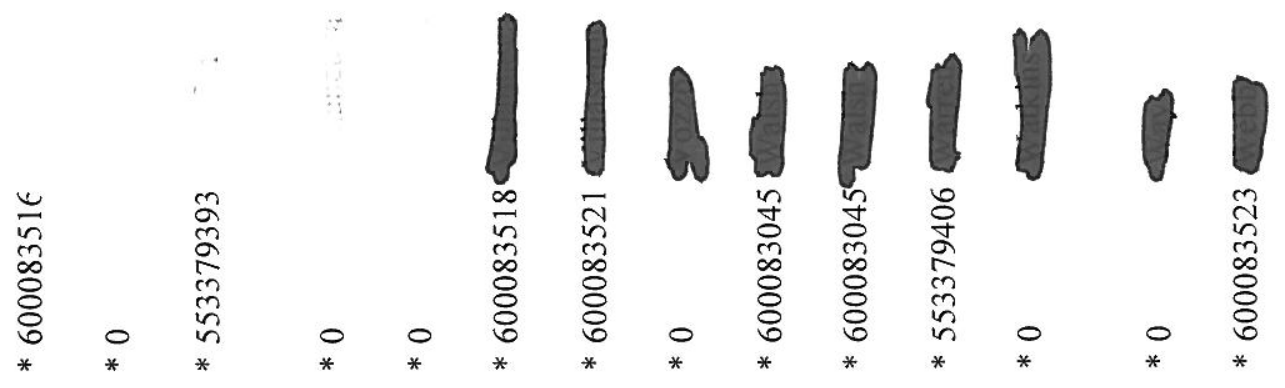




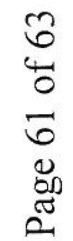

$x \quad x \quad x \quad x \quad x \quad x \quad x \quad x \quad x \quad x \quad x \quad x \quad x$

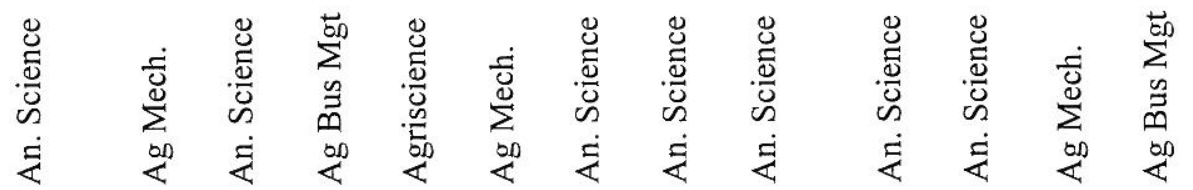

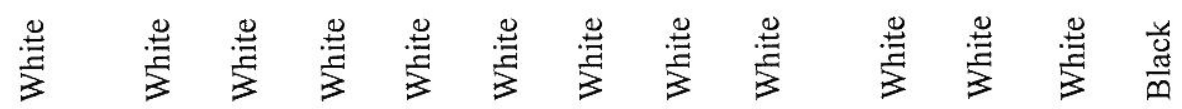
$x \quad x$

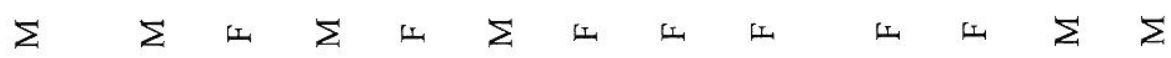

$=\circ \circ 8 \circ=\circ 8=8 \simeq \circ=$

$m-4-4 m-4-m-4$

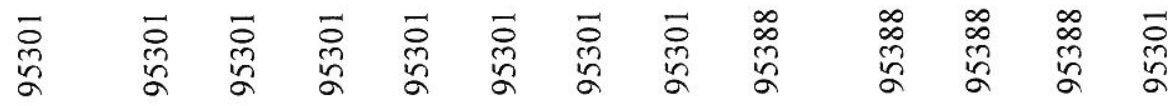

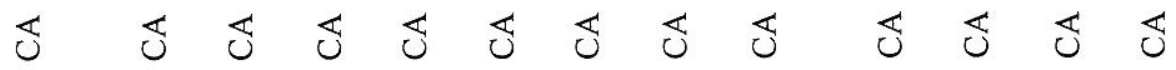

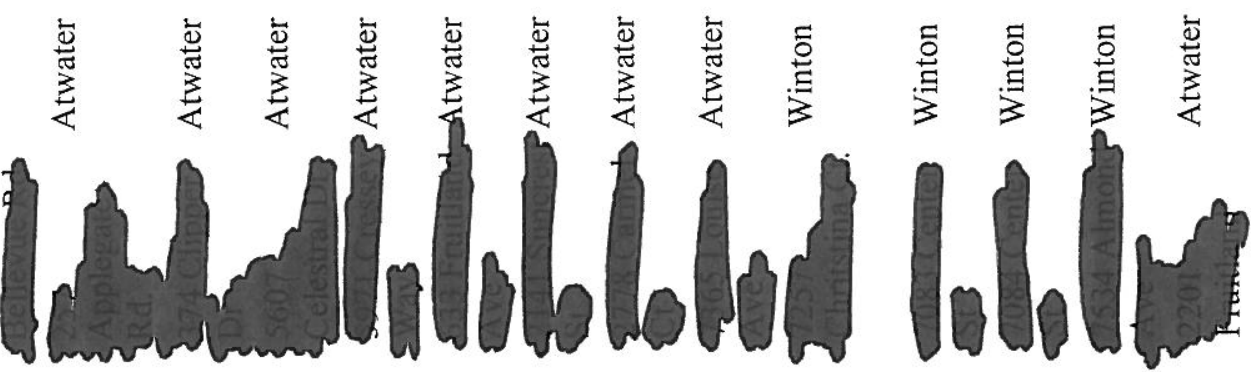

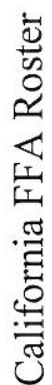

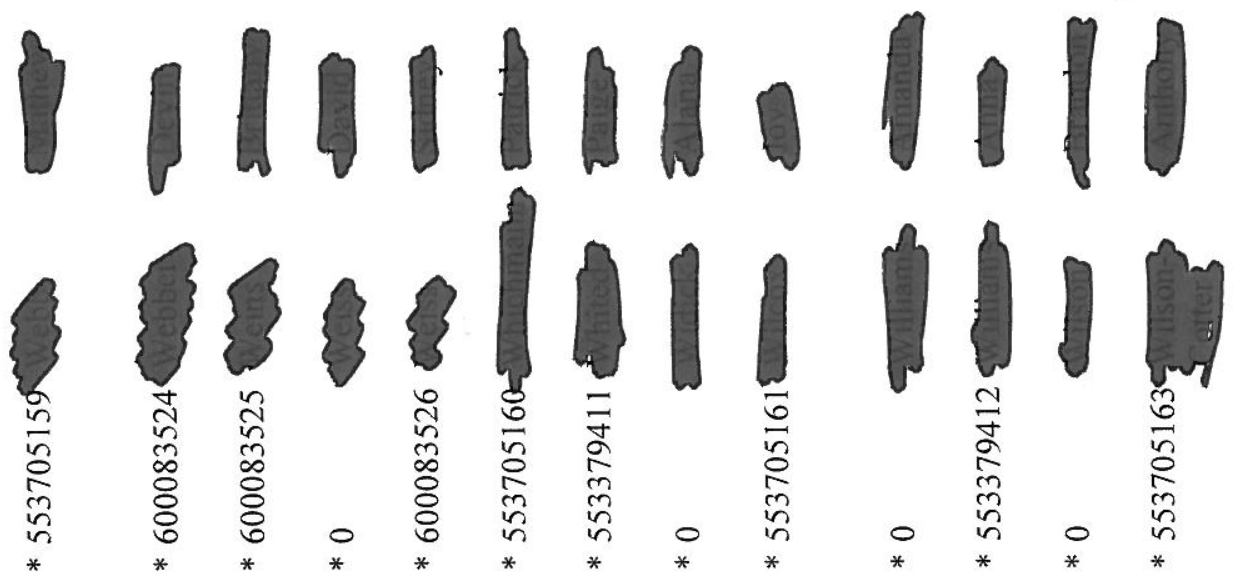




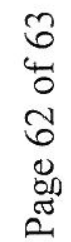

$x \times x \times x \quad x \quad x \quad x \quad x \quad x \quad x \quad x \quad x$

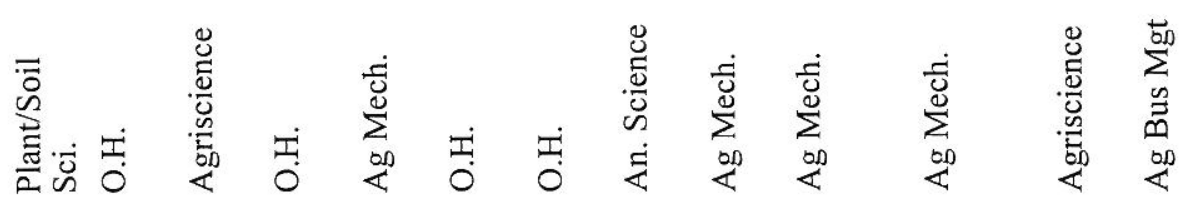

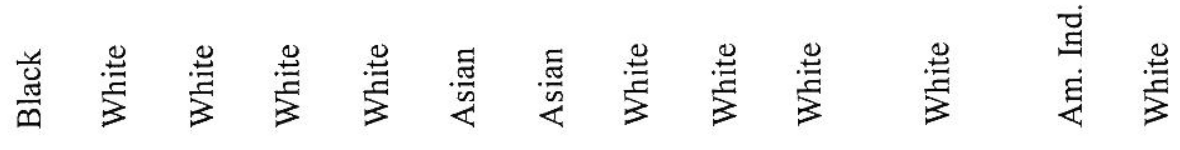

$x \times$

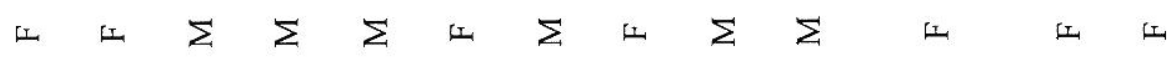

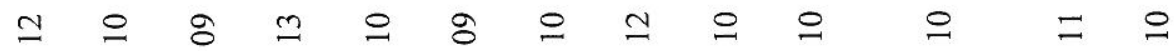

$\rightarrow 4-64-4+444-4$

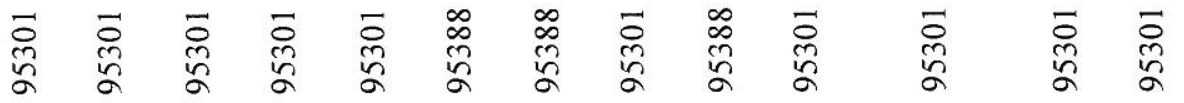

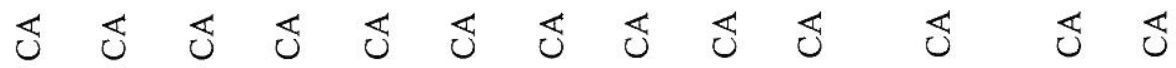

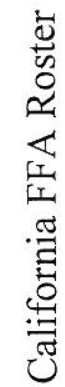

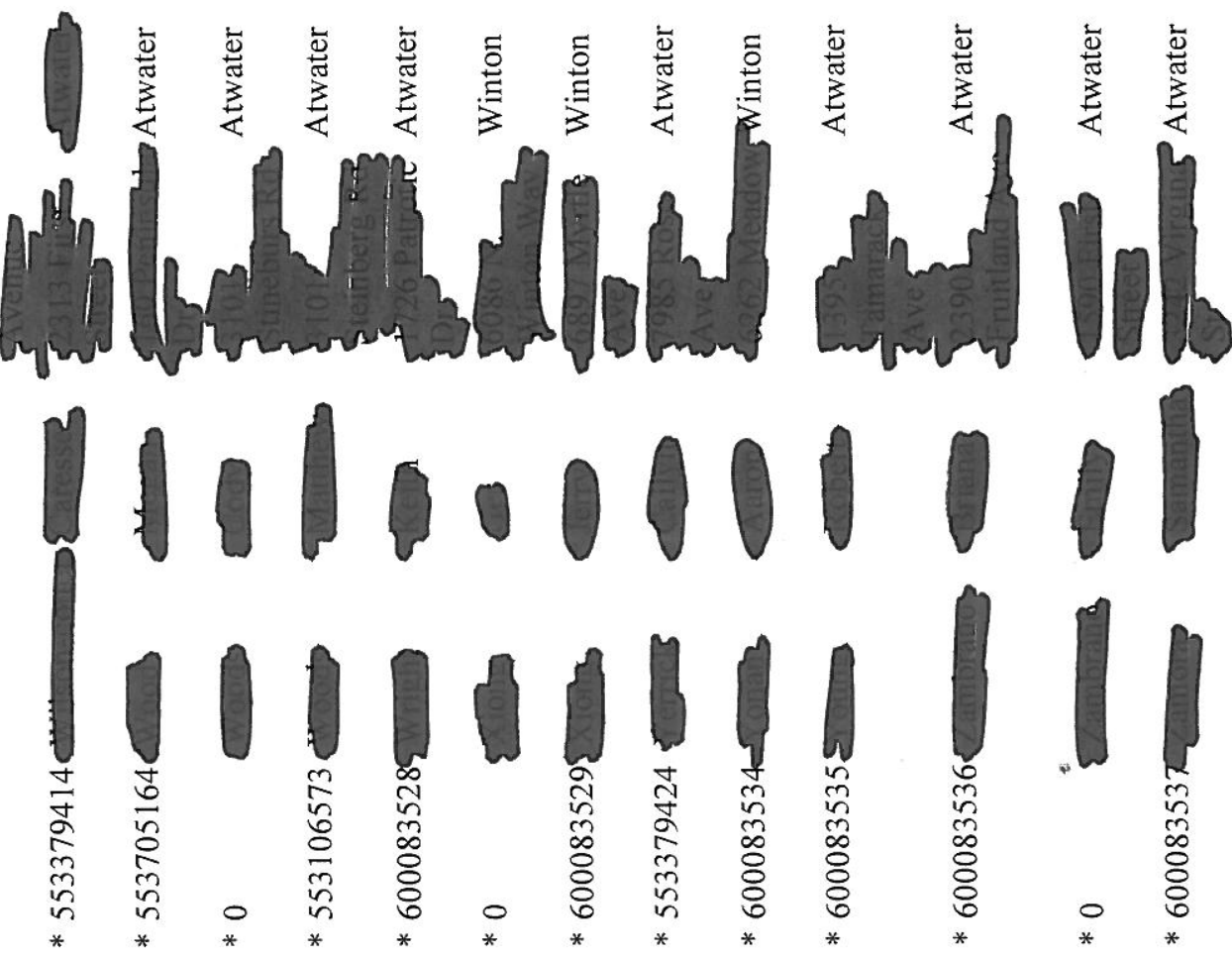




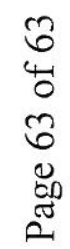

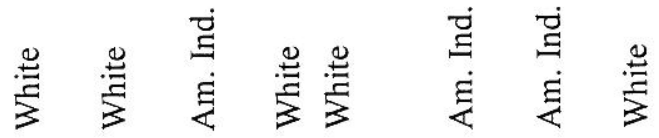

$x \times x \times x \times x$

山 $\Sigma \Sigma \Sigma \Sigma \Sigma \Sigma 山 山$

웅 요 \& 8 으

$4-4-4-4$

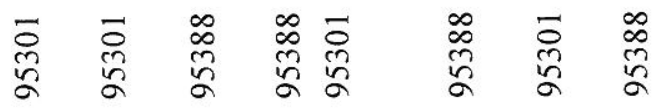

తు
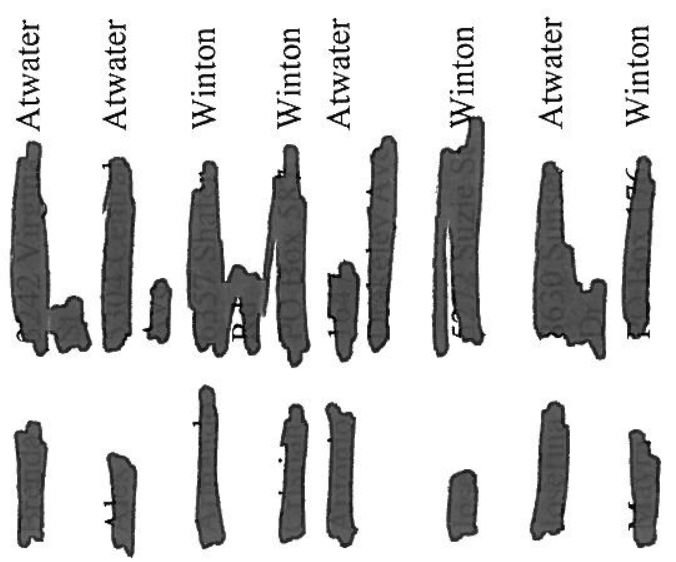

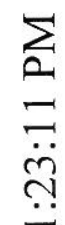

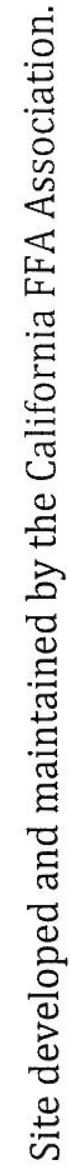

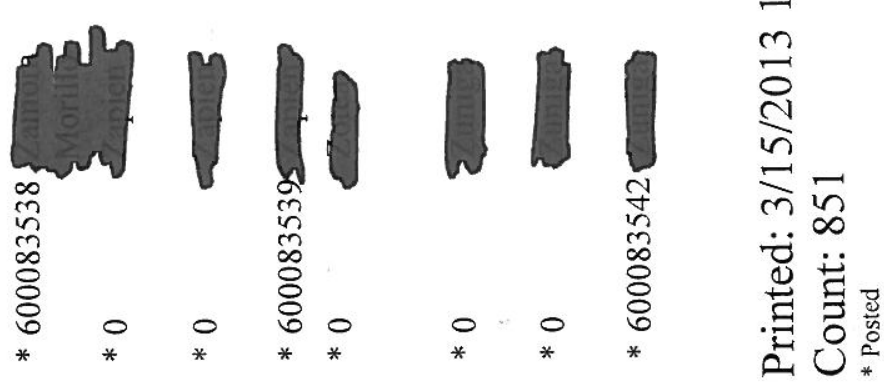




\section{Atwater High School Agriculture / FFA Enrollment History}

California Agriculture Education - R-2 Enrollment

(Individual students enrolled in agriculture courses)

$\begin{array}{lll}2002 & 287 \text { students } & 2017 \\ 2003 & 300 \text { students } & 2018 \\ 2004 & 330 \text { students } & 2019 \\ 2005 & 328 \text { students } & 2020 \\ 2006 & 344 \text { students } & 2021 \\ 2007 & 426 \text { students } & 2022 \\ 2008 & 647 \text { students } & 2023 \\ 2009 & 868 \text { students } & 2024 \\ 2010 & 821 \text { students } & 2025 \\ 2011 & 878 \text { students } & 2026 \\ 2012 & 858 \text { students } & 2027 \\ 2013 & & 2028 \\ 2014 & & 2029 \\ 2015 & & 2030 \\ 2016 & & 2031\end{array}$

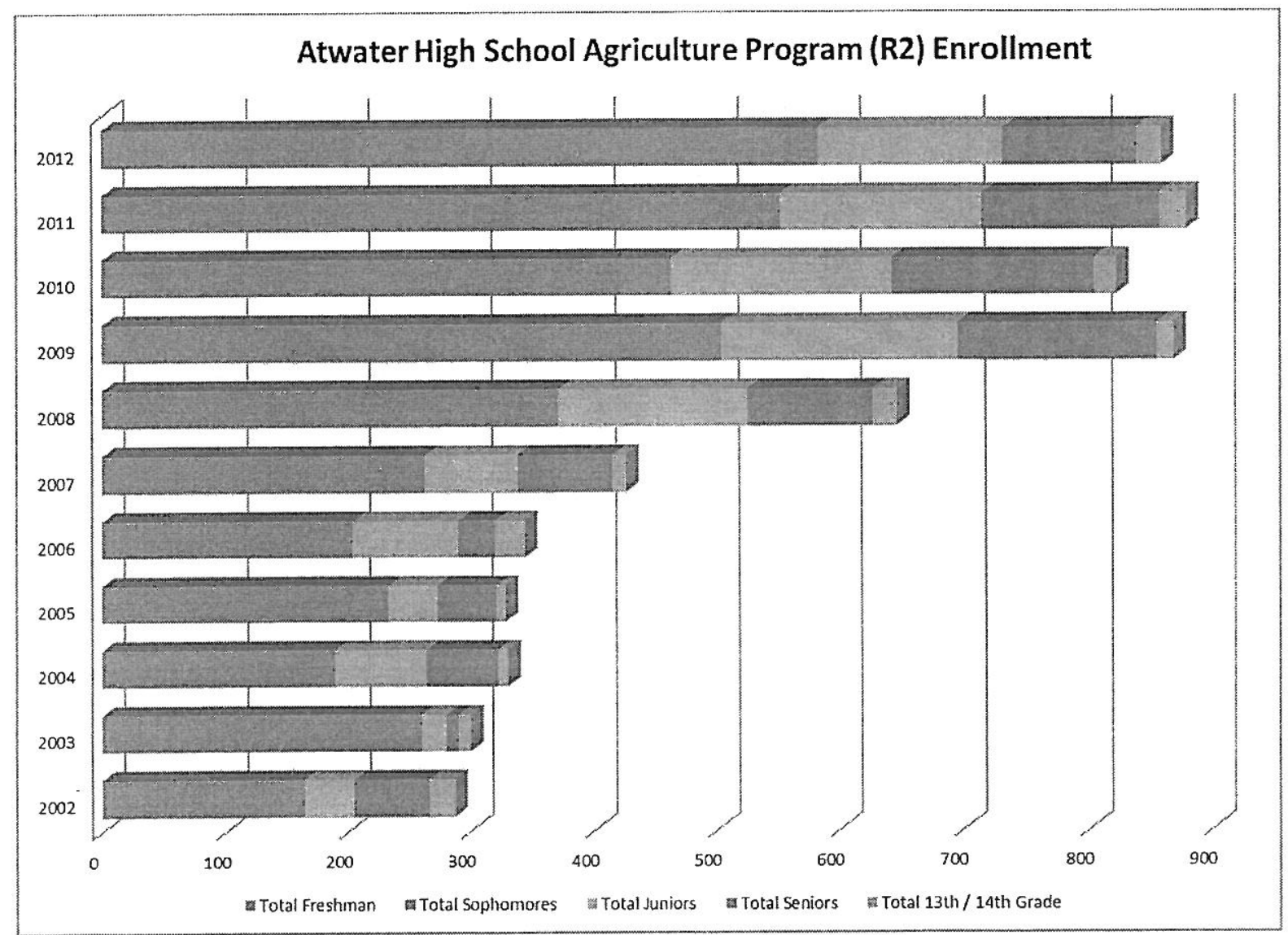

54 l' lage 


\section{Atwater High School Agriculture Department Course Enrollment Data}

\begin{tabular}{|c|c|c|c|c|c|c|c|c|c|c|c|c|c|}
\hline \multicolumn{3}{|c|}{ Course Enrollment } & 2002 & 2003 & 2004 & 2005 & 2006 & 2007 & 2008 & 2009 & 2010 & 2011 & 2012 \\
\hline \multirow{4}{*}{$\begin{array}{l}\text { 1st Year } \\
\text { Courses }\end{array}$} & $* \star$ & Ag Biology & 26 & 44 & 50 & 78 & 114 & 147 & 211 & 332 & 191 & 265 & 227 \\
\hline & & Ag Life Science & n/a & $\mathrm{n} / \mathrm{a}$ & $n / a$ & $n / a$ & $\mathrm{n} / \mathrm{a}$ & n/a & 90 & 76 & 110 & 111 & 107 \\
\hline & & Ag Shop Skills & 28 & 22 & 57 & 55 & 52 & 27 & 92 & 126 & 56 & 86 & 106 \\
\hline & & Exploration in Agriculture & $n / a$ & 15 & 55 & 56 & 52 & 51 & $n / a$ & $n / a$ & $n / a$ & $n / a$ & $n / a$ \\
\hline \multirow{5}{*}{$\begin{array}{c}\text { 2nd / 3rd } \\
\text { Year }\end{array}$} & $n+$ & $\mathrm{Ag}$ Earth Science & $\mathrm{n} / \mathrm{a}$ & 65 & 60 & 93 & 61 & 63 & 96 & 146 & 104 & 115 & 152 \\
\hline & & Ag Environmental Science & $\mathrm{na}$ & $n / a$ & $\mathrm{n} / \mathrm{a}$ & $n / a$ & $n / a$ & $\mathrm{n} / \mathrm{a}$ & $\mathrm{n} / \mathrm{a}$ & 34 & 65 & 72 & 35 \\
\hline & & Small Engines & 13 & $* * * 56$ & 11 & $\mathrm{n} / \mathrm{a}$ & $\mathrm{n} / \mathrm{a}$ & 33 & 11 & 27 & 27 & 26 & 24 \\
\hline & & Welding Tech 1 & 11 & 15 & 14 & 32 & 23 & 56 & 33 & 40 & 53 & 57 & 65 \\
\hline & & Wood Construction 1 & $n / a$ & $\mathrm{n} / \mathrm{a}$ & n/a & $n / a$ & $n / a$ & $n / a$ & 19 & 31 & 59 & 18 & 26 \\
\hline \multirow{10}{*}{$\begin{array}{c}\text { 3rd / 4th } \\
\text { Year } \\
\text { Courses }\end{array}$} & & Ag Economics / Government & $\mathrm{r} / \mathrm{a}$ & $\mathrm{n} / \mathrm{a}$ & $\mathrm{n} / \mathrm{a}$ & $\mathrm{n} / \mathrm{a}$ & $\mathrm{na}$ & $\mathrm{n} / \mathrm{a}$ & $\mathrm{n} / \mathrm{a}$ & $n / a$ & 38 & 38 & 34 \\
\hline & & $\mathrm{Ag}$ Leadership & 16 & 26 & 22 & 23 & 22 & 24. & 19 & 29 & 26 & 28 & 35 \\
\hline & & Equipment Construction & 13 & $\mathrm{n} / \mathrm{a}$ & $\mathrm{n} / \mathrm{a}$ & $\mathrm{n} / \mathrm{a}$ & $n / a$ & 20 & 10 & 10 & 8 & 4 & 5 \\
\hline & & Floral Design $1 / I$ & 20 & 43 & 51 & 17 & 11 & $\mathrm{n} / \mathrm{a}$ & 79 & 80 & 128 & 122 & 116 \\
\hline & & Horticulture & $\mathrm{n} / \mathrm{a}$ & $n / a$ & $n / a$ & $\mathrm{n} / \mathrm{a}$ & $n / a$ & 22 & 12 & 34 & 16 & 35 & 31 \\
\hline & & Power Mechanics & $n / a$ & $n / a$ & $n / a$ & $\mathrm{n} / \mathrm{a}$ & $\mathrm{n} / \mathrm{a}$ & $\mathrm{n} / \mathrm{a}$ & 0 & 31 & 19 & 26 & 31 \\
\hline & & Veterinary Science & $n / a$ & $n / a$ & $n / a$ & $n / a$ & $n / a$ & $\mathrm{n} / \mathrm{a}$ & 34 & 32 & 59 & 36 & 37 \\
\hline & & Welding Tech II & 6 & 4 & 2. & 6 & 17 & 12 & 18 & 14 & 14 & 19 & 22 \\
\hline & & Wood Construction II & $n / a$ & $n / a$ & $\mathrm{n} / \mathrm{a}$ & $n / a$ & $n / a$ & $n / a$ & 13 & 20 & 23 & 25 & 6 \\
\hline & & Wood Construction III & $n / a$ & $\mathrm{n} / \mathrm{a}$ & $n / a$ & $n / a$ & $n / a$ & $\mathrm{n} / \mathrm{a}$ & 3 & 5 & 13 & 3 & 12 \\
\hline \multirow{8}{*}{$\begin{array}{l}\text { Courses } \\
\text { Closed }\end{array}$} & & Ag Science I & 86 & $n / a$ & $n / a$ & $n / a$ & $n / a$ & $n / a$ & $n / a$ & $\mathrm{n} / \mathrm{a}$ & $n / a$ & n/a & $n / a$ \\
\hline & & Ag Science /I & 22 & n/a & $n / a$ & $\mathrm{n} / \mathrm{a}$ & $\mathrm{n} / \mathrm{a}$ & n/a & $n / a$ & $n / a$ & $n / a$ & $n / a$ & $n / a$ \\
\hline & & Animal Anatomy \& Physiology & 16 & $n / a$ & $\mathrm{n} / \mathrm{a}$ & $\mathrm{n} / \mathrm{a}$ & $\mathrm{n} / \mathrm{a}$ & $n / a$ & $n / a$ & n/a & $\mathrm{n} / \mathrm{a}$ & $n / a$ & $n / a$ \\
\hline & & Intemships in Ag I/II & 18 & 14 & 23 & 16 & 13 & 22 & $n / a$ & $\mathrm{n} / \mathrm{a}$ & $n / a$ & $n / a$ & $n / a$ \\
\hline & & Total Course Enrollment: & 275 & 248 & 345 & 376 & 365 & 477 & 740 & 1067 & 1009 & 1086 & 1071 \\
\hline & & & \multicolumn{3}{|c|}{ * Freshman entry course } & & & & & & & & \\
\hline & & & \multicolumn{4}{|c|}{ *" Science Graduation Credit } & & & & & & & \\
\hline & & & \multicolumn{6}{|c|}{ *** Primarily non-Ag students. Covered Industrial Tech sludents } & & & & & \\
\hline
\end{tabular}

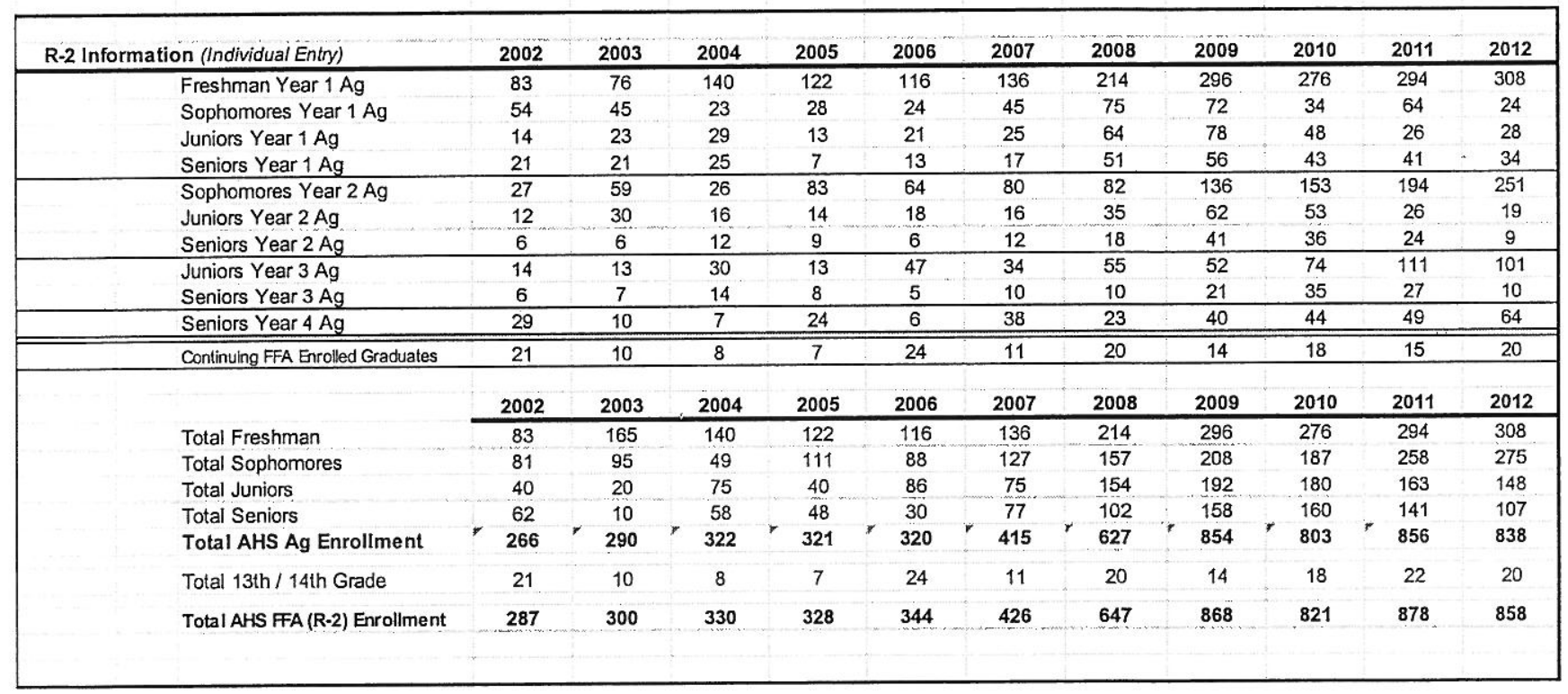

This chart reflecls our numbers that are tabulated each fall for our annual "Fall Ag Advisory Committee Meeting" where we invite the local feeder school counselors \& principals, AHS adminsitration, School Board, District personnel, Ag Advisory Board, Ag Booster representatives, AHS counselors, and community representatives to present a "State of the Union" presentation to share (1) Where We Are and (2) Where We Are Going. The meeting provides valubale insight and communication to our programs "vision" and goals. It also provides an opportunity to share ideas, concerns, and current events. Additional charts, packets, marketing/promotional material is presented each year. This annual meeting has proven very beneficial and productive. 


\section{$\underline{Y}$ \\ Extended Contract Rationale}

The rational or justification documentation on file with the board was not accessible at this time. This will be a document that will be located and copied in the near future for verification and substantial proof for maintaining our extended contracts.

Currently, Agriculture instructors at Atwater High School are compensated $20 \%$ of their salary, surpassing the minimum $\$ 2000$, for year-round instruction. 5 of the 6 teachers are fulltime agriculture instructors within the school day and throughout the summers to provide adequate supervision of SAE projects. Following is the R-2 Teacher Information Form. 


\section{$\underline{\mathbf{Z}}$ \\ Travel Plan}

In the Merced Unified High School District, travel plans must be submitted any time a district employee and/or students are spending the night somewhere. The plans must be submitted prior to the event and must be approved by the department head, high school principal, superintendent and school board.

The travel request covers the logistics of the trip as well as estimated expenses incurred on the trip.

\section{Attached you will find:}

- Example of a completed travel request 


\section{Atwater High School \\ FIELD TRIP REQUEST \\ For Best Results}

$\underline{\text { Submit request at least } 3 \text { weeks in advance to Scott Weimer }}$

Person Requesting Trip:

Contact Number:

Destination:

Departure Date and Time:

Return Date and Time:

Departure Location:

Return Location:

Method of Transportation:

Funding Source:

Budget Number:

Person Authorizing Expense:

Chaperones:
Beth Knapp

\begin{tabular}{l}
\hline Modesto, CA \\
\hline 2/18 10:30 AM \\
\hline 2/19 1:00 PM \\
\hline AHS Ag Department \\
\hline AHS Ag Department \\
\hline MUHSD Suburbans and Ag Truck \\
\hline Perkin's and AG Dept Transportation Funds \\
\hline NA \\
\hline Beth Knapp \\
\hline Dave Gossman / Natalie Kirschner
\end{tabular}

\section{Policy Regarding Field Trips}

Field trips may NOT be scheduled during the FIRST THREE WEEKS of a school year, the LAST WEEK of each grading period, or the LAST TWO WEEKS prior to the end of the school year.

\section{Eligibility Requirements}

To be eligible to participate in extracurricular and co-curricular activities, students must demonstrate satisfactory educational progress in the previous grading period including but not limited to:

1. Maintenance of a minimum of 2.0 grade point average on a 4.0 scale

2. Earning no more than two Us in citizenship

3. Earning no more than two F's

4. Maintenance of minimum progress toward meeting high school graduation requirements

5. Juniors and Seniors must have passed CAHSEE. (No Freshman or Sophomores allowed if going during a school day)

A five-day home suspension will result in the loss of eligibility for nine weeks.

\section{Approval}

At lest three weeks prior turn in this form completed and a completed Transportation Request

Approved

Denied

\section{Check Off List}

Checked Eligibility

Permission Slips (One copy for you and one turned into SBO three days prior)

Attendance forms filled out and signed (One copy to SBO and one to Attendance) 


\section{DAY OF TRIP \\ ONE COPY TO ATTENDANCE OFFICE \& ONE COPY TO SBO}

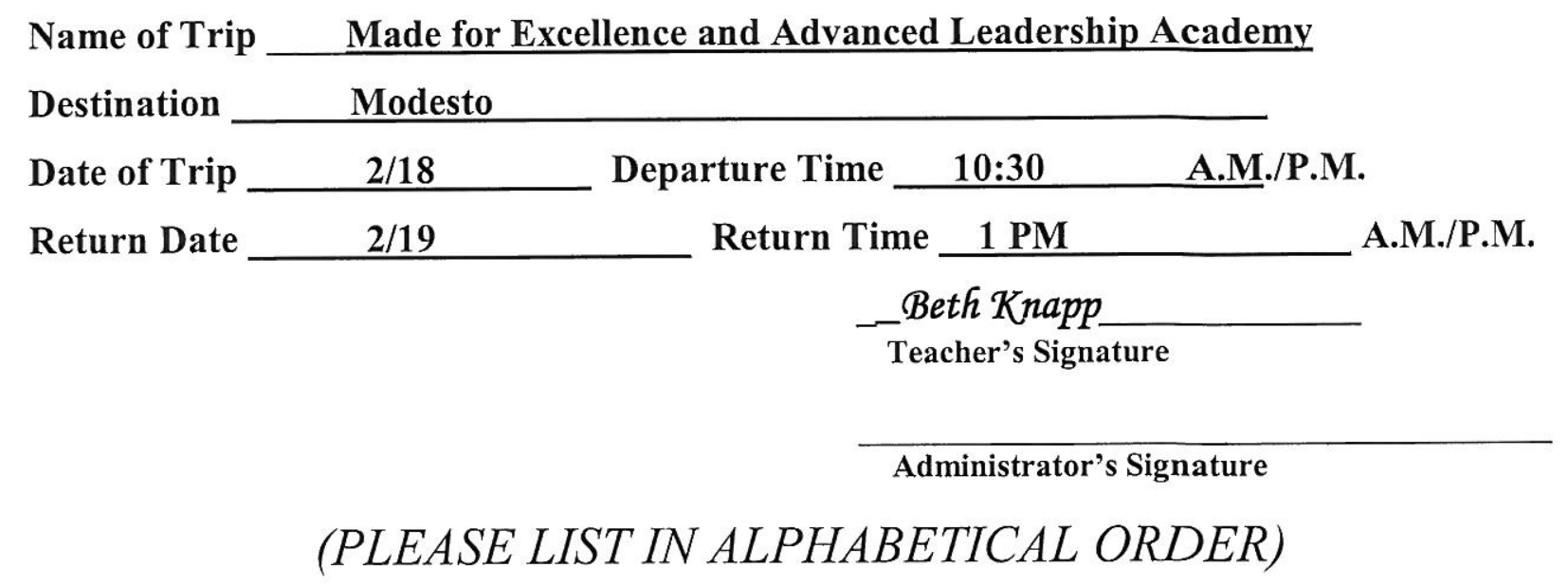

\begin{tabular}{|c|c|c|}
\hline Student ID Number & LAST NAME & FIRST NAME \\
\hline 68542 & Del Toro & Vanessa \\
\hline 68583 & Flores & Sandra \\
\hline 68651 & Hernandez & Nayeli \\
\hline 69860 & Hernandez & Mayra \\
\hline 68676 & Jorge & Marisa \\
\hline 70183 & Manuel & Trazarra \\
\hline 68765 & Miscione & Courtney \\
\hline 68808 & Pena & Joana \\
\hline 68861 & Rogers & Sarah \\
\hline 70145 & Schiber & Carolyn \\
\hline 70002 & Schoonover & Cheyenne \\
\hline 67948 & Summerton & James \\
\hline 69609 & Vang & Padee \\
\hline 68947 & Vasquez & Jackie \\
\hline 69634 & Willson-Cotter & Caresse \\
\hline 69652 & Yerrick & Cailyn \\
\hline & & \\
\hline & & \\
\hline & & \\
\hline & & \\
\hline
\end{tabular}




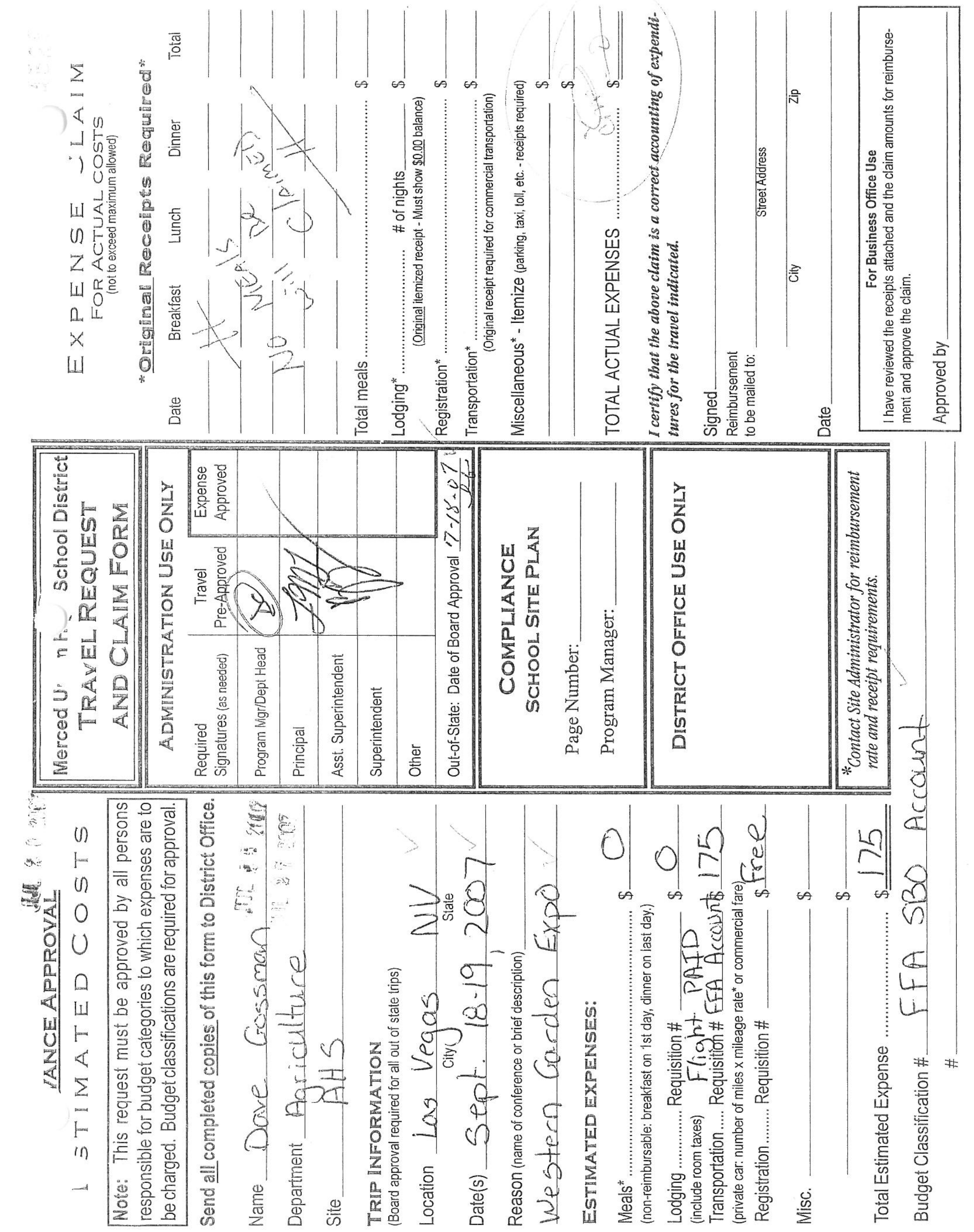




\section{$\underline{A A}$ \\ CATA Membership}

All instructors in the Atwater Agriculture Department are paid, voting members of the California Agriculture Teachers' Association.

Attached you will find:

- Copy of Ag Teacher dues 


\section{CALIFORNIA AGRICULTURAL TEACHERS' ASSOCIATION MEMBERSHIP APPLICATION}

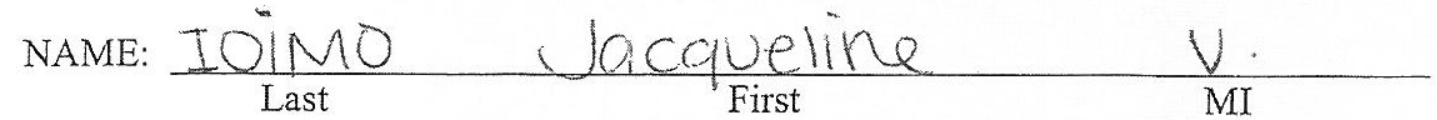

HOME ADDRESS:

CITY/STATE/ZIP CODE: Merced,CA CS348

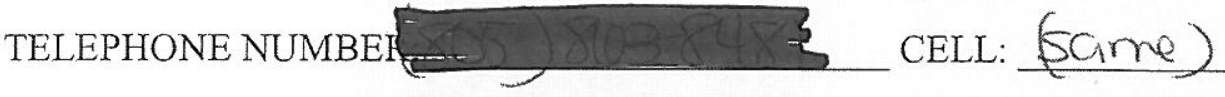

WORK NUMBER:

E-MAIL ADDRESS:<smiles>C=[GeH2]</smiles>

Merced 1

CATA REGION: Central CATA SECTION: MaveIpora SCHOOL: Atr vatep CATA has my permission to distribute my home address and telephone number to other ag teachers.

Regular Dues - $\$ 140$

Ag Teachers less than $1 / 2$ time (FTE) - $\$ 70$

Signature:

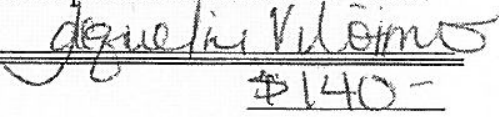

Installment Billing - at least $\$ 26$ *

Associate - $\$ 15$

New Teacher - $\$ 70$

Life Membership - $\$ 1,400.00$

Optional - ACTE Dues - $\$ 80$

Optional - NAAE Dues - $\$ 60$

Optional - Contribution to CATA Scholarship Fund

\section{SUB TOTAL DUES $\longdiv { 4 0 9 }$}

$\$ 10$ $\$ 25$ $\$ 50$ $\$ 100$ Other TOTAL (Please make check payable to CATA.) $140=$

\section{Important Tax Notice to CATA Members}

Contributions or gifts to CATA are not deductible as charitable contributions for income tax purposes. However, CATA dues may be tax deductible as an ordinary and necessary business expense. Please consult your tax advisor.

Charge my dues to: $\quad$ VISA Master Card

Card \# Expiration Date

Signature:

Installment dues are $\$ 140+$ service charge of $\$ 16$

Installment dues for New Teachers are $\$ 70+$ service charge of $\$ 8$

*Service charge is for Installment Dues ONLY*

Please note that members electing to pay monthly are agreeing to pay the full amount whether or not they decide to pay off their dues early.

Signature:

Mail to: California Agricultural Teachers' Assn.

P.O. Box 834

Elk Grove, CA 95759-0834

Receipt No. $\overline{\text { Member Card No. } \overline{01.02 .01}}$

Rev: 2011 


\section{CALIFORNIA AGRICULTURAL TEACHERS' ASSOCIATION MEMBERSHIP APPLICATION}

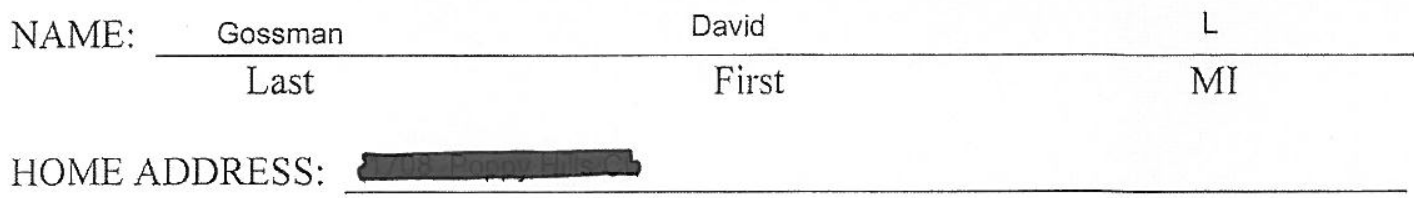

CITY/STATE/ZIP CODE: Merced, CA 95340

TELEPHONE NUMBER:

CELL:

WORK NUMBER:

FAX:

שרח

E-MAIL ADDRESS:

CATA REGION: Central

CATA SECTION: $\mathrm{M} / \mathrm{M}$

SCHOOL: Atwater

CATA has my permission to distribute my home address and telephone number to other ag teachers.

Yes No Signature:

Regular Dues - $\$ 140$
Ag Teachers less than $1 / 2$ time (FT
Installment Billing - at least $\$ 2$
Associate - $\$ 15$
New Teacher - $\$ 70$
Life Membership - $\$ 1,400.00$
Optional - ACTE Dues - $\$ 80$
Optional - NAAE Dues - $\$ 60$

Optional - Contribution to CATA Scholarship Fund

\section{SUB TOTAL DUES}

$\$ 10$ $\$ 25$

\section{TOTAL (Please make check payable to CATA.)}

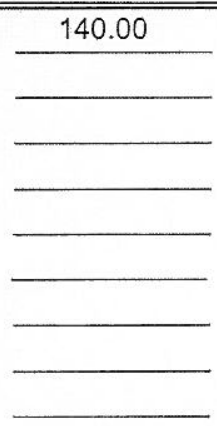

\section{Important Tax Notice to CATA Members}

Contributions or gifts to CATA are not deductible as charitable contributions for income tax purposes. However, CATA dues may be tax deductible as an ordinary and necessary business expense. Please consult your tax advisor.

Charge my dues to:

VISA Master Card

Card \# Expiration Date

Signature:

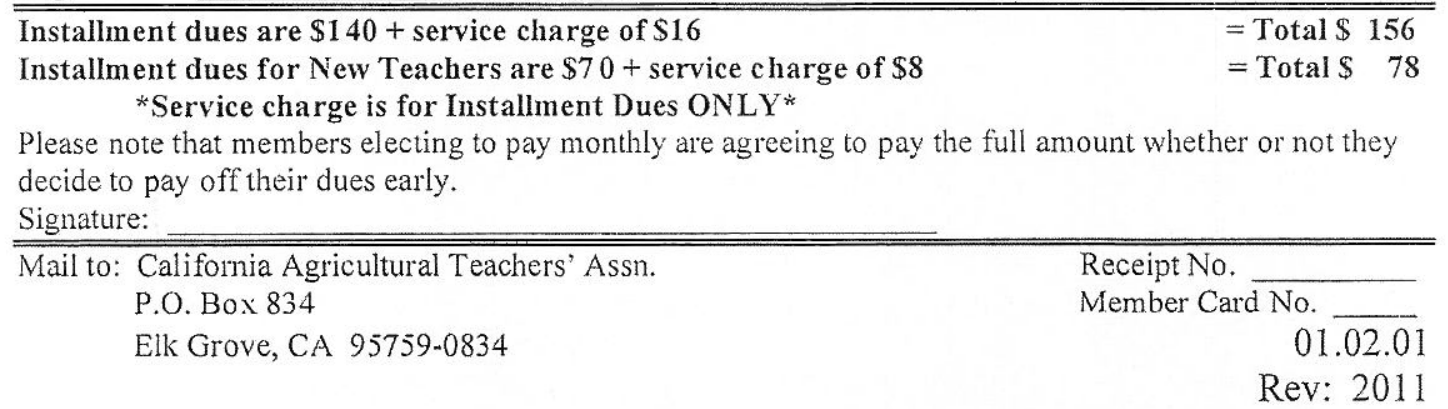




\section{CALIFORNIA AGRICULTURAL TEACHERS' ASSOCIATION MEMBERSHIP APPLICATION}

NAME:

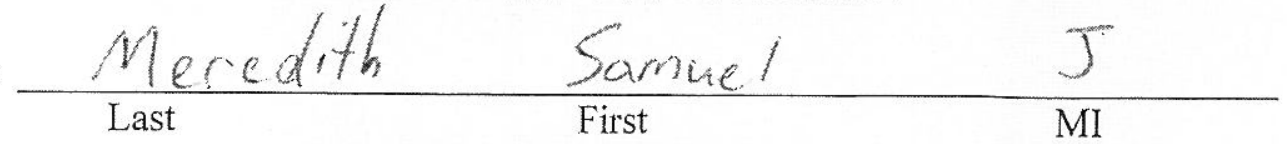

HOME ADDRESS:

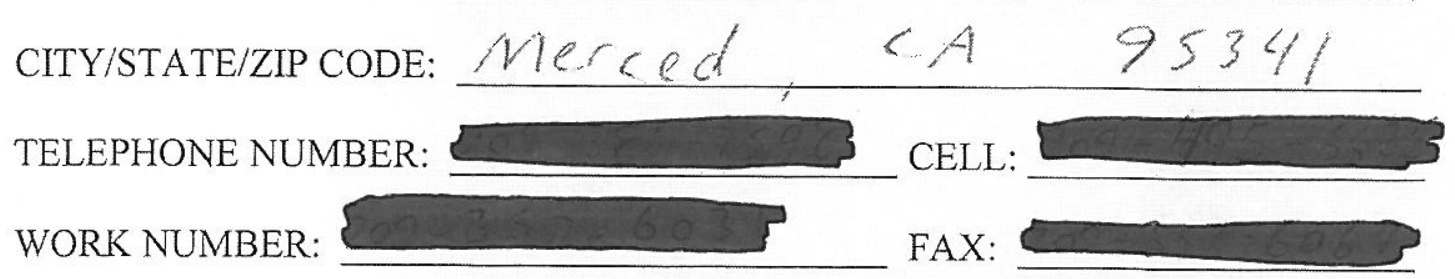

E-MAIL ADDRESS:

CATA REGION: Cen tral CATA SECTION: M/M SCHOOL: Atwater CATA has my permission to distribute my home address and telephone number to other ag teachers.

Yes $\infty$ No

Regular Dues - \$140

Ag Teachers less than $1 / 2$ time (FTE) - $\$ 70$

Installment Billing - at least $\$ 26^{*}$

Associate - $\$ 15$

New Teacher - $\$ 70$

Life Membership - $\$ 1,400.00$

Optional - ACTE Dues - $\$ 80$

Optional - NAAE Dues - $\$ 60$

Option
$\$ 10$

$$
\$ 25
$$

SUB TOTAL DUES

Signature:
Sin.

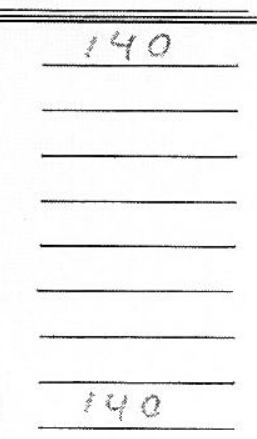
TOTAL (Please make check payable to CATA.)

340

Important Tax Notice to CATA Members

Contributions or gifts to CATA are not deductible as charitable contributions for income tax purposes. However, CATA dues may be tax deductible as an ordinary and necessary business expense. Please consult your tax advisor.

Charge my dues to:

VISA Master Card

Card \# Expiration Date

Signature:

\begin{tabular}{cc}
\hline \hline Installment dues are $\$ 140+$ service charge of $\$ 16$ & $=$ Total $\$ 156$ \\
Installment dues for New Teachers are $\$ 70+$ service charge of $\$ 8$ & $=$ Total $\$ 78$ \\
* Service charge is for Installment Dues ONLY* &
\end{tabular}

Please note that members electing to pay monthly are agreeing to pay the full amount whether or not they decide to pay off their dues early.

Signature:

Mail to: California Agricultural Teachers' Assn.

P.O. Box 834

Elk Grove, CA 95759-0834

Receipt No.

Member Card No.

$01 . \overline{02.01}$

Rev: 2011 


\section{CALIFORNIA AGRICULTURAL TEACHERS' ASSOCIATION MEMBERSHIP APPLICATION}

NAME:

$\frac{\text { Flatt Dan }}{\text { Last }}$ First

$S$

HOME ADDRESS:

CITY/STATE/ZIP CODE: Atwater CA $\$ 5301$

TELEPHONE NUMBER: CELL:

WORK NUMBER:

FAX:

E-MAIL ADDRESS:

CATA REGION: Cetal CATA SECTION: meed/man SCHOOL: Atweter Hiyh CATA has my permission to distribute my home address and telephone number to other ag teachers. Yes $x$ No_ Signature:

Regular Dues - $\$ 140$

$\mathrm{Ag}$ Teachers less than $1 / 2$ time (FTE) - $\$ 70$ 140 Installment Billing - at least $\$ 26^{*}$

Associate - $\$ 15$

New Teacher - $\$ 70$

Life Membership - \$1,400.00

Optional - ACTE Dues - $\$ 80$

Optional - NAAE Dues - $\$ 60$

Optional - Contribution to CATA Scholarship Fund

SUB TOTAL DUES

$\$ 10$ $\$ 25$ $\$ 50 \_\$ 100$

Other

TOTAL (Please make check payable to CATA.)

1400

\section{Important Tax Notice to CATA Members}

Contributions or gifts to CATA are not deductible as charitable contributions for income tax purposes. However, CATA dues may be tax deductible as an ordinary and necessary business expense. Please consult your tax advisor.

Charge my dues to: VISA Master Card

Card \# Expiration Date

Signature:

Installment dues are $\$ 140+$ service charge of $\$ 16$

$=$ Total $\$ 156$

Installment dues for New Teachers are \$70 + service charge of \$8

$=$ Total $\$ 78$

*Service charge is for Installment Dues ONLY*

Please note that members electing to pay monthly are agreeing to pay the full amount whether or not they decide to pay off their dues early.

Signature:

Mail to: California Agricultural Teachers' Assn.

P.O. Box 834

Receipt No.

Elk Grove, CA 95759-0834

Member Card No.

01.02 .01

Rev: 2011 


\section{CALIFORNIA AGRICULTURAL TEACHERS'ASSOCIATION MEMBERSHIP APPLICATION}

NAME:
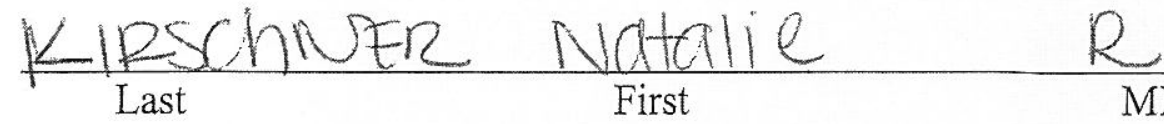

First

MI

HOME ADDRESS

CITY/STATE/ZIP CODE: AHWAKER, CA 95301

TELEPHONE NUMBER:

CELIF.

WORK NUMBER:

FAX:

E-MAIL ADDRESS:

CATA REGION: Central CATA SECTION: m/m SCHOOL: AHWateer CATA has my permission to distribute my home address and telephone number to other ag teachers.

Yes X No

Signature:

Regular Dues - $\$ 140$

Ag Teachers less than $1 / 2$ time (FTE) - $\$ 70$

Installment Billing - at least $\$ 26^{*}$

Associate - \$15

New Teacher - $\$ 70$

Life Membership - \$1,400.00

Optional - ACTE Dues - $\$ 80$

Optional - NAAE Dues - $\$ 60$

Optional - Contribution to CATA Scholarship Fund

\section{SUB TOTAL DUES}

$140-$

$\$ 10$ $\$ 25$

$\$ 50$ $\$ 100$

Other TOTAL (Please make check payable to CATA.)

\section{Important Tax Notice to CATA Members}

Contributions or gifts to CATA are not deductible as charitable contributions for income tax purposes. However, CATA dues may be tax deductible as an ordinary and necessary business expense. Please consult your tax advisor.

Charge my dues to: VISA Master Card

Card \# Expiration Date

Signature:

Installment dues are $\$ 140+$ service charge of $\$ 16$

$=$ Total $\$ 156$

Installment dues for New Teachers are $\$ 70+$ service charge of $\$ 8$

$=$ Total $\$ 78$

*Service charge is for Installment Dues ONLY*

Please note that members electing to pay monthly are agreeing to pay the full amount whether or not they decide to pay off their dues early.

Signature:

Mail to: California Agricultural Teachers' Assn.

P.O. Box 834

Receipt No.

Elk Grove, CA 95759-0834

Member Card No.

01.02 .01

Rev: 2011 


\section{CALIFORNIA AGRICULTURAL TEACHERS' ASSOCIATION MEMBERSHIIP APPLICATION}

NAME:

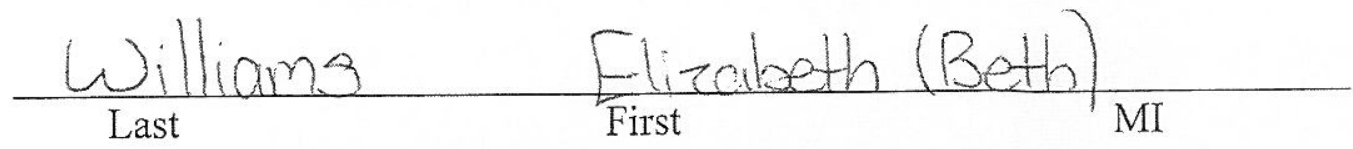

HOME ADDRESS:

CITY/STATE/ZIP CODE: Atwater, CA 95301

TELEPHONE NUMBER:

WORK NUMBER:

FAX:

\section{E-MAIL ADDRESS:}

CATA REGION: Central CATA SECTION: Mariposa SCHOOL: Atwater CATA has my permission to distribute my home address and telephone number to other ag teachers. $\quad$ Yes_N No Signature:

Regular Dues - $\$ 140$

Ag Teachers less than $1 / 2$ time (FTE) - $\$ 70$

Installment Billing - at least $\$ 26^{*}$

Associate - \$15

New Teacher - $\$ 70$

Life Membership - $\$ 1,400.00$

Optional - ACTE Dues - $\$ 80$

Optional - NAAE Dues - $\$ 60$

Optional - Contribution to CATA Scholarship Fund

\section{SUB TOTAL DUES}

\$140

$\$ 10$ $\$ 25$ $\$ 50$ $\$ 100$

Other

\section{TOTAL (Please make check payable to CATA.)}

\section{Important Tax Notice to CATA Members}

Contributions or gifts to CATA are not deductible as charitable contributions for income tax purposes. However, CATA dues may be tax deductible as an ordinary and necessary business expense. Please consult your tax advisor.

Charge my dues to: $\quad$ VISA

Card \#
Master Card

Expiration Date

Signature:

Installment dues are $\$ 140+$ service charge of $\$ 16$

Installment dues for New Teachers are $\$ 70+$ service charge of $\$ 8$

$=$ Total $\$ 156$

*Service charge is for Installment Dues ONLY*

Please note that members electing to pay monthly are agreeing to pay the full amount whether or not they decide to pay off their dues early.

Signature:

Mail to: California Agricultural Teachers' Assn.

P.O. Box 834

Elk Grove, CA 95759-0834

Receipt No.

Member Card No.

01.02 .01

Rev: 2011 
BB

Meeting Reports

The Atwater Agriculture Department meets weekly to discuss current events, old business, future events and other business necessary. Weekly collaboration meeting also occur between agriculture and science department to maintain communication and aligned courses to meet the standards. Minutes for these meetings are not taken.

Attached you will find:

- Copy of Ag Department Meeting Agenda / Minutes 
Date: January 9, 2013

\section{Atwater Agriculture Department \\ Department Meeting}

Roll / Attendance

$\begin{array}{llll}\text { Dan Flatt } & - & \text { Dave Gossman } & \text { Natalie Kirschner } \\ -\quad \text { Beth Knapp } & - & \text { Jackie loimo } & \\ \text { Stephanie Kuhr } & - & - & \end{array}$

1. Old Business

MFE / ALA (Update) - Feb. $15^{\text {th }}$ and 16th

Cal Poly State Finals Hotel

* Need to "estimate"/confirm student \#'s (M/F's) and Staff

* Trying to get last year's rate (recent quote is $\$ 150 / \$ 170$ per night)

- $\quad$ Food Science Course Update

2. New Business

a. Calendar Items / Updates

Date / Time Activity/Event

1. Jan 15

2. Jan $17-18$

3. Jan 16

4. Jan 16

5. Jan $16-17$

6. Jan 22

7. $\operatorname{Jan} 23$

8. $\operatorname{Jan} 26$

9. $\operatorname{Jan} 28-F e b 1$

10. Jan/Feb?

11. Feb 1

12. Feb 1

13. Feb 2

14. Feb 6

15. Feb 13

16. Feb $15-16$

17. Feb $19-22$

18. Feb 23

19. Feb 23

"Super Saturday" Manuscripts Due Student Teacher Conclave (Stephanie Attending) Gossman/Peterson Visit to Galt for Partnership Academy Inquiry FFA "Movie Night" Mtg CATA Governing Board Mtg - Galt Stephanie Taking MUHSD Sub Class - Gone All Day Merced Fair Student/Exhibitor Mtg "Super Saturday" Fair Deposit Week Regional FFA Officer Applications Due? State FFA Award Applications Due Cal Poly Cooperating Teacher Workshop (Meredith/Kirschner?) Arbuckle Field Day Project Competition Banquet Central Region Prelims MFE-ALA Conference National FFA Week Central Region CATA Mtg / Regional Speaking Finals (MJC) Ag Booster Dinner

b. Business

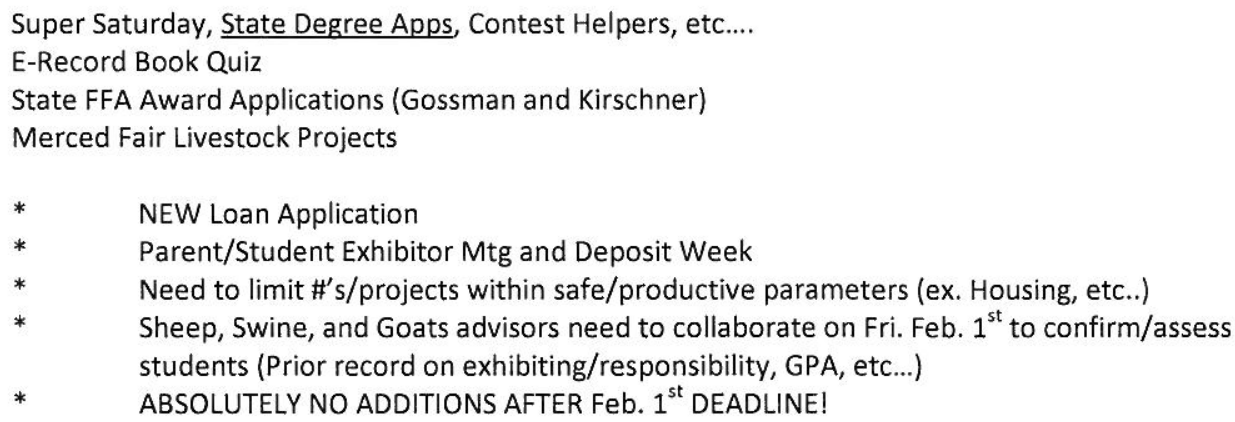


Date: January 9, 2013

- $\quad$ Merced Fair Registration, Show, Buyer's Gift, Insurance, etc... Expenses (Need to increase?)

- Merced Fair Project Supplies - Antibiotics? / Wormer? (Restock?)

- $\quad 8^{\text {th }}$ Grade Recruitment - Confirming Dates

- NEW photos for web (classes/registration) - Especially current $9^{\text {th }}$ grade students

- $\quad$ State CATA Conference - First Call (June 23-27)

- $\quad$ Budget Update

- $\quad$ Perkins 2012-2013 Remaining

* Fetal Pig and Lab Equipment $(\$ 600)$

* MFE/ALA (\$2200)

* CATA Conference $(\$ 3700)$

* State Leadership $(\$ 3000)$

- $\quad$ Perkins "Just in Case" Plan (2012-2013)

* Wood/Metal Shop Equipment Requests

* Sheep Panels (Pens)

Perkins 2013-2014 Site Plan

* Non Acquired Wood/Metal Shop Equipment Requests

* Non Acquired Sheep Panels (Pens)

* Annual Reoccurring Expenses From Previous Years / Site Plans

c. Other 
Date: February 5, 2013

\section{Atwater Agriculture Department \\ Department Meeting}

Roll / Attendance

$\begin{array}{llll}\text { Dan Flatt } & - & \text { Dave Gossman } & \text { Natalie Kirschner } \\ \text { Beth Knapp } & -\quad \text { Jackie loimo } & \\ \text { Stephanie Kuhr } & - & - & \text { Sam Meredith }\end{array}$

1. Old Business

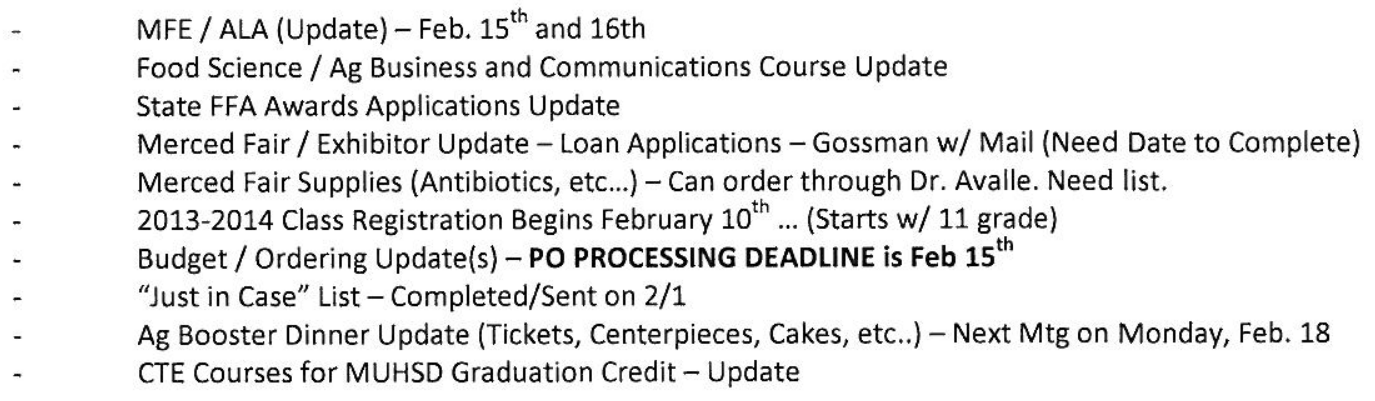

2. New Business

a. Calendar Items / Updates

\begin{tabular}{|c|c|c|}
\hline & Date / Time & Activity/Event \\
\hline 1. & Feb 6 & Project Competition Banquet \\
\hline 2. & Feb 13 & Central Region Prelims \\
\hline 3. & Feb 14 & Mitchell Senior Recruitment \\
\hline 4. & Feb 14 & Curriculum Council Mtg - DO \\
\hline 5. & Feb $15-16$ & MFE-ALA Conference \\
\hline 6. & Feb 20 & Stephanie at Fresno State University \\
\hline 7. & Feb $19-22$ & National FFA Week (Ag Olympics, Basketball, etc...) \\
\hline 8. & Feb 23 & Central Region CATA Mtg / Regional Speaking Finals (MJC) \\
\hline 9. & Feb 23 & Ag Booster Dinner \\
\hline 10. & Feb 24 & Arnold's Farm Clean-Up Day (2-4pm) \\
\hline 11. & Mar 2 & UC Davis Field Day \\
\hline 12. & Mar 5-8 & SLE Conference (Schiber) \\
\hline 13. & Mar 9 & Chico State Field Day \\
\hline 14. & Mar 14 & Take-Out BBQ \#3 \\
\hline 15. & Mar 15 & End of $3^{\text {rd }}$ Quarter \\
\hline
\end{tabular}

b. Business

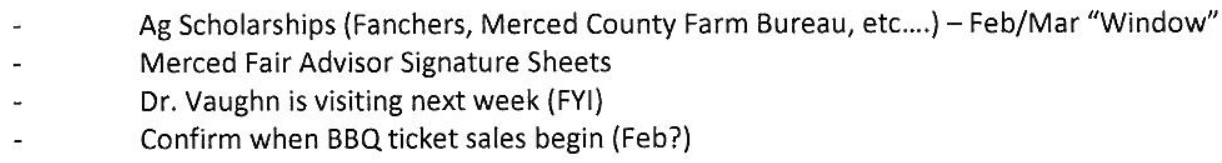

c. Other 
Date: March 6, 2013

\section{Atwater Agriculture Department Department Meeting}

Roll / Attendance

\begin{tabular}{llll} 
Dan Flatt & - & Dave Gossman & Natalie Kirschner \\
$-\quad$ Beth Knapp & $-\quad$ Jackie loimo & \\
\hline & Stephanie Kuhr & - & -
\end{tabular}

1. Old Business

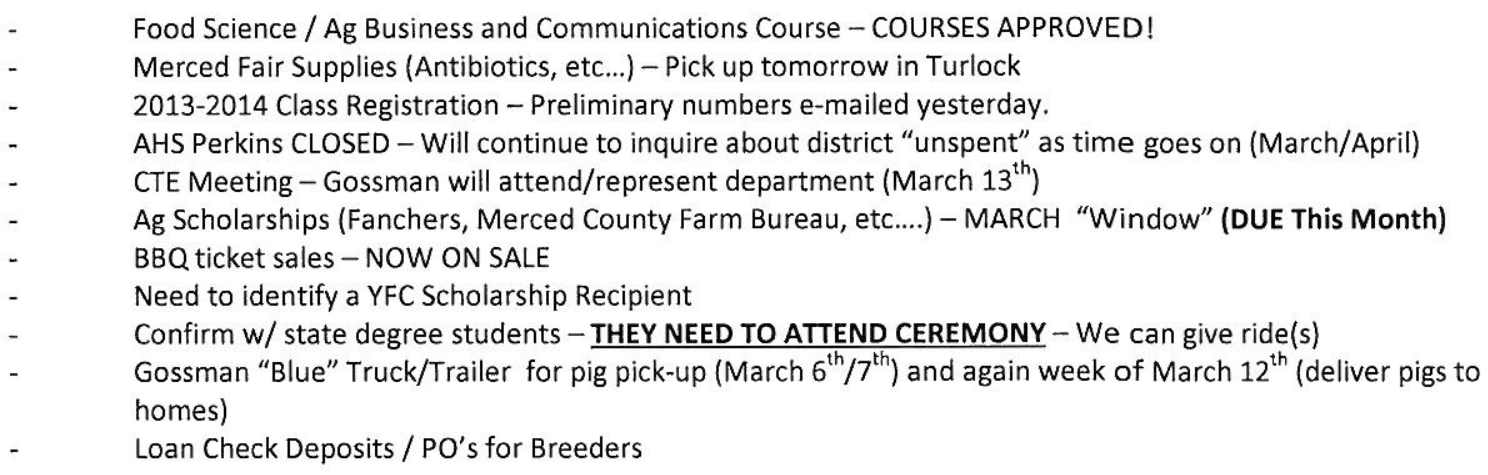

2. New Business

a. Calendar Items / Updates

$\begin{array}{lll}\text { 1. } & \text { Date / Time } & \text { Activity/Event } \\ \text { 2. } & \text { Mar } 9 & \text { SLE Conference (Schiber) } \\ \text { 3. } & \text { Chico State Field Day (Depart at 3am - Info Memo?) } \\ \text { 4. } 13 & \text { Mar } 13 & \text { CAHSEE Testing (Plan accordingly) } \\ \text { 5. Mar } 14 & \text { CTE Meeting @ DO (Gossman) } \\ \text { 6. Mar } 14 & \text { Take-Out BBQ \#3 } \\ \text { 7. Mar } 15 & \text { Stephanie at Fresno State } \\ \text { 8. Mar } 16 & \text { End of } 3^{\text {rd }} \text { Quarter } \\ \text { 9. Mar } 18 & \text { Merced College Field Day } \\ \text { 10. Mar } 18 & \text { Ag Booster Mtg } \\ \text { 11. Mar } 21 & \text { FFA Bowling Mtg } \\ \text { 12. Mar } 22 & \text { Mr. Atwater Contest } \\ \text { 13. Mar } 26 & \text { FFA Scrapbook and POA DUE (Before 11am) } \\ \text { 14. Mar } 26-27 & \text { FFA State Degree Ceremony - MJC } \\ \text { 15. Mar } 29-\text { Apr } 7 & \text { 3 } & \text { Spring Break - No School } \\ \text { 16. Apr } 6 & \text { Cosumnes River College Field Day } \\ \text { 17. Apr } 11 & \text { Sectional FFA CoOp / Sectional CATA Mtg - LHS } \\ \text { 18. Apr } 13 & \text { Reedley FFA Field Day } \\ \text { 19. Apr } 16 & \text { FFA Burrito Bingo Mtg }\end{array}$

b. Business

Merced Fair Forms are DUE by before May $9^{\text {th }}$

c. Other 


\section{$\underline{\mathrm{CC}}$ \\ Wish List}

My wish list includes materials and supplies for my Floral Design classes, Ag Biology classes, and the sheep facility that I advise. Every year, as a department we discuss what our goals are as a department and what we want to improve in our program. Depending on where the funds went the year before determines where other funds can be spent on.

Attached is my 2013-2014 wish list. 
1. Replace Laptops (3)

2. Long Term Horticulture Growing Facility Fence / Irrigation

3. Forklift (Ag Shops)

4. Permanent Goat Pens on Campus

5. Permanent Rabbit Pens on Campus

6. (2) Classroom Visualizers

7. (2) Replacement Printers

8. Plasma Cam Software Update

9. Ag Office Software Update

10. (3) Computers for Plasma Cam

11. Expand Sheep Facilities at School Farm

\section{$\underline{2012-2013}$}

1. Ipads for each instructor

2. Installation of Crop Science Unit Fence

3. Crop Science Irrigation

4. Small Tractor for Crop Science Unit

5. Replacement Ag Truck

6. Video Recorder Equipment/Software

7. (3) LCD Projector Update/Replacement

8. Horticulture / Landscape Equipment

\section{3-2014}

1. Replace Laptops (3)

2. (2) Replacement Printers

3. (3) LCD Projector Update/Replacement

4. Purchase of Mini Laptop Cart

5. Horticulture Text Books

6. Floriculture Text Books

7. Text Book to meet Common Core and New Science Standards (Bio and Earth)

\section{$\underline{2014-2015}$}

1. Replacement of Current Storage Containers

2. Replacement of Microscopes

3. Large animal scale

4. Update Ag Leadership Computers

5. Aluminum Stock Trailer

6. Vet Science Text Books

7. Text Book to meet Common Core and New Science Standards (Life and Enviro)

$\underline{2015-2016}$

1. Replacement of (4) Student Desktop Computers

2. Updated software for all computers

3. Replace half the welders

4. Update irrigation system 


\section{$\underline{\text { DD }}$ \\ Advisory Committee Agenda}

The Atwater FFA Advisory Committee meets twice a year. Here we discuss and ROP business, and other business relevant to our program's success for the upcoming year. Those invited to participate in the fall meeting are Agriculture instructors, committee members, ROP career technicians, and other special guests.

Our spring advisory committee meeting focuses on recruitment, summary of the year's success thus far, and proposals for future changes to better our department. This meeting includes Agriculture instructors, committee members, $8^{\text {th }}$ grade principals, administration, and counselors, AHS administration and counselors, and other special guests.

\section{Attached you will find:}

- Advisory Committee Meeting Agendas 


\title{
Atwater High School Agriculture Department
}

\author{
Fall 2012 Ag Advisory Meeting
}




\section{Atwater High School \\ Agriculture Department Advisory Committee Meeting \\ Tuesday, October 30, 2012 \\ 6:00 PM}

2011-2012 Advisory Committee Members

TERM: $2012-2015$

$\begin{array}{ll}\text { Mark Anglin } & \text { Modesto Junior College Dean of Agriculture } \\ \text { Christina Bylsma } & \text { Full Circle Dairy and B\&B Pastures } \\ \text { Sarah Bell } & \text { Merced County Farm News }\end{array}$

TERM: $2011-2014$

$\begin{array}{ll}\text { Roger Wood } & \text { Community Agriculturalist } \\ \text { Craig Arnold } & \text { Arnold Farms } \\ \text { Bryan Tassey } & \text { Merced College - Horticulture }\end{array}$

TERM: $2010-2013$

$\begin{array}{ll}\text { Ben Migliazzo } & \text { Sierra Cascade Nursery } \\ \text { Dan Royer } & \text { Wolfsen, Inc. } \\ \text { Chris Morrow } & \text { Morrow Backhoe Service }\end{array}$

Invited Special Guest(s)

$\begin{array}{ll}\square & \text { Alan Peterson } \\ \square & \text { Robert Ruiz } \\ \square & \text { Paul Bristow } \\ \square & \text { Amy Pellissier } \\ \square & \text { Joyce Harrison } \\ \square & \text { Nathan Braga } \\ \square & \text { Colleen Dougherty } \\ \square & \text { Joel Dickson } \\ \square & \text { Carmen Ildefonzo } \\ \square & \text { Gena Lanz } \\ \square & \text { Lorraine Boothe }\end{array}$

Atwater High School Principal Atwater High School Associate Principal Atwater High School Associate Principal Atwater High School Associate Principal Atwater High School Associate Principal Director of Activities Atwater High School Counselor Atwater High School Counselor Atwater High School Counselor Atwater High School Counselor Atwater High School EL Advisor / Counselor 
Phil Schiber Scott Scambray

Dave Honey

Mike Carpenter

Ida Johnson

Sam Spangler

Kurt Kohlman

Sandy Schiber

George Sziraki

Leonard Kahn

Tammie Calzadillas

Dina Faretta

Ana Machado

Ron Perez

Nancy Arnold

Representative

Mary Whited

Jeanne Knapp
AHS BTSA Mentor

MUHSD Superintendent

MUHSD Board of Trustees

MUHSD Board of Trustees

MUHSD Board of Trustees

MUHSD Board of Trustees

MUHSD Board of Trustees

MUHSD Assistant Superintendent

MUHSD Assistant Superintendent

MUHSD Assistant Superintendent

MUHSD Executive Director Educational Services

MUHSD CTE Coordinator

MUHSD Program Administrator

MUHSD Maintenance/Operations Director

Winton Middle School Counselor

Mitchell Senior Elementary Counselor

Merced County ROP

Merced County ROP

AHS Ag Department

Instructors

Beth Knapp

Sam Meredith

Dave Gossman

Jackie loimo

Dan Flatt

Natalie Kirschner

I. Dinner

II. Introduction of Committee, Guests and Instructors

III. Minutes from the Previous Meeting

IV. Review / Approval of Ag Advisory Committee Constitution

V. Recognition of Term Ending Members and Election of Committee Officers

VI. Review of 2011-2012 Goals

Highlights -

- Completed NEW long term horticulture facility and grapevine (viticulture) facility

- Constructed a NEW organic compost area

- Constructed a NEW rabbit facility (pole barn)

- Constructed a NEW goat / small livestock facility (pole barn) 
VII. Program of Activities Presentation

- 2012-2013 Goals

\section{Highlights -}

- Maintain/strengthen program recruitment

- Strengthen advanced welding and wood enrollment \#'s

- Repair/revise Arnold Farm Swine facility

- Explore and identify Arnold Farm Sheep facility upgrade/expansion

- Continue to expand technology/communication resources

- Add new concrete walkway near new nursery area

- Add new concrete pad around rabbit facility

- Construct a new supply/equipment shed in pole barn

- Calendar of Activities (available on www.AwaterFFA.org) - New POA will be mailed when completed

VIII. 2012-2013 Budget Overview (General 2012-2013 Operational Budget)

\section{MUHSD Transportation Budget}

\section{Revenue}

Site Disbursement

$\$ 7,046$

Total Revenue $\$ \$ 7,050$

\section{Expenses}

FFA Judging Contests

$\$ 4,500$

FFA Leadership/Professional Conferences

$\$ 1,750$

FFA Officer/Staff Retreat

$\$ 800$

Total Expenses $\quad \$ 7,050$

\section{AHS Site Budget}

Revenue

Site Disbursement

$\$ 2,000$

Total Revenue

$\$ 2,000$

\section{Expenses}

Office Depot (Office/Operation Supplies)

$\$ 1,400$

Nasco (Lab Supplies) 


\section{Ag Incentive Grant Budget}

\section{Revenue}

Incentive Grant Disbursement

$\$ 20,451$

Total Revenue

$\$ 20,451$

Expenses

$\begin{array}{lc}\text { Airgas (Shop) } & \$ 2,000 \\ \text { CATA Memberships } & \$ 840 \\ \text { Davis Digital (Office Services) } & \$ 900 \\ \text { FFA Membership Dues } & \$ 7,530 \\ \text { FFA State Conference Lodging } & \$ 2,300 \\ \text { FFA State Finals Lodging } & \$ 2,100 \\ \text { FFA Supplies } & \$ 2,000 \\ \text { New Professionals Conference } & \$ 250 \\ \text { Team Wear - Officer Supplies } & \$ 1,000 \\ \text { UC Davis Field Day Transportation } & \$ 1,531\end{array}$

Total Expenses $\quad \$ \mathbf{2 0 , 4 5 1}$

\section{Carl Perkins Funding Budget}

Revenue

2012-2013 Disbursement

\section{Expenses}

\footnotetext{
All Data Subscription (Wood)

Biology Lab Equipment

CATA Road Show / Conference

CATA Summer Conference (SLO)

FFA Leadership Conference (Fresno State)

FFA Leadership Conferences (MFE / ALA)

Indianapolis Car Rentals (National FFA)

Indianapolis Hotel (National FFA)

Pole Barn Shed

Shop/Classroom Computers

Welding Shop Tools

Wood Shop Tools
}

$\$ 1,000$

$\$ 600$

$\$ 1,266$

$\$ 3,700$

$\$ 3,000$

$\$ 2,200$

$\$ 1,200$

$\$ 2,000$

$\$ 3,182$

$\$ 13,745$

$\$ 1,000$

$\$ 1,000$ 
$\underline{\text { ROP Funding Budget }}$

Revenue

Veterinary Science \$1,098

Horticulture \$981

Floral Design $\quad \$ 2,772$

Total Revenue $\quad \$ 4,851$

Expenses

Flowers / Supplies $\quad \$ 1,200$

Nasco (Lab Supplies) \$400

CVE (Curriculum Materials) $\$ 300$

Chico State Field Day Transportation $\$ 1,861$

Promo Direct (Project Promotional Supplies) $\quad \$ 1,090$

Total Expenses $\quad \$ 4,851$

\section{AHS Ag Mechanics (Welding) - FFA Metal Shop Budget}

\section{Revenue}

Atwater Ag Boosters $\$ 500$

Custom Plasma Projects $\$ 1,200$

Donations from Repairs $\$ \$ 1,400$

Fall Fest Fundraiser $\$ \$ 1,500$

Merced County Fair Projects $\$ 1,200$

Metal Art Sales (During Plant Sales) $\$ 2,000$

Project Payments $\$ \$ 8,500$

Scrap Metal Recycling \$1,500

Total Revenue $\quad \$ 17,800$

\section{Expenses}

$\begin{array}{lc}\text { Equipment Repairs } & \$ 600 \\ \text { Freshman Ag Shop Skills Projects } & \$ 3,500 \\ \text { General Shop Supplies / Materials } & \$ 1,200 \\ \text { Misc. Supplies / Equipment } & \$ 2,500 \\ \text { Modesto Steel / Custom Metal (Material) } & \$ 8,500 \\ \text { Powder Coating Projects } & \$ 500 \\ \text { Welding Supplies / Airgas } & \$ 1,000\end{array}$

Total Expenses $\quad \$ 17,800$ 
Revenue

Atwater Ag Boosters $\$ 500$

District Funds $\$ \$ 6,500$

Fall Fest Fundraiser $\$ 1,500$

Sale of Mowers / Engine Repair $\$ 250$

Sale of Wood Projects $\$ \$ 1,500$

Total Revenue $\quad \$ 10,250$

\section{Expenses}

Classroom/Lab Supplies Student Projects $\quad \$ 6,500$

Equipment Repair $\$ 1,000$

General Shop Supplies / Materials $\$ 2,750$

Total Expenses $\quad \$ 10,250$

\section{$\underline{\text { AHS Horticulture / Floral Design Budget }}$}

\section{Revenue}

Fall Fest Fundraiser $\quad \$ 1,000$

Fall Plant Sale $\$ 2,000$

Floral Projects $\$ \$ 5,000$

Merced County Fair Projects $\quad \$ 5,000$

Spring Plant Sale $\$ \$ 2,000$

Total Revenue $\quad \$ 15,000$

\section{Expenses}

Facility Concrete / Fencing Projects $\$ 1,500$

FFA Activities / Events $\$ 1,000$

FFA Judging Teams (Nationals) $\$ 2,000$

Floral Supplies / Equipment $\$ 3,000$

Horticulture Equipment $\$ 2,000$

Horticulture Facility Projects $\$ 1,500$

Horticulture Supplies $\$ \$ 4,000$

Total Expenses $\quad \$ 15,000$ 


\section{AHS General FFA Budget}

Revenue

Ag Booster Donation $\quad \$ 8,000$

Fall Fest Fundraiser $\$ \$ 6,000$

National Finals Trip Donations $\$ \$ 9,000$

Placemat Ad Sales $\$ 5,500$

Save Mart SHARES Program $\$ 2,000$

Take-Out BBQ's (4) $\$ 10,000$

Total Revenue $\$ \$ 40,500$

\section{Expenses}

Fair Equipment/Supplies $\quad \$ 1,000$

FFA Field Day Registrations \$2,500

FFA Greenhand Conference $\$ \$ 800$

FFA Meetings (Food, Supplies, etc..) $\$ 2,000$

FFA National Finals Trip $\$ 13,000$

FFA Recreational Trip(s) Transportation $\$ 2,200$

FFA Student Fundraising Incentives $\$ \$ 4,000$

FFA Supplies $\$ 2,000$

Office/Operation Supplies $\$ \$ 3,000$

Promotion/Marketing \$4,500

Staff iPads / Computers $\$ \$ 5,500$

Total Expenses $\$ \$ 40,500$

TOTAL 2012-2013 Revenue/Expense Budget - \$151,795.00

IX. Program / Agriculture Courses / R - 2 Data

A. $\quad$ Overall Program Objectives

1. Provide students the resources and opportunities for personal growth, educational development, and career success.

2. Get students involved

3. Maximize the agricultural education model

- Classroom

- $\quad$ FFA

- $\quad$ SAE (apply classroom/FFA experience through "hands-on" application)

B. 2012-2013 Program Status/Update

1. 858 Individual Agriculture Students 
2. Primary Reasons for Overall Sustained Growth

- Organized/Established Pathways and Courses

* Ag Mechanics

* Agricultural Sciences (Horticulture and Animal Science)

$9^{\text {th }}$ Grade Ag/FFA "Foundation" Courses/Enrollment

- $\quad$ Quality of Ag Biology / Environmental Ag Science / Earth Science Curriculum and Test Results

- $\quad$ Expanded opportunities with "advanced" agriculture courses including Floral Design (UC " $\mathrm{F}$ " Credit), Ag Economics/Government, and Horticulture.

- $\quad$ Students have "bought" into program - Students are involved in/out of the classroom

3. Enrollment Comparisons ('11-12 vs '12-'13)

\section{Largest Growth}

Wood Construction III

Wood Construction I

Ag Earth Science

$3 \quad 12$

$75 \%$

$18 \quad 26$

$115 \quad 152$

$31 \%$

Ag Shop Skills

$86 \quad 106$

$24 \%$

$19 \%$

\section{Relatively Steady}

\section{Equipment Construction}

Ag Leadership

4

28

Welding Tech 1

Welding Tech II

Power Mechanics

26

Veterinary Science

36

Ag Life Science

111

Floral Design I/II

Small Engines

Ag Economics / Government

Horticulture

\section{2}

26

38

35

5
35
65
22
31
37
107
116
24
34
31

$20 \%$

$20 \%$

$14 \%$

$14 \%$

$16 \%$

$3 \%$

$-4 \%$

$-5 \%$

$-8 \%$

$-12 \%$

$-13 \%$

\section{Largest Decrease}

Ag Biology

Ag Environmental Science

Wood Construction II

$\begin{array}{ccc}265 & 227 & -17 \% \\ 72 & 35 & -106 \% \\ 25 & 6 & -317 \%\end{array}$

\section{Highlight Summary of Enrollment Data}

- Ag Shop Skills course enrollment increased for second straight year after major decrease 2 years ago. Issues that affect enrollment in this course include:

1. $9^{\text {th }}$ graders faced with limited "elective" opportunities based on academic needs/requirements 
2. Course conflicted with other interests (athletics, band, etc..)

- Welding Tech I / Wood Construction I-Slight increase due to last years Ag Shop Skills foundation numbers (increased last year from year before)

- $\quad$ Ag Biology-Decrease was due to eliminating a section (over-enrolled). Last year's \#'s are based on an extra prep period.

- Environmental Ag Science - Similar to "Ag Biology". Section closed to accommodate higher Earth Science \#'s.

- $\quad$ Ag Economics / Government - Very popular with students. Could have easily filled 2 sections if available (over 110 students enrolled).

- Wood II / III, Welding Tech II / Equipment Construction - Steady decrease correlates with decrease in opportunities for students due to other conflicts (required courses, remediation, etc...)

4. Program / Facility Updates

- Long Term Horticulture Growing Area Completed $-80^{\prime} \times 50^{\prime}$ fenced growing area is located behind the county building. Vineyard (Grapes) is in place for viticulture lab. New garden plots installed for MCOE special education students. Area landscaped.

- Pole Barn Rabbit and Goat Facility - New rabbit and goat facility project has been completed in the pole barn. A new storage shed for supplies/equipment is scheduled to be installed later this Fall.

- $\quad$ Positive Impact of School, District, Community, and Industry Support - Direct correlation towards support of the agriculture program and production in student involvement/achievement.

X. Program Priorities for 2012-2013

A. Continue Establishing Opportunities for Students to Complete 4 Year Agriculture Pathway

1. Maintain strong student enrollment in "Foundation" courses Year \#1. (see attached Pathway/Course list)

- Ag Shop Skills (Ag Mech Pathway)

- Ag Biology

- Ag Life Science

2. Maintain / expand enrollment in "advanced" agriculture pathway courses

- Floral Design

- Horticulture

- Veterinary Science

- Ag Economics / Government 
3. Benefits / Advantages to Four Year Pathway Students

- Increase school involvement

- Increase motivation/desire towards academics/careers

- Increase college / university / trade school enrollment

- 75\%+ of 2011-2012 3-4 year ag pathway students currently enrolled in $2 \mathrm{yr} / 4 \mathrm{yr}$ college/universities or military.

- LARGE increase of 3-4 year ag pathway students going directly into a 4 year university

\section{Vision for Future Growth / Opportunity}

\section{A. Encourage District Towards Expansion of Class Periods / Opportunities}

- Recognizing today's budget challenges and the state/federal requirements pertaining to standardized testing, we cannot overlook the need to provide students the opportunity to explore interests, "life skill" classes, career pathway courses that extend beyond core academic classes.

- Students are extremely limited with today's 6 period schedule/format

- A recommendation towards the future is to have a plan in place to expand and/or reformat current schedule when economic opportunities become available.

- Current pathway/classes hardest hit is the Ag Mechanics (Shop).

B. Explore opportunities in Ag Business pathway courses and Food Science pathway courses as staff CTE retirement(s) loom ahead.

C. Expand Student SAE (agriculture projects) Opportunities and Project \#'s

\section{Program Needs / Inquiries / Concerns}

A. If you ask a senior ( $12^{\text {th }}$ grade) student what they plan to do after graduation, the most common answer is "I don't know". Are we really meeting the needs of our students/community?

B. Primary focus last few years has been on A-G and "API / Scores", the opportunities for students in APPLICABLE education courses, SKILL development, and the ability to explore and identify a "direction" in one's future has decreased and/or been ignored. As required graduation / CST test courses increased, career tech and "life" courses have decreased.

C. Solution to "B" would take all parties involved (DTA, District, community, etc...), but with a common vision of expanding opportunities for ALL students that focus on all avenues of post high school education opportunities. Goal should be to add a $7^{\text {th }}$ class/period to a student's schedule.

XIII. Discussion Items

- $\quad$ Ag Incentive Grant Review

- Next meeting date - FEBRUARY - Date/Place: TBA

- Other 


\section{$\underline{E E}$}

\section{Advisory Committee Charter \& By-Laws}

The advisory committee consists of community members, college professors, past students and current parents of the program. There sole purpose is to advise the instructors and inform us of what the industry and community is looking for in our future citizens. Included is a sample of the functions and duties for the Ag advisory committee and instructions for the Atwater Ag advisory committee members. These important pieces are in the Comprehensive Program Plan documents.

\section{Attached you will find:}

- Advisory Committee By-Laws 


\section{Advisory Committee for Agriculture Education \\ Merced Union High School District \\ Merced, California \\ Approved 2011}

Atwater High School

Livingston High School

Buhach Colony High School

Merced High School

Golden Valley High School

\section{SECTION A- PURPOSE:}

Article 1. The agriculture Advisory Committee shall exist only during such time as it is authorized by the administration of the District of the Board of Education.

Article 2. The Advisory Committee may direct its advice and recommendations toward the Agriculture teachers, the school and district administration or the Board of Education. It shall limit its activities to matters concerning the Agriculture Education Department.

Article 3. It shall be the duty of the Advisory committee to:

a) Study the needs of the community related to the work of the Agriculture Department

b) Suggest and advise in areas of education pertaining to the objectives of the district's Agriculture Education program(s).

c) Review the departments' ability to meet state standards in Agriculture Education.

d) Review and evaluate facilities and equipment available for the use of instruction.

e) Assist in evaluation the agriculture programs instruction, curriculum and course content being provided to the students.

f) Study the programs of Agriculture Departments in other communities with the idea of encouraging the use in this community of those objectives and practices that may be applicable.

g) Serve as an avenue of communication between the Agriculture Department and the community.

h) Provide special committees to work with various groups participating in the Agriculture Education Program such as FFA members, parents and the FFA Booster Club.

i) The Advisory committee shall have an appointed chair, vice chair. The secretary shall be one of the Agriculture instructors from the department.

\section{Section B- Membership}

Article 1. There shall be a maximum of 14 members on the Agriculture Advisory Committee, with a variety of representation from the animal science, horticulture, agriculture mechanics, and agriculture business pathways as well as other business, community, and educational representatives who serve the agriculture industry or agriculture department. 
Article 2 Members shall be selected in such a way that they represent a crosssection of the farm and business community served by the Agriculture Department.

Article 3. Members shall be nominated by the Agriculture Department Staff and shall be notified of their appointment by the Agriculture Department Chairman.

Article 4. Members:

A) The term of membership shall be for three years and can be renewed at the end of the term.

B) Be appointed and re-appointed as the need arises.

C) Have the only voting rights of the committee.

D) Appoint/approve an acting chairman, vice chairman and secretary.

Article 5. In case of vacancies, new members shall be elected to fill those vacancies as set down in Article 3 of this section, but shall serve for only the time remaining of the vacancy filled.

Article 6. An individual shall lose membership if he/she fails to take an active role in the committee's activities or is no longer a positive contributing member of the committee. The committee will make this decision after consulting with the Agriculture Department Staff.

Article 7. The Board of Education shall appoint a Board Member and the District superintendent or his representative to act as a non-voting member of the committee.

Article 8. The Superintendent and Board Members will not be voting members but may attend meetings.

Article 9. The Agriculture Education Staff will be non-voting members and will attend all meetings.

\section{Section C- Meetings}

Article 1. The committee shall meet no less than two times per year, ideally three times per year. The Agriculture Department Chairman and the Agriculture Advisory Committee Chairman will decide on meeting dates.

Article 2. The Chairman as necessary may call special meeting during the year.

Article 3. Written notices of all regular meetings will be prepared and mailed to all committee members and guests by the Agriculture Department Chairman.

Article 4. The meetings shall not continue for more than two hours unless so voted by the committee members present. 
Article 5. A quorum will consist of a majority $(50 \%+1)$ of the total eligible voting members of the committee.

\section{Section D- Chairman}

Article 1. The Agriculture Advisory Committee Chairman shall be elected each fall from the group of members who has served on the existing committee for at least one year. His duties shall be:

a) To preside at all committee meetings.

b) To appoint special committees which may include persons other than the committee members

c) To call special meetings as needed.

Article 2. The duties of the Agriculture Department Chairman shall be:

a) To keep attendance records of the committee members.

b) To keep a record of discussion, recommendations, motions passed and committee appointments.

c) To maintain a permanent record file of all committee activities.

d) To distribute minutes of the committee meetings and copies of other committee documents to the committee members, Board of Education members, school site administration, superintendent, agriculture staff, and others who may be concerned. The school facilities and office staff shall be available for this purpose.

e) To prepare the agenda for the committee meetings if requested to do so by the committee.

\section{Section E- Changes in By-Laws and Constitution:}

Article 1. Suggestions for changes in the Constitution and By-Laws must be presented to the chairman and then must be approved by a majority vote of the committee membership. Then said suggestions must be passed by the Board of Education before adopting. 


\section{$\underline{\text { FF }}$ \\ Budget Reports}

Budget Proposals are completed during the summer and used to determine where funds will be allotted for the upcoming school year. Our budget is maintained through a district system. Financial activity reports are printed bi-monthly to keep track of expenditures and remaining funds.

The Atwater Agriculture Department is responsible for maintaining all purchases orders, money transfers, and other financial activities.

\section{Attached you will find:}

- 2012-2013 Budget Report 
Total Grant

$\$ 20,886.00$

Current Grant Available

$\$ 7.48$

\section{Supplies}

Company

National FFA

\begin{tabular}{|l|l}
\hline Airgas & \\
\hline
\end{tabular}

Team Wear

Trophy Case

CA Association FFA

Office Depot

\begin{tabular}{|l|l|}
\hline Use & Open/ltemized \\
\hline Banquet & Open \\
\hline & \\
\hline Ag Mechanics Supplies & Open \\
\hline Officer Retreat & Open \\
\hline Banquet Awards & Open \\
\hline Student Membership Dues & Itemized \\
\hline & \\
\hline & \\
\hline
\end{tabular}

TOTAL

Amount

$\$ 1,700,00$

$\$ 2,000.00$

$\$ 1,000.00$

$\$ 600.00$

$\$ 7,382,50$

$\$ 930,00$

$\$ 13,612.50$

Equipment

\begin{tabular}{|l|l|l|r|}
\hline Company & Use & Open/ltemized & Amount \\
\hline & & & $\$ 0.00$ \\
\hline
\end{tabular}

Travel

\begin{tabular}{|l|l|l|r|}
\hline Company & Use & Open/ltemized & Amount \\
\hline & & & \\
\hline & & & \\
\hline & & & $\$ 0.00$ \\
\hline
\end{tabular}

Dues \& Memberships

\begin{tabular}{|l|l|l|r|}
\hline Company & Use & Open/ltemized & Amount \\
\hline & & & \\
\hline & & & \\
\hline & & & \\
\hline & & & $\$ 0.00$ \\
\hline
\end{tabular}

Rentals

Company

Use

Open/Itemized

TOTAL

Field Trips

Company

Fairfield Inn \& Suites

Use

Open/Itemized

Itemized

Itemized

TOTAL

Amount

Hampton Inn \& Suites

FFA State Conference

Hotel for Cal Poly State Finals

Amount

$\$ 2,533.87$

$\$ 3,025.00$

$\$ 5,558.87$

Professional Services

Company

Use

Open/Itemized

Amount 


\begin{tabular}{|l|l|l|r|}
\hline VIA & UC Davis & & $\$ 1,707.15$ \\
\hline & & & \\
\hline & & & $\$ 1,707.15$ \\
\hline
\end{tabular}




\section{AHS Agriculture Site Account 2012-2013}

Total Allowance

$\$ 1,800.00$

Current Monies Available

$\$ 0.00$

\section{Supplies}

Company

Office Depot

Nasco

Use

Ag Biology / Earth Science Supplies

\begin{tabular}{l} 
Open/Itemized \\
Open \\
Open \\
\hline
\end{tabular}

TOTAL
Amount

$\$ 400.00$

$\$ 560.00$

$\$ 0.00$

$\$ 960.00$

\section{Dues \& Memberships}

Company

'
Use

CATA Dues

Open/Itemized

TOTAL
Amount

$\$ 840.00$

$\$ 840.00$

\begin{tabular}{l} 
Rentals \\
Company \\
\hline \\
\hline \\
\hline \\
\hline
\end{tabular}

\begin{tabular}{|l|}
\hline Use \\
\hline \\
\hline
\end{tabular}

\begin{tabular}{|l|l|}
\hline Open/ltemized & \\
\hline & \\
\hline
\end{tabular}

TOTAL

Amount

\begin{tabular}{|l|l|}
\hline & \\
\hline & \\
\hline 0.00
\end{tabular}

Transportation

\begin{tabular}{|l|l|l|l|}
\hline Location & Use & Open/ltemized & Amount \\
\hline & & & \\
\hline & & & \\
\hline & & & \\
\hline & & & \\
\hline & & & \\
\hline & & & \\
\hline & & & \\
\hline & & & \\
\hline & & TOTAL & \\
\hline
\end{tabular}

Travel

\begin{tabular}{|l|l|l|l|}
\hline Company & Use & Open/Itemized & Amount \\
\hline & & & \\
\hline & & & \\
\hline & & & \\
\hline & & & \\
\hline & & & \\
\hline
\end{tabular}


AHS Agriculture ROP Account 2012-2013

Total Allowance

$\$ 4,686.00$

Current Monies Available

$\$ 1.51$

Supplies
\begin{tabular}{|l|l|l|r|}
\hline Company & Use & Open/ltemized & Amount \\
\hline Fresh Ideas & & & $\$ 1,000.00$ \\
\hline Fresh Ideas & & & $\$ 340.00$ \\
\hline CVE & & & $\$ 195.00$ \\
\hline Promo Direct & Fair Buyer's Bifts & Open & $\$ 1,200.00$ \\
\hline & & & \\
\hline & & & $\$ 2,735.00$ \\
\hline
\end{tabular}

Equipment

\begin{tabular}{|l|l|l|l|}
\hline Company & Use & Open/ltemized & Amount \\
\hline & & & \\
\hline & & & \\
\hline
\end{tabular}

Field Trips

\begin{tabular}{|l|l|l|r|}
\hline Company & Use & Open/ltemized & Amount \\
\hline & & & \\
\hline & & & \\
\hline & & & $\$ 0.00$ \\
\hline
\end{tabular}

\begin{tabular}{|l|l|l|r|}
\hline Professional Services & Open/ltemized & Amount \\
\hline Company & Use & & \\
\hline & & Itemized & $\$ 1,949.49$ \\
\hline Via Bus & Chico Field Day & & $\$ 1,949.49$ \\
\hline & \multicolumn{3}{|c|}{ TOTAL }
\end{tabular}




\section{FFA Budget (General Account)}

\section{Revenue}

Ag Booster Donation

$\$ 11,000$

Fall Fest Fundraiser

$\$ 6,000$

National Finals Trip Donations

$\$ 9,000$

Placemat Ad Sales

$\$ 5,500$

Save Mart SHARES Program

$\$ 2,000$

Take-Out BBQ's (4)

$\$ 10,000$

Total Revenue

$\$ 43,500$

\section{Expenses}

Fair Equipment/Supplies

$\$ 2,000$

FFA Field Day Registrations

$\$ 3,000$

FFA Greenhand Conference

$\$ 800$

FFA Meetings (Food, Supplies, etc..)

$\$ 3,500$

FFA National Finals Trip

$\$ 13,000$

FFA Recreational Trip(s) Transportation

$\$ 2,200$

FFA Student Fundraising Incentives

$\$ 4,000$

FFA Supplies

$\$ 2,000$

Office/Operation Supplies

$\$ 3,000$

Promotion/Marketing

$\$ 4,500$

Staff iPads / Computers

$\$ 5,500$

Total Expenses

$\$ 43,500$

\section{FFA Horticulture Account}

\section{Revenue}

Fall Fest Fundraiser

$\$ 1,000$

Fall Plant Sale

$\$ 2,000$

Floral Projects

$\$ 5,000$

Merced County Fair Projects

$\$ 5,000$

Spring Plant Sale

$\$ 2,000$

Total Revenue

$\$ 15,000$

\section{Expenses}

Facility Concrete / Fencing Projects

$\$ 1,500$

FFA Activities / Events

$\$ 1,000$ 
FFA Judging Teams (Nationals)

$\$ 2,000$

Floral Supplies / Equipment

$\$ 3,000$

Horticulture Equipment

$\$ 2,000$

Horticulture Facility Projects

$\$ 1,500$

Horticulture Supplies

$\$ 4,000$

Total Expenses

$\$ 15,000$

\section{FFA Wood Shop / Small Engines Account}

\section{Revenue}

Atwater Ag Boosters $\$ 500$

District Funds $\$ \$, 500$

Fall Fest Fundraiser $\quad \$ 1,500$

Sale of Mowers / Engine Repair $\$ 250$

Sale of Wood Projects $\$ 1,500$

Total Revenue $\quad \$ 10,250$

\section{Expenses}

Classroom/Lab Supplies Student Projects $\$ \$ 6,500$

Equipment Repair $\$ 1,000$

General Shop Supplies / Materials $\quad \$ 2,750$

Total Expenses $\quad \$ 10,250$

\section{FFA Welding / Metal Fabrication Account}

\section{Revenue}

Atwater Ag Boosters $\$ 500$

Custom Plasma Projects $\$ 1,200$

Donations from Repairs $\$ 1,400$

Fall Fest Fundraiser $\quad \$ 1,500$

Merced County Fair Projects $\$ 1,200$

Metal Art Sales (During Plant Sales) $\$ 2,000$

Project Payments $\$ \$ 8,500$

Scrap Metal Recycling $\$ 1,500$

Total Revenue $\quad \$ 17,800$

\section{Expenses}


Equipment Repairs $\quad \$ 600$

Freshman Ag Shop Skills Projects $\$ 3,500$

General Shop Supplies / Materials $\$ \$ 1,200$

Misc. Supplies / Equipment $\$ 2,500$

Modesto Steel / Custom Metal (Material) \$8,500

Powder Coating Projects $\$ 500$

Welding Supplies / Airgas $\quad \$ 1,000$

Total Expenses $\quad \$ 17,800$

\section{Carl Perkins Funding}

\section{Revenue}

2012-2013 Disbursement

$\$ 33,893$

Total Revenue

$\$ 33,893$

\section{Expenses}

All Data Subscription (Wood)

$\$ 1,000$

Biology Lab Equipment

$\$ 600$

CATA Road Show / Conference

$\$ 1,266$

CATA Summer Conference (SLO)

$\$ 3,700$

FFA Leadership Conference (Fresno State)

$\$ 3,000$

FFA Leadership Conferences (MFE / ALA)

$\$ 2,200$

Indianapolis Car Rentals (National FFA)

$\$ 1,200$

Indianapolis Hotel (National FFA)

$\$ 2,000$

Pole Barn Shed

$\$ 3,182$

Shop/Classroom Computers

$\$ 13,745$

Welding Shop Tools

$\$ 1,000$

Wood Shop Tools

$\$ 1,000$

Total Expenses

$\$ 33,893$

\section{ROP Funding}

\section{$\underline{\text { Revenue }}$}

Veterinary Science

$\$ 1,098$

Horticulture

$\$ 981$

Floral Design

$\$ 2,772$

Total Revenue

$\$ 4,851$ 
Expenses

Flowers / Supplies $\quad \$ 1,200$

Nasco (Lab Supplies) \$400

CVE (Curriculum Materials) $\$ 300$

Chico State Field Day Transportation $\$ 1,861$

Promo Direct (Project Promotional Supplies) \$1,090

Total Expenses $\quad \$ 4,851$

\section{Ag Incentive Grant Funding}

Revenue

Incentive Grant Disbursement

$\$ 20,451$

Total Revenue

$\$ 20,451$

\section{Expenses}

Airgas (Shop)
CATA Memberships
Davis Digital (Office Services)
FFA Membership Dues
FFA State Conference Lodging
FFA State Finals Lodging
FFA Supplies
New Professionals Conference
Team Wear - Officer Supplies
UC Davis Field Day Transportation

$\$ 2,000$

$\$ 840$

$\$ 900$

$\$ 7,530$

$\$ 2,300$

$\$ 2,100$

$\$ 2,000$

$\$ 250$

$\$ 1,000$

$\$ 1,531$

Total Expenses

$\$ 20,451$

\section{AHS Site Funding}

\section{Revenue}

Site Disbursement

$\$ 2,000$

Total Revenue

$\$ 2,000$

\section{Expenses}


Office Depot (Office/Operation Supplies)

Nasco (Lab Supplies)

$\$ 1,400$

$\$ 600$

Total Expenses

$\$ 2,000$

\section{MUHSD Transportation Account}

Revenue

Site Disbursement

$\$ 7,046$

Total Revenue

$\$ 7,050$

\section{Expenses}

FFA Judging Contests

FFA Leadership/Professional Conferences

FFA Officer/Staff Retreat

Total Expenses
$\$ 4,500$

$\$ 1,750$

$\$ 800$

$\$ 7,050$ 


$$
\stackrel{\underline{G G}}{\text { VEA District Allocation }}
$$

Our account is managed by the District System. Currently, one staff member is responsible for keep accurate records and submitting requests and reimbursements. All spending must have prior approval from the district before purchases can be made.

Attached you will find:

- 2012-2013 District Allocation 
File Options Help

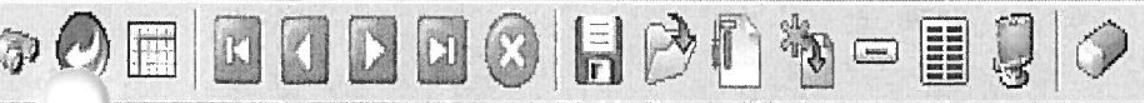

Page: 1 of 1

O Lookup | Bdvanced Search |

- Search by

6. Account

District Yeat

C Advanced

?

Year FD-RESC-Y-OBJT.SO-GOAL-FUNC-SCH-DD1-DD2

Iv Show Summary

$\sqrt{\nabla}$ Show Accounts

『v OpenAccounts Only

Columins to show-

6. Standard

C All C Minimal

Expense Summary Wioking Revised Aproved

\begin{tabular}{rrrr} 
Budget: & $10,814.29$ & $10,814.29$ & .00 \\
\hline Expense: & $5,464.94$ & & \\
Pending: & .00 & & \\
Encumbered: & $4,251.30$ & & \\
\hline Total Commited: & $9,716.24$ & & \\
\hline Balance: & $1,098.05$ & $1,098.05$ & $.9,716.24$
\end{tabular}

\begin{tabular}{|c|c|c|c|c|c|c|c|c|}
\hline & FD-RESC-Y-OBJT . S0-GOAL-FUNC-SCH-DD1-D] ST & Pseudo & Working & Expensed & Pending & Encumberec & Committed & Balance \\
\hline 1 & $\mid 01-0000-0-4300.00-1110-1000-110-100-0 ; 0$ & & $4,450,00$ & 981.78 & . 00 & $1,365,30$ & $2,347,08$ & $2,102,92$ \\
\hline 2 & $01-0000-0-4300.90-1110-1000-110-100-0: 0$ & & .00 & 480,66 & .00 & .00 & 480,66 & $-480,66$ \\
\hline 3 & $01-0000-0-5200.00-1110-1000-110-100-0 ; 0$ & & $3,182.14$ & .00 & .00 & .00 &, 00 & $3,182,14$ \\
\hline 4 & $01-0000-0-5300.00-1110-1000-110-100-0$ & & .00 & 700,00 & .00 & .00 & 700,00 & $-700,00$ \\
\hline 5 & $01-0000-0-5640.00-1110-1000-110-100-0 ; 0$ & & .00 & .00 & .00 & .00 & .00 & .00 \\
\hline 6 & $01-0000-0-5711.00-1110-1000-110-100-0 ; 0$ & & $3,182.15$ & $3,302,50$ & .00 & $2,886,00$ & $6,188,50$ & $-3,006,35$ \\
\hline 7 & $01-0000-0-5866.00-1110-1000-110-100-0: 0$ & & .00 & .00 & .00 & .00 & .00 & , 00 \\
\hline
\end{tabular}


File Options Help

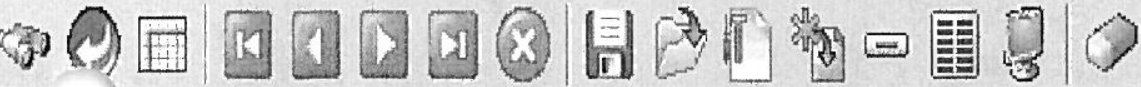

2024w accounts Read, 6 Accounts Qualified, 6 Expense Accounts

- Lookup | Bdyanced Search|

Search by

(6) Account

CAdvanced

$? \sqrt{24 \nabla \sqrt{10}} \sqrt{01-7010-0-? ? ? ? . ? ?-3824-1000-110-100-025}$

$\sqrt{v}$ Show Summary

『v Show Áccounts

$\sqrt{\nabla}$ Open Accounts Only

- Columns to show

c. Standard

C All C Minimal

Expense Summary

Working

Revised

Approved

Budget:

$17,843.79$

$17,843.79$

.00

\begin{tabular}{rr}
\hline Expense: & $12,595.60$ \\
Pending: & .00 \\
Encumbered: & $5,006.18$ \\
\hline Total Commited: & $17,601.78$
\end{tabular}

Balance:

242.01

242.01

$.17,601.78$

\begin{tabular}{|c|c|c|c|c|c|c|c|c|}
\hline & FD-RESC-Y-OBJT . SO-GOAL-FUNC-SCH-DD1-D] 5 & $5 T$ Pseudo & Working & Expensed & Pending & Encumberec & Committed & Balance \\
\hline 1 & $01-7010-0-4300.00-3824-1000-110-100-0: 0$ & & $17,743.79$ & $9,194,39$ & .00 & $3,406.18$ & $12,600.57$ & $5,143,22$ \\
\hline 2 & $\mid 01-7010-0-5200.00-3824-1000-110-100-0 ; 0$ & & 100.00 & 893.59 & .00 & .00 & 893.59 & $-793,59$ \\
\hline 3 & $01-7010-0-5300.00-3824-1000-110-100-0 ; 0$ & & .00 & .00 & .00 & .00 & .00 & ,00 \\
\hline 4 & $01-7010-0-5620.00-3824-1000-110-100-0 ; 0$ & & .00 & .00 & .00 & .00 & .00 & .00 \\
\hline 5 & $01-7010-0-5805.00-3824-1000-110-100-0 ; 0$ & & .00 & $2,507,62$ & .00 & .00 & $2,507,62$ & $-2,507,62$ \\
\hline 6 & $01-7010-0-5866.00-3824-1000-110-100-0 ; 0$ & & .00 & ,00 & .00 & $1,600,00$ & $1,600,00$ & $-1,600,00$ \\
\hline
\end{tabular}


File Options Help

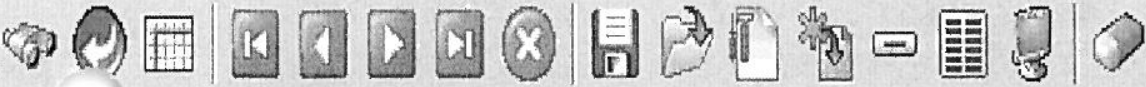

2024w ..ccounts Read, 3 Accounts Qualified, 3 Expense Accounts

- Lookup | Bdvanced Search

Search by

(6) Account

is Advanced

$?$

Distric

District Ye

Year FD-RESC-Y-OBIT. 50-GOUL-FUNC-SCH-DD1-DD2

01-9350-0-???? ??-7110-1000-110-100-025 -

$\sqrt{v}$ Show Summary

『v Show Accounts

$\sqrt{\nabla}$ Open Áccounts Only
Columns to show-

c. Standard

C \&ll C Minimal

\begin{tabular}{rrrr} 
Expense Summary & Working & Rievised & Approved \\
Budget: & $5,859.00$ & $5,859.00$ & .00 \\
\hline Expense: & $5,304.37$ & & \\
Pending: & .00 & & \\
Encumbered: & 583.89 & & \\
\hline Total Commited: & $5,888.26$ & & \\
\hline Balance: & .29 .26 & .29 .26 & $.5,888.26$
\end{tabular}

\begin{tabular}{|c|c|c|c|c|c|c|c|c|}
\hline & FD-RESC-Y-OBJT. S0-GOAL-FUAC-SCH-DD1-D] 5 & T) Pseudo & Working & Expensed & Pending & Encumberec & Committed & Balance \\
\hline 1 & $01-9350-0-4300.00-7110-1000-110-100-0 ; 0$ & & $5,859,00$ & $2,217,55$ & .00 & 583.89 & $2,801,44$ & $3,057,56$ \\
\hline 2 & $01-9350-0-4400.90-7110-1000-110-100-0 ; 0$ & & .00 & ,00 & , 00 & .00 & .00 & .00 \\
\hline 3 & $01-9350-0-5866.00-7110-1000-110-100-0 ; 0$ & & .00 & $3,086,82$ & .00 & .00 & $3,086,82$ & $-3,086,82$ \\
\hline
\end{tabular}


File Options Help

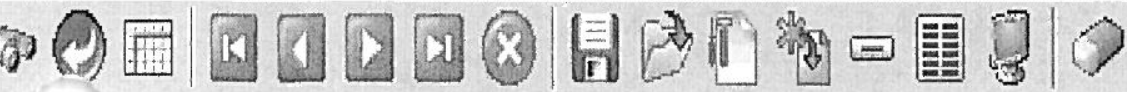

2024. ..ccounts Read, 9 Accounts Qualified, 9 Expense Accounts

Page: 1 of 1

O Lookup |Advanced Search|

- Search by

(6) Account

$C$ Advanced

$? \sqrt{24 \sqrt{10}} \frac{\text { District Year FD-RESC-Y-OBJT. SO-GOLL-FUNC-SCH-DD1-DD2 }}{01-3550-0-? ? ? ? . ? ?-3800-1000-110-895-1025}$

『v Show Summary

『v Show Áccounts

$\sqrt{V}$ Open Accounts Only

- Columns to show-

6. Standard

$C$ all $C$ Minimal

Expense Summary

Working

Rievised

Approved

Budget:

$26,364,83$

$15,988.75$

.00

\begin{tabular}{rr}
\hline Expense: & $30,525.81$ \\
Pending: & .00 \\
Encumbered: & $6,002.78$ \\
\hline Total Commited: & $36,528.59$
\end{tabular}

Total Commited:

$36,528.59$

Balance:

$.10,163.76$

$\cdot 20,539.84$

$.36,528.59$

\begin{tabular}{|c|c|c|c|c|c|c|c|c|}
\hline & FD-RESC-Y-OBJT . S0-GOAL-EUAC-SCH-DD1-D] S & 5T Pseudo & Working & Expensed & Pending & Encumberec & Committed & Balance \\
\hline 1 & $01-3550-0-4200.00-3800-1000-110-895-0$ & 0 & .00 & .00 & 00 & 00 & .00 & .00 \\
\hline 2 & $01-3550-0-4300.00-3800-1000-110-895-0$ & 0 & $3,638.07$ & $4,324,27$ &, 00 & 8.46 & $4,332.73$ & -694.66 \\
\hline 3 & $01-3550-0-4300.90-3800-1000-110-895-0$ & 0 & $3,754.43$ & $3,754,43$ & .00 & 75.54 & $3,829,97$ & $-75,54$ \\
\hline 4 & $01-3550-0-4400.00-3800-1000-110-895-0$ & 0 & $1,576.24$ & $1,576.24$ & .00 & $4,420,03$ & $5,996.27$ & $-4,420,03$ \\
\hline 5 & $01-3550-0-4400.90-3800-1000-110-895-0 ; 0$ & 0 & $7,834.19$ & $11,616,97$ & .00 & $1,190,75$ & $12,807,72$ & $-4,973,53$ \\
\hline 6 & $|01-3550-0-5200.00-3800-1000-110-895-0 ;|$ & 0 & $3,642,90$ & $3,334,90$ & .00 & 308,00 & $3,642,90$ & .00 \\
\hline 7 & $01-3550-0-5300.00-3800-1000-110-895-0 ; 0$ & 0 & .00 & .00 &, 00 & 00 & .00 & .00 \\
\hline 8 & $01-3550-0-5805.00-3800-1000-110-895-0 ;$ & & $4,875,00$ & $4,875,00$ & .00 & .00 & $4,875,00$ & .00 \\
\hline
\end{tabular}




\section{$\underline{\mathrm{HH}}$ \\ District Budget Process}

The Merced Union High School District maintains the agriculture budget through a district computer program. The Atwater Ag Department is responsible to submit all purchase orders, budget transfers, transportation/travel requests, or any other paper work necessary. The budget includes four accounts: Ag Incentive funds, $\mathrm{Ag}$ Site (district) funds, ROP funds, and our FFA account through the Student Body Office.

Reports are received bi-monthly to keep track of expenditures and current funds available. The agriculture department maintains a binder for each account used in the district to keep track of all paperwork and receipts. Regular, purchase orders are signed off and district account records are checked against department records.

At the end of the year, accounts are closed out and all purchase orders are signed off. A report of expenditures is completed to best determine changes in the budget for the following year. This report is also used to compare with our proposal and see if we stayed within our budget estimates for the past year. It is sent in to the California FFA for approval. 


\section{II \\ Department Chair Duties}

The Atwater Agriculture Instructors decided that the Department Chair Duties be shared. The title is shared by two and each instructor has their own duties that they maintain.

The duties are incorporated into our chart of responsibilities. This method will only hold true during the time when these specific agriculture instructors maintain position in the agriculture department: Dave Gossman and Beth Williams.

\section{Attached you will find:}

- 2012-2013 Chart of Responsibilities 


\section{2 - 2013 AHS Agriculture Department \\ Staff Assignments}

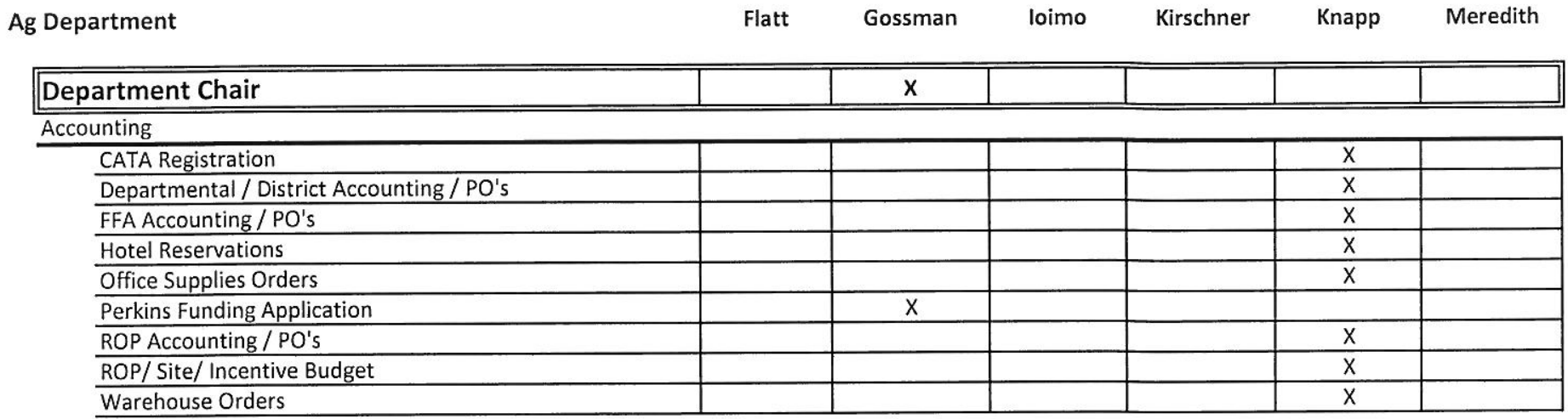

General Program / Facility

5-year Equipment Allocation

Advisory Committee Roster \& Minutes

Ag Advisory Committee Planning and Agenda

$\mathrm{Ag}$ Booster Committee

Chart of Staff Responsibilities

Comprehensive Program Plan

Department Marketing / PR / Liason

Graduate Follow-Up

Incentive Grant

Incentive Grant Reviews

In-Service Activities List

Maintain Comprehensive Progrom Plan Binder

Maintain Program Management Binder

Maintenance Requests

Quarterly / Yearly CATA Meetings / Events

R2 Report \& Roster

Recruitment

Report of Expenditures

Transportation Requests/Requisitions

\begin{tabular}{|c|c|c|c|c|c|}
\hline & & & & $\bar{x}$ & \\
\hline & $X$ & & & & \\
\hline & $x$ & & & & \\
\hline & $x$ & & & & \\
\hline & $x$ & & & & \\
\hline & & & & $x$ & \\
\hline & $x$ & & & & \\
\hline & & & & $x$ & \\
\hline & & & & $x$ & \\
\hline & & & & $x$ & \\
\hline & & & & $x$ & \\
\hline & & & & $X$ & \\
\hline & & & & $X$ & \\
\hline & $X$ & & & & \\
\hline$x$ & $X$ & $X$ & $x$ & $x$ & $x$ \\
\hline & & & & $x$ & \\
\hline & $X$ & & & & \\
\hline & & & & $X$ & \\
\hline & $X$ & & & & \\
\hline
\end{tabular}

\section{FFA Advisor}

Advance Leadership Academy Conference

American FFA Degree Applications

Chapter Officer Leadership Conference

Chapter Reportor

Greenhand Conference

Made for Excellence Leadership Conference

Organize Local Project Competition

Organize Sectional Project Competition

Oversee Planning for FFA Meetings

Quarterly FFA Activities List for Class Grading

Regional Officer Leadership Conference

Registration for CDE Contest

Registration for Conferences

Scrapbook

Sectional Officer Leadership Conference

State FFA Degree Applications

State FFA Leadership Conference

\begin{tabular}{|c|c|c|c|c|c|}
\hline & & & X & & \\
\hline & $X$ & & $x$ & & \\
\hline \multirow[t]{14}{*}{$x$} & $x$ & $x$ & $x$ & $X$ & $x$ \\
\hline & & & $x$ & & \\
\hline & $x$ & & & & \\
\hline & & & $x$ & & \\
\hline & $x$ & & $x$ & & \\
\hline & & & & & $x$ \\
\hline & & & & & $x$ \\
\hline & & & $X$ & & \\
\hline & & & $X$ & & \\
\hline & & & $x$ & & \\
\hline & $x$ & & & & \\
\hline & & & $x$ & & \\
\hline & & $x$ & & & \\
\hline & & & $x$ & & \\
\hline$X$ & $X$ & $x$ & $x$ & $x$ & $x$ \\
\hline$x$ & $X$ & $x$ & $X$ & $x$ & $x$ \\
\hline
\end{tabular}




\section{2 - 2013 AHS Agriculture Department Staff Assignments}

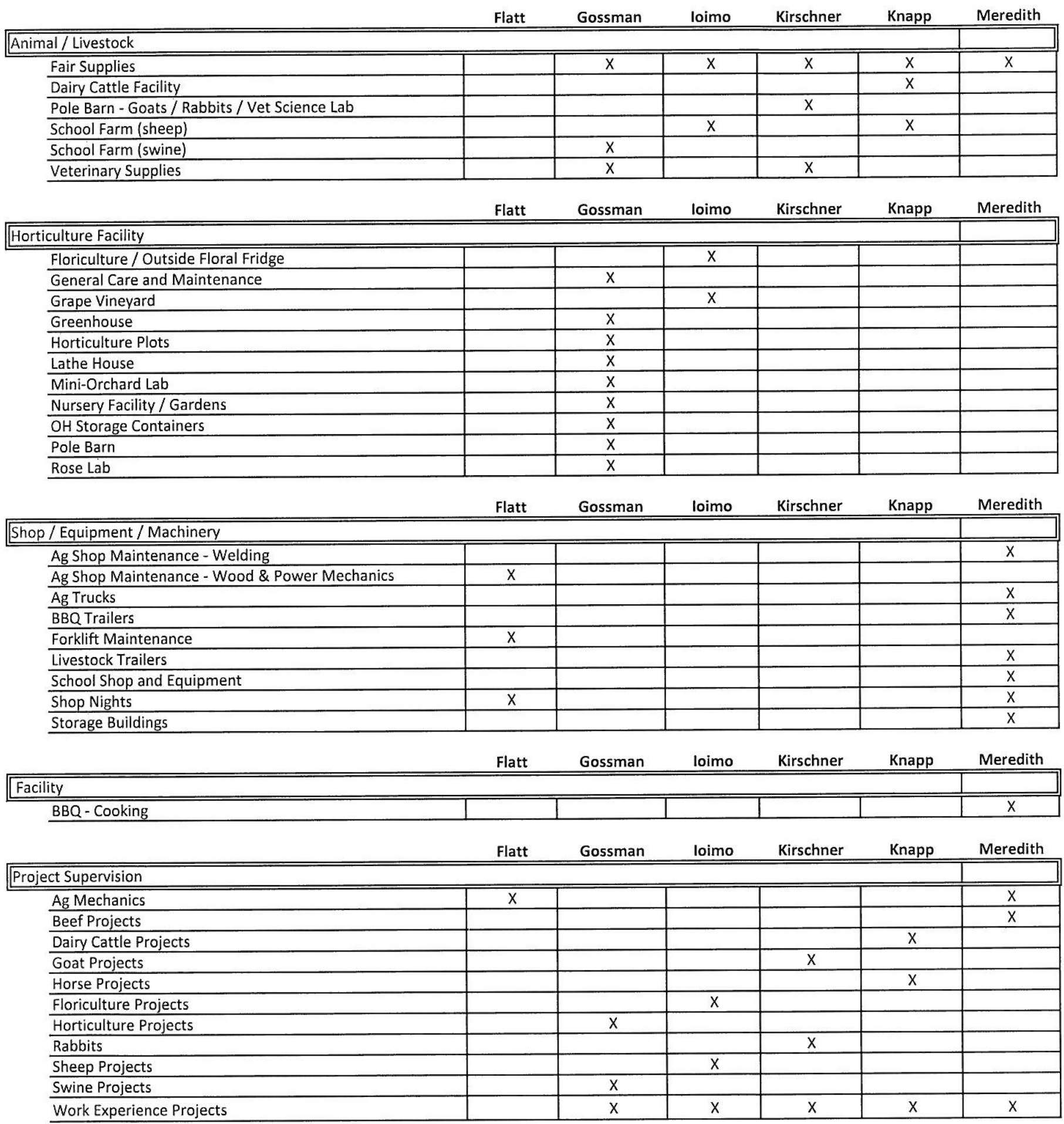




\section{2 - 2013 AHS Agriculture Department Staff Assignments}

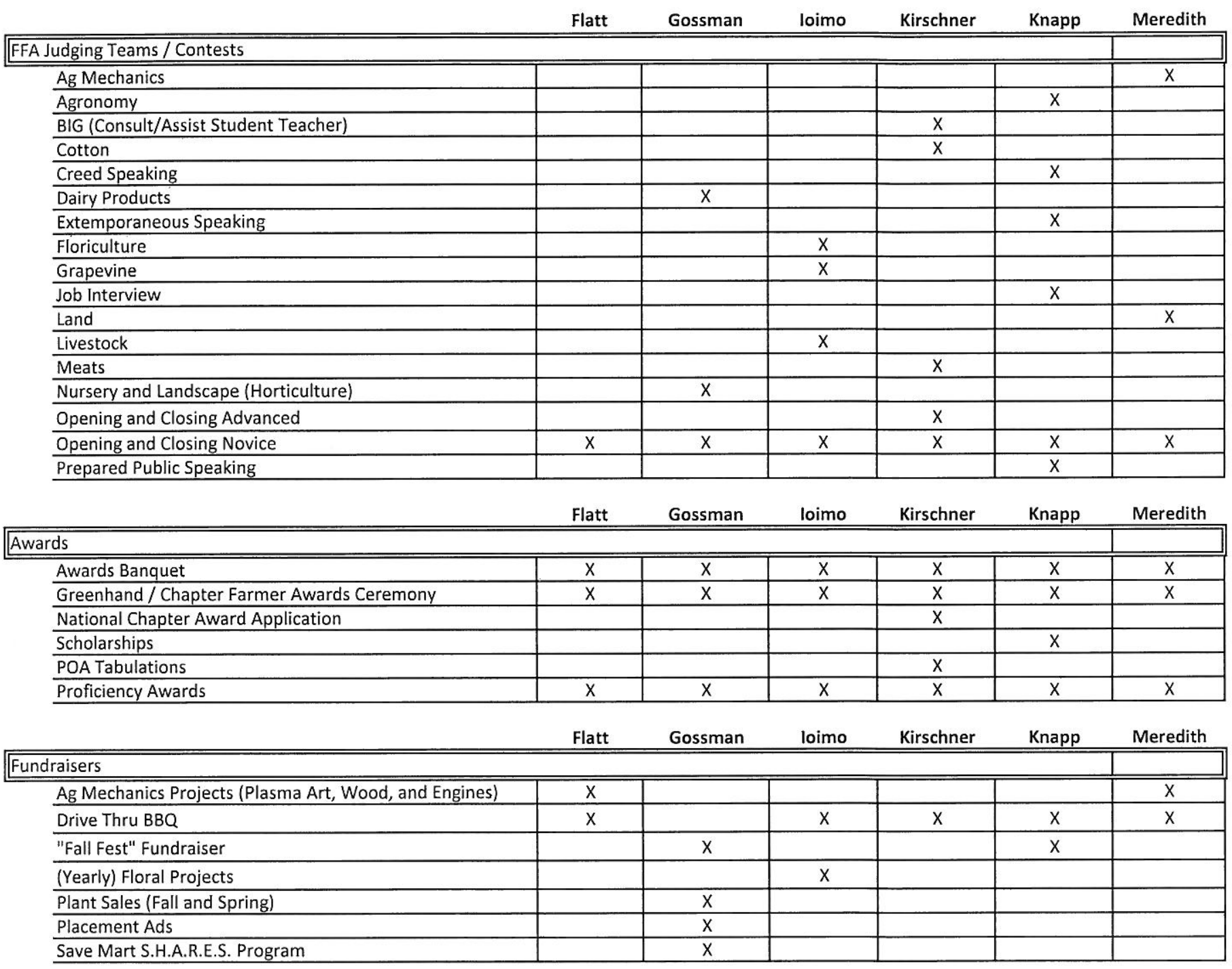




\section{$\underline{\mathrm{JJ}}$ \\ Chart of Responsibilities}

The Atwater Agriculture Department's chart of responsibilities is updated each summer to best reflect each advisor's duties. The chart shows which area each advisor is responsible for maintaining and what specific duties are expected in each of those areas. The chart of responsibilities represents the FFA activities, SAE advising duties, department activities, and events throughout the year. This is submitted to the administration at Atwater High School each year for informal purpose.

\section{Attached you will find:}

- 2012-2013 Chart of Responsibilities 


\section{2 - 2013 AHS Agriculture Department Staff Assignments}

\begin{tabular}{|c|c|c|c|c|c|c|}
\hline gepartment & Flatt & Gossman & loimo & Kirschner & Knapp & Meredith \\
\hline Department Chair & & $x$ & & & & \\
\hline \multicolumn{7}{|l|}{ Accounting } \\
\hline CATA Registration & & & & & $\mathrm{x}$ & \\
\hline Departmental / District Accounting / PO's & & & & & $x$ & \\
\hline FFA Accounting / PO's & & & & & $\mathrm{X}$ & \\
\hline Hotel Reservations & & & & & $\mathrm{x}$ & \\
\hline Office Supplies Orders & & & & & $\mathrm{x}$ & \\
\hline Perkins Funding Application & & $\mathrm{x}$ & & & & \\
\hline ROP Accounting / PO's & & & & & $\mathrm{x}$ & \\
\hline ROP/Site/ Incentive Budget & & & & & $x$ & \\
\hline Warehouse Orders & & & & & $x$ & \\
\hline
\end{tabular}

General Program / Facility

5-year Equipment Allocation

Advisory Committee Roster \& Minutes

Ag Advisory Committee Planning and Agenda

Ag Booster Committee

Chart of Staff Responsibilities

Comprehensive Program Plan

Department Marketing / PR / Liason

Graduate Follow-Up

Incentive Grant

Incentive Grant Reviews

In-Service Activities List

Maintain Comprehensive Progrom Plan Binder

Maintain Program Management Binder

Maintenance Requests

Quarterly / Yearly CATA Meetings / Events

R2 Report \& Roster

Recruitment

Report of Expenditures

Transportation Requests/Requisitions

\begin{tabular}{|c|c|c|c|c|c|c|}
\hline & & & & & $x$ & \\
\hline is & & $x$ & & & & \\
\hline \multirow[t]{9}{*}{ Agenda } & & $x$ & & & & \\
\hline & & $x$ & & & & \\
\hline & & $x$ & & & & \\
\hline & & & & & $x$ & \\
\hline & & $x$ & & & & \\
\hline & & & & & $X$ & \\
\hline & & & & & $x$ & \\
\hline & & & & & $x$ & \\
\hline & & & & & $x$ & \\
\hline an Binder & & & & & $x$ & \\
\hline \multirow[t]{2}{*}{$\mathrm{er}$} & & & & & $x$ & \\
\hline & & $x$ & & & & \\
\hline \multirow[t]{5}{*}{ vents } & $x$ & $x$ & $x$ & $\mathrm{X}$ & $x$ & $x$ \\
\hline & & & & & $x$ & \\
\hline & & $x$ & & & & \\
\hline & & & & & $x$ & \\
\hline & & $x$ & & & & \\
\hline
\end{tabular}

\begin{tabular}{|c|c|c|c|c|c|c|}
\hline FFA Advisor & & & & $\mathrm{x}$ & & \\
\hline Advance Leadership Academy Conference & & $x$ & & $\mathrm{x}$ & & \\
\hline American FFA Degree Applications & $\mathrm{X}$ & $\mathrm{x}$ & $\mathrm{x}$ & $\mathrm{x}$ & $\mathrm{x}$ & $\mathrm{x}$ \\
\hline Chapter Officer Leadership Conference & & & & $\mathrm{X}$ & & \\
\hline Greenhand Conference & & & & $\mathrm{x}$ & & \\
\hline Made for Excellence Leadership Conference & & $\mathrm{x}$ & & $\mathrm{x}$ & & \\
\hline Organize Local Project Competition & & & & & & $\mathrm{x}$ \\
\hline Quarterly FFA Activities List for Class Grading & & & & $\mathrm{x}$ & & \\
\hline Regional Officer Leadership Conference & & & & $\mathrm{x}$ & & \\
\hline Registration for CDE Contest & & $x$ & & & & \\
\hline Registration for Conferences & & & & $\bar{x}$ & & \\
\hline Scrapbook & & & $\mathrm{x}$ & & & \\
\hline Sectional Officer Leadership Conference & & & & $\mathrm{x}$ & & \\
\hline
\end{tabular}




\section{2 - 2013 AHS Agriculture Department Staff Assignments}

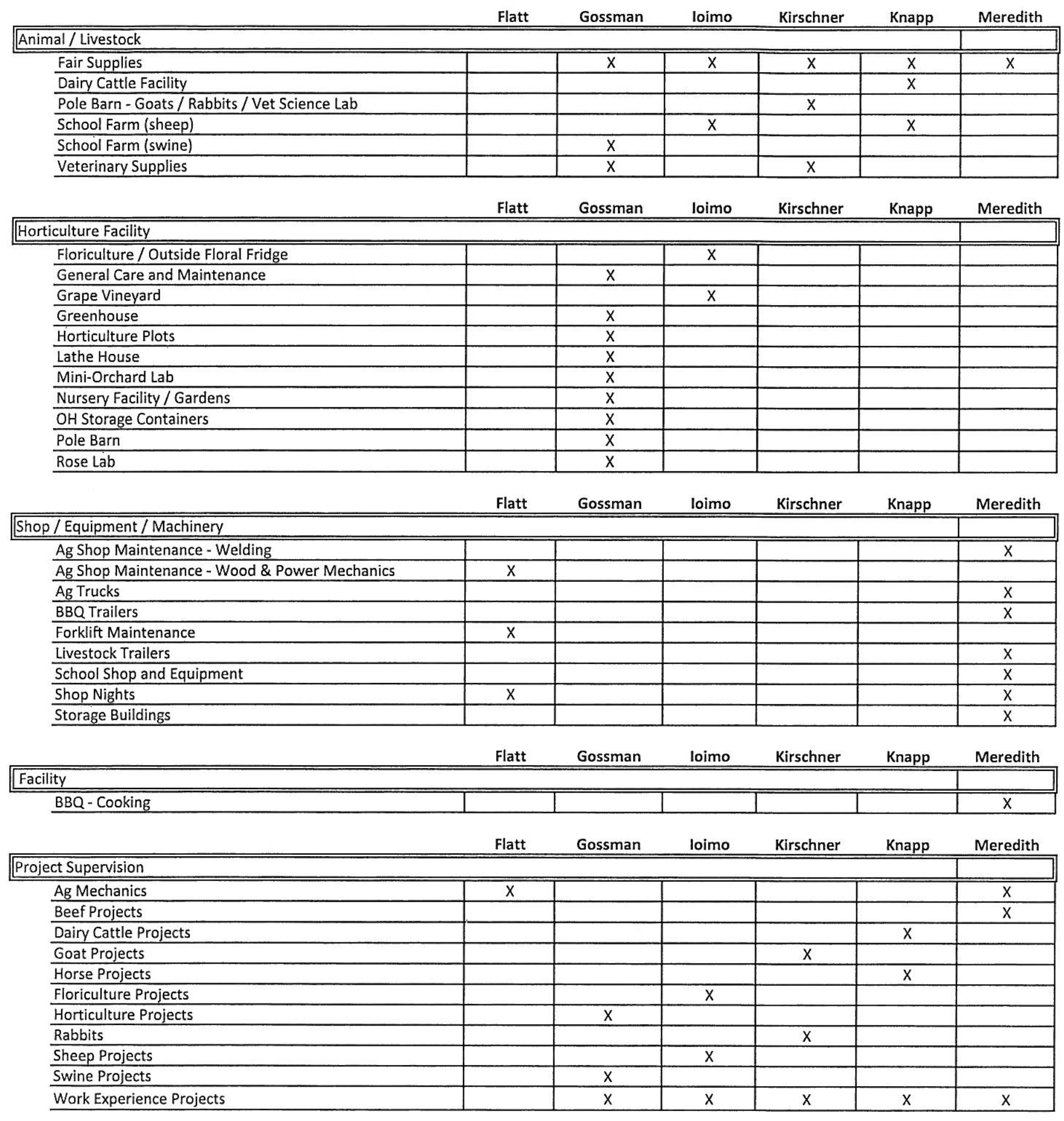




\section{2 - 2013 AHS Agriculture Department Staff Assignments}

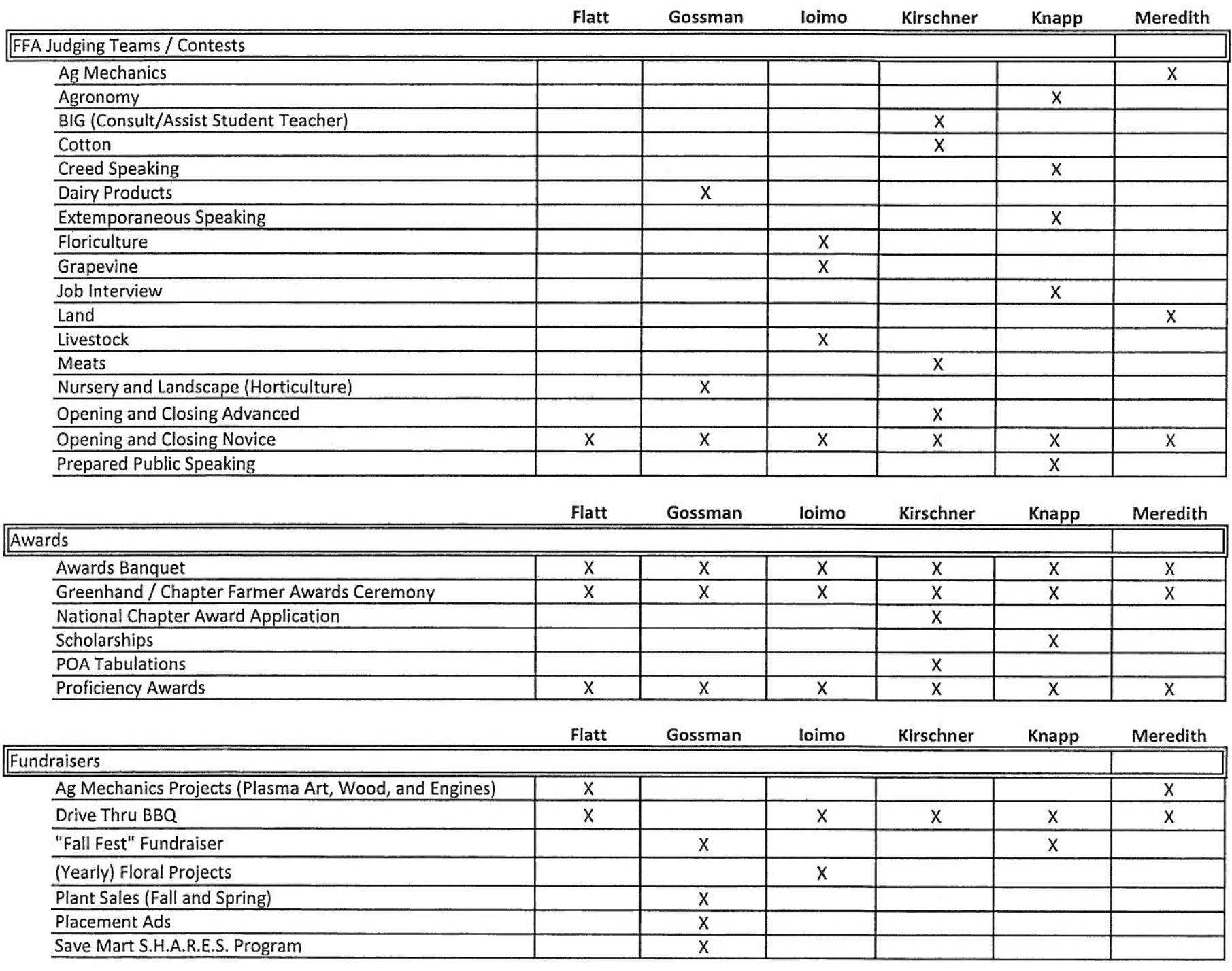




\section{$\underline{\text { KK }}$ \\ Substitute Procedure \& Plans}

All substitution requests have to be made online through the district's "subfinder". Substitutes that are specifically requested are notified of the job opening via email.

To make sure that my classes run correctly, I leave a substitution binder on my desk for the substitute giving specific detail on what to teach.

My substitute binder consists of the following:

- Lesson Plan

- Class Roster \& Seating Chart

- Behavioral Chart

- Classroom Policies

- Map of Campus

- Emergency Medical Forms

- Lock Down Procedures

\section{Attached you will find:}

- Copy of my Substitution Binder 


\section{March $4^{\text {th }} 2013$ Substitute Lesson Plan \\ Thes. Ioinke}

\section{THANK YOU FOR SUBBING FOR MY CLASSES!}

- Please take roll and mark any absences on the last page. Seating chart should be in the sub folder.

- Student Assistants: $1^{\text {st }}$ : Heather Lewandowski \& Nathan Acosta, $2^{\text {nd }}:$ Karla Nuno, $3^{\text {rd: }}$ Gio Perez, $4^{\text {th: }}$ Cynthia Vera, and $6^{\text {th }}$ Mauricio Vasquez

Notes for my TA is located on the left table. Please make sure they do these things for me :)

*** Florall classes meed the mini laptops. IDlease have TA's get the mini lamtoms once they get into the classrom ***

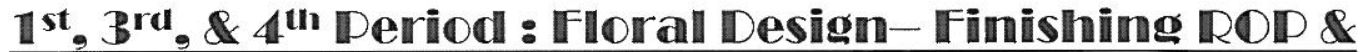

\section{Welpmages:}

* Please pass out the Week 9 Floral Packets (located on the side table).

* Click on the Floral Week 9 Powerpoint at the bottom of the screen ( The first one should be floral). Find Objective for 4/4. Have students write it out.

* After students have done that, please read the following:

- Happy Monday! Today you'll be working on your ROP portfolios \& blogs! If you need to print out your ROP paperwork, please ask to be excused to the library. Make sure you place all your ROP paperwork into your classroom file folder located in the filing cabinet. If you are done with your ROP portfolios, please work on your blogs.

Remember to be on your best behavior! Please demonstrate what a "good classroom" behaves like. Anything below a " 9 " will have consequences!!

- Please monitor students when they are using the mini laptops. Make sure they are either working on their ROP paperwork (GoogleDocs) or the webpages. If they are finished with everything, please tell them to place the mini laptops back on the carts. Thanks!

- When the 7 minute bell rings, please tell students to log off and put their laptops away properly (no cords hanging out, all going into the correct area, all laptops are plugged in).

${ }^{*} M y 1^{{ }^{s t}}$ period class is very quiet (first class of the day) I don't know if they are awake sometimes.

${ }^{*}$ My $3^{\text {rd }}$ period class is very helpful and gets stuff done.

*My $4^{\text {th }}$ period has a lot of boys and they tend to chat a lot - this is my smallest class of floral. 


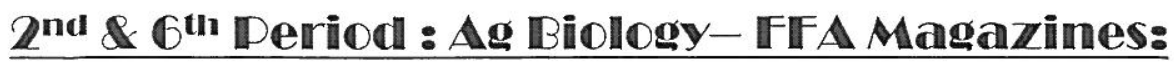

* Please pass out the Week 9 Biology Packets (located on the side desk).

* Click on the Bio Week 9 Powerpoint at the bottom of the screen (The second one should be Bio). Find Objective for $4 / 4$. Have students write it out.

* $\quad$ Please pass out the FFA Magazines (located on the side desk)

* After students have done that, please read the following:

- Happy Monday! Today you will be reading what is happening in FFA! Please use the worksheet in your packet and the FFA packets that are being passed out to you to complete this assignment.

Remember to be on your best behavior! Please demonstrate what a "good classroom" behaves like. Anything below a "9" will have consequences!!

- Please tell students to flip to the page in their packet labeled "FFA Magazine Search". Please make sure students are working by themselves and are using the FFA magazines. If students finish early, please encourage them to do their homework on the back of their packet or other work for another class.

$M y 2^{\text {nd }}$ period class is somewhat large and are really good kids - a lot of them are in athletics.

My $6^{\text {th }}$ period class is a little more talkative. They still get stuff done, but sometimes it takes them longer. (SMALL CLASS)

\section{Thanks for Everything!}

Please do not hesitate to send students out or write down names of students that are rude or disruptive and I will personally deal with them when I get back! 
1 - ArtHistFIDsgn1 -

Spring

Attondance chart

\begin{tabular}{|c|c|c|c|c|c|c|c|c|}
\hline & Stu\# & Name & Grd & Monoxy & TUESPAy & & & \\
\hline 1 & 69850 & 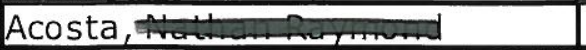 & 12 & & th & & & \\
\hline 2 & 70584 & Aldrich, Eamoly, Rnen & 11 & & & & & \\
\hline 3 & 69743 & Beatty, dattroman & 12 & & ph & & & \\
\hline 4 & 70608 & Boesch, thombenting & 11 & & & & & \\
\hline 5 & 69848 & Brasil, Surmant & 12 & & & & & \\
\hline 6 & 73865 & Brumett, & 12 & & & & & \\
\hline 7 & 70126 & Bryant, dessicantiman & 12 & & & & & \\
\hline 8 & 70624 & 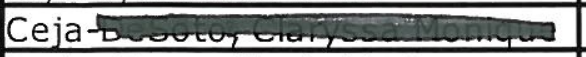 & 11 & & & & & \\
\hline 9 & 72301 & De La Torre, & 12 & & & & & \\
\hline 10 & 71576 & 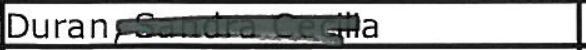 & 10 & & & & & \\
\hline 11 & 71057 & Enriquez, enimifer & 11 & & & & & \\
\hline 12 & 69938 & Estrada, & 12 & & & & & \\
\hline 13 & 72126 & Farias, Argenteduado & 11 & & & & & \\
\hline 14 & 69673 & Favela, Ounnare & 12 & & & & & \\
\hline 15 & 69837 & Harrison, sanyundery & 12 & & & & & \\
\hline 16 & 69816 & 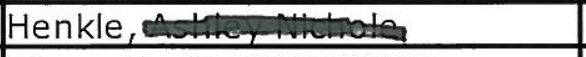 & 12 & & ok & & & \\
\hline 17 & 69931 & 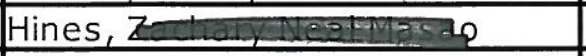 & 12 & & 06 & & & \\
\hline 18 & 69648 & 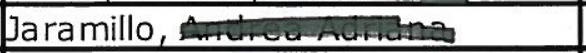 & 12 & & & & & \\
\hline 19 & 69809 & Junsay, Bmom-fayiot & 12 & $A s+0 k$ & & & & \\
\hline 20 & 69728 & Lagoy, sencunyath & 12 & & & & & \\
\hline 21 & 69717 & Langley, & 12 & 4350 & en. & & & \\
\hline 22 & 73197 & Langston, Darremnad & 12 & & & & & \\
\hline 23 & 71192 & Lewandowski, & 11 & & & & & \\
\hline 24 & 69846 & 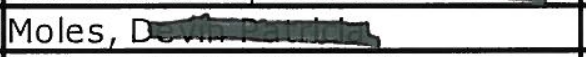 & 12 & & & & & \\
\hline 25 & 69810 & Nielsen, & 12 & & & & & \\
\hline 26 & 71889 & Olmos, dey shanemelipa & 10 & & & & & \\
\hline 27 & 70827 & Reyna, ce linamentifer & 11 & & 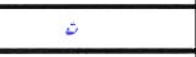 & & & \\
\hline 28 & 71914 & Rios, Eansy & 10 & & & & & \\
\hline 29 & 70950 & Rodriguez, serwwingeng & 11 & & & & & \\
\hline 30 & 69736 & Ruiz, my,csaminate & 12 & & & & & \\
\hline 31 & 70849 & Schmidt, Ashuynchisthe & 11 & & & & & \\
\hline 32 & 73239 & Schmidt, Gritarmanes & 12 & $A+s i k$ & $0 k$ & & & \\
\hline 33 & 71008 & Smelcer catmonomanms & 11 & & & & & \\
\hline 34 & 71234 & Tafoya, Jesoottani & 11 & & & & & \\
\hline 35 & 71951 & Tinoco, be Guadrater & 10 & & & & & \\
\hline 36 & 69739 & 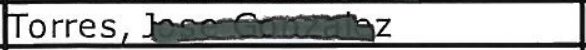 & 12 & & & & & \\
\hline 37 & 70986 & Vargas,era mavich & 11 & Abient & AlGYENT & & & \\
\hline 38 & 72520 & Vasquez, steinathe & 11 & & & & & \\
\hline
\end{tabular}




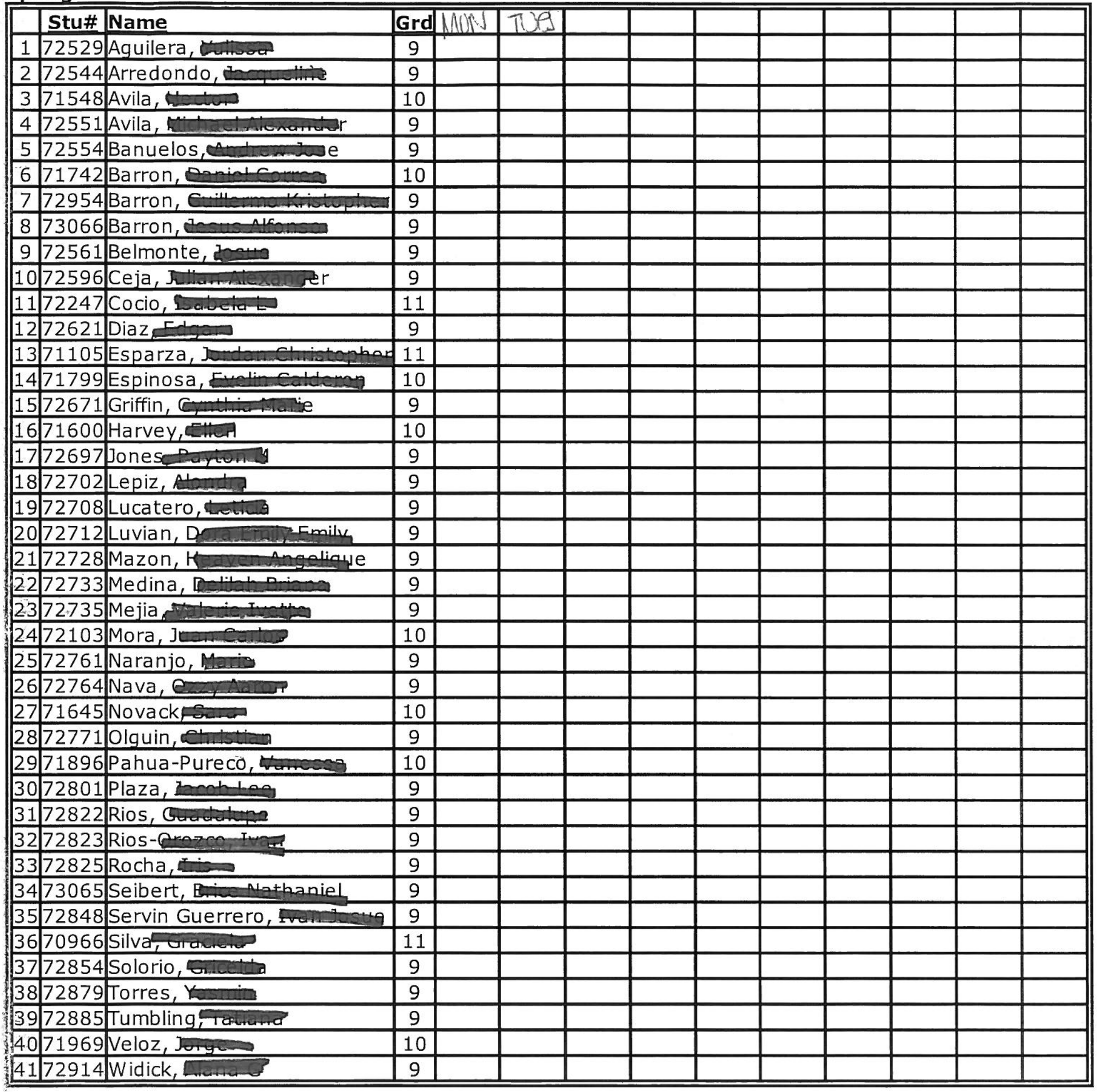




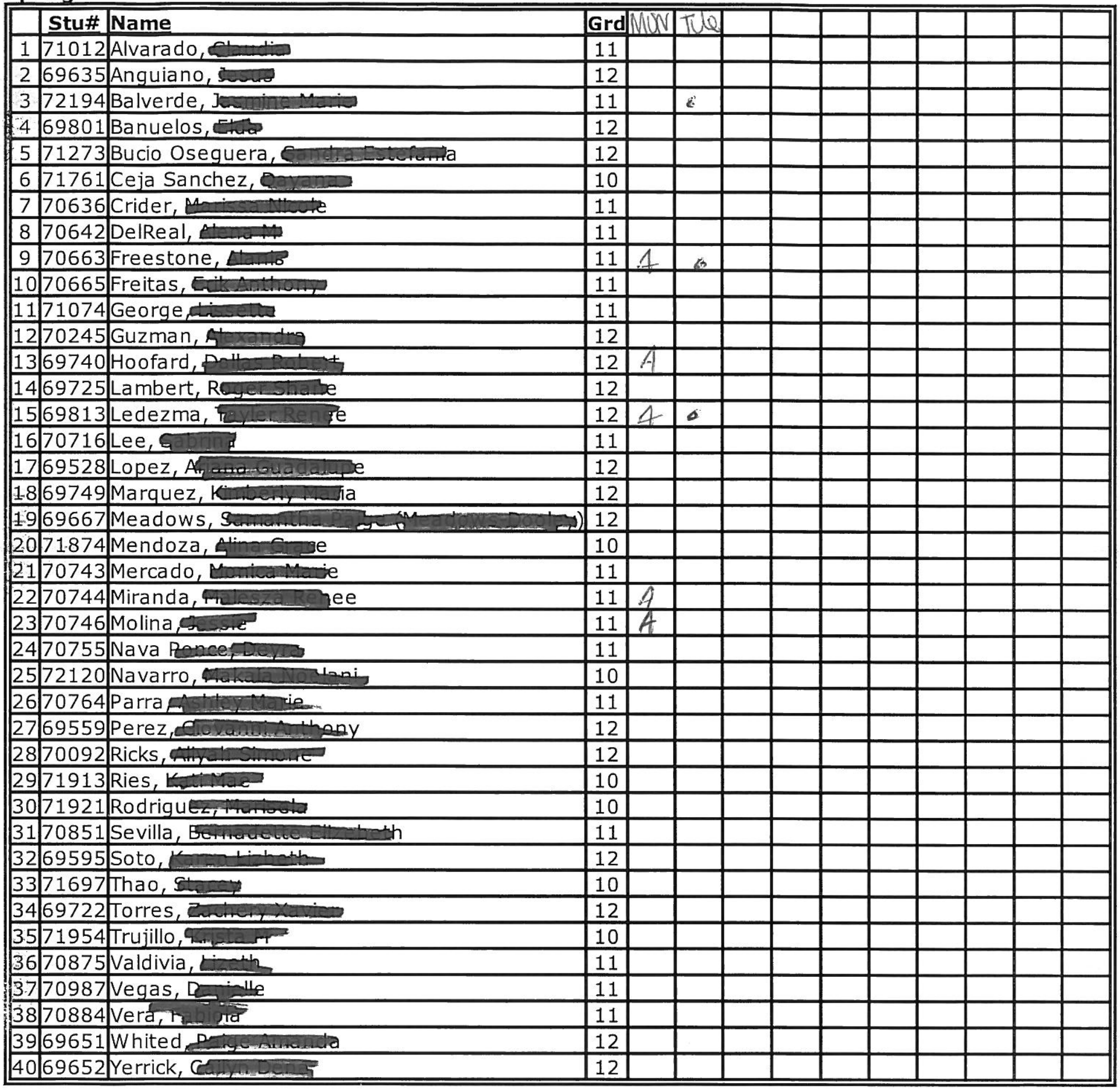




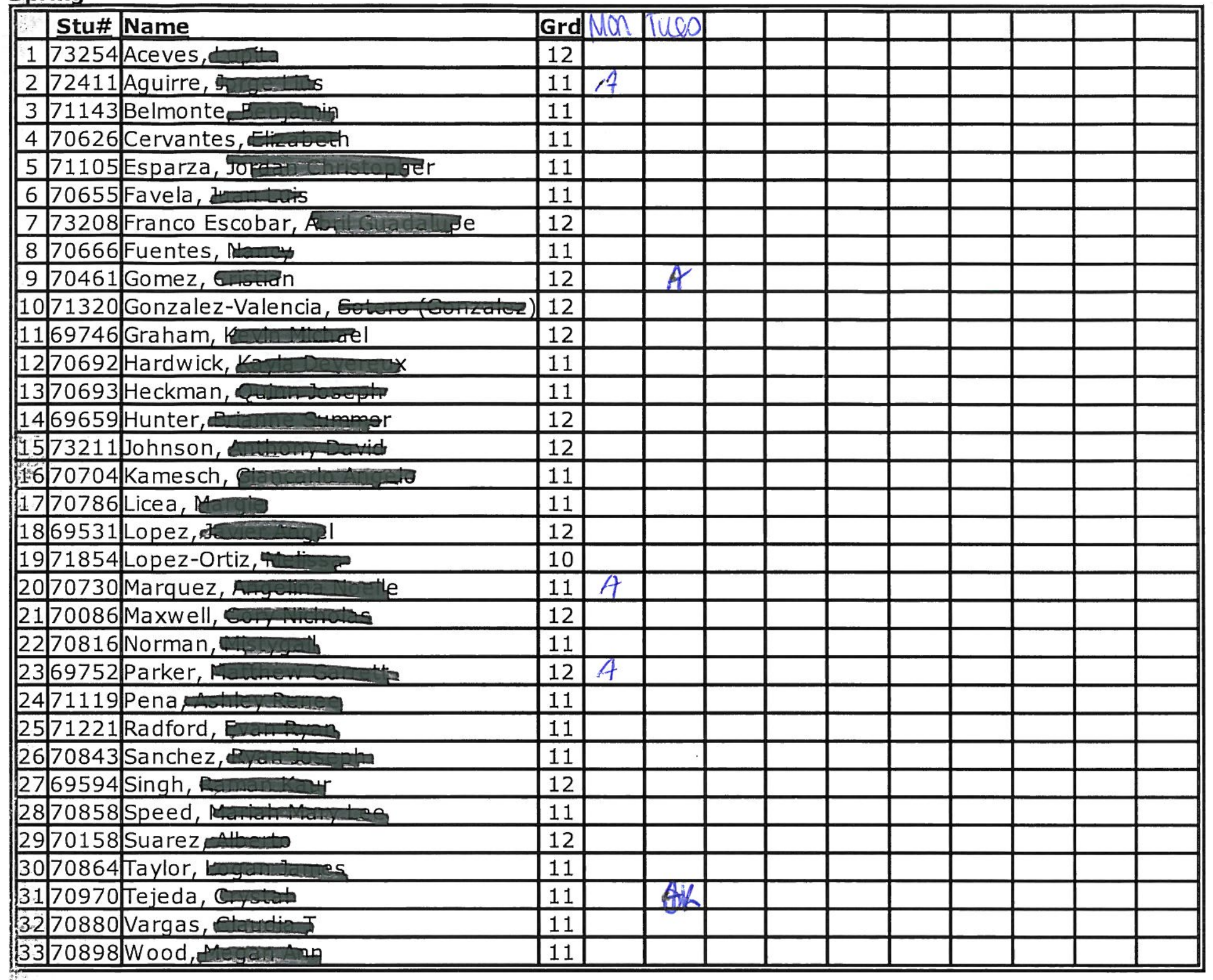




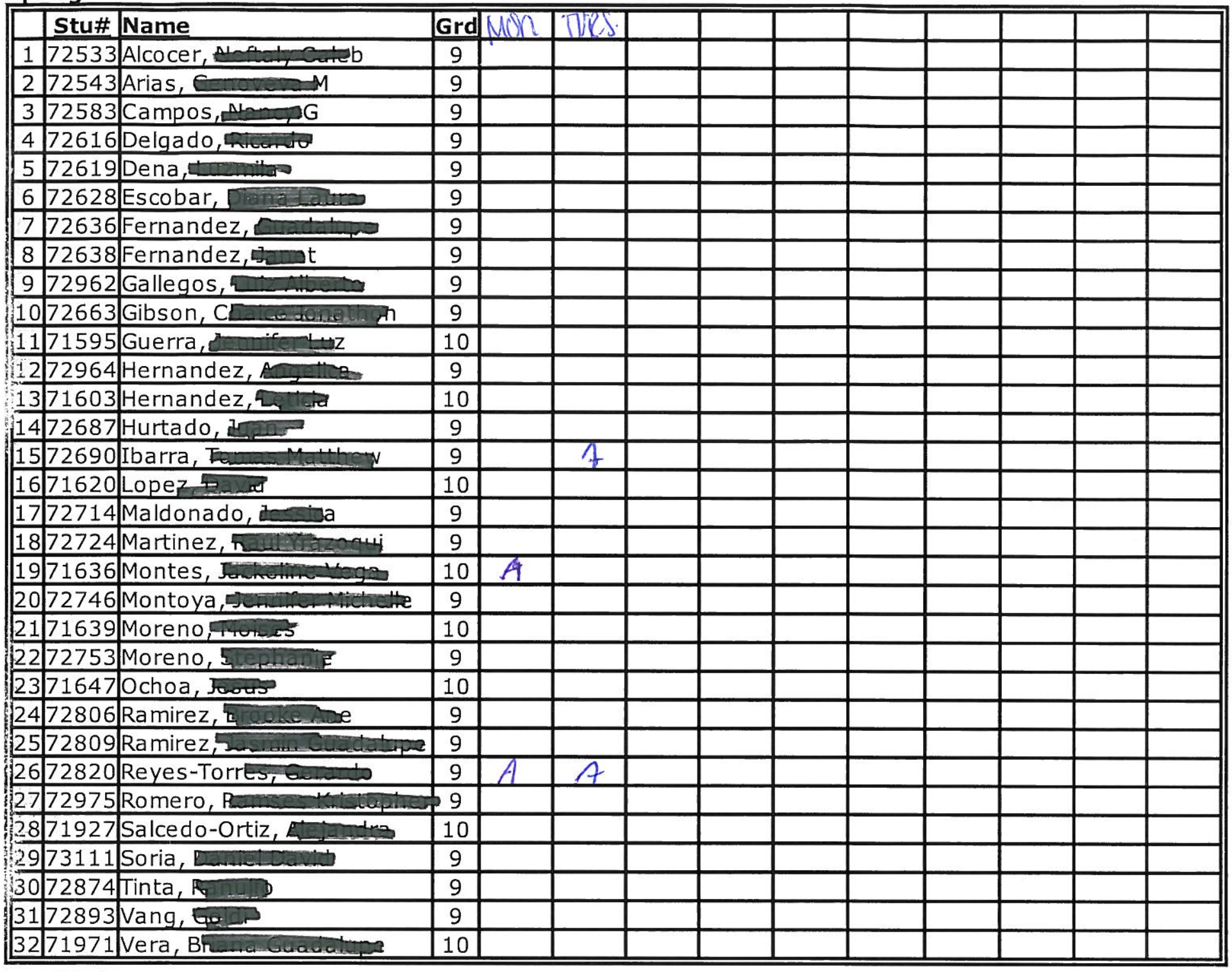

33 7266) GARIBAY, 10 

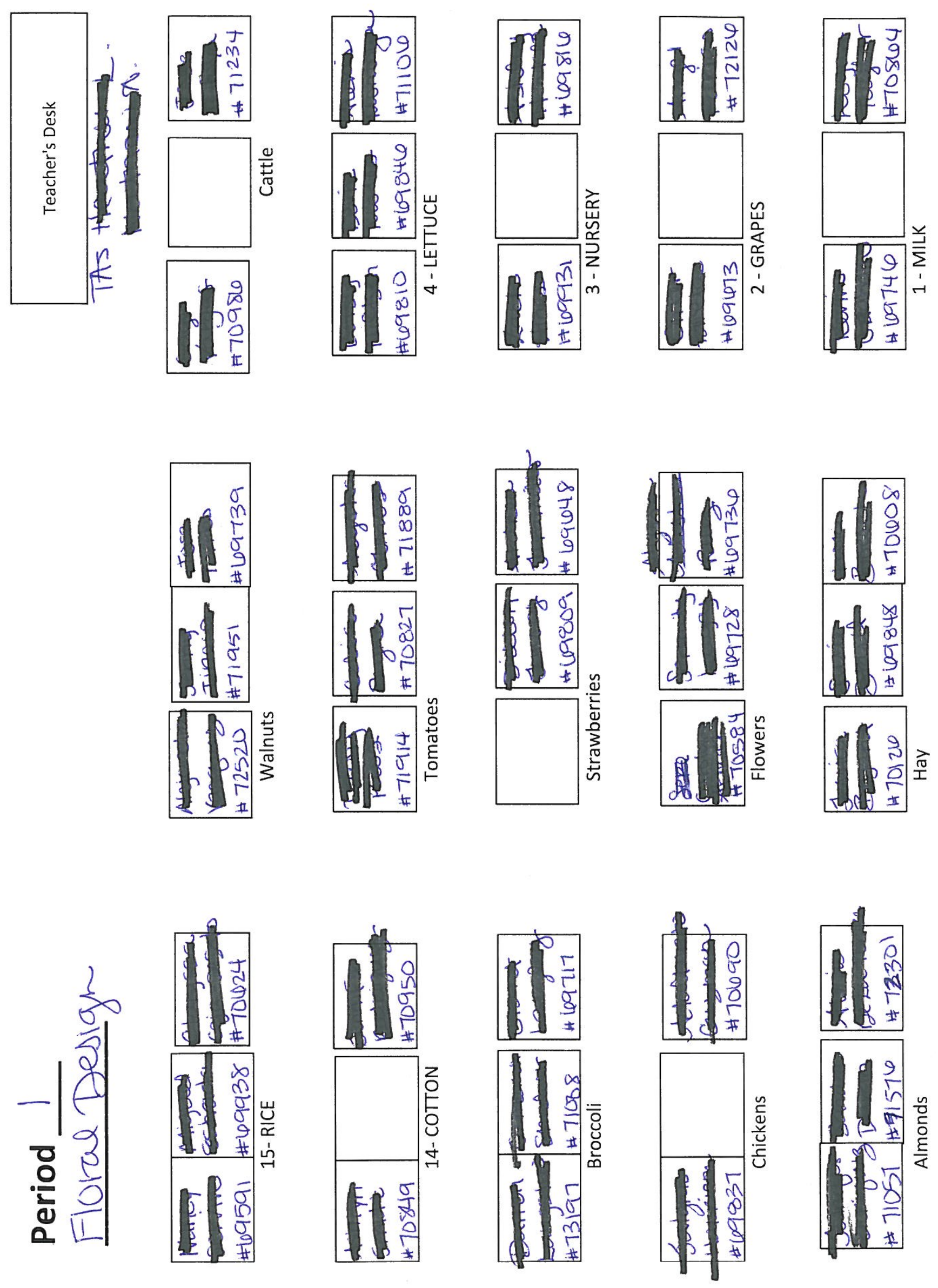

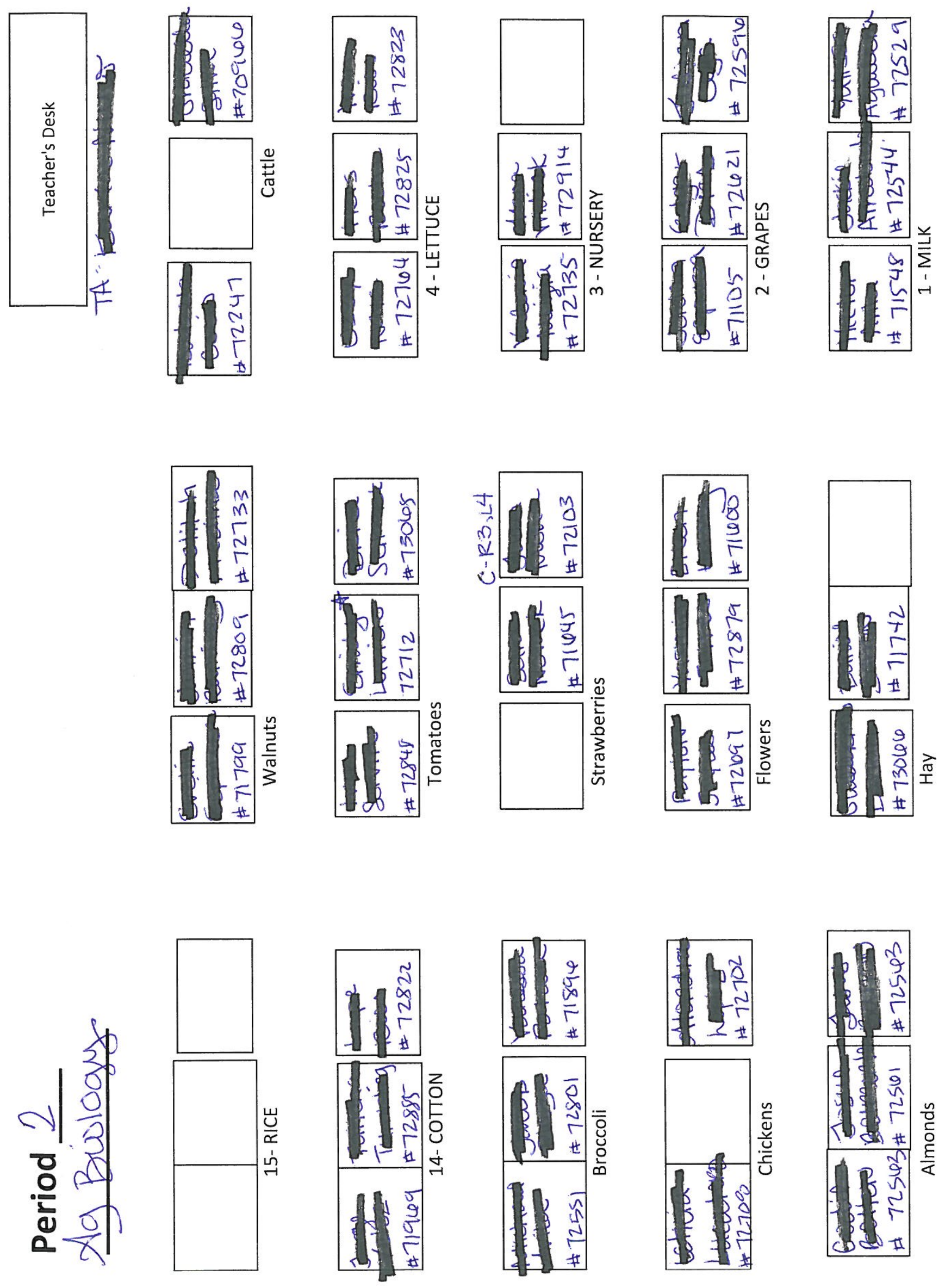

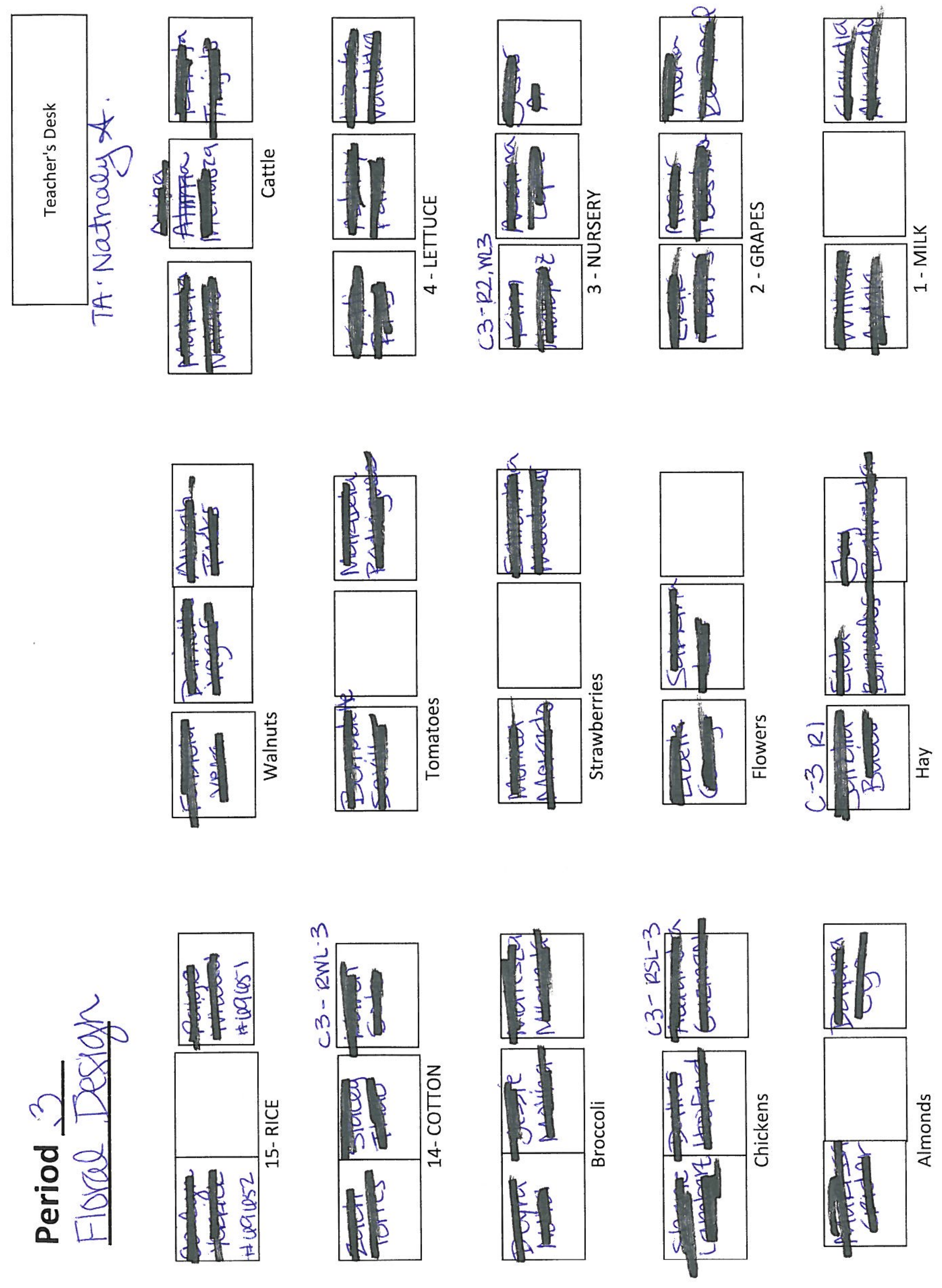

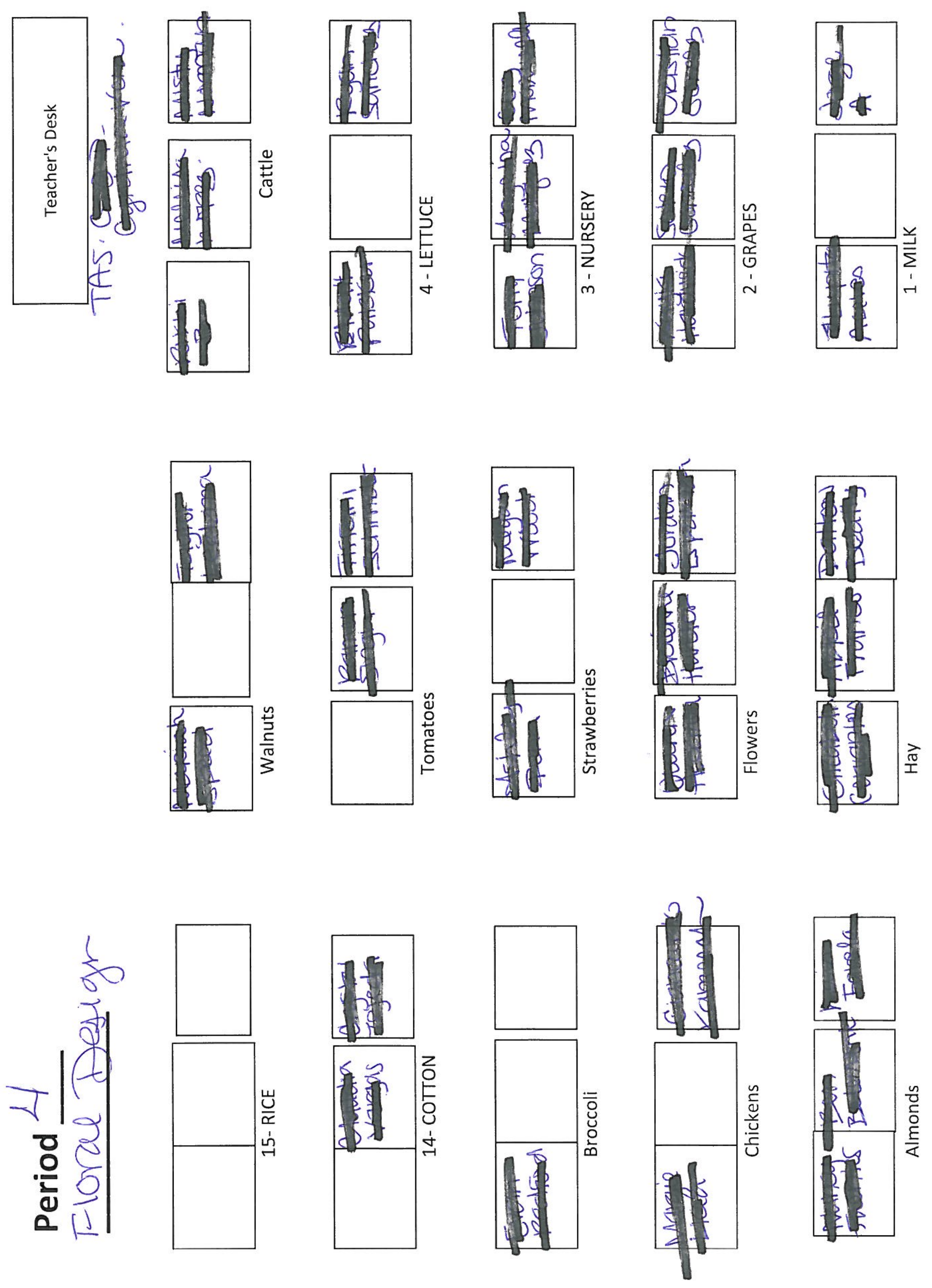


\section{Period 1 Floral Design}

Attendance / Behavior: $\quad * \quad$ Seating chart is enclosed.

* $\quad$ Please take the time to write out absences and/or tardies on this sheet.

Students Tardy:

1.

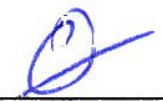

2.

Students Absent:

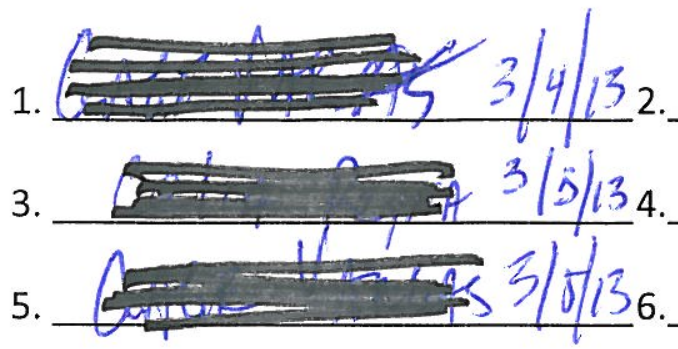

Disruptive / Disrespectful Students

1.

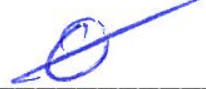

2.

Helpful/On Task Students

1. 2.

\section{Summary:}

$$
\text { Gutstaning }
$$

Overall Behavior:

Please describe the class behavior and atmosphere on a scale of 1 (poor) - 10 (excellent).

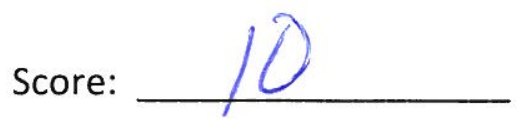




\section{Period 2 \\ Ag Biology}

Attendance / Behavior: $\quad * \quad$ Seating chart is enclosed.

* $\quad$ Please take the time to write out absences and/or tardies on this sheet.

Students Tardy:

1.

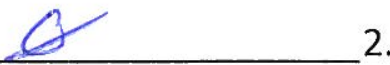

Students Absent:

1. $3 / 4 / 38$

3.

4.

5.

6.

Disruptive / Disrespectful Students

1.

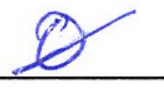

2.

Helpful/On Task Students

1.

2.

\section{Summary:}

\section{Outsitaninle}

\section{Overall Behavior:}

Please describe the class behavior and atmosphere on a scale of 1 (poor) - 10 (excellent).

Score:

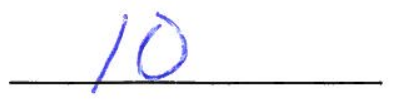


Period 3

Floral Design

Attendance / Behavior: $\quad * \quad$ Seating chart is enclosed.

* Please take the time to write out absences and/or tardies on this sheet.

Students Tardy:

1. 2.

Students Absent:

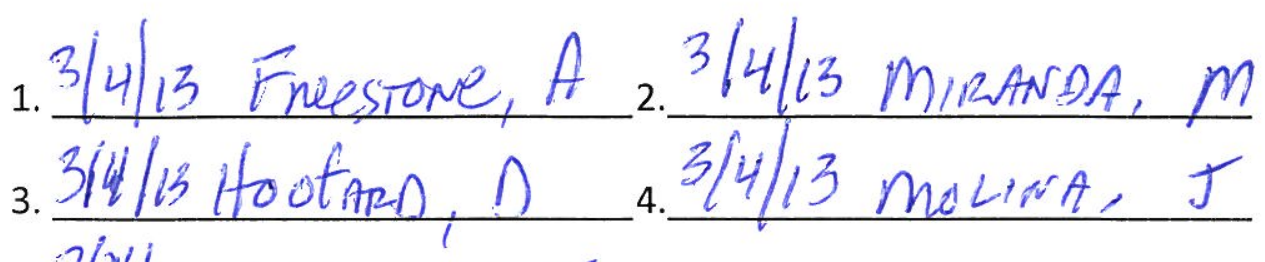

5. 3 解访 lenezmA, T6.

Disruptive / Disrespectful Students

1. 2.

Helpful/On Task Students

1. ALl 2.

Summary:

OuTs BANDinG

Overall Behavior:

Please describe the class behavior and atmosphere on a scale of 1 (poor) - 10 (excellent).

Score:

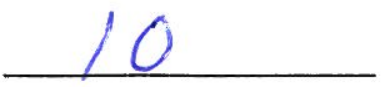


Period 4

Floral Design

Attendance / Behavior: $\quad * \quad$ Seating chart is enclosed.

* Please take the time to write out absences and/or tardies on this sheet.

Students Tardy:

1. 2.

Students Absent:

1. 3/4/B Aguirre, J $2.3 / 5 / 13$ Gomez, $C$

3. $3 / 41$ i M MARquez, A 4 .

5. $3 / 4 / 13$ Parker, $M$. 6.

Disruptive / Disrespectful Students

1. 2.

Helpful/On Task Students

1. ALL 2.

Summary:

Outstanding

Overall Behavior:

Please describe the class behavior and atmosphere on a scale of 1 (poor) - 10 (excellent).

Score:

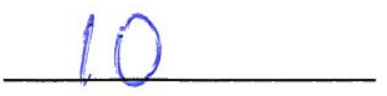


Period 6

Ag Biology

$\begin{array}{lll}\text { Attendance / Behavior: } & * & \text { Seating chart is enclosed. } \\ & * \quad \text { Please take the time to write out absences and/or tardies on this sheet. }\end{array}$

Students Tardy:

1. 2.

Students Absent:

1.3/4/13 montes, $52.3 / 5 / 13$ lateen, $T$

3.

4. $3 / 5 / 13$ Reyes -Tonnes, $G$.

5. 6.

Disruptive / Disrespectful Students

1.

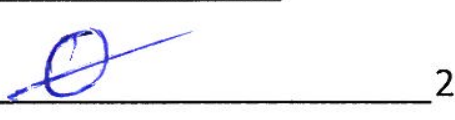

Helpful/On Task Students

Al 2.

Summary:

New Silent $3 / 4 / 13$ : CARIBAN, SAN ORA

$$
\text { OuTSTANDING }
$$

Overall Behavior:

Please describe the class behavior and atmosphere on a scale of 1 (poor) - 10 (excellent).

Score:

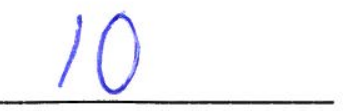




\section{TOOHJS HOIH 배}

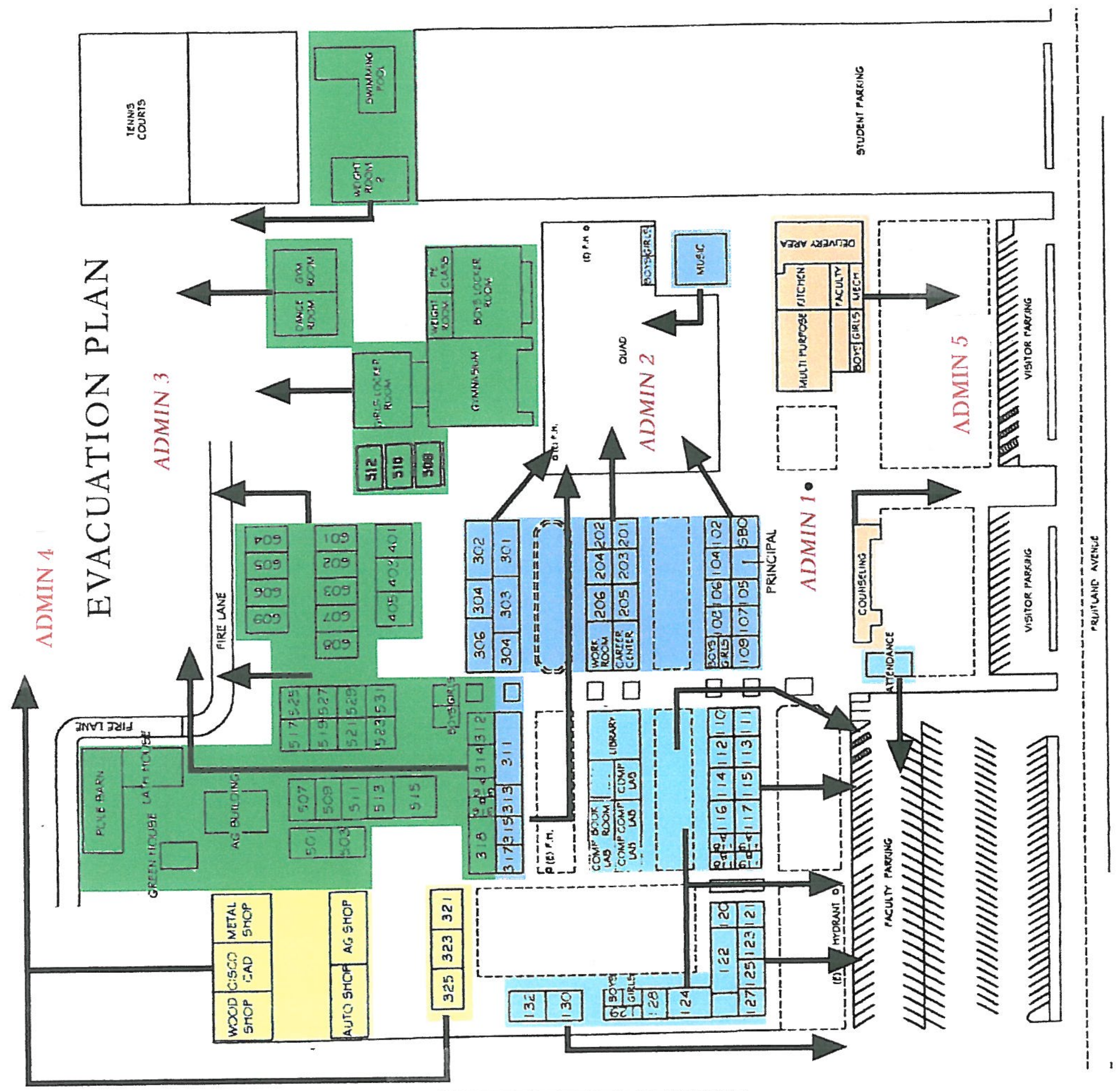

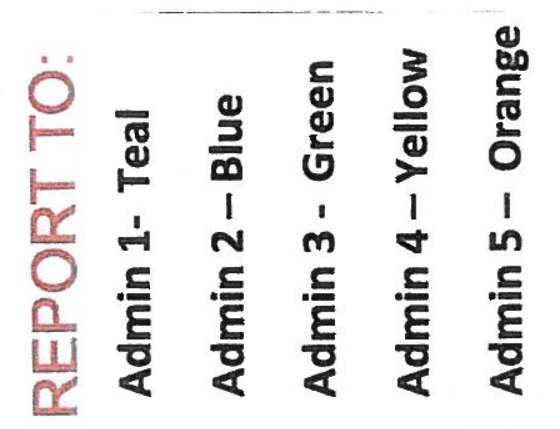




\section{$\underline{\mathrm{LL}}$ \\ Agriculture Student Proficiency}

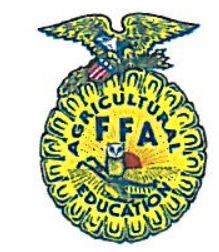

Our grade book displays our students' achievements throughout the year; therefore we as a department do not have a certificate acknowledging their proficiencies in our classes. Their grades display their achievements through FFA activities, SAE projects, and other course requirements. Each student has a grade given for his or her record book as well.

Many of our courses are based upon district standards and other assessments because they are UC A-G accredited. These standards are addressed each day and written on the board for student knowledge. 


\section{MIM \\ $\underline{2+2}$ College Articulations}

Currently, the Atwater Agriculture Department has a 2+2 articulation with Modesto Junior College for Veterinary Sciences. We also have an articulation with Merced Junior College for their Weld 06, Horticulture and Floral Design courses.

\section{Attached you will find:}

- Veterinary Science articulation with Modesto Junior College 


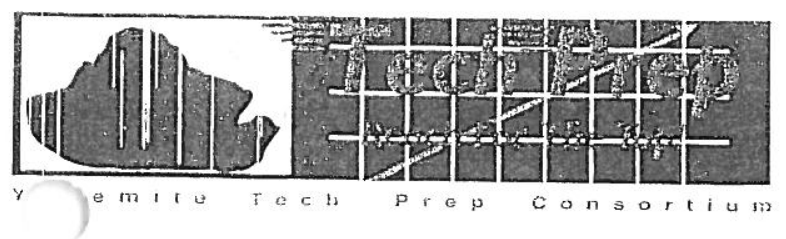

Modesto Junior College

435 COLLEGE AVENUE NODESTO CA 95350 (209) 575.7858

\section{MODESTO JUNIOR COLLEGE \\ SECONDARY-POST SECONDARY ARTICULATION \\ 2+2 AGREEMENT}

\section{STATEMENT OF INTENT}

This agreement enables students to receive college credit and/or a prerequisite waiver for course work completed at the secondary level. The granting of college credit is based on the achievement of competencies through a course or sequence of courses as defined below.

\section{TERMS OF AGREEMEN'T}

This agreement shall remain in force for three years but shall be reviewed for consideration or continuation at the completion of each academic year. This review will include an examination of the current course outlines and final examination. A discussion of current teaching methodologies may be required by college faculty. Either party may terminate this agreement at the close of any academic year by written notice to the MJC Articulation Officer or the principal/ROP Director of the high school.

\section{SECONDARY INSTITUTION}

\section{ATWATER HIGH SCHOOL School/District or ROP}

Agrees to certify those students who have successfully completed Introduction to Veterinary Science with a $B$ grade or better.

\section{COLLEGE DATA}

Upon receipt of grades for students from the high school/district or ROP teacher from the above named secondary institution, Modesto Junior College agrees to award 3 units of college credit for:

\section{ANSC 55 Introduction to Veterinary Technology}

\section{Contract Date: Fall 2008 -Summer 2011}

\section{Modesto Junior College}

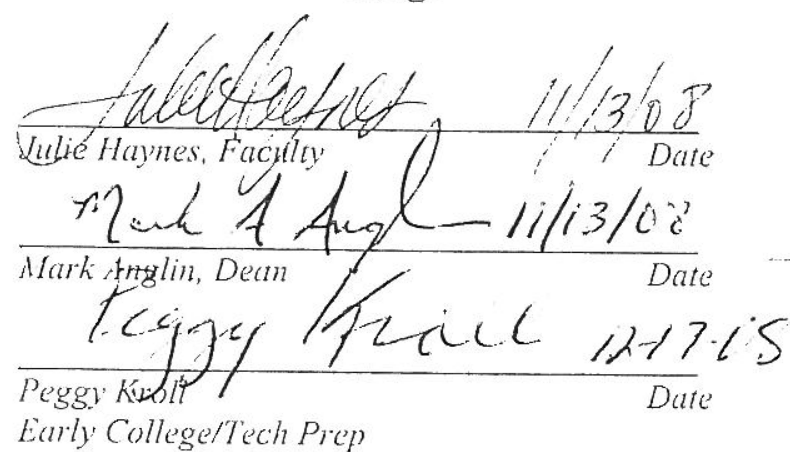

Atwater High School

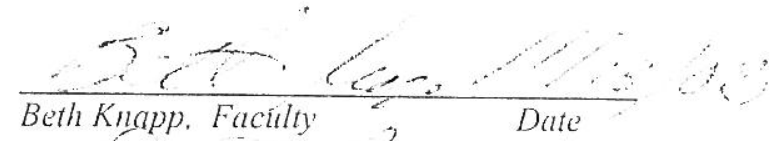

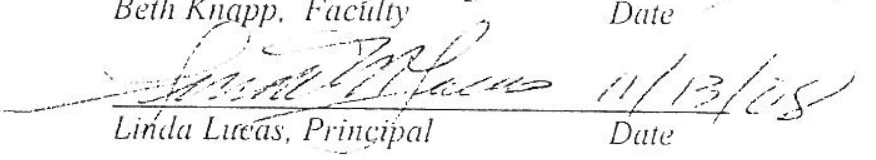




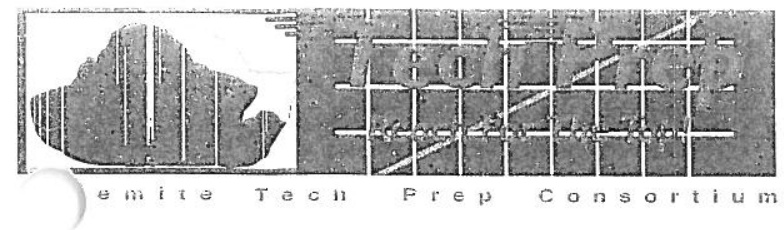

Date: $\quad$ December 17, 2008

To: $\quad$ Beth Knapp

Linda Lucas, Principal

From: $\quad$ Peggy Kroll, Director Early College/Tech Prep

Modesto Junior College

Subject: Articulation Agreement

Thank you for returning the signed articulation for ANSC 55 Introduction to Veterinary Technology with MJC and Atwater High School. The attached articulation will be renewed through Summer 2011. I am enclosing a copy for your records.

Again, thank you, this is a great opportunity for high school students. Your efforts are much appreciated.

Sincerely,

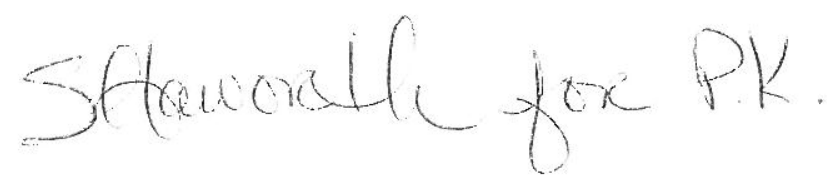

Peggy Kroll

Articulation/Tech Prep Director

Modesto Junior College

435 College Ave.

Modesto CA 95357

krollp@mjc.edu 


\section{OO \\ Reimbursements}

Atwater High School Agriculture instructors are reimbursed for personal expenses while participating in FFA, SAE, and professional development activities. Instructors must fill out a requisition form through the Student Body Office before spending their personal expenses at the specific FFA, SAE or professional development event. Instructors must provide the purchase order number stating their reimbursement as well as their receipts when filling out the payment authorization form. Once the payment authorization form is complete, the instructor will receive their reimbursement. Reimbursements are usually given towards the end of the month.

\section{Attached you will find:}

- Forms needed for reimbursement

- Requisition Form

- Payment Authorization Form

- Receipts 


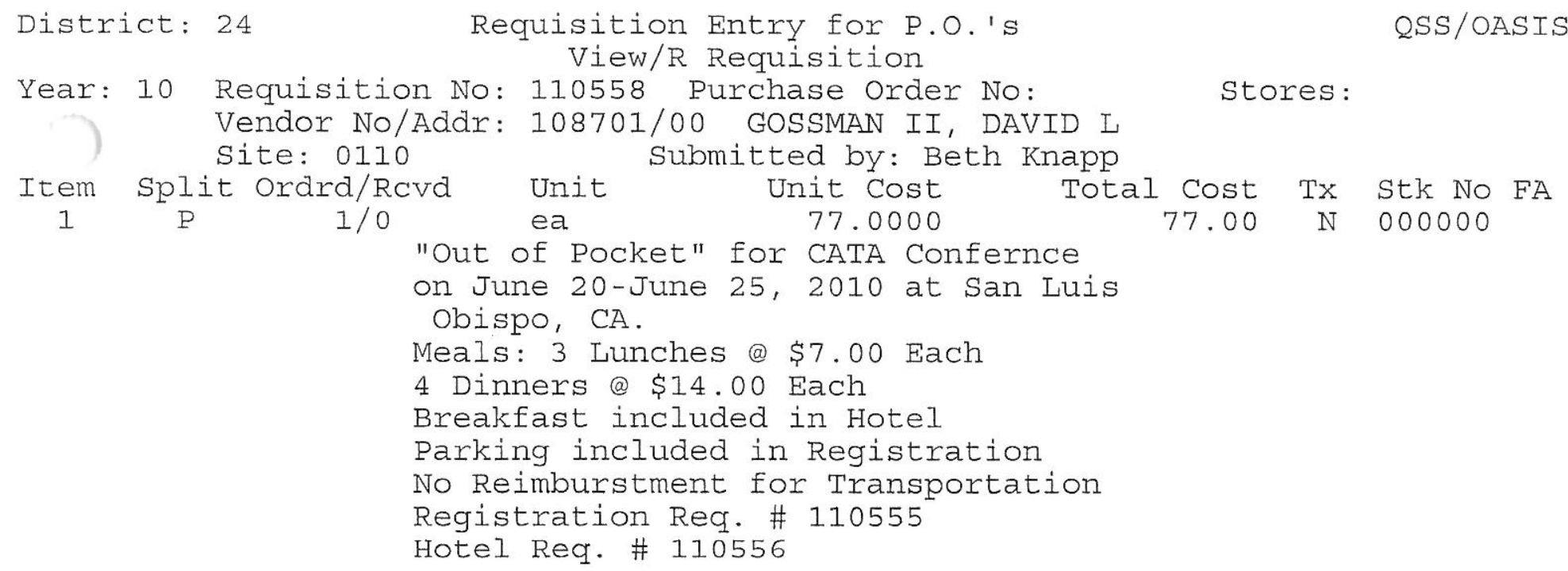

Orig Print: 
Year: 10 Requisition No: 110559 Purchase Order No:

View/R Requisition

Vendor No/Addr: 173075/00 KNAPP, ELIZABETH

Site: $0110 \quad$ Submitted by: Beth Knapp

$\begin{array}{cccrrr}\text { Item } & \text { Split Ordrd/Rcvd } & \text { Unit } & \text { Unit Cost } & \text { Total Cost } & \text { Tx Stk No FA } \\ 1 & \mathrm{P} & / 0 & 0.0000 & 0.00 & 00000\end{array}$

$2 \quad P$

$1 / 0$

ea

77.0000

"Out of Pocket" for CATA Confernce

$77.00 \quad \mathrm{~N} 000000$

on June 20-25, 2010 in San Luis

Obispo, CA

Meal: 3 Lunches@ $\$ 7.00$ ea

4 Dinners@\$14.00 ea

Breakfast included in Hotel

Parking included in tranportation

No Tranportation Reimburstment

Registration Req. 110555

Hotel Paid out of non-district funds

Acct Summary:

Ln. FD-RESC-Y-OBJT . SO-GOAL-FUNC-SCH-DD1-DD2

Page: 1 of 2 Chg Order: 0 Orig Print:

Amount

\# Times Printed: 0 


\section{$\underline{P P}$}

\section{Point Awards System}

The Point Award System recognizes and gives award to members who have shown the most activity throughout the school year. Members who have participated in various FFA activities are asked to fill out a form at the end of the year regarding what they have participated in. Each activity has a certain amount of points that are connected to them. Students that have the most points receive recognition at our annual awards banquet in May. The top twenty members are also invited to the Point Awards Trip that is sponsored by the FFA. The Point Awards Trip is usually occurs the week after school ends.

\section{Attached you will find:}

- Point Awards Form

- Invitation to the Point Awards Trip

- Pictures from last year's Point Awards Trip 
1. Did you get elected or receive an award at banquet last year? If not see question \#2

- Elected into Chapter Office................................................................................................

- Elected into Sectional or Regional Office ...........................................................................

- Star Greenhand............................................................................................................

- Star Chapter Farmer.........................................................................................................._ /

- Outstanding FFA Member/Freshman/Sophomore/Junior/Senior.....................................__ / 50

2. Did you exhibit a project at the 2011 Merced Fair? If not see questions \#4

- Small Ag Mechanics Project (10 Points per project entered)............................................__

- Large Ag Mechanics Project .................................................................................................

- Landscape Plot Project...................................................................................................

- Plant Project (s) (10 Points per project entered) ..............................................................

- Beef or Dairy Project.......................................................................................................

- Swine/Goat/Sheep Project.............................................................................................

- Rabbit Project..............................................................................................................

3. Did you win $1^{\text {st }}$ or $2^{\text {nd }}$ in your market class or make it to the top 10 in showmanship? If not see question \#4

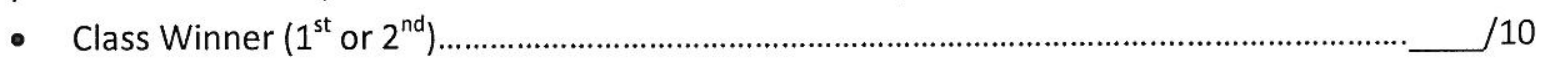

- Breed Champion............................................................................................................... / /

- Overall Champion (Grand or Reserve) .............................................................................._. 25

- Top 10 Showmanship(15 Pts) Showmanship Winner(25 Pts) Round Robin Winner (50 Pts)___ /50

4. Did you sell Placemat Ads? 20 Points per Ad.............................................................................._. 20

5. Did you help Gossman, loimo, Meredith or Flatt BBQ at a Football Game? 20Points per game.___ 20

6. Did you sell BBQ Ticket at any of the BBQs? 10pts per ticket sold (add up all the tickets you sold)___ $/ 10$

7. Did you help with the homecoming float? (15Points per day) ......................................................_. 15

8. Did you help at the Fall or Spring plant sale? ....................................................................... 25

9. Did you attend Atwater Beautification? (5 Points per Hour) ..........................................................__ / $10 \mathrm{Max}$

10. Did you attend the Greenhand Chapter Farm Degree Ceremony at Buhach Theater or State Degree at GV?

- Attended.........................................................................................................................

- Greenhand Degree.....................................................................................................

- Chapter Degree..................................................................................................................

- State Degree ...........................................................................................................................

11. Did you participate in Project Competition? If not see question \#12

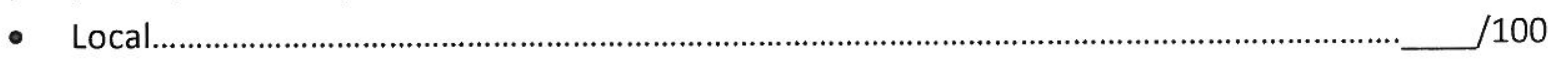

- Gold at Section............................................................................................................__

- Silver at Section............................................................................................................

12. Did you attend any FFA Meetings?

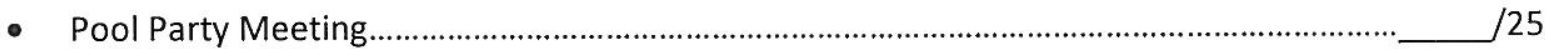

- Corn Maze Meeting at Ag Department Lawn......................................................................__

- Morning Wave Meeting......................................................................................................

- Movie Night Meeting..............................................................................................................

- Bowling Meeting .............................................................................................................

- Burrito Bingo ....................................................................................................................

- Central Region Meeting...................................................................................................._ 25

- Sectional Meeting at Livingston...................(If you took the co-op Quiz add 25)..............___ $/ 25$ 
13. Did you participate in Creed, Job Interview or Prepare Public Speaking?

- Creed, Job Interview or Prepare Public Speaking at Super Saturday..................................___ 25

- Creed, Job Interview or Prepare Public Speaking at Regional Level.................................__

- Creed, Job Interview or Prepare Public Speaking at State Level........................................__ /50

14. Did you attend any Conferences? If not see question \#16

- Greenhand Conference.....................................................................................................

- MFE/ALA ....................................................................................................................

- State FFA Conference One Day........................................................................................

- State FFA Conference Four Day.........................................................................................

- National Convention (50 Points per day) .............................................................................. _ /

15. Did you participate in any community service?

- Can Food Drive 5pts / can ..................................................................................................

- Floral Arrangements with Seniors..................................................................................... 15

- Kops for Kids......................................................................................................................_

- Atwater Rose Show.......................................................................................................... / 15

16. Did you participate on a Judging Team? (Arbuckle, UC Davis, Chico, Reedley, Consumes, Merced, MJC, Fresno)

- Participation at each Contest is worth 20 Points each.........................................................__

- Each Top 5 Individual placing is worth 20 pts and Top 10 Individual is worth 10 pts......__

- Each Top 5 Team placing is worth 20 pts and Top 10 Team is worth 10 pts....................__ _ 10

17. Did you go to State Finals?

- Participation at State Finals..............................................................................................

- Top 5 Individual is worth 40 pts or Top 10 Individual is worth 20 pts...............................__ 20

- Top Team is worth 40 pts or Top 10 Team is worth 20 pts............................................... 20

18. Did you compete on a National Judging team..............................................................................._. 200

19. GPA Points

- 3.5-4.0+ Overall GPA at Semester 1..................................................................................

- 3.0-3.9 Overall GPA at Semester 1.................................................................................__ /

- 2.5-2.99 Overall GPA at Semester 1 .................................................................................._ / 
To: $\quad$ Top "20" Plus Nom-Com Students, Advisors

From: $\quad$ Ag Dept. Staff

Date: $\quad$ May 17, 2012

Re: $\quad$ Point Award Trip

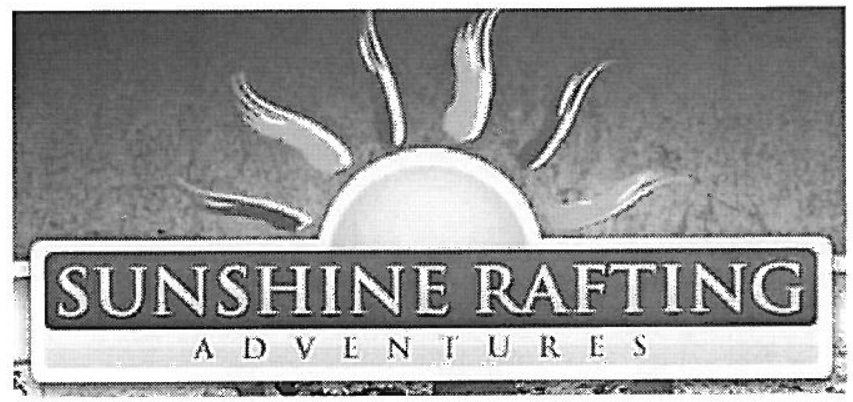

\section{Congratulations on being a 2011-2012 Atwater FFA Point Award winner!}

This year's trip is to Great America. The itinerary is as follows:

Depart AHS Ag Department to Knight's Ferry _ - $\quad$ Tuesday June 5th @ 8:30 am

Depart Knight's Ferry to AHS Ag Department _ - $\quad$ Tuesday June 5th @ 3:00 pm

(Estimated return to AHS 4:30 pm)

\section{Itinerary / Logistics:}

Transportation / Cost- The Atwater FFA will provide transportation and rafting ticket. You must put down a $\$ 5$ deposit to confirm your spot. You will receive a refund only if you show up.

Things to Bring -

Sunscreen

Short/ T-shirt / tank top

Water guns and water toys

Swimsuit

Bring backpack w/

towels/sunscreen

\section{Confirmation:}

All students planning to attend MUST confirm with Ms. Knapp by Friday, May $25^{\text {th }}$ !! 


\section{Point Awards System}

The Point Award System was developed in order to recognize and award those members who are most active in various FFA activities throughout the year. The top twenty individuals will receive an award and recognition at our awards banquet in May. The top twenty members were invited to participate in a Point Award trip sponsored by the Atwater FFA. In 2012, the Point Award members went to on a river rafting trip.
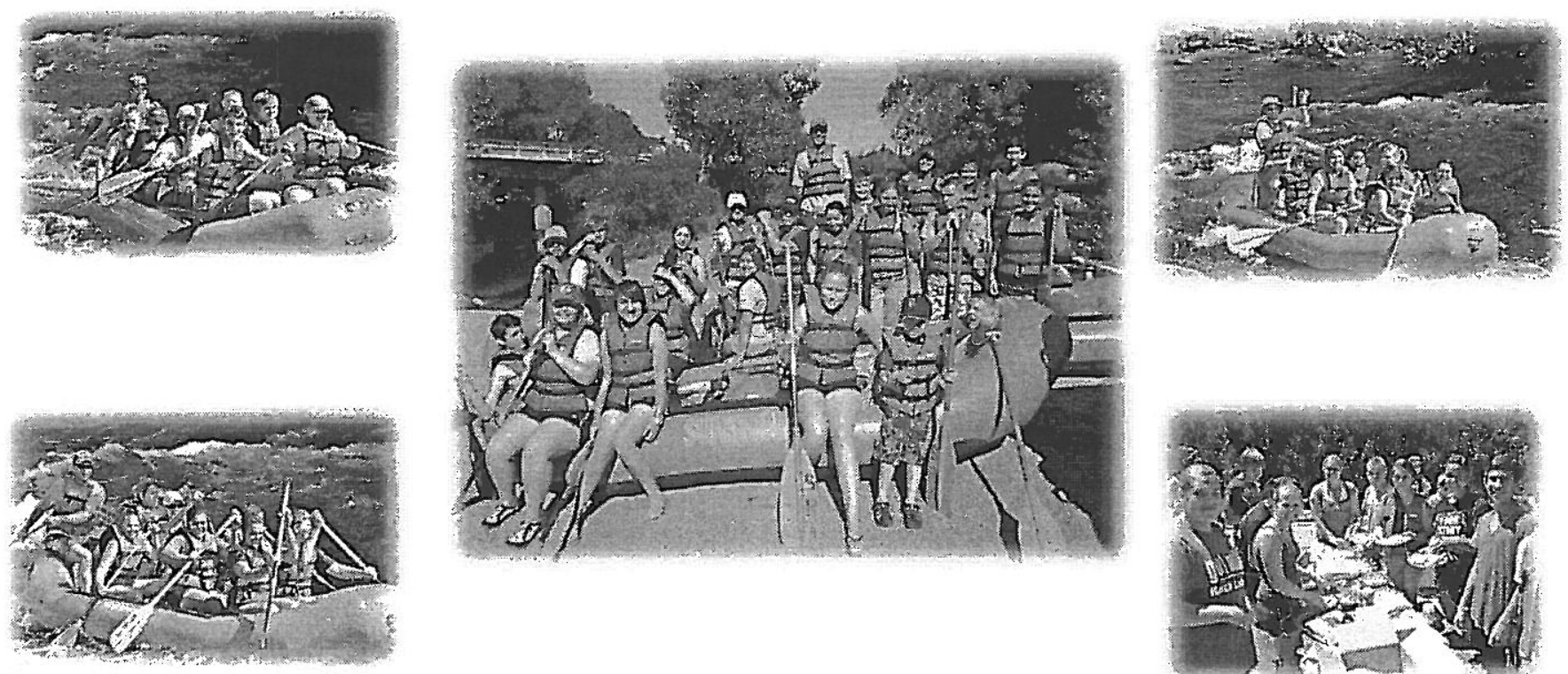

\section{1 - 2012 Point Award Winners}

Carolyn Schiber

Cheyenne Schoonover

Donald Moles

Giancarlo Kamesch

Hans vanWarmerdam

Heather Lewandowski

James Bray
Jesse Tafoya
Joana Pena
Joy Wilcox
Luis Favela
Makala Navarro
Maria Ceja
Mayra Hernandez

\author{
Mekayla Coughran \\ Morgan Briner \\ Noemy Escamilla \\ Sandra Flores \\ Sandy Xiong \\ Taylor Ferreira
}

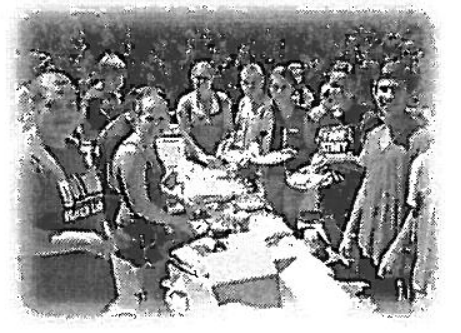

For June 2013, the officer team selected a trip to a San Francisco Giants game and Fisherman's Wharf. The Point Award System is an evaluation resource used by the Advisors towards selecting each year's Star Chapter Greenhand and Star Chapter Farmer award recipient 


\section{Point Awards System}

\section{Atwater FFA Point Awards List}

\section{FFA Leadership / Community Service / Work Day Activities}
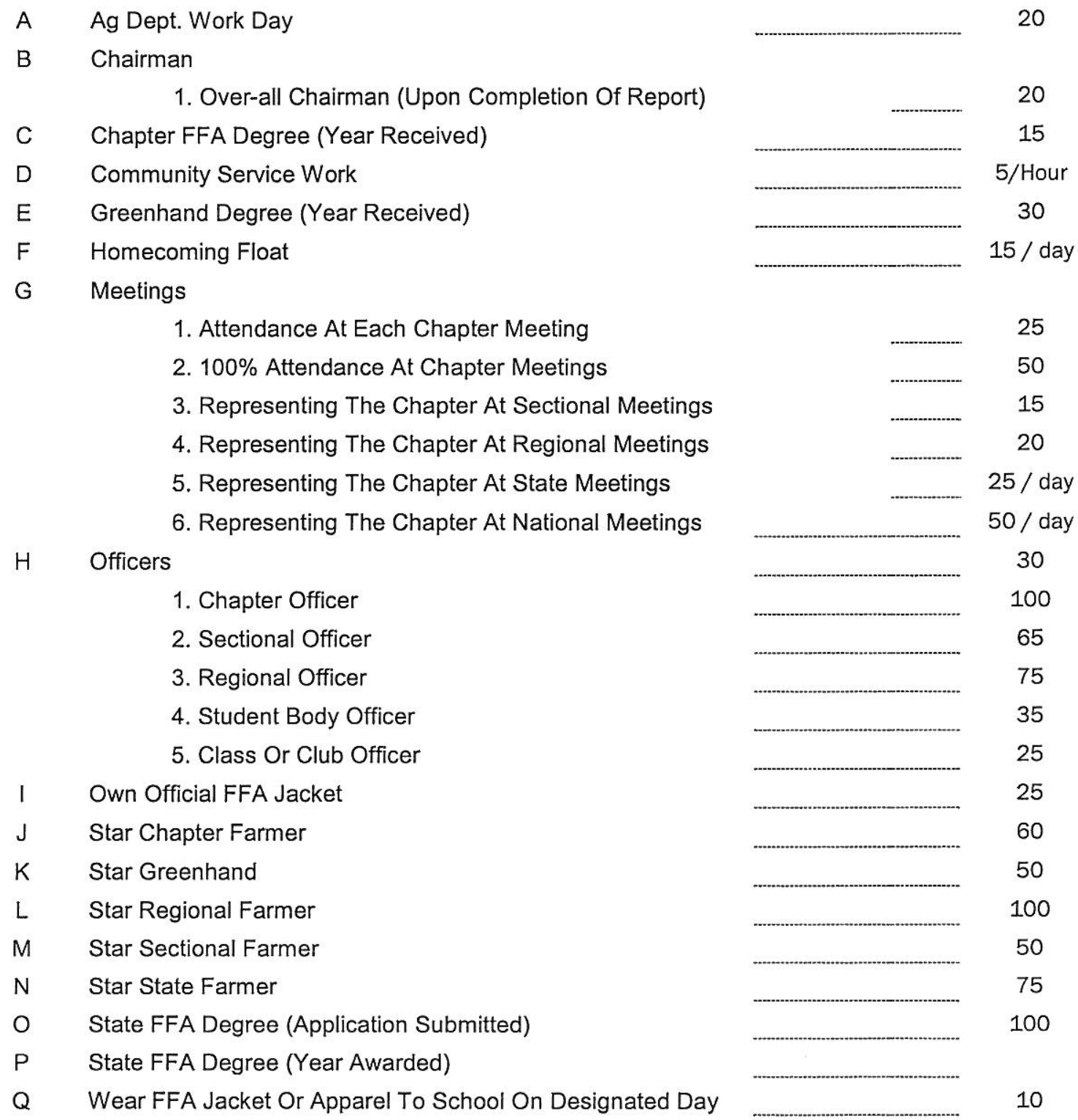

\section{Fundraisers}

1. Attendance At Each Chapter Meeting

2. $100 \%$ Attendance At Chapter Meetings

3. Representing The Chapter At Sectional Meetings

4. Representing The Chapter At Regional Meetings

5. Representing The Chapter At State Meetings

6. Representing The Chapter At National Meetings

$\mathrm{H} \quad$ Officers

1. Chapter Officer

2. Sectional Officer

3. Regional Officer

4. Student Body Officer

5. Class Or Club Officer

I Own Official FFA Jacket

J Star Chapter Farmer

K Star Greenhand

L Star Regional Farmer

M Star Sectional Farmer

N Star State Farmer

O State FFA Degree (Application Submitted)

$P \quad$ State FFA Degree (Year Awarded)

Q Wear FFA Jacket Or Apparel To School On Designated Day

10

A AHS Football Game BBQ Crew 
B FFA Plant Sale

C Placement Ad Sales

$20 / \mathrm{Ad}$

D Take-Out BBQ Tickets

10 / ticket

\section{Süpervised Occupational Experience Program (SAE)}

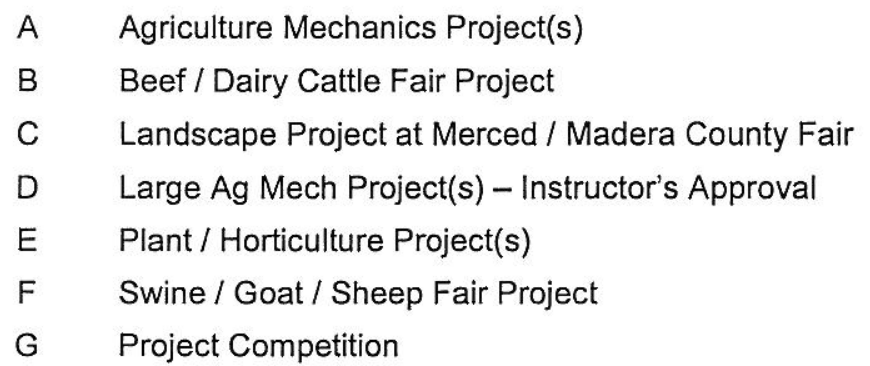

25

125

50

75

25

75

1. Local Competitions

50

2. Sectional Competition

a. Gold Award Winner

100

b. Silver Award Winner

$\mathrm{H} \quad$ Exhibition At Fairs And Shows

1. Animal Projects

a. Class Winner $\left(1^{\text {st }}\right.$ or $\left.2^{\text {nd }}\right)$

b. Breed Champion 15

c. Overall Champion (Grand or Reserve) ……....... 25

2. Agriculture Mechanics / Horticulture Projects

a. Outstanding Project

25

4. Showmanship

a. Top 10 Showmanship 15

b. Showmanship Champion _............................. 25

c. Round Robin Winner 50

\section{Scholarship (Based On Semester Grade Only)}

A 3.5-4.0+ Overall School Year GPA (all AHS classes)

50

B $\quad 3.0-3.49$ Overall School Year GPA (all AHS classes)

25

C $\quad 2.5-2.99$ Overall School Year GPA (all AHS classes)

10

\section{Judging Teams}

A Participation (Official FFA Contest) 
Individual Placing

1. Top 5 Overall

20

2. Top 10 Overall

Team Placing

1. Top 5 Overall

20

2. Top 10 Overall

(Double All Of The Judging Team Point For State Finals)

The Coach Of Each Individual Team Will Award Each Time Member That He Feels Is Deserving A One Time Award Of 150 Point At The End Of The Year.

V Best Informed Greenhand, Co-Op Quiz, Public Speaking, Parliamentary Procedure, Creed And Opening And Closing Ceremonies Contest
A Chapter Competition

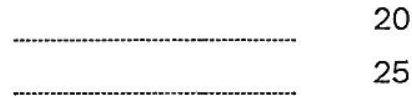
B Sectional Competition
C Regional Competition 30
D State Competition 50

\section{National Competitions (Participation)}
A Judging Teams
B Parliamentary Procedures

200

200

\section{Proficiency Awards}
A Local
Submitting Regional Application
D Nation
E Final Four
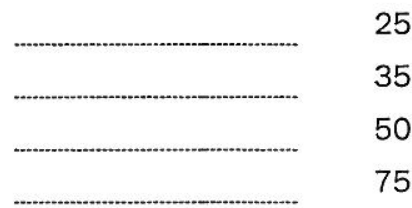

75 


\section{QQ \\ Chapter Goals}

During the FFA Chapter Officer Retreat, our officers create the Chapter Goals for the oncoming year. At the retreat, officers are given goals that were established the year before and are asked to analyze them. The officers then create the Chapter Goals for the year that they are in service. Our 2012-2013 FFA Officers Team created the following chapter goals during our annual FFA Chapter Officer Retreat held at South Lake Tahoe.

\section{Attached you will find:}

- 2012-2013 Chapter Goals 


\section{Chapter Goals}

Our 2012-2013 FFA officer team created the following chapter goals during our annual FFA Chapter Officer Retreat held at South Lake Tahoe in August 2012:

\section{Develop Strong and Effective Chapter Leadership}

- Develop and strengthen communication skills

- Increase student involvement \& participation

- $\quad$ Expand leadership classroom resources / supplies

- Improve scrapbook efficiency, development, and equipment

- Improve secretary \& treasurer record keeping

- Increase \& improve agriculture leadership curriculum \& resources

- $\quad$ Expand technology communication with student-made video announcements

2. Develop and Strengthen Agriculture Resources and Curriculum

- Increase large and medium ag mechanics projects

- $\quad$ Expand curriculum technology resources - teaching/learning tools

- $\quad$ Expand and develop wood SAE projects

- $\quad$ Expand and develop horticulture SAE projects

\section{Expand Student Involvement and Participation}

- Increase student attendance and participation at chapter meetings

- Increase SAE projects (animal, plant, and ag mech)

- $\quad$ Expand and strengthen FFA competition opportunities / teams

- Improve organization and planning of events/activities

- Increase state and improve development of national FFA applications (National Chapter Award)

\section{Develop Strong Recruitment \& Retention Program}

- $\quad$ Strengthen and expand middle school relationships \& communication

- Maintain / improve recruitment presentations \& education

- $\quad$ Strengthen advanced Ag Welding and Ag Wood enrollment \#'s

- Maintain/strengthen agriculture "foundation" $\left(9^{\text {th }}\right.$ grade) courses 


\title{
Chapter Goals
}

\section{Expand \& Develop Agriculture Facilities / Resources}

\author{
Horticulture
}

- $\quad$ Acquire plant labeling system

- Install new (concrete) walkway and gate in-between pole barn and storage sheds

- $\quad$ Expand plant SAE/projects/sales with perennials, shrubs, and trees

- Install new brick walkway area at NW corner of ag department driveway

\section{Arnold's Farm}

- $\quad$ Explore need for swine water antibiotic system

- Improve/upgrade swine pump/septic system

- Install eye-bolts in each pen so feeders can be connected to walls

- Improve cleaning/operation efficiency

- $\quad$ Explore new/improved sheep pens (facility upgrade opportunities)

$\underline{\text { Pole Barn }}$

- Install new storage (Tuff) shed for goat/rabbit supplies \& equipment

- Pour new concrete slabs (example - shed)

- Install "above ground" Popper storage rack

Agriculture Mechanics / Shops

- Create/install TIG welding lab / work area

- Build/create new cylinder storage area

- Remove storage container in-between shop buildings

- Paint new storage containers 


\section{$\underline{\mathbf{R} R}$}

\section{Permission Slip and Waiver Notice}

In the beginning of the year, the Atwater Agriculture Department has their students fill out a permission slip and waiver notice. Students are given this permission slip and waiver notice the same time they receive their Ag department and classroom policies. Students then have to have their permission slip, wavier form, Ag department policies and classroom policies all signed and dated by the end of the first week. A copy of the permission slip and wavier notice documents are kept in the agriculture department in a large binder. One copy is also sent to the administration. This wavier allows any of the six instructors to drive or seek medical attentions for the students if I problem were to arise. If an FFA event is off campus, the binder is taken to the event in case any emergencies follow.

\section{Attached you will find:}

- Permission Slip

- Medical Wavier Form 


\section{Atwater High School Agriculture Department}

Atwater High School / Merced Union High School District
FFA Advisors:

Ms. loimo

Mrs. Williams

Ms. Kirschner
Mr. Gossman

Mr. Meredith

Mr. Flatt

\section{Permission Slip and Waiver Notice}

permission to attend all FFA activities during the

I hereby give my son/daughter

town. This agreement shall begin on August 1, 2012

2012-2013 school year. I unders

and end on August 31, 2013.

\section{Waiver / Permission to Transport Student}

I hereby waive on behalf of the pupil listed above, all claims against the Merced Union High School District and any and all states in which said activities take place, for injury, accident, illness or death occurring during or by reason of the above-listed activities, and all acts incidental or related thereto, for which this permission slip is given.

\section{Student's Photo/Work Release}

Student's work, photo and/or first name may be considered for publication on the World Wide Web during the school year. All student work will appear with a notice prohibiting copying without the express written permission of MUHSD, the student and the parent(s). No student's full name, home address or telephone number will be published on the MUHSD web pages or pages created with MUHSD resources. In addition, MUHSD may take photographs of students, singly or in a group, for use in audiovisual presentations and related printed materials that may be provided to District staff and/or to the staff of other school districts. MUHSD will not exercise control over the persons who may view and copy student's likeness or how such persons may otherwise use the photographs.

\section{Medical Authorization}

I/We, the undersigned, parent(s) / legal guardian(s) of the pupil listed above, do hereby authorize consent to any $\mathrm{x}$-ray examination, anesthetic, medical or surgical diagnosis, or treatment and hospital care for the above named individual which is deemed advisable by and is to be rendered under the general or specific supervision of any physician and/or surgeon licensed under the provisions of the Medicine Practice Act whether such diagnosis or treatment is rendered at the office of said physician or at a hospital.

It is understood that this authorization is given in advance of any specific diagnosis, treatment, or hospital care being required but is given to provide authority and power on the part of said physician to render any and all such diagnoses, treatment, or hospital care which the aforementioned physician, in exercise of his/her best judgment, may deem advisable for my/our son/daughter.

This authorization shall be effective beginning August 1, 2012 and ending August 31, 2013 while participating in Atwater High School Agriculture Department and FFA activities.

In case of emergency, please try to contact:

Name

Name
Telephone:

Telephone:

Please list (on reverse side) any special conditions about the above named student which a physician should be aware of. Be sure to list any medications which the student is allergic to or ones currently prescribed. Also, list on the reverse all personal data and medical insurance coverage information.

\section{Signatures}


A.

\section{MVEDICAL INIORIVATION}

Does student have any chronic health problems?

$\square$ Yes $\square$ No

If YES, please check those which apply to your child:

$\square$ Asthma (carries inhaler)

Ear (hearing aid)

$\square$ Allergies (dust/pollen)

$\square$ ADD/ADHD

Diabetes

Seizures

$\square$ Nose Bleeds

Heart Problems

$\square$ Eye (glasses) $\square$ Anaphylaxis (severe bee sting or food allergy)

Allergies to food (Please list):

Does student take prescription medication on a regular basis?

$\square$ Yes $\square$ No

If YES, please list below:

Is student allergic to any medication?

Yes $\square$ No

If YES, please list below:

B. Data on my/our son/daughter named on the reverse side of this form:

Student's Full Name:

Complete Home Address:

Home Telephone Number:

Date of Birth:

Father's Full Name:

Mother's Full Name:

Legal Guardian Currently With:

C. Medical Insurance Data relative to my/our son/daughter named on the reverse of this form *:

\section{Medical / Medicaid}

Private/Other Insurance Company:

Company Address:

Company Telephone \#

If a Group Policy, Group Insured:

Name of Policy Holder:

Group Number:

Individual Number:

* This section is MANDATORY in order to attend field trips off campus.

D. Other pertinent information: 